\title{
A PROTEÇÃO DA PRIVACIDADE NAS COMUNICAÇÕES ELETRÔNICAS NO BRASIL
}

\author{
Dissertação de mestrado \\ Candidato: Rodrigo Octávio de Godoy Bueno Caldas Mesquita \\ Orientador: Professor Titular Enrique Ricardo Lewandowski
}

FACULDADE DE DIREITO

SÃO PAULO 



\section{A PROTEÇÃO DA PRIVACIDADE NAS COMUNICAÇÕES ELETRÔNICAS NO BRASIL}

Dissertação apresentada à Faculdade de Direito da Universidade de São Paulo para a obtenção do grau de Mestre em Direito.

Área de concentração: Direito do Estado

Orientador: Professor Titular Enrique Ricardo Lewandowski

\section{SÃO PAULO}




\section{FOLHA DE APROVAÇÃO}

Candidato: Rodrigo Octávio de Godoy Bueno Caldas Mesquita

Título: A proteção da privacidade nas comunicações eletrônicas no Brasil

Dissertação apresentada à Faculdade de Direito da Universidade de São Paulo para obtenção do título de Mestre.

Área de concentração: Direito do Estado

Aprovado em:

Banca examinadora 


\section{AGRADECIMENTOS}

Embora a elaboração de uma dissertação de mestrado revele-se, muitas vezes, um empreendimento solitário, dificilmente poderia tomar forma sem a colaboração de outras pessoas.

Gostaria de agradecer, primeiramente, a orientação do Professor Enrique Ricardo Lewandowski e a colaboração de seu gabinete do Supremo Tribunal Federal, a do Doutor Aloisio Marcel Lewandowski e a da Professora Maria Sylvia Zanella Di Pietro.

Agradeço também à Professora Ada Pellegrini Grinover e ao Professor Carlos Alberto Salles, por gentilmente cederem uma cópia do Anteprojeto da Comissão de Juristas do Ministério da Justiça, de 2003, e ao Professor Manoel Gonçalves Ferreira Filho, pelas lições sobre direitos fundamentais nas suas aulas da Pós-Graduação na Faculdade de Direito da Universidade de São Paulo, de 2006.

Foi também de fundamental importância, na pesquisa, a ajuda dos colegas Paulo Fernando Campana Filho, Ricardo Augusto Negrini, Niva Azevedo Secretário e Victor Maida Albuquerque Magalhães, da Biblioteca do Tribunal de Justiça do Estado de São Paulo e do Desembargador José Carlos Gonçalves Xavier de Aquino, bem como o incentivo de Fernando Furlanetto Galuppo.

Por último, agradeço à minha família, Cid, Wanda e Marcus, pelo apoio e pelas discussões sobre o tema, e a Gabriela Piai de Assis, pela paciência e pela ajuda na correção do texto, inclusive com as traduções do francês. 


\section{RESUMO}

A dissertação aborda a proteção da privacidade nas comunicações eletrônicas reservadas no Brasil. Objetiva apresentar a situação atual dessa questão no país e fazer uma análise crítica comparativa. Conceitua "privacidade", "comunicações", "reservadas" e "dados pessoais" como requisitos para a compreensão do assunto. Analisa o direito dos Estados Unidos da América, da União Européia e do Conselho da Europa, os Projetos de Lei em trâmite no Senado Federal e na Câmara dos Deputados e a situação brasileira atual. A metodologia de pesquisa consiste na consulta e interpretação de fontes jurídicas nacionais, internacionais e de direito estrangeiro, como os tratados, leis e jurisprudência atinentes à questão da privacidade nas comunicações eletrônicas, a partir da qual se desenvolve uma construção argumentativa, dedutiva e indutiva para uma crítica construtiva. Conclui que a mencionada proteção é desequilibrada e inadequada e propõe alterações interpretativas e legislativas.

Palavras-chave: Privacidade. Sigilo. Comunicações eletrônicas reservadas. Interceptação. Brasil. 


\begin{abstract}
The paper approaches the protection of the reserved electronic communications privacy in Brazil. Its goal is to present the current situation of this matter in the country and to develop a critical comparative analysis. It conceptualizes "privacy", "communications", "reserved" and "personal data" as requirements to understand the subject. It analyses the law of the United States of America, of the European Union and of the Council of Europe, the bills in the Federal Senate and in the House of Representatives and the current Brazilian legislation. Its methodology consists of examination and interpretation of national, international and foreign sources of law, such as treaties, statutes and case-law related to the electronic communications privacy question, which forms a basis from which it develops an argumentative, deductive and inductive reasoning for a constructive criticism. It concludes that the mentioned protection is imbalanced and inadequate and proposes legislative and interpretative changes.
\end{abstract}

Keywords: Privacy. Secret. Reserved electronic communications. Interception. Brazil. 


\section{SUMÁRIO}

1. INTRODUÇÃ

2. UMA APRESENTAÇÃO DO DIREITO FUNDAMENTAL À "PRIVACIDADE" NO

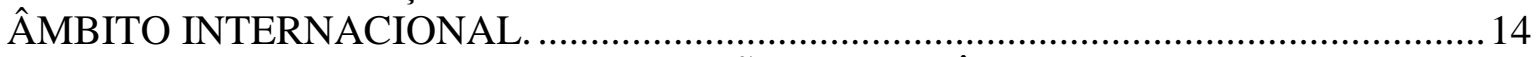

3. A PRIVACIDADE NAS COMUNICAÇÕES ELETRÔNICAS NOS ESTADOS

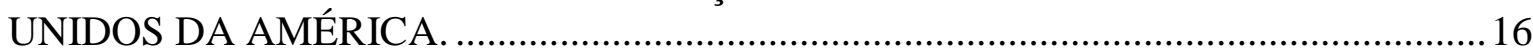

3.1. Uma passagem breve pelo desenvolvimento da "privacidade". .............................. 16

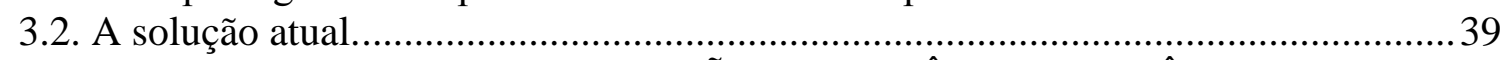

4. A PRIVACIDADE NAS COMUNICAÇÕES ELETRÔNICAS NO ÂMBITO

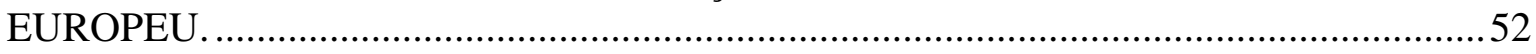

4.1. Uma passagem breve pelo desenvolvimento da "privacidade". .............................52

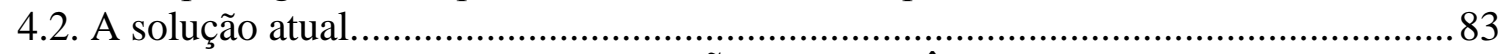

5. A PRIVACIDADE NAS COMUNICAÇÕES ELETRÔNICAS NO BRASIL. ............ 102

5.1. Uma passagem pelo desenvolvimento e construção da "privacidade" no Brasil. .. 102

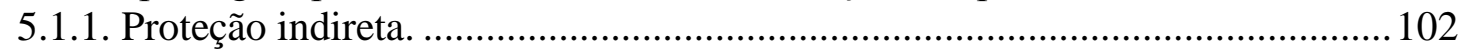

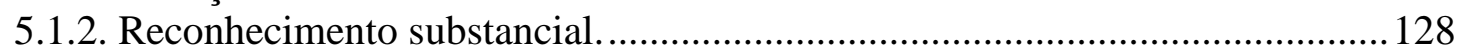

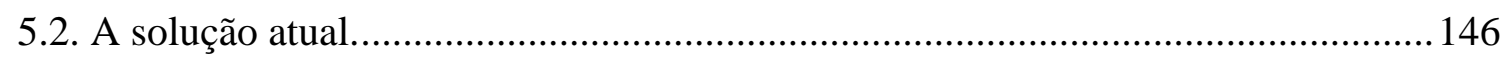

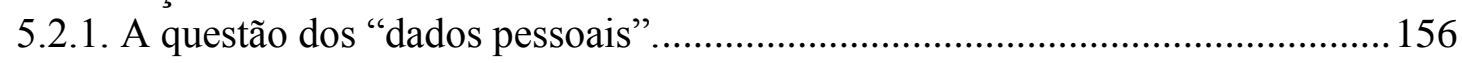

5.2.1.1. O habeas data e outras leis referentes ao acesso a bancos de dados ou

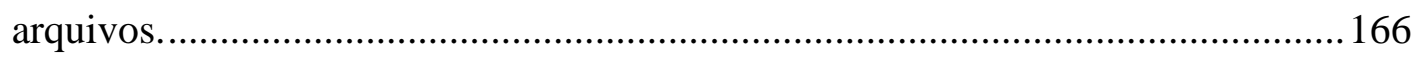

5.2.2. Regulação da Internet no Brasil, com enfoque na segurança nas comunicações

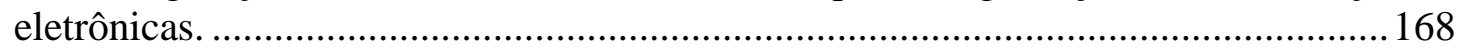

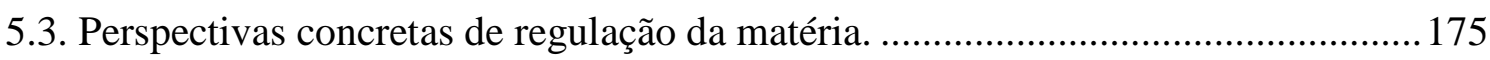

5.3.1. Projetos de Lei em trâmite no Senado Federal. ............................................. 175

5.3.2. Projetos de Lei em trâmite na Câmara dos Deputados.................................... 179

5.3.3. O Anteprojeto da Comissão de Juristas do Ministério da Justiça de 2003 e os

Projetos de Lei 3.272/2008 e 4.036/2008............................................................. 184

5.4. Análise crítica das perspectivas de regulação, levando-se em consideração o sistema vigente no país, nos Estados Unidos da América e no âmbito supranacional europeu. 192

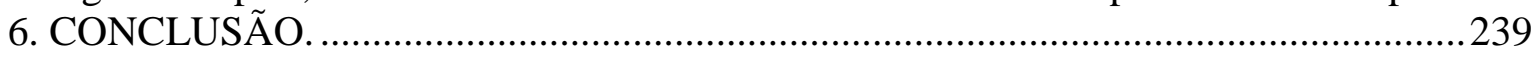

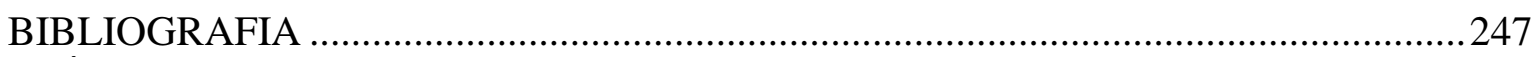

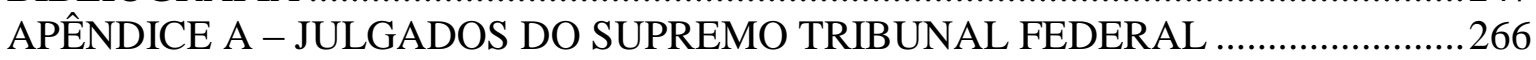

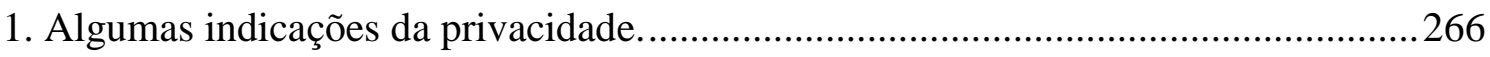

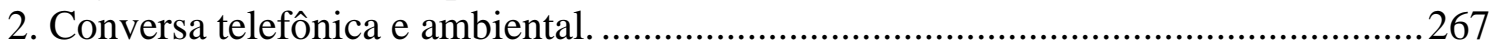

3. Interceptação telefônica, escuta ambiental e prova emprestada. …..........................278

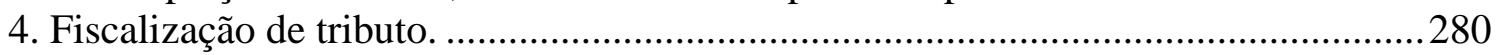

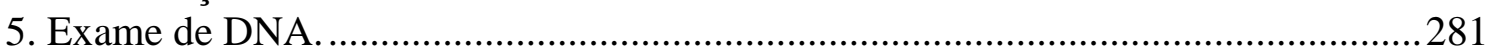

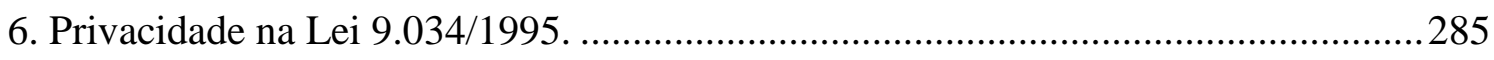

7. Privacidade e o Código Penal Militar. .................................................................... 286

8. Publicidade dos atos processuais, Comissão Parlamentar de Inquérito e privacidade.

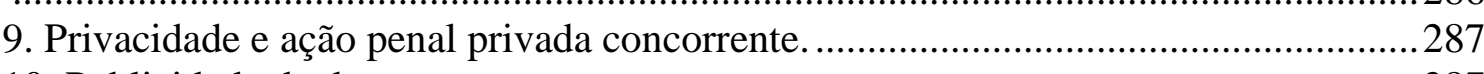

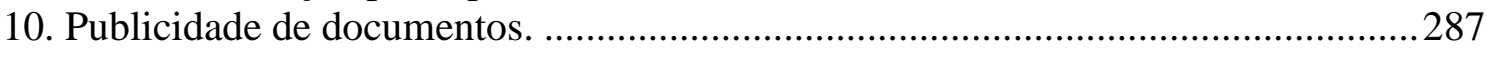

11. Informação jornalística, gravação clandestina e privacidade. ...............................28

12. Sigilo de dados bancários, fiscais, telefônicos e outros.......................................28

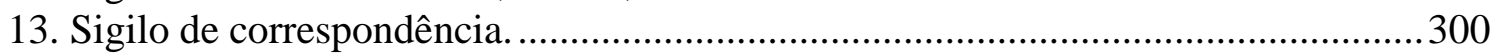

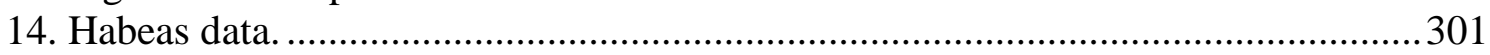

APÊNDICE B - JULGADOS DO SUPERIOR TRIBUNAL DE JUSTIÇA.....................303 


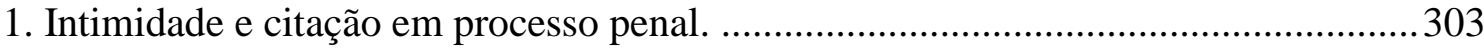

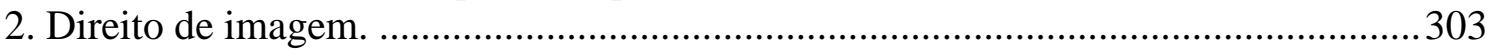

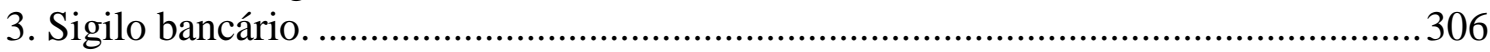

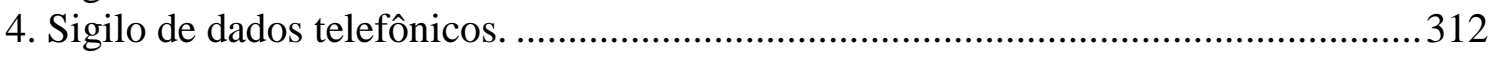

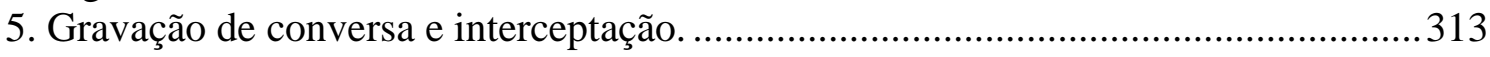

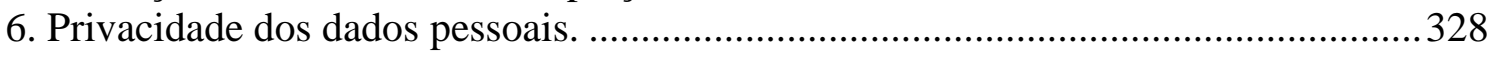

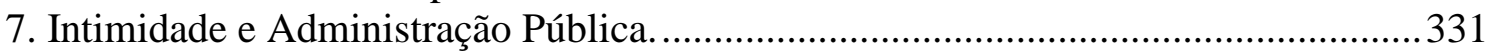

8. Sigilo da análise da conduta pessoal e social do concursando. ....................................331

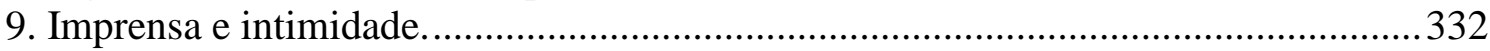

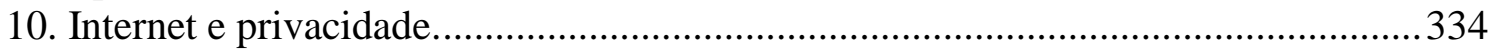

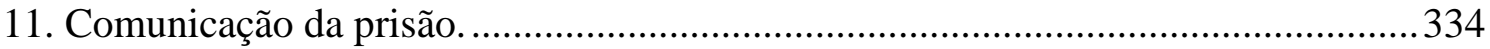

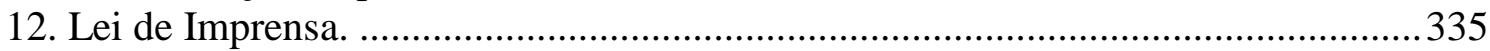

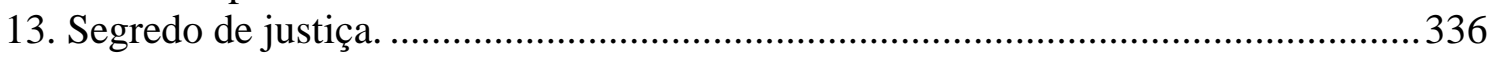

14. Sanção administrativa do ECA: direito de imagem da criança e do adolescente.... 336

15. Instrumento processual para proteger o direito à intimidade......................................337

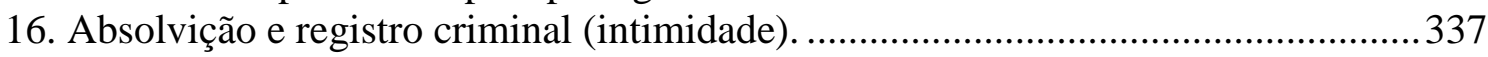

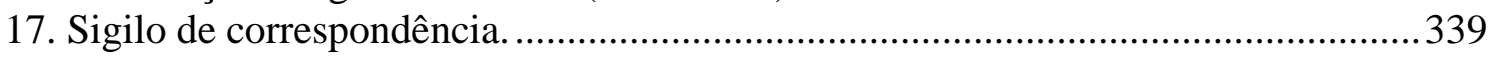

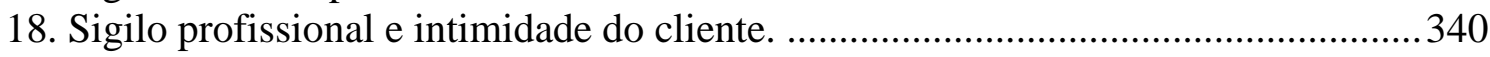

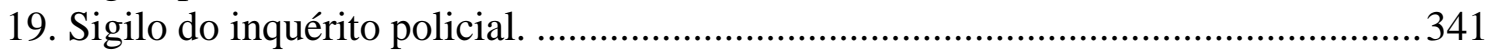

20. Dano moral decorrente de violação de direitos da personalidade em geral...............341

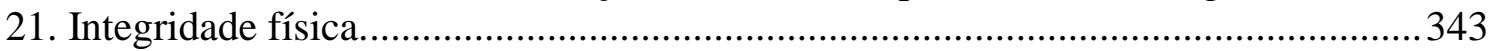

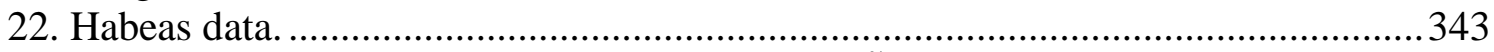

ANEXO A - ANTEPROJETO DE LEI DA COMISSÃO MINISTERIAL ........................348

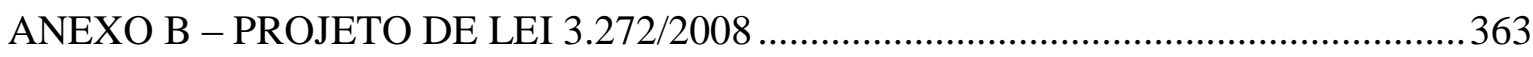

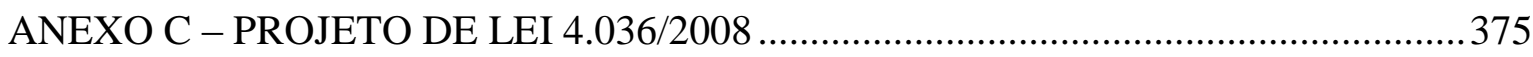




\section{INTRODUÇÃO}

O tema abordado nesta dissertação é a privacidade nas comunicações eletrônicas no Brasil, e sua importância reside no fato de que o desenvolvimento da eletrônica e a conseqüente digitalização e convergência das redes de telecomunicações em nível nacional e global tornaram obsoletos muitos dos conceitos e soluções até então aplicados, tornando imperativo um estudo que leve em consideração essas mudanças e a necessidade de conformação com a proteção dos direitos fundamentais presentes em documentos jurídicos internacionais e, no Brasil, nos incisos X e XII do artigo $5^{\circ}$ da Constituição Federal.

O objetivo é apresentar a situação atual dessa questão no país e fazer uma análise crítica comparativa com sugestões de mudanças.

A metodologia de pesquisa aplicada é a de consulta e análise de fontes jurídicas nacionais, internacionais e de direito estrangeiro, como os tratados, leis e jurisprudência, atinentes à questão da privacidade nas comunicações eletrônicas, a partir da qual se desenvolve uma construção argumentativa, dedutiva e indutiva de crítica construtiva.

O texto é dividido em seis Capítulos, incluindo esta introdução, mais a bibliografia de referência, dois apêndices e três anexos. Essa divisão almeja estabelecer os pressupostos necessários à compreensão do tema no Capítulo 5.4, sem comprometer a fluidez da leitura.

O Capítulo 2 apresenta brevemente a complexidade do tema na seara internacional, a começar pelos diferentes termos e redações empregados nos documentos internacionais e suas diversas traduções.

Como um dos métodos de pesquisa utilizados foi o de direito comparado, apresentamos primeiro o tratamento da matéria nos Estados Unidos da América e na Europa (União Européia e Conselho da Europa), nos Capítulos 3 e 4, para então nos valer de amplas referências ao direito de ambos, incluindo alguns países europeus.

Dentre várias opções, valemo-nos dos Estados Unidos da América porque lá o direito à privacidade ("privacy") e a regulação da interceptação das comunicações desenvolveram-se mais cedo e nos proporcionam vasto material jurídico para estudo.

Por sua vez, a União Européia e o Conselho da Europa foram escolhidos porque produziram, principalmente desde a década de 1970, inúmeros documentos internacionais, incluindo tratados, recomendações, diretivas e estudos, além da rica jurisprudência da Corte Européia de Direitos Humanos, com o objetivo de harmonizar o tratamento da matéria nos respectivos âmbitos. Assim, considerando que muitos dos países europeus têm 
forte influência sobre nosso sistema jurídico, como a Itália e a França, que o tema acaba envolvendo, pela natureza transfronteiriça das comunicações eletrônicas, a articulação entre as nações, como bem demonstra a elaboração da Convenção sobre o Cibercrime, de 2001, que os países mais relevantes para o Brasil seguem a tradição da "civil law", e que ambas as instituições englobam um número significativo de participantes ${ }^{1}$, mostra-se indispensável a apresentação do estado atual da questão na Europa.

Contudo, para explicar a questão da privacidade nas comunicações eletrônicas nos Estados Unidos da América e na Europa e nos valer das referências com maior precisão, preferimos abrir Capítulos separados para ambos, subdivididos cada qual em duas partes: o direito à privacidade e a privacidade nas comunicações eletrônicas hoje. Isso porque o direito à privacidade não apresenta um conceito uniforme e universal, nem mesmo dentro de cada país, o que faz necessário uma apresentação contextual do entendimento das respectivas doutrina e jurisprudência, e não apenas dos textos legais nacionais e transnacionais.

Do mesmo modo, antes de adentrar no objeto da dissertação, dividimos o Capítulo 5 de modo a trazer, nessa ordem, a evolução sintética do direito à privacidade e do sigilo das comunicações no país, apresentar a discussão sobre eles na doutrina e na jurisprudência pátrias, e, por fim, trazer os nossos conceitos.

Assim, adiantamos que entendemos a "privacidade" como uma liberdade qualificada consubstanciada no direito de ampla autodeterminação do indivíduo, com poderes que daí derivam, incluindo o controle sobre os "dados pessoais", isto é, das informações relativas a uma pessoa identificável ou identificada. A privacidade pode ser limitada devido a outros interesses públicos específicos relevantes, como a segurança pública, ou direitos de terceiros. Com as devidas explicações do Capítulo 5.1.2, as expressões "privacidade", "intimidade" e "vida privada" são consideradas sinônimas, e utilizamos, conforme o contexto, "privacidade" para se referir ao próprio direito ou ao seu objeto.

As comunicações de que tratamos são as reservadas, isto é, aquelas travadas entre um número delimitado de interlocutores, cujo conteúdo destina-se exclusivamente a seu conhecimento, e incluem, dentre outros, "e-mails", telefonia por protocolo da Internet ("VoIP") e vídeo. Ficam excluídas, portanto, as comunicações sociais, aquelas destinadas a uma coletividade indefinida, incluindo os "blogs", comunidades virtuais abertas e

\footnotetext{
${ }^{1}$ A União Européia conta com vinte e sete países e o Conselho da Europa, com quarenta e sete países até $1^{\circ}$ de janeiro de 2009.
} 
periódicos eletrônicos.

A adoção do adjetivo "eletrônicas" para "comunicações" não pretende reduzir a questão a uma única forma tecnológica, a eletrônica, mas utilizá-la como paradigma de qualquer tecnologia atual ou vindoura que proporcione um acúmulo grande de informações a baixo custo. No caso, de dados externos (dados de tráfego, como identificação dos interlocutores, horário e duração das comunicações) e internos (conteúdo das comunicações). O adjetivo também é utilizado porque distingue essa realidade da das comunicações "tradicionais" ("analógicas") e porque a expressão é adotada no âmbito normativo dos Estados Unidos da América e da União Européia, o que inclusive facilita o estudo posterior da matéria e a sua compreensão.

Relativamente aos dados externos, enquadramo-nos na categoria jurídica de "dados pessoais", desenvolvendo as repercussões dessa classificação à luz do ordenamento jurídico brasileiro. Nesse ponto, cuidamos também do "habeas data".

Tratamos, no Capítulo 5.2.3, da regulação da Internet no país, com ênfase nas comunicações eletrônicas, para que se conheça o que e quanto existe de regulação a respeito, enquanto, no Capítulo 5.3, trazemos vários Projetos de Lei em trâmite no Senado Federal e na Câmara dos Deputados, a título de perspectivas concretas de mudanças, com destaque ao Anteprojeto da Comissão de Juristas do Ministério da Justiça de 2003 e aos Projetos de Lei 3.272/2008 e 4.036/2008, ambos de iniciativa do Poder Executivo.

Então, finalmente, no Capítulo 5.4, apresentamos a análise crítica construtiva da privacidade nas comunicações eletrônicas no Brasil, em comparação com a situação nos Estados Unidos da América e na Europa, levando em consideração a legislação atual, a doutrina e a jurisprudência do Supremo Tribunal Federal (“STF”) e do Superior Tribunal de Justiça ("STJ"), e as perspectivas concretas de mudanças representadas pelos Projetos de Lei ativos no Congresso Nacional, com destaque aos citados Projetos de Lei 3.272/2008 e 4.036/2008. Aí expomos o nosso entendimento e propomos mudanças.

No Capítulo 6, são resumidos os principais pressupostos, críticas e propostas trazidos na dissertação. A referência bibliográfica vem em seguida.

Para facilitar o entendimento e apresentar mais detalhes das principais decisões do STF e do STJ, foram elas reunidas, respectivamente, nos Apêndices A e B, subdivididos, na medida do possível, em seções temáticas.

Por último, vêm os Anexos A, B e C, que trazem os textos do aludido Anteprojeto da Comissão de Juristas do Ministério da Justiça e dos Projetos de Lei 3.272/2008 e $4.036 / 2008$, para facilitar a consulta. 
Na redação da dissertação, foi utilizado o português brasileiro anterior ao Acordo Ortográfico da Língua Portuguesa, assinado em Lisboa, em 16 de dezembro de 1990, aprovado pelo Decreto Legislativo 54, de 18 de abril de 1995, do Congresso Nacional, e promulgado pelo Decreto 6.583, de 29 de setembro de 2008, por estarmos no período de transição, conforme autorizado pelo parágrafo único do artigo $2^{\circ}$ deste último, que permite a coexistência das normas ortográficas de $1^{\circ}$ de janeiro de 2009 até 31 de dezembro de 2012. As citações diretas do português lusitano foram mantidas na sua forma original.

Os responsáveis pelas traduções dos textos em outras línguas foram devidamente creditados nas hipóteses em que não existe tradução oficial para o português, e a dissertação foi elaborada observando-se, no que cabível, a Resolução FD/PÓS 01, de 10 de setembro de 2002, e Funaro (2004). 


\section{UMA APRESENTAÇÃO DO DIREITO FUNDAMENTAL À "PRIVACIDADE" NO ÂMBITO INTERNACIONAL.}

A Declaração Universal dos Direitos Humanos, adotada pela Assembléia Geral da Organização das Nações Unidas em 10 de dezembro de $1948^{2}$, assegura, em seu artigo 12 , na versão original em inglês:

[n]o one shall be subjected to arbitrary interference with his privacy, family, home or correspondence, nor to attacks upon his honour and reputation. Everyone has the right to the protection of the law against such interference or attacks $^{3}$. (destaque nosso).

O texto oficial em francês refere-se a "vie privée", no lugar de "privacy", o que foi traduzido para "vida privada", ao invés de "privacidade" (ou até "intimidade"), no português. A disparidade de expressões empregadas no texto oficial publicado da Resolução da Assembléia Geral já demonstra a árdua tarefa de estudar o tema, a começar pela própria nomenclatura do direito.

É sabido que em muitos outros textos, inclusive diplomas normativos supranacionais, foi empregada, em inglês, a expressão "private life". Por outro lado, em francês existe a palavra "intimité", que corresponde a um dos vários sentidos de "intimacy", em inglês. E todas elas apresentam cognatos na língua portuguesa, quais sejam, vida privada, intimidade e privacidade.

O Pacto Internacional sobre Direitos Civis e Políticos, adotado pela XXI Sessão da Assembléia Geral da Organização das Nações Unidas, em 16 de dezembro de 1966, e promulgado, no Brasil, pelo Decreto 592, de 6 de julho de 1992, protege o mesmo direito em seu artigo, de redação muito parecida com o do artigo 12 da Declaração Universal, acrescentando, contudo, menção a interferências ilegais:

\section{ARTIGO 17 \\ 1. Ninguém poderá ser objetivo de ingerências arbitrárias ou ilegais em sua vida privada, em sua família, em seu domicílio ou em sua correspondência, nem de ofensas ilegais às suas honra e reputação. \\ 2. Toda pessoa terá direito à proteção da lei contra essas ingerências ou ofensas.}

A sua versão oficial remete a "privacy", em inglês, "vie privée", em francês, e

\footnotetext{
${ }^{2}$ Através da Resolução "217 A (III)".

${ }^{3}$ Em português: "ninguém será submetido a interferências arbitrárias em sua privacidade, família, casa ou correspondência, nem a ataques contra sua honra e reputação. Todos têm o direito à proteção da lei contra tais interferências ou ataques" (tradução nossa).
} 
"vida privada", em espanhol.

A Declaração Americana dos Direitos e Deveres do Homem, aprovada na Nona Conferência Internacional Americana, em 1948, em Bogotá, determina a "proteção da lei contra os ataques abusivos à sua honra, à sua reputação e à sua vida particular e familiar", bem como afirma o direito à inviolabilidade do domicílio e da correspondência e sua circulação ${ }^{5}$. Note-se que, dessa vez, a versão em inglês refere-se a "private and family life"

O artigo 11 da Convenção Americana sobre Direitos Humanos (Pacto de São José da Costa Rica), adotada no âmbito da Organização dos Estados Americanos em 22 de novembro de 1969, que entrou em vigor internacionalmente em 1978 e só foi promulgada no Brasil pelo Decreto 678, de 6 de novembro de 1992, praticamente repete essa proteção, apenas referindo-se, dessa vez, à proibição de interferências arbitrárias ou "abusivas", em vez de "ilegais",

O desenvolvimento do tema passa, então, pela análise e definição do direito à privacidade e por uma explicação e separação de várias expressões utilizadas no Brasil e no exterior.

\footnotetext{
${ }^{4}$ Artigo V.

${ }^{5}$ Artigos IX e X.

${ }^{6}$ Artigo V.

${ }^{7}$ É um tratado que pode ser feito valer por meio da Comissão Interamericana de Direitos Humanos ou por meio da Corte Interamericana de Direitos Humanos, a cuja jurisdição, aliás, o Brasil se submete, sob reserva de reciprocidade e a tempo indeterminado, a partir de 10 de dezembro de 1998, para fatos posteriores a essa data, conforme Decreto 4.463, de 8 de novembro de 2002. Somente os Estados e a Comissão Interamericana têm acesso à Corte, na interpretação e aplicação da Convenção e de outros tratados aplicáveis à América, no modo estabelecido no Pacto de São José.
} 


\title{
3. A PRIVACIDADE NAS COMUNICAÇÕES ELETRÔNICAS NOS ESTADOS UNIDOS DA AMÉRICA.
}

\subsection{Uma passagem breve pelo desenvolvimento da "privacidade".}

O tratamento jurídico da privacidade, enquanto um direito específico, começou nos Estados Unidos da América, no século XIX, como se vê mais adiante, embora proteção legal do que hoje costumam ser consideradas suas projeções ou proteções formais tenha aparecido antes, mais exatamente na Quarta Emenda à Constituição.

Originalmente, ela não trazia uma declaração de direitos, ou "bill of rights", o que serviu como forte argumento, por vários estados, contra a sua ratificação ${ }^{8}$. Alguns haviam escrito suas próprias declarações, como a considerada pioneira Declaração de Direitos da Virgínia, adotada unanimemente por sua Convenção Constitucional em 12 de junho de 1776 (NARA, 2007b).

Mesmo assim, a Constituição acabou sendo aprovada em 15 de setembro de 1787 e entrou em vigor, oficialmente, quando o Congresso da Confederação, reunido em New York, recebeu a notícia, em 2 de julho de 1788, de que New Hampshire a havia ratificado (NARA, 2007a).

Em 2 de outubro de 1789, o Presidente George Washington enviou aos estados uma cópia das doze Emendas aprovadas pelo Congresso em setembro. Duas não foram ratificadas, e a Declaração de Direitos ("Bill of Rights"), como ficaram conhecidas as dez primeiras Emendas, entrou em vigor em 15 de dezembro de 1791.

Dentre essas, destacam-se a Quarta e a Nona Emendas:

\begin{abstract}
O direito do povo à inviolabilidade de suas pessoas, casas, papéis e haveres contra busca e apreensão arbitrárias não poderá ser infringido; e nenhum mandado será expedido a não ser mediante indícios de culpabilidade confirmados por juramento ou declaração, e particularmente com a descrição do local da busca e a indicação das pessoas ou coisas a serem apreendidas ${ }^{9}$.
\end{abstract}

A enumeração de certos direitos na Constituição não poderá ser interpretada

\footnotetext{
${ }^{8}$ Ver, dentre outros, Stephens Jr. e Scheb II (2008).

9 Tradução da Embaixada dos Estados Unidos no Brasil, disponível em: <http://www.embaixadaamericana.org.br/index.php?action=materia\&id=643\&submenu=106\&itemmenu=110>. Acesso em: $2 \mathrm{dez}$. 2008. No original: " $[\mathrm{t}]$ he right of the people to be secure in their persons, houses, papers, and effects, against unreasonable searches and seizures, shall not be violated, and no Warrants shall issue, but upon probable cause, supported by Oath or affirmation, and particularly describing the place to be searched, and the persons or things to be seized". A inviolabilidade da casa, dentre outros, contra buscas e apreensões não razoáveis, que só podiam ser feitas mediante ordem judicial baseada em causa provável, encontrou similares em textos legais de outros países e na evolução jurisprudencial da Suprema Corte dos Estados Unidos da América.
} 
como negando ou coibindo outros direitos inerentes ao povo ${ }^{10}$.

A Nona Emenda teve como uma de suas principais finalidades evitar interpretações no sentido de as oito primeiras serem uma lista exaustiva e de, a "contrario sensu", levar à conclusão de que aquilo não expressamente proibido é permitido ${ }^{11}$. Funciona, desse modo, como uma salvaguarda da Bill of Rights e, ao mesmo tempo, como "cláusula de abertura" a novos direitos, além de explicitar a reserva de poderes às pessoas e, no atinente ao sistema norte-americano, aos estados federados de tudo aquilo não expressamente atribuído ao governo federal.

A Décima Quarta Emenda, aprovada pelo Congresso em 13 de junho de 1866, e ratificada, entrando em vigor, em 9 de julho de 1868, viria a colaborar, mais tarde, com o desenvolvimento do direito à "privacy", ao tornar expressamente aplicáveis certos direitos garantidos na Constituição Federal aos estados da federação na segunda parte de sua Seção 1, especialmente na porção final:

[...] Nenhum Estado elaborará ou fará valer qualquer lei que reduza os privilégios ou imunidades dos cidadãos dos Estados Unidos; nem qualquer Estado privará qualquer pessoa da vida, da liberdade ou da propriedade sem o devido processo legal; nem negará a qualquer pessoa dentro de sua jurisdição a igual proteção da lei. (tradução nossa) ${ }^{12}$.

10 Tradução da Embaixada dos Estados Unidos no Brasil, disponível em: <http://www.embaixadaamericana.org.br/index.php?action=materia\&id=643\&submenu=106\&itemmenu=110>). Acesso em: $2 \mathrm{dez}$. 2008. No original: "[t]he enumeration in the Constitution, of certain rights, shall not be construed to deny or disparage others retained by the people".

11 "Esta Corte, em uma série de decisões, tem mantido que a Décima Quarta Emenda absorve e aplica aos Estados as determinações das primeiras oito emendas que expressam direitos pessoais fundamentais. A linguagem e história da Nona Emenda revelam que os Pais da Constituição acreditavam que há direitos fundamentais adicionais, protegidos de infringências governamentais, que existem ao lado daqueles direitos fundamentais especificamente mencionados nas oito primeiras emendas constitucionais. A Nona Emenda diz: 'A enumeração de certos direitos na Constituição não poderá ser interpretada como negando ou coibindo outros direitos inerentes ao povo'. A Emenda é quase inteiramente o trabalho de James Madison. Ela foi introduzida no Congresso por ele e passou pela Câmara e pelo Senado com pouco ou nenhum debate e virtualmente nenhuma mudança na redação. Foi proferida para aquietar medos expressados de que uma carta de direitos especificamente enumerados podia não ser suficientemente ampla para cobrir todos os direitos essenciais e que a específica menção a certos direitos pudesse ser interpretada como uma negativa de que outros eram protegidos" (Griswold v. Connecticut, 381 U.S. 479, 488-9, excerto do voto do Justice Goldberg, tradução nossa). No original: "This Court, in a series of decisions, has held that the Fourteenth Amendment absorbs and applies to the States those specifics of the first eight amendments which express fundamental personal rights. The language and history of the Ninth Amendment reveal that the Framers of the Constitution believed that there are additional fundamental rights, protected from governmental infringement, which exist alongside those fundamental rights specifically mentioned in the first eight constitutional amendments. The Ninth Amendment reads, 'The enumeration in the Constitution, of certain rights, shall not be construed to deny or disparage others retained by the people'. The Amendment is almost entirely the work of James Madison. It was introduced in Congress by him and passed the House and Senate with little or no debate and virtually no change in language. It was proffered to quiet expressed fears that a bill of specifically enumerated rights could not be sufficiently broad to cover all essential rights and that the specific mention of certain rights would be interpreted as a denial that others were protected". Ver a respeito, também, Stephens Jr. e Scheb II (2008).

${ }^{12}$ No original: "No State shall make or enforce any law which shall abridge the privileges or immunities of 
A "privacy", porém, não consta expressamente dessas Emendas, e nem das posteriores.

Então, em 1890, Warren e Brandeis escreveram um artigo jurídico que se tornou internacionalmente famoso por tentar fundamentar a criação ou o reconhecimento de um direito à privacidade, cujo título é "The right to privacy", publicada na Harvard Law Review ${ }^{13}$.

Nesse ensaio, mostrando preocupação com a difusão de retratos privados e da invasão da vida íntima das pessoas pelos jornais, aprofundada pela evolução tecnológica das máquinas fotográficas e alimentada pela demanda sobre detalhes acerca da vida alheia, os autores afirmam que a "common law" assegura a cada indivíduo o direito de determinar, ordinariamente, em que extensão seus pensamentos, sentimentos e emoções devem ser comunicados a outros, e que a existência desse direito independe do meio de expressão adotado (palavras, sinais, escultura, pintura, dentre outros), e com ele não se confunde.

Traçando um histórico da jurisprudência no Reino Unido, refutam a teoria contratualista acerca da privacidade, pela qual o dever de respeito por parte de outros surgiria de um contrato implícito em que haveria uma cláusula de dever de sigilo, baseada, por vezes, numa relação de confiança, pois deixava de lado a questão de invasão por terceiros com os quais não se travasse qualquer relação jurídica.

Ao final, consideram a privacidade um direito geral do qual emanam outros, sendo ele próprio parte do direito mais amplo à "imunidade" do indivíduo, à sua personalidade ("right to the immunity of the person", "the right to one's personality").

No ano seguinte, a Suprema Corte dos Estados Unidos referiu-se ao "right to be let alone" em Union Pac. Ry. Co. v. Botsford ${ }^{14}$, quando confirmou sentença do juiz de instância inferior que indeferira o pedido do réu de realizar na requerente uma cirurgia para analisar a extensão dos danos que lhe havia causado, nas palavras do Justice Gray:

citizens of the United States; nor shall any State deprive any person of life, liberty, or property, without due process of law; nor deny to any person within its jurisdiction the equal protection of the laws". Ver Stephens Jre Scheb II (2008).

${ }^{13}$ Os autores citam o Judge Cooley em relação ao direito de ser deixado em paz ("to be let alone"), mas há discussão na doutrina norte-americana quanto ao fato de a citação ter sido colocada fora de contexto. Ver, por exemplo, de passagem, Beard (1978). Como bem explica Solove (2002, p. 1087): "O direito de estar só de Cooley era, de fato, uma maneira de explicar que a tentativa de toque físico era um 'tort' de dano; ele não estava tentando definir um direito à privacidade. $\mathrm{O}$ uso da frase por Warren e Brandeis foi consistente com o propósito do seu artigo: demonstrar que muitos dos elementos de um direito à privacidade existiam dentro da "common law". No original: "Cooley's right to be let alone was, in fact, a way of explaining that attempted physical touching was a tort injury; he was not defining a right to privacy. Warren and Brandeis's use of the phrase was consistent with the purpose of their article: to demonstrate that many of the elements of a right to privacy existed within the common law".

${ }^{14} 141$ U.S. 250 (1891). 
Nenhum direito é considerado mais sagrado ou mais cuidadosamente guardado pela "common law" do que o direito de todo indivíduo à posse e controle de sua própria pessoa, livre de qualquer restrição ou interferência de outros senão por clara e inquestionável autoridade da lei. Como bem dito pelo juiz Cooley: "O direito à própria pessoa pode ser entendido como um direito de completa imunidade; de ser deixado só" $"$.

Segundo Gormley (1992, p. 1353-1355), nos anos que se seguiram ao artigo de Warren e Brandeis, apareceram em alguns estados leis buscando proteger a "privacy", geralmente direcionadas a abusos cometidos por jornais e anunciantes que publicavam os nomes ou fotografias de indivíduos, sem seu consentimento, para fins comerciais. Algumas delas leis duraram.

Em 1928, a Suprema Corte entendeu que o "grampeamento" não violava a Quarta Emenda porque não importava uma invasão física da casa. O caso era Olmstead v. United States ${ }^{16}$.

Olmstead e outros eram parte de uma organização que tinha por objetivo importar, manter e vender bebidas alcoólicas ilegalmente, violando o National Prohibition Act. As evidências contra eles foram, em sua maior parte, obtidas por "grampos" telefônicos instalados por oficiais federais, responsáveis pelo cumprimento desse Act, no porão do prédio em que ficava o escritório central da organização e nas linhas que saíam dos postes nas ruas e iam até as casas dos envolvidos. Tudo isso sem invasão da propriedade ("without trespass upon any property") de quaisquer dos réus ${ }^{17}$.

A Corte entendeu que, no caso, não se aplicava a Quinta Emenda, que, dentre outros, protege os acusados da auto-incriminação e, segundo a sua própria jurisprudência, contra provas obtidas ilegalmente, com violação da Quarta Emenda, pois

[...] Não houve evidência de coerção para induzir os réus a conversar por seus muitos telefones. Eles estavam contínua e voluntariamente fazendo negócios sem o conhecimento da interceptação. [.... $]^{18}$.

Discorreu sobre precedentes quanto à inadmissibilidade de provas obtidas ilicitamente, em violação à Quarta Emenda, apesar de vozes discordantes a essa tese que

15141 U.S. 250, 251 (tradução nossa). No original: "No right is held more sacred or is more carefully guarded by the common law than the right of every individual to the possession and control of his own person, free from all restraint or interference of others unless by clear and unquestionable authority of law. As well said by Judge Cooley: 'The right to one's person may be said to be a right of complete immunity; to be let alone"”. O caso tratava da inviolabilidade da própria pessoa (141 U.S. 250, 252).

16277 U.S. 438 (1928). Ver mais em Fisher e Adler (2007).

17277 U.S. $438,457$.

18277 U.S. 438, 462 (tradução nossa). No original: "There was no evidence of compulsion to induce the defendants to talk over their many telephones. They were continually and voluntarily transacting business without knowledge of the interception. [...]". 
entendiam que, se essas objeções fossem pertinentes, o máximo que caberia ao acusado ou réu seria uma ação por danos ${ }^{19}$.

A Quarta Emenda só protegeria bens materiais, como as cartas seladas, e não comunicações telefônicas ou telegráficas, em que não há busca e apreensão, mas só "escuta" ou "visão" 20 , e a sua aplicação, segundo a Corte, não podia ser estendida para incluir linhas telefônicas, abarcando todo o mundo fora da casa ou escritório do réu, pois elas não são parte de sua casa ou escritório mais do que as estradas ao redor $^{21}$, ressalvando que o Congresso poderia fazer uma lei protegendo o segredo dessas comunicações ${ }^{22}$.

Mas a votação não foi unânime. O Justice Holmes entendeu que o governo não pode incentivar e pagar seus oficiais para obter provas criminosamente, em violação à Quarta Emenda, e que toda evidência assim obtida deve ser excluída ${ }^{23}$.

O Justice Brandeis, o mesmo que escrevera o artigo sobre o "right of privacy", dissentiu da maioria, afirmando que a Constituição deve adaptar-se aos tempos, não ficando confinada à época em que surgiu, aos males que fizeram surgir a proteção nela assegurada $^{24}$. Ele criticou a interpretação excessivamente literal da Quarta Emenda feita pela Suprema Corte citando vários precedentes, mas ressaltou que não havia, ao contrário do entendido pelos demais, diferença substancial entre uma carta selada e uma comunicação telefônica $^{25}$, e escreveu:

[...] Os elaboradores de nossa Constituição ocuparam-se de assegurar condições favoráveis à procura da felicidade. Eles reconheceram a significância da natureza espiritual do homem, de seus sentimentos e de seu intelecto. Eles sabiam que apenas uma parte da dor, prazer e satisfações da vida deve ser encontrada em coisas materiais. Eles procuraram proteger os americanos em suas crenças, seus pensamentos, suas emoções e suas sensações. Eles conferiram, contra o governo, o direito de ser deixado só - o mais abrangente dos direitos e o direito mais valorizado pelos homens civilizados. Para protegê-lo, cada intrusão injustificada pelo governo na privacidade do indivíduo, quaisquer que sejam os meios empregados, deve ser considerada uma violação da Quarta Emenda. E o uso como evidência num processo criminal de fatos conhecidos por tal intrusão deve ser considerado uma violação da Quinta ${ }^{26}$.

19277 U.S. 438, 462-3.

20277 U.S. 438,464 e 465.

21277 U.S. $438,465$.

22277 U.S. $438,465-6$.

${ }^{23} 277$ U.S. $438,470-1$.

24277 U.S. $438,472-3$.

25 “[...] O correio é um serviço público fornecido pelo governo. O telefone é um serviço público fornecido por sua autoridade. Não há, em essência, diferença entre a carta selada e a mensagem telefônica privada. [...]" (277 U.S. 438, 475, tradução nossa). No original: "The mail is a public service furnished by the government. The telephone is a public service furnished by its authority. There is, in essence, no difference between the sealed letter and the private telephone message. [...]”.

${ }^{26} 277$ U.S. 438, 478-9 (tradução nossa). No original: "The makers of our Constitution undertook to secure conditions favorable to the pursuit of happiness. They recognized the significance of man's spiritual nature, of his feelings and of his intellect. They knew that only a part of the pain, pleasure and satisfactions of life 
Veio, seis anos depois, o - "ambíguo”, segundo Gormley (1992, p. 1363) - Federal Communications Act de 1934, que tinha por escopo, ou intenção, regular a interceptação de comunicações por fio ("wiretapping").

A Suprema Corte, em Nardone v. United States ${ }^{27}$, entendeu que essa lei proibia a interceptação de comunicações telefônicas sem autorização do "remetente" ("sender") da mensagem, e a divulgação de seu conteúdo por qualquer pessoa ${ }^{28}$, o que não impediu, porém, que o governo continuasse a "grampear" linhas telefônicas e fazer uso de outros instrumentos de vigilância e espionagem eletrônica nas décadas de 1950 e 1960 (GORMLEY, 1992, p. 1363).

O direito à "privacy", em 1939, encontrou referência, no âmbito federal da responsabilidade civil, no First Restatement of Torts, de 1939, baseado no "tort" 29 criado por Warren e Brandeis (GORMLEY, 1992, p. 1355).

O entendimento de Olmstead teve continuidade em Goldman v. United States ${ }^{30}$, em que policiais instalaram-se em um escritório adjacente ao dos suspeitos e utilizaram-se de um aparelho ("detectaphone") que lhes permitia escutar conversas mantidas ali "através" da parede. Aí, como em Olmstead, a maioria entendeu que não houve "busca" e

are to be found in material things. They sought to protect Americans in their beliefs, their thoughts, their emotions and their sensations. They conferred, as against the government, the right to be let alone-the most comprehensive of rights and the right most valued by civilized men. To protect, that right, every unjustifiable intrusion by the government upon the privacy of the individual, whatever the means employed, must be deemed a violation of the Fourth Amendment. And the use, as evidence in a criminal proceeding, of facts ascertained by such intrusion must be deemed a violation of the Fifth".

27302 U.S. 379 (1937).

28302 U.S. $379,382$.

29 "Tort" pode ser entendido, em síntese, como um ato que gera uma responsabilidade civil extracontratual. “Um 'tort' é uma causa de ação legal especificamente estabelecida numa lei (em oposição à Constituição), ou que faz parte do que se conhece como a 'common law' geral - i.e., lei que as cortes reconhecem com base na história legal e outros casos. Por exemplo, alguns 'torts' bem conhecidos são 'negligência', 'invasão' e 'difamação'. Direito de 'tort', ao contrário do direito constitucional federal, pode variar de estado para estado. Só há uma Constituição federal, e quando a Suprema Corte dos Estados Unidos interpreta a Constituição, sua decisão torna-se a lei da terra para o país inteiro. Em contraste, no direito de 'tort', cada legislatura é livre para elaborar leis reconhecendo certos 'torts' e rejeitando outros. Da mesma forma, cada sistema judiciário estadual interpreta suas próprias leis e jurisprudência de acordo com precedente naquele estado particular. Como resultado, o mesmo caso pode ensejar uma causa válida de ação por invasão de privacidade em um estado, mas não ser admitido pelo tribunal no estado ao lado" (ALDERMAN; KENNEDY, 1997, p. 155, tradução nossa). No original: "A tort is a legal cause of action that is specifically set out in a statute (as opposed to the Constitution), or is part of what is known as the general 'common law' - i.e., law that courts recognize based on legal history and other cases. For example, some well-known torts are 'negligence', 'trespass' and 'defamation'. Tort law, unlike federal constitutional law, can vary from state to state. There is only one federal Constitution, and when the United States Supreme Court interprets the Constitution, its ruling becomes the law of the land for the entire country. In contrast, in tort law each state legislature is free to draft statutes recognizing certain torts while rejecting others. Likewise, each state court system interprets its own statutes and case law according to precedent in that particular state. As a result, the same case may provide a valid cause of action for invasion of privacy in one state but be thrown out of court in the state next door".

30316 U.S. 129 (1942). 
“apreensão", isto é, invasão de propriedade ("trespass")

Em Griswold v. Connecticut ${ }^{32}$, a Corte julgou inconstitucional alguns dispositivos de lei do estado de Connecticut que proibiam e criminalizavam o uso de qualquer método contraceptivo, bem como responsabilizava qualquer um que contribuísse de qualquer maneira para esse uso ${ }^{33}$.

O Justice Douglas, relator da opinião da Corte, após citar, exemplificativamente, inúmeros precedentes quanto a projeções e garantias relacionadas à Primeira Emenda ${ }^{34}$, escreveu que garantias específicas da Bill of Rights têm "penumbras", formadas por emanações dessas garantias que as ajudam a dar vida e substância, reconhecendo o que denomina "zonas de "privacy":

[...] Várias garantias criam zonas de privacidade. O direito de associação contido na penumbra da Primeira Emenda é um, como vimos. A Terceira Emenda, em sua proibição ao aquartelamento de soldados "em qualquer casa" em tempo de paz sem o consentimento do proprietário, é outra faceta daquela privacidade. A Quarta Emenda explicitamente afirma o "direito do povo à inviolabilidade de suas pessoas, casas, papéis e haveres contra busca e apreensão arbitrárias”. A Quinta Emenda em sua cláusula de auto-incriminação permite que o cidadão crie uma zona de privacidade de que o governo não pode forçá-lo a abrir mão em seu detrimento. A Nona Emenda dispõe: "A enumeração de certos direitos na Constituição não poderá ser interpretada como negando ou coibindo outros direitos inerentes ao povo" ${ }^{35}$.

O Justice Goldberg, acompanhado pelo Justice Brennan, citando James Madison e o Justice Story, votou pelo provimento do recurso, argumentando que

[...] considerar que um direito tão básico e fundamental e tão enraizado em nossa sociedade como o direito à privacidade no casamento pode ser infringido porque tal direito não está garantido com todas as palavras pelas primeiras oito emendas à Constituição é ignorar a Nona Emenda e conferir-lhe nenhum efeito. Além disso, uma construção judicial de que esse direito fundamental não é protegido pela Constituição porque não é mencionado em termos explícitos por uma das oito primeiras emendas ou em qualquer outro lugar da Constituição violaria a

\footnotetext{
${ }^{31}$ Segundo Fisher e Adler (2007, p. 735), mencionando Goldstein v. United States, 316 U.S. 114 (1942), o Federal Communications Act de 1934 não impedia que o governo usasse "grampos" para "induzir" pessoas cujas conversas haviam sido captadas a entregar para o Estado evidências e testemunhar para o governo.

32381 U.S. 479 (1965).

33381 U.S. 479,480 e 485.

${ }^{34} 381$ U.S. 479, 482-3.

35381 U.S. 479, 484 (tradução nossa). No original: "Various guarantees create zones of privacy. The right of association contained in the penumbra of the First Amendment is one, as we have seen. The Third Amendment in its prohibition against the quartering of soldiers 'in any house' in time of peace without the consent of the owner is another facet of that privacy. The Fourth Amendment explicitly affirms the 'right of the people to be secure in their persons, houses, papers, and effects, against unreasonable searches and seizures'. The Fifth Amendment in its Self-Incrimination Clause enables the citizen to create a zone of privacy which government may not force him to surrender to his detriment. The Ninth Amendment provides: 'The enumeration in the Constitution, of certain rights, shall not be construed to deny or disparage others retained by the people"".
} 


\section{Nona Emenda $[\ldots]^{36}$.}

Afirmou, também, que o "right of privacy" é um direito pessoal fundamental que emana da totalidade do esquema constitucional em que vivem ${ }^{37}$.

A decisão não foi unânime. O Justice Harlan concordou com o dispositivo, mas não com a argumentação. Para ele, a lei era inconstitucional porque não trazia limites razoáveis à liberdade individual e familiar para atingir os objetivos do legislador, que, aliás, sequer eram muito definidos ou justificados ${ }^{38}$.

O Justice Black, acompanhado pelo Justice Stewart, entendeu que a Constituição não protegia mais do que dizia, que o "right of privacy" não existia enquanto direito geral, e que a Suprema Corte não podia considerar leis inconstitucionais por considerá-las caprichosas, desarrazoadas, ou irracionais ${ }^{39}$.

O Justice Stewart, por sua vez, limitou-se a declarar que não encontrara em nenhuma disposição da Constituição e em nenhum outro caso decidido pela Corte o "right of privacy, ${ }^{40}$.

O prenúncio da decisão da Suprema Corte considerada pela doutrina como “constitucionalizadora" do "right of privacy” só veio em Berger v. New York ${ }^{41}$.

Um indivíduo fora acusado de tentativa de suborno de uma autoridade do estado de New York com base, fundamentalmente, em extensa transcrição de conversas gravadas por meio de um aparelho eletrônico instalado secretamente em seu escritório por autoridades policiais, com autorização judicial amparada em lei estadual. A Corte, por maioria apertada, entendeu que a Quarta Emenda protege também conversas, e que a sua captação por meios eletrônicos consiste em busca ("search") para efeitos de sua aplicação.

Em Katz v. United States ${ }^{42}$, a Corte finalmente reverteu, ao menos formalmente, Olmstead v. United States, de 1928, e Goldman v. United States, de 1942.

$\mathrm{O}$ caso tratava de um indivíduo que usava uma cabine telefônica para passar informações de apostas a outros estados, em violação a uma lei federal. Agentes do Federal

\footnotetext{
${ }^{36} 381$ U.S. 479, 491-2 (tradução nossa). No original: “[...] [t]o hold that a right so basic and fundamental and so deep-rooted in our society as the right of privacy in marriage may be infringed because that right is not guaranteed in so many words by the first eight amendments to the Constitution is to ignore the Ninth Amendment and to give it no effect whatsoever. Moreover, a judicial construction that this fundamental right is not protected by the Constitution because it is not mentioned in explicit terms by one of the first eight amendments or elsewhere in the Constitution would violate the Ninth Amendment [...]".

${ }^{37} 381$ U.S. $479,494$.

${ }^{38} 381$ U.S. $479,504-507$.

39381 U.S. $479,507-527$.

${ }^{40} 381$ U.S. $479,527-531$.

${ }^{41} 388$ U.S. 41 (1967).

${ }^{42} 389$ U.S. 347 (1967).
} 
Bureau of Investigation ("FBI") haviam instalado um microfone em cima da cabine e gravaram a ponta da conversa do suspeito, baseando a ação judicial nas provas assim colhidas. A Corte, por maioria, entendeu que a doutrina da "invasão" ("trespass") estava superada, e, revertendo as decisões das instâncias inferiores, decidiu que a escuta ("eavesdropping") feita pelo governo violara a privacidade na qual se fiara o acusado enquanto usava a cabine telefônica e, portanto, constituía uma busca e apreensão para efeitos da Quarta Emenda: “[...] Porque a Quarta Emenda protege pessoas em vez de lugares, seu alcance não pode depender da presença ou ausência de uma intrusão física em algum recinto fechado $[\ldots]^{\natural, 43}$.

O Justice Stewart, relator da opinião da Corte, anotou que o que uma pessoa conscientemente expõe ao público, ainda que em sua casa ou escritório, não encontra guarida na Quarta Emenda, enquanto que aquilo que busca preservar como privado, mesmo em uma área acessível ao público, pode encontrar proteção constitucional ${ }^{44}$.

As provas foram invalidadas, porém, porque os agentes agiram sem autorização judicial $^{45}$, mas, para o que nos interessa, esse caso traz, dentre outros, dois pontos importantes.

Primeiro, pareceu estabelecer, ou pretender estabelecer, um método para averiguar qual proteção, em termos de "privacy", a Quarta Emenda oferece às pessoas. Esse (denominado) "teste de razoabilidade" para a proteção da "privacy" apareceu no voto do Justice Harlan, segundo o qual há um requisito desdobrado em duas partes: (i) que a pessoa tenha demonstrado uma real (subjetiva) expectativa de "privacy" e (ii) que tal expectativa seja uma a que a sociedade esteja preparada para reconhecer como razoável ("reasonable") 46 .

Segundo, a Corte afirmou que a Quarta Emenda não se traduz num direito constitucional geral à "privacy", que ela protege a "privacy" de um indivíduo contra algumas intrusões governamentais, mas sua proteção vai além, e, muitas vezes, não tem nada a ver com esse direito. Além disso, outras normas da Constituição protegem a "privacy" pessoal de intrusões governamentais, como a Primeira, a Terceira e a Quinta Emendas, e que o direito geral de uma pessoa à "privacy" (o "right to be let alone by other people", em referência direta ao artigo de Warren e Brandeis) é, como a proteção à

\footnotetext{
${ }^{43} 389$ U.S. 347. No original: [...] Because the Fourth Amendment protects people rather than places, its reach cannot turn on the presence or absence of a physical intrusion into any given enclosure. [...]".

${ }^{44} 389$ U.S. $347,351-2$.

${ }^{45} 389$ U.S. 347, 354-5.

${ }^{46} 389$ U.S. $347,361$.
} 
propriedade e à vida, deixada, em grande parte, à lei dos estados ${ }^{47}$.

Esse teste de legítima expectativa razoável de "privacy" foi aplicado em inúmeros casos subseqüentes. A Corte entendeu havê-la, por exemplo, dentre outros, em: (i) Camara v. Municipal Court ${ }^{48}$, em que decidiu que a Quarta Emenda impede uma pessoa de ser processada por se recusar a autorizar a inspeção, sem mandado judicial, de sua residência ${ }^{49}$; (ii) United States v. United States District Court ${ }^{50}$, em que entendeu que vigilância eletrônica não pode ser determinada pelo Presidente sem obtenção de ordem judicial; (iii) G.M. Leasing Corp. v. United States ${ }^{51}$, em que considerou inconstitucional a invasão de escritório sem mandado judicial, e constitucional a apreensão de bens em locais "públicos", como ruas, estacionamentos e outros locais abertos ${ }^{52}$; (iv) United States v. Chadwick $^{53}$, pois os réus, acusados de tráfico de drogas, haviam sido presos e tiveram apreendido um baú trancado que carregavam, sem autorização judicial e sem necessidade de uma imediata inspeção ${ }^{54}$; (v) Delaware v. Prousse ${ }^{55}$, em que um policial parou aleatoriamente um motorista, sem qualquer suspeita ou sinal de violação a qualquer lei e regulamento, para averiguar sua habilitação de motorista e o registro do automóvel, e acabou encontrando maconha no chão, prendendo-o ${ }^{56}$; (vi) Arkansas v. Sanders ${ }^{57}$, em que

47389 U.S. $347,350-1$.

48387 U.S. 523 (1967).

49 “[...] [o] propósito básico da Quarta Emenda, aplicável contra os Estados através da Décima Quarta, através de sua proibição de buscas e apreensões 'não razoáveis' é salvaguardar a privacidade e segurança dos indivíduos contra invasões arbitrárias por autoridades governamentais" (387 U.S. 523, 523 e 528, tradução nossa). No original: "[...] [t]he basic purpose of the Fourth Amendment, which is enforceable against the States through the Fourteenth, through its prohibition of 'unreasonable' searches and seizures is to safeguard the privacy and security of individuals against arbitrary invasions by governmental officials".

${ }^{50} 407$ U.S. 297 (1972).

${ }^{51} 429$ U.S. 338 (1977).

52429 U.S. $338,339$.

${ }^{53} 433$ U.S. 1 (1977).

${ }^{54}$ Ver 433 U.S. 2.

${ }^{55} 440$ U.S. 648 (1979).

56 “"...] Exceto quando haja razoável e articulável suspeita de que um motorista esteja sem licença ou que um automóvel não esteja registrado, ou que o veículo ou o um ocupante esteja de qualquer modo sujeito a apreensão por violação de lei, parar um automóvel e deter o motorista para checar sua carteira de habilitação e o registro do veículo não é razoável sob a Quarta Emenda [...] Um indivíduo operando ou viajando em um automóvel não perde toda a sua razoável expectativa de privacidade simplesmente porque o automóvel e o seu uso são sujeitos a regulação governamental. As pessoas não são despidas de toda a proteção da Quarta Emenda quando põem os pés para fora de casa na calçada pública, nem são despidas desses interesses quando passam da calçada e entram em seus automóveis" (440 U.S. 648 e 649, tradução nossa). No original: "[...] Except where there is at least articulable and reasonable suspicion that a motorist is unlicensed or that an automobile is not registered, or that either the vehicle or an occupant is otherwise subject to seizure for violation of law, stopping an automobile and detaining the driver in order to check his driver's license and the registration of the automobile are unreasonable under the Fourth Amendment [...] An individual operating or traveling in an automobile does not lose all reasonable expectation of privacy simply because the automobile and its use are subject to government regulation. People are not shorn of all Fourth Amendment protection when they step from their homes onto the public sidewalk; nor are they shorn of those interests when they step from the sidewalks into their automobiles". 
uma bagagem foi apreendida no porta-malas de um táxi e aberta sem autorização de seu dono e sem mandado judicial; (vii) Walter v. United States ${ }^{58}$, em que várias caixas seladas contendo filmes pornográficos foram entregues erroneamente a um terceiro e, depois, ao FBI, que os apreendeu e assistiu a eles sem consentimento do proprietário dos filmes ou autorização judicial e ajuizou uma ação contra o consignante e o consignatário da encomenda $^{59}$; e (viii) United States v. Karo ${ }^{60}$, em que oficiais da Drug Enforcement Administration ("DEA"), agência governamental responsável pelo combate ao tráfico de entorpecentes, plantaram um dispositivo de rastreamento, através de um informante, em um tambor posteriormente transportado a várias casas e armazéns, a partir do qual efetuaram-se as prisões de Karo e outros. Segundo a Suprema Corte, a ilegalidade não estava na instalação do dispositivo, mas, sim, no monitoramento do mesmo em locais fechados ao público sem autorização judicial ${ }^{61}$.

Por outro lado, entendeu não existir expectativa razoável de "privacy" em, dentre outros: (i) United States v. White ${ }^{62}$, em que houve gravação de conversas de uma quadrilha por um informante da polícia vestindo equipamento de transmissão; (ii) United States v. Dionisio ${ }^{63}$, em que um "grand jury" intimara inúmeras pessoas a fornecerem amostras de voz $^{64}$; (iii) United States v. Miller ${ }^{65}$, em que um indivíduo foi processado com base em informações bancárias obtidas pelas autoridades junto aos próprios bancos. Segundo a Corte, não há expectativa de "privacy" sobre documentos usados em transações comerciais e outros dados passados voluntariamente a terceiros, e que a intimação a terceiros para

${ }^{57} 442$ U.S. 753 (1979).

58447 U.S. 649 (1980).

59 “ $[. .$.$] O fato de que os agentes do FBI estivessem legalmente de posse das caixas de filmes não lhes deu a$ autoridade de vasculhar seu conteúdo. A autoridade de um oficial para apreender um pacote é distinta daquela de examinar seu conteúdo, e quando o conteúdo consiste de livros ou outros materiais defensavelmente protegidos pela Primeira Emenda, e a base para sua apreensão é a desaprovação da mensagem que contêm, é especialmente importante que o requisito de garantia [mandado] da Quarta Emenda seja escrupulosamente observado" (447 U.S. 649 e 650, tradução nossa). No original: "[...] The fact that FBI agents were lawfully in possession of the boxes of film did not give them authority to search their contents. An officer's authority to possess a package is distinct from his authority to examine its contents, and when the contents of the package are books or other materials arguably protected by the First Amendment, and the basis for the seizure is disapproval of the message contained therein, it is especially important that the Fourth Amendment's warrant requirement be scrupulously observed".

${ }^{60} 468$ U.S. 704 (1984).

${ }^{61}$ Ver 468 U.S. 704, 706.

62401 U.S. 745 (1971).

${ }^{63} 410$ U.S. 1 (1973).

${ }^{64}$ E que "[a] obrigatória produção dos exemplares de voz não violaria o privilégio da Quinta Emenda contra a auto-incriminação compulsória porque seriam usados somente para fins de identificação, e não pelo conteúdo testemunhal ou comunicativo dos discursos" (410 U.S. 1, tradução nossa). No original: "[t]he compelled production of the voice exemplars would not violate the Fifth Amendment privilege against compulsory self-incrimination, since they were to be used only for identification purposes, and not for the testimonial or communicative content of the utterances".

${ }^{65} 425$ U.S. 435 (1976). 
produção de provas contra um acusado (ou réu) não viola, também, a Quarta Emenda ${ }^{66}$; (iv) Smith v. Maryland ${ }^{67}$, em que provas foram obtidas contra um acusado com base em um aparelho ("pen register"), instalado pela companhia telefônica a pedido das autoridades policiais, sem autorização judicial, que registrava os números de telefone por ele discados. A Corte entendeu, seguindo argumento parecido com o caso anterior, que não há expectativa legítima de "privacy" nos números discados, já que a própria companhia telefônica os registra e arquiva para diversos propósitos ${ }^{68}$; (v) United States v. Knotts ${ }^{69}$, em que um dispositivo de rastreamento por rádio foi colocado em um tambor de clorofórmio, a pedido de autoridades policiais, pelo vendedor. Com base nesse rastreamento e em vigilância pessoal e visual, seguiram o automóvel do suspeito até uma cabine. Obtiveram um mandado judicial, adentraram a cabine e encontraram um laboratório de drogas. A Corte entendeu que o tambor, colocado no porta-malas de um carro, não gerava a seu proprietário uma expectativa razoável de "privacy", pois não há reserva quanto aos movimentos de um automóvel por vias e lugares públicos ${ }^{70} 71$.

Em Stanley vs. Georgia ${ }^{72}$, um indivíduo havia tido sua casa revistada, com mandado judicial, por suposto envolvimento em práticas de "bookmaking" (apostas), quando as autoridades policiais acharam em seu quarto alguns filmes, projetaram-nos e, considerando-os obscenos, prenderam-no, processaram-no e obtiveram sua condenação.

A Suprema Corte julgou inconstitucional, por violar a Primeira Emenda, aplicável aos estados por força da Décima Quarta Emenda, essa lei do Estado da Georgia que tipificava como crime a mera possessão de material (filmes) obsceno, embora tenha ressalvado a possibilidade da legislação controlar a distribuição e venda de materiais dessa natureza.

O Justice Marshall, dando a opinião da Corte, escreveu que

[...] já se encontra bem estabelecido que a Constituição protege o direito de receber informações e idéias. [...] Este direito de receber informações e idéias, a despeito de seu valor social, [...] é fundamental para a nossa sociedade livre.

\footnotetext{
${ }^{66}$ Ver 425 U.S. 435 e 436.

${ }^{67} 442$ U.S. 735 (1979).

${ }^{68}$ Ver 442 U.S. 735 e 736.

${ }^{69} 460$ U.S. 276 (1983).

${ }^{70}$ Ver 460 U.S. 276 e 277.

${ }^{71}$ Gormley traz uma lista mais ampla de casos nos dois sentidos, especialmente decisões em que a Suprema Corte entendeu não haver expectativa em automóveis e seus compartimentos, em diversas situações (1992, p. 1368-1370). Barrett (2002) critica esse teste baseado no contexto de Katz no âmbito das novas tecnologias porque permite que a abrangência do direito à "privacy" do indivíduo dependa, entre outros, do estado da tecnologia existente. Mais sobre a razoável expectativa de "privacy” em Edgett (2002-2003) e Jones (19961997).

72394 U.S. 557 (1969).
} 


\begin{abstract}
Além disso, no contexto deste caso - um processo [criminal] pela mera posse de material impresso ou filmado na privacidade de sua própria casa - aquele direito ganha uma outra dimensão. Porque também é fundamental o direito de ser livre, exceto em circunstâncias muito limitadas, de indesejada intrusão governamental na própria privacidade. [...] nós pensamos que a mera categorização desses filmes como "obscenos" é justificativa insuficiente para tal invasão drástica das liberdades pessoais garantidas pela Primeira e Décima Quarta Emendas. Quaisquer que sejam as justificativas para outras leis regulando obscenidade, não pensamos que atinjam a privacidade da própria casa de uma pessoa. Se a Primeira Emenda significa algo, significa que o Estado não tem a incumbência de dizer a um homem, sentado sozinho em sua casa, que livros pode ler ou a que filmes pode assistir. [... $]^{73}$.
\end{abstract}

O Justice Stewart, acompanhado por Brennan e White, entendeu que a ilegalidade estava na própria apreensão do material, que fugiu da autorização e do objeto do mandado judicial, e também não encontrava amparo em nenhuma exceção, como óbvia (visível) evidência de prática de atividades criminosas. Segundo ele,

\begin{abstract}
[a]ceitar o que aconteceu aqui é convidar um oficial do governo a usar um mandado aparentemente preciso e legal apenas como um bilhete para entrar na casa de um homem e, uma vez lá dentro, empreender buscas sem limites e apreensões indiscriminadas como se armado com todo o desenfreado e ilegal poder de um mandado genérico ${ }^{74}$.
\end{abstract}

Em Roe v. Wade ${ }^{75}$, a Suprema Corte julgou inconstitucional uma lei do Texas que criminalizava o aborto, ou sua tentativa, exceto por conselho médico para salvar a vida da mãe. Ela citou decisões passadas, em que encontrara o "right of privacy", ou zonas de “privacy”, em algumas Emendas, como a Primeira, a Quarta, a Quinta, a Nona e a primeira parte da Décima Quarta, e em outras situações, como casamento, procriação, contracepção, relacionamentos familiares e criação e educação das crianças ${ }^{76}$, e entendeu que o "right of privacy”, encontrado na concepção de liberdade individual da Décima Quarta Emenda, conforme a opinião da Corte, ou na reserva de poderes às pessoas, da Nona, como

\footnotetext{
73394 U.S. 557, 564-565 (tradução nossa). No original: "[i]t is now well established that the Constitution protects the right to receive information and ideas. [...] This right to receive information and ideas, regardless of their social worth, $[\ldots]$ is fundamental to our free society. Moreover, in the context of this case $-\mathrm{a}$ prosecution for mere possession of printed or filmed matter in the privacy of a person's own home - that right takes on an added dimension. For also fundamental is the right to be free, except in very limited circumstances, from unwanted governmental intrusions into one's privacy. [...] we think that mere categorization of these films as 'obscene' is insufficient justification for such a drastic invasion of personal liberties guaranteed by the First and Fourteenth Amendments. Whatever may be the justifications for other statutes regulating obscenity, we do not think they reach into the privacy of one's own home. If the First Amendment means anything, it means that a State has no business telling a man, sitting alone in his own house, what books he may read or what films he may watch. [...]".

${ }^{74} 394$ U.S. 557, 572. No original: "[t]o condone what happened here is to invite a government official to use a seemingly precise and legal warrant only as a ticket to get into a man's home, and, once inside, to launch forth upon unconfined searches and indiscriminate seizures as if armed with all the unbridled and illegal power of a general warrant".

${ }_{75} 410$ U.S. $113(1973)$

${ }^{76} 410$ U.S. $113,152-3$.
} 
entendera a Corte Distrital ("District Court"), é amplo o bastante para abranger o direito de a mulher decidir terminar ou não a gravidez, mas com limitações impostas pela legislação visando a salvaguardar a saúde, manter padrões médicos e proteger a saúde da potencial vida $^{77}$, estabelecendo algumas “diretivas" nesse sentido ${ }^{78}$.

O Justice Rehnquist discordou da decisão da maioria, afirmando que encontrava dificuldade em ver o "right of privacy" envolvido nesse caso, pois a realização de um aborto não é uma transação "privada" no sentido ordinário da palavra, além de não ser nem um "parente distante" da liberdade contra buscas e apreensões protegida pela Quarta Emenda $^{79}$.

Por outro lado, em Paris Adult Theatre I vs. Slaton ${ }^{80}$, em que dois cinemas e seus proprietários e gerentes foram processados civilmente por violar a legislação do estado da Georgia ao exibir dois filmes alegadamente obscenos ao público adulto, mostrando cenas de sexo simulado, a Corte entendeu que a Primeira Emenda não protege materiais obscenos e não opera restrições via Décima Quarta Emenda aos estados da federação, e que, principalmente,

[...] a idéia de um direito à "privacidade" e a de um lugar de acomodação pública são, neste contexto, mutuamente excludentes. Conduta ou retratos de conduta que o poder de polícia estatal pode proibir numa via pública não se tornam automaticamente protegidos pela Constituição meramente porque a conduta é deslocada para um bar ou um palco de um teatro "ao vivo", não mais do que uma performance "ao vivo" de um homem e uma mulher em um ato sexual ao meiodia na Times Square é protegida pela Constituição porque simultaneamente se encontram travando um diálogo político válido. [...] Onde a comunicação de idéias, protegida pela Primeira Emenda, não está envolvida, ou a particular privacidade da casa protegida por Stanley, ou qualquer das outras "áreas ou zonas" de privacidade protegida constitucionalmente, o simples fato de que, como conseqüência, alguns "discursos" ou "pensamentos" possam ser incidentalmente afetados não proíbe o Estado de agir para proteger interesses estatais legítimos ${ }^{81}$.

${ }^{77}$ Ver 410 U.S. 113, 153-4.

${ }^{78}$ Ver 410 U.S. 113, 164-6.

${ }^{79} 410$ U.S. 113, 172. No original: "If the Court means by the term 'privacy' no more than that the claim of a person to be free from unwanted state regulation of consensual transactions may be a form of "liberty" protected by the Fourteenth Amendment, there is no doubt that similar claims have been upheld in our earlier decisions on the basis of that liberty".

${ }^{80} 413$ U.S. 49 (1973).

${ }^{81} 413$ U.S. 49, 66-7 (tradução nossa). No original: “[...][t]he idea of a 'privacy’ right and a place of public accommodation are, in this context, mutually exclusive. Conduct or depictions of conduct that the state police power can prohibit on a public street do not become automatically protected by the Constitution merely because the conduct is moved to a bar or a 'live' theater stage, any more than a 'live' performance of a man and woman locked in a sexual embrace at high noon in Times Square is protected by the Constitution because they simultaneously engage in a valid political dialogue. [...] Where communication of ideas, protected by the First Amendment, is not involved, or the particular privacy of the home protected by Stanley, or any of the other 'areas or zones' of constitutionally protected privacy, the mere fact that, as a consequence, some human 'utterances' or 'thoughts' may be incidentally affected does not bar the State from acting to protect legitimate state interests". 
Ainda segundo a Corte, se material obsceno não protegido pela Primeira Emenda carregasse em si mesmo uma penumbra de "privacy" constitucionalmente protegida, não teria sido necessário decidir Stanley v. Georgia na estreita base da "privacidade da casa" ("privacy of the home"), que apenas seria uma reafirmação da máxima "a casa de um homem é seu castelo" (“a man's home is his castle") ${ }^{82}$.

A decisão foi por maioria apertada, sendo que o Justice Brennan entendeu que mesmo materiais obscenos encontram guarida na Primeira Emenda, desde que medidas sejam tomadas para evitar exposição a menores e a adultos que não consintam com ela ${ }^{83}$.

Quatro anos mais tarde, em Whalen v. $\operatorname{Roe}^{84}$, a Suprema Corte entendeu que a identificação de pacientes pelo preenchimento de um formulário oficial, com uma via sendo depositada junto ao Departamento de Saúde do Estado (“State Health Department”), para a prescrição de certas drogas legais potencialmente danosas, estabelecida por uma lei do estado de New York, não feria o direito à "privacy" dos pacientes, mesmo que houvesse risco de "vazamento" dessas informações. A Corte afirmou também que, às vezes, os casos considerados como de "privacy" julgados por ela envolveram pelo menos dois tipos diferentes de interesses: (i) o interesse individual de evitar divulgação de assuntos ("matters") pessoais, e (ii) o interesse de independência na tomada de certos tipos de decisões importantes ${ }^{85}$.

Um ponto digno de nota desse julgamento é a expressa preocupação da Corte com bancos de dados armazenados e geridos por computadores, que era o caso desse sistema implantado pela lei de New York. O Justice Stevens, pela Corte, escreveu:

\begin{abstract}
Não estamos desatentos à ameaça à privacidade implícita na acumulação de vastas quantidades de informações pessoais em bancos de dados ou outros grandes arquivos governamentais. [...] Reconhecendo que em algumas circunstâncias aquele defensavelmente tem suas raízes na Constituição, mesmo assim o esquema legal de New York, e suas medidas administrativas de implementação, evidenciam uma adequada preocupação com e a proteção do interesse individual na privacidade. Nós, portanto, não precisamos, e não o fazemos, decidir qualquer questão que possa ser apresentada pela divulgação não autorizada de dados privados acumulados - intencional ou não - ou por um sistema que não contenha provisões de segurança compatíveis. Nós simplesmente consideramos que este arquivo não estabelece uma invasão de qualquer direito ou liberdade protegido pela Décima Quarta Emenda ${ }^{86}$.
\end{abstract}

\footnotetext{
82413 U.S. 49, 66.

${ }^{83}$ Ver 413 U.S. 49, 103-114.

84 429 U.S. 589 (1977).

85429 U.S. 589, 598-600.

${ }^{86} 429$ U.S. 589, 605-6 (tradução nossa). No original: "We are not unaware of the threat to privacy implicit in the accumulation of vast amounts of personal information in computerized data banks or other massive government files. [...] Recognizing that in some circumstances that duty arguably has its roots in the
} 
O Justice Brennan, acompanhando essa linha de raciocínio, afirmou:

[o] que é mais preocupante sobre esse esquema, entretanto, é o arquivamento central por computador dos dados assim coletados. Obviamente, como o Estado sustenta, a coleta e armazenamento de dados pelo Estado que é, em si mesma, legítima não se torna inconstitucional simplesmente porque nova tecnologia torna as suas operações mais eficientes. Entretanto, como o exemplo da Quarta Emenda demonstra, a Constituição põe limites não somente ao tipo de informação que o Estado pode recolher, mas também sobre o meio que pode usar para o fazer. $\mathrm{O}$ armazenamento central e a fácil acessibilidade de dados computadorizados aumentam vastamente o potencial para abuso dessa informação, e não estou preparado para dizer que futuros desenvolvimentos não demonstrarão a necessidade de certas limitações a tal tecnologia ${ }^{87}$.

Por outro lado, o Justice Stewart, embora concordando com a decisão, entendeu que a "ratio decidendi" de Griswold não reconhece um interesse geral de liberdade contra a divulgação de informações pessoais ${ }^{88}$.

Em United States v. Jacobsen ${ }^{89}$, a Corte afirmou que a Quarta Emenda protege a propriedade e a "privacy" "90, mas não contra indivíduos privados que não atuem como agentes do governo, ou com a participação ou conhecimento de alguma autoridade governamental $^{91}$.

Constitution, nevertheless New York's statutory scheme, and its implementing administrative procedures, evidence a proper concern with, and protection of, the individual's interest in privacy. We therefore need not, and do not, decide any question which might be presented by the unwarranted disclosure of accumulated private data - whether intentional or unintentional - or by a system that did not contain comparable security provisions. We simply hold that this record does not establish an invasion of any right or liberty protected by the Fourteenth Amendment".

${ }^{87} 429$ U.S. 589, 606-7 (tradução nossa). No original: “[w] hat is more troubling about this scheme, however, is the central computer storage of the data thus collected. Obviously, as the State argues, collection and storage of data by the State that is in itself legitimate is not rendered unconstitutional simply because new technology makes the State's operations more efficient. However, as the example of the Fourth Amendment shows, the Constitution puts limits not only on the type of information the State may gather, but also on the means it may use to gather it. The central storage and easy accessibility of computerized data vastly increase the potential for abuse of that information, and I am not prepared to say that future developments will not demonstrate the necessity of some curb on such technology".

${ }^{88} 429$ U.S. 589, 609.

89466 U.S. 109 (1984).

90 “A primeira cláusula da Quarta Emenda prevê que 'o direito do povo à inviolabilidade de suas pessoas, casas, papéis e haveres contra busca e apreensão arbitrárias não poderá ser infringido...'. Este texto protege dois tipos de expectativa, uma envolvendo 'buscas', outra 'apreensões'. Uma 'busca' ocorre quando uma expectativa de privacidade que a sociedade está preparada para considerar como razoável é infringida. Uma 'apreensão' de propriedade ocorre quando há alguma interferência significativa nos interesses possessórios de um indivíduo naquela propriedade" (466 U.S. 109, 113, tradução nossa). No original: "The first Clause of the Fourth Amendment provides that the 'right of the people to be secure in their persons, houses, papers, and effects, against unreasonable searches and seizures, shall not be violated..." This text protects two types of expectations, one involving 'searches', the other 'seizures'. A 'search' occurs when an expectation of privacy that society is prepared to consider reasonable is infringed. A 'seizure' of property occurs when there is some meaningful interference with an individual's possessory interests in that property".

91466 U.S. 109, 113. 
Em Bowers v. Hardwick ${ }^{92}$, uma lei do estado da Georgia criminalizando a sodomia entre indivíduos, sem referência a serem do mesmo sexo ou não, foi considerada constitucional, por maioria, sob o entendimento de que a Constituição não protege o direito de ter relações sexuais homossexuais de sodomia.

A tese vencedora, como apontado pelo Justice Blackmun, em voto dissidente, não atentou para a linguagem da lei contestada, que não se referia a relações homossexuais ${ }^{93}$. Ele entendeu que a questão posta tinha a ver com o "right to be alone" ${ }^{94}$, especificamente com o direito de um indivíduo conduzir seus relacionamentos íntimos na intimidade de sua casa (como quiser), desde que não haja interferência com direitos de terceiros ${ }^{95}$.

Em Planned Parenthood of Southeastern Pa. v. Casey ${ }^{96}$, a Corte, em decisão de longas folhas, tumultuada e de opiniões conflitantes e recortadas, entendeu que o estado pode regular o aborto, desde que não imponha obstáculos indevidos ("undue burden") às mulheres que procuram fazê-lo, observado o núcleo do raciocínio de Roe v. Wade.

Os Justices Rehnquist, Scalia, White e Thomas ressalvaram que prévias decisões, incluindo Griswold, não defendem um "super abrangente" ("all-encompassing") "right of privacy" 97 , e entenderam que o direito ao aborto não deveria ser protegido sob a rubrica de "personal or family privacy or autonomy", mas como um direito "sui generis", pois envolve a destruição de um feto (uma vida) ${ }^{98}$.

Os Justices O’Connor, Kennedy e Souter afirmaram que existem direitos que advêm, embora não expressos na Constituição, da palavra "liberties" contida na Décima Quarta Emenda, pela cláusula do devido processo legal substantivo: “[é] uma promessa da Constituição que exista um campo de liberdade pessoal no qual o governo não pode entrar"99.

Em Lawrence v. Texas ${ }^{100}$, superando expressamente o precedente de Bowers v. Hardwick, a Corte invalidou uma lei estadual que condenava a prática de certas condutas sexuais apenas entre indivíduos do mesmo gênero:

[...] Os requerentes têm direito ao respeito por suas vidas privadas. O Estado não

92478 U.S. 186 (1986).

${ }^{93} 478$ U.S. $186,200$.

${ }^{94} 478$ U.S. $186,199$.

${ }^{95}$ Ver 478 U.S. 186, 206, 208 e 213.

${ }^{96} 505$ U.S. 833 (1992).

${ }^{97}$ Ver 505 U.S. 833, 951.

${ }^{98} 505$ U.S. $833,951-2$.

${ }^{99} 505$ U.S. 833,847 , tradução nossa. No original: "[i]t is a promise of the Constitution that there is a realm of personal liberty which the government may not enter".

${ }^{100} 539$ U.S. 558 (2003). 
pode aviltar sua existência ou controle sobre seu destino tornando sua conduta sexual privada um crime. Seu direito à liberdade sob a cláusula do devido processo legal dá-lhes o pleno de direito de praticarem a sua conduta sem a intervenção do governo [... $]^{101}$. (tradução nossa)

Enfim, embora a existência do "right of privacy" seja agora reconhecido quase unanimemente no direito norte-americano, o debate quanto ao seu conteúdo e à sua aplicação prática prossegue. O relato que fizemos do desenvolvimento desse direito, embora não exaustivo, mostra o quão difícil e variado é o entendimento da própria Suprema Corte, que o "constitucionalizou".

Por sua vez, vários autores propuseram-se a conceituar ou definir esse direito por lá, sem se chegar a um consenso ou algo próximo a isso.

Stephens Jr. e Scheb II (2008, p. 386) entendem que o direito constitucional de “privacy" protege o indivíduo de interferências não autorizadas (sem mandado, "unwarranted") do governo em relacionamentos e atividades íntimos, e inclui a liberdade de fazer escolhas fundamentais envolvendo sexo, reprodução, vida familiar e outros relacionamentos pessoais íntimos ${ }^{102}$.

Prosser (1960, p. 389), tratando de "torts" envolvendo o direito à "privacy", encontra quatro diferentes tipos de invasão de quatro interesses distintos do requerente (“plaintiff”), ligados por um nome comum, mas não tendo nenhuma relação entre si, exceto pelo fato de fazerem parte do direito de o indivíduo ser deixado em paz: (i) invasão da reclusão ou solidão do indivíduo, ou de seus assuntos (“affairs") privados; (ii) difusão pública de fatos particulares embaraçosos sobre a vida do indivíduo; (iii) publicidade que põe uma falsa luz sobre o indivíduo aos olhos do público; e (iv) apropriação, para proveito do demandado, do nome ou aparência do demandante.

Gross, rebatendo o reducionismo de Prosser de "privacy" a outros direitos então já

101539 U.S. 558, 578. No original: "[...] The petitioners are entitled to respect for their private lives. The State cannot demean their existence or control their destiny by making their private sexual conduct a crime. Their right to liberty under the Due Process Clause gives them the full right to engage in their conduct without intervention of the government $[\ldots]$ ".

102 "O direito constitucional de privacidade protege o indivíduo de interferência governamental sem autorização em relacionamentos pessoais íntimos ou atividades. Como tomou forma desde meados dos anos de 1960, o direito de privacidade inclui a liberdade de o indivíduo fazer escolhas fundamentais envolvendo sexo, reprodução, vida familiar e outros relacionamentos pessoais íntimos. [...]" (tradução nossa, destaque dos autores). No original: "The constitutional right of privacy protects the individual from unwarranted government interference in intimate personal relationships or activities. As it has taken shape since the mid1960s, the right of privacy includes the freedom of the individual to make fundamental choices involving sex, reproduction, family life, and other intimate personal relationships. [...]". Prosseguem em outro ponto afirmando que o debate sobre esse direito é, em última análise, um debate entre duas visões radicalmente diferentes da lei: a libertária, segundo a qual a lei existe para proteger os indivíduos uns dos outros, e a clássica conservadora, que vê a lei e a moralidade como inseparáveis e considera que a manutenção da moralidade social é uma das funções essenciais do sistema legal (STEPHENS JR; SCHEB II, 2008, p. 387). Ver também Sykes (2000). Defendendo uma terceira visão, denominada de “comunitária”, Etzioni (1999). 
reconhecidos pelo ordenamento jurídico, sugere que "[...] privacidade é a condição da vida humana na qual familiaridade com uma pessoa ou com assuntos de sua vida que lhe são pessoais é limitado"103 (1967, p. 35-6, tradução nossa).

Para Douse (1972-1973, p. 166), a "privacy" consiste na faculdade (“ability") do agente de manter a integridade de sua unidade de "privacy", que é o seu domínio de atividade autônoma ou espaço de livre movimentação, existindo duas classes de violação dessa unidade que podem dar-se, tendo em vista a Quarta Emenda: (i) invasão ("invasion" ou "intrusion”), que ocorre quando o ser ("self”) é invadido por forças exteriores que vê como ofensivas ou indesejáveis; e (ii) apropriação (“appropriation”), quando elementos do ser (“self”) tornam-se conhecidos, são utilizados ou são tomados por outros de um modo que o agente vê como ofensivo ou indesejável (p. 168).

A invasão referir-se-ia ao influxo de forças ambientais, que seriam ofensivas por causa de sua presença dentro da unidade de "privacy", enquanto a apropriação referir-se-ia ao efluxo de elementos internos ao ser, considerado ofensivo pela dispersão e perda, pelo agente, desses elementos. O poder de regular o influxo é o de "admissão seletiva", e do efluxo, “disseminação seletiva” (DOUSE, 1972-1973, p. 168-9).

Feita essa exposição, Douse (1972-1973, p. 171-2) relaciona quatro usos distintos que as Cortes e doutrinadores tenderiam a fazer da palavra "privacy", em vista de sua abertura e ambigüidade: (i) como uma expressão larga e aberta para todo e qualquer aspecto de integridade pessoal e autonomia; (ii) como expressão daqueles ideais especificamente incorporados na Quarta Emenda, em exclusão a outras facetas abertas da “privacy” que não são legalmente protegidas, ou são protegidas por outros mecanismos legais; (iii) como uma categoria operacional representando os tipos de situações fáticas em que uma Corte irá ou deveria reconhecer uma intrusão ou apropriação como uma busca ou apreensão; e (iv) como uma segunda e mais estreita categoria operacional de situações fáticas em que uma busca e apreensão, se ocorrerem, seriam constitucionalmente desarrazoadas.

Gormley, rejeitando uma definição precisa de "privacy”, prefere dividi-la em cinco espécies legais dominantes, que se desenvolveram desde 1890 e se inter-relacionam (1992, p. 1340): (i) "tort privacy", segundo ele, a espécie original, de Warren e Brandeis; (ii) "privacy" da Quarta Emenda ("Fourth Amendment privacy"), relacionada a buscas e apreensões governamentais sem mandado judicial; (iii) "privacy" da Primeira Emenda

\footnotetext{
${ }^{103}$ No original: "[...] privacy is the condition of human life in which acquaintance with a person or with affairs of his life which are personal to him is limited".
} 
("First Amendment privacy”), uma "“privacy' quase constitucional" ("quasi-constitutional" "privacy”) que existe quando a liberdade de expressão de um indivíduo colide com a de pensamento e solidão ("solitude") de outro; (iv) "privacy" de decisões fundamentais ("fundamental-decision privacy"), envolvendo decisões pessoais fundamentais protegidas pela cláusula do devido processo (“due process clause”) da Décima Quarta Emenda, geralmente necessária para esclarecer e preencher as lacunas do contrato social original; e (v) "“privacy' constitucional estadual" ("state constitutional privacy”), uma mistura dessas quatro espécies anteriores, mas pressupostas em diferentes garantias constitucionais estaduais que, muitas vezes, trazem direitos "híbridos".

Solove (2002, p. 1092), por sua vez, traz seis concepções de "privacy" para abranger as diferentes idéias que se têm a respeito: (i) "o direito de ser deixado só" ("the right to be let alone"), de Warren e Brandeis; (ii) "acesso limitado ao indivíduo" ("limited access to the self"), a faculdade ("ability") de se proteger de acesso indesejado de outros; (iii) "segredo" ("secrecy"), o acobertamento de certas matérias ou assuntos ("matters") de outros; (iv) "controle sobre informações pessoais" ("control over personal information"), a faculdade ("ability") de exercer o controle da informação sobre si mesmo; (v) "personalidade" ("personhood"), a proteção da personalidade, individualidade e dignidade do indivíduo; e (vi) "intimidade" ("intimacy"), controle sobre, ou acesso limitado a, relacionamentos íntimos ou aspectos da vida.

Mas ele ressalta que as diferentes concepções sobrepõem-se e não são independentes entre si, e, no final, entende que o melhor não é conceituar "privacy" através de um (inexistente) denominador comum, mas a partir de uma corrente filosófica que considera que certas coisas apresentam similaridades suficientes para serem agrupadas sob um mesmo nome, embora todas elas não compartilhem necessariamente de um mesmo traço comum (é o que denomina "semelhanças familiares"), levando-se em consideração o contexto, e não um conceito geral abstrato ${ }^{104}$.

Garner (2007, p. 1233) define "privacy" como a "condição ou estado de estar livre da atenção pública à intrusão ou interferência nos atos ou decisões de alguém"105 (tradução nossa), sendo a "autonomy privacy" o

\footnotetext{
${ }^{104}$ Ver Solove (2002, p. 1092, 1126-1129, 1154-1155). Em artigo posterior, Solove afirma que "privacy" é um termo guarda-chuva, que se refere a um vasto e disparatado grupo de coisas, sendo melhor focar nas atividades que a violam em vez de se buscar um único conceito simplificado, colocando-as em quatro grupos: (i) coleta de informações; (ii) processamento de informações; (iii) disseminação de informações; e (iv) invasão (2006).

${ }^{105}$ No original: "[t]he condition or state of being free from public attention to intrusion into or inteference with one's acts or decisions".
} 
direito de um indivíduo de controlar suas atividades pessoais ou escolhas íntimas pessoais sem interferência externa, observação ou intrusão. Se o interesse do indivíduo em uma atividade ou decisão é fundamental, o Estado deve mostrar um interesse público relevante antes que o interesse privado seja ultrapassado. Se o interesse do indivíduo é reconhecido como sendo menos fundamental ou é controvertido, então a corte deve aplicar um teste de ponderação. 'Hill v. NCAA', 865 P.2d 633, 653, 654 (Cal. 1994) ${ }^{106}$. (tradução nossa).

A "informational privacy" seria o "direito de uma pessoa privada de escolher determinar se, como e em que extensão [qualquer] informação sobre si é comunicada a outros, especialmente informação sensível e confidencial"107, enquanto o "right of privacy" é "[o] direito à autonomia pessoal [the right to personal autonomy]" (GARNER, 2007, p. 1350 , traduções nossas) ${ }^{108}$.

Enfim, além do problema de conceituar o "right of privacy", a sua aplicação prática não tem sido tranqüila, especialmente quando envolve o direito ou expectativa de um indivíduo de não ver sua esfera privada, ou elementos dela, invadida ou apreendida por outros.

Autores apontam para a linha de proteção da Suprema Corte, e de Cortes inferiores, baseada em interesses, ou direitos, de propriedade, ou seja, o indivíduo só estaria protegido se provasse domínio sobre ou domicílio em determinado lugar ${ }^{109}$, ou enquanto o locatário de um apartamento, de um quarto de hotel ou de um armário mantivesse-se em dia com suas obrigações ${ }^{110}$.

Mesmo o advento do teste de expectativa de privacidade, já mencionado, não teria trazido mudanças para esse cenário.

Kerr, afirmando que uma expectativa de "privacy" torna-se "razoável" somente quando apoiada por um direito de excluir outros "emprestado" (inspirado) do direito de propriedade real (2003-2004b, p. 809-10) ${ }^{111}$, cita inúmeros casos em que as Cortes, inclusive a Suprema Corte, entenderam não violar essa expectativa instrumentos intrusivos de vigilância que não importam em violação do direito de propriedade (p. 813).

\footnotetext{
${ }^{106}$ No original: “An individual's right to control his or her personal activities or intimate personal decisions without outside interference, observation, or intrusion. - If the individual's interest in an activity or decision is fundamental, the state must show a compelling public interest before the private interest can be overcome. If the individual's interest is acknowledged to be less than fundamental or is disputed, then a court must apply a balancing test. 'Hill v. NCAA', 865 P.2d 633, 653,654 (Cal. 1994)".

No original: "A private person's right to choose to determine whether, how, and to what extent information about oneself is communicated to others, esp. sensitive and confidential information".

${ }^{108}$ Mais discussões sobre o direito à "privacy" em Barrera e Okai (1999), Cate (1999-2000), Gerstein (1970), Kerr (2003-2004a), Lusky (1972), Parent (1983), e Posner (1981).

${ }^{109}$ O que excluiria, por exemplo, hóspedes e convidados. Ver Douse (1972-1973, p. 177-8).

${ }^{110}$ Ver Kerr (2003-2004b, p. 811-2).

${ }^{111}$ Em artigo posterior, apesar de parecer o contrário, Kerr afirma que não defende um teste de "invasão física" de propriedade em relação à "privacy” (2003-2004a).
} 
Swire entende que a Suprema Corte abandonou, em 1967, a jurisprudência que existia antes baseada no direito de propriedade para adotar uma nova, conferindo menos proteção, principalmente a partir de Warden v. Hayden ${ }^{112}$, em que abandonou a regra da "mera evidência" ("mere evidence rule"), que limitava a aptidão de um mandado de busca autorizar a coleta de documentos e outras "meras evidências" de um crime ${ }^{113}$ (2003-2004, p. 906).

Por outro lado, Colb (2003-2004) entende que a "privacy" é protegida independentemente de se basear, num sentido amplo, em direitos de propriedade, citando, a seu favor, Kyllo v. United States, 533 U.S. 27 (2001), em que a Suprema Corte julgou ilegal o uso de um detector de calor, sem mandado judicial, para averiguar se um suspeito plantava maconha dentro de sua casa.

Assim, considerando-se a jurisprudência desenvolvida pela Suprema Corte baseada num conceito ampliado de direito de propriedade ou não, o fato é que poucas vezes ela tem entendido haver a razoável expectativa de "privacy". Quando fica à discrição das Cortes preencher o que seria essa expectativa, em vista do entendimento e compreensão da sociedade, tem-se privilegiado a invasão ${ }^{114}$.

Aliás, esse fato de a "privacy" não ser considerada em relação à expectativa subjetiva do indivíduo de que sua esfera pessoal não seja invadida só aumenta a discricionariedade, e, no caso, a não proatividade dos juízes em preencher positivamente seu conteúdo. Pelo contrário, vêem-se regras criadas casuisticamente, sem uma aparente linha lógica. Por exemplo, em Illinois v. Caballes, n. 03-923, de 2005, a Suprema Corte entendeu que a conduta governamental que somente revela a posse de contrabando (no caso, através de cão farejador) não viola a expectativa legítima de "privacy", enquanto em

\footnotetext{
112387 U.S. 294 (1967).

113 "A regra da 'mera evidência' era uma questão de senso comum sob a abordagem baseada na propriedade da Quarta Emenda. Um mandado de busca podia ser legalmente expedido para itens nos quais o interesse de propriedade do governo fosse superior ao da pessoa detentora do objeto. Notadamente, um indivíduo não podia alegar interesse de propriedade legítimo sobre os frutos de um crime, como: bens roubados; suas instrumentalidades, como a faca usada no crime; ou em contrabando, como os narcóticos ilegais. Em contraste, os papéis privados de uma pessoa há muito eram entendidos como fora do alcance de um mandado de busca sob a autoridade do caso de 'Entick v. Carrington', de 1765, como interpretado pela Suprema Corte em 'Boyd v. United States' e 'Gouled v. United States”' (SWIRE, 2003-2004, p. 906, tradução nossa). No original: "The 'mere evidence' rule was a matter of common sense under the property-based approach to the Fourth Amendment. A search warrant could lawfully issue for items where the property interest of the government was superior to that of the person holding the object. Notably, an individual could claim no legitimate property interest in the fruits of a crime, such as: stolen goods; its instrumentalities, such as the knife used in the crime; or in contraband, such as illegal narcotics. By contrast, a person's private papers were long understood to be outside the reach of a search warrant under the authority of the 1765 case of 'Entick v. Carrington', as interpreted by the Supreme Court in 'Boyd v. United States' and 'Gouled v. United States"”.

${ }^{114}$ Nesse sentido, Doernberg (2005-2006).
} 
Kyllo, como visto, entendeu que o uso de sensores térmicos para obter evidências quanto ao plantio de maconha dentro de uma casa violava essa expectativa, embora o aparelho só mostrasse manchas de calor ${ }^{115}$.

Enfim, a situação geral nos Estados Unidos da América é a seguinte: (i) o "right to privacy" é reconhecido pela jurisprudência e doutrina como parte do ordenamento jurídico do país, derivado de "penumbras" de várias das Emendas à Constituição, especialmente, mas não só, da Quarta e Décima Quarta, e envolve inúmeras situações diversas, como procriação, educação e direito de aborto, não se resumindo ao clássico "right to be let alone"116; (ii) até 1967, a Suprema Corte baseava-se explicitamente numa política de proteção da "privacy" através de uma aplicação ampliada dos direitos de propriedade. Em 1967, abandonou, ao menos oficialmente, tal posição, reconhecendo um direito autônomo de "privacy"; (iii) o teste de razoabilidade da expectativa de "privacy", que surgiu com essa "virada" na jurisprudência, não tem se mostrado, desde então, um instrumento de melhor proteção desse direito ou interesse, haja vista seu altíssimo grau, senão absoluto, de abstração, pois “descobrir” qual a expectativa que a sociedade está preparada para aceitar, ao invés de analisar a expectativa subjetiva do indivíduo em questão ou adotarem-se parâmetros concretos, é tarefa temerária, a que os juízes não têm, no geral, preenchido positivamente, dando prevalência às invasões ou apropriações ${ }^{117}$.

No mais, existem leis esparsas e segmentadas que têm por objetivo proteger a "privacy", direta ou incidentalmente, como o aludido Privacy Act, de 1974, que se aplica ao setor público, o Fair Credit Reporting Act, de 1970, que se aplica aos dados sobre créditos dos consumidores, e o Financial Privacy Act, de $1978^{118}$, o Cable Communications Policy Act, de 1984, o Video Privacy Protection Act, de 1988, o Driver's Privacy Protection Act, de $1994^{119}$, e o Children's Online Privacy Protection Act, de 1998, dentre outros ${ }^{120}$.

\footnotetext{
${ }^{115}$ Fora outras inúmeras decisões, além das já citadas, como a recente United States v. Flores Montano, n. 021794,2004 , em que se afirmou que a expectativa de "privacy" nas fronteiras era menor do que no interior.

${ }^{116}$ Fisher e Adler (2007) entendem que, se a "privacy" protege o direito de uma pessoa de evitar a instrusão em certos pensamentos e atividades, é então protegida pela Primeira, Terceira, Quarta e Quinta Emendas, além de, em certos aspectos, segundo alguns doutrinadores, pela Nona Emenda. Os autores também desenvolvem outros direitos, como à reputação, o de morrer e os dos homossexuais.

${ }_{117}^{117}$ Ver, por exemplo, Doernberg (2005-2006).

118 Por vezes, como aconteceu com o Financial Privacy Act, o legislativo age no vácuo ou devido ao não reconhecimento da "privacy" em certas áreas, como se infere de Fisher e Adler (2007, p. 946-947, 952-953).

${ }^{119}$ Ver Shimanek (2000-2001).

120 Ver Reidenberg (2001-2002) e Schriver (2001-2002). Sobre a intenção, até agora sem êxito, de estabelecer uma legislação básica padrão, ver Federal Trade Commission (2000) e Brown e Blevins (2002).
} 


\subsection{A solução atual.}

Em Julho de 1973, foi publicado nos Estados Unidos da América um relatório intitulado "Records, Computers and the Rights of Citizens", também conhecido como "HEW Report", elaborado pelo então formado "Comitê de Estudos sobre Sistemas Automatizados de Dados Pessoais" (Advisory Committee on Automated Personal Data Systems), a pedido do Secretário de Estado do Ministério da Saúde, Educação e Bem-Estar (Department of Health, Education and Welfare) ${ }^{121}$.

Seu objetivo era fornecer subsídios para um adequado tratamento das relações entre indivíduos e organizações de armazenamento de dados. Conforme o Prefácio, almejava-se responder à crescente preocupação sobre as conseqüências danosas que pudessem resultar da aplicação descontrolada de tecnologias de computação e telecomunicações para a coleta, armazenagem e uso de dados sobre cidadãos individuais.

Incumbia ao Comitê analisar e fazer recomendações sobre tais conseqüências danosas, como salvaguardas contra elas, medidas que pudessem trazer reparação ou retificação, e políticas e práticas relacionadas à emissão e uso de números da Seguridade Social $^{122}$.

Suas conclusões quanto ao tratamento de dados automatizados influenciaram a legislação que se seguiu, inclusive o Privacy Act, de 1974 (PRIVACILLA.ORG, 2001), e trouxeram uma série de recomendações, que deveriam ser positivadas através de um Código de Práticas de Boa Informação (Code of Fair Information Practice), a que se sujeitariam todos os sistemas automatizados de dados pessoais (Secretary of Health, Education and Welfare, 1973).

Os cinco princípios básicos do Código para assegurar adequação aos requisitos de “salvaguardas" são: (i) a proibição de bancos de dados pessoais cuja própria existência seja secreta; (ii) a existência de um meio que permita ao indivíduo descobrir quais informações suas estão em um registro e como são utilizadas; (iii) a existência de um meio para que o indivíduo possa evitar que informações sobre si obtidas para um certo propósito sejam

\footnotetext{
${ }^{121}$ Ver, dentre outros, Kambas (2002-2003).

122 Nos Estados Unidos da América, o número da Seguridade Social, um serviço federal, é um número nacional criado, inicialmente, para controlar a concessão e manutenção de seus benefícios, mas que, com o decorrer do tempo, através de leis e de usos e costumes, passou a ser usado como um identificador universal "de fato", devido às peculiaridades do federalismo lá, em que os Estados são dotados de grande margem de autonomia legislativa. Embora para muitos países, inclusive o Brasil, onde existe o CPF, seja normal a existência de um número de identidade único, que acompanha o indíviduo do nascimento à morte, tem-se o temor de se estabelecer um elemento de identificação dessa natureza, como se vê, dentre outros, em Hendricks, Hayden e Novik (1990).
} 
usadas ou disponibilizadas para outros objetivos sem o seu consentimento; (iv) a existência de um meio para o indivíduo corrigir ou melhorar um registro de informações identificáveis sobre si; e (v) a obrigação de qualquer organização que crie, mantenha, use ou dissemine registros de informações pessoais identificáveis de assegurar a confiabilidade dos dados para o seu propósito e de tomar precauções contra o seu mau uso.

Esse "Código" nunca foi transformado em lei, inexistindo, até hoje, uma lei geral de proteção de dados pessoais, à semelhança do que se implantou em vários países europeus, especialmente após as Diretivas específicas da União Européia. Ademais, não se percebe, aí, uma visão do tratamento de dados como algo possivelmente ligado às comunicações.

A privacidade de algumas comunicações era objeto do Título III do Omnibus Crime Control and Safe Streets Act, de 1968, alterado pelo Electronic Communications Privacy Act ("ECPA”), de 1986, aplicável aos setores público e privado.

O ECPA $^{123}$ é composto de três partes ${ }^{124}$ (MARTIN, 2006-2007; SOLOVE; ROTENBERG; SCHWARTZ, 2006): o Wiretap Act, o Stored Communications Act e o Pen Register Act, sendo que, em linhas gerais, o primeiro protege as comunicações "em trânsito", o segundo regula as armazenadas, e o terceiro, alguns outros dados específicos $^{125}$.

O parágrafo 2510 traz inúmeras definições aplicáveis à primeira e segunda partes do ECPA, sendo que as principais podem ser assim sintetizadas ${ }^{126}$ : (i) comunicação por

${ }^{123}$ O USA PATRIOT Improvement and Reauthorization Act, de 2005, tornou permanentes 14 das 16 alterações temporárias feitas pelo PATRIOT ACT, de 2001, que aumentou os poderes das autoridades. Ver Lee (2003) e Fisher e Adler (2007).

124 Codificadas, respectivamente, nos parágrafos 2510 a 2522, 2701 a 2712 e 3121 a 3127 do Título 18 do United States Code.

${ }^{125}$ Segundo Martin (2006-2007, p. 450), o "Pen Register Act" protege comunicações de "não-conteúdo", enquanto o "Stored Communications Act" protege tanto dados de conteúdo quanto de não-conteúdo armazenados.

${ }^{126}$ No original: "(1) 'wire communication' means any aural transfer made in whole or in part through the use of facilities for the transmission of communications by the aid of wire, cable, or other like connection between the point of origin and the point of reception (including the use of such connection in a switching station) furnished or operated by any person engaged in providing or operating such facilities for the transmission of interstate or foreign communications or communications affecting interstate or foreign commerce; (2) 'oral communication' means any oral communication uttered by a person exhibiting an expectation that such communication is not subject to interception under circumstances justifying such expectation, but such term does not include any electronic communication; [...] (4) 'intercept' means the aural or other acquisition of the contents of any wire, electronic, or oral communication through the use of any electronic, mechanical, or other device. [...] (8) 'contents', when used with respect to any wire, oral, or electronic communication, includes any information concerning the substance, purport, or meaning of that communication; [...] (12) 'electronic communication' means any transfer of signs, signals, writing, images, sounds, data, or intelligence of any nature transmitted in whole or in part by a wire, radio, electromagnetic, photoelectronic or photooptical system that affects interstate or foreign commerce, but does not include (A) any wire or oral communication; (B) any communication made through a tone-only paging device; (C) 
fio: qualquer transferência que contenha a voz humana em qualquer ponto realizada através do auxílio de fio, cabo ou outra conexão similar entre o ponto de origem e o ponto de recepção; (ii) comunicação oral: aquela feita por uma pessoa exibindo uma expectativa de que não seja interceptada sob circunstâncias que justifiquem tal expectativa, excluída qualquer comunicação eletrônica; (iii) comunicação eletrônica: qualquer transferência de signos, sinais, escritos, sons, imagens, informação ou inteligência de qualquer natureza transmitida no todo ou em parte por um sistema de fio, de rádio, eletromagnético, fotoeletrônico ou fotóptico, excluídas quaisquer comunicações por fio ou orais, as feitas por um sistema de "pager" por tom apenas, as advindas de um sistema de rastreamento, ou informações de transferências eletrônicas de fundos armazenadas por uma instituição financeira em sistema de comunicação que tenha por função o armazenamento e a transferência eletrônicos de fundos; (iv) armazenamento eletrônico: qualquer armazenamento temporário, intermediário, de uma comunicação por fio ou eletrônica incidental a essa própria comunicação, bem como qualquer armazenamento realizado por um serviço de comunicação eletrônica para o propósito de cópia de proteção da comunicação; (v) interceptação: a aquisição auditiva ou por outro modo do conteúdo de qualquer comunicação por fio, oral ou eletrônica através do uso de dispositivo eletrônico, mecânico ou outro; (vi) conteúdo: informação relativa à substância, propósito ou significado de uma comunicação por fio, oral ou eletrônica.

Em poucas palavras, essa Lei considera "wire communication" (comunicação por fio) qualquer transferência que contenha a voz humana em qualquer ponto entre o envio e a recepção, feita por cabo ou algo similar, no todo ou em parte; "oral communication" (comunicação oral), a transmissão de voz por uma pessoa que tenha expectativa razoável de não a ter captada por estranhos; e "electronic communications" (comunicações eletrônicas), as que não se encaixem nas duas primeiras definições, e nem na daquela vinda de um "tracking device" (dispositivo de rastreamento), conforme o parágrafo 3117 do Título 18 do United States Code.

Há várias exceções, que não constituem interceptação ilegal, como a que se dá em virtude da operação normal da prestação de um serviço de comunicação, ou então quando há consentimento de uma das partes, seja agindo sob autoridade legal ou não, exceto para o

any communication from a tracking device (as defined in section 3117 of this title); or (D) electronic funds transfer information stored by a financial institution in a communications system used for the electronic storage and transfer of funds; [...] (17) 'electronic storage' means - (A) any temporary, intermediate storage of a wire or electronic communication incidental to the electronic transmission thereof; and (B) any storage of such communication by an electronic communication service for purposes of backup protection of such communication; [...]". 
propósito de praticar crimes ou outros atos ilícitos.

São enumeradas as autoridades legitimadas a postular a interceptação, que pode ser pedida quando relacionada a uma vasta, diga-se, lista de crimes, em conformidade com o procedimento previsto no parágrafo 2518. Os pedidos devem ser formulados por escrito, fundamentadamente, sob juramento ou afirmação ("oath" ou “affirmation”), a um juiz competente, por uma autoridade legítima. A petição deve ser o mais detalhada possível em relação ao que se busca e à interceptação, indicando, inclusive, as autoridades que pleiteiam a medida e as que a autorizaram. Em situações excepcionais, o pedido pode ser feito posteriormente ao início das interceptações.

Cabe ao juiz determinar se há "causa provável” ("probable cause”) apta a permitir a instauração do procedimento, que só pode dar-se se outros métodos normais de investigação foram tentados, sem resultado, ou se razoavelmente não tiverem possibilidades de êxito, ou forem excessivamente perigosos.

As interceptações têm o prazo máximo de trinta dias, mas podem ser renovadas, seguindo-se o mesmo procedimento do primeiro pedido, e devem ser minimizadas as intrusões o máximo possível:

[...] O período de extensão não será maior do que o que o juiz autorizador considerar necessário para atingir os propósitos para os quais foi concedida [a interceptação] e em nenhuma circunstância maior do que trinta dias. Cada ordem e extensão sua deverá conter uma provisão de que a autorização para interceptar deverá ser executada o mais breve possível, de que será conduzida de modo a minimizar a interceptação de comunicações de nenhum modo sujeitas à interceptação sob este capítulo, e de que deve terminar com a consecução do objetivo autorizado, ou, em qualquer circunstância, dentro de trinta dias. [.... ${ }^{127}$.

De todo modo, elas devem ser gravadas e mantidas sob sigilo, bem como as petições que nelas resultaram, e preservadas por dez anos. As pessoas que forem seu objeto devem ser notificadas posteriormente, podendo até ter acesso às partes das comunicações a elas pertinentes.

Aqueles que violarem essas proibições ficam sujeitos a sanções civis e penais, e as evidências obtidas em violação ao Wiretap Act são protegidas pela "exclusionary rule", ou

\footnotetext{
${ }^{127}$ Parágrafo 2518(5) do Título 18 do United States Code (tradução nossa). No original: “[...] The period of extension shall be no longer than the authorizing judge deems necessary to achieve the purposes for which it was granted and in no event for longer than thirty days. Every order and extension thereof shall contain a provision that the authorization to intercept shall be executed as soon as practicable, shall be conducted in such a way as to minimize the interception of communications not otherwise subject to interception under this chapter, and must terminate upon attainment of the authorized objective, or in any event in thirty days. [...]".
} 
seja, o direito de excluí-las do processo $^{128}$ :

Sempre que qualquer comunicação por fio ou oral tiver sido interceptada, nenhuma parte de seu conteúdo e nenhuma evidência daí derivada pode ser recebida como prova em qualquer julgamento, audiência, ou qualquer outro procedimento em ou perante qualquer tribunal, grande júri, departamento, oficial, agência, órgão regulador, comitê legislativo, ou outra autoridade dos Estados Unidos, um Estado, ou uma subdivisão política sua se a divulgação dessa informação se der em violação deste capítulo ${ }^{129}$.

Todos os juízes e "general attorneys" devem informar ao Escritório Administrativo das Cortes dos Estados Unidos todos os pedidos concedidos e negados de interceptação, o qual, a seu turno, deve remeter ao Congresso, todo ano, um relatório consolidado.

Às comunicações por fio ou eletrônicas armazenadas, aplica-se o Stored Communications $\mathrm{Act}^{130}$. Mais precisamente, aplica-se às comunicações em “armazenamento eletrônico”, conforme definição do Wiretap Act.

A interceptação, aí, pode ser pedida por qualquer entidade governamental, e não necessariamente necessita de autorização judicial, podendo, por exemplo, ser uma intimação administrativa permitida por lei.

A ordem judicial só é indispensável se as comunicações estiverem armazenadas por menos de cento e oitenta dias, devendo a autoridade mostrar fatos específicos demonstrando que há fundamentos razoáveis de que seu conteúdo seja relevante para uma investigação criminal em andamento.

Vê-se, desse modo, que os requisitos são menos rigorosos que os do Wiretap Act (MARTIN, 2006-2007; SOLOVE; ROTENBERG; SCHWARTZ, 2006) ${ }^{131}$.

\footnotetext{
${ }^{128} \mathrm{~A}$ "exclusionary rule" refere-se à doutrina geral que exclui provas ilegalmente obtidas de julgamento, e é formada tanto pela jurisprudência quanto por ações do Legislativo e do Executivo (FISHER; ADLER, 2007, p. 744). Essa norma surgiu de julgados da Suprema Corte, principalmente nos casos Weeks v. United States, 232 U.S. 383 (1914) e Mapp v. Ohio, 367 U.S. 643 (1961), como se vê, ainda, em Doernberg (2005-2006). Ver também Garner (2007).

${ }^{129}$ Parágrafo 2515 do Título 18 do United States Code, tradução nossa. No original: "Whenever any wire or oral communication has been intercepted, no part of the contents of such communication and no evidence derived therefrom may be received in evidence in any trial, hearing, or other proceeding in or before any court, grand jury, department, officer, agency, regulatory body, legislative committee, or other authority of the United States, a State, or a political subdivision thereof if the disclosure of that information would be in violation of this chapter".

${ }^{130}$ O PATRIOT ACT mudou as comunicações por fio armazenadas para o Stored Communications Act, pois este é um pouco menos rígido que o Wiretap Act no tocante às autorizações para interceptação.

${ }^{131}$ Importante notar que a ampla definição de "interceptação", que corresponde à aquisição do conteúdo de qualquer das três modalidades de comunicação do Wiretap Act, por qualquer meio, não se restringe, a princípio, à captação contemporânea à transferência, mas o conceito de acesso a comunicação armazenada que se aplique a um caso concreto é determinante para se aplicar o regime do Wiretap Act ou do Stored Communication Act. A importância fica evidente, por exemplo, no caso do "e-mail", já que, tecnologicamente, é uma comunicação que se encontra "em trânsito" e "armazenada" desde o envio até o recebimento, pois vai sendo armazenada, ao menos temporariamente, ao longo do caminho até o destinatário. Ver Martin (2006-2007).
} 
Os prestadores de serviços de comunicações têm o dever de colaborar com as autoridades, sendo obrigados até, se requisitados, a gerar e manter cópias daquelas objeto da interceptação, e existe a regra geral de notificação do usuário ou consumidor, que pode ser postergada em certas hipóteses, principalmente quando puder prejudicar o andamento das investigações.

Dados concernentes aos usuários ou consumidores podem ser livremente divulgados a qualquer pessoa, exceto uma entidade governamental, desde que não se refiram ao conteúdo das comunicações ${ }^{132}$. Entidades governamentais podem obtê-las se o provedor do serviço entender que há risco sério à vida ou integridade física de alguém, ou, então, no concernente às seguintes informações relativas ao usuário ou consumidor, desde que exista uma intimação, judicial ou administrativa, por parte da autoridade, que nem precisa notificar o sujeito alvo da requisição: (i) nome; (ii) endereço; (iii) registros das ligações telefônicas, ou dos horários e duração das conexões; (iv) duração e tipos de serviço utilizados; (v) número de identificação, inclusive aqueles temporários atribuídos em redes; e (vi) meio e origem de pagamento, incluindo números de cartão de crédito ou conta bancária.

O Stored Communications Act traz, também, penalidades civis e penais para os infratores da lei, mas não a "exclusionary rule", e exime de responsabilidade o provedor de serviços por quaisquer informações por ele prestadas em virtude de ordens judiciais, administrativas, autorizações legais ou certificações emitidas de acordo com ele.

O Pen Register Act, por sua vez, regula os "pen registers" e "trap and trace devices" conforme definidos no parágrafo 3127(3) e (4) do Tìtulo 18 do United States Code. "Pen registers" são equipamentos ou processos que revelam números de telefone discados, endereços na Internet, informações de roteamento, enfim, elementos de identificação daquele que origina a transmissão, dados que "saem" de um ponto, enquanto "trap and trace devices" referem-se a dados desse tipo que "chegam", excluído o conteúdo das comunicações. O governo só precisa certificar que essas informações são relevantes para uma investigação em andamento ${ }^{133}$.

Também prevê penalidades civis e penais, mas, assim como o Stored Communications Act, não traz a "exclusionary rule" e exime os provedores de serviço de responsabilidade por informações ou assistência prestadas de conformidade com a Lei ${ }^{134}$.

\footnotetext{
${ }^{132}$ Conforme o parágrafo 2702(c)(6) do Título 18 do United States Code.

${ }^{133}$ Parágrafo 3123(a)(1) do Tìtulo 18 do United States Code.

${ }^{134}$ Conforme parágrafo 3124 (d) do Título 18 do United States Code.
} 
Enfim, no conjunto, o ECPA, notadamente após as modificações feitas pelo USA PATRIOT ACT, contém tantas exceções e isenções que as autoridades públicas podem ter acesso a praticamente quaisquer informações concernentes a comunicações, tanto ao conteúdo quanto a seus dados de identificação, existindo incentivo, e, de certa forma, obrigação por parte dos provedores de serviços de comunicações de colaborar com o governo e denunciar possíveis ilícitos, amparados pela isenção de responsabilidade por dados passados de acordo com a Lei, sendo que a "exclusionary rule" só existe para as hipóteses do Wiretap Act.

Veja-se, por exemplo, que há uma "válvula de escape" no parágrafo 2517(5) do Título 18 do United States Code, que permite o uso e divulgação de informações a outras autoridades a respeito de crimes outros que não o do objeto da autorização da interceptação, sem restrições, que pode abranger, a princípio, até aqueles não enumerados no extenso parágrafo 2516.

Isso além do Foreing Intelligence Surveillance Act, de 1978, conhecido como FISA, que se tornou "super abrangente" com as modifcações do USA PATRIOT ACT, de 2001, a ponto de permitir escutas remotas em massa, mesmo de cidadãos estadunidenses $^{135}$.

A União Européia, após a entrada em vigor da Diretiva 95/46/CE, que exige níveis mínimos de proteção da privacidade dos dados pessoais para permitir o seu fluxo internacional, viu-se obrigada a construir uma solução, mais política do que jurídica, com os Estados Unidos da América, e, pensamos, de certa maneira, inócua.

Havia o temor de uma interrupção dessas transferências de dados pela falta de "proteção adequada" no ordenamento jurídico norte-americano, requisito estabelecido no artigo 25 dessa Diretiva.

O Departamento de Comércio (Department of Commerce) dos Estados Unidos iniciou, então, em 1998, com a União Européia, negociações para que fosse criado um "porto seguro" ("safe harbor", em inglês) a que as empresas pudessem aderir e, dessa forma, continuar a trocar dados com os países da Comunidade, mesmo que a proteção aos dados pessoais provida pela legislação do país fosse considerada "inadequada", para efeitos da Diretiva, pela Comissão Européia (“U.S...., 2001) ${ }^{136}$.

Em 26 de julho de 2000, a Comissão aprovou os princípios do Safe Harbor e

\footnotetext{
${ }^{135}$ Ver a respeito, dentre outros, Solove, Rotenberg e Schwartz (2006).

${ }^{136}$ Mais sobre o processo de negociação que levou ao Safe Harbor e discussão a seu respeito em Brown e Blevins (2002), Kambas (2002-2003), Regan (2003), Schriver (2001-2002), Shimanek (2000-2001), Soma, Rynerson e Beall-Eder (2003-2004) e Sunosky (2000).
} 
respectivas questões mais freqüentes ("FAQ") emitidos pelo Department of Commerce dos Estados Unidos, decisão 2000/520/CE ${ }^{137}$, apesar de vários pareceres desfavoráveis do Grupo de Trabalho do Artigo $29^{138}$ (1999; 2000) e preocupações do Parlamento Europeu, traduzidas na Resolução A5-0177/2000 ${ }^{139}$.

Pelo Safe Harbor não ter natureza normativa, não sendo também um tratado, mas um acordo político, mostra-se um meio de proteção fraco, pois não é propriamente (juridicamente) coercitivo. Além disso, aplica-se somente a transferências que se dêem entre os Estados Unidos da América e a União Européia, não incidindo sobre as internas e as com terceiros países.

A adesão é voluntária e se efetua por uma "autocertificação" feita pela “organização" junto ao Department of Commerce, que deve ser renovada, pelo menos, uma vez por ano, declarando a adesão aos princípios do Safe Harbor e sua política de privacidade. O Department compromete-se a manter uma lista pública atualizada dessas organizações participantes $^{140}$.

Os princípios que devem ser implementados, análogos aos da Diretiva 95/46/CE, são sete: (i) aviso; (ii) escolha; (iii) retransferência; (iv) segurança; (v) integridade dos dados; (vi) acesso; e (vii) aplicação.

"Aviso" significa que os indivíduos devem ser informados

[...] quanto aos fins a que se destinam a recolha e utilização dos dados que lhes dizem respeito, à forma de contactar a organização para qualquer questão ou queixa, aos tipos de terceiros a quem a informação é comunicada e às opções e meios que a organização coloca à disposição dos cidadãos para limitarem a utilização e comunicação desses dados ${ }^{141}$.

“Escolha" importa na faculdade atribuída às pessoas de escolha ("opt out", direito de "sair", de não participação) quanto à divulgação de seus dados a terceiros ou para fins incompatíveis com os autorizados, e de exigência de afirmação explícita (“opt in”) para o tratamento de "dados sensíveis", quais sejam, "informações pessoais relativas a condições de saúde ou doenças, origem racial ou étnica, opiniões políticas, crenças religiosas ou filosóficas, pertença a sindicatos ou informações relativas à vida sexual da pessoa"142 ${ }^{\text {. }}$

A opção deve ser assegurada a qualquer momento, devendo as organizações ter

\footnotetext{
${ }^{137}$ Publicada no JO L 215 de 25 de agosto de 2000, p. 7.

${ }^{138}$ Em referência ao Grupo criado pelo artigo 29 da Diretiva 95/46/CE.

${ }^{139}$ Publicada no JOCE C 121/152-156, de 24 de abril de 2001.

${ }^{140}$ FAQ 6 do Safe Harbor.

141 Safe Harbor.

${ }^{142}$ Safe Harbor.
} 
prazos razoáveis para implementá-las ${ }^{143}$.

$\mathrm{Na}$ "retransferência", conforme descrito no Safe Harbor,

[...] as organizações só o poderão fazer na condição de se certificar de que a parte terceira subscreve os princípios de "porto seguro", cumpre as disposições da directiva ou outras disposições adequadas, e de estabelecer um acordo escrito com esse terceiro, exigindo que este garanta, pelo menos, o mesmo nível de protecção da vida privada requerido pelos princípios pertinentes. Se a organização cumprir estes requisitos, não será responsável (salvo quando estabeleça um acordo em contrário) pelo tratamento da informação transferida realizado por terceiros, que viole os limites ou as normas estabelecidas, a menos que a organização tenha conhecimento ou devesse ter conhecimento de que o terceiro processaria a informação de forma contrária aos princípios e não tome quaisquer medidas razoáveis para evitar ou pôr fim a esse tratamento da informação.

Essa disposição fragiliza mais ainda o acordo, pois se a autocertificação e a declaração de política de privacidade é o que atrai a competência fiscalizatória da Federal Trade Comission (FTC) nos casos da lei, a transferência a terceiro que simplesmente se comprometa a assegurar nível equivalente de proteção passa ao âmbito estritamente contratual, alheia ao indivíduo a que se referem aos dados e à supervisão governamental ${ }^{144}$.

O quarto princípio é o da "segurança":

As organizações que criam, mantêm, utilizam ou divulgam ficheiros de informações pessoais devem tomar precauções razoáveis para evitar a perda, utilização indevida e acesso, revelação, alteração ou destruição não $\operatorname{autorizados}^{145}$.

Deve ser assegurada a "integridade dos dados" (quinto princípio) ${ }^{146}$, bem como o “acesso" a eles (sexto), que significa a faculdade da pessoa ratificar, alterar ou eliminar informações inexatas,

[...] salvo se os encargos ou as despesas para facultar esse acesso forem desproporcionados em relação aos riscos para a vida privada da pessoa em causa, ou sempre que os legítimos direitos de terceiros incorram em risco de violação $^{147}$.

O último é o da "aplicação", tradução lusitana não muito adequada do vocábulo inglês "enforcement", que significa "fazer valer", ou seja, efetivamente aplicar a lei. Ele determina a existência de mecanismos

\footnotetext{
${ }^{143}$ FAQ 12 do Safe Harbor.

${ }^{144}$ De acordo com o Grupo de Trabalho do Artigo 29 (2000), "[e]sta abordagem é incoerente com as regras gerais estabelecidas de garantia de aplicação e de responsabilização das organizações abrangidas pelo 'porto seguro'. [...] nestas condições as re-transferências só deveriam ser permitidas com o consentimento da pessoa em causa".

145 Safe Harbor.

${ }^{146}$ Isto é, eles devem ser confiáveis, exatos, completos e atuais.

${ }^{147}$ Safe Harbor.
} 
[...] que garantam o cumprimento dos princípios de "porto seguro", recursos para os cidadãos a que se referem os dados e que tenham sido afectados pelo incumprimento dos princípios, bem como consequências para as organizações sempre que os princípios não sejam seguidos. Estes mecanismos devem incluir, no mínimo: a) mecanismos de recurso independentes, imediatamente disponíveis e pouco onerosos através dos quais as queixas e os litígios dos cidadãos possam ser investigados e resolvidos e os danos reparados sempre que a lei aplicável ou as iniciativas privadas o prevejam, b) procedimentos de acompanhamento para indagar da veracidade das atestações e alegações das empresas em relação às suas práticas em matéria de protecção da vida privada e para verificar se essas práticas relativas à vida privada foram executadas da forma apresentada, e c) a obrigação de solucionar problemas decorrentes do incumprimento dos princípios por organizações que tenham anunciado a sua adesão e consequências para essas organizações. As sanções devem ser suficientemente rigorosas de modo a garantirem o cumprimento por parte das organizações ${ }^{148}$.

A verificação (requisito "b”) é feita pela própria organização, numa espécie de auto-avaliação ou autocertificação, ou por entidades externas, que devem atestar a conformidade de sua política com o Safe Harbor, de acordo com seu FAQ $7^{149}$. Os requisitos "a" e "c" podem ser cumpridos se a organização comprometer-se, em sua declaração à FTC, a cooperar com as autoridades européias de proteção de dados, nos termos do FAQ 5, ou, então, de qualquer outro mecanismo, vinculativo, como explicado no FAQ 11 do Safe Harbor.

Os mecanismos de controle devem notificar, se for o caso, a autoridade respectiva e o Department of Commerce, sempre que tenha notícia de violações aos princípios do Safe Harbor. Uma organização pode perder os benefícios do acordo e ser removida da lista do FTC por seu "incumprimento persistente"150.

Vê-se, do conjunto, que o Safe Harbor é quase um código de "boas práticas" de tratamento de dados pessoais nos Estados Unidos em relação a transferências da União Européia, a fim de buscar assegurar a observância das regras de privacidade estabelecidas pelas regras comunitárias ${ }^{151}$.

A autoridade da FTC não advém de uma competência legal para proteger a "vida privada" dos indivíduos, mas, no caso, da possibilidade que tem de investigar, processar e punir organizações de caráter comercial que desrespeitem o por elas declarado quanto a

\footnotetext{
${ }^{148}$ Safe Harbor. Como ainda explica o seu FAQ 11, "[a]s sanções devem incluir tanto a publicação de casos de incumprimento como a supressão de dados, em determinadas circunstâncias. Outras sanções podem consistir na suspensão ou retirada de autorização, em compensações a pessoas que sofram perdas decorrentes de não conformidade e injunções".

149 Através da adesão, por exemplo, a "selos" ou órgãos de auto-regulação que atestam a observância, por parte de seus membros, dos princípios do acordo, como a TRUSTe. Críticas a esses "selos" são feitas por Reidenberg (2001-2002) e Dhont et al. (2004), devido a falhas e deficiências.

${ }^{150}$ FAQ 11 do Safe Harbor.

${ }^{151}$ Ver Sunosky (2000).
} 
suas políticas de privacidade, enquadrando essa conduta no parágrafo 5 do Federal Trade Commission Act, consolidado no Título 15 United States Code, parágrafos 41-58, mais especificamente no parágrafo 45(a)(1), que dispõe: “[m]étodos injustos de competição no ou afetando o comércio e práticas ou atos injustos ou enganosos no ou afetando o comércio são declarados ilegais" $" 152$.

Conforme o Anexo III da Decisão 2000/520/CE da Comissão Européia:

No exercício da autoridade que lhe incumbe por força da Section 5, a FTC considera prática enganosa a prestação ao consumidor de informação falsa ou incorrecta sobre as finalidades da recolha de dados no consumidor ou a sua utilização.

Logo, como já afirmado, a primeira e mais evidente limitação da atuação da FTC concerne às hipóteses de ausência de qualquer declaração da empresa quanto à coleta de dados pessoais, ou então quando não haja declaração falsa ou enganosa ${ }^{153}{ }^{154}$. Outra se refere à falta de competência da FTC para averiguar atos que não afetem o comércio, “[...] a recolha e o uso de informação pessoal para fins não comerciais, como os relacionados com a angariação de fundos para instituições de solidariedade social, por exemplo"155.

Também não são abarcados pela $\mathrm{FTC}^{156}$ : (i) instituições financeiras, incluindo bancos, instituições de poupança e crédito e cooperativas de crédito $^{157}$; (ii) redes de telecomunicações e sociedades de transportes interestaduais; (iii) transportadoras aéreas; e (iv) carregadores e entrepostos. A FTC, dentro desses limites, pode tomar medidas $\operatorname{administrativas}^{158}$, civis $^{159}$ e penais ${ }^{160}$.

O Department of Transportation, a única outra autoridade governamental

\footnotetext{
${ }^{152}$ No original: "[u]nfair methods of competition in or affecting commerce, and unfair or deceptive acts or practices in or affecting commerce, are hereby declared unlawful”.

${ }^{153}$ Ver Anexo III da referida Decisão 2000/520/CE.

${ }^{154}$ A FTC inclusive agiu contra algumas companhias que violaram sua própria política de "privacy", embora, como relata Schriver, tenham terminado em acordo até 2002 (2001-2002, p. 2800-2803). Esse fato é corroborado por uma pesquisa no "site" da entidade, que relata outros 18 casos de 2002 a 2008 relacionados à "privacy" de informações de consumidores, todos terminados com acordos, como se vê em <http://www.ftc.gov/privacy/privacyinitiatives/promises_enf.html>. Acesso em: 2 dez. 2008. DiLascio ainda nota que os casos referidos pela FTC nas negociações do Safe Harbor junto à União Européia para afirmar a sua competência terminaram em acordos nos quais não ficou expresso a reparação por danos causados aos consumidores individuais (2004, p. 421-423).

${ }_{155}^{15}$ Anexo III da Decisão 2000/520/CE. Ver, também, Soma, Rynerson e Beall-Eder (2003-2004, p. 208).

${ }^{156}$ Ver Título 15 do United States Code, parágrafo 45(a)(2), e Anexo III da Decisão 2000/520/CE.

${ }^{157}$ Ver Tallman (2002-2003).

158 Tais como decisões ou normas administrativas. Ver Anexo III da Decisão 2000/520/CE.

${ }^{159}$ Restrições ou proibições temporárias ou permanentes. Ver Anexo III da Decisão 2000/520/CE e 15 U.S.C. parágrafo 53(b).

${ }^{160} \mathrm{O}$ descumprimento da empresa às declarações públicas referentes à política de tratamento de dados pessoais pode levar, assim, a processo por "declarações falsas" do Título 18 do United States Code, parágrafo 1001(a)(2). Ver FAQs 6 e 11 do Safe Harbor.
} 
reconhecida pelo Safe Harbor, só abrange as companhias de transporte aéreo, e segundo o Anexo III da Decisão 2000/520/CE, nunca exerceu sua competência para proteção da vida privada dos usuários, embora “[...] o 'Secretary of Transportation' [esteja] autorizado a tomar medidas para 'evitar práticas desleais, desonestas, predatórias ou anticoncorrenciais nos transportes aéreos'[...]".

Além disso, o Safe Harbor aplica-se somente aos consumidores que se encontram na União Européia, deixando de fora todos os outros, inclusive os norte-americanos ${ }^{161}$, o que ensejou inúmeros artigos jurídicos sobre o tema, até mesmo sobre discriminações no comércio mundial que podem eventualmente ser levadas à Organização Mundial do Comércio, como discute, por exemplo, Reidenberg (2001-2002) e Shapiro (2002-2003).

O sistema de aplicação (“enforcement”) do acordo também é confuso e dúbio, pois depende da vontade das empresas a ele aderentes e dos mecanismos de resolução de controvérsia, sejam internos ou externos, assim como de vontade institucional da FTC para fiscalizar e sancionar os violadores, a partir de denúncias da União Européia, seus países, consumidores ou terceiros, e mesmo que a empresa venha a ser eventualmente excluída do Safe Harbor, pode continuar trocando dados por meio das isenções ou das garantias prestadas na forma do artigo 26, número 2, da Diretiva 95/46/CE ${ }^{162}$.

Por fim, o próprio acordo prevê sua derrogação

[...] por legislação, regulamento governamental ou jurisprudência que criam obrigações contraditórias ou autorizações explícitas, desde que, no exercício de tal autorização, uma organização possa demonstrar que o seu incumprimento dos princípios se limita ao necessário para respeitar os legítimos interesses superiores avançados por essa autorização $[\ldots]^{163}$.

O Anexo IV da Decisão 2000/520/CE insinua uma restrição às “autorizações explícitas” do legislador pátrio, mas, logo em seguida, alinhado com o Anexo I, afirma que mesmo "regulamento" ou "decisão judicial” constituem exceções, sem grandes considerações quanto à abrangência.

Disso tudo, verifica-se que o Safe Harbor é uma solução só para os Estados Unidos da América quanto a transferências de dados pessoais de residentes da União Européia, relativas a operações comerciais, aplicável apenas no âmbito de competência da FTC e do Department of Transportation, tudo nesses estritos limites ${ }^{164}$.

\footnotetext{
${ }^{161}$ Reidenberg (2001-2002, p. 740-741) e Soma, Rynerson e Beall-Eder (2003-2004, p. 207-208) apontam ser discutível a competência da FTC para fiscalizar negócios com o exterior ou consumidores estrangeiros.

${ }^{162}$ Ver DiLascio (2004) e Grupo de Trabalho do Artigo 29 (1999, 2000, 2003a).

${ }^{163}$ Ver Anexo I da Decisão 2000/520/CE.

${ }^{164}$ Ver mais sobre o Safe Harbor, inclusive sobre seus limites, em Heimes (2002), Regan (2003), Reidenberg
} 
(2001-2002) e Sunosky (2000). Destaque para o estudo encomendado pela Comissão Européia sobre a implementação do Safe Harbor (DHONT ET AL., 2004), que conclui, em síntese, quanto aos princípios: (i) as políticas de "privacy" e os avisos careciam de transparência e clareza; (ii) a escolha não era claramente mencionada ou faltava inteiramente; (iii) no tocante à retransferência, o "status" do terceiro ("third party") não era claro, e, conseqüentemente, as suas responsabilidades; (iv) certas empresas pesquisadas não informaram a adoção de qualquer medida de segurança quanto aos dados; (v) em relação à integridade dos dados, a sua relevância para o uso pretendido era difícil de determinar, já que "propósito", "tipo de dado" ou as "atividades" conduzidas não eram especificadas ou claramente formuladas; (vi) o "acesso" tendia a ser fracamente implementado, pois cingia-se a informações limitadas ou de contato, inexistindo, também, no geral, notícia sobre acessibilidade econômica (“affordability”) (p. 105-106). A autocertificação junto à FTC apresentava as mais variadas respostas, inclusive informações quanto à competência dela para supervisionar dados concernentes a recursos humanos (a qual é, no mínimo, dúbia) e adesão a programas que não eram exatamente de "privacy" (p. 106). A maioria das empresas, quanto à aplicação ("enforcement"), garantiam cooperação com o Painel da Autoridade de Dados Pessoais, consoante o FAQ 11 do acordo, mas não asseguravam observância de suas decisões, nem a publicidade de suas decisões e de outros aspectos (p. 107). Por fim, os programas de "privacy" então analisados não incorporavam todos os princípios do Acordo ou incorporavam alguns deles deficientemente (p. 107). 


\title{
4. A PRIVACIDADE NAS COMUNICAÇÕES ELETRÔNICAS NO ÂMBITO EUROPEU.
}

\subsection{Uma passagem breve pelo desenvolvimento da "privacidade".}

$\mathrm{Na}$ Europa, o principal documento internacional de proteção do direito à "privacidade" é a Convenção Européia de Direitos Humanos, mais especificamente o artigo $8^{\circ}$, celebrado no seio do Conselho da Europa, cuja redação é a seguinte:

\begin{abstract}
Artigo $8^{\circ}$. Direito ao respeito pela vida privada e familiar
1. Qualquer pessoa tem direito ao respeito da sua vida privada e familiar, do seu domicílio e da sua correspondência.

2. Não pode haver ingerência da autoridade pública no exercício deste direito senão quando esta ingerência estiver prevista na lei e constituir uma providência que, numa sociedade democrática, seja necessária para a segurança nacional, para a segurança pública, para o bem-estar económico do país, a defesa da ordem e a prevenção das infracções penais, a protecção da saúde ou da moral, ou a protecção dos direitos e das liberdades de terceiros ${ }^{165}$.
\end{abstract}

Ainda no tocante à "privacidade", costuma-se aplicar, especificamente no setor da imprensa (liberdade de expressão), o artigo 10 do mesmo diploma:

\begin{abstract}
Artigo $10^{\circ}$ Liberdade de expressão
1. Qualquer pessoa tem direito à liberdade de expressão. Este direito compreende a liberdade de opinião e a liberdade de receber ou de transmitir informações ou ideias sem que possa haver ingerência de quaisquer autoridades públicas e sem considerações de fronteiras. O presente artigo não impede que os Estados submetam as empresas de radiodifusão, de cinematografia ou de televisão a um regime de autorização prévia.
\end{abstract}

2. O exercício desta liberdades, porquanto implica deveres e responsabilidades, pode ser submetido a certas formalidades, condições, restrições ou sanções, previstas pela lei, que constituam providências necessárias, numa sociedade democrática, para a segurança nacional, a integridade territorial ou a segurança pública, a defesa da ordem e a prevenção do crime, a protecção da saúde ou da moral, a protecção da honra ou dos direitos de outrem, para impedir a divulgação de informações confidenciais, ou para garantir a autoridade e a imparcialidade do poder judicial.

A Resolução 428/1970 da Assembléia Parlamentar do Conselho da Europa, contendo uma declaração sobre os meios de comunicação em massa e os direitos humanos

\footnotetext{
${ }^{165}$ Segundo Moutouh e Rivero (2003a, tomo I, p. 80-81), a originalidade dessa Convenção reside no fato de, após definir com precisão os direitos que protege, indica seus limites, tanto gerais, no artigo 15 , quanto maiores e específicos, nos artigos $8^{\circ}, 10$ e 11 e no artigo $2^{\circ}$ do Protocolo ${ }^{\circ} 4$, permitindo um equilíbrio necessário entre os direitos individuais e os interesses da sociedade democrática com que podem entrar em conflito.
} 
("containing a declaration on mass communication media and human rights"), além de reconhecer explicitamente um "right to privacy" $" 166$, conforme o seu cabeçalho "C" e seu item 1 , traz a seguinte definição:

[...] O direito à privacidade consiste essencialmente no direito de viver a própria vida com um mínimo de interferência. Ele concerne a vida privada, familiar e doméstica, a integridade física e moral, a honra e reputação, a evitação de ser posto sob falsa luz, a não revelação de fatos irrelevantes e embaraçosos, a publicação não autorizada de fotografias privadas, a proteção contra o mau uso de comunicações privadas, a proteção contra a divulgação de informação passada ou recebida pelo indivíduo confidencialmente. Aqueles que, por suas próprias ações, tiverem encorajado revelações indiscretas sobre as quais reclamem mais tarde não podem valer-se do direito à privacidade ${ }^{167}$.

Reconhece a necessidade de se enfrentar o problema de informações obtidas por dispositivos tecnológicos "modernos", como "grampeamento" de linhas, microfones escondidos e o uso de computadores, que infringem o direito à "privacy"168, e determina que onde se constituam bancos de dados computacionias regionais, nacionais ou internacionais, o indivíduo não deve tornar-se totalmente exposto e transparente pelo acúmulo de informações relativas até mesmo à sua vida privada, devendo os dados serem apenas os necessários para propósitos de tributação, sistemas de pensão e seguridade social e outros ${ }^{169}$. Além disso, dispõe que a lei deve proteger esses direitos do indivíduo, não só contra as autoridades, mas contra pessoas "privadas" ou instituições, inclusive a mídia de $\operatorname{massa}^{170}$.

Por sua vez, a Resolução 1165/1998 da Assembléia Parlamentar do Conselho da Europa acrescenta à definição de "right to privacy" da Resolução 428/1970 o direito de controlar os próprios dados (ou informações), em virtude das "novas" tecnologias de comunicação que permitem o armazenamento e uso de dados pessoais ${ }^{171}$.

166 O "right of privacy" decorrente do artigo $8^{\circ}$ da Convenção é reconhecido em várias Resoluções e Recomendações da Assembléia, sendo temerário tentar enumerar todas. Essa Resolução 428/1970 não é o primeiro documento no âmbito do Conselho da Europa a mencioná-lo, pois, por exemplo, a Recomendação 509/1968 já o fizera no seu item 3. Note-se que a versão original oficial em francês refere-se a "droit au respect de la vie privée".

167 "C", item 2, da Resolução 428/1970 (tradução nossa). No original: “[...] The right to privacy consists essentially in the right to live one's own life with a minimum of interference. It concerns private, family and home life, physical and moral integrity, honour and reputation, avoidance of being placed in a false light, non-revelation of irrelevant and embarrassing facts, unauthorised publication of private photographs, protection against misuse of private communications, protection from disclosure of information given or received by the individual confidentially. Those who, by their own actions, have encouraged indiscreet revelations about which they complain later on, cannot avail themselves of the right to privacy".

168 “C”, item 4, da Resolução 428/1970.

169 “C", item 5, da Resolução 428/1970.

170 “C”, itens 5 e 6, da Resolução 428/1970.

${ }^{171}$ Item 5. No original: "[...] In view of the new communication technologies which make it possible to store and use personal data, the right to control one's own data should be added to this definition". 
A Resolução 1120/1997, sobre o impacto das novas tecnologias de comunicação e informação na democracia ("on the impact of the new communication and information technologies on democracy”), conclama os Estados-Membros a adotar várias medidas, dentre elas, no plano legal, a de evitar a introdução de regras complexas e impraticáveis que possam obstaculizar o desenvolvimento das novas tecnologias de informação, e, em caso de necessidade de regulação, de se valer do princípio da proporcionalidade para estabelecer regras que atinjam um adequado equilíbrio entre as medidas que se adotem e os objetivos perseguidos, entre o respeito às liberdades ("freedoms"), a proteção da "privacy" e a luta contra o crime ${ }^{172}$.

De grande importância e influência no desenvolvimento do conceito de "privacy" e sua proteção é a jurisprudência da Corte Européia de Direitos Humanos, notadamente na aplicação dos artigos $8^{\circ}$ e 10 da Convenção Européia.

Alguns dos julgados lembram-nos opiniões da Suprema Corte dos Estados Unidos da América quanto ao que constitui violação da vida privada, como em DUDGEON v. THE UNITED KINGDOM ${ }^{173}$ e MODINOS v. CYPRUS ${ }^{174}$, em que foram considerados ilegais dispositivos que criminalizavam a prática consensual de relações sexuais entre homens adultos, e, dentre outros, HALFORD v. THE UNITED KINGDOM ${ }^{175}$, PERRY v. THE UNITED KINGDOM ${ }^{176}$ e PEEV v. BULGARIA ${ }^{177}$, em que há menção a um "teste” de "razoável expectativa de privacidade".

Em DUDGEON v. THE UNITED KINGDOM, a Corte entendeu que, embora diferenças sociais e culturais possam originar e permitir legislações diferentes em certos países e proibi-las em outros, a criminalização de condutas homossexuais, até mesmo em privado, é desproporcional ao fim almejado de proteção moral, não sendo "necessário numa sociedade democrática”. A Corte confirmou entendimento de que o requisito "necessidade" é diretamente vinculado a "sociedade democrática".

Em KLASS AND OTHERS v. GERMANY ${ }^{178}$, vários cidadãos impugnaram leis da então República Federal da Alemanha que instituíram a possibilidade de monitoramento

\footnotetext{
172 Item 4, I, "b".

${ }^{173}$ Application 7525/76, julgado pelo Plenário em 22 de Outubro de 1981. Todos os casos da Corte Européia de Direitos Humanos foram retirados do seu "site": < http://www.echr.coe.int/ECHR/EN/Header/CaseLaw/HUDOC/HUDOC+database/>. Acessado em diversas datas de 2008.

${ }^{174}$ Application 15070/89, julgado pela Câmara em 22 de abril de 1993.

175 Application 20605/92, julgado pela Câmara em 25 de junho de 1997.

${ }^{176}$ Application 63737/00, julgado pela Terceira Seção em 17 de julho de 2003, decisão tornada definitiva em 17 de outubro de 2003.

177 Application 64209/01, julgado pela Quinta Seção em 26 de julho de 2007, decisão tornada definitiva em 26 de outubro de 2007.

${ }^{178}$ Application 5029/71, julgado pelo Plenário em 6 de setembro de 1978.
} 
secreto de correspondência e telecomunicações.

A Corte entendeu que tal legislação aplicava-se a situações bastante restritas, como crimes, tipificados no Código Criminal, contra a paz ou segurança do Estado, a ordem democrática, a segurança externa e a segurança das tropas aliadas lá estacionadas, desde que não houvesse possibilidade ou chance de sucesso de emprego de outro método, e providenciava as contramedidas assecuratórias adequadas, como, por exemplo, a notificação posterior do alvo do monitoramento pelas autoridades, desde que não pusesse em risco o propósito desse monitoramento ${ }^{179}$, e a necessidade de autorização por certas autoridades específicas do alto escalão. Apesar de essa legislação excluir da apreciação do Poder Judiciário a possibilidade de contestar o monitoramento, substituindo-o por uma Comissão composta por pessoas eleitas pelo povo, a Corte entendeu não ter havido violação do artigo $8^{\circ}$ da Convenção.

Pouco depois, veio o caso de MALONE v. THE UNITED KINGDOM ${ }^{180}$, considerado, no âmbito do Conselho da Europa, um dos precedentes fundamentais na proteção da vida privada.

O reclamante, Malone, alegou que a polícia interceptara clandestinamente suas correspondências e conversas telefônicas, sem seu consentimento ou conhecimento, bem como todos os números discados do seu telefone e o horário e duração das chamadas, através de um aparelho de "metering". A polícia confirmou apenas uma interceptação telefônica, que teria sido feita sob autorização ("warrant", mandado) do Secretário de Estado.

Após traçar um histórico dos procedimentos de interceptação das comunicações (correspondência e telefônica) na Inglaterra e País de Gales, a Corte, restringindo sua análise ao arcabouço legislativo quanto às interceptações efetuadas pela ou em nome da polícia dentro de um contexto geral de investigações criminais, e não ligadas a outros serviços como seguridade social ou controle aduaneiro, passou à análise de sua conformidade com o texto da Convenção Européia.

Primeiro, quanto ao cumprimento da expressão "de acordo com a lei”, do parágrafo $2^{\circ}$ do artigo $8^{\circ}$, explicou que o termo "lei" ("law" ou "loi", respectivamente, nas versões oficiais em inglês e francês do tratado) refere-se tanto a lei escrita quanto a não escrita, e deve fazer parte da ordem jurídica doméstica.

\footnotetext{
${ }^{179}$ A proibição irrestrita de notificação fora derrubada pela Corte Constitucional Federal da Alemanha, segundo consta desse mesmo acórdão.

${ }^{180}$ Application 8691/79, julgado pelo Plenário da Corte, em 2 de agosto de 1984.
} 
Essa "lei" deve ser, ainda, de qualidade compatível com o Estado de Direito (ou "rule of law"), importando na existência de certa proteção legal do indivíduo contra interferências arbitrárias por parte de autoridades públicas nos direitos salvaguardados pelo parágrafo $2^{\circ}$ do artigo $8^{\circ}$ da Convenção, especialmente quando existe um poder que pode ser exercido secretamente.

Mais ainda, tal lei deve ter duas propriedades: deve ser razoavelmente acessível, no sentido de permitir ao indivíduo o entendimento de sua aplicabilidade em dado caso; e deve ser razoavelmente precisa para permitir ao indivíduo regular sua conduta, isto é, deve permitir-lhe prever, se necessário, com aviso prévio, com certo grau de certeza, as conseqüências que sua conduta pode trazer-lhe ${ }^{181}$.

A Corte considerou que a lei da Inglaterra e de Gales não era suficientemente clara e precisa quanto às interceptações, não conferindo aos cidadãos a mínima proteção legal a que fazem jus sob um Estado de Direito numa sociedade democrática ${ }^{182}$, posto que, embora sejam necessárias para combater a criminalidade, devem trazer garantias contra abuso.

Quanto ao "metering", a Corte chegou à conclusão de que a liberação de tais dados, obtidos desse modo, principalmente os números discados, para a polícia, sem o consentimento do titular, interfere em um direito assegurado pelo artigo $8^{\circ}$ da Convenção ${ }^{183}$, e que a prática de o Correio fornecer às autoridades policiais tais informações voluntariamente, sem base legal, embora também não proibida por qualquer

\footnotetext{
${ }^{181}$ Considerações sobre tais qualidades da "lei" foram expendidas, inicialmente, no caso de THE SUNDAY TIMES v. THE UNITED KINGDOM, Application no. 6538/74, julgado pelo Plenário em 26 de abril de 1979, que tratava da figura do "contempt of court". Constou do parágrafo 47 aquele acórdão: "[...] a Corte não atribui importância aqui ao fato de que o 'contempt of court' [punição ao desrespeito à decisão de um juiz] seja uma criatura da 'common law' e não da legislação. Seria claramente contrário à intenção dos elaboradores da Convenção entender que uma restrição imposta em virtude da 'common law' não seja 'prescrita pela lei' com o só fundamento de que não está enunciada em legislação: isso privaria um Estado de 'common law' que é parte da Convenção da proteção do artigo 10 (2) (art. 10-2) e atingiria as próprias raízes do sistema legal daquele Estado. De fato, os requerentes não alegam que a expressão 'prescrita pela lei' necessita de legislação em todos os casos; sua afirmação é de que legislação é necessária se - como no presente caso - as normas de 'common law' são tão incertas que não satisfazem o que os requerentes argumentam como o conceito incrustado naquela expressão, qual seja, o princípio da segurança jurídica" (tradução nossa). No original: "[...] the Court does not attach importance here to the fact that contempt of court is a creature of the common law and not of legislation. It would clearly be contrary to the intention of the drafters of the Convention to hold that a restriction imposed by virtue of the common law is not 'prescribed by law' on the sole ground that it is not enunciated in legislation: this would deprive a commonlaw State which is Party to the Convention of the protection of Article 10 (2) (art. 10-2) and strike at the very roots of that State's legal system. In fact, the applicants do not argue that the expression 'prescribed by law' necessitates legislation in every case; their submission is that legislation is required only if - as in the present case - the common-law rules are so uncertain that they do not satisfy what the applicants maintain is the concept enshrined in that expression, namely, the principle of legal certainty".

182 Parágrafo 79 do acórdão.

183 Parágrafo 84 do acórdão.
} 
lei, violava o mesmo artigo $8^{\text {o184 }}$.

No caso KRUSLIN v. FRANCE ${ }^{185}$, o peticionário reclamou que teve conversas telefônicas suas gravadas pela polícia enquanto se encontrava hospedado na casa de outrem, este, sim, alvo das interceptações feitas com autorização judicial. Numa dessas conversas, com um terceiro, o reclamante referia-se a outro crime, não relacionado com o que ensejara originalmente a autorização de interceptação da outra pessoa, e, com base nela, acabou sendo preso.

A Corte, em sua análise, entendeu que houve violação da vida privada e correspondência por uma autoridade pública para efeitos do artigo $8^{\circ}$ da Convenção ${ }^{186}$. Explicou, novamente, que o termo "law", na Convenção, deve ser entendido em sentido "substantivo", e não meramente "formal", podendo ser lei não escrita ("unwritten law") e até leis formalmente inferiores à lei em sentido formal (lei escrita, ou, em inglês, "statute") ${ }^{187}$, e que, no caso específico, embora a legislação francesa não previsse expressamente o poder de o juiz autorizar ou determinar a interceptação de comunicações telefônicas, a jurisprudência ("case-law") francesa entendia há anos que havia, implicitamente, tal permissão ${ }^{188}$.

Contudo, a Corte entendeu que o direito francês não previa com precisão o escopo e maneira de exercício do poder de discrição relevante conferido às autoridades públicas, mas, no máximo, uma prática não regulada ${ }^{189}$. O entendimento, então, foi de que houve violação do artigo $8^{\circ}$ da Convenção.

O caso HUVIG v. FRANCE ${ }^{190}$ foi julgado no mesmo dia, envolvendo basicamente a mesma matéria de direito de KLASS. Um dos únicos diferenciais relevantes é o fato de que da interceptação telefônica que originou, ao final, a reclamação junto à Corte Européia,

\footnotetext{
${ }^{184}$ Parágrafo 87 do acórdão. Impulsionado, dentre outros fatores, pela decisão desse caso, entrou em vigor, no Reino Unido, em 10 de abril de 1986, o Interception of Communications Act 1985, cujo escopo oficial era estabelecer um arcabouço legal escrito dentro do qual a interceptação de comunicações em sistemas públicos fosse autorizada e controlada de modo a oferecer segurança. Ver parágrafo 21 do caso HALFORD v. THE UNITED KINGDOM.

${ }^{185}$ Application 11801/85, julgado pela Câmara da Corte em 24 de abril de 1990.

${ }^{186}$ Parágrafo 26 do acórdão.

${ }^{187}$ Parágrafo 29 do acórdão.

188 Parágrafos 28 e 29 do acórdão.

189 Como consta do parágrafo 33 do acórdão: “Grampeamento' e outras formas de interceptação de conversações telefônicas representam uma séria interferência na vida privada e na correspondência e devem estar devidamente baseadas em 'lei' que seja particularmente precisa. É essencial ter normas claras e detalhadas sobre a questão, especialmente quando a tecnologia disponível para uso está continuamente se tornando mais sofisticada" (tradução nossa). No original: "Tapping and other forms of interception of telephone conversations represent a serious interference with private life and correspondence and must accordingly be based on a 'law' that is particularly precise. It is essential to have clear, detailed rules on the subject, especially as the technology available for use is continually becoming more sophisticated".

190 Application 11105/84, julgado pela Câmara da Corte em 24 de abril de 1990.
} 
não surgira nenhuma evidência aproveitável no julgamento dos vários crimes dos quais era acusado o reclamante. Nesse ponto, a Corte entendeu que o dano é irrelevante para caracterizar a violação ao artigo $8^{\circ}$, somente o sendo para fins de reparação de danos, nos termos do então artigo 50 (atual 41) da Convenção ${ }^{191}$.

Em LAMBERT v. FRANCE ${ }^{192}$, um indivíduo recorrera à Corte de Cassação francesa contra interceptação telefônica autorizada com base no Código de Processo Criminal que captara algumas de suas conversas, que entendeu não haver legitimidade ativa processual, pois a linha era de terceiro. A Corte Européia entendeu violado o artigo $8^{\circ}$ da Convenção, pois a interpretação dada pela Corte de Cassação retiraria, na prática, a proteção de todas as pessoas que se utilizassem de linhas telefônicas de terceiros, numa distinção que o Código de Processo Criminal não faz, privando-as de "efetivo controle".

NIEMIETZ v. GERMANY ${ }^{193}$ cuida do caso em que um telefax foi enviado, sob dado nome, para um juiz alemão, ofendendo-o e buscando pressioná-lo quanto à decisão em um processo pendente de seu julgamento. O remetente era um número de caixa postal, de onde a correspondência era enviada para o endereço de um advogado. Para obter a identidade do autor da carta e intimá-lo, para processo criminal, um juiz determinou busca e apreensão, dentre outros, no escritório desse causídico. Não se conseguiu descobrir a identidade do autor, mas o advogado entrou na justiça alemã, em vários graus, contra a invasão de seu escritório, aduzindo ter sido ela ilegal.

A Corte entendeu que houve uma interferência nos direitos do indivíduo nos termos do artigo $8^{\circ}$ da Convenção, que foi de acordo com a lei nacional e perseguiu fins legítimos (a honra do juiz ofendido), mas que a medida tomada não foi proporcional a eles, especialmente porque a ordem judicial determinou a busca e apreensão ampla e indiscriminada de "documentos", o que, na Alemanha, mostra-se ainda mais grave, porque lá não há previsão de qualquer garantia no procedimento de revista de escritório de advogados, como, por exemplo, a presença de um observador imparcial. Restou configurada a violação do artigo $8^{\circ}$.

Esse acórdão ainda é importante, tendo sido citado em várias decisões posteriores, pelas longas considerações que tece a respeito da expressão "vida privada":

29. A Corte não considera possível ou necessário tentar uma definição exaustiva da noção de "vida privada". Entretanto, seria muito restritivo limitar a noção a um "círculo interior" no qual o indivíduo pode viver sua própria vida pessoal

\footnotetext{
${ }^{191}$ Ver parágrafo 35 do acórdão.

192 Application 23618/94, julgado pela Câmara em 24 de agosto de 1998.

193 Application no. 13710/88, julgado pela Câmara da em 16 de dezembro de 1992.
} 
como escolher e excluir dali totalmente o mundo exterior não englobado por tal círculo. Respeito pela vida privada também deve compreender, até um certo grau, o direito de estabelecer e desenvolver relacionamentos com outros seres humanos.

Parece, ademais, não haver razão, em princípio, por que o entendimento dessa noção de "vida privada" deve levar a excluir atividades de natureza profissional ou comercial, já que, afinal, no curso de sua vida profissional, a maioria das pessoas tem uma significante, senão a maior, oportunidade de desenvolver relacionamentos com o mundo externo. Esta visão é amparada pelo fato de que, como corretamente apontado pela Comissão [Européia de Direitos Humanos], não é sempre possível distinguir claramente quais das atividades de um indivíduo fazem parte de sua vida profissional ou comercial e quais não o fazem. Então, especialmente no caso de uma pessoa exercendo uma profissão liberal, seu trabalho naquele contexto pode fazer parte de sua vida a tal ponto que se torne impossível saber a qual título está atuando em dado momento.

Negar a proteção do artigo $8^{\circ} \mathrm{com}$ o fundamento de que a medida contra a qual se insurge relaciona-se somente a atividades profissionais - como o Governo sugeriu que se deveria proceder no presente caso - pode, adicionalmente, levar a uma desigualdade de tratamento, em que a proteção permaneceria disponível a uma pessoa cujas atividades profissionais e não profissionais fossem tão interligadas que não houvesse meios de distingui-las. De fato, a Corte não traçou aqui tais distinções: concluiu que houve uma interferência na vida privada mesmo quando a interceptação telefônica cobria tanto chamadas de negócio e privadas [...] [citação de HUVIG v. FRANCE, parágrafos $8^{\circ}$ e 25]; e, quando uma busca foi dirigida somente quanto a atividades comerciais, não se baseou nesse fato como fundamento para excluir a aplicabilidade do artigo 8 sob o cabeçalho de "vida privada" [...] [cita CHAPPELL v. THE UNITED KINGDOM, parágrafos 26 e 51].

30. Com relação à palavra "casa" ["home"], como aparece no texto em inglês do artigo $8^{\circ}$, a Corte observa que em certos Estados Contratantes, notavelmente na Alemanha [...], foi aceita a estender-se a locais de negócios. Tal interpretação é, além disso, totalmente consoante com o texto em francês, já que a palavra "domicílio" ["domicile"] tem uma conotação mais ampla do que a palavra "home" e pode estender-se, por exemplo, ao escritório profissional de uma pessoa.

Ainda nesse contexto, não é sempre possível traçar distinções precisas, pois atividades que são relacionadas com uma profissão ou negócio podem muito bem ser conduzidas da residência privada de uma pessoa e atividades que não são tão relacionadas podem ser desempenhadas em um escritório ou sala comercial. Uma interpretação estreita das palavras "casa" ["home"] e "domicílio" ["domicile"] pode, portanto, ensejar o mesmo risco de desigualdade de tratamento que uma interpretação estreita da noção de "vida privada" (ver parágrafo 29).

31. No geral, interpretar as palavras "vida privada" ["private life"] e "casa" ["home"] como incluindo certas atividades ou locais profissionais ou comerciais estaria em consonância com o objeto e propósito do artigo $8^{\circ}$, nomeadamente proteger o indivíduo contra interferências arbitrárias por parte de autoridades públicas [...] [cita MARCKX v. BELGIUM, parágrafo 31]. Tal interpretação não atravancaria indevidamente os Estados Contratantes, pois eles reteriam seu direito de "interferir" na extensão do permitido pelo parágrafo $2^{\circ}$ do artigo $8^{\circ}$; esse direito poderia muito bem ser mais profundo onde atividades ou locais profissionais ou negociais estejam envolvidos do que seria, de outro modo, o caso.

[...]

Novamente, em vários casos relacionados à correspondência com um advogado (ver, por exemplo, Schönenberger and Durmaz v. Switzerland, julgado em 20 de junho de 1988, Series A no. 137, e Campbell v. the United Kingdom, julgado em 25 de março de 1992, Series A no. 233), a Corte sequer advertiu sobre a 
possibilidade de que o artigo $8^{\circ}$ pudesse ser inaplicável sob o fundamento de que a correspondência era de natureza profissional ${ }^{194}$.

\section{KOPP v. SWITZERLAND ${ }^{195}$ tratava do caso de um indivíduo, Kopp, cuja esposa}

era membro do Conselho Federal e chefe do Departamento Federal de Justiça e Polícia, suspeita de vazar informações confidenciais a que teve acesso devido a seu cargo.

Kopp teve suas conversas telefônicas interceptadas na qualidade de "terceiro"

("third party"), com base em dispositivo legal que o permitia quando houvesse evidência

de que este estivesse enviando ou recebendo informações de um acusado ou suspeito ${ }^{196}$.

\footnotetext{
${ }^{194}$ Parágrafos 29 a 32, tradução nossa. No original, em inglês: "29. The Court does not consider it possible or necessary to attempt an exhaustive definition of the notion of 'private life'. However, it would be too restrictive to limit the notion to an 'inner circle' in which the individual may live his own personal life as he chooses and to exclude therefrom entirely the outside world not encompassed within that circle. Respect for private life must also comprise to a certain degree the right to establish and develop relationships with other human beings. There appears, furthermore, to be no reason of principle why this understanding of the notion of 'private life' should be taken to exclude activities of a professional or business nature since it is, after all, in the course of their working lives that the majority of people have a significant, if not the greatest, opportunity of developing relationships with the outside world. This view is supported by the fact that, as was rightly pointed out by the Commission, it is not always possible to distinguish clearly which of an individual's activities form part of his professional or business life and which do not. Thus, especially in the case of a person exercising a liberal profession, his work in that context may form part and parcel of his life to such a degree that it becomes impossible to know in what capacity he is acting at a given moment of time. To deny the protection of Article 8 (art. 8) on the ground that the measure complained of related only to professional activities - as the Government suggested should be done in the present case - could moreover lead to an inequality of treatment, in that such protection would remain available to a person whose professional and non-professional activities were so intermingled that there was no means of distinguishing between them. In fact, the Court has not heretofore drawn such distinctions: it concluded that there had been an interference with private life even where telephone tapping covered both business and private calls (see the Huvig v. France judgment of 24 April 1990, Series A no. 176-B, p. 41, para. 8, and p. 52, para. 25); and, where a search was directed solely against business activities, it did not rely on that fact as a ground for excluding the applicability of Article 8 (art. 8) under the head of 'private life' (see the Chappell v. the United Kingdom judgment of 30 March 1989, Series A no. 152-A, pp. 12-13, para. 26, and pp. 21-22, para. 51.). 30. As regards the word 'home', appearing in the English text of Article 8 (art. 8), the Court observes that in certain Contracting States, notably Germany (see paragraph 18 above), it has been accepted as extending to business premises. Such an interpretation is, moreover, fully consonant with the French text, since the word 'domicile' has a broader connotation than the word 'home' and may extend, for example, to a professional person's office. In this context also, it may not always be possible to draw precise distinctions, since activities which are related to a profession or business may well be conducted from a person's private residence and activities which are not so related may well be carried on in an office or commercial premises. A narrow interpretation of the words 'home' and 'domicile' could therefore give rise to the same risk of inequality of treatment as a narrow interpretation of the notion of 'private life' (see paragraph 29 above). 31. More generally, to interpret the words 'private life' and 'home' as including certain professional or business activities or premises would be consonant with the essential object and purpose of Article 8 (art. 8), namely to protect the individual against arbitrary interference by the public authorities (see, for example, the Marckx v. Belgium judgment of 13 June 1979, Series A no. 31, p. 15, para. 31). Such an interpretation would not unduly hamper the Contracting States, for they would retain their entitlement to 'interfere' to the extent permitted by paragraph 2 of Article 8 (art. 8-2); that entitlement might well be more far-reaching where professional or business activities or premises were involved than would otherwise be the case. [...] Again, in a number of cases relating to correspondence with a lawyer (see, for example, the Schönenberger and Durmaz v. Switzerland judgment of 20 June 1988, Series A no. 137, and the Campbell v. the United Kingdom judgment of 25 March 1992, Series A no. 233), the Court did not even advert to the possibility that Article 8 (art. 8) might be inapplicable on the ground that the correspondence was of a professional nature". ${ }_{195}$ Application 23224/94, julgado pela Câmara em 25 de março de 1998.

${ }^{196}$ Ver parágrafos 31, "b", e 35 do acórdão.
} 
Ele foi informado pelas autoridades nacionais de que as conversas dele e dos demais advogados de seu escritório haviam sido desconsideradas e destruídas.

Outra norma, por outro lado, eximia os advogados de fornecerem informações obtidas no exercício de sua profissão ${ }^{197}$. O governo argumentou, com base em jurisprudência interna e artigos acadêmicos, em síntese, que o sigilo abrangia apenas assuntos ligados à profissão de advogado ${ }^{198}$.

73. Porém, a Corte discerne a contradição entre o texto claro da legislação que protege o privilégio profissional legal quando um advogado está sendo monitorado como um terceiro e a prática adotada no presente caso. Apesar de a jurisprudência ter estabelecido o princípio, que é, além disso, geralmente aceito, de que o privilégio profissional legal abrange apenas o relacionamento entre o advogado e seus clientes, a lei não estabelece claramente como, sob quais condições e por quem a distinção deve ser feita entre assuntos especificamente conectados com o trabalho de um advogado sob instruções de uma parte e aqueles relacionados a atividade outra que aquela de advocacia.

74. Acima de tudo, na prática, é, para dizer o mínimo, surpreendente que essa tarefa caiba a um oficial do departamento legal dos Correios, que é um membro do Executivo, sem supervisão por um juiz independente, especialmente nessa área sensível de relações confidenciais entre um advogado e seus clientes, que concernem diretamente os direitos de defesa ${ }^{199}$. (tradução nossa).

A conclusão foi de que houve violação do artigo $8^{\circ}$ da Convenção.

A Corte, em AMANN v. SWITZERLAND ${ }^{200}$, reiterou que ligações recebidas em lugares privados ou de negócios são cobertas pelas noções de "vida privada" e “correspondência" no significado do artigo $8^{\text {o }}$, parágrafo $1^{\text {o201 }}$.

Uma pessoa da então embaixada soviética telefonou para o reclamante, comerciante, encomendando um aparelho de depilação. Essa conversa foi interceptada pelo Escritório do Promotor Público Federal, que requisitou ao Serviço de Inteligência do Cantão de Zürich que o investigasse e as mercadorias que vendia.

As informações passadas foram registradas em um cartão, em 1981, que foi

\footnotetext{
${ }^{197}$ Parágrafo 35 do acórdão.

${ }^{198}$ Parágrafo 71 do acórdão.

${ }^{199}$ Parágrafos 73 e 74 do acórdão. No original: “73. However, the Court discerns a contradiction between the clear text of legislation which protects legal professional privilege when a lawyer is being monitored as a third party and the practice followed in the present case. Even though the case-law has established the principle, which is moreover generally accepted, that legal professional privilege covers only the relationship between a lawyer and his clients, the law does not clearly state how, under what conditions and by whom the distinction is to be drawn between matters specifically connected with a lawyer's work under instructions from a party to proceedings and those relating to activity other than that of counsel. 74. Above all, in practice, it is, to say the least, astonishing that this task should be assigned to an official of the Post Office's legal department, who is a member of the executive, without supervision by an independent judge, especially in this sensitive area of the confidential relations between a lawyer and his clients, which directly concern the rights of the defence".

${ }^{200}$ Application no. 27798/95, julgado pela Grande Câmara em 16 de fevereiro de 2000.

${ }^{201}$ Parágrafo 44 do acórdão.
} 
arquivado no banco de dados de segurança nacional.

Em 1990, veio a público a existência desse índice nacional contendo fichas sobre vários cidadãos, dentre eles, o reclamante, que pediu compensação junto ao Departamento Federal de Finanças, que restou negada. Mais tarde, ajuizou uma ação pedindo compensação, além da "inutilização" de sua ficha, o que foi julgado, por fim, improcedente.

Sua reclamação referia-se à falta de base legal para a interceptação de sua conversa e à ausência de um remédio efetivo contra a violação de seu direito.

A Corte entendeu que não havia um dos requisitos básicos para verificar a obediência da interceptação à lei, pois faltava à norma pelo menos uma característica, a sua previsibilidade $^{202}$. Isso porque o indivíduo em questão, como acedeu o próprio governo suíço, teve sua conversa captada "fortuitamente", por ter sido um "participante necessário" numa ligação telefônica interceptada pelas autoridades cujo alvo era um membro da embaixada soviética, e o ordenamento não regulava esses casos e, tampouco, as precauções a serem tomadas em relação a essas pessoas ${ }^{203}$.

Concluiu-se que a interferência na vida privada do reclamante não podia ser considerada "em conformidade com a lei” ("in accordance with the law") porque a lei suíça não indicava com suficiente claridade o escopo e as condições do exercício do poder discricionário das autoridades nessa área, havendo violação do artigo $8^{\circ}$ da Convenção ${ }^{204}$.

A mesma conclusão deu-se em relação à criação e ao armazenamento do cartão, pois constituiu uma interferência na vida privada do indivíduo sem previsão legal, já que os textos legais que autorizariam tal medida não mencionavam a existência de um arquivo e foram redigidos em termos muito gerais ${ }^{205}$.

Por outro lado, considerou haver remédio efetivo, o que, como enfatizou, não significa a certeza de uma decisão favorável ao indivíduo, e, portanto, inviolado o artigo 13 da Convenção ${ }^{206}$.

Em A. v. FRANCE ${ }^{207}$, um indivíduo contratado para matar outro foi até a polícia, contou a história toda a um oficial e contatou a suposta contratante, gravando a conversa na sala do policial e entregando-lhe a fita.

Essa evidência foi usada num processo contra a acusada, que, por sua vez,

\footnotetext{
${ }^{202}$ Parágrafo 54 do acórdão.

${ }^{203}$ Parágrafo 61 do acórdão.

${ }^{204}$ Parágrafo 62 do acórdão.

${ }^{205}$ Parágrafos 78 a 80 do acórdão.

${ }^{206}$ Parágrafos 88 a 90 do acórdão.

${ }^{207}$ Application 14838/89, julgado pela Câmara em 23 de novembro de 1993.
} 
contestou a validade da prova com base na violação da sua "privacidade" ("privacy"). A Corte entendeu que houve violação do artigo $8^{\circ}$ da Convenção porque a lei francesa não previa a gravação de conversa por autoridades do modo como foi efetuada, isto é, com o uso da sala, do aparelho de telefone e do gravador do policial. O próprio Governo acedera que a interferência dera-se em desacordo com a lei.

O caso de KHAN v. THE UNITED KINGDOM ${ }^{208}$ reafirmou a necessidade de lei para permitir a interferência das autoridades públicas em quaisquer dos direitos do artigo $8^{\circ}$ da Convenção para proteger o indivíduo contra arbitrariedades do poder público.

A polícia havia instalado, sob ordem de uma alta autoridade do departamento, um aparelho de escuta ambiental num "flat", que captou inúmeras conversas, inclusive uma em que o reclamante admitia participação em importação ilegal de drogas. Como à época não existia lei prevendo tal procedimento, apenas "guidelines" (orientações) que não eram nem vinculantes e nem publicamente disponíveis, considerou-se o procedimento em desacordo com a lei ("law”). Considerou-se violado também o artigo 13 da Convenção, por se entender que não existia remédio interno adequado à proteção do direito do reclamante.

Em P.G. AND J.H. v. THE UNITED KINGDOM ${ }^{209}$, parte da discussão é a mesma da de KHAN, avançando, contudo, em alguns outros pontos correlatos.

A similaridade diz respeito justamente à instalação sub-reptícia de aparelho de escuta pela polícia no apartamento de um dos suspeitos, que gerou prova usada em processo criminal, procedimento não regulado por lei na época dos fatos (a lei só viria em 1997).

Voltou-se à discussão quanto ao "metering”, processo já mencionado:

[...] [a] Corte nota, entretanto, que o "metering', que não ofende "per se" o Artigo $8^{\circ}$ se, por exemplo, feito pela companhia telefônica para propósitos de cobrança, deve, por sua natureza, ser diferenciado da interceptação de comunicação que pode ser indesejável e ilegítima em uma sociedade democrática, salvo se justificada [...] [cita MALONE v. THE UNITED KINGDOM, parágrafos 83 e 84$)^{210}$. (tradução nossa).

Entendeu-se que os dados especificamente obtidos, quais sejam, os números de

\footnotetext{
${ }^{208}$ Application 35394/97, julgado pela Terceira Seção em 12 de maio de 2000, decisão tornada definitiva em 4 de outubro de 2000.

${ }^{209}$ Application 44787/98, julgado pela Terceira Seção em 25 de setembro de 2001, decisão tornada definitiva em 25 de dezembro de 2001.

${ }^{210}$ Parágrafo 42 do acórdão. No original: "[t]he Court notes, however, that metering, which does not 'per se' offend against Article 8 if, for example, done by the telephone company for billing purposes, is by its very nature to be distinguished from the interception of communications which may be undesirable and illegitimate in a democratic society unless justified [...] [cita MALONE v. THE UNITED KINGDOM, parágrafos 83 e 84 )".
} 
telefone discados em dado espaço de tempo, sem revelação de quem teria feito as ligações ou as recebido, bem como sem qualquer captação de conteúdo das conversas travadas, eram bastante limitados, encontrando essa interferência amparo no Telecommunications Act 1984 e no Data Protection Act 1984. A falta de previsão legal quanto a seu armazenamento e destruição não afetava a legalidade desses dados e de sua requisição e utilização nos termos em que se deram ${ }^{211}$.

Terceiro ponto abordado nesse julgamento foi o uso de aparelhos de captação de som pelos policiais para gravar a conversa dos presos na delegacia de polícia sem seu conhecimento ou consentimento. Inicialmente, analisou-se se esse tipo de gravação interferia com a vida privada dos indivíduos. A Corte, lembrando, como o fizera anteriormente, que "vida privada" é uma expressão ampla não exaustiva, enumerou, citando sua própria jurisprudência, alguns elementos que a integram, como a identificação de gênero, nome, orientação e vida sexual, todos da esfera pessoal. Afirmou que o artigo $8^{\circ}$ da Convenção protege também o direito à identidade e ao desenvolvimento pessoal, e o direito a estabelecer e a desenvolver relacionamentos com outros seres humanos e o mundo exterior, e que pode englobar atividades de natureza profissional ou negocial (ou comercial), determinando a existência, portanto, de uma zona de interação de uma pessoa com outras, mesmo em um contexto público, que pode cair no escopo de "vida privada",212.

Foram tecidas várias considerações relativas à delimitação da vida privada do indivíduo:

57. Há diversos elementos relevantes para uma consideração se a vida privada de
uma pessoa tem relação com medidas tomadas fora de sua casa ou áreas
privadas. Já que há ocasiões em que as pessoas sabida ou intencionalmente se
envolvem em atividades que são ou podem ser gravadas ou relatadas de uma
maneira pública, as expectativas razoáveis de uma pessoa à privacidade podem
ser um significante, embora não necessariamente conclusivo, fator. Uma pessoa
que caminha pela rua será, inevitavelmente, visível a qualquer membro do
público que também esteja presente. Monitoramento por meio tecnológico da
mesma cena pública (por exemplo, um segurança vendo através de um circuito
fechado de televisão) é de caráter similar. Considerações relativas à vida privada
podem surgir, porém, uma vez que qualquer registro sistemático ou permanente
vem a existir a partir desse material do domínio público. É por essa razão que
arquivos recolhidos por serviços de segurança sobre um indivíduo específico
caem no escopo do Artigo $8^{\circ}$, mesmo onde a informação não tenha sido obtida
por qualquer método intrusivo ou secreto (ver ROTARU v. ROMANIA [GC],
no. $28341 / 95$, parágrafos $43-44$, ECHR $2000-V$ ). A Corte já se referiu neste
contexto à Convenção do Conselho da Europa de 28 de janeiro de 1981 para a
proteção de indivíduos relativamente ao processamento automatizado de dados
pessoais, que entrou em vigor em $1^{\circ}$ de outubro de 1985 , cujo propósito é
"garantir, no território de cada Parte, a todas as pessoas singulares ... o respeito

${ }^{211}$ Ver parágrafos 44 a 52 do acórdão.

${ }^{212}$ Ver parágrafo 56 do acórdão. 
por seus direitos e liberdades fundamentais, e especialmente o seu direito à privacidade, face ao tratamento automatizado dos dados de caráter pessoal que lhes digam respeito" (Artigo $1^{\circ}$ ), tais dados definidos como "qualquer informação relativa a uma pessoa singular ou suscetível de identificação" (Artigo $2^{\circ}$ ) (ver AMANN v. SWITZERLAND [GC], no. 27798/95, parágrafos 65-67, ECHR 2000-II, onde o armazenamento de informação sobre o requerente em um cartão em um arquivo foi considerado uma interferência na vida privada, apesar de não conter informação sensível e nem nunca provavelmente ter sido consultado).

58. No caso de fotografias, a Comissão [Européia de Direitos Humanos] tinha previamente considerado, para o propósito de delimitar o escopo de proteção conferido pelo Artigo $8^{\circ}$ contra interferências arbitrárias por autoridades públicas, se tirá-las constituía uma intrusão na privacidade do indivíduo, fossem as fotografias relacionadas a assuntos privados ou incidentes públicos e fosse o material obtido com o propósito de um uso limitado ou para provável disponibilização para o público em geral [...]. Onde as fotografias de um requerente foram tiradas em uma demonstração pública em um lugar público e mantidas pela polícia em um arquivo, a Comissão não encontrou interferência na vida privada, dando peso ao fato de que a fotografia fora tirada e mantida como um registro da demonstração e nenhuma ação havia sido tomada para identificar as pessoas fotografadas na ocasião por meio de processamento de dados $[\ldots]^{213}$. (tradução nossa).

\section{Em relação à captação de vozes ou conversas, a Corte explicou ${ }^{214}$ :}

59. A jurisprudência da Corte entendeu, em inúmeras ocasiões, que a gravação secreta de conversações telefônicas cai no escopo do Artigo $8^{\circ}$ em ambos os

213 Parágrafos 57 e 58 do acórdão. No original: " 57 . There are a number of elements relevant to a consideration of whether a person's private life is concerned by measures effected outside a person's home or private premises. Since there are occasions when people knowingly or intentionally involve themselves in activities which are or may be recorded or reported in a public manner, a person's reasonable expectations as to privacy may be a significant, although not necessarily conclusive, factor. A person who walks down the street will, inevitably, be visible to any member of the public who is also present. Monitoring by technological means of the same public scene (for example, a security guard viewing through closed-circuit television) is of a similar character. Private-life considerations may arise, however, once any systematic or permanent record comes into existence of such material from the public domain. It is for this reason that files gathered by security services on a particular individual fall within the scope of Article 8, even where the information has not been gathered by any intrusive or covert method (see 'Rotaru v. Romania' [GC], no. 28341/95, §§ 43-44, ECHR 2000-V). The Court has referred in this context to the Council of Europe's Convention of 28 January 1981 for the protection of individuals with regard to automatic processing of personal data, which came into force on 1 October 1985 and whose purpose is 'to secure in the territory of each Party for every individual ... respect for his rights and fundamental freedoms, and in particular his right to privacy, with regard to automatic processing of personal data relating to him' (Article 1), such data being defined as 'any information relating to an identified or identifiable individual' (Article 2) (see 'Amann v. Switzerland' [GC], no. 27798/95, §§ 65-67, ECHR 2000-II, where the storing of information about the applicant on a card in a file was found to be an interference with private life, even though it contained no sensitive information and had probably never been consulted). 58. In the case of photographs, the Commission previously had regard, for the purpose of delimiting the scope of protection afforded by Article 8 against arbitrary interference by public authorities, to whether the taking of the photographs amounted to an intrusion into the individual's privacy, whether the photographs related to private matters or public incidents and whether the material obtained was envisaged for a limited use or was likely to be made available to the general public (see 'Friedl', cited above, opinion of the Commission, p. 21, §§ 49-52). Where photographs were taken of an applicant at a public demonstration in a public place and retained by the police in a file, the Commission found no interference with private life, giving weight to the fact that the photograph was taken and retained as a record of the demonstration and no action had been taken to identify the persons photographed on that occasion by means of data processing (ibid., §§ 51-52)".

${ }^{214}$ Parágrafos 59 e 60 do acórdão. 
aspectos do direito garantido, nomeadamente o respeito pela vida privada e a correspondência. Enquanto seja geralmente o caso de que as gravações tenham sido feitas com o propósito de usar o conteúdo das conversas de algum modo, a Corte não está convencida de que as gravações feitas para uso como amostras de voz possam ser consideradas como escapando ao escopo de proteção fornecida pelo Artigo $8^{\circ}$. Um registro permanente da voz da pessoa foi, de qualquer modo, feito e está sujeito a um processo de análise diretamente relevante à identificação daquela pessoa no contexto de outros dados pessoais. Embora seja verdade que os requerentes, quando estavam sendo indiciados, tenham respondido perguntas formais em um local onde autoridades policiais estavam escutando-os, a gravação e a análise de suas vozes nessa ocasião devem ainda ser consideradas como relativas ao processamento de dados pessoais sobre os requerentes.

60. A Corte conclui, portanto, que a gravação das vozes dos requerentes quando estavam sendo indiciados e quando em suas celas na polícia revela uma interferência em seu direito ao respeito à vida privada no significado do Artigo $8^{\circ}$, parágrafo $1^{\circ}$, da Convenção ${ }^{215}$. (tradução nossa).

Quanto à legalidade dessa gravação, rememorando casos anteriores, entendeu que não há diferença substancial quando o aparelho de gravação é operado, sem o conhecimento ou consentimento do indivíduo em questão, em estabelecimento policial. $\mathrm{O}$ princípio subjacente de que a legislação doméstica deve prover proteção contra arbitrariedades e abuso no uso de técnicas de vigilância sub-reptícias aplica-se igualmente nessa situação ${ }^{216}$.

A gravação acabou sendo julgada ilegal, pois sequer existia lei regulando a matéria na época dos fatos ${ }^{217}$. Foi considerado violado, também, o artigo 13 da Convenção, por ausência de remédios internos adequados para a proteção do direito.

PECK v. THE UNITED KINGDOM ${ }^{218}$ cuidou de um caso em que um indivíduo tentou suicidar-se em uma via pública monitorada por câmeras de vigilância ("CCTV"), mas que foi impedido por autoridades policiais que o viram. As imagens da tentativa em si não foram divulgadas, mas as da ação policial foram difundidas em noticiários na televisão e na mídia escrita, principalmente na região em que o individuo em questão residia, muitas

\footnotetext{
${ }^{215}$ No original: "59. The Court's case-law has, on numerous occasions, found that the covert taping of telephone conversations falls within the scope of Article 8 in both aspects of the right guaranteed, namely, respect for private life and correspondence. While it is generally the case that the recordings were made for the purpose of using the content of the conversations in some way, the Court is not persuaded that recordings taken for use as voice samples can be regarded as falling outside the scope of the protection afforded by Article 8. A permanent record has nonetheless been made of the person's voice and it is subject to a process of analysis directly relevant to identifying that person in the context of other personal data. Though it is true that when being charged the applicants answered formal questions in a place where police officers were listening to them, the recording and analysis of their voices on this occasion must still be regarded as concerning the processing of personal data about the applicants. 60 . The Court concludes therefore that the recording of the applicants' voices when being charged and when in their police cell discloses an interference with their right to respect for private life within the meaning of Article $8 \S 1$ of the Convention".

${ }^{216}$ Ver parágrafo 62 do acórdão.

${ }^{217}$ Posteriormente veio o Regulation of Investigatory Powers Act 2000.

${ }^{218}$ Application 44647/98, julgado pela Quarta Seção da Corte em 28 de janeiro de 2003, decisão tornada definitiva em 28 de abril de 2003.
} 
vezes sem qualquer método de não identificação, total ou parcial, o que permitiu o seu reconhecimento por parte de amigos, familiares e colegas de serviço.

A Corte entendeu que o Conselho responsável pelo CCTV poderia ter tomado inúmeras medidas para proteger a vida privada do indivíduo, como a sua identificação prévia para obtenção de consentimento para exibição das imagens, o seu mascaramento nas imagens distribuídas à mídia ou o controle para que esta as mascarasse.

Notando que o indivíduo sequer fora acusado de qualquer crime, mas teve sua imagem exposta até em um programa de televisão que mostrava a efetividade da CCTV no combate à criminalidade, a Corte entendeu que essa difusão de imagens constituiu uma interferência desproporcional e, portanto, ilegítima em face do artigo $8^{\circ}$ da Convenção, mormente porque não acompanhada das devidas salvaguardas. Considerou também que houve violação do artigo 13 do tratado.

Em HATTON AND OTHERS v. THE UNITED KINGDOM ${ }^{219}$, citando alguns precedentes, explicou que, embora a Convenção não assegure o direito a um ambiente limpo e silencioso, sempre que um indivíduo seja direta e seriamente afetado por barulho ou outro tipo de poluição pode surgir uma questão no escopo do artigo $8^{\circ}$ da Convenção. Esta, segundo a Corte, tem caráter subsidiário, cabendo às autoridades nacionais avaliar as necessidades e condições locais e definir e estabelecer a sua política legislativa e decisional. A responsabilidade do Estado pode surgir, nesse tipo de caso, quando é o causador direto da poluição ou quando esta decorre de falha na regulação da indústria privada nesse sentido.

Dois são, então, os aspectos que devem ser considerados: (i) o aspecto material da decisão governamental, em termos de compatibilidade com o artigo $8^{\circ}$; e (ii) o processo decisional, para averiguar se foi dado o devido peso aos interesses individuais.

O caso tratava de um esquema de vôos noturnos implementados em 1993 no aeroporto de Heathrow, na Inglaterra, que gerou um aumento no tráfego e, por conseguinte, do nível de ruído nesse período.

A Corte acabou julgando que a pesquisa efetuada pelo governo britânico em 1992, para decidir o modelo em disputa, com base em amostra estatística do grau de perturbação ao sono e da sensibilidade dos habitantes das proximidades do aeroporto em relação ao nível de ruído gerado pelos aviões, era adequado para os fins de equilibrar os interesses econômicos do país com os dos indivíduos afetados, não encontrando violação do artigo $8^{\circ}$.

${ }^{219}$ Application no. 36022/97, julgado pela Grande Câmara em 8 de julho de 2003. 
Entendeu-se violado, no entanto, o artigo 13 da Convenção, pois, à época, não havia qualquer forma de se fazer valer o texto desse tratado na Inglaterra ${ }^{220}$.

Em WORWA v. POLAND ${ }^{221}$, a reclamante alegou que sucessivas ordens judiciais em um curto espaço de tempo, de várias autoridades da mesma região, determinando sua reavaliação psiquiátrica, em virtude de várias ações judiciais concernentes aos mesmos fatos, violava o seu direito à vida privada.

A Corte entendeu que a determinação de avaliação psiquiátrica para se aferir a probabilidade de uma pessoa cometer uma infração penal não é por si ilícita, mas não pode o Estado abusar dessa prerrogativa, julgando violado o artigo $8^{\circ}$.

Em ÉDITIONS PLON v. FRANCE ${ }^{222}$, uma editora entrou com uma reclamação contra a França, por violação ao artigo 10 da Convenção, porque as cortes nacionais haviam proibido a circulação de um livro que contava detalhes médicos sobre a vida do exPresidente francês François Mitterrand. O livro, que fora escrito por um jornalista e por um indivíduo que fora médico particular do Presidente por muitos anos, contava a história de como se teve dificuldade de esconder a doença do público por tanto tempo, já que o paciente fora diagnosticado com câncer pouco depois da eleição para seu primeiro mandato de sete anos, em 1981, situação só tornada oficialmente pública em 1992.

A Corte entendeu que a suspensão temporária da distribuição do livro, no primeiro momento, era razoável, mas não o seu banimento definitivo, que não se afigurava "necessário numa sociedade democrática", sendo uma medida desproporcional à proteção dos interesses e direitos dos herdeiros do Presidente, em virtude do desvanecimento da "necessidade social urgente" ("pressing social need").

Argumento perigoso, a nosso ver, utilizado nesse particular caso pela Corte foi o de que, embora a legislação francesa proibisse categoricamente a divulgação de segredos médicos pelo profissional, salvo em pouquíssimas situações excepcionais, sob pena de responsabilidade civil e criminal, a ampla divulgação do conteúdo do livro pela expressiva quantidade de exemplares vendidos então e até pela Internet suplantava-a, pois os fatos haviam deixado de ser, na prática, secretos. Estar-se-ia transformando uma situação ilícita em lícita tão-só pela constante e ampla violação da lei.

VON HANNOVER v. GERMANY ${ }^{223}$ refere-se a várias fotos da princesa Caroline

\footnotetext{
${ }^{220}$ Ver parágrafos 140 a 142 do acórdão.

${ }^{221}$ Application 26624/95, julgado pela Terceira Seção em 27 de novembro de 2003.

${ }^{222}$ Application 58148/00, julgado pela Segunda Seção em 18 de maio de 2004, decisão tornada definitiva em 18 de agosto de 2004.

${ }^{223}$ Application 59320/00, julgado pela Terceira Seção em 24 de junho de 2004, decisão tornada definitiva em
} 
von Hannover, filha do príncipe Rainier III, de Mônaco, tiradas por tablóides alemães sem seu consentimento, em situações que considerava reservadas. A reclamação contra a Alemanha deu-se pela falta de adequada proteção por parte do Estado à sua vida privada e imagem.

A Corte afirmou, quanto a esse ponto:

\begin{abstract}
[...] embora o objeto do Artigo $8^{\circ}$ seja essencialmente aquele de proteger o indivíduo contra a interferência arbitrária das autoridades públicas, ele não apenas compele o Estado a se abster de tal interferência: em adição a este propósito primariamente negativo, pode haver obrigações positivas inerentes a um efetivo respeito pela vida privada e familiar. Essas obrigações podem envolver a adoção de medidas criadas para assegurar o respeito pela vida privada mesmo na esfera de relações dos indivíduos entre si mesmos (ver, "mutatis mutandis", X and Y v. the Netherlands, julgado em 26 de março de 1985, Series A no. 91, p. 11, parágrafo 23; Stjerna v. Finland, julgado em 25 de novembro de 1994, Series A no. 299-B, pp. 60-61, parágrafo 38; and Verliere v. Switzerland (dec.), no. 41953/98, ECHR 2001-VII). Isso também se aplica à proteção do retrato de uma pessoa contra o abuso por outros (ver Schüssel [...]).

A fronteira entre as obrigações positivas e negativas do Estado sob essa disposição não se presta a uma precisa definição. Os princípios aplicáveis são, apesar disso, similares. Em ambos os contextos deve-se levar em consideração o justo equilíbrio que deve ser atingido entre os interesses concorrentes do indivíduo e da comunidade como um todo; e em ambos os contextos o Estado desfruta de uma certa margem de apreciação $[\ldots]^{224}$. (tradução nossa).
\end{abstract}

Segundo a Corte, a proteção da vida privada tem que ser equilibrada com a da liberdade de expressão ${ }^{225}$, e que, por princípio, se deve analisar o quanto a disseminação das fotos, ou fatos, contribui com a discussão de um tema de interesse geral, mas não pelo critério espacial, que se mostra impreciso e extremamente opressivo à proteção da "privacidade" 226 . Na espécie, considerou não haver esse requisito, posto que as situações retratadas eram de natureza essencialmente "privada" e a reclamante não exercia qualquer

24 de setembro de 2004.

${ }^{224}$ Parágrafo 57 do acórdão. No original: "[...] although the object of Article 8 is essentially that of protecting the individual against arbitrary interference by the public authorities, it does not merely compel the State to abstain from such interference: in addition to this primarily negative undertaking, there may be positive obligations inherent in an effective respect for private or family life. These obligations may involve the adoption of measures designed to secure respect for private life even in the sphere of the relations of individuals between themselves (see, 'mutatis mutandis', ' $\mathrm{X}$ and $\mathrm{Y}$ v. the Netherlands', judgment of 26 March 1985, Series A no. 91, p. 11, § 23; 'Stjerna v. Finland', judgment of 25 November 1994, Series A no. 299-B, pp. 60-61, § 38; and 'Verliere v. Switzerland' (dec.), no. 41953/98, ECHR 2001-VII). That also applies to the protection of a person's picture against abuse by others (see 'Schüssel', cited above). The boundary between the State's positive and negative obligations under this provision does not lend itself to precise definition. The applicable principles are, nonetheless, similar. In both contexts regard must be had to the fair balance that has to be struck between the competing interests of the individual and of the community as a whole; and in both contexts the State enjoys a certain margin of appreciation (see, among many other authorities, 'Keegan v. Ireland', judgment of 26 May 1994, Series A no. 290, p. 19, § 49, and 'Botta', cited above, p. 427, § 33)".

${ }^{225}$ Ver parágrafo 58 do acórdão.

${ }^{226}$ A Corte fez uma crítica direta à denominada "teoria das esferas" ou "teoria dos níveis" alemã. Sobre essa teoria, ver ainda Albuquerque (2008), Cachapuz (2006), Doneda (2006), Ferraz Junior (1992), I. Ferreira (1994), Jabur (2000); Mendes (1999); criticando-a, Canotilho e Moreira (2007) e Miranda e Medeiros (2005). 
atividade oficial, como autoridade, não sendo relevante ou necessária para a "sociedade democrática" a sua exposição não consentida ${ }^{227}$. Julgou-se violado o artigo $8^{\circ}$ da Convenção.

Através de sua Segunda Seção, a Corte julgou ilegal, em SIDABRAS AND DŽIAUTAS v. LITHUANIA ${ }^{228}$, por violação à vida privada, lei da Lituânia que proibia, por dez anos desde sua entrada em vigor, a procura e assunção de cargos públicos por exoficiais do serviço secreto da ex-União das Repúblicas Socialistas Soviéticas (“URSS”), já que o direito à vida privada abrange, também, as atividades profissionais do indivíduo, como esclarecido em NIEMIETZ v. GERMANY.

Além disso, a publicidade do "status" de ex-membros da KGB (serviço secreto da URSS), principalmente muitos anos depois do regime soviético, quando não era mais possível prever que tal pudesse ocorrer, impôs aos reclamantes constrangimentos e obstáculos no gozo de sua vida privada ${ }^{229}$ :

48. Voltando aos fatos do presente caso, a Corte observa que, como resultado da
aplicação da seção 2 do KGB Act a eles, os requerentes foram banidos de 1999 a
2009 de se envolverem em atividades profissionais de vários ramos do setor
privado em virtude de seu estado de "antigos oficiais da KGB" [...].
Admitidamente, o banimento não afetou a aptidão dos requerentes de
desenvolver certos tipos de atividade profissional. A proibição, contudo, afetou
sua habilidade de desenvolver relacionamentos com o mundo exterior em um
grau bastante significativo e lhes criou sérias dificuldades em termos de auto
sustento, com óbvias repercussões no gozo de suas vidas privadas.

49. A Corte também nota o argumento dos requerentes de que, como resultado da publicidade causada pela adoção do KGB Act e a sua aplicação, sofreram constante embaraço como resultado de suas atividades passadas. Ela aceita que os requerentes continuam a carregar o fardo do estado de "antigo agente da KGB" e esse fato pode, em si mesmo, ser considerado um impedimento ao estabelecimento de contatos com o mundo exterior - sejam eles relacionados a emprego ou outros - e que essa situação indubitavelmente afeta mais do que apenas sua reputação; afeta também o gozo de sua "vida privada". A Corte aceita que não se pode basear no Artigo $8^{\circ}$ reclamação da perda de reputação como consequiência previsível das ações de alguém, como, por exemplo, a comissão de uma infração criminal. Além disso, durante o considerável período que passou entre a queda da antiga União Soviética (e as resultantes mudanças políticas na Lituânia) e a entrada em vigor da legislação impugnada em 1999, pode-se razoavelmente supor que os requerentes não podiam vislumbrar as consequiências que seu anterior emprego na KGB trar-lhes-ia. De qualquer modo, no presente caso, há mais em jogo para os requerentes do que a defesa de seu bom nome. Eles estão marcados aos olhos da sociedade em virtude de sua prévia associação a um regime opressivo. Portanto, e em virtude do amplo alcance das restrições de emprego que os requerentes têm que sofrer, a Corte considera que o possível impedimento de que levem uma vida pessoal normal deve ser considerado como um fator relevante para determinar se os fatos reclamados

\footnotetext{
${ }^{227}$ Ver especialmente os parágrafos 61 a 81 do acórdão.

${ }^{228}$ Applications 55480/00 e 59330/00, em 27 de julho de 2004, decisão tornada definitiva em 27 de outubro de 2007.

${ }^{229}$ Parágrafos 48 e 49 do acórdão.
} 
caem dentro do âmbito do Artigo $8^{\circ}$ da Convenção ${ }^{230}$. (tradução nossa).

\author{
Acrescendo à noção de "vida privada" uma esfera individual dentro da qual o \\ indivíduo pode livremente perseguir o desenvolvimento e satisfação de sua \\ personalidade ${ }^{231}$, afirma a decisão:
}

\begin{abstract}
45. No recente caso de Smirnova v. Russia (nos. 46133/99 and 48183/99, parágrafos 96-97, ECHR 2003-IX), a Corte examinou o efeito na "vida privada" do requerente da apreensão por autoridades de um documento oficial (passaporte interno), mesmo apesar de nenhuma interferência específica ter sido alegada pelo requerente como resultado da apreensão. A Corte entendeu que a própria ausência do passaporte causava inúmeras inconveniências diárias tomadas em sua inteireza, já que o requerente precisava do passaporte quando desempenhava funções mundanas como trocar moeda ou comprar bilhetes de trem. Foi também notado, em particular, que o passaporte era exigido por aquele requerente para necessidades mais cruciais como encontrar emprego ou receber tratamento médico. A Corte concluiu que a privação do passaporte em Smirnova representara uma contínua interferência na "vida privada" do requerente.
\end{abstract}

46. A Corte também já entendeu que a falta de acesso ao serviço [público] civil como tal não pode ser base para uma reclamação sob a Convenção (ver

\footnotetext{
${ }^{230}$ No original: " 48 . Turning to the facts of the present case, the Court notes that, as a result of the application of section 2 of the KGB Act to them, the applicants have been banned from 1999 until 2009 from engaging in professional activities in various branches of the private sector on account of their status as 'former KGB officers' (see paragraph 27 above). Admittedly, the ban has not affected the applicants' ability to engage in certain types of professional activity. The ban has, however, affected their ability to develop relationships with the outside world to a very significant degree and has created serious difficulties for them in terms of earning their living, with obvious repercussions on the enjoyment of their private lives. 49. The Court also notes the applicants' argument that, as a result of the publicity caused by the adoption of the KGB Act and its application to them, they have suffered constant embarrassment as a result of their past activities. It accepts that the applicants continue to be burdened with the status of 'former KGB officers' and that fact may in itself be considered an impediment to the establishment of contacts with the outside world - be they employment-related or other - and that this situation undoubtedly affects more than just their reputation; it also affects the enjoyment of their 'private life'. The Court accepts that Article 8 cannot be relied on in order to complain of a loss of reputation which is the foreseeable consequence of one's own actions such as, for example, the commission of a criminal offence. Furthermore, during the considerable period which elapsed between the fall of the former Soviet Union (and the ensuing political changes in Lithuania) and the entry into force of the impugned legislation in 1999, it can reasonably be supposed that the applicants could not have envisaged the consequences their former KGB employment would entail for them. In any event, in the instant case there is more at stake for the applicants than the defence of their good name. They are marked in the eyes of society on account of their past association with an oppressive regime. Hence, and in view of the wide-ranging scope of the employment restrictions the applicants have to endure, the Court considers that the possible impediment to their leading a normal personal life must be taken to be a relevant factor in determining whether the facts complained of fall within the ambit of Article 8 of the Convention".

${ }^{231}$ Ver parágrafo 43 do acórdão: “[...] A Corte decidiu em inúmeras ocasiões que "vida privada' é um termo amplo não suscetível de definição exaustiva [...]. Ela observou, entretanto, que o artigo $8^{\circ}$ protege a integridade moral e física do indivíduo [...], incluindo o direito de viver privadamente, longe de atenção indesejada. Também garante ao indivíduo uma esfera dentro da qual pode livremente buscar o desenvolvimento de sua personalidade [...]" (tradução nossa). No original: "43. The Court has on a number of occasions ruled that "private life" is a broad term not susceptible to exhaustive definition (see, as a recent authority, 'Peck v. the United Kingdom', no. 44647/98, § 57, ECHR 2003-I). It has nevertheless also observed that Article 8 protects the moral and physical integrity of the individual (see ' $\mathrm{X}$ and $\mathrm{Y}$ v. the Netherlands', judgment of 26 March 1985, Series A no. 91, pp. 11-13, §§ 22-27), including the right to live privately, away from unwanted attention. It also secures to the individual a sphere within which he or she can freely pursue the development and fulfilment of his or her personality (see 'Brüggeman and Scheuten v. Germany', no. 6959/75, Commission's report of 12 July 1977, Decisions and Reports 10, p.115, § 55)”.
} 
Glasenapp e Kosiek v. Germany, julgamento de 28 de agosto de 1986 (Series A no. 104 , p. 26, parágrafo 49 , e no. 105 , p. 20, parágrafo 35); o princípio acima foi também reiterado em Vogt v. Germany (julgamento de 26 de setembro de 1995 , Series A no. 323, pp. 22-23, parágrafos 43-44). Em Thlimmenos v. Greece ([GC], no. 34369/97, parágrafo 41, ECHR 2000-IV), onde a um requerente tinha sido negado registro como um contador certificado por conta de uma prévia condenação, a Corte também estabeleceu que o direito de escolher uma profissão determinada não era garantido como tal pela Convenção.

47. Todavia, considerando, em particular, as noções atualmente prevalecentes nos Estados democráticos, a Corte considera que uma vedação "super abrangente" de assumir emprego no setor privado afeta, sim, a "vida privada". Ela atribui particular peso, neste aspecto, ao texto do Artigo $1^{\circ}$, parágrafo $2^{\circ}$, da Carta Social Européia e a interpretação dada pelo Comitê Europeu de Direitos sociais [...] e os textos adotados pela OIT [...]. Ela reitera, ademais, que não há uma divisão nítida separando a esfera de direitos sociais e econômicos do campo coberto pela Convenção (ver Airey v. Ireland, julgamento de 9 de outubro de 1979, Series A no. 32, pp. 14-16, parágrafo 26).

\section{$[\ldots]$}

50. À luz do acima, a Corte considera que a vedação impugnada afetou, em um grau significativo, a faculdade dos requerentes de buscar várias atividades profissionais e que houve efeitos conseqüenciais no gozo de seu direito ao respeito por sua "vida privada" no significado do Artigo $8^{\circ}$. Segue-se que o Artigo 14 da Convenção é aplicável às circunstâncias deste caso em conjunto com o Artigo $8^{\text {o232 }}$. (tradução nossa).

Em PANTUSO c. ITALIE ${ }^{233}$, o requerente alegou que a lei de falência italiana, ao

${ }^{232}$ Parágrafos 45 a 47 e 50 do acórdão. No original: “45. In the recent case of 'Smirnova v. Russia' (nos. 46133/99 and 48183/99, §§ 96-97, ECHR 2003-IX), the Court examined the effect on an applicant's 'private life' of the seizure by the authorities of an official document (internal passport), even though no specific interference had been alleged by that applicant as a result of the seizure. The Court ruled that the absence of the passport itself caused a number of everyday inconveniences taken in their entirety, as the applicant needed the passport when performing such mundane tasks as exchanging currency or buying train tickets. It was also noted in particular that the passport was required by that applicant for more crucial needs such as finding employment or receiving medical care. The Court concluded that the deprivation of the passport in 'Smirnova' had represented a continuing interference with that applicant's 'private life'. 46. The Court has also ruled that lack of access to the civil service as such cannot be the basis for a complaint under the Convention (see 'Glasenapp' and 'Kosiek v. Germany', judgments of 28 August 1986 (Series A no. 104, p.26, $\S 49$, and no. 105, p.20, $\S 35$ ); the above principle was also reiterated in 'Vogt v. Germany' (judgment of 26 September 1995, Series A no. 323, pp. 22-23, §§ 43-44). In 'Thlimmenos v. Greece', ([GC], no. 34369/97, § 41, ECHR 2000-IV), where an applicant had been refused registration as a chartered accountant because of a previous conviction, the Court also stated that the right to choose a particular profession was not as such guaranteed by the Convention. 47. Nevertheless, having regard in particular to the notions currently prevailing in democratic States, the Court considers that a far-reaching ban on taking up private sector employment does affect 'private life'. It attaches particular weight in this respect to the text of Article $1 \S 2$ of the European Social Charter and the interpretation given by the European Committee of Social Rights (see paragraph 31 above) and to the texts adopted by the ILO (see paragraph 32 above). It further reiterates that there is no watertight division separating the sphere of social and economic rights from the field covered by the Convention (see 'Airey v. Ireland', judgment of 9 October 1979, Series A no. 32, pp. 14-16, § 26). [...] 50. In the light of the above, the Court considers that the impugned ban affected, to a significant degree, the applicants' ability to pursue various professional activities and that there were consequential effects on the enjoyment of their right to respect for their 'private life' within the meaning of Article 8 . It follows that Article 14 of the Convention is applicable in the circumstances of this case taken in conjunction with Article 8 ".

${ }^{233}$ Requête 21120/02, julgado pela Terceira Seção em 24 de maio de 2006, decisão tornada definitiva em 11 de dezembro de 2006. 
proibi-lo de exercer atividades profissionais ou comerciais após ter seu nome inscrito no rol dos falidos, bem como condicionar o início do processo de reabilitação ao decurso do prazo de cinco anos contados do término do processo de falência, violava o seu direito à vida privada, principalmente pela demora do Poder Judiciário em concluir o processo.

A Corte entendeu que a falta de avaliação (individualizada) e controle jurisdicional sobre a aplicação da penalidade de incapacidade e do lapso de tempo não são "necessários a uma sociedade democrática" a ponto de justificar uma ingerência desse modo, no sentido do parágrafo $2^{\circ}$ do art. $8^{\circ}$ da Convenção ${ }^{234}$. A alegação de violação de correspondência pelo síndico da falência não foi conhecida por não esgotamento dos recursos internos, nos termos do artigo 35, números 1 e 4 , da Convenção.

WAINWRIGHT v. THE UNITED KINGDOM ${ }^{235}$ estabeleceu que a revista de visitantes de presos, numa penitenciária, é possível, desde que se dê em conformidade com a lei nacional, seja seguido um procedimento razoável e haja respeito à dignidade da pessoa humana ${ }^{236}$.

RADIO TWIST, A.S. v. SLOVAKIA ${ }^{237}$ trata do caso de uma conversa telefônica, obtida por meios não revelados, entre duas altas autoridades da Eslováquia, divulgada por uma rádio daquele país. Uma das autoridades processou a rádio, que foi condenada pelas cortes nacionais, sob o entendimento de que o direito à "privacy" estende-se às conversas telefônicas mantidas por autoridades oficiais. A rádio entrou, então, com uma reclamação na Corte Européia, alegando violação de um direito assegurado pelo artigo 10 da Convenção.

A Corte entendeu que a conversa travada tinha conteúdo político, pois cuidava da luta em torno de privatizações e gerenciamento de empresas então controladas pelo Estado, assunto de interesse geral, afirmando claramente que "[...] a Corte não consegue discernir qualquer dimensão de vida privada nos eventos impugnados. O critério especial de tolerância estabelecido na jurisprudência da Convenção é, portanto, aplicável [...]”238 (tradução nossa), e que o mero fato de a fita ter sido obtida ilegalmente por terceiros, o que nunca foi investigado, não pode privar a empresa de telecomunicação de divulgar seu

\footnotetext{
${ }^{234}$ Ver parágrafo 24 do acórdão.

${ }^{235}$ Application 12350/04, julgado pela Quarta Seção em 26 de setembro de 2006, decisão tornada definitiva em 26 de dezembro de 2006.

${ }^{236}$ Ver parágrafos 44 a 49 do acórdão.

${ }^{237}$ Application 62202/00, julgado pela Quarta Seção em 19 de dezembro de 2006, decisão tornada definitiva em 19 de março de 2007.

${ }^{238}$ Parágrafo 58 do acórdão. No original: "[...] the Court is unable to discern any private-life dimension in the impugned events. The special standard of tolerance established in the Convention case-law is therefore applicable [...]".
} 
conteúdo, julgando, assim, violado o artigo 10.

Em VAN VONDEL v. THE NETHERLANDS ${ }^{239}$, a Corte entendeu que gravações de conversas telefônicas e daquelas travadas pessoalmente, feitas por um dos interlocutores, "particular", sem autorização legal, com equipamentos fornecidos por uma entidade do governo, ainda que a pedido desse indivíduo, como ocorreu, viola o artigo $8^{\circ}$ da Convenção, pois constitui, em seus termos, uma violação da vida privada por uma autoridade pública:

[...] A Corte já notou que a gravação de conversas (telefônicas) por um interlocutor e o uso privado de tais gravações não ofende "per se" o Artigo $8^{\circ}$ se é feito com meios privados, mas isso, por sua própria natureza, deve ser distinguido do monitoramento e da gravação secretos de comunicações por uma pessoa privada no contexto e em benefício de um inquérito oficial - criminal ou outro - e com a conivência e assistência técnica de autoridades públicas de investigação. Nesse aspecto, a Corte observa que, no presente caso, embora as gravações das conversações do requerente tenham sido feitas pelo $\mathrm{Sr}$. R. voluntariamente e para seus próprios propósitos, o equipamento foi providenciado pelas autoridades, que em pelo menos uma ocasião deram-lhe instruções específicas relativas a que informações deveria obter do reclamante. Nessas circunstâncias, a Corte considera que as autoridades "tiveram uma contribuição crucial na execução do esquema" e não está persuadida de que o Sr. R. estava, no fim das contas, no controle dos eventos. Entender de outro modo seria equivalente a permitir as autoridades de investigação a se evadirem de suas responsabilidades sob a Convenção pelo uso de agentes privados (ver M.M. v. the Netherlands $[\ldots]^{240}$. (tradução nossa).

Note-se, porém, que a razão que levou a Corte a decidir pela violação do artigo $8^{\circ}$ da Convenção foi a ausência de lei regulando esse tipo de vigilância e monitoramento pelas autoridades.

Em HALFORD v. UNITED KINGDOM, uma mulher que exercia alto cargo no departamento de polícia de Merseyside, na Inglaterra, postulou, por inúmeras vezes, uma promoção para o cargo mais alto do departamento, sem sucesso.

Após a última tentativa fracassada, ajuizou uma ação contra o departamento de

\footnotetext{
${ }^{239}$ Application 38258/03, julgado pela Terceira Seção em 25 de outubro de 2007, decisão tornada final em 25 de janeiro de 2008.

${ }^{240}$ Parágrafo 49 do acórdão. No original: “[...] The Court would note that the recording of private (telephone) conversations by a conversation partner and the private use of such recordings does not 'per se' offend against Article 8 if this is done with private means, but that by its very nature this is to be distinguished from the covert monitoring and recording of communications by a private person in the context of and for the benefit of an official inquiry - criminal or otherwise - and with the connivance and technical assistance of public investigation authorities. In that respect, the Court observes that in the present case, although the recordings of the applicant's conversations were made by $\mathrm{Mr} \mathrm{R}$. on a voluntary basis and for his own purposes, the equipment was provided by the authorities, who on at least one occasion gave him specific instructions as to what information should be obtained from the applicant. In these circumstances, the Court considers that the authorities 'made a crucial contribution to executing the scheme' and it is not persuaded that it was ultimately $\mathrm{Mr} \mathrm{R}$. who was in control of events. To hold otherwise would be tantamount to allowing investigating authorities to evade their responsibilities under the Convention by the use of private agents (see 'M.M. v. the Netherlands', cited above, § 40)'.
} 
polícia por discriminação. Tempos depois, alegou ter evidências de que seus telefones do trabalho e de casa estavam sendo "grampeados", com o fim de se obter provas contra ela no caso de discriminação.

Depois de buscar as instâncias jurisdicionais de seu país, ingressou com uma reclamação na Comissão Européia de Direitos Humanos, alegando que a interceptação de chamadas feitas de seus telefones constituíam interferências injustificáveis no seu direito à vida privada e à liberdade de expressão, em violação aos artigos $8^{\circ}$ e 10 da Convenção Européia, que não tinha remédios domésticos contra tal violação, de acordo com o artigo 13, e que estava sendo discriminada, em afronta ao artigo 14.

No julgamento, a Corte reafirmou o entendimento de que as chamadas feitas a partir do telefone de serviço podem cair no conceito de "vida privada" e “correspondência”, para efeitos do parágrafo $1^{\circ}$ do artigo $8^{\circ}$ da Convenção, e que, no caso, as chamadas feitas pelo telefone de serviço, especificamente, gozavam de razoável expectativa de privacidade ("privacy"), pois não fora dado à reclamante nenhum aviso quanto à possibilidade de monitoramento de suas ligações, foram-lhe conferidas duas linhas de telefone, sendo uma exclusivamente para uso particular, além de ter autorização por escrito para usar a linha de serviço com o objetivo de cuidar de assuntos relacionados à ação judicial por discriminação ${ }^{241}$.

A Corte entendeu haver indícios de que realmente houve interceptações com a finalidade assinalada, que a interceptação de seu telefone do serviço era ilegal, pois integrava uma rede interna de telecomunicações, não abrangida pela lei de interceptações, configurando violação aos artigos $8^{\circ}$ e 13 da Convenção, inexistindo evidências de interceptação, contudo, no telefone de casa.

Em VALENZUELA CONTRERAS v. SPAIN ${ }^{242}$, a Corte entendeu violado o artigo $8^{\circ}$ da Convenção porque a legislação espanhola, antes da alteração de 1988 do Código de Processo Criminal da Espanha (“Ley de Enjuiciamiento Criminal”), à exceção do artigo 18.3 da Constituição, não previa sequer a interceptação telefônica, e não cumpria, portanto, o requisito de previsibilidade, como

[...] as condições relativas à definição das categorias de pessoas sujeitas a terem seus telefones "grampeados" por ordem judicial, um limite à duração da interceptação, o procedimento para desenvolver os relatórios resumidos contendo as conversas interceptadas e o uso e destruição das gravações $[\ldots]^{243}$. (tradução

\footnotetext{
${ }^{241}$ Parágrafo 45 do acórdão.

${ }^{242}$ Application 27671/95, julgado pela Câmara em 30 de julho de 1998.

${ }^{243}$ Parágrafo 59 do acórdão. No original: "The Court notes that some of the conditions necessary under the Convention to ensure the foreseeability of the effects of the "law" and, consequently, to guarantee respect for
} 
nossa).

O caso de PERRY v. THE UNITED KINGDOM ${ }^{244}$ tratava de um indivíduo acusado de inúmeros roubos que se recusara a participar de sessões marcadas pela polícia para identificação por testemunhas. A polícia resolveu, sem o conhecimento do acusado ou de seu advogado, filmá-lo na área de custódia de uma penitenciária e, então, apresentar a fita a testemunhas para reconhecimento. Não lhe foi dada a oportunidade de assistir à fita antes de seu uso no julgamento em que foi condenado por alguns dos crimes.

O reclamante alegou à Corte Européia que foi filmado secretamente, em afronta ao artigo $8^{\circ}$ da Convenção, que, mais uma vez, expandiu o conceito de "vida privada":

36. Vida privada é um termo amplo não suscetível de definição exaustiva. Aspectos como identificação de gênero, nome, orientação sexual e vida sexual são importantes elementos da esfera pessoal protegidas pelo Artigo $8^{\circ}$. O Artigo também protege um direito à identidade e desenvolvimento pessoal, e o direito de estabelecer e desenvolver relacionamentos com outros seres humanos e o mundo exterior, e pode incluir atividades de natureza profissional ou comercial. Há, portanto, uma zona de interação de uma pessoa com outras, mesmo num contexto público, que pode cair no escopo de "vida privada" (P.G. and J.H. v. the United Kingdom, no. 44787/98, parágrafo 56, ECHR 2001-IX, com mais referências).

37. Não se pode, portanto, excluir [a possibilidade de] que a vida privada de uma pessoa possa ser afetada por medidas tomadas fora de sua casa ou lugares reservados. Expectativas razoáveis de uma pessoa quanto à privacidade são um fator significante, mas não conclusivo (P.G. and J.H v. United Kingdom, parágrafo 57$)^{245}$. (tradução nossa).

A Corte afirmou que uso de câmeras de vigilância, "per se", não constitui uma interferência na vida privada, mas que, no caso, a câmera foi especificamente ajustada por um engenheiro, sob permissão de um superior da polícia, para produzir uma imagem

private life and correspondence are not included either in Article $18 \S 3$ of the Constitution or in the provisions of the Code of Criminal Procedure cited in the order of 19 November 1985 (see paragraphs 14 and 30 above). They include, in particular, the conditions regarding the definition of the categories of people liable to have their telephones tapped by judicial order, the nature of the offences which may give rise to such an order, a limit on the duration of telephone tapping, the procedure for drawing up the summary reports containing intercepted conversations and the use and destruction of the recordings made [...]". Ver também Sánchez (2001).

${ }^{244}$ Application 63737/00, julgado pela Terceira Seção em 17 de julho de 2003, decisão tornada definitiva em 17 de outubro de 2003.

${ }^{245}$ Parágrafos 36 e 37 do acórdão. No original: “36. Private life is a broad term not susceptible to exhaustive definition. Aspects such as gender identification, name, sexual orientation and sexual life are important elements of the personal sphere protected by Article 8. The Article also protects a right to identity and personal development, and the right to establish and develop relationships with other human beings and the outside world and it may include activities of a professional or business nature. There is, therefore, a zone of interaction of a person with others, even in a public context, which may fall within the scope of 'private life' ('P.G. and J.H. v. the United Kingdom', no. 44787/98, § 56, ECHR 2001-IX, with further references). 37. It cannot therefore be excluded that a person's private life may be concerned in measures effected outside a person's home or private premises. A person's reasonable expectations as to privacy is a significant though not necessarily conclusive factor ('P.G. and J.H v. United Kingdom', § 57)". 
cristalina do reclamante com a finalidade de apresentá-lo para identificação por testemunhas em acusações de roubo, e que tal fita foi obtida secretamente sem o seu consentimento ou conhecimento, gravada com objetivo diverso daquele pelo qual existe (segurança do local), ainda mais porque o uso de tais imagens para montagem importa em processamento de dados pessoais ${ }^{246}$.

A Corte julgou que houve interferência na vida privada do indivíduo, que havia lei nacional prevendo o uso desse tipo de evidência, mas que o procedimento adotado pelas autoridades deu-se em desacordo com essa lei, tendo sido violado, portanto, o artigo $8^{\circ}$ da Convenção.

PEEV v. BULGARIA ${ }^{247}$ tratava do caso de Peev, que escrevera uma carta a dois periódicos de seu país e ao Conselho Judicial Supremo reclamando da atuação opressiva de seu mais alto superior, o Procurador Chefe. A carta dizia que chegou a pensar em se demitir do cargo que ocupava, tendo redigido dois rascunhos de pedido de demissão, mas que mudara de idéia.

Na mesma data da publicação da carta, seu escritório foi revistado por oficiais e, no dia seguinte, seu acesso a ele foi barrado. Dois dias mais tarde, descobriu que sua carta de demissão havia sido aceita pelo Procurador Chefe, embora nunca a tivesse enviado. Inspeção posterior revelou que, dentre os itens que haviam sumido de seu escritório, estavam os dois rascunhos de pedido de demissão.

A Corte entendeu que o indivíduo tinha uma expectativa razoável de privacidade (“privacy”), se não em relação a todo o seu escritório, pelo menos no tocante a suas gavetas e arquivos, indicada pela grande quantidade de objetos pessoais que ali mantinha e pelo fato de não haver nenhuma peculiaridade no caso que pudesse levar a outra conclusão, como a existência de uma explícita política por parte do empregador de desencorajar a guarda de papéis e objetos pessoais no local de trabalho. Afirmou, também, que o simples fato de o empregador ser uma autoridade pública e de seu escritório situar-se em um prédio do governo não alterava essa situação.

Houve interferência na vida privada por uma autoridade pública, e o governo não mencionou à Corte qualquer provisão legal que tenha embasado a sua atuação, o que a levou a entender ter havido violação do artigo $8^{\circ}$ da Convenção, além dos artigos 10, que cuida da liberdade de expressão, e 13, em conjunto com os dois anteriores, por não haver

\footnotetext{
${ }^{246}$ Ver parágrafos 41 a 43 do acórdão.

247 Application 64209/01, julgado pela Quinta Seção em 25 de julho de 2007, decisão tornada definitiva em 26 de outubro de 2007.
} 
remédios adequados para a proteção do direito em questão no ordenamento jurídico interno.

Da análise desses julgados, vê-se que a Corte procura, em suma, encontrar no caso concreto, sucessiva e concomitantemente, os seguintes requisitos: (i) a verificação da existência de uma ingerência num direito protegido pelo artigo $8^{\circ}$, parágrafo $1^{\circ}$, da Convenção Européia de Direitos Humanos; (ii) a interferência do Estado, por ação ou omissão, nesse direito; (iii) a sua previsão legal no ordenamento jurídico nacional, sendo que a lei não precisa ser escrita, mas tem que o ser em sentido material e suficiente e razoavelmente precisa para que o indivíduo possa prever o resultado de suas ações e, conforme a situação, agir de acordo; (iv) a presença de uma das hipóteses da parte final do parágrafo $2^{\circ}$ do artigo $8^{\circ}$ da Convenção (segurança nacional, segurança pública, dentre outros ali arrolados); e a (v) "necessidade" dessa ingerência numa "sociedade democrática", o que tem se traduzido, na prática, numa verificação da proporcionalidade entre os meios adotados e os fins almejados pela legislação, que deve salvaguardar, o tanto quanto possível, os direitos do indivíduo arrolados no parágrafo $1^{\circ}$ do artigo $8^{\circ}$ da Convenção ${ }^{248}$.

Além disso, o conceito de "vida privada" com que a Corte trabalha não é fechado, e envolve diversos aspectos, como aqueles relacionados à identificação de pessoas, notadamente gênero, nome, orientação sexual e vida sexual; um direito à identidade e desenvolvimento pessoal; e o direito de estabelecer e desenvolver relacionamentos com outros seres humanos e o mundo exterior, podendo incluir atividades de natureza profissional ou comercial, independente de onde se desenrolem. Considera-se protegida uma zona de interação de uma pessoa com outras, mesmo num ambiente público ${ }^{249}$.

No âmbito da União Européia, a proteção aos direitos humanos dá-se, em larga

\footnotetext{
${ }^{248}$ Ver também, a respeito dos critérios, B. Rodrigues (2008).

${ }^{249}$ Embora os países que fazem parte da Convenção Européia de Direitos Humanos tenham de observá-la e à jurisprudência da Corte, cada país apresenta uma história evolutiva diferente do direito de privacidade. Ver, dentre outros, a respeito da "riservatezza", na Itália, Caldirola (2006), Cossu (1998), Crisafulli e Paladin (1990), Markesinis e Alpa (1997), Mauro (2000), Niger (2006) e Rossato (1999). Na França, Rigaux (1991) entende que existem dois setores entrelaçados na privacidade ("privacy"), um que garante a liberdade de fazer, sem ingerência do Estado, as escolhas essenciais dentro dos domínios sensíveis da esfera privada, outro que protege o direito ao segredo. Mais a respeito do que se entende abranger a vida privada lá ("vie privée") em Colliard e Letteron (2005), Moutouh e Rivero (2003b) e Oberdorff (2008). Em Portugal, sobre o direito à reserva da intimidade da vida privada e familiar, ver Miranda e Medeiros (2005), para quem “[o] direito não merece contudo a abrangência que lhe tem dado a jurisprudência americana, onde o 'right to privacy' surge como a expressão paradigmática de todos os direitos pessoais" (p. 290, grifo dos autores). Ela abrange o segredo bancário, conforme Acórdão no 278/95 do Tribunal Constitucional (MIRANDA; MEDEIROS, 2005, p. 291). C. Castro (2005), por sua vez, entende que o direito à intimidade da vida privada é um direito sobre a informação, que não se confunde com um direito geral de personalidade. Ver ainda Almeida (2003), Canotilho e Moreira (2007), Costa e Moniz (1997) e Pinto (2000). Na Espanha, ver Sánchez (2001).
} 
medida, através de cláusulas esparsas em inúmeros tratados e de outros diplomas normativos "extracomunitários", como a própria Convenção Européia e os tratados celebrados sob a égide da Organização das Nações Unidas e da Organização Internacional do Trabalho.

Proteção direta dá-se por meio dos artigos $6^{\circ}$ e $7^{\circ}$ do Tratado da União Européia (“Tratado UE”) e do artigo 309 do Tratado da Comunidade Européia (“Tratado CE”). O Tratado da União Européia dispõe em seu artigo $6^{\circ}$, números 1 e 2:

1. A União assenta nos princípios da liberdade, da democracia, do respeito pelos direitos do Homem e pelas liberdades fundamentais, bem como do Estado de direito, princípios que são comuns aos Estados-Membros.

2. A União respeita os direitos fundamentais tal como os garante a Convenção Europeia de Salvaguarda dos Direitos do Homem e das Liberdades Fundamentais, assinada em Roma em 4 de Novembro de 1950, e tal como resultam das tradições constitucionais comuns aos Estados-Membros, enquanto princípios gerais do direito comunitário.

O Tratado de Amsterdã, de 1997, com as alterações efetuadas pelo Tratado de Nice, de 2001, inseriu um artigo $7^{\circ 250}$ ao Tratado UE, estabelecendo um sistema de proteção ativa, preventiva e repressiva, dos direitos fundamentais em seu âmbito, cujo poder de decisão e execução concentra-se no Conselho Europeu, que, provocado por um terço dos Estados-Membros, do Parlamento ou da Comissão, pode emitir desde recomendações aos Estados-Membros até determinar a suspensão de alguns dos seus direitos, como o seu direito de voto no Conselho.

$\mathrm{O}$ artigo $7^{\circ}$ confere um alto grau de discricionariedade ao Conselho, que se submete apenas a um parecer prévio do Parlamento Europeu, não podendo o Tribunal de Justiça das Comunidades Européias controlar as razões do entendimento acerca de "grave violação" dos direitos fundamentais, mas somente a observância dos procedimentos, em virtude do disposto no artigo 46, alínea "e", do Tratado UE. Além disso, ao contrário da Convenção Européia, não permite acesso direto dos indivíduos, e traz dúvidas, por exemplo, sobre quais direitos podem ser suspensos, se somente os "institucionais" (políticos), atinentes ao Estado como agente político no âmbito da União, como o direito de voto no Conselho, citado expressamente, ou se outros, como a livre circulação de pessoas e mercadorias, já que, por outro lado, determina que "[a]o fazê-lo [aplicar a pena], o Conselho terá em conta as eventuais consequências dessa suspensão nos direitos e obrigações das pessoas singulares e colectivas”, e que "[o] Estado-Membro em questão continua, de qualquer

\footnotetext{
${ }^{250}$ Foi inserido o análogo e correspondente artigo 309 no Tratado CE. Mais a respeito do impacto trazido no âmbito da União Européia pelas modificações do Tratado de Amsterdã em Moutouh e Rivero (2003a).
} 
modo, vinculado às obrigações que lhe incumbem por força do presente Tratado" 251 .

Em 2000, a Carta dos Direitos Fundamentais da União Européia foi proclamada pelo Parlamento Europeu, o Conselho e a Comissão, estabelecendo no seu artigo $7^{\circ}$ que "[t]odas as pessoas têm direito ao respeito pela sua vida privada e familiar, pelo seu domicílio e pelas suas comunicações" (grifo nosso), valendo-se de um vocábulo atualizado e mais amplo, além de prever o direito de proteção de dados pessoais, no artigo $8^{\circ}$ :

1. Todas as pessoas têm direito à protecção dos dados de carácter pessoal que lhes digam respeito.

2. Esses dados devem ser objecto de um tratamento leal, para fins específicos e com o consentimento da pessoa interessada ou com outro fundamento legítimo previsto por lei. Todas as pessoas têm o direito de aceder aos dados coligidos que lhes digam respeito e de obter a respectiva rectificação.

3. O cumprimento destas regras fica sujeito a fiscalização por parte de uma autoridade independente.

Esses direitos encontram-se nesse documento dentre os direitos de "liberdade", ou "liberdades", merecendo menção o fato de que essa Carta encontra-se dividida em sete partes (capítulos), sendo que seis delas podem ser consideradas como "gêneros" de direitos fundamentais, nessa ordem: dignidade, liberdades, igualdade, solidariedade, cidadania e justiça.

O sétimo capítulo traz disposições gerais, que determinam, essencialmente, que: (i) os destinatários da Carta são as instituições e órgãos da União, na observância do princípio da subsidiariedade, bem como os Estado-Membros, quando apliquem normas da União, não criando nenhuma nova atribuição ou competência e nem modificando as estabelecidas nos $\operatorname{Tratados}^{252}$; (ii) restrições aos direitos e liberdades previstos pela Carta devem ser previstos em lei e respeitar seu "conteúdo essencial", devendo-se observar o princípio da proporcionalidade, só podendo ser introduzidas se forem necessárias e corresponderem efetivamente a objetivos de interesse geral reconhecidos pela União, ou à necessidade de proteção dos direitos e liberdades de terceiros ${ }^{253}$; e (iii) o disposto na Carta não pode restringir ou eliminar de qualquer forma os direitos garantidos por outros documentos, especialmente a Convenção Européia de Direitos Humanos, podendo o direito da União, no entanto, conferir garantias mais amplas ${ }^{254}$.

Essa Carta, porém, não tem, por ora, natureza jurídica de tratado ou norma

\footnotetext{
${ }^{251}$ Artigo $7^{\circ}$, número 3 , do Tratado UE.

${ }^{252}$ Artigos 51 e 52, número 2.

${ }^{253}$ Artigo 52, número 1.

${ }^{254}$ Artigos 52, número 3, 53 e 54.
} 
comunitária aplicável, não sendo vinculativa.

O Tratado que pretendia estabelecer uma Constituição para a Europa, assinado em 2004, incorporava-a ao seu texto, de modo que, se fosse ratificado, tornar-se-ia de observância obrigatória. Tal Tratado, porém, acabou por ser retirado por uma Conferência Intergovernamental (“CIG”) convocada pelo Conselho Europeu de 21 e 22 de junho de 2007, devido à grande dificuldade na sua aprovação, pois foi rejeitada por alguns plebiscitos realizados em Estados-Membros, e substituído por um Tratado Modificativo (ou Reformador) (UNIÃO EUROPÉIA, 2008).

Esse Tratado Reformador consubstanciou-se no Tratado de Lisboa, assinado em 13 de dezembro de 2007, que, dentre várias modificações, altera o artigo $6^{\circ}$, 1 , estabelecendo que "[a] União reconhece os direitos, as liberdades e os princípios enunciados na Carta dos Direitos Fundamentais da União Europeia, de 7 de Dezembro de 2000, com as adaptações que lhe foram introduzidas em 12 de Dezembro de 2007, em Estrasburgo, e que tem o mesmo valor jurídico que os Tratados" (destaque nosso), e o artigo $6^{\circ}, 2$ e 3 , determinando a adesão da União Européia à Convenção Européia de Direitos Humanos e a expressa integração deste no direito comunitário, enquanto princípios gerais.

Se esse tratado entrar em vigor, nos termos do seu artigo $6^{\circ}$, número $2^{255}$, estará finalmente positivada a Carta dos Direitos Fundamentais da União Européia, bem como se tornará aplicável à União, por sua parte, a Convenção Européia de Direitos Humanos, havendo inclusive um Protocolo ao Tratado de Lisboa estabelecendo certas condições que devem ser observadas quando esse fato concretizar-se.

Do lado do Conselho da Europa, a União Européia está para legalmente vir a se vincular à Convenção Européia de Direitos Humanos, já que o Protocolo 14, de 13 de maio de 2004, do Conselho da Europa (“Convenção 194" ou "ETS 194”), dentre outras alterações, inseriu um novo parágrafo ao artigo 59 desse Tratado ${ }^{256}$ permitindo expressamente essa adesão.

O Protocolo não entrou em vigor, pois depende do consentimento de todos os membros do Conselho da Europa ${ }^{257}$, sendo que, até a presente data, falta apenas a ratificação da Rússia.

A União Européia, enquanto entidade supranacional, passaria a ser sujeito de

\footnotetext{
${ }^{255}$ É o texto desse dispositivo: "O presente Tratado entra em vigor no dia 1 de Janeiro de 2009, se tiverem sido depositados todos os instrumentos de ratificação ou, na falta desse depósito, no primeiro dia do mês seguinte ao do depósito do instrumento de ratificação do Estado signatário que proceder a esta formalidade em último lugar".

${ }^{256}$ Artigo 17, número 1, do Protocolo.

257 Artigos 18 e 19 do Protocolo.
} 
direitos e obrigações previstos na Convenção Européia de Direitos Humanos, passível de submissão à apreciação e julgamento da Corte Européia de Direitos Humanos.

De qualquer modo, do quanto visto, embora o Tribunal de Justiça das Comunidades Européias não tenha competência para verificar, "per se", a aplicação da Convenção Européia de Direitos Humanos no âmbito da União Européia ${ }^{258}$, pelo menos desde $1974^{259}$, em seus julgamentos, tem entendido que os direitos fundamentais fazem parte dos princípios gerais de direito, que devem ser observados na aplicação das normas comunitárias $^{260}$.

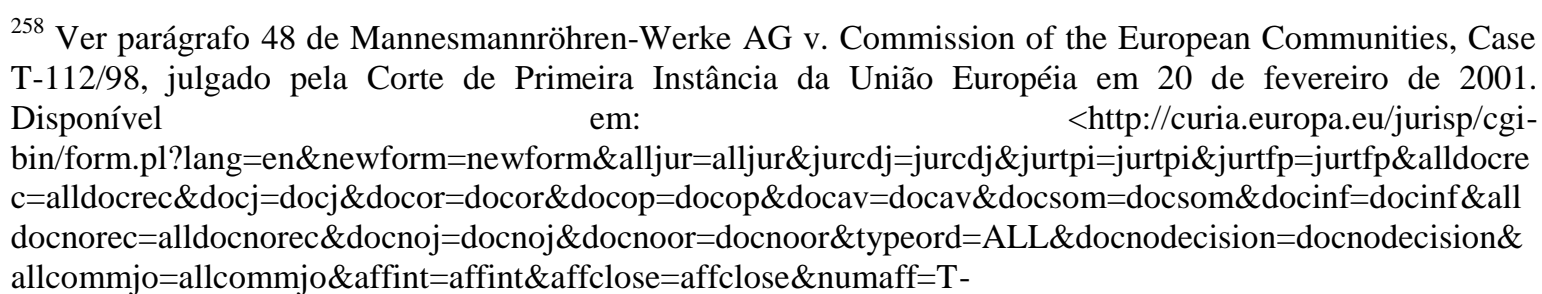

$112 \% 2 \mathrm{~F} 98 \&$ ddatefs $=\&$ mdatefs $=\&$ ydatefs $=\&$ ddatefe $=\&$ mdatefe $=\&$ ydatefe $=\&$ nomusuel $=\&$ domaine $=\&$ mots $=$ \&resmax=100\&Submit=Submit>. Acesso em: 5 jan. 2009.

259 "De 1974 em diante, a Corte de Justiça afirmou que os direitos fundamentais estão entre os princípios gerais de direito que tem de preservar. Com o passar dos anos, proferiu decisões em situações individuais em que reconhece direitos fundamentais como a dignidade humana e o princípio da não discriminação. Os mais importantes direito fundamentais individuais reconhecidos até agora pela Corte de Justiça são os seguintes: dignidade humana (Casagrande, 1974); - princípio da igualdade (Klöckner-Werke AG, 1962); - não discriminação (Defrenne v Sabena, 1976); - liberdade de associação (Confédération syndicale, Massa, etc., 1974); - liberdade de religião e de crença (Prais, 1976); - proteção da vida privada (National Panasonic, 1980); - segredo médico (Commission v Germany, 1992); - direitos de propriedade [domínio] (Hauer, 1979); - liberdade de desenvolver uma profissão (Hauer, 1979); - liberdade de comércio (Intern. Handelsgesellschaft, 1970); - liberdade econômica (Usinor, 1984); - liberdade de competição (France, 1985); - respeito pela vida familiar (Commission v Germany, 1989); - direito à efetiva proteção pelos tribunais e processo justo (Johnston v Chief Constable of the Royal Ulster Constabulary, 1986; Pecastaing v Belgium, 1980); - inviolabilidade da casa (Hoechst AG v Commission, 1989); - liberdade de opinião e de publição (VBVB, VBBB, 1984)" (UNIÃO EUROPÉIA, 2007, tradução nossa). No original: "From 1974 on, the Court of Justice affirmed that fundamental rights were among the general principles it must uphold. Over the years, it has given rulings on individual situations in which it recognises such fundamental rights as human dignity and the principle of non-discrimination. The most important individual fundamental rights recognised so far by the Court of Justice are the following: - human dignity (Casagrande, 1974); - principle of equality (Klöckner-Werke AG, 1962); - non-discrimination (Defrenne v Sabena, 1976); - freedom of association (Confédération syndicale, Massa, etc., 1974); - freedom of religion and beliefs (Prais, 1976); - protection of private life (National Panasonic, 1980); - medical secrecy (Commission v Germany, 1992); - rights of property ownership (Hauer, 1979); - freedom to engage in an occupation (Hauer, 1979); - freedom of trade (Intern. Handelsgesellschaft, 1970); - economic freedom (Usinor, 1984); - freedom of competition (France, 1985); - respect for family life (Commission v Germany, 1989); - right to effective protection by the courts and fair procedure (Johnston v Chief Constable of the Royal Ulster Constabulary, 1986; Pecastaing v Belgium, 1980); - inviolability of the home (Hoechst AG v Commission, 1989); - freedom of opinion and publication (VBVB, VBBB, 1984)".

260 "Adicionamente a esses princípios gerais, o princípio da não discriminação com base na nacionalidade está incrustado no Tratado CE. O Tratado de Amsterdã estende esse princípio ao possibilitar o Conselho a agir 'para combater discriminação baseada no sexo, origem racial ou étnica, religião ou crença, deficiência, idade ou orientação sexual' (artigos 12 e 13 do Tratado CE). O Tratado de Amsterdã também dispõe que: - os países candidatos devem respeitar os princípios estabelecidos no artigo 6(1) do Tratado UE (artigo 49 do Tratado UE); - a Corte de Justiça das Comunidades Européias assegurará que as instituições européias respeitem os direitos fundamentais (artigo 46 do Tratado UE)" (UNIÃO EUROPÉIA, Glossary, 2007, tradução nossa). No original: "In addition to these general principles, the principle of non-discrimination on grounds of nationality is enshrined in the EC Treaty. The Treaty of Amsterdam extends this principle by 
Foi criada, ainda, no âmbito da União Européia, em setembro de 2002, pela Comissão Européia, uma rede de "experts" independentes para avaliar o estado de salvaguarda dos direitos fundamentais no âmbito comunitário, através de relatórios anuais, bem como para prover informações e opiniões específicas à Comissão, quando solicitadas, tudo isso para o fim de ajudá-la e o Parlamento Europeu a desenvolver e melhorar políticas na área (COMISSÃO EUROPÉIA, 2007).

Por fim, em 15 de fevereiro de 2007, foi criada ${ }^{261}$ a Agência dos Direitos Fundamentais da União Européia, dotada de personalidade jurídica própria, resultado da transformação do Observatório Europeu do Racismo e da Xenofobia, englobando, inclusive, as atividades deste. Entrou em funcionamento em $1^{\circ}$ de março do mesmo ano e tem por objetivo:

[...] proporcionar às instituições, órgãos, organismos e agências da Comunidade, bem como aos seus Estados-Membros, quando aplicarem o direito comunitário, assistência e competências no domínio dos direitos fundamentais, a fim de os ajudar a respeitar plenamente estes direitos quando tomarem medidas ou definirem acções no âmbito das respectivas esferas de competência ${ }^{262}$.

Deve colaborar com outros órgãos da União Européia e outros internacionais, como o Conselho da Europa, para que não haja duplicidade de esforços ${ }^{263}$, mas não tem funções executivas, jurisdicionais ou legislativas, não substituindo o sistema de proteção do artigo $7^{\circ}$ do Tratado da União Européia, e, tampouco, o do Conselho da Europa ${ }^{264}$.

\subsection{A solução atual.}

Os países da União Européia devem transpor para seu ordenamento jurídico interno as normas comunitárias, denominadas Diretivas, sob pena de sanções. Ou seja, embora não haja uma aplicabilidade imediata das Diretivas, elas acabam por impor, com certo grau de discricionariedade, variável conforme a matéria e a norma comunitária, uma harmonização das legislações nacionais.

O começo da preocupação com a privacidade no âmbito europeu, contudo, precede,

making it possible for the Council to take action 'to combat discrimination based on sex, racial or ethnic origin, religion or belief, disability, age or sexual orientation' (Articles 12 and 13 of the EC Treaty). The Amsterdam Treaty also provides that: - the applicant countries must respect the principles set out in Article 6(1) of the EU Treaty (Article 49 of the EU Treaty); - the Court of Justice of the European Communities will ensure that the European Institutions respect fundamental rights (Article 46 of the EU Treaty)".

${ }^{261}$ Pelo Regulamento (CE) 168/2007.

${ }^{262}$ Artigo $2^{\circ}$ do Regulamento (CE) 168/2007.

${ }^{263}$ Vejam-se, especialmente, os artigos $6^{\circ}$ a 10 do Regulamento.

${ }^{264}$ Artigo $4^{\circ}$, número 2, do Regulamento (CE) 168/2007 e FRA (2007). 
em muito, a União, e deu-se com a Convenção Européia de Direitos Humanos, notadamente nos seus artigos $8^{\circ}$ e 10 , como já visto.

O Conselho debateu, nos anos de 1970, a necessidade de atualização dessa proteção, especialmente em virtude das novas tecnologias (EDPS, 2005, p. 7), o que acabou resultando na "Convenção 108" (ou ainda "ETS 108") "para a proteção das pessoas relativamente ao tratamento automatizado de dados de caráter pessoal", de $1981^{265}$. Segundo o Annual Report do European Data Protection Supervisor ("EDPS", ou, em português, Autoridade Européia para a Proteção de Dados) (EDPS, 2005, p. 7),

[a] Convenção trata de "protecção de dados" enquanto protecção dos direitos e das liberdades fundamentais das pessoas, nomeadamente o direito à privacidade, no que se refere ao tratamento de dados pessoais que lhes dizem respeito. Isto prova que a "protecção de dados" é mais ampla do que a "protecção da privacidade", uma vez que também abrange outras liberdades e direitos fundamentais das pessoas singulares, e simultaneamente mais específica, pois apenas respeita ao tratamento de dados pessoais. Neste contexto, deve ter-se consciência de que muitas actividades dos sectores público ou privado geram, hoje em dia, dados de carácter pessoal ou importam esse tipo de dados. O verdadeiro objectivo consiste, como tal, em proteger cada cidadão contra a recolha, o armazenamento, a utilização e a divulgação dos seus dados pessoais.

\section{O Preâmbulo da Convenção deixa claro o objetivo que persegue:}

[...] alargar a protecção dos direitos e das liberdades fundamentais de todas as pessoas, nomeadamente o direito ao respeito pela vida privada, tendo em consideração o fluxo crescente, através das fronteiras, de dados de carácter pessoal susceptíveis de tratamento automatizado [...] [e] conciliar os valores fundamentais do respeito pela vida privada e da livre circulação de informação entre os povos ${ }^{266}$.

Foram estabelecidas regras gerais, a partir das definições de "dados de caráter pessoal”, que seria qualquer informação relativa a uma pessoa identificada ou identificável, "ficheiro automatizado", "tratamento automatizado" e "responsável pelo ficheiro"267,

\footnotetext{
${ }^{265}$ Mesmo Estados não membros do Conselho da Europa podem aderir a essa Convenção, conforme seu artigo 23. Lembre-se que, em 23 de setembro de 1980, a OCDE adotou as "Guidelines on the Protection of Privacy and Transborder Flows of Personal Data" ("Diretrizes sobre a Proteção da Privacidade e do Fluxo Transfronteiriço de Dados Pessoais"), que influenciou, dentre outros, a Convenção 108 (OECD, 2008). Ver OECD (1980).

${ }^{266} \mathrm{O}$ que é praticamente repetido no artigo $1^{\circ}$ da Convenção.

${ }^{267}$ É a redação integral do artigo $2^{\circ}$ : “[definições] [p] ara os fins da presente Convenção: a) 'Dados de carácter pessoal' significa qualquer informação relativa a uma pessoa singular identificada ou susceptível de identificação ('titular dos dados'); b) 'Ficheiro automatizado' significa qualquer conjunto de informações objecto de tratamento automatizado; c) 'Tratamento automatizado' compreende as seguintes operações, efectuadas, no todo ou em parte, com a ajuda de processos automatizados: registo de dados, aplicação a esses dados de operações lógicas e ou aritméticas, bem como a sua modificação, supressão, extracção ou difusão; d) 'Responsável pelo ficheiro' significa a pessoa, singular ou colectiva, autoridade pública, serviço ou qualquer outro organismo competente, segundo a lei nacional, para decidir sobre a finalidade do ficheiro automatizado, as categorias de dados de carácter pessoal que devem ser registadas e as operações que lhes serão aplicadas".
} 
direitos e deveres das partes, a questão da qualidade e segurança dos dados, bem como consideração especial a certas espécies ou categorias de dados (origem racial, opiniões políticas, convicções religiosas ou outras, relativos à saúde e à vida sexual, bem como às condenações penais).

A “internalização"268 dessa Convenção pelos Estados signatários foi criando, contudo, diferenças nas normas de cada um, o que ameaçava prejudicar o desenvolvimento do mercado europeu (EDPS, 2005, p. 7), posto que esse tratado confere larga margem de liberdade a seus aderentes, além de existirem possibilidades expressas (e abertas) de derrogações.

A Comissão Européia ${ }^{269}$, então, no começo dos anos 1990, iniciou um esforço para harmonizar a legislação de tratamento dos dados pessoais no âmbito da União Européia, originando a Diretiva 95/46/CE ${ }^{270}$, de 24 de outubro de 1995, "relativa à protecção das pessoas singulares no que diz respeito ao tratamento de dados pessoais e à livre circulação desses dados", que se baseou na e "expandiu"271 a Convenção $108^{272}$.

A preocupação com a necessidade e o aumento do fluxo de informações pessoais transfronteiriças, de um lado, e a proteção da privacidade, de outro, é constante em todo o texto, aparecendo desde seu início, inclusive expressamente ${ }^{273}$, dispondo essa Diretiva no seu artigo $1^{\circ}$ :

1. Os Estados-membros assegurarão, em conformidade com a presente directiva, a protecção das liberdades e dos direitos fundamentais das pessoas singulares, nomeadamente do direito à vida privada, no que diz respeito ao tratamento de dados pessoais.

2. Os Estados-membros não podem restringir ou proibir a livre circulação de dados pessoais entre Estados-membros por razões relativas à protecção assegurada por força do $\mathrm{n}^{\circ} 1$.

A Diretiva 97/66/CE, de 15 de dezembro de 1997, especificou a proteção do tratamento dos dados pessoais e da proteção da privacidade no âmbito das telecomunicações, mas foi logo substituída pela Diretiva 2002/58/CE, de 12 de julho de

\footnotetext{
${ }^{268}$ A produção de normas internas refletindo o disposto nesse tratado.

${ }^{269}$ Não se deve confundir a Comissão Européia, que integra a Comunidade Européia, com o Conselho da Europa, outra instância político-institucional, juridicamente fora da Comunidade.

${ }^{270}$ As Diretivas vinculam o Estado-Membro destinatário quanto ao resultado que visam a alcançar, mas deixam a ele competência para regular a forma e os meios, tendo por objetivo harmonizar as legislações, conforme os artigos 249 e 94 do Tratado CE.

${ }^{271}$ As aspas foram postas porque o Conselho da Europa, no âmbito do qual foi adotada a Convenção 108, não faz parte da estrutura jurídica da Comunidade Européia, embora coexistam. Assim, a Convenção 108 tem natureza jurídica distinta das normas adotadas no âmbito da União Européia, especificamente, no caso, as Diretivas, que foram criadas pelo Tratado CE.

${ }^{272}$ EDPS (2005) e item 11 dos “considerandos" da própria Diretiva 95/46/CE.

${ }^{273}$ Como nos itens 2, 9, 10 e 11 dos "considerandos" dessa Diretiva.
} 
2002, "relativa ao tratamento de dados pessoais e à protecção da privacidade no sector das comunicações electrónicas".

O Tratado de Amsterdã, de 1997, que reformou o Tratado UE, introduziu, dentre outros, o atual artigo 286, que, no número 1, dispõe:

\begin{abstract}
A partir de 1 de Janeiro de 1999, os actos comunitários relativos à protecção das pessoas singulares em matéria de tratamento de dados de carácter pessoal e de livre circulação desses dados serão aplicáveis às instituições e órgãos instituídos pelo presente Tratado, ou com base nele.
\end{abstract}

Dentre as principais normativas, há, ainda, a Diretiva 2002/21/CE, de 7 de março de 2002, "relativa a um quadro regulamentar comum para as redes e serviços de comunicações eletrônicas (diretiva-quadro)", e, por fim, a Diretiva 2006/24/CE, de 15 de março de 2006, que

[...] visa harmonizar as disposições dos Estados-Membros relativas às obrigações dos fornecedores de serviços de comunicações electrónicas publicamente disponíveis ou de uma rede pública de comunicações em matéria de conservação de determinados dados por eles gerados ou tratados, tendo em vista garantir a disponibilidade desses dados para efeitos de investigação, de detecção e de repressão de crimes graves, tal como definidos no direito nacional de cada Estado-Membro ${ }^{274}$.

O tratamento normativo parte de dois pressupostos gerais: (i) a necessidade de se assegurar a proteção da privacidade e dos dados pessoais e a circulação destes, indispensável às relações comerciais e também ao atendimento de outros interesses relevantes, como a segurança pública; e (ii) a necessidade de que, para se atingir tal objetivo, haja uma uniformização das legislações nacionais, e destas com países de fora da Comunidade, a fim de evitar obstáculos ao desenvolvimento do comércio e riscos à proteção dos dados pessoais.

A Diretiva 95/46/CE estabelece as regras gerais para o tratamento dos dados pessoais, trazendo, de início, várias definições, como a de "dados pessoais"275, parecida com a da Convenção 108, e "tratamento de dados pessoais", que procura abranger um universo amplo de condutas relativamente a esses dados, exemplificando-as ${ }^{276}$.

\footnotetext{
${ }^{274}$ Artigo $1^{\circ}$, número 1, mas não se aplica ao conteúdo das comunicações eletrônicas, conforme o número 2 desse artigo.

${ }^{275}$ Veja-se Grupo de Trabalho do Artigo 29 (2007a), que destrincha o conceito de "dados pessoais".

${ }^{276}$ Dispõe o artigo $2^{\circ}$ da Diretiva: "Para efeitos da presente directiva, entende-se por: a) 'Dados pessoais', qualquer informação relativa a uma pessoa singular identificada ou identificável ('pessoa em causa'); é considerado identificável todo aquele que possa ser identificado, directa ou indirectamente, nomeadamente por referência a um número de identificação ou a um ou mais elementos específicos da sua identidade física, fisiológica, psíquica, económica, cultural ou social; b) 'Tratamento de dados pessoais' ('tratamento'), qualquer operação ou conjunto de operações efectuadas sobre dados pessoais, com ou sem meios
} 
A Diretiva aplica-se ao tratamento de dados pessoais automatizados ou não, mas não ao tratamento de dados que tenha como objeto a segurança pública, a defesa, a segurança do Estado e as atividades deste na área penal, bem como àquele efetuado por uma pessoa física no âmbito exclusivamente pessoal ou doméstico ${ }^{277}$.

Os Estados-Membros têm autorização para estabelecer isenções ou derrogações aos Capítulos IV a VI da Diretiva para o tratamento de dados efetuado para fins exclusivamente jornalísticos ou de expressão artística ou literária, somente na medida em que sejam necessárias para conciliar o direito à "vida privada" com as normas que regem a liberdade de expressão ${ }^{278}$.

Destaque-se que a Diretiva determina a sua aplicação, por meio das respectivas leis nacionais de transposição, se o responsável pelo tratamento dos dados valer-se de meios situados no território de um Estado-Membro, exceto se forem utilizados para trânsito, devendo, no entanto, designar, aí, um representante ${ }^{279}$. Aplica-se também ao tratamento efetuado "no contexto das actividades de um estabelecimento do responsável" por ele situado num Estado-Membro, posto que, se assim não o fosse, bastaria deslocar, ou terceirizar, o tratamento de dados para qualquer país situado fora da abrangência do direito comunitário.

Estabelece uma série de "princípios relativos à qualidade dos dados" nas alíneas do número 1 do artigo $6^{\text {o280 }}$, e prevê as hipóteses em que dados podem ser revelados, em

automatizados, tais como a recolha, registo, organização, conservação, adaptação ou alteração, recuperação, consulta, utilização, comunicação por transmissão, difusão ou qualquer outra forma de colocação à disposição, com comparação ou interconexão, bem como o bloqueio, apagamento ou destruição; c) 'Ficheiro de dados pessoais' ('ficheiro'), qualquer conjunto estruturado de dados pessoais, acessívelsegundo critérios determinados, que seja centralizado, descentralizado ou repartido de modo funcionalou geográfico; d) 'Responsável pelo tratamento', a pessoa singular ou colectiva, a autoridade pública, o serviço ou qualquer outro organismo que, individualmente ou em conjunto com outrem, determine as finalidades e os meios de tratamento dos dados pessoais; sempre que as finalidades e os meios do tratamento sejam determinadas por disposições legislativas ou regulamentares nacionais ou comunitárias, o responsável pelo tratamento ou os critérios específicos para a sua nomeação podem ser indicados pelo direito nacional ou comunitário; e) 'Subcontratante', a pessoa singular ou colectiva, a autoridade pública, o serviço ou qualquer outro organismo que trata os dados pessoais por conta do responsável pelo tratamento; f) 'Terceiro', a pessoa singular ou colectiva, a autoridade pública, o serviço ou qualquer outro organismo que não a pessoa em causa, o responsável pelo tratamento, o subcontratante e as pessoas que, sob a autoridade directa do responsávelpel o tratamento ou do subcontratante, estão habilitadas a tratar dos dados; g) 'Destinatário', a pessoa singular ou colectiva, a autoridade pública, o serviço ou qualquer outro organismo que receba comunicações de dados, independentemente de se tratar ou não de um terceiro; todavia, as autoridades susceptíveis de receberem comunicações de dados no âmbito duma missão de inquérito específica não são consideradas destinatários; h) 'Consentimento da pessoa em causa', qualquer manifestação de vontade, livre, específica e informada, pela qual a pessoa em causa aceita que dados pessoais que lhe dizem respeito sejam objecto de tratamento".

${ }^{277}$ Artigo $3^{\circ}$, números 1 e 2 .

278 Artigo $9^{\circ}$.

${ }^{279}$ Artigo $4^{\circ}$, número 1, “c”, e número 2.

${ }^{280}$ São essas alíneas: “a) Objecto de um tratamento leal e lícito [que deve ser assegurado pelo responsável pelo tratamento, de acordo com o número 2 do artigo $6^{\circ}$; b) Recolhidos para finalidades determinadas, 
síntese, quando inequivocamente autorizados e aqueles necessários para as relações comerciais e para missões de interesse público ou exercício de autoridade pública ${ }^{281}$.

Alguns tipos de dados, que se costumam denominar "dados sensíveis", têm tratamento reforçado, que são os referentes a origem racial ou étnica, opiniões políticas, convicções religiosas ou filosóficas, filiação sindical, e aqueles relativos à saúde e vida sexual, cujo tratamento é vedado ou restrito, como regra geral, e de derrogação controlada $^{282}$. Porém, as derrogações arroladas nas alíneas do número 2 do artigo $8^{\circ}$ são amplas, além de haver uma autorização de levantamento dessas informações "por motivos de interesse público importante", "sob reserva de serem prestadas as garantias adequadas", através das legislações nacionais, ou por autorização da autoridade de controle do artigo $28^{283}$, bem como existem restrições tomadas como necessárias à segurança do Estado, à defesa, à prevenção, investigação, detecção e repressão de infrações penais e de violações da deontologia das profissões regulamentadas, de um interesse econômico ou financeiro importante de um Estado-Membro ou da União Européia, de missões relativas ao exercício da autoridade pública, ou à proteção do próprio indivíduo ou dos direitos de outrem ${ }^{284}$.

Não podem ser tratados de maneira automatizada, produzindo efeitos na esfera jurídica pessoal ou afetando-a significativamente, dados destinados a avaliar determinados aspectos da personalidade, como a capacidade profissional, o crédito, nível de confiança que o indivíduo merece, e comportamento, salvo se para possibilitar a defesa dos seus interesses ou ponto de vista ${ }^{285}$.

É assegurado às pessoas o direito de serem informadas da identidade do responsável pelo tratamento de seus dados, qual a sua finalidade e outras informações que forem tidas como obrigatórias, além de lhes serem atribuídos alguns direitos específicos, como um dito "direito de acesso", que corresponde a uma versão pouco mais abrangente

explícitas e legítimas, e que não serão posteriormente tratados de forma incompatível com essas finalidades. O tratamento posterior para fins históricos, estatísticos ou científicos não é considerado incompatível desde que os Estados-membros estabeleçam garantias adequadas; c) Adequados, pertinentes e não excessivos relativamente às finalidades para que são recolhidos e para que são tratados posteriormente; d) Exactos e, se necessário, actualizados; devem ser tomadas todas as medidas razoáveis para assegurar que os dados inexactos ou incompletos, tendo em conta as finalidades para que foram recolhidos ou para que são tratados posteriormente, sejam apagados ou rectificados; e) Conservados de forma a permitir a identificação das pessoas em causa apenas durante o período necessário para a prossecução das finalidades para que foram recolhidos ou para que são tratados posteriormente. Os Estados-membros estabelecerão garantias apropriadas para os dados pessoais conservados durante períodos mais longos do que o referido, para fins históricos, estatísticos ou científicos".

${ }^{281}$ Ver artigo $7^{\circ}$.

282 Ver artigo $8^{\circ}$.

${ }^{283}$ Artigo $8^{\circ}$, número 4.

${ }^{284}$ Artigo 13.

285 Artigo 15. 
do nosso "habeas data"286, e um direito de oposição, que é o de não ver seus dados $\operatorname{tratados}^{287}$. A Diretiva prevê expressamente a garantia de acesso judicial para defesa dos direitos decorrentes da sua implementação ${ }^{288}$, bem como a responsabilização por prejuízos causados pelo tratamento ilícito de dados ${ }^{289}$ e outras sanções ${ }^{290}$.

Aqueles que realizam o tratamento dos dados, por sua vez, estão submetidos a uma séria de deveres: de sigilo ${ }^{291}$; de estabelecimento de medidas adequadas e razoáveis de segurança no tratamento ${ }^{292}$; de notificação da "autoridade de controle", com algumas possíveis simplificações e isenções ${ }^{293}$; e, também, o de notificação prévia de tratamentos que possam representar "riscos específicos" aos direitos das pessoas ${ }^{294}$.

Novidade que a Diretiva impõe é a criação de autoridades de controle nacionais pelos Estados-Membros para fiscalizar a sua implementação interna, dotadas de "total independência" no exercício de suas funções ${ }^{295}$, às quais confere amplos poderes, inclusive "de inquérito" (poderes requisitórios) e "efetivos de intervenção", como o de ordenar o bloqueio, o apagamento ou a destruição dos dados e o de proibir temporária ou definitivamente o tratamento dos dados, e o de intervir nos processos judiciais ${ }^{296}$.

Essas autoridades nacionais, além das funções mencionadas, devem manter um registro público dos tratamentos notificados ${ }^{297}$, devem cooperar entre $\mathrm{si}^{298}$, e seus membros e agentes ficam sujeitos à “obrigação de segredo profissional” em relação às informações a que tenham acesso, mesmo após a cessação de suas atividades ${ }^{299}$.

Foi criado também um Grupo consultivo para auxiliar a Comissão Européia na proteção e desenvolvimento de ações na área de proteção de dados pessoais ${ }^{300}$, conhecido como "Grupo de Trabalho do Artigo 29" (ou "Grupo de protecção de pessoas no que diz respeito ao tratamento de dados pessoais").

\footnotetext{
${ }^{286}$ Artigo 12.

${ }^{287}$ Artigo 14.

${ }^{288}$ Artigo 22.

${ }^{289}$ Artigo 23. Esse artigo, nos números 1 e 2, estabelece a responsabilidade do "responsável pelo tratamento", como definido, pela reparação de prejuízos causados a qualquer pessoa devido ao tratamento ilícito de dados ou a qualquer outro ato incompatível com as disposições nacionais de execução dessa Diretiva, salvo se provar que o fato que causou o dano não lhe é imputável.

290 Artigo 24.

291 Artigo 16.

${ }^{292}$ Artigo 17.

293 Artigo 18.

${ }^{294}$ Artigo 20, números 1 e 2.

295 Artigo 28, número 1.

${ }^{296}$ Artigo 28, número 3.

${ }^{297}$ Artigo 21.

${ }^{298}$ Artigo 28, número 6.

${ }^{299}$ Artigo 28, número 7.

${ }^{300}$ Artigos 29 e 30.
} 
Os artigos 25 e 26 cuidam dos princípios e derrogações que regem as transferências de dados para terceiros países. A Diretiva estabelece a regra geral de que os países destinatários das transferências assegurem um "nível de proteção adequado", apreciado de acordo com o artigo 25, número 2, cuja inexistência ou inobservância pode levar à interrupção do fluxo de dados pessoais, de acordo com o número 4 do mesmo artigo.

O Grupo de Trabalho do Artigo 29 (1997) teceu algumas explicações sobre tal "nível de proteção adequado":

[...] uma análise exaustiva do conceito [...] deve compreender duas vertentes de base: o teor das regras aplicáveis e os meios destinados a assegurar a sua aplicação eficaz.

Partindo da Directiva 95/46/CEE, e tomando em consideração as disposições de outros textos internacionais relativos à protecção de dados, deve ser possível extrapolar princípios fundamentais respeitantes ao "teor" das regras de protecção dos dados e às obrigações "em matéria processual/de aplicação", podendo a observância destes princípios e obrigações ser considerada como um requisito mínimo para assegurar um nível de protecção adequado. Contudo, esta lista de condições mínimas não deve ser fixada de forma rígida, uma vez que, nalguns casos, justificar-se-ão aditamentos, enquanto noutras poderá mesmo ser possível reduzir o número de condições dela constante. $\mathrm{O}$ grau de risco resultante da transferência para a pessoa cujos dados são tratados [...] representará um importante factor na determinação dos requisitos precisos de um caso específico. Não obstante esta reserva, é certo que a compilação de uma lista básica de condições mínimas constitui um bom ponto de partida para qualquer análise ${ }^{301}$.

O artigo 26, números 1 e 2, da Diretiva estabelece exceções, como a existência de autorização da pessoa em questão ${ }^{302}$, além da possibilidade de cláusulas-modelo, ou outros tipos de garantias, como códigos de conduta ${ }^{303}$, que podem constar em contratos de que seja parte o responsável pelo tratamento dos dados ${ }^{304}$, desde que autorizadas pelo EstadoMembro ou pela Comissão Européia.

O Grupo de Trabalho do Artigo 29 (1998b, p. 26) esclarece:

$\mathrm{O} \mathrm{n}^{\mathrm{o}} 1$ do artigo $26^{\circ}$ da directiva prevê um número limitado de situações que podem beneficiar de uma derrogação à exigência de "adequação" no que se refere às transferências de dados para países terceiros. Tais derrogações, previstas de forma exaustiva, referem-se na maior parte dos casos a situações em que o risco para as pessoas em causa é relativamente reduzido ou em que outros interesses (interesses públicos ou interesses da própria pessoa cujos dados foram objecto de tratamento) se sobrepõem ao direito da pessoa em causa à protecção da vida privada. Tratando-se de derrogações a um princípio de natureza geral, terão de ser objecto de uma interpretação restritiva. Para além disso, os Estados-Membros poderão estabelecer, na sua legislação nacional, a inaplicabilidade das derrogações a determinados casos. Tal poderá ocorrer, nomeadamente, devido à necessidade de proteger grupos de pessoas especialmente vulneráveis, tais como os trabalhadores ou os pacientes.

\footnotetext{
${ }^{301}$ Essa posição foi repetida em outro documento do Grupo de Trabalho do Artigo 29 (1998b).

302 Número 1, "a" e, implicitamente, "b" desse artigo 26.

${ }^{303}$ Ver Grupo de Trabalho do Artigo 29 (2005c).

${ }^{304}$ Número 2 do artigo 26.
} 
Desse modo, em relação ao número 1 do artigo 26 da Diretiva, a derrogação da alínea "a" exige manifestação clara e inequívoca de vontade e consentimento livre ${ }^{305}$; a das alíneas "b" e "c" deve ser limitada aos dados estritamente necessários à execução do contrato; a da primeira parte da "d", aos interesses "importantes"; a da "e", a um interesse essencial à vida da pessoa em causa, o que exclui, em princípio, informações financeiras, relativas à propriedade e à família; e a "f" não abrange, por exemplo, a coleta para fins comerciais $^{306}$.

Essas derrogações permitidas não excluem a aplicação de outros dispositivos da Diretiva 95/46/CE, como o artigo $8^{\circ}$, e não podem levar à violação dos direitos fundamentais, sendo que o Grupo de Trabalho do Artigo 29 (2005c, p. 9-10) inclusive recomenda que seja utilizada preferencialmente a solução do artigo 26, número 2, e apenas quando se mostre inapropriada ou impraticável, a do artigo 26, número 1, para garantir ao indivíduo a que se referem os dados maior proteção.

A "solução contratual", além de repartir as responsabilidades pelo tratamento de dados entre o "cedente" e o "destinatário", deve

\section{[...] ainda fornecer garantias adicionais à pessoa em causa, necessárias pelo facto de o destinatário no país terceiro não estar sujeito a um conjunto de regras relativas à protecção dos dados exequível e que garanta um nível de protecção adequado. (GRUPO DE TRABALHO DO ARTIGO 29, 1998b, p. 17).}

Ou seja, o contrato deve suplantar eventuais deficiências do país fora da Comunidade em relação às normas da Diretiva, sendo que um dos principais problemas concerne aos direitos do terceiro, a pessoa a que os dados referem, em relação ao contrato celebrado entre o "cedente" e o "destinatário", que muitas vezes não será um mero "subcontratado", mas um verdadeiro "responsável pelo tratamento"307.

Outro ponto frágil da abordagem contratual é a questão da "primazia da lei”: a lei do país destinatário situado fora do âmbito Comunitário europeu pode estabelecer obrigações e restrições que não guardam semelhança com as normas internas da União Européia $^{308}$.

\footnotetext{
${ }^{305}$ Por "livre", deve-se entender a existência de verdadeira escolha (GRUPO DE TRABALHO DO ARTIGO 29,2005 c, p. 12).

${ }^{306}$ Ver Grupo de Trabalho do Artigo 29 (1998b, p. 26-28) e "considerando" número 58 da Diretiva 95/46/CE.

${ }^{307}$ Ver Grupo de Trabalho do Artigo 29 (1998b, p. 19-21).

${ }^{308}$ A adoção de cláusulas-modelo, ou cláusulas-tipo, não é a única solução permitida sob o artigo 26, 2, da Diretiva 95/46/CE, sendo admitidas quaisquer outras que respeitem requisitos necessários à adequada proteção dos dados pessoais, como, por exemplo, código de conduta ou regras empresariais vinculativas
} 
De todo modo, a Comissão Européia aprovou um conjunto de "cláusulas contratuais-tipo aplicáveis à transferência de dados pessoais para países terceiros, nos termos da Directiva 95/46/CE", através da Decisão 2001/497/CE ${ }^{309}$.

A Diretiva 2002/58/CE cuida da proteção dos dados pessoais especificamente no âmbito das comunicações eletrônicas, em virtude dos novos riscos que o desenvolvimento de redes a elas referentes criam à privacidade ${ }^{310}$, como a "capacidade crescente em termos de armazenamento e de processamento informático de dados relativos a assinantes e utilizadores"311. Seu objetivo é assegurar um nível adequado e idêntico de proteção dos dados pessoais e da privacidade independentemente das tecnologias empregadas ${ }^{312}$, ou, segundo seu artigo $1^{\circ}$, número 1 ,

[a] presente directiva harmoniza as disposições dos Estados-Membros
necessárias para garantir um nível equivalente de protecção dos direitos e
liberdades fundamentais, nomeadamente o direito à privacidade, no que respeita
ao tratamento de dados pessoais no sector das comunicações electrónicas, e para
garantir a livre circulação desses dados e de equipamentos e serviços de
comunicações electrónicas na Comunidade ${ }^{313}$.

Ao lado das definições da Diretiva 95/46/CE e das da Diretiva 2002/21/CE, são trazidas, dentre outras, as seguintes, no artigo $2^{\circ}$, alíneas "a", "b", “c", “d" e "h": (i) "utilizador": "qualquer pessoa singular que utilize um serviço de comunicações electrónicas publicamente disponível para fins privados ou comerciais, não sendo necessariamente assinante desse serviço"; (ii) "dados de tráfego": "quaisquer dados tratados para efeitos do envio de uma comunicação através de uma rede de comunicações electrónicas ou para efeitos da facturação da mesma"; (iii) "dados de localização": “quaisquer dados tratados numa rede de comunicações electrónicas que indiquem a posição geográfica do equipamento terminal de um utilizador de um serviço de comunicações electrónicas publicamente disponível"; (iv) "comunicação": "qualquer informação trocada ou enviada entre um número finito de partes, através de um serviço de comunicações electrónicas publicamente disponível", excluindo-se as informações

("binding corporate rules"), abordadas pelo Grupo de Trabalho do Artigo 29 (2003a, 2005a, 2005b). Ver ainda "considerando" no 5 da Decisão 2001/497/CE da Comissão Européia.

${ }^{309}$ Ver mais a respeito em Grupo de Trabalho do Artigo 29 (1998a, 2001a, 2001b, 2003b).

310 "Considerando" número 6.

311 "Considerando" número 7.

312 "Considerando" número 5.

${ }^{313}$ Mas, de acordo com o artigo $1^{\circ}$, número 3, “[...] não é aplicável a actividades fora do âmbito do Tratado que institui a Comunidade Europeia, tais como as abrangidas pelos títulos V e VI do Tratado da União Europeia, e em caso algum é aplicável às actividades relacionadas com a segurança pública, a defesa, a segurança do Estado (incluindo o bem-estar económico do Estado quando as actividades se relacionem com matérias de segurança do Estado) e as actividades do Estado em matéria de direito penal”. 
enviadas no âmbito de um serviço de difusão ao público em geral, através de uma rede de comunicações eletrônicas, salvo na medida em que a informação possa ser relacionada com o assinante ou utilizador identificável que recebe a informação; e (v) "correio eletrônico": "qualquer mensagem textual, vocal, sonora ou gráfica enviada através de uma rede pública de comunicações que pode ser armazenada na rede ou no equipamento terminal do destinatário até o destinatário a recolher”.

Segue, em linhas gerais, o adotado na Diretiva 95/46/CE, no concernente à segurança e à confidencialidade, principalmente, quanto a esta, as exceções ${ }^{314}$.

Determina a proibição da escuta, da instalação de dispositivos de escuta, do armazenamento ou outras formas de interceptação ou vigilância de comunicações e dos respectivos dados de tráfego por pessoas que não os "utilizadores", sem o seu consentimento ou fora das hipóteses do artigo 15, número 1, ressalvado o armazenamento indispensável tecnicamente para o envio de uma comunicação ${ }^{315}$ e as gravações realizadas no âmbito de práticas comerciais lícitas para o efeito de constituir prova do negócio ${ }^{316}$.

Os dados de tráfego também têm proteção especial: devem ser armazenados somente pelo tempo necessário para a transmissão, para a fatura de serviço ou para a resolução de litígios referentes, especialmente, a ambos, ou com o consentimento, que pode ser a qualquer momento retirado, do indivíduo a que se referem ${ }^{317}$.

Além disso, é assegurada ao "utilizador" ou assinante a total transparência quanto ao processamento dos seus dados ${ }^{318}$, bem como a possibilidade de impedir a identificação da linha "chamadora" ou conectada e dos dados de localização ${ }^{319}$. Excetuam-se as hipóteses de chamadas mal intencionadas ou que causam incômodo e as ligações para as organizações que recebem chamadas de emergência reconhecidas como tal pelos EstadosMembros, nos termos do artigo 10, números 1 e 2.

Há um artigo dedicado às "comunicações não solicitadas",320, que autoriza sistemas automatizados de chamada sem intervenção humana, de aparelhos de fax ou de correio eletrônico para fins de comercialização direta ${ }^{321}$ para assinantes que tenham dado o seu consentimento prévio, permitindo-lhes, a qualquer tempo, a sua retirada, através do

\footnotetext{
${ }^{314}$ Artigo 15, número 1. O artigo 15 dispõe expressamente sobre a aplicabilidade da Diretiva 95/46/CE, mas em outros pontos a Diretiva 2002/58/CE adota dispositivos com redação idêntica ou parecida aos desta.

${ }^{315}$ Artigo $5^{\circ}$, número 1.

${ }^{316}$ Artigo $5^{\circ}$, número 2.

${ }^{317}$ Ver artigos $5^{\circ}$, número 3, e $6^{\circ}$.

${ }^{318}$ Artigo $5^{\circ}$, número 3.

${ }^{319}$ Artigos $8^{\circ}$ e $9^{\circ}$.

${ }^{320}$ Artigo 13.

${ }^{321}$ O que se costuma denominar "mala direta", embora eletrônica, ou "spam".
} 
fornecimento dessa possibilidade expressamente a cada mensagem, vedada a dissimulação ou o anonimato da identidade do remetente.

Completando o tratamento comunitário da matéria, veio a Diretiva 2006/24/CE, de 15 de março de 2006, "relativa à conservação de dados gerados ou tratados no contexto da oferta de serviços de comunicações electrónicas publicamente disponíveis ou de redes públicas de comunicações, e que altera a Directiva 2002/58/CE”, que, não se aplicando ao conteúdo das comunicações eletrônicas ${ }^{322}$,

[...] visa harmonizar as disposições dos Estados-Membros relativas às obrigações dos fornecedores de serviços de comunicações electrónicas publicamente disponíveis ou de uma rede pública de comunicações em matéria de conservação de determinados dados por eles gerados ou tratados, tendo em vista garantir a disponibilidade desses dados para efeitos de investigação, de detecção e de repressão de crimes graves, tal como definidos no direito nacional de cada Estado-Membro ${ }^{323}$.

Derrogando os artigos $5^{\circ}, 6^{\circ}$ e $9^{\circ}$ da Diretiva 2002/58/CE, estabelece a obrigação de conservação dos dados de tráfego e de localização e outros necessários à identificação do utilizador ou assinante, na medida em que sejam

[...] gerados ou tratados no contexto da oferta dos serviços de comunicações em causa por fornecedores de serviços de comunicações electrónicas publicamente disponíveis ou de uma rede pública de comunicações quando estes fornecedores estejam sob a sua jurisdição ${ }^{324}$.

Esses dados devem ser conservados por um período de seis meses a dois anos, contados da data da comunicação ${ }^{325}$, sendo que a Diretiva cria cinco categorias de $\operatorname{dados}^{326}$ : (i) dados necessários para encontrar e identificar a fonte de uma comunicação; (ii) dados necessários para encontrar e identificar o destino de uma comunicação; (iii) dados necessários para identificar a data, a hora e a duração de uma comunicação; (iv) dados necessários para identificar o tipo de comunicação; e (v) dados necessários para identificar o equipamento de telecomunicações dos utilizadores, ou o que se considera ser o seu equipamento. Contudo, pró́be a conservação de quaisquer dados que revelem o conteúdo das comunicações ${ }^{327}$.

Prevê, ainda, uma autoridade de controle nacional, independente, para controlar a aplicabilidade do determinado na Diretiva no tocante à segurança e proteção dos dados,

\footnotetext{
${ }^{322}$ Artigo $1^{\circ}$, número 2.

${ }^{323}$ Artigo $1^{\circ}$, número 1.

${ }^{324}$ Artigo $3^{\circ}$, número 1.

${ }^{325}$ Artigo $6^{\circ}$.

${ }^{326}$ Artigo 50, número 1, alíneas "a" a "e".

${ }^{327}$ Artigo $5^{\circ}$, número 2.
} 
que pode ser a mesma referida na Diretiva $95 / 46 / \mathrm{CE}^{328}$.

Por fim, acrescentou o número 1-A ao artigo 15 da Diretiva 2002/58/CE, que afasta expressamente as derrogações do número 1 desse mesmo artigo ao tratamento dos dados conservados nos termos dessa Diretiva 2006/24/CE.

Existem, portanto, três diplomas normativos básicos no âmbito da União Européia tratando da questão da privacidade nas comunicações eletrônicas: (i) a Diretiva 95/46/CE, que trata da proteção material dos dados pessoais, ou seja, quanto ao conteúdo e a diferença de regulação em relação aos diferentes tipos; (ii) a Diretiva 2002/58/CE, que estabelece regras gerais sobre a proteção da privacidade no âmbito das comunicações eletrônicas, especificando e complementando a primeira Diretiva, derrogada, em parte, pela (iii) Diretiva 2006/24/CE, que, na prática, passou a regular a obrigação dos fornecedores de serviços de comunicações publicamente disponíveis ou de uma rede pública de comunicações de gerar e manter determinados tipos de dados em certas condições $^{329}$.

Todos continuam vigentes, sendo que esta última sobreveio pela necessidade de estabelecer uma harmonização entre os requisitos de conservação dos dados, para fins de prevenção e repressão penal, e, mais uma vez, facilitar o desenvolvimento do mercado interno da Comunidade Européia ${ }^{330}$.

Paralelamente, como visto, foi aprovado um Protocolo Adicional à Convenção 108 do Conselho da Europa, "estendendo-lhe" disposições similares às vigentes na União Européia, como a necessidade de criação de uma autoridade de supervisão com independência ${ }^{331}$, e a necessidade de assegurar, legislativa ou contratualmente, a adequada segurança na transferência de dados para países não membros ${ }^{332}$. Neste caso, a autoridade de supervisão deve julgar adequada a salvaguarda, numa análise caso a caso ${ }^{333}$.

Ainda no âmbito do Conselho da Europa, foi aprovada a Convenção sobre o Cibercrime, em 23 de novembro de 2001 (“Convenção 185” ou “ETS 185”), com o fim de aproximar as legislações dos países e facilitar a cooperação no combate a esse tipo de

\footnotetext{
${ }^{328}$ Artigo $9^{\circ}$.

${ }^{329}$ O seu "considerando" número 15 ressalta expressamente que as Diretivas 95/46/CE e 2002/58/CE lhe são aplicáveis. O "considerando" número 16 afirma que as medidas que devem ser tomadas para assegurar a qualidade dos dados, bem como para salvaguardar a sua confidencialidade e segurança de tratamento (artigos $6^{\circ}, 16$ e 17 da Diretiva 95/46/CE), são plenamente aplicáveis aos dados conservados em conformidade com essa Diretiva 2006/24/CE.

${ }^{330}$ Ver "considerandos" números 5 e 6 da Diretiva 2006/24/CE.

${ }^{331}$ Artigo $1^{\circ}$.

${ }^{332}$ Artigo $2^{\circ}$.

${ }^{333}$ Artigo $2^{\circ}$, número 2, "b”, e Relatório Explicativo ao Protocolo Adicional, números 26 e 27.
} 
criminalidade ${ }^{334}$. Países de fora do Conselho da Europa podem aderir a ela, a convite, nos termos do artigo 37.

A Convenção define "dados informáticos" como "qualquer representação de factos, de informações ou de conceitos sob uma forma susceptível de processamento num sistema de computadores, incluindo um programa, apto a fazer um sistema informático executar uma função" 335 , determinando às partes que adotem como tipo penal o acesso ilegítimo a sistema informático ${ }^{336}$, a interceptação ilegítima de $\operatorname{dados}^{337}$ e a interferência neles (ato de intencional e ilegitimamente danificar, apagar, deteriorar, alterar ou eliminar dados informáticos) $)^{338}$, a interferência em sistemas ${ }^{339}$, bem como o uso abusivo de dispositivos para tais finalidades ${ }^{340}$, além da falsidade informática ${ }^{341}$, burla informática ${ }^{342}$, infrações relacionadas à pornografia infantil ${ }^{343}$, e infrações relacionadas com a violação do direito de autor e dos direitos conexos ${ }^{344}$. O Protocolo Adicional à Convenção sobre o Cibercrime (“Convenção 189" ou "ETS 189"), adotado em 28 de janeiro de 2003, acresce a criminalização de atos de natureza racista ou xenofóbica praticados através de sistemas informáticos.

As sanções a serem estabelecidas devem ser "eficazes, proporcionais e dissuasivas, incluindo penas privativas de liberdade ${ }^{\text {"345, }}$, devendo ser abrangidas também as pessoas

\footnotetext{
${ }^{334}$ O item 16 da Minuta do Relatório Explicativo sobre a Convenção sobre o Cibercrime afirma que "[a] Convenção tem por objeto principal (1) a harmonização dos elementos relativos a infracções no contexto do direito penal substantivo de âmbito nacional e das disposições conexas na área de cibercriminalidade, (2) a definição, ao abrigo do código de processo penal interno, dos poderes necessários para investigar e intentar acções penais relativamente a tais infracções, assim como a outras infracções cometidas por meio de um sistema informático ou às provas com elas relacionadas e existentes sob a forma electrónica, (3) a implantação de um regime rápido e eficaz de cooperação internacional”. Nesse sentido, também o Preâmbulo da própria Convenção.

335 Artigo $1^{\circ}$, "b".

${ }^{336}$ Artigo $2^{\circ}$. De acordo com o artigo $2^{\circ}$, “a”: "“Sistema informático' significa qualquer dispositivo isolado ou grupo de dispositivos relacionados ou interligados, em que um ou mais de entre eles, desenvolve, em execução de um programa, o tratamento automatizado dos dados". Além dessa definição e da de dado informático, há também as de: (i) "fornecedor de serviço": "[q]ualquer entidade pública ou privada que faculte aos utilizadores dos seus serviços a possibilidade de comunicar por meio de um sistema informático e [...] [q]ualquer outra entidade que processe ou armazene dados informáticos em nome do referido serviço de comunicação ou dos utilizadores desse serviço", conforme artigo 20, "c", i e ii; e (ii) "dados de tráfego": "todos os dados informáticos relacionados com uma comunicação efectuada por meio de um sistema informático, gerados por este sistema como elemento de uma cadeia de comunicação, indicando a origem da comunicação, o destino, o trajecto, a hora, a data, o tamanho, a duração ou o tipo do serviço subjacente", conforme artigo $2^{\circ}$, “d”.

${ }^{337}$ Artigo $3^{\circ}$.

${ }^{338}$ De acordo com o artigo $4^{\circ}$.

${ }^{339}$ Artigo $5^{\circ}$.

${ }^{340}$ Artigo $6^{\circ}$.

${ }^{341}$ Artigo $7^{\circ}$.

${ }^{342}$ Artigo $8^{\circ}$.

${ }^{343}$ Artigo $9^{\circ}$, especialmente o seu número 1.

${ }^{344}$ Artigo 10.

${ }^{345}$ Artigo 13, número 1.
} 
coletivas $^{346}$.

Ela prevê medidas legislativas e outras que se revelem necessárias para assegurar a conservação de dados informáticos armazenados e a de dados de tráfego ${ }^{347}$, e enumera uma série de poderes que devem ser estabelecidos às autoridades, como a "recolha em tempo real de dados relativos ao tráfego"348 e a "interceptação de dados relativos ao conteúdo"349.

Embora a Convenção não defina "dados de conteúdo", “designa[m] o conteúdo informativo da comunicação, ou seja, o significado ou o teor da comunicação, ou a mensagem ou informação veiculada pela comunicação (que não a relativa aos dados de tráfego)", de acordo com o item 209 de seu Relatório Explicativo.

$\mathrm{O}$ artigo 15 determina que as medidas processuais implementadas e aplicadas devem estar sujeitas às condições e salvaguardas estabelecidas pela legislação nacional,

[...] que deve assegurar uma protecção adequada dos direitos do Homem e das liberdades, designadamente estabelecidas em conformidade com as obrigações decorrentes da aplicação da Convenção do Conselho da Europa para a Protecção dos Direitos do Homem e das Liberdades Fundamentais dos Cidadãos (1950), do Pacto Internacional das Nações Unidas sobre os Direitos Civis e Políticos, (1966), bem como de outros instrumentos internacionais aplicáveis relativos aos Direitos do Homem e que deve integrar o princípio da proporcionalidade ${ }^{350}$.

Estabelece ainda que, tendo em conta a natureza do poder ou procedimento em questão, tais condições e salvaguardas incluirão um controle judicial ou outras formas de controle independente, os fundamentos que justificam a sua aplicação, bem como a

\footnotetext{
346 Artigos 13, número 2, e 12.

${ }^{347}$ Artigos 16 e 17.

348 Artigo 20.

349 Artigo 21, que dispõe: “[c]ada Parte adoptará as medidas legislativas e outras que se revelem necessárias para habilitar as suas autoridades competentes relativamente a um leque de infracções graves, a definir em direito interno $^{349}$, a: a) Recolher ou registar, através da aplicação de meios técnicos existentes no seu território, e b) Obrigar um fornecedor de serviços, no âmbito da sua capacidade técnica existente, a: i. Recolher ou registar através da aplicação de meios técnicos no seu território, ou ii. Prestar às autoridades competentes o seu apoio e a sua assistência para recolher ou registar, em tempo real, dados relativos ao conteúdo de comunicações específicas no seu território, transmitidas através de um sistema informático. 2. Quando a Parte em virtude dos princípios estabelecidos pela sua ordem jurídica interna, não pode adoptar as medidas descritas no n. ${ }^{\circ}$, alínea $a$ ), pode, em alternativa, adoptar as medidas legislativas e outras que se revelem necessárias, para assegurar a recolha ou o registo em tempo real dos dados relativos ao conteúdo associados a comunicações específicas transmitidas no seu território através da aplicação de meios técnicos existentes nesse território. 3. Cada Parte adoptará as medidas legislativas e outras que se revelem necessárias, para obrigar um fornecedor de serviços a manter secreto o facto de qualquer um dos poderes previstos no presente artigo ter sido executado, bem como qualquer informação a esse respeito. 4. Os poderes e procedimentos referidos no presente artigo devem estar sujeitos aos artigos $14^{\circ}$ e $15^{\circ}$ ". Veja-se ainda o item 212 do Relatório Explicativo sobre a Convenção sobre o Cibercrime: "[n]o que concerne à interceptação em tempo de dados de conteúdo, em muitos casos, a lei prescreve que apenas se deve recorrer a esta medida quando se trate da investigação de infracções graves ou de categorias de infracções graves. As referidas infracções são identificadas como graves, a este título e ao abrigo das legislações nacionais, sendo incluídas numa lista descritiva das infracções às quais a medida é passível de ser aplicada, ou sendo englobadas nesta categoria com base numa determinada pena máxima de prisão, aplicável a estas infracções. [...]”.

${ }^{350}$ Artigo 15, número 1.
} 
limitação do âmbito de sua aplicação e a sua duração ${ }^{351}$. A implantação dos poderes e procedimentos deve levar em consideração o seu impacto sobre os direitos, responsabilidades e interesses legítimos de terceiros, na medida em que seja do interesse público, especialmente da boa administração da justiça ${ }^{352}$.

O Capítulo III da Convenção trata da cooperação internacional nessa área, inclusive quanto à obtenção de provas concernentes aos dados de tráfego e aos de conteúdo das comunicações $^{353}$, devendo ser designada uma ou mais autoridades centrais (nacionais) encarregadas de enviar, receber e executar os pedidos de auxílio mútuo ${ }^{354}$, devendo ser estabelecido, ainda, um ponto de contato constantemente disponível, a qualquer momento $^{355}$.

Essa Convenção não substitui outros tratados multilaterais ${ }^{356}$ ou bilaterais entre os Estados contratantes que cuidam da mesma matéria, ou de alguns pontos em comum. Todavia, esses acordos atuais ou futuros devem, ao menos, ser compatíveis com os seus princípios e objetivos $^{357}$.

Por sua vez, o Comitê de Ministros do Conselho da Europa emitiu, ao longo dos anos, algumas Recomendações e Resoluções concernentes à privacidade no tratamento dos $\operatorname{dados}^{358}$, como a Recomendação R/99 5, para a proteção da privacidade na Internet ${ }^{359}$, e a R/95 4, sobre a proteção de dados pessoais na área dos serviços de telecomunicação, com referência particular a serviços telefônicos ("on the protection of personal data in the area of telecommunication services, with particular reference to telephone services"), que estabelece, em essência, a correlação entre a coleta e processamento dos dados e o propósito almejado, e certas restrições à sua comunicação ${ }^{360}$.

O Memorando Explanatório sobre a Recomendação R/95 4 ainda explica, com o

\footnotetext{
${ }^{351}$ Artigo 15, número 2.

352 Artigo 15, número 3.

${ }^{353}$ Artigos 33 e 34.

${ }^{354}$ Artigo 27, número 2, "a". A Convenção possibilita a recusa, justificada, da prestação de auxílio, como se vê, por exemplo, no artigo 25 , número 4 , e no artigo 27 , número 4 , "a" e "b".

355 Artigo 35.

${ }^{356}$ Como, principalmente, pela Convenção Européia de Auxílio Mútuo em Matéria Penal (Convenção 30), de 1959, com as modificações feitas pelo Protocolo Adicional (“Convenção 99" ou "ETS 99"), de 1978, e o Segundo Protocolo Adicional (“Convenção 182” ou “ETS 182”), de 2001.

${ }^{357}$ Ver artigo 39, números 1 e 2, e artigo 27, número 1.

${ }^{358}$ Relembre-se que, por coincidência, e não por qualquer obrigação legal, todos os países que fazem parte da União Européia integram o Conselho da Europa, sujeitando-se aos tratados ratificados e em vigor, em termos que variam de caso a caso, celebrados nessa sede.

${ }^{359}$ Em que se afirma, por exemplo, que o endereço de "e-mail" é um dado pessoal.

${ }^{360}$ Como, por exemplo, a do último parágrafo do item 2.5, que dispõe que se o operador da rede ou provedor do serviço for "instruído" por uma autoridade pública a efetuar uma interceptação ("interference", ou interferência), os dados assim coletados devem ser comunicados apenas ao órgão designado na autorização que a determinou.
} 
que concordamos:

[...] o comitê de especialistas é consciente do fato que alguns desses novos serviços [de telecomunicações] (por exemplo, identificação de chamada) geram dados pessoais quando usados, enquanto a digitalização das redes em geral resultará num maior armazenamento de dados de serviço pelos operadores das redes (como ilustrado pela disponibilidade do detalhamento das faturas). Para o grupo de estudo [atinente aos dados pessoais do Conselho da Europa], esses aspectos de desenvolvimento podem não só ameaçar a privacidade ["privacy"] dos assinantes e usuários em geral, mas também inibir a sua liberdade de comunicação, já que diminuirá o grau de anonimato de que os assinantes e usuários podem querer valer-se enquanto usam o telefone por obrigá-los a revelar suas identidades ou deixar para trás rastros eletrônicos que permitam o monitoramento de seus telefones ${ }^{361}$. (tradução nossa).

Há duas Resoluções sobre os bancos de dados, uma sobre a proteção da privacidade ("privacy") do indivíduo em face dos bancos de dados no setor público e outra no privado, respectivamente de número 7429 e 73 22, que determinam, cada qual em seu âmbito de aplicação, regras que restringem o uso dos dados pessoais para outros propósitos e necessidades além dos quais foram coletados e armazenados, principalmente a cessão para terceiros, exceto no quanto estritamente regulado pelos Estados, dentro de certos limites, especialmente no atinente a informações sobre a "vida privada" e àquelas de que possam originar discriminação.

A Recomendação R/91 10, sobre a comunicação para terceiros de dados pessoais mantidos por órgãos públicos ("on the communication to third parties of personal data held by public bodies"), cujas disposições podem ser estendidas a pessoas coletivas (pessoas jurídicas) ${ }^{362}$ pelos países aderentes, proíbe a transferência de dados se incompatível com as finalidades para as quais foram coletados, a não ser que haja consentimento expresso do titular dessas informações, ou autorização legislativa específica, mas somente se, concomitantemente, propiciar salvaguardas e garantias particularmente destinadas a assegurar a privacidade ("privacy") ${ }^{363}$. A interconexão ou cruzamento de bancos de dados

\footnotetext{
${ }^{361}$ No original: "[...] the committee of experts is conscious of the fact that certain of these new services (for example, calling-line identification) generate personal data when used, while the digitalisation of networks in general will result in the greater storage of service data by network operators (as illustrated by the availability of detailed invoices). For the project group, these aspects of development may not only threaten the privacy of subscribers and users in general, they may also inhibit their freedom of communication since they diminish the degree of anonymity which subscribers and users may wish to avail of when using the telephone by obliging them to reveal their identities or to leave behind electronic traces which allow their use of the telephone to be monitored". Essa Recomendação busca, portanto, de acordo com esse Memorando, o equilíbrio entre a liberdade de comunicação e o respeito à privacidade ("privacy"), de um lado, e o atendimento do interesse público na prevenção e repressão de certas práticas, possibilitando interceptações "legítimas".

${ }^{362}$ Independentemente da forma jurídica adotada por elas, ainda que despersonalizadas, conforme o item 1.2 do seu Apêndice.

${ }^{363}$ Itens 2.1 e 2.2 do Apêndice da Recomendação R/91 10.
} 
por terceiros com a finalidade de criar um novo arquivo deve ser proibida, exceto se providenciadas as suficientes salvaguardas ${ }^{364}$.

Além disso, os indivíduos têm o direito de serem notificados da comunicação de seus dados, das bases legais da sua coleta e processamento, bem como qual é o interesse público que a justifica $^{365}$.

Já a Recomendação R/87 15, que regula o uso de dados pessoais no setor policial ("regulating the use of personal data in the police sector"), compreendendo as tarefas concernentes à prevenção e repressão criminal e manutenção da ordem ${ }^{366}$, além de ressaltar a necessidade de um equilíbrio entre a necessidade de comunicação e uso desses dados e a proteção da privacidade ("privacy") ${ }^{367}$, sugere a criação de uma autoridade supervisora independente para salvaguardar esta última, dissociada da autoridade policial, inclusive para consulta prévia quanto à introdução de novas tecnologias e a necessidade de notificação de arquivos permanentes ${ }^{368}$, estando em consonância, como visto, com a linha adotada pela União Européia.

Dentre outros, essa Recomendação proíbe a coleta de dados de indivíduos baseada somente em sua origem racial, convicções religiosas específicas, comportamento sexual ou opiniões políticas ou pelo fato de pertencerem a certos movimentos ou organizações não proscritos pela $1 \mathrm{i}^{369}$.

Podem-se mencionar, ainda, as Recomendações R/2002 9, sobre a proteção de dados pessoais coletados e processados para fins de seguro, R/97 18, sobre a proteção de dados pessoais coletados e processados para fins estatísticos, a R/97 5, sobre dados médicos, a R/90 19, sobre a proteção em pagamentos e outras operações, a R/89 2, para propósitos de contratação de empregados, a R/86 1, para seguridade social, e a R/85 20,

\footnotetext{
${ }^{364}$ Item 7 do Apêndice da Recomendação R/91 10.

365 Item 4.2 do Apêndice da Recomendação R/91 10.

366 Terceiro parágrafo da seção "âmbito e definições" do Apêndice a essa Recomendação.

367 O parágrafo 17 do Memorando Explicativo dessa Recomendação ressalta que "[e]mbora o preâmbulo refira-se a possível ameaça à privacidade individual através do mau uso de métodos de processamento automático, deve-se ter em mente que a privacidade não deve ser interpretada simplesmente em termos de proteção da esfera privada de um indivíduo contra conduta intrusiva. É por essa razão que o preâmbulo chama a atenção para o artigo $8^{\circ}$ da Convenção Européia de Direitos Humanos, e a legalidade de certos meios técnicos de vigilância para obter informações sobre indivíduos deve ser testada contra as provisões do artigo $8^{\circ}$ e as decisões relevantes da Corte Européia de Direitos Humanos" (tradução nossa). No original: "[a]lthough the preamble refers to the possible threat to the privacy of the individual through the misuse of automated processing methods, it should be borne in mind that privacy is not to be interpreted simply in terms of protection of one's private sphere against intrusive conduct. It is for this reason that the preamble draws attention to Article 8 of the Convention for the Protection of Human Rights and Fundamental Freedoms, and the legality of certain technical surveillance means to obtain data on individuals must be tested against the provisions of Article 8 and the relevant rulings of the European Court of Human Rights".

${ }^{368}$ Princípio 1, "controle e notificação", itens 1.1 e 1.3 do Apêndice da Recomendação R/87 15.

369 Princípio 2, "coleta de dados", item 2.4 do Apêndice da R/87 15.
} 
para "marketing" direto.

Por último, note-se que todas as normas, comunitárias ou nacionais, têm de seguir os parâmetros construídos pela jurisprudência da Corte Européia de Direitos Humanos ${ }^{370}$.

${ }^{370}$ Existe consternação, principalmente no seio da Europa, a respeito do sistema internacional de espionagem "Echelon", que nasceu de um pacto de cooperação em matéria de "inteligência de sinal" entre os Estados Unidos da América, o Reino Unido, o Canadá, a Austrália e a Nova Zelândia, denominado "U.K.-U.S.A. Security Agreement", com capacidade buscar e localizar palavras-chave em conversas transmitidas ao redor do globo e interceptá-las. Mais detalhes a respeito em Lepage e Waty (2004). 


\section{A PRIVACIDADE NAS COMUNICAÇÕES ELETRÔNICAS NO BRASIL.}

\subsection{Uma passagem pelo desenvolvimento e construção da "privacidade" no Brasil.}

\subsubsection{Proteção indireta.}

Aspectos do que hoje podem ser considerados atinentes à privacidade surgiram desde a Constituição do Império, de 1824, como na proteção contra a invasão da casa e do segredo das cartas, ou no Código Civil de $1916^{371}$, artigo $573^{372}$, cujo objetivo era resguardar a vida privada do vizinho ${ }^{373}$.

Neste capítulo, daremos ênfase, em virtude do objeto da dissertação, à proteção conferida às comunicações e aos dados, considerando-a como direitos assecuratórios do resguardo dos indivíduos contra estranhos.

Ao traçarmos um histórico do desenvolvimento constitucional da proteção das comunicações, verificamos que: (i) a Constituição de 1824 dizia que o segredo das cartas era inviolável, ficando a administração do Correio rigorosamente responsável por qualquer violação dessa proteção ${ }^{374}$; (ii) a Constituição de 1891 simplesmente afirmava que o sigilo de correspondência era inviolável ${ }^{375}$; (iii) a Constituição de 1934 repetia esse dispositivo $^{376}$; (iv) a Constituição de 1937 protegia a inviolabilidade de correspondência junto com a de domicílio, "salvas as exceções expressas em lei"377; (v) a Constituição de 1946 voltou a afirmar a simples inviolabilidade do sigilo de correspondência ${ }^{378}$; (vi) a Constituição de 1967, introduzindo referência às comunicações telegráficas e telefônicas, afirmava a inviolabilidade do sigilo dessas e a da correspondência, sem ressalvas ${ }^{379}$; e (vii) a Emenda Constitucional 1/1969 apenas reafirmou, com pequeno rearranjo de palavras, a inviolabilidade do sigilo da correspondência e das comunicações telegráficas e

\footnotetext{
${ }^{371}$ Lei 3.071 , de $1^{\circ}$ de janeiro de 1916.

372 "O proprietário pode embargar a construção do prédio que invada a área do seu, ou sobre este deite goteiras, bem como a daquele, em que, a menos de metro e meio do seu, se abra janela, ou se faça eirado, terraço, ou varanda".

${ }^{373}$ Ver Recurso Extraordinário 100037/RS, Relator Ministro Francisco Rezek, no Apêndice A, número 1, desta dissertação.

${ }^{374}$ Ver artigo 179 , inciso XXVII.

375 Artigo 72, parágrafo 18.

376 Artigo 113, número 8.

377 Artigo 122, $6^{\circ}$.

${ }^{378}$ Artigo 141, parágrafo $6^{\circ}$.

${ }^{379}$ Artigo 150, parágrafo $9^{\circ}$.
} 
telefônicas $^{380}$.

A correspondência e as comunicações telegráficas e telefônicas vêm protegidas no inciso XII do artigo $5^{\circ}$ da vigente Constituição Federal de 1988, só que, agora, com uma novidade, a inclusão dos "dados", e dois problemas, o âmbito de proteção desses "dados" e a ressalva constante da parte final do dispositivo, cuja redação é a seguinte:

é inviolável o sigilo da correspondência e das comunicações telegráficas, de dados e das comunicações telefônicas, salvo, no último caso, por ordem judicial, nas hipóteses e na forma que a lei estabelecer para fins de investigação criminal ou instrução processual penal.

Logo, deve-se iniciar a análise desse inciso XII do artigo $5^{\circ}$ da Constituição Federal pelos elementos que visa a proteger, isto é, o sigilo: (i) da correspondência; (ii) das comunicações telegráficas; (iii) das comunicações telefônicas; e (iv) dos dados.

Algo sigiloso é algo sobre o que se deve manter segredo, a salvo do conhecimento de outros. O sigilo pode ser definido como o dever de manutenção de segredo que recai sobre algo, a que corresponde o direito de ver observado segredo sobre esse algo.

A seu turno, a palavra "correspondência" pode se referir tanto à troca de cartas quanto às próprias cartas. Uma leitura do dispositivo parece utilizá-la no primeiro sentido, já que se refere, pelo menos, às comunicações telegráficas e às telefônicas, e não aos telegramas, por exemplo.

O Decreto 29.151, de 17 de janeiro de 1951, que aprovava o Regulamento dos Serviços Postais e de Telecomunicações, definia “correspondência postal com caráter de mensagem" como "objeto que contém comunicação ou nota atual e pessoal, dirigida a outrem" 381 , enquanto carta era definida como "todo papel, mesmo sem envoltório, com endereço e comunicação ou nota de caráter atual e pessoal", bem como "todo objeto de correspondência com endereço, cujo conteúdo só possa ser desvendado por violação" 382 .

O artigo 142 desse Decreto ainda definia "correspondência de telecomunicação" como "a que se faz por meio de telegrama, radiotelegrama, telefonema, radiotelefonema e demais modalidades de comunicação a distância [...]". "Telegrama” era "a mensagem transmitida por sinalização elétrica ou radioelétrica, a ser convertida em recado escrito para entrega ao destinatário" 383 , mas o serviço de telegrama, ainda que não transmitido por

\footnotetext{
${ }^{380}$ Artigo 153 , parágrafo $9^{\circ}$.

381 Artigo 35.

382 Artigo 36, “caput” e parágrafo único.

383 Artigo 144, além de a mensagem recebida em transmissão sem fio, por processo elétrico ou não e sinalização visual, e da mensagem escrita em formula própria e copiada para ser entregue ao destinatário, mesmo que não esteja sujeita à teletransmissão, conforme seu parágrafo único, alíneas "a" e "b", desse
} 
qualquer sistema, era considerado serviço de telecomunicação ${ }^{384}$.

Posteriormente, a Lei 6.538, de 22 de junho de 1978, que regula os serviços postais até hoje, define, para sua aplicação, "correspondência" como "toda comunicação de pessoa a pessoa, por meio de carta, através da via postal, ou por telegrama", "carta" como "objeto de correspondência, com ou sem envoltório, sob a forma de comunicação escrita, de natureza administrativa, social, comercial, ou qualquer outra, que contenha informação de interesse específico do destinatário", e "telegrama" como "mensagem transmitida por sinalização elétrica ou radioelétrica, ou qualquer outra forma equivalente, a ser convertida em comunicação escrita, para entrega ao destinatário"385 " "Objeto de correspondência", de acordo com artigo $7^{\circ}$, parágrafo $1^{\circ}$, alíneas “a” a “e”, é considerado carta, cartão-postal ${ }^{386}$, impresso $^{387}$, cecograma ${ }^{388}$ e pequena encomenda ${ }^{389}$.

A Portaria 1.351, de 21 de dezembro de 1978, do Ministério das Comunicações, considera telegrama, de modo similar ao que o fazia o parágrafo único e alíneas do artigo 144 do Decreto 29.151/1951, a mensagem transmitida através de qualquer meio de telecomunicação a ser convertida em comunicação escrita para entrega ao destinatário, e a mensagem escrita em formulário próprio e copiada para ser entregue ao destinatário, mesmo que não esteja sujeita a transmissão ${ }^{390}$.

O Decreto 83.858, de 15 de agosto de 1979, que revogara o Decreto 29.151/1951 e aprovara o Regulamento dessa Lei de 1978, e que subsistiu até a revogação operada pelo Decreto "sem número" de 15 de fevereiro de 1991, considerava também correspondência “o objeto [postal] com endereço, cujo conteúdo só possa ser desvendado por meio de abertura do invólucro, postado em consonância com as condições de aceitação da carta, e como tal, franqueado"391. O parágrafo único do artigo 140 desse Decreto repetia as definições de telegrama da Portaria 1.351/1978 do Ministério das Comunicações.

Portanto, correspondência é, aí, a troca de mensagens escritas entre pessoas, com conteúdo de interesse específico do destinatário, transportadas pelo serviço postal e

\footnotetext{
mesmo artigo.

${ }^{384}$ Parágrafo único do artigo $6^{\circ}$.

385 Artigo 47.

${ }^{386}$ No artigo 47: “[O]bjeto de correspondência, de material consistente, sem envoltório, contendo mensagem e endereço".

387 No artigo 47: "[R]eprodução obtida sobre material de uso corrente na imprensa, editado em vários exemplares idênticos".

${ }^{388}$ No artigo 47: “[O]bjeto de correspondência impresso em relevo, para uso dos cegos. Considera-se também cecograma o material impresso para uso dos cegos".

${ }^{389}$ No artigo 47: “[O]bjeto de correspondência, com ou sem valor mercantil, com peso limitado, remetido sem fins comerciais".

${ }^{390}$ Item I. 1 .

${ }^{391}$ Artigo $8^{\circ}$, parágrafo único.
} 
telegráfico estabelecido pela Lei 6.538/1978. São objetos de correspondência a carta e o telegrama, comunicações "fechadas", em oposição às comunicações "abertas", aquelas destinadas a conhecimento geral, de um público restrito ou amplo.

No que tange às comunicações em geral, a Constituição de 1891 referia-se em vários pontos a regulamentação dos serviços de correios e telégrafos federais e estaduais $^{392}$, e a de 1934, a serviços de correios, telégrafos e radiocomunicação ${ }^{393}$, assim como a de $1937^{394}$, que inseriu referência a comunicações internacionais ${ }^{395}$.

A Constituição de 1946 referia-se ainda a radiodifusão e telefonia ${ }^{396}$, junto aos serviços postais, telegráficos e de radiocomunicação ${ }^{397}$, enquanto a de 1967 mencionava o serviço postal e o de telecomunicações ${ }^{398}$, o que se repetiu na Emenda Constitucional $1 / 1969^{399}$.

A redação original do inciso XI do artigo 21 da Constituição de 1988, que relaciona as competências da União, aludia explicitamente a "[...] serviços telefônicos, telegráficos, de transmissão de dados e demais serviços públicos de telecomunicações [...]”, além da competência para legislar sobre serviço postal ${ }^{400}$ e telecomunicações ${ }^{401}$.

A Lei 4.117, de 27 de agosto de 1962, que instituíra o Código Brasileiro de Telecomunicações, definia, para sua aplicação, "serviços de telecomunicação" como "a transmissão, emissão ou recepção de símbolos, caracteres, sinais, escritos, imagens, sons ou informações de qualquer natureza, por fio, rádio, eletricidade, meios óticos ou qualquer outro processo eletromagnético"; "telegrafia" como "o processo de telecomunicação destinado à transmissão de escritos, pelo uso de um código de sinais"; e "telefonia" como “o processo de telecomunicação destinado à transmissão da palavra falada ou de sons"402.

O Decreto 52.026, de 20 de maio de 1963, que aprovara o Regulamento Geral dessa Lei, arrolava o serviço de telefonia e o de transmissão de dados dentro dos serviços de telecomunicações ${ }^{403}$. As definições de "telefonia" e "telegrafia" 404 eram as mesmas da Lei. "Dados", novidade, eram definidos como "[...] sinais especiais, portadores de informações

\footnotetext{
${ }^{392}$ Ver artigo $34,15^{\circ}$, artigo $7^{\circ}, 4^{\circ}$, artigo $9^{\circ}$, parágrafo $1^{\circ}, 2^{\circ}$.

${ }^{393}$ Ver artigo $5^{\circ}$, incisos VII e VIII, e artigo $6^{\circ}$, inciso II.

${ }^{394}$ Ver artigo 15, incisos VI e VII, artigo 16, inciso X, artigo 18, alínea “b”, e artigo 20, inciso II.

${ }^{395}$ Ver artigo 16, inciso XI.

${ }^{396}$ Ver artigo $5^{\circ}$, inciso XII.

${ }^{397}$ Ver artigo $5^{\circ}$, incisos XI e XII.

${ }^{398}$ Ver artigo $8^{\circ}$, incisos XI, XIV, alínea “a”, e XVII, alínea “i”.

${ }^{399}$ Ver artigo $8^{\circ}$, incisos XII, XIV, alínea "a”, e XVII, alínea “i”.

${ }^{400}$ Artigo 21, inciso V.

${ }^{401}$ Artigo 21, inciso IV.

402 Artigo $4^{\circ}$.

${ }^{403}$ Artigo 4", 1", alíneas "a" e "e".

${ }^{404}$ Artigo $6^{\circ}$, números 57 e 58.
} 
destinadas à execução automática de controles ou estudos de diversas espécies, veiculados através de linhas ou circuitos de telecomunicações" ${ }^{\text {405 }}$.

Vinte e cinco anos mais tarde, a extensa alteração do Regulamento Geral aprovado pelo Decreto 97.057, de 10 de novembro de 1988, após praticamente repetir a definição anterior de serviços de telecomunicação do Regulamento, arrolou a telefonia, a telegrafia e a transmissão de dados entre as formas de telecomunicação ${ }^{406}$.

A "telefonia" passou a ser definida como a "forma de telecomunicação caracterizada pela transmissão da voz e de outros sons audíveis" "407, a "telegrafia" como a "forma de telecomunicação caracterizada pela transmissão de matéria escrita destinada a ser apresentada através de sinais gráficos, utilizando um código digital adaptado a baixas velocidades de transmissão" apresentada ao destinatário após transmissão por telegrafia" 409 e "dado" como "informação sistematizada, codificada eletronicamente, especialmente destinada a processamento por computador e demais máquinas de tratamento racional e automático da informação"410. Adicionalmente, definiu "transmissão" como "transferência unilateral de informação de um ponto a outro por meio de sinais"411 e "transmissão de dados" como "forma de telecomunicação caracterizada pela especialização na transferência de dados de um ponto a outro" $" 412$.

Esse Regulamento Geral da Lei 4.117/1962 foi finalmente revogado em 1991, pelo

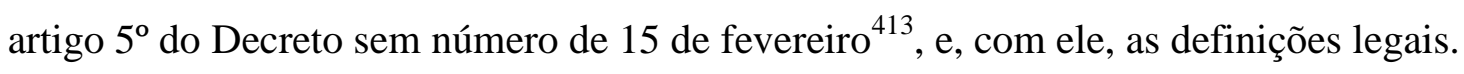

O Anexo sobre telecomunicações, aprovado junto com a Ata Final da Rodada Uruguai do GATT, que criou a Organização Mundial do Comércio (“'OMC”), pelo Decreto Legislativo 30, de 15 de dezembro de 1994, e promulgada pelo Decreto 1.355, de 30 de dezembro de 1994, define "telecomunicações" como "a transmissão e recepção de sinais por qualquer meio eletromagnético",414. Após definir, também, que "serviço público de transporte de telecomunicações" é "qualquer serviço de telecomunicações que um Membro determine, expressamente ou de fato, seja oferecido ao público em geral”, dispõe que

\footnotetext{
${ }^{405}$ Artigo $6^{\circ}$, número 5.

${ }^{406}$ Artigo 4", inciso I, alíneas "a", "b" e "d".

${ }^{407}$ Artigo $6^{\circ}, 145^{\circ}$.

${ }^{408}$ Artigo $6^{\circ}, 146^{\circ}$.

${ }^{409}$ Artigo $6^{\circ}, 147^{\circ}$.

${ }^{410}$ Artigo $6^{\circ}, 23^{\circ}$.

${ }^{411}$ Artigo $6^{\circ}, 157^{\circ}$.

${ }^{412}$ Artigo $6^{\circ}, 158^{\circ}$.

${ }^{413}$ Publicado no DOFC de 18 de fevereiro de 1991, página 003056.

${ }^{414}$ Número 3, "a".
} 
[e]ntre tais serviços podem figurar os de telégrafo, telefone, telex e transmissão de dados, que envolvem, normalmente, a transmissão entre dois ou mais pontos em tempo real de informações fornecidas pelo cliente, sem que haja qualquer modificação de um ponto a outro da forma e conteúdo das informações em questão $^{415}$.

Em 1995, a Emenda Constitucional 8, de 15 de agosto, alterou o inciso XI do artigo 21, que passou a se referir simplesmente a "[...] serviços de telecomunicações, nos termos da lei [...]"416. Essa Lei é a 9.472, de 16 de julho de 1997, a denominada Lei Geral de Telecomunicações, que sucedeu a Lei 4.117/1962 $2^{417}$, estabelecendo um novo marco regulatório para o setor, inclusive com a criação e funcionamento de um órgão regulador, a Agência Nacional de Telecomunicações (“ANATEL”), autarquia de regime especial vinculada ao Ministério das Comunicações ${ }^{418}$.

Segundo essa Lei, “[s]erviço de telecomunicações é o conjunto de atividades que possibilita a oferta de telecomunicação" ou recepção, por fio, radioeletricidade, meios ópticos ou qualquer outro processo eletromagnético, de símbolos, caracteres, sinais, escritos, imagens, sons ou informações de qualquer natureza" 420 , “[e]stação de telecomunicações é o conjunto de equipamentos ou aparelhos, dispositivos e demais meios necessários à realização de telecomunicação, seus acessórios e periféricos, e, quando for o caso, as instalações que os abrigam e complementam, inclusive terminais portáteis" 421 , enquanto "forma de telecomunicação",422 é

\footnotetext{
${ }^{415}$ Número 3, "b".

${ }^{416} \mathrm{O}$ objetivo principal dessa Emenda foi o de permitir a prestação por agentes privados, em ambiente competitivo, de serviços de telecomunicações, antes restrita a entes estatais ou sob controle estatal.

${ }^{417} \mathrm{O}$ artigo 215 revogou-a, salvo quanto à matéria penal não tratada na nova Lei e quanto aos preceitos relativos à radiodifusão. Observamos que o Decreto 3.896, de 23 de agosto de 2001, procurando dirimir dúvidas quanto à vigência de várias normas anteriores ao novo marco regulatório, dispõe que todos os serviços de telecomunicações são regidos pelas normas e resoluções editadas pela ANATEL, ressalvado o disposto no inciso II do artigo 214 da Lei 9.472/97 Ver artigos $1^{\circ}$ e $2^{\circ}$, "caput" e parágrafo único, desse Decreto.

${ }_{418}$ Artigo $8^{\circ}$.

${ }^{419}$ Artigo 60, "caput". A definição de "serviço de telecomunicações" dessa Lei vincula-se à existência de um consumidor (ou "usuário"), a quem o serviço é prestado (MINISTÉRIO DAS COMUNICAÇÕES, 1996, p. 48). O Regulamento dos Serviços de Telecomunicações, aprovado pela Resolução 73, de 25 de novembro de 1998, do Conselho Diretor da ANATEL, manteve, no artigo $2^{\circ}$, a definição de "serviço de telecomunicações" da Lei 9.472/1997, acrescentando que não o são, além dos serviços de valor adicionado, o provimento de capacidade de satélite e a atividade de habilitação ou cadastro de usuário e de equipamento para acesso a serviços de telecomunicações, abrindo margem à Agência para estabelecer outras situações que não constituam "serviços de telecomunicação". Ver artigo $3^{\circ}$, incisos I, II e III, e parágrafo único, desse Regulamento.

${ }^{420}$ Artigo 60, parágrafo $1^{\circ}$

${ }^{421}$ Artigo 60, parágrafo $2^{\circ}$.

${ }^{422}$ Artigo 69, parágrafo único.
} 
[...] o modo específico de transmitir informação, decorrente de características particulares de transdução, de transmissão, de apresentação da informação ou de combinação destas, considerando-se formas de telecomunicação, entre outras, a telefonia, a telegrafia, a comunicação de dados e a transmissão de imagens. (destaque nosso).

Cabe à ANATEL definir as modalidades de serviço em função de sua finalidade, âmbito de prestação, forma, meio de transmissão, tecnologia empregada ou de outros atributos ${ }^{423}$.

O intuito do legislador foi mesmo o de estabelecer uma definição razoavelmente aberta de "telecomunicações", excluindo daí alguns serviços, mas estabelecendo algumas características para a sua verificação (MINISTÉRIO DAS COMUNICAÇÕES, 1996, p. 49). Logo, não há mais uma definição legal setorial de "comunicações telefônicas" e "de dados", mas somente de "telecomunicações", na qual se inserem para efeitos de regulação ${ }^{424}$.

Desse modo, observa-se que a legislação estabelece dois grupos de “comunicações": (i) a correspondência, de um lado, que engloba, basicamente, cartas; e (ii) as telecomunicações, de outro, que englobam as comunicações telefônicas e de dados. A telegrafia é inserida pela Lei 9.472/1997 dentro das "telecomunicações", e o telegrama, dentro da definição de "correspondência" da Lei 6.538/1978.

Uma explicação para isso reside no fato de que a comunicação telegráfica, em si, não se distingue essencialmente de outras formas de telecomunicação, necessitando de cabeamentos ou outros meios de transporte dos sinais que resultarão na mensagem final, daí surgindo a necessidade de regulação pela Lei 9.472/1997, enquanto o telegrama, a mensagem que se transmite, por se parecer com as cartas tradicionais, ao menos no aspecto de ser mensagem escrita entre duas ou mais pessoas, foi incluído dentre a proteção especial conferida às cartas, especialmente pelo motivo de ser necessária a intermediação de um agente dos Correios para a sua transmissão.

Essas definições fechadas dirimem dúvidas quanto aos objetos expressamente referidos, mas suscitam dúvidas quanto àqueles não especificados, mas afins. O “fax”, por

\footnotetext{
${ }^{423}$ Artigo 69, "caput”, da Lei 9.472/1997, e artigo 17, inciso I, do Decreto 2.338, de 7 de outubro de 1997.

${ }^{424}$ Existem, portanto, várias definições específicas constantes de regulamentos, de acordo com a finalidade, modalidade, tecnologia envolvida e outros parâmetros. Por exemplo, o Regulamento do Serviço Telefônico Fixo Comutado ("STFC"), aprovado pela Resolução 426, de 9 de dezembro de 2005, do Conselho Diretor da Anatel, define o STFC destinado ao público em geral como "serviço de telecomunicações que, por meio de transmissão de voz e de outros sinais, destina-se à comunicação entre pontos fixos determinados, utilizando processos de telefonia" (artigo $3^{\circ}$, inciso XXIII), e "processos de telefonia" como "aqueles que permitem a comunicação entre pontos fixos determinados, de voz e outros sinais, utilizando técnica de transmissão nos modos 3,1 kHz-voz ou $7 \mathrm{kHz}$-áudio ou até $64 \mathrm{kbit} / \mathrm{s}$ irrestrito, por meio de fio, radioeletricidade, meios ópticos ou qualquer outro processo eletromagnético" (artigo $3^{\circ}$, inciso XVIII).
} 
exemplo, não é um objeto de serviço postal, e o seu envio também não é um serviço prestado por operadoras, embora seja usado, comumente, o sistema telefônico para a sua transmissão. A mensagem enviada e recebida é, por sua vez, em geral, um documento escrito impresso. É o "fax", então, uma espécie de correspondência, ou é uma modalidade de comunicação telefônica? Sua transmissão é absolutamente inviolável, ou pode ser interceptada por ordem judicial, dependendo da interpretação que se dê ao inciso XII do $\operatorname{artigo~} 5^{\circ}$ da Constituição?

A ampla definição de "telecomunicações" da Lei 9.472/1997, a princípio, abarca qualquer modalidade de comunicação que se encaixe nos seus parâmetros. A transmissão de "fax," desse modo, seria uma forma de telecomunicação, pois é um conjunto de sinais, escritos ou imagens emitido, transmitido e recebido por fio ou outros meios eletromagnéticos ${ }^{425}$. Contudo, a Lei 9.472/1997 restringe-se aos "serviços" de telecomunicação, isto é, pressupõe a oferta de um serviço ("produto") a um consumidor, sendo que apenas nessa medida é que terá aplicação, incidindo regulação expressa da ANATEL nesse ponto. O que escapa da definição do "caput" do artigo 60 escapa da aplicação dessa Lei.

Analisando-se o texto constitucional, observa-se ainda que há parcial discrepância entre ele e a legislação inferior, pois embora o inciso XI do artigo 21 refira-se atualmente a "serviços de telecomunicações", o inciso XII do artigo $5^{\circ}$ alude, num primeiro bloco, a "correspondência" e "comunicações telegráficas", e, num segundo bloco, a "dados" e "comunicações telefônicas", possibilitando o entendimento de que cada um deles engloba tipos afins de comunicação.

A referência a comunicações telefônicas, telegráficas e a correspondência tem explicação, em parte, na evolução histórica brasileira dessa proteção.

A menção à correspondência, e depois, ao longo dos anos, à telefonia e telegrafia deu-se em função do aparecimento das novas tecnologias, conforme se foi percebendo a necessidade de extensão da proteção a novas formas de comunicação. A própria redação original do inciso XI do artigo 21 da Constituição Federal vigente referia-se expressamente a "serviços telefônicos, telegráficos, de transmissão de dados e demais serviços públicos de telecomunicações" (destaque nosso), numa espécie de "ponte" entre a tradição ${ }^{426}$ e a tendência atual, de proteção abrangente e aberta a novas formas de telecomunicação ${ }^{427}$.

\footnotetext{
${ }^{425}$ Ver artigo 60, parágrafo $1^{\circ}$, combinado com o artigo 69, parágrafo único.

${ }^{426}$ Mantida no inciso XII do artigo $5^{\circ}$.

427 Veja-se a redação do artigo $1^{\circ}$, “caput” e parágrafo único, da Lei 9.296/1996, que se refere a
} 
As exceções e restrições ao sigilo das comunicações não começaram, porém, com a Constituição Federal de 1988, tampouco com a Lei 9.296/1996.

As exceções extraordinárias já vinham previstas desde a nossa primeira Constituição, a de 1824, segundo a qual ${ }^{428}$ os "Poderes Constitucionais" não podiam suspender a Constituição, no que dizia respeito aos direitos individuais, nos casos de rebelião ou invasão de "inimigos", salvo nos termos do inciso XXXV do artigo 179, que tratava de rebelião ou de invasão de inimigos ${ }^{429}$.

A Constituição de 1891 estabelecia a hipótese de suspensão das garantias individuais por tempo determinado, quando a segurança da República o exigisse, em caso de agressão estrangeira ou comoção intestina.

A brevíssima Constituição de 1934 previa a declaração de estado de sítio, autorizando "medidas de exceção" como a "censura de correspondência de qualquer natureza, e das publicações em geral" e a "busca e apreensão em domicílio" ${ }^{430}$, enquanto a

comunicações telefônicas "de qualquer natureza" e estende o regime de interceptação telefônica ao "fluxo de comunicações em sistemas de informática e telemática".

${ }^{428}$ Artigo 179, inciso XXXIV.

429 "Nos casos de rebellião, ou invasão de inimigos, pedindo a segurança do Estado, que se dispensem por tempo determinado algumas das formalidades, que garantem a liberdade individual, poder-se-ha fazer por acto especial do Poder Legislativo. Não se achando porém a esse tempo reunida a Assembléa, e correndo a Patria perigo imminente, poderá o Governo exercer esta mesma providencia, como medida provisoria, e indispensavel, suspendendo-a immediatamente que cesse a necessidade urgente, que a motivou; devendo num, e outro caso remetter á Assembléa, logo que reunida fôr, uma relação motivada das prisões, e d'outras medidas de prevenção tomadas; e quaesquer Autoridades, que tiverem mandado proceder a ellas, serão responsaveis pelos abusos, que tiverem praticado a esse respeito".

${ }^{430}$ Ver artigo 175, número 2, alíneas "c" e "e", e artigos 40, alíneas "d" e “j”, e 56, parágrafo 13. Era a redação do artigo 175: “Art 175 - O Poder Legislativo, na iminência de agressão estrangeira, ou na emergência de insurreição armada, poderá autorizar o Presidente da República a declarar em estado de sítio qualquer parte do território nacional, observando-se o seguinte: 1) o estado de sítio não será decretado por mais de noventa dias, podendo ser prorrogado, no máximo, por igual prazo, de cada vez; 2) na vigência do estado de sítio só se admitem estas medidas de exceção: a) desterro para outros pontos do território nacional, ou determinação de permanência em certa localidade; b) detenção em edifício ou local não destinado a réus de crimes comuns; c) censura de correspondência de qualquer natureza, e das publicações em geral; d) suspensão da liberdade de reunião e de tribuna; e) busca e apreensão em domicílio. $\S 1^{\circ}$ - A nenhuma pessoa se imporá permanência em lugar deserto ou insalubre do território nacional, nem desterro para tal lugar, ou para qualquer outro, distante mais de mil quilômetros daquele em que se achava ao ser atingida pela determinação. $\S 2^{\circ}$ - Ninguém será, em virtude do estado de sítio, conservado em custódia, senão por necessidade da defesa nacional, em caso de agressão estrangeira, ou por autoria ou cumplicidade de insurreição, ou fundados motivos de vir a participar nela. $\S 3^{\circ}$ - Em todos os casos, as pessoas atingidas pelas medidas restritivas da liberdade de locomoção devem ser, dentro de cinco dias, apresentadas pelas autoridades que decretaram as medidas com a declaração sumária de seus motivos ao Juiz comissionado para esse fim, que as ouvirá, tomando-lhes, por escrito, as declarações. $\S 4^{\circ}$ - As medidas restritivas da liberdade de locomoção não atingem os membros da Câmara dos Deputados, do Senado Federal, da Corte Suprema, do Supremo Tribunal Militar, do Tribunal Superior de Justiça Eleitoral, do Tribunal de Contas e, nos territórios das respectivas circunscrições, os Governadores e Secretários de Estado, os membros das Assembléias Legislativas e dos Tribunais superiores. $\S 5^{\circ}$ - Não será obstada a circulação de livros, jornais ou de quaisquer publicações, desde que os seus autores, diretores ou editores os submetam à censura. $\S 6^{\circ}$ - Não será censurada a publicação dos atos de qualquer dos Poderes federais, salvo os que respeitem as medidas de caráter militar. $\S 7^{\circ}$ - Se não estiverem reunidas a Câmara dos Deputados e o Senado Federal, poderá o estado de sítio ser decretado pelo Presidente da República, com aquiescência prévia da Seção Permanente do Senado 
de 1937 permitia a declaração de estado de emergência, "[e]m caso de ameaça externa ou iminência de perturbações internas ou existências de concerto, plano ou conspiração, tendente a perturbar a paz pública ou pôr em perigo a estrutura das instituições, a segurança do Estado ou dos cidadãos [...]", ou de estado de guerra, se se tornasse necessário o emprego das forças armadas para a defesa do Estado ${ }^{431}$, permitindo, dentre outras medidas, a "censura da correspondência e de todas as comunicações orais e escritas" e a "busca e apreensão em domicílio" ${ }^{432}$. Além disso, determinava, na segunda parte do artigo 123, logo após o elenco dos direitos e garantias individuais, que "[o] uso desses direitos e garantias terá por limite o bem público, as necessidades da defesa, do bem-estar, da paz e da ordem coletiva, bem como as exigências da segurança da Nação e do Estado em nome dela constituído e organizado nesta Constituição", tendo-se em consideração ainda o fato de que a inviolabilidade de correspondência e de domicílio, como visto, era submetida a exceções expressas em $1 \mathrm{ei}^{433}$.

A Constituição de $1946^{434}$ permitia a suspensão de garantias constitucionais, mas de uma maneira inversa às anteriores, pois dispunha que a lei que decretasse o estado de sítio, em caso de guerra externa ou no de comoção intestina grave, atual ou iminente, com o caráter de guerra civil, deveria especificar aquelas que continuariam em vigor, ao invés daquelas que seriam suspensas ${ }^{435}$. Limitava as medidas que podiam ser tomadas no caso da comoção intestina, dentre outras, "[à] censura de correspondência ou de publicidade, inclusive a de radiodifusão, cinema e teatro" e "[à] busca e apreensão em domicílio"436,

Federal. Nesse caso se reunirão trinta dias depois, independentemente de convocação. $\S 8^{\circ}$ - Aberta a sessão legislativa, o Presidente da República relatará, em mensagem especial, os motivos determinantes do estado de sítio, e justificará as medidas que tenha adotado, apresentando as declarações exigidas pelo $\S 3^{\circ}$, e mais documentos necessários. O Poder Legislativo passará em seguida a deliberar sobre o decreto expedido, revogando-o, ou não, podendo também apreciar, desde logo, as providências trazidas ao seu conhecimento, e autorizar a prorrogação do estado de sítio, nos termos do $\mathrm{n}^{\circ} 1$ deste artigo. $\S 9^{\circ}$ - Proceder-se-á na conformidade dos parágrafos precedentes, quando se haja de prorrogar o estado de sítio. $\S 10$ - Decretado este, o Presidente da República designará, por ato publicado oficialmente, um ou mais magistrados para os fins do $\S 3^{\circ}$, assim como as autoridades que tenham de exercer as medidas de exceção, e estabelecerá as normas necessárias para a regularidade destas. $§ 11$ - Expirado o estado de sítio, cessam, desde logo, todos os seus efeitos. § 12 - As medidas aplicadas na vigência do estado de sítio, logo que ele termine, serão relatadas pelo Presidente da República, em mensagem à Câmara dos Deputados, com as declarações prestadas pelas pessoas detidas e mais documentos necessários para que ele os aprecie. § 13 - O Presidente da República e demais autoridades serão responsabilizados, civil ou criminalmente, pelos abusos que cometerem. $\S 14$ - A inobservância de qualquer das prescrições deste artigo tornará ilegal a coação, e permitirá aos pacientes recorrerem ao Poder Judiciário. § 15 - Uma lei especial regulará o estado de sítio em caso de guerra, ou de emergência de guerra".

${ }^{431}$ Ver artigos 166 a 173, e artigo 74, alínea " $k$ ".

${ }^{432}$ Ver artigo 168, alíneas "b" e "d".

${ }^{433}$ Ver artigo $122,6^{\circ}$.

${ }^{434}$ Ver artigo $5^{\circ}$, inciso III, artigo 87, inciso XIII, e artigos 206 a 215.

${ }^{435}$ Ver artigo 207.

${ }^{436}$ Artigo 208, parágrafo único, incisos I e III. 
mas não o fazia em caso de guerra externa ${ }^{437}$.

A Constituição de $1967^{438}$ autorizava a decretação de estado de sítio em caso de "grave perturbação da ordem ou ameaça de sua irrupção" e de guerra ${ }^{439}$, ocasião em que permitia as "medidas coercitivas", dentre outras, de "busca e apreensão em domicílio" e "censura de correspondência, da imprensa, das telecomunicações e diversões públicas" além da possibilidade de outras medidas estabelecidas em lei, "[a] fim de preservar a integridade e a independência do País, o livre funcionamento dos Poderes e a prática das instituições, quando gravemente ameaçados por fatores de subversão ou corrupção [...]"441.

A Emenda Constitucional 1/1969, ao contrário da Constituição de 1967, que previa a suspensão de direitos políticos, por dois a dez anos, daqueles que abusassem dos direitos de liberdade de pensamento, de profissão, de reunião e de associação para atentar contra a ordem democrática ou praticar a corrupção ${ }^{442}$, dispunha que o abuso de direito individual ou político, indiscriminadamente, com o fim de subverter o regime democrático ou de corrupção, importaria em suspensão desses direitos, sem especificar se a referência era a ambos ou somente aos políticos ${ }^{443}$.

Praticamente repetindo a Constituição anterior ${ }^{444}$, continuou a permitir a suspensão de garantias individuais em caso de estado de sítio, e, posteriormente, com a Emenda Constitucional 11, de 13 de outubro de 1978, também no "estado de emergência" e na adoção de "medidas de emergência" que não justificassem a decretação de um dos dois “estados". Dentre as "medidas coercitivas" permitidas, que podiam ser estendidas a outras não enumeradas no texto constitucional, estavam a busca e apreensão em domicílio e a censura da correspondência, da imprensa, das telecomunicações e diversões públicas ${ }^{445}$.

A atual Constituição Federal traz o "estado de sítio" e o "estado de defesa"446. O "estado de defesa" pode ser decretado

[...] para preservar ou prontamente restabelecer, em locais restritos e

\footnotetext{
${ }^{437}$ Artigo 208 combinado com os artigos 206, inciso II, e 207.

${ }^{438}$ Ver artigo $8^{\circ}$, inciso III, artigo 47, inciso IV, artigo 83, XIV, e artigos 152 a 156.

${ }^{439}$ Artigo 152, incisos I e II.

${ }^{440}$ Artigo 152, parágrafo $2^{\circ}$, alíneas "c" e "e".

${ }^{441}$ Ver artigo 152 , parágrafo $3^{\circ}$.

${ }^{442}$ Ver artigo 151.

${ }^{443}$ Ver artigo 154.

${ }^{444}$ Ver artigo $8^{\circ}$, inciso III, artigo 44, inciso IV, artigo 81, inciso XVI, e artigos 155 a 159.

${ }^{445}$ Conforme artigo 155, parágrafo $2^{\circ}$, alíneas "c" e "e", da redação original da Emenda 1/1969, e artigo 156, parágrafo $2^{\circ}$, alíneas "c" e " $\mathrm{f}$ ", primeira parte, com as alterações promovidas pela Emenda Constitucional $13 / 1978$.

${ }^{446}$ Ver artigos 136 a 141, artigo 21, inciso V, artigo 49, inciso IV, artigo 53, parágrafo $7^{\circ}$, na redação original, parágrafo $8^{\circ}$, com a Emenda Constitucional 35, de 20 de dezembro de 2001, artigo 84, inciso IX, artigo 90, inciso I, e artigo 91, parágrafo $1^{\circ}$, inciso II.
} 
determinados, a ordem pública ou a paz social ameaçadas por grave e iminente instabilidade institucional ou atingidas por calamidades de grandes proporções na natureza ${ }^{447}$.

Dentre as "medidas coercitivas" autorizadas, estão, dentre outras arroladas exaustivamente, restrições aos direitos de "sigilo de correspondência" e "sigilo de comunicação telegráfica e telefônica" 448 .

Já o "estado de sítio" pode ser decretado em dois $\operatorname{casos}^{449}$ : (i) comoção grave de repercussão nacional ou ocorrência de fatos que comprovem a ineficácia de medida tomada durante o estado de defesa; e (ii) declaração de estado de guerra ou resposta a agressão armada estrangeira.

No primeiro caso, dentre as medidas taxativamente enumeradas, podem ser adotadas "restrições relativas à inviolabilidade da correspondência, ao sigilo das comunicações, à prestação de informações e à liberdade de imprensa, radiodifusão e televisão, na forma da lei" e a "busca e apreensão em domicílio"450. No segundo, a Constituição não estabelece limites a restrições de direitos e garantias, mas fica assegurada, em qualquer dos estados, a responsabilização dos agentes ou executores, com a sua cessação $^{451}$.

Observa-se, logo, que todas as Constituições previam casos ou situações excepcionais, de emergência, em que se podiam suspender, com maior ou menor amplitude, os direitos e garantias individuais, como a inviolabilidade do sigilo de correspondência e das comunicações telefônicas e telegráficas. Mas, à exceção da Constituição de 1937 e a atual, nenhuma trouxe qualquer ressalva explícita a essa inviolabilidade, em situações de normalidade, o que, no entanto, acabou sendo feito, muitas vezes, pela legislação inferior.

O Código Criminal do Império, de 1830, considerava crime "[t]irar maliciosamente do Correio cartas que lhe não pertencerem, sem autorização da pessoa, a quem vierem dirigidas" 452 , bem como "[t]irar, ou haver as cartas da mão, ou do poder de algum portador particular por qualquer maneira que seja" ${ }^{\natural 53}$, com penas de prisão e de multa ${ }^{454}$, dobradas

\footnotetext{
${ }^{447}$ Artigo 136, "caput".

${ }^{448}$ Artigo 136, parágrafo $1^{\circ}$, inciso I, alíneas "b" e "c".

${ }^{449}$ Ver artigo 137, incisos I e II.

${ }^{450}$ Ver artigo 139, incisos III e V. As restrições à liberdade de comunicação e difusão de pensamento não abrangem os pronunciamentos de parlamentares efetuados em suas Casas Legislativas, desde que liberados pela respectiva Mesa, como consta do parágrafo único do artigo 139.

${ }^{451}$ Ver artigo 141.

${ }^{452}$ Artigo 215.

453 Artigo 216. Antes mesmo da Constituição de 1824 e do Código Criminal do Império, já havia normas destinar a proteger o segredo das correspondências, como noticia Barros Neto (2004, p. 24-25): "No Brasil, o
} 
"em caso de se descobrir a outro o que nas cartas se contiver, em todo ou em parte" ${ }^{455}$, sendo que "[a]s cartas que fôrem tiradas por qualquer das maneiras mencionadas não serão admitidas em juízo"456.

O Decreto 3.288, de 20 de junho de 1864, que aprovava o Regulamento para a repartição dos telégrafos, impunha penalidades ao empregado que, dentre outros, violasse o "segredo dos recados" ou cometesse qualquer outro abuso ${ }^{457}$, enquanto o Decreto 9.912-A, de 26 de março de 1888, que reformava os Correios do Império, estabelecia penalidade de multa para quem embaraçasse a circulação, transmissão e entrega de correspondência ${ }^{458}$, além de afirmar que o segredo das cartas era inviolável, qualquer que fosse o Poder público que pretendesse devassá-lo, e qualquer que fosse o fundamento ou pretexto alegado ${ }^{459}$. O empregado dos Correios que violasse o segredo podia ser suspenso ${ }^{460}$, e determinava a prisão daqueles que fossem pegos em flagrante ${ }^{461}$.

O Decreto 368-A, de $1^{\circ}$ de maio de 1890 , que reformava os Correios da República, era quase uma cópia do Decreto anterior. No ponto, a única mudança foi a possibilidade de pena de demissão para o empregado que violasse o segredo das cartas ${ }^{462}$.

O Código Penal aprovado pelo Decreto 847, de 11 de outubro de 1890, tipificava como crime a "perturbação" da transmissão de telegrama, ou sua interceptação, "[...] por meio de derivação estabelecida por fio preso ao fio do telégrafo" 463 , sendo que o artigo 155 equiparava aos telégrafos, para efeitos de aplicação da lei penal, “[...] os telefones de propriedade da Nação, ou dos Estados, ou destinados ao serviço publico".

Correio da Corte foi estabelecido em 24 de abril de 1798, administrado pela Fazenda Real, e a Administração do Correio, [sic] instalou-se no Rio de Janeiro, junto às instalações do Tribunal da Relação e da Casa da Moeda, no Paço Real, onde eram distribuídas as cartas que chegavam de Portugal. [...] As Juntas de Fazenda eram as responsáveis pela direção, governo e criação dos novos Correios, além de fazer as nomeações. Os empregados estavam sujeitos a duras penas, caso não cumprissem com suas obrigações: 'faltando qualquer destes empregados à sua obrigação em parte essencial da mesma depois de haver sido admoestado, será despedido, e provido o seu lugar; se cometer o crime de abrir cartas, ou de as entregar maliciosamente, e de caso pensado a outra pessoa que não seja seu Dono, será preso, e punido segundo as Leis' (artigo $8^{\circ}$ da Instrução para as Juntas de Fazenda dos Estados do Brasil sobre os Correios, que complementava o alvará de 1728). Cabe aqui ressaltar que a inviolabilidade da correspondência, um dos mais importantes princípios do serviço postal, foi, dessa forma, garantido em lei, procedimento recorrente em toda a legislação postal subseqüente" (destaque do autor).

${ }^{454}$ Prisão de um a três meses, e de multa de dez a cinqüenta mil réis, aplicáveis também se para cometer o crime do artigo 216 usasse o réu de violência ou arrombamento. Ver mais sobre o Código Criminal do Império em Pierangeli (2004).

${ }_{455}$ Artigo 217.

${ }^{456}$ Artigo 218.

${ }^{457}$ Artigo 60.

${ }^{458}$ Artigo 91.

${ }^{459}$ Artigo 204.

${ }^{460}$ Artigo 187, número 12.

${ }^{461}$ Artigo 188.

${ }^{462}$ Artigo 192, $8^{\circ}$.

${ }^{463}$ Artigo 154 combinado com o artigo 153. 
Tipificava ainda como crime: (i) abrir "maliciosamente" carta, telegrama, ou papel fechado endereçado a outrem, apossar-se de correspondência epistolar ou telegráfica alheia, ainda que não estivesse fechada, e que por qualquer meio lhe viesse às mãos, bem como tirá-la de repartição pública ou do poder de portador particular, para conhecer-lhe o conteúdo $^{464}$. No caso de ser revelado em todo, ou em parte, o segredo da correspondência violada, a pena era aumentada de um terço ${ }^{465}$; (ii) suprimir correspondência epistolar ou telegráfica endereçada a outrem $^{466}$; (iii) publicar o destinatário de uma carta, ou correspondência, sem consentimento da pessoa que a endereçou, o conteúdo não sendo em defesa de direitos, e de uma ou outra resultando dano ao remetente ${ }^{467}$.

Também sofria a mesma pena do artigo 192 o empregado do Correio que se apoderasse de carta não fechada, ou a abrisse, se fechada, para conhecer-lhe o conteúdo, ou comunicá-lo a alguém, e bem assim o do telégrafo que, para fim idêntico, violasse telegrama, ou propagasse a comunicação nele contida. Se os empregados suprimissem ou extraviassem a correspondência, ou não a entregassem ou comunicassem ao destinatário, a pena era maior ${ }^{468}$. A autoridade que de posse de carta ou correspondência particular utilizasse-a para qualquer intuito, ainda que fosse para descoberta de um crime, ou prova deste, incorreria na pena de perda do emprego e na de multa de $100 \$$ a $500 \$ 000^{469}$. As cartas obtidas por meios criminosos não seriam admitidas em juízo ${ }^{470}$.

Aparentemente, o Código estabelecia, lendo apenas os tipos, uma proteção absoluta, em conformidade com a proteção decorrente da dicção das Constituições de 1824 e 1891. Entretanto, apesar de os tipos em si não terem trazido exceções, salvo a do artigo 191, aplicavam-se a eles as disposições gerais do Código, dentre outras, as que não consideravam criminosos $^{471}$ aqueles que praticassem a conduta para evitar um mal maior, desde que reunidas as condições do artigo $33^{472}$, ou em legítima defesa, própria ou de outrem, não limitada à proteção da vida, mas compreendendo todos os direitos que podem ser lesados, desde que reunidas as condições do artigo $34^{473}$. Em outras palavras, eram

\footnotetext{
${ }^{464}$ Artigo 189.

${ }^{465}$ Artigo 189, parágrafo único.

${ }^{466}$ Artigo 190.

467 Artigo 191.

468 Ver artigo 193, "caput” e parágrafo único.

${ }^{469}$ Artigo 194.

${ }^{470}$ Artigo 195.

${ }^{471}$ Ver artigo 32.

472 Certeza do mal que se propôs evitar, falta absoluta de outro meio menos prejudicial e probabilidade da eficácia do que se empregou.

473 Agressão atual, impossibilidade de prevenir ou obstar a ação, ou de invocar e receber socorro da autoridade pública, emprego de meios adequados para evitar o mal e em proporção da agressão, e ausência de
} 
exceções gerais que podiam ser aplicadas à inviolabilidade.

O Decreto 1692-A, de 10 de abril de 1894, que aprovara outro Regulamento dos Correios da República, praticamente repetia a afirmação de segredo dos Regulamentos anteriores, explicitando, contudo, que era inviolável o segredo das cartas entregues ao Correio $^{474}$. Estabelecia que nenhuma autoridade podia abrir ou fazer abrir objetos de correspondência em poder do Correio $^{475}$, e que cabia aos seus empregados tomar todas as medidas necessárias, dentro dos limites da competência de cada um, para assegurar a preservação do sigilo, um dever seu ${ }^{476}$.

Configurava violação do sigilo $^{477}$ : (i) a abertura, por qualquer meio, de carta fechada ou objeto fechado como carta, endereçado a outrem, para conhecer-lhe o conteúdo; (ii) a subtração ou supressão, nas estações postais, de pacotes, malas, sacos do Correio, cartas fechadas ou abertas, bilhetes postais, ou quaisquer outros objetos de correspondência equiparados à carta; (iii) a divulgação, no todo ou em parte, do assunto ou texto das correspondências mencionadas nos itens (i) e (ii) ou das que tivessem conhecimento em razão de seu ofício; (iv) a divulgação, no todo ou em parte, do assunto ou texto de correspondência oficial, reservada ou não, de cujo expediente estivesse encarregado, (v) bem como a divulgação, por qualquer meio, das pessoas que mantivessem entre si relações pelo Correio.

Previa a penalidade de demissão do empregado do Correio que cometesse irregularidades repetidas que levassem à suspeita de violação do sigilo das correspondências, praticadas em serviço, e que importassem na perda de confiança nele, bem para aquele que, de fato, a violasse $e^{478}$, além de prisão em flagrante do empregado que praticasse quaisquer dos crimes arrolados no artigo $385,1^{\mathrm{o}^{479}}$, do Regulamento ${ }^{480}$.

O Decreto 2.230, de 10 de fevereiro de 1896, que aprovara outro Regulamento para os Correios Federais, praticamente repetiu essas disposições ${ }^{481}$, como o fez, mais tarde, o Decreto 9.080, de 3 de novembro de 1911, o que se incorporou no Regulamento seguinte,

\footnotetext{
provocação que ocasionasse a agressão.

${ }^{474}$ Ver artigo 15.

${ }^{475}$ Ver artigo 17.

${ }^{476}$ Ver artigo 18.

477 Artigo 19 e incisos e artigo 20.

${ }^{478}$ Ver artigo $385,4^{\circ}$ e 11.

479 “Art. 385. A pena de demissão será imposta, além de outros casos previstos na lei: $1^{\text {o }}$, ao empregado ou encarregado de serviço postal condemnado por crime de prevaricação, peita, suborno, concussão, abuso ou excesso de autoridade, falsidade, peculato, moeda falsa, furto, roubo, estellionato, homicidio e nos outros crimes previstos no Codigo Penal, e bem assim em penas correccionaes, que envolvam participação e manifestações de perturbação contra a ordem publica, ou falta de probidade".

${ }^{480}$ Conforme artigos 386 e 389.

481 À exceção da infração de suspeita de violação de sigilo.
} 
aprovado pelo Decreto 14.722, de 16 de março de 1921.

O Decreto-lei 2.848, de 7 de dezembro de 1940, que instituiu o Código Penal vigente, e sofreu várias alterações ao longo do tempo, principalmente na Parte Geral, inteiramente reformada pela Lei 7.209, de 11 de julho de 1984, $\operatorname{traz}^{482}$ alguns crimes relacionados à inviolabilidade: (i) devassar indevidamente o conteúdo de correspondência fechada, dirigida a outrem ${ }^{483}$; (ii) apossar-se indevidamente de correspondência alheia, embora não fechada e, no todo ou em parte, sonegá-la ou destruí-la ${ }^{484}$; (iii) indevidamente divulgar, transmitir a outrem ou utilizar abusivamente comunicação telegráfica ou radioelétrica dirigida a terceiro, ou conversação telefônica entre outras pessoas ${ }^{485}$; (iv) impedir a comunicação ou a conversação telegráfica, radioelétrica ou telefônica ${ }^{486}$; (v) instalar ou utilizar estação ou aparelho radioelétrico, sem observância de disposição legal ${ }^{487}$; e (vi) abusar da condição de sócio ou empregado de estabelecimento comercial ou industrial para, no todo ou em parte, desviar, sonegar, subtrair ou suprimir correspondência, ou revelar a estranho seu conteúdo ${ }^{488}$.

As penas são aumentadas de metade, se resultar dano para outrem ${ }^{489}$, e são aumentadas se o agente cometer o crime com abuso de função em serviço postal, telegráfico, radioelétrico ou telefônico ${ }^{490}$, caso em que a ação é penal pública incondicionada, assim como no tipo do inciso IV do parágrafo $1^{\circ}$ do artigo 151.

É também crime divulgar alguém, sem justa causa, conteúdo de documento particular ou de correspondência confidencial, de que é destinatário ou detentor, e cuja divulgação possa produzir dano a outrem ${ }^{491}$, e revelar alguém, sem justa causa, segredo, de que tem ciência em razão de função, ministério, ofício ou profissão, e cuja revelação possa produzir dano a outrem ${ }^{492}$.

Veja-se que o crime de "grampo" previsto no Código anterior, embora limitado, deixou de existir. O tipo do artigo 151, parágrafo $1^{\circ}$, inciso II, protege apenas indiretamente contra essa conduta, pois o agente só incide nesse crime se divulgar,

\footnotetext{
${ }^{482} \mathrm{Ou}$ trazia, de acordo com o entendimento que se tenha em relação a alguns dos crimes devido a leis supervenientes, como explicamos mais adiante.

${ }^{483}$ Artigo 151.

${ }^{484}$ Ver artigo 151 , parágrafo $1^{\circ}$, inciso I.

${ }^{485}$ Artigo 151, parágrafo $1^{\circ}$, inciso II.

${ }^{486}$ Artigo 151, parágrafo $1^{\circ}$, inciso III.

${ }^{487}$ Artigo 151, parágrafo $1^{\circ}$, inciso IV.

${ }^{488}$ Artigo 152.

${ }^{489}$ Artigo 151, parágrafo $2^{\circ}$.

${ }^{490}$ Artigo 151, parágrafo $3^{\circ}$.

${ }^{491}$ Artigo 153.

${ }^{492}$ Artigo 154.
} 
transmitir ou utilizar "abusivamente" comunicação entre terceiros. Por conseguinte, não é crime, aí, a utilização de conversa gravada por um dos interlocutores, e nem a de terceiros, desde que não "abusiva" ou "indevida".

Mas, de qualquer modo, a Parte Geral do Código Penal prevê situações que não configuram crime, ou são isentas de pena, apesar de se subsumirem a um dos tipos penais. Assim, desde a redação original, que, nesse ponto, continua praticamente a mesma, se o fato, por exemplo, é cometido sob coação irresistível ou em estrita obediência a ordem, não manifestamente ilegal, de superior hierárquico, só é punível o autor da coação ou da ordem $^{493}$. Além disso, não há crime quando o agente pratica o fato em estado de necessidade ${ }^{494}$, em legítima defesa ${ }^{495}$ ou em estrito cumprimento do dever legal ou no exercício regular de direito ${ }^{496}$. Em outras palavras, continuam as exceções gerais que podem aplicar-se à inviolabilidade.

O Decreto 29.151/1951, por sua vez, afirmava a inviolabilidade de correspondência, salvo as "exceções legais" "497.

$\mathrm{O}$ artigo 26 desse Regulamento arrolava as hipóteses que não constituíam, em seu âmbito de aplicação, violação do sigilo de correspondência ou do "segredo profissional indispensável à manutenção daquele": (i) a exibição de autógrafo de telegrama ou radiotelegrama e o fornecimento de informação, cópia ou certidão sobre existência, texto ou trânsito de correspondência postal com caráter de mensagem, telegrama ou radiotelegrama, exclusivamente ao remetente ou expedidor, destinatário, ou a seus procuradores ou representantes legais; (ii) a abertura de objeto de correspondência postal com caráter de mensagem: (a) endereçada a pessoa de nome igual ao de outra, na mesma localidade; (b) de refugo definitivo; (c) que contivesse artigo sujeito a pagamento de taxas fiscais ou direitos aduaneiros; (d) apreendida por apresentar selo servido, falso ou falsificado; (e) por suspeita de conter valor não declarado; e (f) que atentasse contra a segurança nacional ou o regime.

$\mathrm{O}$ artigo 21, a seu turno, arrolava as hipóteses que configuravam violação desse

\footnotetext{
493 Artigo 22 atual.

494 “Considera-se em estado de necessidade quem pratica o fato para salvar de perigo atual, que não provocou por sua vontade, nem podia de outro modo evitar, direito próprio ou alheio, cujo sacrifício, nas circunstâncias, não era razoável exigir-se" (artigo 24, "caput”); “[n]ão pode alegar estado de necessidade quem tinha o dever legal de enfrentar o perigo" (artigo 24, parágrafo $1^{\circ}$ ); "[e]mbora seja razoável exigir-se o sacrifício do direito ameaçado, a pena poderá ser reduzida de um a dois terços" (artigo 24, parágrafo $2^{\circ}$ ).

495 "Entende-se em legítima defesa quem, usando moderadamente dos meios necessários, repele injusta agressão, atual ou iminente, a direito seu ou de outrem" (artigo 25).

${ }^{496}$ Artigo 23 atual.

497 Artigo 20.
} 
sigilo: (i) devassar indevidamente o conteúdo de objeto de correspondência postal com caráter de mensagem, fechado e endereçado a outrem; (ii) apossar-se indevidamente de objeto de correspondência postal com caráter de mensagem, embora aberto, endereçado a outrem e, no todo ou em parte, sonegá-lo ou destruí-lo; (iii) divulgar indevidamente, transmitir a outrem ou utilizar abusivamente comunicação telegráfica ou radioelétrica dirigida a terceiro, ou conversação telefônica entre outras pessoas; (iv) impedir a comunicação ou a conversação referidas no item (iii); e (v) instalar ou utilizar estação ou aparelho radioelétrico, sem observância de disposição legal.

Note-se que esse Regulamento não considerava violação do sigilo a interceptação de comunicações telefônicas, e nem a divulgação do seu conteúdo, mas tão-só o seu uso "abusivo" ou "indevido".

A fim de assegurar o sigilo, o Regulamento estabelecia um correspondente dever de "segredo profissional" a todos aqueles responsáveis pela prestação e execução desses serviços de comunicação ${ }^{498}$, dispondo que as autoridades e os servidores do Departamento de Correios e Telecomunicações, então órgão da Administração Direta federal, os concessionários, permissionários e seus empregados eram obrigados a tomar providências indispensáveis à manutenção da inviolabilidade do sigilo da correspondência ${ }^{499}$. Vedava a entrada de pessoa estranha no recinto destinado à execução dos serviços postais e de telecomunicações, inclusive de servidor do Departamento e de empregado do concessionário ou permissionário que não estivesse de serviço ${ }^{500}$, bem como a intervenção nesses serviços por qualquer autoridade estranha, salvo por solicitação do diretor do Departamento $^{501}$.

O artigo 25 dispunha que constituía violação do segredo profissional indispensável à manutenção da inviolabilidade do sigilo da correspondência: (i) divulgar, no todo ou em parte, assunto ou texto de correspondência de que, em razão do ofício, tivesse conhecimento; (ii) divulgar nomes de pessoas que tivessem entre si relações pelo correio ou por telecomunicação; (iii) informar pessoa não legalmente autorizada da existência de correspondência dirigida a terceiro; (iv) fornecer a pessoa não legalmente autorizada cópia ou certidão de correspondência postal aberta com caráter de mensagem; (v) fornecer certidão ou informar a pessoa não legalmente autorizada sobre trânsito de correspondência postal com caráter de mensagem ou telegrama; (vi) informar alguém do nome de assinante

\footnotetext{
${ }^{498}$ Ver artigos 25 e 22.

499 Artigo 22.

${ }^{500}$ Artigo 24, "caput” e parágrafo único.

${ }^{501}$ Artigo 23.
} 
de caixa postal ou do número desta, bem como do endereço telegráfico ou do nome do seu possuidor, quando houver pedido em contrário do usuário; (vii) informar outrem do modo por que ou do local em que qualquer pessoa recebe correspondência; e (viii) divulgar fato que a terceiro possibilite o conhecimento indevido sobre a expedição de correspondência com caráter de mensagem ou de telegrama. Em relação às telecomunicações, a única restrição referia-se à divulgação dos nomes das pessoas que tivessem participado de uma conversa.

Assim, da conjugação do artigo 25 com o 21, vê-se que as comunicações em geral comportavam a divulgação de informações a pessoas "legalmente autorizadas", e, no tocante especificamente às telecomunicações, não havia restrições absolutas contra a divulgação do conteúdo, somente que não fosse "abusiva" ou "indevida".

A Lei 4.117/1962 afirmava que a telecomunicação era inviolável, em seus termos $^{502}$, e estabelecia o que não consistia violação ${ }^{503}$ : (i) a recepção de telecomunicação dirigida por quem diretamente ou como cooperação esteja legalmente autorizado; e (ii) o conhecimento dado: (a) ao destinatário da telecomunicação ou a seu representante legal; (b) aos intervenientes necessários ao curso da telecomunicação; (c) ao comandante ou chefe, sob cujas ordens imediatas estivesse servindo; (d) aos fiscais do Governo junto aos concessionários ou permissionários; e (e) ao juiz competente, mediante requisição ou intimação deste.

Essa Lei tem uma parte penal, que se traduz no crime de "violação de telecomunicação", praticado por aquele que, transgredindo lei ou regulamento, exiba autógrafo ou qualquer documento do arquivo, divulgue ou comunique, informe ou capte, transmita a outrem ou utilize o conteúdo, resumo, significado, interpretação, indicação ou efeito de qualquer comunicação dirigida a terceiro ${ }^{504}$, ou receba, divulgue ou utilize, telecomunicação interceptada ${ }^{505}$.

O artigo 70 tipifica a "[...] a instalação ou utilização de telecomunicações, sem observância do disposto nesta Lei e nos regulamentos", punível com detenção de um a dois anos.

O artigo 58, com alterações promovidas pelo Decreto-lei 236, de 28 de fevereiro de 1967, traz as seguintes penas:

\footnotetext{
502 Artigo 55.

${ }^{503}$ Artigo 56, incisos I e II.

${ }^{504}$ Artigo 56, "caput".

${ }^{505}$ Artigo 56, parágrafo $1^{\circ}$.
} 
Art. 58. Nos crimes de violação da telecomunicação, a que se referem esta Lei e o artigo 151 do Código Penal, caberão, ainda as seguintes penas:

I - Para as concessionárias ou permissionárias as previstas nos artigos 62 [multa] e 63 [suspensão], se culpados por ação ou omissão e independentemente da ação criminal.

II - Para as pessoas físicas:

a) 1 (um) a 2 (dois) anos de detenção ou perda de cargo ou emprego, apurada a responsabilidade em processo regular, iniciado com o afastamento imediato do acusado até decisão final;

b) para autoridade responsável por violação da telecomunicação, as penas previstas na legislação em vigor serão aplicadas em dobro;

c) serão suspensos ou cassados, na proporção da gravidade da infração, os certificados dos operadores profissionais e dos amadores responsáveis pelo crime de violação da telecomunicação.

A Lei 9.472/1997 manteve a parte penal dessa Lei 4.117/1962, trazendo apenas um tipo: "[d]esenvolver clandestinamente atividades de telecomunicação" ${ }^{506}$, sendo que "clandestina" é a atividade desenvolvida sem a competente concessão, permissão ou autorização de serviço, de uso de radiofreqüência e de exploração de satélite ${ }^{507}$.

Por sua vez, a Lei 9.296, de 24 de julho de 1996, que regulamenta o inciso XII, parte final, do artigo $5^{\circ}$ da Constituição Federal de 1988, estabeleceu um outro tipo penal $^{508}$ : “[...] realizar interceptação de comunicações telefônicas, de informática ou telemática, ou quebrar segredo da Justiça, sem autorização judicial ou com objetivos não autorizados em lei”. A pena é de dois a quatro anos de reclusão, e multa.

Esse conjunto de dispositivos que se sucederam no tempo em diversas leis, sem revogação ou derrogação direta e bem delimitada, criam uma situação de incerteza sobre quais tipos continuam vigentes e em que termos ${ }^{509}$.

\footnotetext{
${ }^{506}$ Artigo 183.

${ }^{507}$ Artigo 184, parágrafo único.

${ }^{508}$ Artigo 10 .

${ }^{509} \mathrm{O}$ "caput" do artigo 58 da Lei 4.117/1962 remete a penas que caberão "ainda" nos crimes dessa Lei e nos do artigo 151 do Código Penal, dando a entender que só serão arroladas penas adicionais nos seus incisos I e II. O inciso I traz uma penalidade administrativa para as concessionárias ou permissionárias, e não uma pena criminal acessória, pois a sua parte final dispõe que a multa e suspensão independem da ação penal. Encontra-se, portanto, revogado, exceto no tocante à radiodifusão (a outra matéria mantida pelo artigo 251, inciso I, da Lei 9.472/1997). O inciso II parece "misturar" num mesmo dispositivo uma pena criminal e outra administrativa. Lembre-se que, à época da Lei 4.117/1962, o Código Penal previa a perda (automática) de função pública, eletiva ou de nomeação, como pena acessória decorrente da condenação daquele que houvesse cometido crime com abuso de poder ou violação de dever inerente a função pública (artigo 67, inciso I, e artigo 68, inciso I, na redação anterior às modificações promovidas pela Lei 7.209/1984). Além disso, a menção a "processo regular" para apuração da responsabilidade certamente não se referia a processo penal, pois o devido processo legal, no campo penal, encontrava-se expressamente previsto no parágrafo 25 do artigo 141 da Constituição de 1946, que também já estabelecia que os funcionários públicos somente poderiam perder o cargo por decisão judicial transitada em julgado, no caso dos vitalícios, ou, quando
} 


\title{
De qualquer modo, o Código Penal de 1940, o Decreto 29.151/1951 e a Lei
}

\subsection{7/1962 introduziram uma flexibilidade ao sigilo das comunicações, incluindo o}

\author{
telegrama, exceto da correspondência, antes praticamente inexistente no ordenamento \\ jurídico brasileiro (na legislação escrita, ao menos), mesmo não havendo autorização direta
}

estáveis, também na hipótese de extinção do cargo ou na de serem demitidos mediante processo administrativo em que se lhes tivesse sido assegurada a ampla defesa (ver artigo 189, incisos I e II). Ora, os serviços de telecomunicação eram executados ou concedidos, autorizados ou permitidos pela União, que os fiscalizava e aplicava, através dos órgãos competentes, as sanções devidas, e as pessoas físicas que trabalhavam nas concessionárias ou permissionárias não eram exatamente "funcionários públicos" para a aplicação da lei penal, que não comporta interpretação extensiva ou analogia para prejudicar o réu. A equiparação a funcionário público promovida pelo então parágrafo único do artigo 327 do Código Penal limitava-se àqueles que exercessem cargo, emprego ou função em entidade paraestatal, o que não era o caso das prestadoras de serviço privadas. Logo, parece-nos que o intuito desse dispositivo foi o de equiparar, obliquamente, os trabalhadores dessas empresas aos funcionários públicos. A pena, aí, contudo, era alternativa, e não cumulativa, o que poderia ser questionado em razão do princípio da isonomia. Observe-se, também, que o tipo penal do artigo 56 da Lei 4.117/1962 é mais amplo que o do inciso II do parágrafo $1^{\circ}$ do artigo 151 do Código Penal, superando-o. A alínea "c" do inciso II do artigo 58 da Lei 4.117/1962 trata de uma penalidade administrativa, que não se aplica à radiodifusão, e foi revogado pela Lei 9.472/1997. O artigo 70 da Lei 4.117/1962 tipifica como crime a "[...] a instalação ou utilização de telecomunicações, sem observância do disposto nesta Lei e nos regulamentos”, punível com detenção de um a dois anos. O tipo é mais amplo que o do inciso IV do parágrafo $1^{\circ}$ do artigo 151 do Código Penal, que se restringe à instalação ou utilização de aparelhos radioelétricos, "sem observância de disposição legal". Assim, este teria sido derrogado por aquele. O problema é que a Lei 9.472/1997, ressalvando a matéria penal da Lei 4.117/62 e a concernente à radiodifusão, revogou-a, e o artigo 70 refere-se a "esta Lei” e regulamentos. Uma interpretação à luz do princípio da estreita legalidade do direito penal levar-nos-ia, assim, à conclusão de que, embora formalmente vigente, o tipo encontra-se inócuo, esvaziado, em função da inexistência da regulamentação da Lei 4.117/1962. Só subsistiria esse crime se passássemos a uma interpretação ligeiramente mais flexível, entendo-se que "esta Lei" pode ser a atual Lei 9.472/1997, ou qualquer outra que a venha substituir. Porém, o inciso IV do parágrafo $1^{\circ}$ do artigo 151 do Código Penal, embora mais restritivo no objeto, referia-se, por exemplo, a qualquer disposição legal (que regulasse a matéria). Em outras palavras, esse tipo do artigo 70 só continua aplicável se entendermos que se deve buscar a razão da lei e "corrigir" a referência a "esta Lei" a simplesmente "qualquer Lei pertinente". Não é o caso, entretanto, segundo o nosso entendimento, no campo do direito penal. Ou seja, o artigo 70 continua vigente, mas é ineficaz, inaplicável, e o inciso IV do parágrafo $1^{\circ}$ do artigo 151 do Código Penal está revogado desde a Lei 4.117/1962. O tipo trazido pela Lei 9.296/1996 (artigo 10) não existia no Código Penal. O tipo do artigo 56 da Lei 4.117/1962 prevê, dentre várias condutas, "captar" comunicação dirigida a terceiro, o que seria, de fato, o sentido jurídico que se atribui à "interceptação", que é a captação das comunicações de outros, que não um ou todos os interlocutores, sem prejuízo do fluxo de informações. Como o artigo 10 da Lei 9.296/1996 trata apenas das comunicações telefônicas, de informática e telemática, a estas se aplica esta Lei, com a sua correspondente pena; às demais, aplica-se o artigo 56 da Lei 4.117/1962. Desse modo, concluímos que: (i) o inciso II do parágrafo $1^{\circ}$ do artigo 151 do Código Penal foi derrogado pelo artigo 56 da Lei 4.117/1962, que continua em vigor, e a pena aplicável é a de detenção, de um a dois anos. Greco Filho entende que tanto o inciso II do parágrafo $1^{\circ}$ do artigo 151 do Código Penal quanto o artigo 56 da Lei 4.117/1962 foram derrogados pelo artigo 10 da Lei 9.296/1996 (2005). L. Gomes (1997) entende que continua vigente esse dispositivo do Código Penal, ao passo que Jesus (1997) entende que foi derrogada apenas a sua parte final pelo artigo 10 da Lei 9.296/1996; (ii) continua vigente o parágrafo $3^{\circ}$ desse artigo 151 , pois refere-se àqueles que trabalham, a qualquer título, nesses serviços, aplicando-se a pena base de um a três anos de detenção; (iii) vige também o aumento de pena previsto na alínea "b" do inciso II do artigo 58 da Lei 4.117/1962, que se aplica, ao contrário do item anterior, às autoridades, àqueles com poder de comando, responsáveis pela ordem que deu origem ao crime de violação de telecomunicação; (iv) continua vigente o aumento de pena previsto no parágrafo $2^{\circ}$ do artigo 151 do Código Penal, inclusive porque o tipo do artigo 56 da Lei 4.117/1962 não exige a existência de dano; (v) está revogado o inciso IV do parágrafo $1^{\circ}$ do artigo 151 pelo artigo 70 da Lei 4.117/1962, que, por sua vez, desde a edição da Lei 9.472/1997, está ineficaz, apesar de formalmente vigente; (vi) pelas mesmas razões expostas quanto ao artigo 70 da Lei 4.117/1962, encontra-se formalmente em vigor o inciso III do parágrafo $1^{\circ}$ do artigo 151 do Código Penal, mas sem eficácia desde a entrada em vigor daquela lei (artigo 56); e (vii) às interceptações de comunicações em geral entre terceiros, aplicam-se os artigos 56 e 58 da Lei 4.117/1962, enquanto às telefônicas, de informática e de telemática, aplica-se o artigo 10 da Lei 9.296/1996. 
constitucional a partir de 1946, e existindo uma autorização muito restrita na de 1988.

A Lei 6.538/1978, que trouxe a atual regulação dos serviços postais, dispõe que não constitui violação de sigilo da correspondência postal a abertura de $\operatorname{carta}^{510}$ : (i) endereçada a homônimo, no mesmo endereço; (ii) que apresente indícios de conter objeto sujeito a pagamento de tributos; (iii) que apresente indícios de conter valor não declarado, objeto ou substância de expedição, uso ou entrega proibidos; e (iv) que deva ser inutilizada, na forma prevista em regulamento, em virtude de impossibilidade de sua entrega e restituição. Dispõe ainda que não constitui violação do sigilo de correspondência o conhecimento do texto de telegrama endereçado a homônimo, no mesmo endereço ${ }^{511}$.

As hipóteses que constituem violação do sigilo foram criminalizadas no artigo 41 sob a rubrica "[q]uebra do segredo profissional":

\begin{abstract}
Art. $41^{\circ}$ - Violar segredo profissional, indispensável à manutenção do sigilo da correspondência mediante:

I - divulgação de nomes de pessoas que mantenham, entre si, correspondência;

II - divulgação, no todo ou em parte, de assunto ou texto de correspondência de que, em razão ao oficio, se tenha conhecimento;

III - revelação do nome de assinante de caixa postal ou o número desta, quando houver pedido em contrário do usuário;

IV - revelação do modo pelo qual ou do local especial em que qualquer pessoa recebe correspondência.
\end{abstract}

Pena: detenção de três meses a um ano, ou pagamento não excedente a cinquienta dias-multa.

O artigo 40 dessa Lei tipifica o crime de "violação de correspondência",512, cominando pena de detenção até seis meses, ou pagamento não excedente a vinte diasmulta $^{513}$; o seu parágrafo primeiro tipifica o crime de "sonegação ou destruição de correspondência", como a conduta de “[...] quem se apossa indevidamente de correspondência alheia, embora não fechada, para sonegá-la ou destruí-la, no todo ou em parte"; e o parágrafo segundo traz uma causa de aumento de pena da metade, se houver

\footnotetext{
510 Artigo 10, incisos I a IV. O Decreto 83.858/79, que regulamentava essa Lei, dispunha sobre o que constituía e o que não constituía violação do sigilo de correspondência (artigos 10 e 14, respectivamente) e do segredo profissional (artigo 13), arrolando, em cada caso, mais hipóteses do que a Lei, o que era, inclusive, de duvidosa validade, especialmente no concernente a reflexos penais.

511 Artigo 28.

512 "Devassar indevidamente o conteúdo de correspondência fechada dirigida a outrem".

${ }^{513}$ A pena alternativa de dias-multa só se tornou aplicável com o advento da Lei 7.209/84, que introduziu o sistema do dia-multa na Parte Geral do Código Penal, ao contrário do tipo previsto no "caput" do artigo 151, que previa, originalmente, uma faixa de multa, e, depois com essa Lei de 1984, passou a se referir apenas a "multa".
} 
dano para outrem.

À exceção da pena e da parte final do parágrafo $1^{\circ}$, esse artigo 40 praticamente reproduz a linguagem do artigo 151, “caput”, e parágrafos $1^{\circ}$, inciso I, e $2^{\circ}$, do Código Penal. A Lei 6.538/1978 não estabelece uma pena mínima, mas como o artigo $9^{\circ}$, na sua redação original, atual artigo 11 do Código Penal, dispõe que se desprezam, na contagem dos prazos, as frações de dia, conclui-se que a pena mínima é de um dia de prisão.

O parágrafo $1^{\circ}$ do artigo 40 da Lei 6.538/1978 difere do tipo do inciso I do parágrafo $1^{\circ}$ do artigo 151 do Código Penal porque este exige o resultado (sonegar ou destruir), enquanto àquele basta a intenção de fazê-lo.

Há autores que entendem que esses tipos do Código Penal foram revogados ou “substituídos" pelo artigo 40 da Lei 6.538/1978 (DELMANTO ET AL., 2000; MIRABETE, 2001). Nosso entendimento, porém, é no sentido de que ambos continuam vigente, pois a Lei de 1978 é uma lei especial que regula os serviços postais e que, por conseguinte, protege uma "correspondência" cujo conceito é mais restrito, ou seja, limitase a cartas enviadas pela via postal, ou telegrama, de acordo com seu artigo 47, enquanto o objeto do artigo 151, "caput" e parágrafo $1^{\circ}$, do Código Penal é toda carta ou comunicação similar que não encontre proteção naquele.

No concernente aos dados e à sua comunicação ou transmissão, não existe uma regulação específica que trate dessa matéria de um modo sistemático e geral, mas leis esparsas que, incidentalmente, cuidam de algumas espécies de dados.

A legislação que cuida do mercado de valores mobiliários, por exemplo, preza pela veracidade e transparência das informações, para evitar distorções e manipulações. Veja-se a Lei 4.728, de 14 de julho de 1965, que disciplina vários aspectos do mercado de capitais, especialmente o seu artigo $4^{\circ}$, que confere ao Banco Central do Brasil poderes de examinar livros e documentos de instituições financeiras e outras entidades.

O Decreto-Lei 161, de 13 de fevereiro de 1967, que autorizou o Poder Executivo a instituir a Fundação Instituto Brasileiro de Geografia e Estatística ("IBGE”), estabeleceu um Plano Nacional de Estatística e a obrigatoriedade de prestação de informações necessárias à sua execução, por parte das pessoas físicas e jurídicas, para uso exclusivo de fins estatísticos, “[...] não podendo tais informações servir de instrumento para qualquer procedimento fiscal ou legal contra os informantes, salvo quanto a esse último, para efeito de cumprimento da presente lei",514.

${ }^{514}$ Artigo $2^{\circ}$, parágrafo $2^{\circ}$. 
A Lei 5.534, de 14 de novembro de 1968, reafirmou essa obrigatoriedade ${ }^{515}$ :

[...] As informações prestadas terão caráter sigiloso, serão usadas exclusivamente para fins estatísticos, e não poderão ser objeto de certidão, nem, em hipótese alguma, servirão de prova em processo administrativo, fiscal ou judicial, excetuado, apenas, no que resultar de infração a dispositivos desta lei ${ }^{516}$.

Configuram infrações a não prestação de informações nos prazos fixados e a prestação de informações falsas ${ }^{517}$, com sanções pecuniárias, aplicáveis pelo IBGE, que não eximem o sujeito da obrigação de prestá-las ${ }^{518}$.

A Lei 5.878, de 11 de maio de 1973, que passou a reger o IBGE, instituiu o Plano Geral de Informações Estatísticas e Geográficas ${ }^{519}$, determinando que se aplicam às informações coletadas em sua execução a Lei 5.534/1968 ${ }^{520}$. O Decreto 73.177, de 20 de novembro de 1973, regulamentou essa Lei, enquanto o Decreto 74.084, de 20 de maio de 1974, regulamentou o Plano, ressaltando o sigilo das informações ${ }^{521}$.

A Lei 7.232, de 29 de outubro de 1984, a primeira "Lei de Informática", estabelece uma Política Nacional de Informática baseada, dentre outros, em dois princípios ${ }^{522}$ : (i) o estabelecimento de mecanismos e instrumentos legais e técnicos para a proteção do sigilo dos dados armazenados, processados e veiculados, do interesse da privacidade e de segurança das pessoas físicas e jurídicas, privadas e públicas; e (ii) o estabelecimento de mecanismos e instrumentos para assegurar a todo cidadão o direito ao acesso e à retificação de informações sobre ele existentes em bases de dados públicas ou privadas.

A Constituição Federal de 1988, por sua vez, criou um novo remédio constitucional, o "habeas data", com duas funções ${ }^{523}$ : (i) assegurar o conhecimento de informações relativas à pessoa do impetrante, constantes de registros ou bancos de dados de entidades governamentais ou de caráter público; e (ii) retificar dados, quando não se prefira fazê-lo por processo sigiloso, judicial ou administrativo.

Esse dispositivo foi regulamentado pela Lei 9.507, de 12 de novembro de 1997, que lhe adicionou uma terceira função, a "anotação nos assentamentos do interessado, de contestação ou explicação sobre dado verdadeiro mas justificável e que esteja sob

\footnotetext{
${ }^{515}$ Ver artigo $1^{\text {o }}$, “caput”.

${ }^{516}$ Artigo $1^{\circ}$, parágrafo único.

517 Artigo 20, alíneas "a" e "b".

${ }^{518}$ Artigos $2^{\circ}$, parágrafos $1^{\circ}$ a $4^{\circ}, 4^{\circ}$ e $5^{\circ}$.

${ }^{519}$ Artigo $5^{\circ}$.

${ }^{520}$ Artigo $6^{\circ}$, parágrafo único.

${ }^{521}$ Artigo $8^{\circ}$.

${ }^{522}$ Artigo $2^{\circ}$, incisos VIII e IX, respectivamente.

${ }^{523}$ Ver artigo $5^{\circ}$, inciso LXXII.
} 
pendência judicial ou amigável”,524, e determinou que

[c]onsidera-se de caráter público todo registro ou banco de dados contendo informações que sejam ou que possam ser transmitidas a terceiros ou que não sejam de uso privativo do órgão ou entidade produtora ou depositária das informações $^{525}$.

O Código de Defesa do Consumidor, Lei 8.078, de 11 de setembro de 1990, trata dos bancos de dados e cadastros de consumidores, garantindo-lhes acesso a informações suas, determinando que sejam objetivas, claras, verdadeiras e em linguagem de fácil compreensão, não podendo ser guardados dados negativos por período superior a cinco $\operatorname{anos}^{526}$. Institui a obrigação de comunicação por escrito ao consumidor de abertura de cadastro, ficha, registro e dados pessoais e de consumo, quando por ele não solicitada, e considera esses bancos de dados, bem como os serviços de proteção ao crédito e congêneres como entidades de caráter público, o que é relevante, dentre outros, para cabimento de "habeas data" 527 . De qualquer modo, assegura expressamente ao consumidor, sempre que encontrar inexatidão nos seus dados e cadastros, o poder de exigir sua imediata correção, devendo o arquivista, no prazo de cinco dias úteis, comunicar a alteração aos eventuais destinatários das informações incorretas ${ }^{528}$.

A Lei 9.472/1997 arrola como direitos do usuário "a não divulgação, caso o requeira, de seu código de acesso" e o "respeito de sua privacidade nos documentos de cobrança e na utilização de seus dados pessoais pela prestadora do serviço" ${ }^{\text {"529 }}$, competindo à ANATEL a adoção das medidas necessárias para reprimir infrações aos direitos dos usuários $^{530}$.

A Lei 9.034, de 3 de maio de 1995, que dispõe sobre "meios de prova e procedimentos investigatórios que versem sobre ilícitos decorrentes de ações praticadas por quadrilha ou bando ou organizações ou associações criminosas de qualquer tipo" ${ }^{, 531}$, permite, em qualquer fase da persecução criminal, o acesso a dados, documentos e informações fiscais, bancárias, financeiras e eleitorais ${ }^{532}$. O seu artigo $3^{\circ}$ trata do procedimento para se assegurar a "preservação do sigilo constitucional", que determina a

\footnotetext{
${ }^{524}$ Conforme art. $7^{\circ}$, inciso III.

${ }^{525}$ Artigo $1^{\circ}$, parágrafo único.

${ }^{526}$ Artigo 43, "caput" e parágrafo $1^{\circ}$.

${ }^{527}$ Artigo 43, parágrafos $2^{\circ}$ e $4^{\circ}$.

${ }^{528}$ Artigo 43, parágrafo $3^{\circ}$.

${ }_{530}$ Artigo $3^{\circ}$, incisos VI e IX, respectivamente.

${ }^{530}$ Artigo 19, inciso XVIII.

${ }^{531}$ Artigo $1^{\circ}$, com a redação dada pela Lei 10.217, de 11 de abril de 2001.

${ }^{532}$ Artigo $2^{\circ}$, inciso III.
} 
realização de diligência pessoal pelo juiz, quando houver risco nesse ponto, cujo auto deve ser mantido em separado, sem intervenção de cartório ou servidor, somente acessível pelas partes legítimas na causa, que não podem valer-se dessas informações para fins estranhos a ela $^{533}$.

A Lei Complementar 105, de 10 de janeiro de 2001, revogou o artigo 38 da Lei 4.595, de 31 de dezembro de 1964, e passou a reger a matéria do sigilo bancário e financeiro. Ela estabelece situações que não constituem quebra de sigilo ${ }^{534}$ e aquelas em que a "quebra" pode ser decretada ${ }^{535}$, conferindo amplo poder às autoridades administrativas, legislativas e judiciais.

Por exemplo, o parágrafo $4^{\circ}$ do artigo $1^{\circ}$ traz um rol ilustrativo de crimes em que permite o levantamento do sigilo, implicando, então, uma autorização genérica. Refere-se, ainda, a qualquer fase do "inquérito" ou do processo judicial, o que pode levar à interpretação de que a quebra pode dar-se, a princípio, mesmo sem autorização do Judiciário.

Às Comissões Parlamentares de Inquérito são reconhecidos poderes requisitórios, com base na Constituição Federal, mas a Lei vai além, atribuindo poder de obtenção de informações e documentos bancários e financeiros ao Poder Legislativo federal, desde que aprovado pelo Plenário da respectiva casa ${ }^{536}$.

Mesmo a Lei 9.034/1995 parece não estabelecer como regra a reserva judicial para a requisição de dados, informações e documentos, já que o "caput" do artigo $2^{\circ}$, não apreciado pelo STF, não determina a autorização de um juiz competente, enquanto seus incisos IV e V fazem-no com relação, respectivamente, à captação e interceptação ambiental de sinais eletromagnéticos, óticos ou acústicos, e o seu registro e análise, e a infiltração por agentes da polícia ou inteligência. Se a ressalva consta apenas de duas das hipóteses, seriam exceções.

A Lei Complementar 105/2001 também estabelece, no seu artigo 10, ser crime, sujeito à pena de reclusão de um a quatro anos e multa, a quebra de sigilo fora das hipóteses arroladas nela, incorrendo na mesma pena quem omitir, retardar ou prestar falsamente as informações requeridas nos termos desse diploma normativo.

\footnotetext{
533 O regime desse artigo $3^{\circ}$, contudo, foi esvaziado pelo STF no julgamento da Ação Direta de Inconstitucionalidade 1570/DF (ver Apêndice A, número 6, desta dissertação).

${ }^{534}$ Incisos do parágrafo $3^{\circ}$ do artigo $1^{\circ}$.

${ }^{535}$ Artigo $1^{\circ}$, parágrafo $4^{\circ}$.

${ }^{536}$ Artigo 4", "caput" e parágrafo $2^{\circ}$.
} 
O Código Civil de $2002^{537}$ procura proteger aspectos da privacidade em alguns dispositivos, principalmente nos artigos 20 e 21:

Art. 20. Salvo se autorizadas, ou se necessárias à administração da justiça ou à manutenção da ordem pública, a divulgação de escritos, a transmissão da palavra, ou a publicação, a exposição ou a utilização da imagem de uma pessoa poderão ser proibidas, a seu requerimento e sem prejuízo da indenização que couber, se lhe atingirem a honra, a boa fama ou a respeitabilidade, ou se se destinarem a fins comerciais.

Parágrafo único. Em se tratando de morto ou de ausente, são partes legítimas para requerer essa proteção o cônjuge, os ascendentes ou os descendentes.

Art. 21. A vida privada da pessoa natural é inviolável, e o juiz, a requerimento do interessado, adotará as providências necessárias para impedir ou fazer cessar ato contrário a esta norma.

Foram inseridos alguns tipos no Código Penal concernente a dados e sistemas informáticos, especialmente no âmbito da Administração Pública, pela Lei 9.983, de 14 de julho de 2000, como se vê no Capítulo 5.2.1.

Enfim, todo esse emaranhado normativo tem por objetivo proteger (e, às vezes, desproteger) diferentes aspectos relacionados à privacidade do indivíduo ${ }^{538}$.

\subsubsection{Reconhecimento substancial.}

O direito positivo brasileiro só foi reconhecendo explicitamente o direito à privacidade recentemente.

A Lei 5.250, de 9 de fevereiro de 1967, também conhecida como "Lei de Imprensa", ainda em vigor, refere-se à "vida privada", quando cuida da responsabilidade civil $^{539}$. Já o Código Penal de 1969, Decreto-lei 1.004, de 21 de outubro de 1969, que teve sua entrada em vigor adiada por inúmeras vezes até ser finalmente revogado em 1978, tipificava o crime de "violação de intimidade" no artigo 162, inserido no Capítulo VI, que cuidava dos crimes contra a liberdade: "[v]iolar, mediante processo técnico, o direito à intimidade da vida privada ou o direito ao resguardo das palavras ou discursos que não forem pronunciados publicamente" (destaque nosso), enquanto as Leis 7.232/1984 e 9.472/1997 mencionam a palavra "privacidade", como visto.

A Constituição Federal, por sua vez, alude à "intimidade" e à "vida privada" no

\footnotetext{
${ }^{537}$ Lei 10.406 , de 10 de janeiro de 2002.

${ }^{538}$ As leis e disposições citadas não esgotam o sistema de tratamento e proteção, principalmente por causa do caráter multifacetário que possui esse aspecto do indivíduo.

${ }^{539}$ Artigo 49, parágrafo $1^{\circ}$.
} 
artigo $5^{\circ}$, inciso $\mathrm{X}$, além de dispor que "a lei só poderá restringir a publicidade dos atos processuais quando a defesa da intimidade ou o interesse social o exigirem",540, e que, nos julgamentos pelo Poder Judiciário, a lei pode limitar a presença, em certos atos, às próprias partes e a seus advogados, ou somente a estes, “[...] em casos nos quais a preservação do direito à intimidade do interessado no sigilo não prejudique o interesse público à informação" 541 .

O Pacto Internacional sobre Direitos Civis e Políticos, adotado pela XXI Sessão da Assembléia Geral da Organização das Nações Unidas, em 16 de dezembro de 1966, e promulgado, no Brasil, pelo Decreto 592, de 6 de julho de 1992, no seu artigo 17, e a Convenção Americana sobre Direitos Humanos ("Pacto de São José da Costa Rica"), adotada no âmbito da Organização dos Estados Americanos em 22 de novembro de 1969, em vigor internacionalmente desde 18 de julho de 1978, e promulgada, no Brasil, pelo Decreto 678, de 6 de novembro de 1992, em seu artigo 11, referem-se à "vida privada".

O Acordo Geral sobre o Comércio de Serviços ("GATS”, em inglês), aprovado na Ata Final da Rodada Uruguai, promulgado pelo Decreto $1.355 / 1994$, usa a palavra “privacidade" no artigo XIV, número 1, alínea “c”, ii.

Já o atual Código Civil não se refere à "privacidade", tampouco à "intimidade", mas protege a "vida privada", arrolada dentre os "direitos da personalidade" ${ }^{\text {" }}$.

A Lei 11.690, de 9 de junho de 2008, ao alterar o artigo 201 do Código de Processo Penal, que cuida do ofendido, inseriu-lhe o seguinte parágrafo $6^{\circ}$ :

O juiz tomará as providências necessárias à preservação da intimidade, vida privada, honra e imagem do ofendido, podendo, inclusive, determinar o segredo de justiça em relação aos dados, depoimentos e outras informações constantes dos autos a seu respeito para evitar sua exposição aos meios de comunicação ${ }^{543}$. (destaque nosso).

O Decreto Legislativo 186, de 9 de julho de 2008, do Congresso Nacional, que aprovou a "Convenção sobre os Direitos das Pessoas com Deficiência e de seu Protocolo Facultativo, assinados em Nova Iorque, em 30 de março de 2007" com força de Emenda Constitucional nos termos do parágrafo $3^{\circ}$ do artigo $5^{\circ}$ da Constituição Federal, refere-se ao "respeito à privacidade" das pessoas com deficiência em seu artigo 22.

Mas, afinal, o que seria a privacidade, e qual a distinção entre ela e a intimidade e a

\footnotetext{
${ }^{540}$ Artigo $5^{\circ}$, inciso LX.

${ }^{541}$ Artigo 93, inciso IX.

542 Artigo 21.

${ }^{543}$ Mas o legislador não cuidou da privacidade do investigado, do indiciado e das testemunhas. Ver Choukr (2001).
} 
vida privada?

A palavra "privacidade" é um anglicismo, derivada do substantivo "privacy". O dicionário Houaiss afirma tratar-se de "empréstimo recente na língua (talvez década de 1970), sugerindo-se em seu lugar o uso de intimidade, liberdade pessoal, vida íntima; sossego etc", atribuindo-lhe as acepções de "vida privada, particular, íntima" (INSTITUTO ANTÔNIO HOUAISS, 2004).

Costa Júnior, embora critique o uso do vocábulo "privacidade", "que é péssimo português e bom anglicismo", defendendo que a "expressão exata, em bom vernáculo, é privatividade, que vem de privativo" (2004, p. 21), afirma:

\begin{abstract}
Na expressão "direito à intimidade" são tutelados dois interesses, que se somam: $o$ interesse de que a intimidade não venha a sofrer agressões e o de que não venha a ser divulgada. $\mathrm{O}$ direito, porém, é o mesmo. O que pode assumir uma gama diversa é o interesse protegido pelo direito. São duas esferas de interesses, abarcadas no mesmo raio de proteção do mesmo direito. No âmbito do direito à intimidade, portanto, podem ser vislumbrados estes dois aspectos: a invasão e a divulgação não autorizada da intimidade legitimamente conquistada. Em termos de conteúdo, todavia, não deve prevalecer a distinção. (2004, p. 31-32).
\end{abstract}

Em outro ponto da obra, o autor subdivide a "esfera da vida privada" em outras esferas menores (2004, p. 34-35): (i) a esfera privada "stricto sensu", de maior âmbito, compreendendo todos aqueles acontecimentos e comportamentos que o indivíduo não quer que se tornem de domínio público, fora da qual se encontram os processos, episódios e condutas de natureza pública; (ii) na qual está contida a esfera da intimidade, ou confidencial, da qual participam apenas as pessoas nas quais o indivíduo deposita certa confiança e com as quais mantém certa amizade; e, (iii) no centro, a esfera do segredo, da qual compartilham uns poucos amigos, "muito chegados", que exclui, inclusive, pessoas da "intimidade" do sujeito, e que merece proteção legal mais intensa.

Cretella Júnior, após lecionar que “intimidade" “é o 'status' ou situação daquilo que é íntimo, isolado, só”, de que "há um 'direito' ou 'liberdade pública' de estar só, de não ser importunado", afirma que "intimidade" e "vida privada" denotam a mesma situação, e que aquela nada mais é do que esta no recesso do lar (1990, p. 257).

Para Bastos (1989, p. 63), que parece não distinguir "intimidade" de "vida privada", a privacidade

[...] [c]onsiste na faculdade que tem cada indivíduo de obstar a intromissão de estranhos na sua vida privada e familiar, assim como de impedir-lhes o acesso a informações sobre a privacidade de cada um, e também impedir que sejam divulgadas informações sobre esta área de manifestação existencial do ser 
humano $^{544}$.

É uma definição tautológica, pois define "privacidade" em relação à própria privacidade, sem qualquer explicação, ainda, sobre a "vida privada" e a "intimidade".

Ferreira Filho (1990, p. 36) não se refere a "privacidade", mas procura conceituar vida privada e intimidade:

[v]ida privada, como é óbvio, opõe-se à vida pública. Esta é a que se desenrola perante os olhos da comunidade. Assim, é conhecida de muitos e pode ser conhecida de todos. A vida privada é a que se desenvolve fora das vistas da comunidade. É a que se desenvolve fora das vistas do público, perante, eventualmente, um pequeno grupo de íntimos. Compreende, portanto, a intimidade, isto é, a vida em ambiente de convívio, no interior de um grupo fechado e reduzido, normalmente, ao grupo familiar.

Diniz enumera alguns sentidos de "privacidade" (1998b, p. 750), dentre eles o que a considera como sinônimo de "intimidade" e o de direito de respeito à vida privada, contra ingerências exteriores, além de uma, sob a rubrica de "Direito Civil", que seria "[...] a pretensão do indivíduo, de grupos ou instituições de decidir, por si, quando, como e até que ponto uma informação sobre eles pode ser comunicada a outrem (Alain Westin)”.

A autora, no verbete "intimidade", arrola também os sentidos de "amizade íntima", “qualidade de íntimo" e "familiaridade" (DINIZ, 1998a, p. 895), enquanto "vida privada" seria a "[v]ida particular ou pessoal da pessoa que gera o direito à intimidade, que é um dos direitos fundamentais do ser humano" (DINIZ, 1998c, p. 731).

Macedo Júnior não distingue vida privada de intimidade, referindo-se ao conceito de ambos como um "direito à liberdade":

\footnotetext{
Liberdade é aqui basicamente entendida em seu sentido de não impedimento, isto é, enquanto direito a fazer o que se bem entende, de estar só, de não ser incomodado, de se tomar decisões na esfera privada sem interferência estatal. Isto inclui a liberdade sexual, a liberdade de não revelar suas condutas íntimas e a liberdade de identidade. (1999, p. 246).
}

S. Rodrigues não chega a conceituar intimidade, mas afirma que a lei deve buscar um meio de proteger o uso do nome, da palavra e da imagem, “[...] pois lhe cabe proteger tudo que diz respeito à intimidade das pessoas" (1999, p. 95), enquanto D. Silva (1967, vol. 2, p. 857-8), não trazendo definições de "privacidade" nem de "vida privada", leciona que "intimidade",

[d]erivado do latim "intimus" (o mais profundo, estreito, íntimo), indica a qualidade ou o caráter das coisas e dos fatos, que se mostram estreitamente

${ }^{544}$ No mesmo sentido, Mendes (1999, p. 66). 
ligados, ou das pessoas, que se mostram afetuosamente unidas pela estima. [...] Nas pessoas, mostra a amizade íntima, revelando a familiaridade existente entre duas pessoas, e as designando como amigas íntimas. Assim, quando se alude à existência de relações íntimas ou de intimidade entre duas pessoas, ressalta-se a confiança, a afeição, a cordialidade que as une. [...]. (destaques do autor).

Por sua vez, Ferraz Junior conceitua o "direito à privacidade" como um "direito subjetivo fundamental" (1992, p. 77):

[...] Como direito subjetivo, manifesta uma estrutura básica, cujos elementos são o sujeito, o conteúdo e o objeto. O sujeito é o titular do direito. Em se tratando de um dos direitos fundamentais do indivíduo, o sujeito é toda e qualquer pessoa, física ou jurídica, brasileira ou estrangeira, residente (ou transeunte [...]) no País (art. 5', "caput"). O conteúdo é a faculdade específica atribuída ao sujeito, que pode ser a faculdade de constranger os outros ou de resistir-lhes (caso dos direitos pessoais) ou de dispor, gozar, usufruir (caso dos direitos reais). A privacidade, como direito, tem por conteúdo a faculdade de constranger os outros ao respeito e de resistir à violação do que lhe é próprio, isto é, das situações vitais que, por lhe dizerem a ele só respeito, deseja manter para si, ao abrigo de sua única e discricionária decisão. O objeto é o bem protegido, que pode ser uma "res" (uma coisa, não necessariamente física, no caso de direitos reais) ou um interesse (no caso dos direitos pessoais). No direito à privacidade, o objeto é, sinteticamente, a integridade moral do sujeito.

E, após discorrer sobre a diferenciação contemporânea entre o "social público" (a área da política), dominado pelo princípio da transparência e da igualdade, o "social privado" (área do econômico ou do mercado), marcado pelo princípio da "diferenciação" (direito de o indivíduo ser diferente), e o terreno da "individualidade privativa", regido pelo princípio da exclusividade, continua o autor:

Este último [“individualidade privativa”], expresso por Hannah Arendt com base em Kant [...], visa a assegurar no indivíduo a sua identidade diante dos riscos proporcionados pela niveladora pressão social e pela incontrastável impositividade do poder político. Aquilo que é exclusivo é o que passa pelas opções pessoais, afetadas pela subjetividade do indivíduo e que não é guiada nem por normas nem por padrões objetivos. No recôndito da privacidade se esconde a intimidade. A intimidade não exige publicidade porque não envolve direitos de terceiros. No âmbito da privacidade, a intimidade é o mais exclusivo dos seus direitos. Há, porém, uma certa gradação nos direitos da privacidade. [...] Embora os comentadores não vejam diferença entre vida privada e intimidade [...], pode-se vislumbrar um grau de exclusividade entre ambas. A intimidade é o âmbito do exclusivo que alguém reserva para si, sem nenhuma repercussão social, nem mesmo ao alcance de sua vida privada que, por mais isolada que seja, é sempre um viver entre os outros (na família, no trabalho, no lazer em comum). Não há um conceito absoluto de intimidade. Mas é possível exemplificá-lo: o diário íntimo, o segredo sob juramento, as próprias convicções, as situações indevassáveis do pudor pessoal, o segredo íntimo cuja mínima publicidade constrange. Já a vida privada envolve proteção de formas exclusivas de convivência. Trata-se de situações em que a comunicação é inevitável (em termos de relação de alguém com alguém que, entre si, trocam mensagens), das quais, em princípio, são excluídos terceiros. [...] A vida privada pode envolver, pois, situações de opção pessoal (como a escolha do regime de bens no casamento) mas que, em certos momentos, podem requerer a comunicação a terceiros (na aquisição, por exemplo, de um bem imóvel). Por aí ela difere da 
intimidade, que não experimenta esta forma de repercussão. [...]. (1992, p. 78-9, destaque do autor $)^{545}$.

J. Silva entende, primeiramente, que os direitos arrolados no inciso $\mathrm{X}$ do artigo $5^{\circ}$ da Constituição Federal são direitos conexos ao da vida, figurando no "caput" desse artigo como reflexo ou manifestação sua (2005, p. 206, 2007, p. 100).

Ele, afirmando que a terminologia não é precisa, prefere usar a expressão "direito à privacidade" para abarcar todas as manifestações "da esfera íntima, privada e da personalidade", conceituando-o, citando J. Matos Pereira, como "o conjunto de informação acerca do indivíduo que ele pode decidir manter sob seu exclusivo controle, ou comunicar, decidindo a quem, quando, onde e em que condições, sem a isso poder ser legalmente sujeito" (2005, p. 206, 2007, p. 100). Entende que a intimidade abrange a esfera secreta da vida do indivíduo, na qual detém o poder de exclusão de terceiros, enquanto vida privada seria, citando Eduardo Novoa Monreal, o conjunto de modo de ser e viver, o direito do indivíduo viver sua própria vida, sendo que a Constituição protegeria as pessoas de dois "atentados": ao segredo da vida privada e à liberdade da vida privada (2005, p. 207-8, 2007, p. 101).

Alguns Ministros do STF e do STJ, julgando questões relacionadas à matéria, esboçaram conceitos e contornos da privacidade e seus desdobramentos.

No Mandado de Segurança 21729-4/DF ${ }^{546}$, julgado pelo STF, o Ministro Maurício Corrêa entendeu que no direito à privacidade estão contidos desdobramentos, como, no caso, o direito ao sigilo bancário e ao fiscal. Segundo ele,

\begin{abstract}
[u]ma das conseqüências do entendimento de que o direito ao sigilo bancário pertence à categoria maior do direito à privacidade é que, destinado a proteger o indivíduo, não protege operações bancárias praticadas em contas fictícias - que não têm privacidade a ser juridicamente protegida - nem pode ser invocado para acobertar crimes ou outros ilícitos, sejam administrativos ou civis. Em suma, este direito tutela, apenas, as operações lícitas. Além disso [e essa é uma parte importante], deve ser considerado que o direito à privacidade é um direito individual que pode ser oposto "erga omnes" e com mais ênfase ao Estado, mas ele, por outro lado, tem por limite interesses maiores - de natureza política - que dizem respeito ao interesse público. Quando dois direitos ungidos em leis da mesma hierarquia entram em conflito, a prevalência de um sobre o outro é decidida segundo uma escala axiológica; mas este padrão de valores não é fornecido pela Constituição, cabendo ao intérprete da lei, orientado pelas regras
\end{abstract}

545 “[...] pode-se perceber que o âmbito da privacidade (o objeto do direito subjetivo, cujo conteúdo é a faculdade de excluir terceiros) tem a ver com aquilo que é nuclear para a auto-consistência moral da pessoa, que lhe confere um lugar na convivência e que não pode ser aberto por qualquer um, salvo por sua iniciativa ou pela iniciativa conjunta dos participantes, e em relação ao que se garante a faculdade de resistir (de excluir) a indevida intromissão de outros. Esse âmbito, cuja existência formal pode ser reconhecida como um universal humano e que conhece variações ditadas pelo tempo, pelo lugar, pelos costumes etc., resume-se no conceito de liberdade" (FERRAZ JUNIOR, 2001, p. 19, 2004, p. 497).

${ }^{546}$ Ver Apêndice A, número 12, desta dissertação. 
de hermenêutica e de exegese e levando em conta o estágio sócio-cultural contemporâneo aos fatos, dizer sobre esta prevalência. Hoje, é aceito pela quase unanimidade que o interesse público prevalece sobre o particular. Esta Corte, em inúmeros julgados, vem dizendo reiteradamente que o direito ao sigilo bancário é um direito limitado, não absoluto, e que pode ceder a interesses públicos em determinadas e restritas situações, sempre orientadas para a busca da verdade no interesse da justiça, seja em causas de natureza penal, administrativa ou civil.

O Ministro Celso de Mello lecionou, a seu turno, que a intimidade é

[...] valor constitucionalmente assegurado [...], cuja proteção normativa busca erigir e reservar, "sempre em favor do indivíduo" - e contra a ação expansiva do arbítrio do Poder Público - uma esfera de autonomia intangível e indevassável pela atividade desenvolvida pelo aparelho do Estado. [...] $\mathrm{O}$ direito à inviolabilidade dessa franquia individual [...] ostenta, no entanto, caráter meramente relativo. Não assume e nem se reveste de natureza absoluta. Cede, por isso mesmo, "e sempre em caráter excepcional", às exigências impostas pela "preponderância" axiológica e jurídico-social do interesse público.

\author{
No Recurso Extraordinário 418416/SC, Relator Ministro Sepúlveda Pertence ${ }^{547}$, o \\ Ministro Carlos Ayres Britto tentou traçar uma distinção entre "vida privada" e \\ "intimidade":
}

[...] a Constituição não confunde privacidade ["rectius": vida privada] com intimidade. Tanto que usa de duas palavras diferentes, ligando uma à outra pela conjunção aditiva "e". Privacidade, para mim, é uma comunicação reservada entre pessoas, digamos, em "en petit comité". É a pessoa se relacionando com os seus amigos, com seus parentes. Ao passo que intimidade é a pessoa consigo mesma, sozinha. Exemplo: alguém escrevendo um diário - está no uso de sua intimidade. [...] Ao passo que uma comunicação por "e-mail” já é privacidade; uma carta já é privacidade. Porém, um diário, não; é absolutamente intimidade. Quando a pessoa está consigo mesma, é intimidade; quando está com os seus amigos, parentes -, aí se dá a privacidade. Agora, tanto a intimidade como a privacidade têm o seu "locus", o seu "habitat" na casa em que se mora ou em que se trabalha. Vejam como os três incisos se entrelaçam [os incisos X, XI e XII, do art. $5^{\circ}$ da Constituição Federal] [...].

No Agravo Regimental no Inquérito 2206/DF, Relator Ministro Marco Aurélio ${ }^{548}$, a

Ministra Cármen Lúcia tece a seguinte distinção:

[...] [o]s segredos do ser são absolutos - aquilo que digo em um confessionário, o que digo ao médico -; os segredos do ter [em referência ao sigilo bancário, que considera, por sua vez, desdobramento do direito à privacidade] não o são [...].

\title{
A Ministra desenvolveu mais esse raciocínio no Recurso Extraordinário 461366/DF, Relator Ministro Marco Aurélio ${ }^{549}$ :
}

Já deixei expresso, aqui, que distingo, no inc. $\mathrm{X}$ do art. $5^{\circ}$, para os efeitos do

\footnotetext{
${ }^{547}$ Ver Apêndice A, número 12, desta dissertação.

${ }^{548}$ Ver Apêndice A, número 12, desta dissertação.

${ }^{549}$ Ver Apêndice A, número 12, desta dissertação.
} 
sigilo bancário e fiscal, o que os portugueses distinguiam entre segredos do "ser" e segredos do "ter". Segredos do "ser" são, sim, absolutos na Constituição. O que você é, pensa e sente são segredos absolutos resguardados na Constituição, porque dizem respeito à vida e à dignidade de cada um. Isso já foi até trazido ao Supremo, por exemplo, em casos de doenças, a pessoa é obrigada, para um emprego, a fazer um exame e o resultado é dado a público ou vaza de uma empresa para outra. Isso é absoluto, porque a pessoa pode querer ou não divulgar a sua condição.

Segredo do "ter" é algo que veio a surgir no Estado Moderno, com a exacerbação do individualismo. Em Portugal, herdamos, ainda, até o início do século passado, o que era chamado romanticamente de "bens ao luar": todo aquele que fosse exercer um cargo público teria que mostrar os seus bens, porque aquilo era o que se punha às claras para se saber quem iria para os cargos públicos. Nesse trabalho, analisei como, antes, tudo tinha que ser mais claro; e, hoje, brigamos pela transparência.

[...] Acho que esses segredos do "ter" são relativos. [... $]^{550}$.

Em outra passagem do mesmo voto, após afirmar haver distinção acadêmica entre privacidade e intimidade, mas sem conceituar esta, diz a Ministra que “[...] privacidade é não tornar público. [...] o contrário de privacidade é publicidade".

O Superior Tribunal de Justiça, no Recurso Especial 440150/RJ ${ }^{551}$, o Relator Ministro Francisco Peçanha Martins escreve que

[o] conceito de intimidade refere-se aos fatos e manifestações verificados na esfera mais restrita dos relacionamentos estabelecidos pela pessoa. São as relações firmadas com a família e com amigos mais íntimos. Outrossim, em se tratando do conceito de vida privada, tem-se o alargamento dessas vinculações. Ela diz respeito aos relacionamentos no âmbito profissional, do ensino regular, acadêmico, comercial, religioso, dentre outros, porém limitados pela proximidade e confiança. [...] Imiscuir-se nessas relações, sem a devida autorização, consiste em violar direito de privacidade, garantia fundamental, inclusive. [...].

\footnotetext{
${ }^{550}$ Desenvolvendo raciocínio nesse sentido, em Portugal, há Canotilho e Moreira (2007, pp. 468-469): “A teleologia intrínseca dos direitos de personalidade justifica fundamentalmente o 'direito ao segredo do ser' (direito à imagem, direito à voz, direito à intimidade da vida privada, direito a praticar actividades fora da esfera íntima sem videovigilância). É problemática a inclusão nestes direito de personalidade do pretenso 'direito ao segredo do ter' ('segredo bancário', 'segredo dos recursos financeiros e patrimoniais', 'segredo de aplicações do dinheiro', sigilo fiscal). Além de não haver qualquer princípio ou regra constitucional a dar guarida normativa a um 'segredo do ter' (o que obriga alguns autores a recorrerem forçada e esforçadamente a 'direitos fundamentais implícitos'), sempre haverá que ter em conta a necessidade da concordância prática com outros interesses (ex.: combate à criminalidade organizada, combate à corrupção e tráfico de influências, combate à fraude fiscal, combate ao branqueamento de capitais, combate ao financiamento do terrorismo, etc.). Note-se que mesmo a aceitar-se algumas refracções do 'segredo do ter' como dimensões dos direitos de personalidade, elas terão sempre maiores restrições do que o 'segredo do ser', desde logo para efeitos de benefícios e subvenções públicas. Quem se candidata a benefícios ou fundos públicos aceita implicitamente limitações nos 'direitos de personalidade patrimoniais'. Relevo autónomo pode adquirir o conceito de segredo no sentido de valor pessoal estritamente ligado à privacidade (segredo de confissão, segredo médico, segredo testamentário) e que tem como principais destinatários todos aqueles que em razão do seu estatuto, ofício, emprego, profissão ou arte têm o dever de não revelar segredos alheios (cfr. Cód. Penal, art. 195). A conexão do segredo com deveres de sigilo profissional aponta também para a dimensão objectiva do segredo (bem jurídico supra-individual)" (destaques dos autores).

${ }^{551}$ Ver Apêndice B, número 2, desta dissertação.
} 
No Recurso Ordinário em Mandado de Segurança 5352/GO ${ }^{552}$, o Relator Ministro Luiz Vicente Cernicchiaro afirma que

[...] intimidade, juridicamente, é o direito que alguém tem de não ser perturbado pela sociedade. É o direito da pessoa ausentar-se do ciclo social, de viver como indivíduo e não como "socius". E a intimidade diz respeito a uma pessoa ou, eventualmente, a pluralidade de agentes. [...].

O trato da questão da privacidade, entretanto, não se resume a esses excertos de votos, a tentativas de conceituação ou definição, mas abarca uma série de casos que nos ajudam a vislumbrar melhor o que é esse instituto jurídico, embora a maioria não trate dele frontalmente. São julgados que cuidam de garantias e desdobramentos da "privacidade", como se vê nos Apêndices A e B.

O conceito de privacidade não é universal, isto é, não é válido para todos os sistemas jurídicos, pois cada qual se desenvolve segundo necessidades e peculiaridades histórico-culturais ${ }^{553}$.

Por exemplo, nos Estados Unidos da América, o conceito de "privacy" desenvolveu-se a partir da proteção trazida pela Constituição Federal à casa do indivíduo e seus documentos. A "privacy" foi construída doutrinária e, principalmente,

\footnotetext{
${ }^{552}$ Ver Apêndice B, número 5, desta dissertação.

553 Moutouh e Rivero (2003b), por exemplo, colocam, na França, o direito à vida privada dentro das "liberdades da pessoa física", mas à parte do direito de dispor sobre o próprio corpo, inclusive o de interromper a gravidez, o que integraria, nos Estados Unidos da América, o "right of privacy". Os autores ainda conceituam vida privada ("vie privée") como o reconhecimento, em proveito de cada um, de uma zona de atividade que lhe é própria, que pode ser vedada a outros. Colliard e Letteron (2005, p. 359) afirmam que é um direito em constante evolução e alargamento, principalmente em virtude de crescentes meios de vulneração, especialmente pelas tecnologias modernas, notadamente as telecomunicações e a informática. Para Canotilho e Moreira (2007, p. 467), “[o] direito à reserva da intimidade da vida privada $\left(\mathrm{n}^{\mathrm{o}} 1\right.$, in fine, e $\mathrm{n}^{\circ} 2$ [do artigo 26 da Constituição de Portugal]) analisa-se principalmente em dois direitos menores: $(a)$ o direito a impedir o acesso de estranhos a informações sobre a vida privada e familiar e $(b)$ o direito a que ninguém divulgue as informações que tenha sobre a vida privada e familiar de outrem (cfr. Ccivil, art. $80^{\circ}$ ). Alguns outros direitos funcionam como garantias deste: é o caso do direito à inviolabilidade do domicílio e da correspondência (art. 34\% ), da proibição do tratamento informático de dados referentes à vida privada (art. $35^{\circ}$-3). Instrumentos jurídicos privilegiados de garantia deste direito são igualmente o sigilo profissional e o dever de reserva das cartas confidenciais e demais papéis pessoais (cfg. Ccivil, arts. $75^{\circ}$ a $78^{\circ}$ ). Aliás, a Constituição incumbe a lei de garantir efectiva protecção a esse direito ( $\left.n^{\circ} 2\right)$, compreendendo-se essa preocupação suplementar face aos sofisticados meios que a técnica hodierna põe à disposição da devassa da vida privada e da colheita de dados sobre ela (cfr. AcsTC no 255/02 e 207/03)" (destaques dos autores). Já Jabur, no Brasil, afirma que "[é] incontroverso que a vida privada, diante da sua infinita capacidade de manifestação, não pode ser apreendida. Não apresenta ela uma definição estática. Verifica-se, ao revés, de acordo com ambiência, a evolução dos homens e de seus costumes. É, pois, mais do que razoável que se atribua proteção adequada ao isolamento sagrado de cada ser humano. O direito à vida privada é um agregado do qual também depende a manifestação livre e eficaz da personalidade, porque o bem-estar psíquico do indivíduo, consubstanciado no respeito à sua esfera íntima, constitui inegável alimento para o desenvolvimento sadio de suas virtudes. O resguardo dessa zona reservada, a subtração da curiosidade, é razão para o bem-viver e progresso da pessoa. Por isso é que o direito à vida privada, corolário de outro valor, supremo que é - a dignidade da pessoa humana -, deve renovar a preocupação sociojurídica em conter as ameaças e lesões que diariamente sofre. [...]" (2000, p. 254).
} 
jurisprudencialmente, evoluindo para uma idéia ampla de liberdade de autodeterminação, negativa e ativa, que pode, no entanto, ser restringida pelo legislador ordinário conforme regras tidas como razoáveis e condizentes com outros objetivos de interesse social ou estatal.

Assim também é que, em Portugal, a Constituição de 1976, com várias alterações, destaca em direitos autônomos o que seriam, nos Estados Unidos da América, aspectos do amplo "right of privacy", como a garantia contra a obtenção ou utilização abusiva de informações pessoais ou familiares e a proteção de dados pessoais.

Não significa dizer que em Portugal os direitos encontram melhor guarida, ou viceversa: às vezes menos direitos considerados essenciais podem permitir um melhor foco para proteção, enquanto, outras vezes, uma redação ampla pode permitir uma melhor guarida por atribuir dinamicidade (adaptabilidade) ao direito.

Observa-se, além disso, que o que parece ser prático, muitas vezes, é falho, como o teste de expectativa razoável de "privacy” dos Estados Unidos da América.

As expressões variam também de acordo com os países, e mesmo dentro deles, não podendo ser diretamente comparados os sistemas nacionais sem se observar o comportamento dos tribunais e o pensamento dos juristas, como vimos.

No Brasil, o direito positivo remete à "privacidade", "intimidade" e "vida privada" ${ }^{\text {"554, }}$, sem um tratamento sistemático de nomenclatura e regulação.

Entendemos, a despeito de doutrina respeitável, que a Constituição Federal, em seu artigo $5^{\circ}$, inciso X, ao enumerar "intimidade" e "vida privada", apenas reforça a proteção à privacidade usando de dois dos nomes que lhe são atribuídos.

No cotidiano, "privacidade" e "intimidade" são palavras que podem ser usadas indistintamente no sentido de algo reservado ou restrito a um ou alguns. Remete a sigilo e a segredo, a exclusão de terceiros não eleitos por aquele dentro de sua vida, de sua vivência, no geral ou em dado evento.

As palavras "privado" e "íntimo", adjetivos, conferem àquilo que qualificam, talvez por metonímia, o caráter de exclusividade, de exclusão da percepção de terceiros. O objeto "privado" ou "íntimo" é, normalmente, de acesso proibido ou restrito, como ocorre com a vida "privada".

Se alguém responde a outrem "isto é privado" ou "íntimo", logo se compreende que

\footnotetext{
${ }^{554}$ Mendes, por exemplo, após arrolar os mais variados nomes pelos quais tal direito é conhecido no Brasil e em outros países, parece indistintamente adotar as expressões "direito à intimidade", privacidade e "reserva da vida privada e da intimidade", dentre outras (1999, pp. 40-46; 66). Sobre a diversidade de termos, vide ainda Doneda (2006), que, particularmente, adota o termo "privacidade", e Szaniawski (1990).
} 
essa pessoa não deseja compartilhar algo que se refere a si.

Costuma-se usar "vida privada" para se referir à convivência familiar, com pais, irmãos e outros parentes, e também com outros com quem se partilha uma relação de confiança, como os amigos, enquanto "intimidade" dá a idéia de um círculo muito mais restrito, ou ainda como algo ligado ao corpo.

"Privacidade" e "intimidade", e suas formas adjetivas, costumam também ser utilizadas para se referir a tudo aquilo que se passa na mente de uma pessoa, suas idéias, seus sentimentos e opiniões sobre si e outros, enfim, seus pensamentos, sua "vida" interior, enquanto normalmente à expressão "vida privada" liga-se a idéia de relacionamento do indivíduo com outros, a vida "exterior".

Esse "relacionamento" não significa exatamente, ou apenas, contato direto com outros seres, mas o seu posicionamento e comportamento em sociedade, às vistas atuais ou potenciais de outros, aquilo que pode ser percebido ou captado externamente.

Algumas vezes, portanto, há superposições, pois, por exemplo, uma relação amorosa é considerada geralmente "íntima", mas pode ser dita como da "vida privada" de ambos.

Enfim, "privacidade", "intimidade" e "vida privada" fazem parte daquele grupo de palavras ou expressões que trazem um sentido comum para os indivíduos, mas que se tem dificuldade de definir ou conceituar, inclusive no campo jurídico, atingindo o direito positivo.

Considerar "intimidade" como algo concernente ao indivíduo sozinho, com ele mesmo, de nada vale, pois o que se passa na mente de uma pessoa, por si só, é juridicamente irrelevante. Somente a partir do momento em que surge uma participação atual ou potencial de outros é que adquire importância nesse sentido. Ocorre que, havendo exteriorização, adentrar-se-ia a "vida privada", considerada como a existência relacional do indivíduo, ele em relação a outros ${ }^{555}$.

Para não tornar sem valor a palavra "intimidade" do inciso X do artigo $5^{\circ}$ da Constituição, outra opção seria considerá-la como abrangente dos poderes "negativos" da pessoa (não fazer), e "vida privada", dos poderes positivos (agir).

555 Apesar disso, há quem faça essa distinção, como, por exemplo, Ceneviva (2005, p. 295): “[...] Considerando que a Constituição não tem palavras inúteis, resulta que intimidade é a qualidade dos fatos e dos atos ou da omissão de qualquer deles, que o ser humano adota ou pratica para com ele mesmo, segundo seus valores pessoais, independentemente de seu relacionamento com terceiros. [...] A vida privada distingue-se da intimidade porque se refere às relações excludentes da proximidade de estranhos, cujo conhecimento não deseja. Corresponde a conduta ativa, exteriorizável, mas a distância daqueles que a pessoa não quer que interfiram em sua existência diária. [...]" (destaques do autor). Também distinguindo, I. Ferreira (1994). 
Entretanto, tal distinção não tem suporte na própria legislação vigente, como se vê no novo Código Civil, que, ao tratar dos "direitos da personalidade" e, mais especificamente, da "vida privada", "inviolável”, dispõe que “[...] o juiz, a requerimento do interessado, adotará as providências necessárias para impedir ou fazer cessar ato contrário a esta norma" 556 . Ou seja, além de não nomear a "intimidade", atribui poderes preventivos e repressivos, indistintamente, para proteger a inviolabilidade da "vida privada" 557.

Além disso, como os textos legais brasileiros valem-se de "intimidade" e "vida privada" indistintamente, essa diferenciação entre um direito de não fazer e de agir levaria a entendimentos absurdos ${ }^{558}$ : (i) nos processos judiciais, estaria resguardado somente o direito de o indivíduo não exteriorizar pensamentos ou aspectos que guarda para $\mathrm{si}^{559}$; (ii) o Código Civil e a Lei de Imprensa só protegeriam a vida relacional; e (iii) nas comunicações regidas pela Lei 9.472/1997, protege-se ora um, ora outro, e ora ambos ou nenhum, pois usa as três palavras, sendo que, lembre-se, "privacidade" não está escrita no texto constitucional ${ }^{560}$.

\footnotetext{
${ }^{556}$ Artigo 21.

${ }^{557}$ Essa não é uma posição compartilhada por todos. Sampaio (1998), embora apresente um conceito de "vida privada" semelhante ao nosso de "privacidade", entende que "[a] intimidade integra a vida privada [...]; cuida-se de sua projeção no âmbito das informações pessoais, do relacionamento comunicativo do ser com os demais, enfim, de uma 'autodeterminação informativa' ou 'informacional'” (p. 351), que envolve o controle das informações emitidas e recebidas (p. 364).

${ }^{558}$ Outra situação em que a aplicação exacerbada do critério interpretativo traduzido no aforismo de que "a lei não contém palavras inúteis" resultaria numa aberração é a do "trabalho penoso" para os menores de dezoito anos: a Constituição Federal proíbe-lhes, enumeradamente, somente o trabalho noturno, perigo ou insalubre (artigo $7^{\circ}$, inciso XXXIII), mas determina a implantação do adicional de remuneração para as atividades penosas, insalubres ou perigosas (artigo $7^{\circ}$, inciso XXIII), além da remuneração do trabalho noturno superior ao do diurno (artigo $7^{\circ}$, inciso IX). Então podem os menores de dezoito anos exercerem trabalhos penosos?

${ }_{559}^{550}$ Artigos 5, inciso LX, e 93, inciso IX, da Constituição Federal.

560 Doneda anota a respeito das expressões "intimidade" e "vida privada" do artigo $5^{\circ}$, inciso X, da Constituição Federal (2006, p. 109-111): “[...] consideramos que não é frutífero insistir em uma conceitualística que intensifique as conotações e diferenças semânticas dos dois termos. Cada um deles possui um campo semântico próprio: na 'vida privada' encontramos o discurso que proclama a distinção entre as coisas da vida pública e as da vida privada, no estabelecimento de limites, numa lógica que também é de exclusão. Não por acaso, ela manifesta ainda os termos em que estas noções se afiguram em sociedades antigas, como a romana, com o risco de induzir a um pensamento moldado em torno de uma dicotomia entre público e privado; entre interesses públicos e privados, indicativo de uma escolha ideológica que arrisca afastar a idéia de um ordenamento jurídico unitário e ordenado em torno de uma tábua axiológica comum. $\mathrm{O}$ outro termo utilizado pelo constituinte, 'intimidade', aparenta referir-se a eventos mais particulares e pessoais, a uma atmosfera de confiança. Evoca, mais do que outra coisa, o aspecto do direito à tranqüilidade, do 'right to be let alone'. Avaliar tal amplitude com a consistência necessária ao discurso e à prática jurídica moderna, porém, não nos parece possível a partir da distinção lingüística, senão por meio de artifícios retóricos. Ainda, o próprio vocábulo em si apresenta uma forte conotação emotiva que dificulta sua objetivação [...] A verdadeira questão que a terminologia constitucional nos apresenta é: se foram utilizados dois termos diversos, estaríamos diante de duas hipóteses diversas que devem ser valoradas de formas diferentes? Responderemos que não, pelos seguintes motivos: (i) a ausência de uma clara determinação terminológica na doutrina e na jurisprudência, além do fato de ser a primeira vez que o tema ganha assento constitucional, podem ter sugerido ao legislador optar pelo excesso, até pelo temor de reduzir a aplicabilidade da norma; (ii) a discussão dogmática sobre os limites entre ambos os conceitos, visto o alto grau de
} 
Desse modo, preferimos considerar as expressões "intimidade" e "vida privada" sinônimas ${ }^{561}$, usando-as indiferentemente para designar a privacidade, um direito de liberdade $^{562}$. Mas uma liberdade qualificada: é o direito de ampla autodeterminação do indivíduo, com os poderes que daí advêm, sejam de agir, não agir ou resistir ${ }^{563}$. É uma liberdade de ser, estar, ir e vir "como quiser" ${ }^{564}$, que pode ser limitada por outros interesses

subjetividade que encerra, desviaria o foco do problema principal, que é a aplicação do direito fundamental da pessoa humana em questão, em sua emanação constitucional [...]".

${ }^{561}$ Carvalho, após citar algumas correntes que postulam uma diferença entre direito à intimidade e direito à privacidade, afirma que "se não se conseguiu discernir claramente um do outro, depois de tantas tentativas, melhor considerá-los uma mesma coisa" (1998, p. 52).

${ }^{562}$ Sobre a liberdade no campo jurídico, veja-se raciocínio que Jabur desenvolve a respeito (2000, p.139147).

${ }^{563}$ Nosso conceito assemelha-se ao expresso, por exemplo, nas Resoluções 428/1970 e 1165/1998 da Assembléia Parlamentar do Conselho da Europa e ao desenvolvido pela jurisprudência da Corte Européia de Direitos Humanos, podendo-se citar, dentre outros, os casos NIEMIETZ v. GERMANY, de 1992, e PERRY v. THE UNITED KINGDOM, de 2003. Lembra também o conteúdo da privacidade enquanto direito explanado por Ferraz Junior (1992, p. 77). Desenvolvendo raciocínio parecido nesse sentido, tem-se ainda Crisafulli e Paladin (1990), especialmente na p. 93, onde consta que "[a] esfera privada como um todo seria, ao contrário, reconhecida e garantida não nesta ou naquela disposição, mas, sim, em um conjunto de disposições referentes mais propriamente aos direitos de liberdade pessoal" (tradução nossa). No original:" [1] a sfera privata nel suo complesso verrebbe invece riconosciuta e garantita non in questa o quella disposizione, bensì in un insieme di disposizioni attinenti più propriamente ai diritti di libertà personale".

${ }^{564}$ Entendemos a privacidade como um regime jurídico de um direito de liberdade do qual derivam várias faculdades e garantias. A privacidade é uma liberdade diferente da liberdade de locomoção, posto que não é apenas uma liberdade de ir, vir ou ficar; é diferente da liberdade de expressão, que é uma liberdade positiva de manifestar pensamento; e é mais ampla do que o direito ao silêncio assegurado ao réu em processo penal (que poderia ser considerado uma especificidade da privacidade). A liberdade religiosa é, certamente, uma ramificação do direito à privacidade, do ponto de vista do indivíduo que segue a crença e, eventualmente, freqüenta certo local de culto, e da liberdade de manifestação do pensamento, do ponto de vista do propagador ou orador de tal crença. Mas, por razões histórico-sociais, acabou por se consolidar no texto constitucional explícita e autonomamente. Do mesmo modo, a liberdade de manifestação do pensamento seria o outro lado da moeda de um aspecto do direito à privacidade, e, mais ainda, dependendo dos destinatários de tal pensamento transmitido, estar-se-ia adentrando o campo da própria privacidade. Vê-se, assim, que os direitos não são necessariamente estanques, podendo existir pontos de contato ou de superposição, já que diferentes aspectos da privacidade podem ser autonomizados conforme a conveniência ou o interesse do legislador. Colliard e Letteron (2005, p. 360) entendem que "[...] a liberdade da vida privada pode ser definida por dois círculos concêntricos [...]: - o núcleo duro é constituído pelo direito de ser deixado em paz [...]. Ele confere a seu titular o direito de se opôr a toda intrusão à esfera de sua vida privada. É um direito de resistência consagrado, dentro do qual o sistema jurídico define um certo número de espaços particularmente protegidos, seja porque são abrigos da vida privada (o domicílio), seja porque neles estejam a expressão mais evidente (segredo das correspondências). - Além deste espaço protegido, aparece igualmente um direito à autonomia da vida privada, que contém o direito de ser deixado em paz, mas que a ele não se reduz. Ele implica a livre escolha de sua vida privada, o direito de ser diferente, ou mesmo de ser imprevisível e de levar sua vida privada como entende, ao abrigo do julgamento de outros. Não se trata mais somente de reconhecer um direito de resistência contra as intrusões, mas também de consagrar um direito de exigência" (tradução e destaque nossos). Por sua vez, discorre I. Ferreira: "[e]mbora essa liberdade [de desfrutar de uma esfera reservada da vida privada], que permite ao indivíduo a segurança e a tranquiilidade de viver a sua vida com um mínimo de ingerência alheia, de permanecer resguardado da curiosidade dos olhares e dos ouvidos, encontre a sua referência física e a sua localização adequada no ambiente domiciliar e nos recantos privados, esses limites da antiga doutrina foram ultrapassados, como assinala René Ariel Dotti, reconhecendo-se possa ela ser fruída em qualquer ambiente ou situação. [...] Em consequiência, essa liberdade não implica necessariamente num [sic] isolamento, mas numa conduta de resguardo das interferências alheias, de não ser o indivíduo importunado pela curiosidade ou pela indiscrição, de poder desfrutar a sua paz de espírito e ver respeitados os atributos de sua personalidade, frente aos outros indivíduos ou ao Estado. Numa evolução paulatina, esse direito tem assumido novas formas e mais recentemente, como observa 
ou direitos específicos relevantes, dependendo do caso concreto.

Restrição que pode ser lembrada é a concernente ao silêncio do indivíduo: o ordenamento jurídico compele-o, em algumas situações, a falar, cominando-lhe sanções, como a do artigo 342 do Código Penal, que traz o crime de "falso testemunho ou falsa perícia", cuja pena, pelo "caput", é de reclusão, de um a três anos, e multa, com a seguinte redação: "[f]azer afirmação falsa, ou negar ou calar a verdade como testemunha, perito, contador, tradutor ou intérprete em processo judicial, ou administrativo, inquérito policial, ou em juízo arbitral" (destaque nosso). O intuito de forçar a expressão (da verdade) é reforçado pelo parágrafo $2^{\circ}$ desse artigo, segundo o qual “[o] fato deixa de ser punível se, antes da sentença no processo em que ocorreu o ilícito, o agente se retrata ou declara a verdade ${ }^{, 565}$

Outra restrição: o indivíduo pode escolher quem quiser como parceiro amoroso e sexual, mas a legislação estabelece limites quanto à idade ${ }^{566}$, quanto aos meios ${ }^{567}$ e quanto aos locais ${ }^{568}$. O direito comparado mostra-nos, inclusive, que em alguns locais há, ou houve, restrições quanto ao gênero do parceiro, vedando, ou até criminalizando, relacionamentos entre indivíduos do mesmo sexo, além de leis que vedavam, ou estabeleciam, certas formas de conjunção carnal.

Claro que esses limites também têm limites, como a proibição geral da prática da tortura $^{569}$, que, caso contrário, poderia vir a ser usada para obter informações das testemunhas ou confissões dos investigados ou acusados.

A privacidade é um direito que acompanha o indivíduo, embora possa ter projeções no mundo físico exterior: uma casa, a edificação, não é garantida contra invasões em virtude de "privacidade", conquanto possa ser protegida por outras razões, como pelo direito de propriedade. $\mathrm{O}$ direito à privacidade só surge quando e enquanto a edificação é habitada por alguém, sendo uma extensão da sua personalidade, a que se confere o "status"

Colliard em sua obra 'Libertés publiques', apareceu como uma espécie de consagração da democracia liberal, configurando um direito do indivíduo em face do Estado ou da Administração Pública: o direito à informação - não mais um direito de defesa mas sim um direito a uma prestação positiva do Estado, de quem o indivíduo pode obter informação e explicações sobre dados pessoais constantes de registros públicos, podendo até mesmo retificá-los. [...]” (1994, p. 96-97). Mais a respeito em Pitombo (1999).

565 Aliás, o direito de "permanecer calado" garantido ao preso, por força do inciso LXIII do artigo $5^{\circ}$ da Constituição Federal, se exercido, embora não importe confissão, pode constituir elemento para a formação do convencimento do juiz, como as demais provas, que devem ser levadas em consideração no julgamento Ver, por exemplo, artigos 198 e 197 do Código de Processo Penal.

${ }^{566}$ Coibindo a pedofilia, por exemplo, através do artigo 224, alínea “a”, do Código Penal.

${ }^{567}$ Coibindo a conjunção carnal ou prática de atos libidinosos mediante violência ou grave ameaça, conforme artigos 213 e 214 do Código Penal.

568 Artigo 233 do Código Penal.

${ }^{569}$ Artigo $5^{\circ}$, incisos III e XLIII, da Constituição Federal, e artigo $1^{\circ}$, inciso I, alínea "a", da Lei 9.455, de 7 de abril de 1997. 
de "asilo",570.

Algo semelhante dá-se quando duas ou mais pessoas travam uma conversa telefônica: a proteção não recai sobre os aparelhos de telefone, ou sobre as linhas telefônicas, mas à comunicação travada entre indivíduos, que gozam de um direito de privacidade, e nessa medida.

Um caderno em branco que tenha escrito em sua capa "diário" não se torna imediatamente objeto de proteção da privacidade, ao passo que um guardanapo que contenha a transcrição de pensamentos pessoais, sim. Ou seja, o lugar ou o objeto não são inerentemente "privados" ou "reservados", mas somente no quanto e enquanto se refira ou remeta a um indivíduo.

Por outro lado, o lugar ou o objeto influenciam o grau de reserva que se pode esperar. Um diário guardado dentro da gaveta tem, certamente, maior nível de proteção do que um publicado em "site" aberto ao público em geral na Internet, como os "blogs". Um estádio de futebol tem menor grau de reserva do que uma festa fechada que ocorre na casa de um indivíduo.

Entretanto, se um diário ${ }^{571}$ for acidentalmente esquecido em um auditório, não se torna de domínio público pelo fato de o local ser aberto ao público; e uma festa de que

570 Artigo 5', inciso XI, da Constituição Federal. "Casa", no texto constitucional, tem sentido amplo, abrangendo, com o apoio da jurisprudência do STF, as hipóteses do artigo 150 , parágrafo $4^{\circ}$, do Código Penal: (i) qualquer compartimento habitado; (ii) aposento ocupado de habitação coletiva; e (iii) compartimento não aberto ao público, onde alguém exerce profissão ou atividade. Ver, dentre outros, o Recurso em Habeas Corpus 90376/RJ, Relator Ministro Celso de Mello, julgado pela Segunda Turma em 3 de abril de 2007, decisão publicada no Diário de Justiça eletrônico 18, divulgado em 17 de maio de 2007 e publicado em 18 de maio do mesmo ano. No mesmo sentido, em Portugal, Miranda e Medeiros (2005) e Canotilho e Moreira (2007).

571 “A obtenção de provas para prossecução da justiça penal através de processo judicial encontra limites constitucionais expressos na vida privada, não sendo permitidas buscas ao domicílio ou ingerências na correspondência, nas telecomunicação [sic] e demais meios de comunicação que se traduzam numa abusiva intromissão na vida privada (artigo $32^{\circ}, \mathrm{n}^{\circ} 8$ [da Constituição de Portugal]). A questão com maior relevo prático é talvez a dos pressupostos e limites das escutas telefónicas. Mas outras questões se colocam. Num caso recente, discutiu-se a admissibilidade de valoração em processo penal de um diário pessoal: apesar de estar em causa a investigação de um crime de abuso sexual de menores, o Tribunal Constitucional considerou que não era admissível a valoração probatória do diário pessoal, pois se estava no âmbito do conteúdo essencial da intimidade da vida privada (Acórdão $n^{0}$ 607/03)" (MIRANDA; MEDEIROS, 2005, p. 291, destaques dos autores). Para Canotilho e Moreira (2007, p. 524), “[o]s interesses do processo criminal encontram limites na dignidade humana (art. $1^{\circ}$ [da Constituição de Portugal]) e nos princípios fundamentais do Estado de direito democrático (art. $2^{\circ}$ ), não podendo, portanto, valer-se de actos que ofendam direitos fundamentais básicos. Daí a nulidade das provas obtidas sob tortura ou coacção (nulidade e não mera irregularidade. Cfr. AcTC n ${ }^{\circ}$ 528/03), obtidas com ofensa da integridade pessoal, da reserva da intimidade da

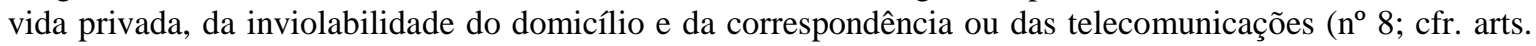
$25^{\circ}-1$ e $34^{\circ}$ ), não podendo tais elementos ser valorizados no processo. A interdição é absoluta no caso do direito à integridade pessoal (cfr. AcTC no 616/98); e, relativa, nos restantes casos, devendo ter-se por abusiva a intromissão quando efectuada fora dos casos previstos na lei e sem intervenção judicial (art. $34^{\circ}-2$ e 4), quando desnecessária ou despropositada ou quando aniquiladora dos próprios direitos (cfr. art. 18º -2 e 3 )" (destaques dos autores). 
participem cem pessoas convidadas, embora ocorra num quarto ou salão de hotel, certamente pode ser considerada restrita.

Os casos devem ser analisados à luz do lugar e da época em questão, sendo, no mínimo, temerário pretender elaborar uma lista de situações que estejam ou não, necessariamente, sob o pálio da privacidade ${ }^{572}$.

Enfim, dessa liberdade de autodeterminação, consistente na privacidade, emanam direitos de "controle", inclusive sobre as conversas e as informações relativas à pessoa.

A rigor, então, o direito à honra e à imagem seriam projeções de alguns aspectos da privacidade ${ }^{573}$, posto que a primeira refere-se a um certo "controle" sobre o sentimento dos outros e de si mesmo pelo indivíduo titular do direito, enquanto o segundo relaciona-se ao controle da reprodução de seus atributos, parciais ou totais, por outros.

A honra é o sentimento acerca de um indivíduo e costuma ser analisada sob duas faces: (i) a subjetiva, concernente ao sentimento que cada um tem a respeito de si próprio; e (ii) a objetiva, referente à reputação ou estima que os outros têm a respeito desse indivíduo $^{574}$. A imagem encontra-se, muitas vezes, associada à honra, e corresponde a qualquer reprodução de uma pessoa ou de seus atributos, todos ou alguns deles, como sua reputação, mas não só, seja pictórica ou descritiva, escrita ou oral, ou por qualquer outro

\footnotetext{
${ }^{572}$ Nesse sentido, Canotilho e Moreira (2007, p. 468): “[...] Alguma doutrina e jurisprudência (cfr. AcTC n ${ }^{\circ}$ 454/93) distinguem entre esfera pessoal íntima (absolutamente protegida) e esfera privada simples (apenas relativamente protegida, podendo ter de ceder em conflito com outro interesse ou bem público); mas à face deste preceito [relativo à reserva da intimidade da vida privada e familiar] da CRP [Constituição da República Portuguesa] parece que tal distinção não é relevante. O critério constitucional deve talvez arrancar dos conceitos de 'privacidade' $\left(\mathrm{n}^{\mathrm{o}}\right.$ 1, 'in fine' [do artigo 26]) e 'dignidade humana' ( $\left.\mathrm{n}^{\mathrm{o}} 2\right)$, de modo a definirse um conceito de esfera privada de cada pessoa, culturalmente adequado à vida contemporânea. O âmbito normativo do direito fundamental à reserva da intimidade da vida privada e familiar deverá delimitar-se, assim, como base num conceito de 'vida privada' que tenha em conta a referência civilizacional sob três aspectos: (1) o respeito dos comportamentos; (2) o respeito do anonimato; (3) o respeito da vida em relação. Estas dimensões devem ser convocadas para eventuais 'renúncias' à protecção da intimidade da vida privada (ex.: caso 'Big-Brother')" (destaques dos autores).

${ }^{573}$ Nesse sentido, Ferraz Junior $(1992$, p. 84, 2001, p. 19, 2004, p. 496-497): “[p]or último, a honra e imagem. A privacidade, nesse caso, protege a informação de dados que envolvam avaliações (negativas) do comportamento que, publicadas, podem ferir o bom nome do sujeito, isto é, o modo como ele supõe e deseja ser visto pelos outros. Repita-se que o direito à privacidade protege a honra, podendo ocorrer a inviolabilidade do sigilo referente a avaliações que um sujeito faz sobre outro e que, por interferir em sua honra, comunica restritivamente, por razões de interesse pessoal. É o caso, por exemplo, de cadastros pessoais que contêm avaliações negativas sobre a conduta (mau pagador, devedor impontual e relapso etc.). No tocante à imagem, para além do que ela significa de boa imagem, assimilando-se, nesse sentido, à honra, a proteção refere-se a dados que alguém fornece a alguém e não deseja ver explorada [sic] (comercialmente, por exemplo) por terceiros". Em sentido contrário, J. Silva (2007, p. 101) e Souza (2003, p. 58).

574 Ver, dentre outros, Cretella Júnior (1990). "A 'honra' é o conjunto de qualidades que caracterizam a dignidade da pessoa, o respeito dos concidadãos, o bom nome, a reputação. [...] A pessoa tem o direito de preservar a própria dignidade - adverte Adriano de Cupis - mesmo fictícia, até contra ataques da verdade, pois aquilo que é contrário à dignidade da pessoa deve permanecer um segredo dela própria. Esse segredo entra no campo da privacidade, da vida privada, e é aqui onde o direito à honra se cruza com o direito à privacidade" (J. SILVA, 2005, p. 209, 2007, p. 101-102). Mais sobre a honra em Jabur (2000).
} 
meio ${ }^{575}$. No entanto, o legislador houve por bem autonomizá-los.

Ao lado da honra e da imagem, a "vida privada" (privacidade) encontra-se expressamente enumerada dentre os chamados "direitos da personalidade",576, nomenclatura só recentemente albergada pela Constituição Federal através do Decreto Legislativo 186/2008, que aprovou a citada "Convenção sobre os Direitos das Pessoas com Deficiência e de seu Protocolo Facultativo, assinados em Nova Iorque, em 30 de março de $2007^{\prime, 577}$.

575 "A 'inviolabilidade da imagem da pessoa' consiste na tutela do aspecto físico, como é perceptível visivelmente [...]" (J. SILVA, 2005, p. 209). Para Souza, imagem é a exteriorização da personalidade, tanto no aspecto físico como no moral (2003, p. 48). Mais a respeito em Jabur (2000).

${ }_{577}^{576}$ Artigos 11 a 21 do novo Código Civil.

${ }^{577}$ Artigos 22 e 31 . A Constituição Federal refere-se à proteção dos direitos e garantias fundamentais, além de incluir, dentre os fundamentos da República Federativa do Brasil, a "dignidade da pessoa humana" (artigo $1^{\circ}$, inciso III). São direitos considerados especiais, concernentes à integridade da pessoa, de alguma forma relacionados à sua dignidade. Ver, por exemplo, Vieira (2002). A "Convenção sobre os Direitos das Pessoas com Deficiência e de seu Protocolo Facultativo, assinados em Nova Iorque, em 30 de março de 2007", aprovada pelo Decreto Legislativo 186/2008, refere-se à "dignidade inerente" das pessoas com deficiência em seus artigos $1^{\circ}$ e $3^{\circ}$, mas não se preocupa em defini-la ou conceituá-la. A Constituição de Portugal também estabelece a "dignidade da pessoa humana" como uma das bases da República (artigo $1^{\circ}$ ), mas não a conceitua. Miranda e Medeiros (2005, p. 141), ao comentarem o número 2 do artigo $8^{\circ}$ do texto constitucional lusitano, segundo o qual "[o]s preceitos constitucionais e legais relativos aos direitos fundamentais devem ser interpretados e integrados de harmonia com a Declaração Universal dos Direitos do Homem", em comparação com o artigo $1^{\circ}$ dessa Declaração, anotam que a dignidade da pessoa humana ligase à razão e consciência de que todos os homens são dotados. Canotilho e Moreira (2007, pp. 198-199) discorrem que "[a]o basear a República [portuguesa] na dignidade da pessoa humana, a Constituição explicita de forma inequívoca que o 'poder' ou 'domínio' da República terá de assentar em dois pressupostos ou precondições: (1) primeiro está a pessoa humana e depois a organização política; (2) a pessoa é sujeito e não objecto, é fim e não meio de relações jurídico-sociais. Nestes pressupostos radica a elevação da dignidade da pessoa humana a trave mestra de sustentação e legitimação da República e da respectiva compreensão da organização do poder político. Com este sentido, a dignidade da pessoa humana ergue-se como linha decisiva de fronteira ('valor-limite') contra totalitarismos (políticos, sociais, religiosos) e contra experiências históricas de aniquilação existencial do ser humano e negadoras da dignidade da pessoa humana (escravatura, inquisição, nazismo, estalinismo, polpotismo, genocídios étnicos). [...] A dignidade da pessoa humana constitui um 'dado prévio' ('a precondição') da legitimação da República como forma de domínio político, mas não se trata de um dado fixista, invariável e abstracto. A dimensão intrínseca e autônoma da dignidade da pessoa humana articula-se com a liberdade de conformação e de orientação da vida segundo o projecto espiritual de cada pessoa, o que aponta para a necessidade de, não obstante a existência de uma constante antropológica, haver uma abertura às novas exigências da própria pessoa humana. Estas novas exigências podem reclamar a necessidade de prestações (públicas ou privadas) enriquecedoras das irradiações físicas e espirituais da pessoa. A dignidade da pessoa humana pressupõe ainda relações de reconhecimento intersubjectivo, pois a dignidade de cada pessoa deve ser compreendida e respeitada em termos de reciprocidade de uns com os outros. A articulação destas três dimensões - a dignidade como dimensão intrínseca do ser humano, a dignidade como dimensão aberta e carecedora de prestações, a dignidade como expressão de reconhecimento recíproco - explicita muitas soluções normativoconstitucionais acolhidas na Constituição da República. [...]" (destaques dos autores). No Comentário da Carta de Direitos Fundamentais da União Européia, produzido pela rede de "experts" independentes, Heyde, tomando por base a jurisprudência do Tribunal Constitucional Federal alemão, conceitua a dignidade da pessoa humana como o valor social e respeito intrínsecos a que tem direito cada pessoa, independentemente de suas características inatas, conquistas e condição social, sendo que o indivíduo é dotado de responsabilidade moral (2006, pp. 26-27). Mas acaba reconhecendo que, em casos concretos, acabam surgindo dificuldades quanto à dignidade humana, pois a expressão é usada em vários contextos e com significados diferentes por razões éticas e teológicas, por interpretações legais e pelo uso na linguagem coloquial, os quais não são congruentes, além da visão de cada Estado-Membro em relação a questões em discussão, como, por exemplo, relativamente à vida em desenvolvimento (vida na fase embrionária) (2006, p. 
O Código Civil dispõe que a personalidade civil começa com o nascimento com vida, assegurados, contudo, desde a concepção, os direitos do nascituro ${ }^{578}$, e termina, a da pessoa natural, com a morte, real ou presumida ${ }^{579}$. Mas não dispõe o que seja personalidade, e nem se a "personalidade civil" é aquela a que se referem os "direitos da personalidade".

Não define também o que sejam estes direitos, apenas estabelece uma regra geral, "com exceção dos casos previstos em lei”, de intransmissibilidade e irrenunciabilidade, "não podendo o seu exercício sofrer limitação voluntária"580. Mas arrola alguns desses direitos: (i) expressamente, o direito ao nome $\mathrm{e}^{581}$, ao pseudônimo $^{582}$ e à vida privada $^{583}$, o direito aos escritos, à palavra e à imagem, se atingirem a honra, a boa fama ou a respeitabilidade da pessoa, ou se se destinarem a fins comerciais ${ }^{584}$, e, (ii) implicitamente, à integridade física e à saúde $\mathrm{e}^{585}$.

Há julgados que qualificam o direito à privacidade, honra, nome e imagem como elementos que fazem parte da integridade moral do indivíduo, expressão dos direitos da personalidade, como se vê no Recurso Especial 890930/RJ, Relatora Ministra Denise Arruda $^{586}$, e no Recurso Especial 818764/ES, Relator Ministro Jorge Scartezzini ${ }^{587}$.

O Recurso Especial 733990/MG, Relatora Nancy Andrighi ${ }^{588}$, inclui o direito à “integridade física”, enquanto o Recurso Especial 521697/RJ, Relator Ministro Cesar Asfor Rocha ${ }^{589}$, citando precedente da própria corte, lembra alguns dos direitos morais do autor $^{590}$ como direitos da personalidade.

O Recurso Especial 506437/SP, Relator Ministro Fernando Gonçalves ${ }^{591}$, além de incluir a reputação e a "intimidade" no rol, citando Orlando Gomes, afirma serem os direitos da personalidade "direitos considerados essenciais à pessoa humana, que a doutrina moderna preconiza e disciplina, a fim de resguardar a sua dignidade".

O STF referiu-se ao menos duas vezes aos direitos da personalidade, uma num caso

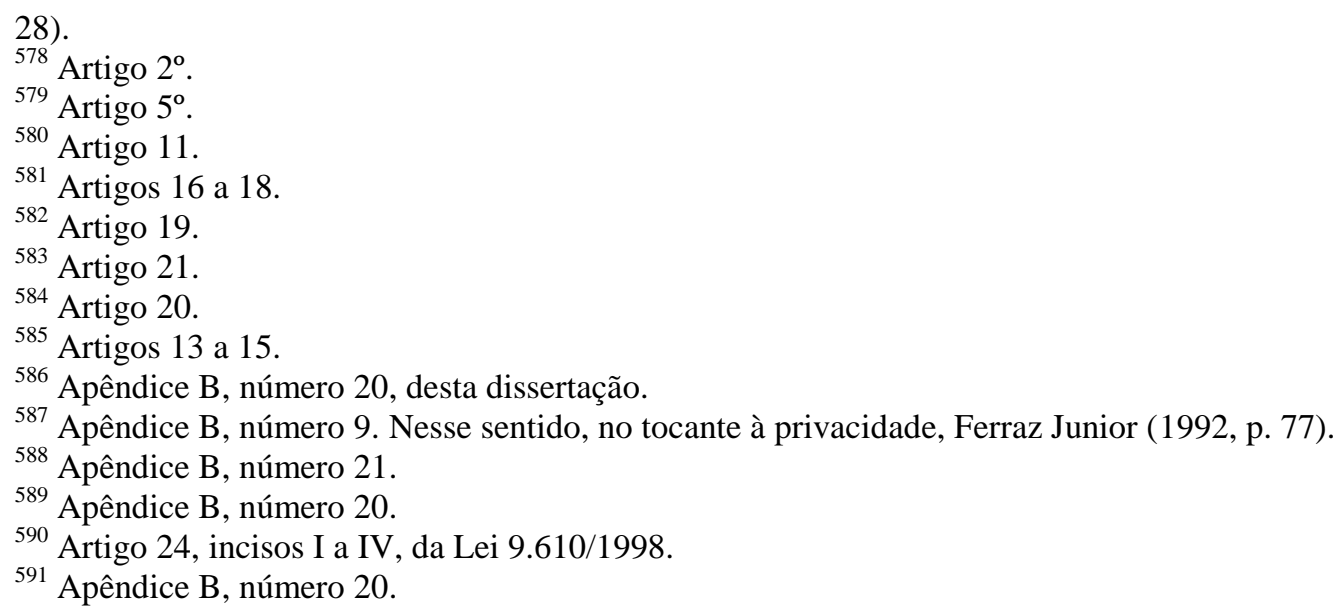


que tratava de uma ação de reconhecimento de paternidade, no Recurso Extraordinário 248869/SP ${ }^{592}$, outra na Petição 2702/RJ ${ }^{593}$, em que se consideraram os direitos arrolados no inciso X do artigo $5^{\circ}$ da Constituição Federal como direitos da personalidade.

A personalidade seria, então, a projeção jurídica da pessoa, da qual emanam direitos, alguns considerados especiais, dignos de maior proteção, que constituem um gênero, dentro do qual está a "privacidade", e que se encontra umbilicalmente ligado à “dignidade da pessoa humana", seja como fundamento, seja como sua própria expressão 594.

\subsection{A solução atual.}

A proteção direta da privacidade (intimidade e vida privada) encontra-se no inciso $\mathrm{X}$ do artigo $5^{\circ}$ da Constituição Federal, que assegura aos indivíduos reparação por danos materiais e morais, e no Código Civil, que lhes garante medidas impeditivas ou repressivas contra violações a esse direito, particularmente no artigo 21.

A inviolabilidade das comunicações, por sua vez, encontra guarida primariamente no inciso XII do artigo $5^{\circ}$ da Constituição, cuja redação é, no mínimo, obscura.

A primeira parte é separada em dois blocos: "sigilo da correspondência e das comunicações telegráficas, de dados e das comunicações telefônicas”.

"Comunicação telegráfica" não é afim de "correspondência" na ordem jurídica brasileira, mas, sim, de comunicação telefônica e de dados, como visto. É uma espécie de “telecomunicação”. O telegrama, objeto da comunicação telegráfica, é afim de carta, mas

592 Apêndice A, número 5.

593 Apêndice A, número 11.

${ }^{594}$ Dispõe o artigo 26, número 1, da Constituição de Portugal: "[a] todos são reconhecidos os direitos à identidade pessoal, ao desenvolvimento da personalidade, à capacidade civil, à cidadania, ao bom nome e reputação, à imagem, à palavra, à reserva da intimidade da vida privada e familiar e à protecção legal contra quaisquer formas de discriminação". Canotilho e Moreira, ao comentarem esse artigo (2007, p. 461), entendem que "[a]o reunir num único artigo nada menos do que nove direitos distintos, a Constituição sublinha aquilo que, para além da sua diversidade, lhes confere carácter comum, e que consiste em todos eles estarem directamente ao serviço da protecção da esfera nuclear das pessoas e da sua vida, abarcando fundamentalmente aquilo que a literatura juscivilista designa por direitos de personalidade (cfr. AcTC $\mathrm{n}^{\circ}$ 110/05)" (destaque dos autores). No Brasil, Jabur, que adota a nomenclatura "direitos personalíssimos", cita o artigo $5^{\circ}$, "caput" e incisos IV, V, VI, IX, X, e XII, da Constituição Federal como exemplos, e após arrolar uma série de características que lhes seriam próprias, define-os como "direitos subjetivos privados, fora do comércio, alguns adquiridos com o simples fato do nascimento (liberdade, privacidade e direito moral do autor), outros coexistentes com a concepção (vida, integridade física, honra, imagem e identidade pessoal), independente da vontade de cada um, irrenunciáveis e excepcionalmente transmissíveis aos sucessores, de conteúdo não-patrimonial, mas com reflexo pecuniário, que possibilitam o desfrute das faculdades do corpo e do espírito, essenciais ao bem-estar, e que encerram, por isso, categoria autônoma, a ponto de não serem absolutamente disponíveis e de merecerem, sem intervenção humana, como nenhum outro direito merece, o predicado da inexpropriabilidade, imprescritibilidade e impenhorabilidade" (2000, p. 94). Para mais sobre o direito ou direitos da personalidade, ver Almeida (2003), Baltazar Junior (2001), Barros (2001), Rigaux (1990) e Vasconcelos (2006). 
somente para a sua proteção em função da definição da Lei 6.538/1978.

Desse modo, se a divisão em dois blocos tem por escopo reunir neles formas históricas de comunicação similares, é falha nesse sentido.

Outro problema diz respeito à referência simples a "dados": deixada de lado a questão da divisão em dois blocos, o dispositivo sofre na sintaxe, pois não há "simetria" entre o primeiro e o segundo bloco. Correspondência é comunicação, então despicienda a referência a "comunicação", mas se o inciso trata de formas de "comunicação", mais correto seria a inserção da palavra "comunicações" ou "transmissão" antes de "de dados", ou retirar "comunicações" antes de "telefônicas", para que se evidenciasse o elenco iniciado com "telegráficas". Como está redigido, o dispositivo comporta basicamente duas interpretações: a inviolabilidade é da comunicação dos dados ou dos dados em si ${ }^{595}$.

Esse fato tem importância porque a parte final desse inciso estabelece as hipóteses de exceção à inviolabilidade: “[...] salvo, no último caso, por ordem judicial, nas hipóteses e na forma que a lei estabelecer para fins de investigação criminal ou instrução processual penal" (destaque nosso). O "último caso" abrange somente as "comunicações telefônicas" ou, também, os dados ou a comunicação "de dados"?

A despeito da redação, o dispositivo leva a crer que seu objeto são modalidades de comunicação ${ }^{596}$, até porque a privacidade encontra-se substancialmente protegida no inciso $\mathrm{X}$, incluindo os dados (pessoais). Se a intenção fosse a de elevar a categoria dos dados

\footnotetext{
${ }^{595}$ Greco Filho encontra uma terceira possibilidade de interpretação: a de que a ressalva pode referir-se à interceptação das comunicações telegráficas, de dados e das comunicações telefônicas, ou só das comunicações telefònicas, e conclui: "Nossa interpretação é no sentido de que 'no último caso' refere-se apenas às comunicações telefônicas, pelas seguintes razões: [s]e a Constituição quisesse dar a entender que as situações são apenas duas, e quisesse que a interceptação fosse possível nas comunicações telegráficas, de dados e das comunicações telefònicas, a ressalva estaria redigida não como 'no último caso', mas como 'no segundo caso'. Ademais, segundo os dicionários, último significa derradeiro, o que encerra, e não, usualmente, o segundo. Por outro lado, a garantia constitucional do sigilo é a regra e a interceptação a exceção, de forma que a interpretação deve ser restritiva quanto a esta ('exceptiora non sunt amplianda')" (2005, p. 16-17). Streck entende que o "último caso" só abrange as comunicações telefônicas, ao passo que a correspondência, as comunicações telegráficas e os dados (estáticos) são absolutos (1997, p. 43-44). Mais sobre as diferentes interpretações em Grinover (1997), Grinover, Fernandes e Gomes Filho (2001), J. Silva (2007) e Mendes (1999).

596 “[...] Note-se, para a caracterização dos blocos, que a conjunção 'e' une correspondência com telegrafia, segue-se uma vírgula e depois, a conjunção de dados com comunicações telefônicas. O que fere a liberdade de omitir pensamento é, pois, entrar na 'comunicação' alheia, fazendo com que o que devia ficar entre sujeitos que se comunicam privadamente passe ilegitimamente ao domínio de um terceiro" (FERRAZ JUNIOR, 1992, p. 83-4). O autor reafirma seu entendimento em texto posterior (FERRAZ JUNIOR, 2001). Em sentido contrário, J. Silva (2007, p. 105-106, destaque do autor): “[...] O que não nos parece conformarse com um bom entendimento da norma é entender que o sigilo de dados só se refere aos registros de uma comunicação telefônica que atestam sua existência, duração, destino etc. Entendemos que sigilo de dados se refere a cadastros de dados em geral, inclusive os utilizados pela ciência da informática e dados dos cadastros bancários. Quer dizer, o sigilo bancário encontra aqui a sua proteção constitucional, não nos parecendo procedente certa tendência da jurisprudência do STF no sentido de que o sigilo bancário não seja de estatura constitucional (MS 21.729-4-DF, Rel. Min. Francisco Rezek)".
} 
pessoais a direito autônomo, deveria ter sido feito no inciso LXXII, em que surgiu a figura do "habeas data" e que remete a "informações relativas à pessoa do impetrante" então, em dispositivo à parte. Além disso, havia a referência a "serviços de transmissão de dados" na redação original do artigo 21, inciso XI, da Constituição Federal. Desse modo, a referência é às comunicações de dados ${ }^{598}$.

"Comunicação" é o processo de transmissão e de recepção de uma mensagem. Nesse contexto, a transmissão reservada de mensagens, com exclusão de outros que não o destinatário.

Ela pode dar-se de diversos modos: pessoalmente ou por intermédio de qualquer tecnologia, como, por exemplo, papel (carta, bilhete), telefone, telégrafo, computador. Não se deve confundir o processo de comunicação com o seu objeto, que pode ser qualquer um (texto, som, imagem estática ou em movimento).

A Constituição Federal separa as comunicações em quatro modalidades, embora a tendência seja de convergência para a comunicação eletrônica ${ }^{599}$, quando então será sinônimo simplesmente de telecomunicação.

As comunicações eletrônicas podem trafegar por qualquer aparelho físico ou lógico compatível com essa tecnologia, mormente, mas não só, por computadores interligados diretamente ou por rede, como a Internet ${ }^{600}$. As informações que trafegam pelos computadores são chamadas genericamente de "dados", inclusive as mensagens. Nesse contexto, "transmissão de dados" equivale a "comunicação".

Os indivíduos podem conectar-se à Internet ou a outras redes, abertas ou restritas, e trocarem mensagens escritas, sonoras ou de vídeo, inclusive ao vivo (em “tempo real”).

\footnotetext{
${ }^{597}$ Alínea "a”. Ver mais a respeito no Capítulo 5.4.

598 Ver Recurso Extraordinário 418416/SC, Relator Ministro Sepúlveda Pertence, no Apêndice A, número 12.

599 Adotamos, a exemplo da União Européia, o adjetivo "eletrônica", como advertíramos, não para excluir as modalidades tradicionais de comunicações, mas para sinalizar o advento de uma tecnologia que facilita o armazenamento de grandes quantidades de informações, bem como a sua estruturação e acesso, e, conseqüentemente, expande as possibilidades de abuso ou mau uso em quantidade, qualidade e velocidade. "Eletrônica" também não pressupõe, neste contexto, a exclusão de outras tecnologias que tenham efeitos iguais ou similares. A evolução tecnológica tende a permitir a coleta e a difusão, cada vez mais rápida, de grandes quantidades de informações de variados tipos com cada vez mais precisão, gerando reações na sociedade. Basta rememorar o artigo jurídico de Warren e Brandeis, que ensejou a discussão sobre o direito de privacidade e teve como estopim problemas que o primeiro estava enfrentando com a mídia no final do século XIX, e que já traz um histórico de casos de violação ou exposição da vida privada.

${ }^{600}$ Os computadores, no início, eram máquinas enormes, normalmente restritos a universidades, centros de pesquisa e alguns órgãos governamentais. Na década de 1980, tornaram-se compactos, e iniciou-se a era dos computadores pessoais ("personal computers" ou "PCs"). Logo uma rede internacional descentralizada de computadores, conhecida como Internet, tornou-se pública, e todos conectados a elas por meio de algum provedor de acesso passaram a trocar dados entre si. A princípio, qualquer um com um equipamento capaz de entender a "linguagem" (protocolo) de navegação da Internet pode enviar e receber informações através dela.
} 
A telefonia é possível através do uso dessas redes, e a mais famosa modalidade de transmissão eletrônica de voz é a de "Voice over Internet Protocol" ("VoIP"), ou "protocolo de voz pela Internet", que permite conexão com aparelhos ligados ao sistema telefônico comum.

Importa notar que os dados que trafegam eletronicamente são neutros, ou seja, sua natureza é essencialmente a mesma, sempre, quaisquer que sejam suas exteriorizações: imagens, sons, textos. A forma como aparecem aos nossos sentidos é apenas resultado de uma tradução de uma interação entre a máquina e o programa ("software") que nela funciona. Esses dados podem ser produzidos, enviados, transmitidos, recebidos e manipulados por quaisquer pessoas.

Portanto, considerando-se que, eletronicamente, toda e qualquer espécie de comunicação tem por objeto "dados", e que existe uma grande facilidade de acesso a eles, bem como de armazenamento e de manipulação, e levando-se em conta, principalmente, o dispositivo constitucional que estabelece a inviolabilidade das comunicações ${ }^{601}$, de grande importância é esse entendimento para a proteção da privacidade do indivíduo, a fim de que não se a aumente ou diminua indevidamente.

Observa-se que a Constituição Federal inequivocamente determina a inviolabilidade do sigilo da correspondência e das comunicações telegráficas e telefônicas, enquanto o STF definiu que a proteção é da comunicação de dados.

Inequívoca, também, a possibilidade de interceptação das comunicações telefônicas, por ordem judicial, para fins de investigação criminal e instrução processual penal, nos termos da lei, que deve definir as hipóteses e a forma. Essa lei, aliás, é a Lei 9.296/1996.

Porém, existem dúvidas se a interceptação abrange as comunicações de dados. Numa primeira leitura, parece que o "último caso"602 refere-se apenas às comunicações telefônicas, por uma razão exposta anteriormente por Ferraz Junior (1992, p. 82) ${ }^{603}$ : as comunicações telefônicas não deixam rastro, são instantâneas, isto é, se não capturadas no momento, perdem-se. Já o objeto das outras três formas de comunicação pode ser, em

\footnotetext{
${ }^{601}$ Artigo $5^{\circ}$, inciso XII.

${ }^{602}$ Artigo $5^{\circ}$, inciso XII, segunda parte, da Constituição Federal.

603 “[...] a comunicação telefônica só é enquanto ocorre. Encerrada, não deixa vestígios no que se refere ao relato das mensagens e aos sujeitos comunicadores. É apenas possível, 'a posteriori', verificar qual unidade telefônica ligou para outra. A gravação de conversas telefônicas por meio [do] chamado 'grampeamento' é, pois, uma forma subreptícia de violação do direito ao sigilo da comunicação mas, ao mesmo tempo, é a única forma tecnicamente conhecida de preservar a ação comunicativa" (destaque do autor).
} 
princípio, apreendido em momento anterior ou posterior à transmissão ${ }^{604}$.

Em conjunto com a lição de interpretação segundo a qual as limitações a direitos devem ser interpretadas restritivamente ${ }^{605}$, chegar-se-ia à conclusão de que o parágrafo único do artigo $1^{\text {o }}$ da Lei 9.296/1996, que estabelece a possibilidade de interceptação do fluxo de comunicações em sistemas de informática e telemática ${ }^{606}$, é inconstitucional ${ }^{607}$.

${ }^{604}$ Veja-se, nesse sentido, a opinião do Ministro Sepúlveda Pertence no MS 21729-4/DF, que chega a mencionar esse estudo de Ferraz Junior, relembrada em seu voto no Recurso Extraordinário 418416/SC, presente no Apêndice A, número 12: “[s]eja qual for o conteúdo da referência a dados no inciso XII, este é absolutamente inviolável. O que, a meu ver, mostra, para não se chegar a uma desabrida absurdidade da Constituição, a ter que concluir que se refere à comunicação de dados. Só, afinal, a telefônica é relativa, porque pode ser quebrada por ordem judicial, o que é fácil de entender, pois a comunicação telefônica é instantânea, ou se colhe enquanto ela se desenvolve, ou se perdeu a prova; já a comunicação de dados, a correspondência, a comunicação telegráfica, não, elas deixam provas que podem ser objeto de busca e apreensão. O que se proíbe é a intervenção de um terceiro num ato de comunicação, em todo o dispositivo, por isso só com relação à comunicação telefônica se teve de estabelecer excepcionalmente a possibilidade da intervenção de terceiros para se obter esta prova, que de outro modo perder-se-ia".

${ }^{605}$ Costuma-se citar a clássica obra de Maximiliano (1981, p. 313): “[...] Interpretam-se estritamente os dispositivos que instituem exceções às regras gerais firmadas pela Constituição. Assim se entendem os que favorecem algumas profissões, classes, ou indivíduos, excluem outros, estabelecem incompatibilidades, asseguram prerrogativas, ou cerceiam, embora temporariamente, a liberdade, ou as garantias da propriedade. Na dúvida, siga-se a regra geral". No entanto, olvidam o que o mesmo autor explica logo a seguir, ao que voltamos no Capítulo 5.4 desta dissertação.

${ }^{606}$ Não há uma definição legal do que seja o fluxo de comunicações em sistemas de informática e telemática. L. Gomes (1997) arrisca a seguinte definição de "telemática": "ciência que cuida da comunicação (transmissão, manipulação) de dados, sinais, imagens, escritos e informações por meio do uso combinado da informática (do computador) com as várias formas de telecomunicação. Sucintamente, telemática é telecomunicação (qualquer uma das suas variadas formas) mais informática” (p. 165). Marinelli, com base na alteração ao Código de Processo Penal italiano promovida pela Lei 547, de 23 de dezembro de 1993 e seus trabalhos preparatórios, entende que a telemática identifica-se com a retransmissão de dados à distância em tempo real através da linha telefônica, enquanto que o fluxo relativo aos sistemas informáticos pressupõe a troca de dados entre computadores, sejam ligados via cabo ou outros meios $(2007$, p. 21)

${ }^{607}$ Ação Direta de Inconstitucionalidade 1488/DF, ajuizada pela Associação dos Delegados de Polícia do Brasil - ADEPOL, em 1996, questionava exatamente esse parágrafo único do artigo $1^{\circ}$ da Lei 9.296/1996. A medida liminar foi indeferida, e, posteriormente, a ação foi julgada extinta por ilegitimidade ativa da autora, em 2001. A Ação Direta de Inconstitucionalidade 4112/DF, ajuizada em julho de 2008, também contesta a constitucionalidade, dentre outros, desse dispositivo. Essa ação está tramitando pelo rito do artigo 12 da Lei 9.868/1999, segundo determinação do Ministro Presidente Gilmar Mendes. Essa Ação contesta também a possibilidade de o Ministério Público requisitar a interceptação na instrução processual penal (parte final do inciso II do artigo $3^{\circ}$ ) e o prazo estabelecido no parágrafo $2^{\circ}$ do artigo $4^{\circ}$. Greco Filho, ao entender que a ressalva constitucional deve ser interpretada restritivamente e que se aplica somente às comunicações telefônicas, afirma a inconstitucionalidade desse parágrafo único (2005, p. 18-19). Grinover, Fernandes e Gomes Filho (2001) entendem que é inconstitucional esse dispositivo porque "comunicações telefônicas" só abrange a "voz", e não, por exemplo, dados que trafeguem pela via telefônica. Avolio (2003) entende que a Lei 9.296/1996 só se aplica às comunicações telefônicas propriamente ditas, ou seja, segundo sua opinião, as que envolvem "voz", podendo excepcionalmente ser autorizadas por aplicação do princípio da proporcionalidade. Por outro lado, Siqueira Filho (1997) entende constitucional esse dispositivo, assim como L. Gomes (1997, p. 175), para quem “em matéria de restrição de direitos fundamentais, não está em proclamar seu absolutismo, que sempre é 'aparente', senão no cuidadoso exame da lei restritiva, para se descobrir se ela atende ou não às exigências de excepcionalidade e proporcionalidade (o que significa que um direito fundamental só pode ser sacrificado, e desde que atendido evidentemente o princípio da legalidade, se colide com outro direito fundamental de maior importância)". Streck também defende sua constitucionalidade, dando a entender que quaisquer informações em tráfego que se encaixem na modalidade "comunicações telefônicas", independentemente dos meios utilizados, podem ser apreendidas sob o regime das interceptações telefônicas (1997, p. 42-44). Jesus (1997) entende que esse dispositivo, embora constitucional, só abrange as comunicações feitas pela via telefônica, mesmo que se trate de dados, mas 
Contudo, entendemos de modo diverso, como explicamos no Capítulo 5.4, sendo que tal dispositivo, até agora, continua vigente.

Adotando uma redação negativa ${ }^{608}$, essa Lei condiciona a interceptação à concorrência de três requisitos: (i) a existência de indícios razoáveis de autoria ou participação em infração penal; (ii) a impossibilidade de realização da prova por outros meios; e (iii) o fato investigado constituir conduta punível com reclusão ${ }^{609}$. Crimes apenados com detenção podem ser apurados com provas obtidas pela interceptação, desde que conexos, segundo a jurisprudência.

O procedimento pode ser instaurado de ofício pelo juiz ${ }^{610}$, ou a pedido de autoridade policial, na investigação criminal, ou de representante do Ministério Público, aí e na instrução processual penal, devendo ser fundamentado, com identificação do objeto da investigação e dos sujeitos, demonstração da necessidade de sua realização, e identificação dos meios a serem utilizados.

O STJ entende que o pedido de interceptação prescinde até mesmo da instauração de inquérito, devido à sua natureza de "medida cautelar preparatória"611.

Há uma limitação temporal: a execução da diligência não poderá exceder o prazo de quinze dias, “[...] renovável por igual tempo uma vez comprovada a indispensabilidade do meio de prova" ${ }^{, 612}$.

Após debate quanto ao sentido de "renovável por igual tempo uma vez", sedimentou-se o entendimento no STF e no STJ de que esse artigo não impõe um prazo

exclui as realizadas por outros meios, como cabo e rádio. Nesses casos, a violação do sigilo só poderia dar-se pela relatividade da norma constitucional (p. 464-465).

${ }^{608}$ Criticada, por levar a entender que a interceptação é a regra, por Greco Filho (2005, p. 20-21) e Grinover (1997).

${ }^{609}$ A Ação Direta de Inconstitucionalidade 4112/DF ataca a constitucionalidade desse inciso, por violação ao princípio da proporcionalidade em sentido estrito. Greco Filho (2005) defende mais um requisito, a ser ponderado pelo juiz: a de que o crime seja especialmente grave. Também nesse sentido, Jesus (1997) e Ada Grinover (1997), sendo que esta entende, ainda, que esse dispositivo é inconstitucional por violação ao princípio da proporcionalidade.

${ }^{610}$ O Procurador Geral da República ajuizou a Ação Direta de Inconstitucionalidade 3450/DF, em trâmite no STF, com o fim de que seja declarada a inconstitucionalidade parcial, sem redução de texto, do artigo $3^{\circ}$ da Lei 9.296/1996, para excluir a interpretação de que o juiz possa, na fase pré-processual, determinar de ofício a interceptação telefônica. Encontra-se com o Relator, Ministro Cézar Pelluso, desde 26 de maio de 2006. Na Ação Direta de Inconstitucionalidade 4112/DF, pede-se a declaração de inconstitucionalidade devido ao comprometimento da imparcialidade do juiz, pois estar-se-ia instituindo a figura do "juiz inquisidor". Streck questiona que, se o artigo $4^{\circ}$ determina que o pedido de interceptação de comunicação conterá a demonstração de que a sua realização é necessária à apuração de infração penal, com indicação dos meios a serem empregados, “quais os requisitos para uma determinação de ofício?” (1997, p. 66). L. Gomes (1997) entende que é absolutamente inconstitucional a possibilidade de determinação de ofício por violar o processo acusatório e a imparcialidade do juiz.

${ }^{611}$ Habeas Corpus 85968/SP, Relator Ministro Napoleão Nunes Maia Filho, no Apêndice B, número 5, desta dissertação. Entendendo tratar-se de medida de natureza cautelar, Avolio (2003), L. Gomes (1997), Greco Filho (2005), Grinover, Fernandes e Gomes Filho (2001) e Jesus (1997).

${ }^{612}$ Artigo $5^{\circ}$, parte final. 
máximo, podendo a interceptação ser estendida indefinidamente, desde que seja entendida como necessária às investigações ${ }^{613}$. Logo, existe um prazo máximo apenas para os blocos de tempo de interceptação, que não podem passar de quinze dias, inexistindo uma duração total final.

$\mathrm{O}$ artigo $6^{\circ}$ determina a ciência da realização das operações pela autoridade policial ao Ministério Público, que poderá acompanhá-las, mas não precisa ser formalmente cientificado de todas as prorrogações ${ }^{614}$.

Se possível, as gravações devem ser transcritas ${ }^{615}$, mas a transcrição não precisa dar-se nos pedidos de renovação, apenas no final das operações. Exige-se apenas uma explicação resumida das conversas captadas até então e da necessidade da continuidade da interceptação ${ }^{616}$.

“A interceptação de comunicação telefônica, de qualquer natureza, ocorrerá em autos apartados, apensados aos autos do inquérito policial ou do processo criminal, preservando-se o sigilo das diligências, gravações e transcrições respectivas”, segundo o artigo 8', "caput", cujo parágrafo único dispõe:

[a] apensação somente poderá ser realizada imediatamente antes do relatório da autoridade, quando se tratar de inquérito policial (Código de Processo Penal, art. $10, \S 1^{\circ}$ ) ou na conclusão do processo ao juiz para o despacho decorrente do disposto nos arts. 407, 502 ou 538 do Código de Processo Penal.

$\mathrm{O}$ artigo 10 , parágrafo $1^{\circ}$, refere-se ao relatório minucioso da autoridade policial que será enviado ao juiz competente. Os artigos 407, 502 e 538 do Código de Processo Penal tratavam, em síntese, do momento processual, após a apresentação da defesa, nos procedimentos do júri, ordinário e sumário, em que o juiz podia permitir a realização de novas diligências. A Lei 9.296/1996 refere-se a esse momento para a juntada das provas decorrentes da interceptação, o que era criticado por alguns autores, como afronta à ampla defesa e contraditório por "surpreender" o réu ${ }^{617}$.

\footnotetext{
${ }^{613}$ Ver Habeas Corpus 83515/RS, Relator Ministro Nelson Jobim, julgado pelo STF, no Apêndice A, número 2, desta dissertação, e Recurso Ordinário em Habeas Corpus 13274/RS, Relator Ministro Gilson Dipp, julgado pelo STJ, no Apêndice B, número 5. Nesse sentido da inexistência de limite máximo, em abstrato, para prorrogações, L. Gomes (1997), Greco Filho (2005) e Jesus (1997).

${ }^{614}$ Habeas Corpus 83515/RS do STF, no Apêndice A, número 2, e Recurso Ordinário em Habeas Corpus 13274/RS e Habeas Corpus 76686/PR do STJ, no Apêndice B, número 5.

${ }^{615}$ Artigo $6^{\circ}$, parágrafo $1^{\circ}$.

616 Ver os já aludidos Habeas Corpus 83515/RS, do STF, e o Recurso Ordinário em Habeas Corpus 13274/RS e Habeas Corpus 76686/PR, do STJ.

${ }^{617}$ Ver, nesse sentido, Streck (1997, p. 81-82). L. Gomes (1997, p. 229-231) diz: “[...] o apensamento da autuação separada aos autos do inquérito ou do processo acontece num determinado momento, previsto no art. $8^{\circ}$, parágrafo único (imediatamente antes do relatório final ou antes da sentença). Mas isso não significa que só nesta altura o investigado e/ou seu advogado terá direito de conhecer o alcance da ingerência
} 
Essa questão deve ser reapreciada, no entanto, em razão das mudanças promovidas no Código de Processo Penal, pois a Lei 11.689, de 9 de junho de 2008, alterou a redação do artigo 407, que passou a cuidar das exceções no processo de competência do Tribunal do Júri, e a Lei 11.719, de 20 de junho de 2008, revogou o artigo 502 e alterou o texto do artigo 538, que passou a dispor sobre a adoção do procedimento sumário nas infrações de menor potencial ofensivo.

A gravação que não “interessar à prova será inutilizada por decisão judicial, durante o inquérito, a instrução processual ou após esta, em virtude de requerimento do Ministério Público ou da parte interessada"618, com participação do Ministério Público, sendo facultada a presença do acusado ou seu representante legal ${ }^{619}$.

A Lei 9.296/1996 não trata do tema da prova emprestada, mas o STF, em decisão proferida na Questão de Ordem no Inquérito 2725/SP, Relator Ministro Carlos Britto, entendeu:

EMENTA: QUESTÃO DE ORDEM. INQUÉRITO POLICIAL. SUPERVISÃO
DO SUPREMO TRIBUNAL FEDERAL. PEDIDO VEICULADO PELO
CONSELHO DE ÉTICA E DECORO PARLAMENTAR DA CÂMARA DOS
DEPUTADOS: COMPARTILHAMENTO DAS INFORMAÇÕES.
FINALIDADE: APURAÇÕES DE CUNHO DISCIPLINAR. PRESENÇA DE
DADOS OBTIDOS MEDIANTE INTERCEPTAÇÃO TELEFÔNICA,
JUDICIALMENTE AUTORIZADA. PROVA EMPRESTADA.
ADMISSIBILIDADE. JUÍZO DE PROPORCIONALIDADE (INCISO XII DO
ART. $5^{\circ}$ E $\S 2^{\circ}$ DO ART. 55 DA CF/88). PRECEDENTES. 1. A medida
pleiteada pelo Conselho de Ética e Decoro Parlamentar da Câmara dos
Deputados se mostra adequada, necessária e proporcional ao cumprimento dos
objetivos do parágrafo $2^{\circ}$ do artigo 55 da Constituição Federal de 1988. 2 .
Possibilidade de compartilhamento dos dados obtidos mediante interceptação
telefônica, judicialmente autorizada, para o fim de subsidiar apurações de cunho
disciplinar. Precedente específico: Segunda Questão de Ordem no Inquérito
2.424 (Ministro Cezar Peluso). 3. Questão de Ordem que se resolve no sentido
do deferimento da remessa de cópia integral dos autos ao Sr. Presidente do
Conselho de Ética e Decoro Parlamentar da Câmara dos Deputados, a quem
incumbirá a responsabilidade pela manutenção da cláusula do sigilo de que se
revestem as informaçôes fornecidas ${ }^{620}$.

autorizada. Uma coisa coisa é o apensamento (que é retardado o mais possível para se evitar qualquer tipo de quebra, frente a terceiros, no sigilo das comunicações), outra bem distinta é o direito de ser informado sobre o conteúdo da interceptação já concluída. [...] concluídas as diligências, gravações e transcrições, deve ser levantado o segredo de justiça frente ao investigado e 'seu' defensor, facultando-lhe acesso à prova. [...]". Grinover, Fernandes e Gomes Filho (2001), após confirmarem que a lei, nesse ponto, nada dispõe, e criticando o momento por ela escolhido para o apensamento, afirmam que "[...] é evidente que o incidente relativo à introdução do resultado da interceptação, em autos apartados, deverá ser necessariamente conduzido em contraditório, em observância ao disposto no art. $5^{\circ}$, inc. LV, da CF: contraditório diferido, em face da natureza cautelar (assecuratória da prova) do procedimento de interceptação, necessariamente realizado 'inaudita altera parte', mas que deverá instaurar-se tão logo se considere que o conhecimento do resultado da diligência não importará em prejuízo ao prosseguimento das investigações ou do processo" (p. 190, destaque dos autores).

${ }^{618}$ Artigo 90, "caput", da Lei 9.296/1996.

${ }^{619}$ Artigo $9^{\circ}$, parágrafo único.

${ }^{620}$ Apêndice A, número 3, desta dissertação. 
Por fim, tipifica como crime "realizar interceptação de comunicações telefônicas, de informática ou telemática, ou quebrar segredo da Justiça, sem autorização judicial ou com objetivos não autorizados em lei", no artigo 10, com pena de reclusão, de dois a quatro anos, e multa ${ }^{621}$.

Quanto às gravações realizadas por um dos interlocutores, há uma lacuna, e a jurisprudência não concorda quanto a suas possibilidades e limites.

Há precedentes do STJ que a admitem amplamente ${ }^{622}$, outros que evitam expressamente o estabelecimento de uma regra "a priori" acerca da admissibilidade e estabelecem uma necessidade de análise caso a caso $^{623}$, enquanto outros julgamentos, ainda, principalmente do STF, tendem a restringi-la a hipóteses de legítima defesa, ou quando há investida criminosa do outro ${ }^{624}$.

Em ao menos um precedente jurisprudencial, o local em que a conversa ocorreu parece ter tido influência na verificação da existência de proteção, como no Habeas Corpus 87341/PR, julgado pelo $\mathrm{STF}^{625}$, em que se entendeu que uma gravação feita numa repartição pública não configura uma situação de intimidade, não sendo passível de proteção nesse sentido. Por sua vez, no Recurso Ordinário em Habeas Corpus 18116/SP, julgado pelo STJ $^{626}$, entendeu-se que “[a] conversa realizada em 'sala de bate papo' da internet, não está amparada pelo sigilo das comunicações, pois o ambiente virtual é de acesso irrestrito e destinado a conversas informais", conforme ementa.

No Recurso Ordinário em Habeas Corpus 14672/RJ ${ }^{627}$, o STJ deu importância, no caso, ao fato de a conversa gravada clandestinamente, além de ter sido feita por um dos interlocutores, ocorrer com funcionários públicos "no exercício de sua função pública, e não de conversa particular ou sigilosa, o que afasta a incidência do art. $5^{\circ}$, inciso $\mathrm{X}$, da Constituição Federal, que garante a intimidade da vida privada" (trecho da ementa) ${ }^{628}$.

621 O bem jurídico tutelado é o sigilo das comunicações, ou o direito de exprimir pensamento reservadamente. Ver L. Gomes (1997).

${ }^{622}$ Recurso Ordinário em Habeas Corpus 14041/PA e Habeas Corpus 33110/SP, ambos no Apêndice B, número 5, desta dissertação.

623 Ver Ação Penal 479/RJ e Habeas Corpus 57961/SP, ambos relatados pelo Ministro Felix Fischer, no Apêndice B, número 5.

${ }^{624}$ Habeas Corpus 74678/SP e Habeas Corpus 75338/RJ, ambos julgados pelo STF, no Apêndice A, número 2.

${ }^{625}$ Apêndice A, número 2.

${ }^{626}$ Apêndice B, número 10.

${ }^{627}$ Apêndice B, número 5.

${ }^{628}$ Veja-se passagem do voto do Ministro Relator Maurício Corrêa no Hábeas Corpus 72588/PB (ver Apêndice A, número 2): “[...] Ora, a garantia que a Constituição dá, até que a lei o defina [não existia ainda a Lei 9.296/1996], não poderá distinguir entre o telefone público e o particular, pois o bem que visa a proteger é o da privacidade das pessoas. Imagine-se se essa construção prevalecesse; geraria incontornável 
Nenhum dispositivo dessa lei determina sua aplicação a interceptações (“captações”) ambientais, ou pretende regulá-las. Somente a Lei 9.034/1995, com a redação dada pela Lei 10.217/2001, que "define e regula meios de prova e procedimentos investigatórios que versem sobre ilícitos decorrentes de ações praticadas por quadrilha ou bando ou organizações ou associações criminosas de qualquer tipo"629, prevê e permite, "em qualquer fase da persecução criminal"630 " "a captação e a interceptação ambiental de sinais eletromagnéticos, óticos ou acústicos, e o seu registro e análise, mediante circunstanciada autorização judicial" ${ }^{\text {631 }}$.

Os registros referentes às ligações telefônicas, tais como os dados do assinante da linha, números discados e recebidos, e tempo de duração das ligações, são regulados pela Lei 9.472/1997 ${ }^{632}$, que assegura ao usuário o direito de não ter divulgado, caso o requeira, o seu código de acesso ${ }^{633}$, e à privacidade na utilização de seus dados pessoais pela operadora $^{634}$, que só poderão ser passados a terceiros com sua anuência expressa e específica $^{635}$. Informações agregadas sobre o uso dos seus serviços podem ser repassadas pela operadora, desde que não permitam a identificação, direta ou indireta, do usuário, ou a violação de sua intimidade ${ }^{636}$.

Em vista do que dispõe o artigo $5^{\circ}$, inciso XII, da Constituição Federal, o conteúdo das comunicações só pode ser interceptado por ordem judicial, enquanto os dados de tráfego podem ser obtidos também, diretamente, pelas Comissões Parlamentares de Inquérito $^{637}$, sempre motivadamente ${ }^{638}$.

As prestadoras de serviços devem tornar disponíveis os recursos tecnológicos e facilidades necessários à suspensão de sigilo de telecomunicações, determinada por autoridade judiciária ou legalmente investida desse poder, e manter controle permanente de todos os casos, acompanhando a efetivação dessas determinações, e zelando para que elas

constrangimento para os funcionários públicos, transformando as suas vidas em verdadeiro pandemônio, além do maléfico incentivo da indústria da delação que ganharia total permissividade para a proliferação generalizada dos 'grampos' oficiais".

${ }^{629}$ Artigo $1^{\circ}$.

${ }^{630}$ Artigo 20 "caput".

${ }^{631}$ Artigo $2^{\circ}$, inciso IV.

${ }^{632} \mathrm{E}$, aparentemente, no âmbito da Lei 9.034/1995, há a possibilidade de acesso a dados em geral, o que incluiria dados telefônicos, segundo o artigo $2^{\circ}$, inciso II.

${ }^{633}$ Artigo $3^{\circ}$, inciso VI.

${ }^{634}$ Artigo $3^{\circ}$, inciso IX.

${ }^{635}$ Artigo 72, parágrafo $1^{\circ}$.

${ }^{636}$ Artigo 72, parágrafo $2^{\circ}$.

${ }^{637}$ Artigo 58, parágrafo $3^{\circ}$, da Constituição Federal.

${ }^{638}$ Ver Mandado de Segurança 23452/RJ, Relator Ministro Celso de Mello, no Apêndice A, número 12, desta dissertação. 
sejam cumpridas, dentro dos estritos limites autorizados, a título oneroso ${ }^{639}$.

\subsubsection{A questão dos "dados pessoais".}

Alguns ordenamentos estabelecem tratamento especial à categoria dos "dados pessoais", entendidos não no sentido de dados sob propriedade, posse ou detenção de alguém, mas de informações referentes a uma pessoa identificada ou identificável ${ }^{640}$.

A legislação brasileira não reconhecia essa categoria, embora ela se insinue no inciso LXXII do artigo $5^{\circ}$ da Constituição Federal, e haja quem a encontre na referência a “dados" do inciso XII desse mesmo artigo ${ }^{641}$, até o citado Decreto Legislativo 186/2008 do Congresso Nacional, que introduziu o dever de proteção da "privacidade dos dados pessoais e dados relativos à saúde e à reabilitação de pessoas com deficiência, em igualdade de condições com as demais pessoas" ${ }^{, 642}$.

Uma noção da importância da proteção dos dados pessoais parece existir em alguns diplomas normativos inferiores ${ }^{643}{ }^{644}$, como no citado artigo 72 da Lei 9.472/1997, na legislação do $\mathrm{IBGE}^{645}$, na redação original do parágrafo $3^{\circ}$ do artigo 11 da Lei 9.311/1996, nos parágrafos $2^{\circ}$ e $4^{\circ}$ do artigo $5^{\circ}$ da Lei Complementar 105/2001 e artigo $2^{\circ}$ do Decreto

\footnotetext{
${ }^{639}$ Artigo 24, “caput” e parágrafo $1^{\circ}$, do Anexo à Resolução 426, de 9 de dezembro de 2005, da ANATEL.

${ }^{640}$ Mais detalhes sobre os dados pessoais em Bellavista (2002), Bonaduce (2001), C. Castro (2005), Cachapuz (2006), Canotilho e Moreira (2007), Cifuentes (1998/1999), Colliard e Letteron (2005), Costa e Moniz (1997), Domínguez (2000), Doneda (2006), Gouveia (1993, 1995), J. Gonçalves (2002), L. Castro (2002), Marques (1991), Martins (1991), Mauro (2000), Miranda e Medeiros (2005) e Silveira (1997).

${ }^{641}$ Como pareceu entender o Ministro Ilmar Galvão na Ação Penal 307-3/DF, em trecho do seu voto transcrito no Apêndice A, número 2.

${ }^{642}$ Artigo 22, número 2, destaque nosso.

${ }^{643}$ No Estado de São Paulo, a Lei 10.177, de 30 de dezembro de 1998, regula o procedimento para obtenção, nos artigos 77 a 82, e retificação de dados pessoais, nos artigos 83 a 85, junto à Administração estadual, assegurando o direito de aviso sobre as informações prestadas (artigo 80) e de vedação de uso para fins diversos (artigo 82), dispondo que “[é] proibida a inserção ou conservação em fichário ou registro de dados nominais relativos a opiniões políticas, filosóficas ou religiosas, origem racial, orientação sexual e filiação sindical ou partidária" (artigo 81).

644 “A necessidade de funcionalização da proteção da privacidade faz [sic] [...] com que ela originasse uma disciplina de proteção de dados pessoais, que compreende pressupostos ontológicos idênticos aos da própria proteção da privacidade: pode-se dizer que é a sua 'continuação por outros meios'. [...] Uma análise do instrumental disponível [no Brasil] para possibilitar a concreta atuação de tais direitos [à privacidade e à proteção dos dados pessoais], porém, deixa entrever uma proteção que, embora devesse corresponder a uma proteção integrada e dirigida pela tábua axiológica constitucional, atua de forma fracionada, em focos de atuação determinados - sejam estes a ação de 'habeas data', as previsões do Código de Defesa do Consumidor ou outras - que tendem a orientar-se mais pela lógica de seus específicos campos do que por uma estratégia baseada na tutela integral da personalidade através da proteção dos dados pessoais" (DONEDA, 2006, p. 27-28).

${ }^{645}$ Artigo $2^{\circ}$, parágrafo $2^{\circ}$, do Decreto-Lei 161/1967, artigo $1^{\circ}$, parágrafo único, da Lei 5.534/1968, artigos $6^{\circ}$, “caput” e parágrafo único, e $8^{\circ}$ da Lei 5.878/1973, artigo $1^{\circ}$ e parágrafos do Decreto 77.624/1976, e artigo $2^{\circ}$, inciso V, do Anexo da Portaria 215/2004 do Ministro de Estado do Planejamento, Orçamento e Gestão.
} 
4.489/2002, no artigo $9^{\circ}$ da Lei $9.296 / 1996^{646}$, no parágrafo $2^{\circ}$ do artigo $8^{\circ}$ da Lei 6.385/1976 ${ }^{647}$, e na Lei 9.049/1995, que dispõe sobre o direito de o cidadão requerer à autoridade expedidora o registro, no respectivo documento pessoal de identificação, do número e da data de validade, se for o caso, da Carteira Nacional de Habilitação, do Título de Eleitor e outros, e, na Cédula de Identidade, informações sucintas sobre tipo sangüíneo, disposição de doar órgãos e condições particulares de saúde cuja divulgação possa contribuir para preservar a saúde ou a vida do titular.

As informações recolhidas ao IBGE têm fins estatísticos e, segundo a legislação, não devem permitir a identificação das pessoas. Desse modo, embora as informações relativas aos indivíduos constituam dados pessoais, a obrigatoriedade de não identificação, enquanto subsistir, evita repercussões na sua vida privada.

O "habeas data" é um remédio constitucional (uma ação) cujas hipóteses de cabimento são, a princípio, exaustivas, e envolve, como se depreende do nome, dados pessoais presentes em certos bancos ${ }^{648}$. O Código de Defesa do Consumidor, por sua vez, traz um artigo sobre bancos de dados relativos a consumidores ${ }^{649}$, com regras sobre transparência, aviso e restrições, ao passo que a Lei 9.472/1997 traz algumas restrições quanto aos dados dos usuários de serviços de telecomunicações.

A Lei Complementar 105/2001, que revogou o artigo 38 da Lei 4.595, de 31 de dezembro de 1964, regula o sigilo dos dados bancários, financeiros e fiscais. A jurisprudência, que não é unânime quanto à estatura constitucional do sigilo desses $\operatorname{dados}^{650}$, busca proteção no inciso $\mathrm{X}$ do artigo $5^{\circ}$ da Constituição Federal ${ }^{651}$. Sob a

\footnotetext{
${ }^{646}$ Inferindo-se que "gravação que não interessar à prova" refira-se às partes do objeto das comunicações que não digam respeito ao que se investiga e, principalmente, digam respeito somente à vida privada do indivíduo investigado e daqueles com quem se comunicou.

${ }^{647}$ Que se refere à proteção da "intimidade".

${ }^{648}$ Artigo 5 $5^{\circ}$, inciso LXXII, alíneas "a" e "b", da Constituição Federal, e artigo $7^{\circ}$, incisos I a III, da Lei 9.507/1997.

${ }^{649}$ Artigo 43. O Código define "consumidor" como pessoa física ou jurídica que adquire ou utiliza produto ou serviço como destinatário final, e "fornecedor" como pessoa física ou jurídica, pública ou privada, nacional ou estrangeira, bem como os entes despersonalizados, que desenvolvem atividade de produção, montagem, criação, construção, transformação, importação, exportação, distribuição ou comercialização de produtos ou prestação de serviços, nos seus artigos $2^{\circ}$ e $3^{\circ}$, respectivamente. Mais sobre a privacidade em relação aos dados dos consumidores em Limberger (2002) e Ribeiro (2002).

${ }^{650}$ É o entendimento do Ministro Francisco Rezek, no Mandado de Segurança 21729-4/DF (Apêndice A, número 12): "[p]arece-me, antes de qualquer coisa, que a questão jurídica trazida à corte neste mandado de segurança não tem estatura constitucional. Tudo quanto se estampa na própria Carta de 1988 são normas que abrem espaço ao tratamento de determinados temas pela legislação complementar. É neste terreno, pois, e não naquele da Constituição da República, que se consagra o instituto do sigilo bancário - do qual já se repetiu 'ad nauseam', neste país e noutros, que não tem caráter absoluto. Cuida-se de instituto que protege certo domínio - de resto nada transcendental, mas bastante prosaico - da vida das pessoas e das empresas, contra a curiosidade gratuita, acaso malévola, de outros particulares, e sempre até o exato ponto onde alguma forma de interesse público reclame sua justificada prevalência. Não que ainda não se tenha tentado levar ao
} 
vigência do artigo 38 da Lei 4.595/1964, existia o entendimento da reserva judicial, isto é, somente o Judiciário podia ordenar o levantamento do sigilo. Já a Lei Complementar 105/2001 estabelece várias hipóteses de não configuração de sigilo e outras várias de seu levantamento, permitindo que outras autoridades façam-no ${ }^{652}$.

A Portaria SRF 580, de 12 de junho de 2001, da Secretaria da Receita Federal, apenas dispõe que "[o] fornecimento de informações protegidas por sigilo fiscal, em meio magnético ou eletrônico, inclusive mediante acesso 'on line', só é admissível quando previsto em convênio", sendo que no fornecimento "on line" deve ser observado pelo menos o uso de senhas pessoais e intransferíveis ${ }^{653}$.

texto constitucional a garantia do sigilo bancário, qual sucedeu, sem êxito, em 1984, conforme lembrado nestes autos pelo Vice-Procurador-Geral Moacir Machado Silva [...]. O empreendimento frustrou-se, e a mesma lei de 31 de dezembro de 1964 [Lei 4.595/1964, cujo artigo 38 disciplinava, então, o sigilo], sede explícita do sigilo bancário, disciplina no seu artigo 38 exceções, no interesse não só da justiça, mas também no do parlamento e mesmo no de repartições do próprio governo - mal se entendendo por quê [sic] um diploma ulterior, como a Lei Complementar 75/93, não as poderia modificar ou estender". No mesmo acórdão, o Ministro Sepúlveda Pertence, entendendo que a Constituição só protege a comunicação dos dados, e não os dados em si, afirma categoricamente que, no Brasil, o sigilo bancário só existe "por força de lei ordinária". Essa é também a posição de Freitas e Trecenti (2005). Em sentido contrário, encontrando o sigilo bancário nas normas constitucionais, especialmente nas de intimidade e vida privada (artigo $5^{\circ}$, inciso X, da Constituição Federal), Adiers (2004), Baltazar Junior (2001), Nigri (1998) e R. Oliveira (1997).

${ }^{651}$ Ver Apêndices A, número 12, e B, número 3.

${ }^{652}$ A Lei Complementar 105/2001, por exemplo, dispõe que as autoridades e agentes fiscais dos entes da federação somente podem analisar livros, documentos e registros das instituições financeiras quando haja processo administrativo, por elas instaurado, e tais exames sejam considerados, por elas, indispensáveis (artigo $6^{\circ}$ ); encontrando indícios de ilícito fiscal ou crime de ação pública, o Banco Central ou a Comissão de Valores Mobiliários devem informar o Ministério Público e outros "órgãos públicos competentes" e juntar os documentos, que incluem os abrangidos, a princípio, pelo sigilo (artigo $9^{\circ}$, "caput" e parágrafo $2^{\circ}$ ); pode existir intercâmbio entre as instituições (artigo $2^{\circ}$, parágrafo $4^{\circ}$ ), expressamente entre o Banco Central e a Comissão de Valores Mobiliários (artigo $7^{\circ}$, parágrafo único); ambos e outros órgãos de fiscalização têm de fornecer informações ao Conselho de Controle de Atividades Financeiras (COAF) (artigo $2^{\circ}$, parágrafo $6^{\circ}$ ); não constitui violação do sigilo a comunicação às autoridades competentes de prática de ilícitos penais ou administrativos, quando houver recursos provenientes de atividade criminosa; e que a quebra pode ser decretada para apuração de ocorrência de qualquer ilícito, em qualquer fase do inquérito ou do processo judicial (parágrafo $4^{\circ}$ do artigo $1^{\circ}$ ). Mas não estabelece claramente, salvo em alguns pontos, uma necessidade de autorização judicial para levantar o sigilo. O próprio parágrafo $4^{\circ}$ do artigo $1^{\circ}$ refere-se ao decreto de quebra, mas não alude por quem. Temperamento desse regime acaba sendo dado pelos tribunais, onde, contudo, as opiniões são de contornos imprecisos e, por vezes, volúveis, não fornecendo segurança jurídica ao indivíduo. Vejam-se os julgados sobre sigilo bancário e fiscal constantes dos Apêndices A, número 12, e B, número 3, desta dissertação.

${ }^{653}$ Artigo $2^{\circ}$, "caput" e parágrafo único. Na prática, mesmo que se considere que o sigilo bancário advém da proteção à intimidade e à vida privada, sua regulação é feita inteiramente pela legislação ordinária. A lei que dispõe sobre o sigilo bancário e fiscal provavelmente é Complementar em virtude do disposto no artigo 192 da Constituição Federal, tanto na redação original quanto na atual. Contudo, deve-se lembrar que a Contribuição Provisória sobre Movimentação ou Transmissão de Valores e de Créditos e Direitos de Natureza Financeira (“CPMF") foi criada pela Lei Ordinária 9.311, de 24 de outubro de 1996, e continha dispositivos que atingiam, direta ou indiretamente, a reserva dos dados bancários e financeiros. Esse tributo, por ser calculado na forma de uma alíquota que incidia sobre qualquer espécie de movimentação financeira, salvo raras exceções, permitia saber, por simples operação matemática, a quantia disponível em nome do responsável pela transação. O artigo 11 , parágrafo $3^{\circ}$, dessa mesma Lei, na redação original, vedava à Secretaria da Receita Federal utilizar as informações obtidas por meio da tributação da CPMF para constituir crédito tributário relativo a outros impostos e contribuições, resguardado o sigilo das informações prestadas "na forma da legislação aplicada à matéria". Porém, em 10 de janeiro de 2001 entrou em vigor a Lei 10.174, 
A Lei 9.296/1996, por sua vez, cuida da inviolabilidade da comunicação de fluxo de dados em sistemas de informática e telemática, ao lhe estender a regulamentação das interceptações telefônicas ${ }^{654}$, e da preservação do sigilo do início ao fim da medida.

A Lei 9.799, de 26 de maio de 1999, procura proteger o trabalhador ao estabelecer restrições à admissão, promoção e demissão no emprego em virtude de sexo, idade, cor, situação familiar ou gravidez, proibindo, dentre outros, a exigência de atestado ou exame, de qualquer natureza, para comprovação de esterilidade ou gravidez ${ }^{655}$, mas não proíbe diretamente a coleta desses dados pessoais "sensíveis" e seu tratamento e transferência.

No geral, a proteção dos dados pessoais só existe quando considerados abarcados pela privacidade, ou dentro de algum sistema específico que exija a coleta e tratamento de dados ou, então, devido à omissão do legislador. Esse último caso é o que se verifica, por exemplo, no sistema de identificação civil nacional.

A Lei 4.862, de 29 de novembro de 1965, permitiu a criação, pelas repartições lançadoras do imposto de renda, de um serviço especial de "Registro das Pessoas Físicas", contribuintes desse imposto, no qual seriam inscritas as pessoas físicas obrigadas a apresentar declaração de rendimentos e de bens ${ }^{656}$. O Decreto-Lei 401, de 30 de dezembro de 1968, transformou esse "Registro" no "Cadastro de Pessoas Físicas" (“CPF”), cuja inscrição, a critério do Ministério da Fazenda, alcançaria pessoas físicas, contribuintes ou não, do imposto de renda, podendo ser feita de ofício ${ }^{657}$. O Decreto 3.000 , de 26 de março de 1999, trata especificamente do CPF nos artigos 33 a 35, mas deixa a cargo da Secretaria da Receita Federal a edição das normas necessárias à sua implantação. Nenhum desses

de 9 de janeiro, que atribuiu o poder à Receita de utilizar esses dados para instaurar procedimento administrativo tendente a verificar a existência de crédito tributário relativo a impostos e contribuições e para lançamento, no âmbito do procedimento fiscal, do crédito tributário porventura existente, com a mesma ressalva quanto ao sigilo. Essa "legislação" aplicável passou a ser a aludida Lei Complementar 105/2001, que arrola as informações obtidas por meio da CPMF como hipótese de ausência de sigilo (artigo $1^{\circ}$, parágrafo $3^{\circ}$, inciso III). A vigência da CPMF foi prorrogada diversas vezes por meio de Emendas Constitucionais, através de alterações no Ato das Disposições Constitucionais Transitórias, até perder vigência em 31 de dezembro de 2007 (artigo 90, com a redação dada pela Emenda 42, de 19 de dezembro de 2003). Informações financeiras e bancárias, a partir de certas quantias, são repassadas, hoje, à Receita Federal do Brasil com base no artigo $5^{\circ}$, "caput", da Lei Complementar 105/2001, no Decreto 4.489/2002 e na Instrução Normativa RFB $802 / 2007$

${ }^{654}$ Artigo $1^{\circ}$, parágrafo único.

${ }^{655}$ Artigo $1^{\circ}$, que inseriu, dentre outros, esse artigo 373A, inciso V, na Consolidação das Leis Trabalhistas. A Lei 9.029, de 13 de abril de 1995, traz regulação adicional nesse ponto, como tipos penais e sanções administrativas, e dispõe no seu artigo $1^{\text {o: }}$ "[f]ica proibida a adoção de qualquer prática discriminatória e limitativa para efeito de acesso a relação de emprego, ou sua manutenção, por motivo de sexo, origem, raça, cor, estado civil, situação familiar ou idade, ressalvadas, neste caso, as hipóteses de proteção ao menor previstas no inciso XXXIII do art. $7^{\circ}$ da Constituição Federal”. A proteção é indireta porque ao vedar a exigência desse tipo de atestado, na prática proíbe a exigência de fornecimento desses dados.

${ }^{656}$ Artigo 11, "caput".

${ }^{657}$ Artigos $1^{\circ}$ e $2^{\circ}$. 
diplomas consigna o que deve ou não, constar do documento de identificação relativo à inscrição da pessoa física no CPF.

Atualmente, é a Instrução Normativa SRF 461, de 18 de outubro de 2004, que rege o CPF, e determina que devem constar do Cartão CPF, obrigatoriamente, três informações ${ }^{658}$ : (i) o número de inscrição no $\mathrm{CPF}$, como regra, único, possuindo cada indivíduo somente um número ${ }^{659}$. Mesmo se cancelado, pode ser restabelecido ${ }^{660}$; (ii) o nome da pessoa física; e (iii) a data de nascimento.

Como a Administração Pública pauta-se pelo princípio da estrita legalidade, isto é, não podendo exigir mais do que permite a legislação, conclui-se que a regulação isoladamente considerada do CPF e de seu cartão de identificação acaba, em certa medida, protegendo os dados pessoais, pois exige pouco e pouco revela.

Contudo, como a cada um só cabe um número de inscrição ${ }^{661}$, e sua utilização é obrigatória em uma série de situações e operações do cotidiano para os indivíduos, como àqueles titulares de conta bancária e sujeitos ao pagamento do imposto de renda ${ }^{662}$, e dadas outras leis que determinam a troca de informações entre instituições, mormente instituições financeiras e órgãos reguladores estatais, e também a existência de bancos de dados que guardam informações, geralmente negativas do inscrito, como o previsto no Código de Defesa do Consumidor e o Cadastro Informativo dos créditos do setor público federal não quitados ("CADIN") 663 , que contém, essencialmente, uma relação de pessoas físicas e jurídicas inadimplentes para com a Administração federal ou que estejam com a inscrição no CPF suspensa ou cancelada, criou-se uma malha de bancos de dados cuja interconexão põe nas mãos da Administração Pública e de entes com ela conveniados ou relacionados um mapa detalhado da vida do indivíduo, o que é bastante facilitado pela informática e pela ausência de um marco regulatório claro e organizado.

A Constituição Federal foi até alterada para incluir um dispositivo que expressamente assegura e permite o compartilhamento de cadastros e de informações

\footnotetext{
${ }^{658}$ Artigo 17, incisos I a III, respectivamente.

${ }^{659}$ Artigo 22.

660 Artigo 54.

${ }^{661}$ Embora possa haver o cancelamento permanente de certo número de CPF, de ofício ou a pedido, nos termos dos artigos 44 a 50, bem como a declaração de sua nulidade, conforme artigos 51 a 53, todos da Instrução Normativa SRF 461/2004.

${ }^{662}$ Artigo 20, incisos VIII e III da Instrução Normativa SRF 461/2004.

${ }^{663}$ Instituído pelo Decreto 1.006 , de 9 de dezembro de 1993, passou a ser regulado pela Lei 10.522/2002. De acordo com o artigo $5^{\circ}$ da Lei 10.522/2002, no tocante às pessoas físicas, no CADIN, devem constar nome e número de inscrição dos devedores, ou nome, número de inscrição e "outros dados identificadores", no caso de CPF suspenso ou cancelado, bem como o nome e número de inscrição no CGC, endereço e telefone do respectivo credor, e a data do registro. O Decreto 1.006/1993 foi, aliás, revogado pelo Decreto 5.913, de 27 de setembro de $2006\left(\operatorname{artigos} 1^{\circ}\right.$ e $2^{\circ}$ ).
} 
fiscais:

[A]s administrações tributárias da União, dos Estados, do Distrito Federal e dos Municípios, atividades essenciais ao funcionamento do Estado, exercidas por servidores de carreiras específicas, terão recursos prioritários para a realização de suas atividades e atuarão de forma integrada, inclusive com o compartilhamento de cadastros e de informações fiscais, na forma da lei ou convênio ${ }^{664}$. (destaque nosso).

Deve-se lembrar, por outro lado, que o parágrafo $1^{\circ}$ do artigo 145 do texto constitucional faculta à administração tributária identificar o patrimônio, os rendimentos e as atividades econômicas do contribuinte, especialmente para conferir aos impostos caráter pessoal e graduá-los conforme a capacidade econômica de cada um, "respeitados os direitos individuais e nos termos da lei" ${ }^{\prime 665}$, e que os direitos do artigo $5^{\circ}$, inclusive à privacidade, são aplicáveis a todas as relações entre Estado e indivíduos.

O nível de detalhamento sobre a vida pessoal aprofunda-se potencialmente com a Lei 9.454, de 7 de abril de 1997, que cria o número único de Registro de Identidade Civil, com o correspondente cadastro, “[...] pelo qual cada cidadão brasileiro, nato ou naturalizado, será identificado em todas as suas relações com a sociedade e com os organismos governamentais e privados" ${ }^{266}$. Será atribuído um número único ${ }^{667}$ a cada indivíduo, reunindo todas as suas informações necessárias às relações com a sociedade, que poderá ser adotado até para receber correspondência ${ }^{668}$.

Nas relações jurídicas em que não figuram o Poder Público, poucas são as proteções, pois aí é permitido o que não é proibido. Inexistindo lei geral sobre dados, ou pelo menos um tratamento sistemático articulado, e nem reconhecimento incontestável da proteção aos dados pessoais como direito autônomo ${ }^{669}$, outros pontos de resguardo são

\footnotetext{
${ }^{664}$ Inciso XXII inserido no artigo 37 pela Emenda Constitucional 42, de 19 de dezembro de 2003.

${ }^{665}$ Esse dispositivo só pode ser interpretado como um reforço da necessidade de estreita relação entre o conhecimento de elementos específicos da vida privada do indivíduo e a administração tributária, pois o respeito aos direitos individuais já decorre naturalmente dos fundamentos do Estado de Direito brasileiro e da declaração de direitos individuais inseridos na Constituição (artigo $1^{\circ}$, inciso III, e artigo $5^{\circ}$ ).

${ }^{666}$ Artigo $1^{\circ}$, destaque nosso.

${ }^{667}$ Que, a rigor, já deveria ter sido adotado, pois o artigo $6^{\circ}$ da Lei determina que no prazo máximo de cinco anos, contados a partir de sua promulgação, perderão a validade todos os documentos em desacordo com ela. Como a Lei foi publicada no Diário Oficial de 8 de abril de 1997, todos os documentos de identificação utilizados ainda hoje, como o RG e CPF, seriam inválidos desde abril de 2002.

${ }^{668}$ Há o risco de o indivíduo ser reduzido a um número e perder qualquer oportunidade privacidade, ao menos no país. Lembramos que a redução do indivíduo a um número é vedado, por exemplo, para os presos, conforme artigo 41, inciso XI, da Lei 7.210, de 11 de julho de 1984, a Lei de Execução Penal, que lhes assegura o direito a chamamento nominal.

${ }^{669}$ Embora, politicamente, o Brasil tenha dado mostras de pretender fazê-lo, ao menos uma vez, ao assinar a Declaração de Santa Cruz de La Sierra, de 2003, na XIII Cúpula Ibero-americana, em que se reconhece, no item 45, que "[...] a protecção de dados pessoais é um direito fundamental das pessoas e destacamos a importância das iniciativas reguladoras ibero-americanas para proteger a privacidade dos cidadãos, contidas
} 
reconhecidos ou construídos pela jurisprudência.

Há precedente do Tribunal Superior do Trabalho ("TST") vedando a anotação na Carteira de Trabalho e Previdência Social (“CTPS”) de ajuizamento de ação trabalhista por parte do trabalhador, em virtude da discriminação que há em relação àqueles que ajuízam ação contra o empregador:

AGRAVO DE INSTRUMENTO. RECURSO DE REVISTA. ANOTAÇÕES APOSTAS NA CTPS. ALUSÃO À RECLAMATÓRIA TRABALHISTA INTERPOSTA. DANOS MORAIS. Caracterizada a divergência jurisprudencial. Agravo de Instrumento a que se dá provimento. RECURSO DE REVISTA. ANOTAÇÕES APOSTAS NA CTPS. ALUSÃO À RECLAMATÓRIA TRABALHISTA INTERPOSTA. DANOS MORAIS. É fato público e notório a intolerância das empresas em relação àqueles empregados que já ajuizaram reclamatória trabalhista, dificultando-lhe o acesso a novo emprego. Ainda que não se trate da denominada lista negra, a anotação aposta na CTPS do Reclamante é suficiente para o colocar às margens do mercado de trabalho, porquanto noticia o ajuizamento de ação trabalhista em face do ex-empregador, revelando-se ato ilícito hábil a ensejar o pagamento da indenização por dano moral. Recurso de Revista conhecido e provido ${ }^{670}$.

Note-se que o parágrafo $4^{\circ}$ do artigo 29 da Consolidação das Leis do Trabalho ${ }^{671}$ somente pró́be anotações "desabonadoras" à conduta do empregado na sua CTPS, o que mostra, aí, uma construção jurisprudencial, não seguida, porém, em outro caso, em que o empregador anotou que o registro do contrato de trabalho deu-se em cumprimento de determinação da Justiça:

DANO MORAL NÃO CARACTERIZAÇÃO - ANOTAÇÃO DO CONTRATO NA CTPS COM A JUSTIFICATIVA DE QUE HOUVE DETERMINAÇÃO JUDICIAL NESSE SENTIDO INDENIZAÇÃO INDEVIDA. A Reclamada, ao proceder ao registro do contrato de trabalho na CTPS com a explicação adicional de que a anotação decorria do cumprimento de determinação contida em ação trabalhista, não praticou ato que maculasse a honra, a dignidade e a imagem profissional do Reclamante. Por um lado, a anotação feita pela Reclamada retrata a realidade, qual seja, de que o contrato foi reconhecido pela via judicial. Por outro, o ajuizamento de ação e o reconhecimento judicial de vínculo empregatício não constitui fato desabonador do Reclamante. Assim, não restou configurado o pretenso ato ilícito capaz de gerar o direito ao pagamento de indenização por dano moral. Recurso de revista conhecido por divergência jurisprudencial e não provido ${ }^{672}$.

Esses casos mostram, aliás, como um ato, a princípio, lícito, viola a privacidade do

na Declaração de Antigua, pela qual se cria a Rede Ibero-Americana de Protecção de Dados, aberta a todos os países da nossa Comunidade".

670 Recurso de Revista 279/2003-669-09-40, Relator Ministro Carlos Alberto Reis de Paula, julgado pela Terceira Turma, decisão publicada no Diário de Justiça de 11 de maio de 2007.

${ }^{671}$ É a redação do dispositivo, introduzido pela Lei 10.270 , de 29 de agosto de 2001: “[é] vedado ao empregador efetuar anotações desabonadoras à conduta do empregado em sua Carteira de Trabalho e Previdência Social".

${ }^{672}$ Recurso de Revista - 65/2003-401-04-00, Relator Ministro Ives Gandra Martins Filho, julgado pela Quarta Turma, decisão publicada no Diário de Justiça de 11 de fevereiro de 2005. 
indíviduo, causando-lhe dano.

Os tribunais também combatem as denominadas "listas negras", que são, em geral, listas de nomes de trabalhadores que ajuizaram ações contra ex-empregadores ou possuem outras características tidas como indesejadas, como se vê, por exemplo, do seguinte acórdão do Tribunal Regional do Trabalho da $15^{\mathrm{a}}$ Região:

\begin{abstract}
LISTA NEGRA - INDENIZAÇÃO POR DANOS MORAIS POSSIBILIDADE - O princípio da não-discriminação está ligado ao princípio da igualdade, pressupondo a vedação de discriminações injustificadas. A lista discriminatória, também conhecida por lista negra, consiste na conduta discriminatória de empregadores em face de trabalhadores, decorrentes de fatos como: o ingresso com reclamações trabalhistas, restrição de crédito ou figurarem como réu em demais processos de natureza civil e criminal, etc. Tal procedimento ofende os artigos $3^{\circ}$, IV, $5^{\circ}$, caput, e $7^{\circ}, \mathrm{XXX}$, da Constituição Federal e ao artigo $1^{\circ}$ da Lei 9.029/95, eis que evidente a discriminação e o abuso de direito, visto que tais fatos não estão ligados diretamente à qualificação do trabalhador. Está comprovado [nos] autos, tendo em vista a prova testemunhal produzida, que a reclamada não contratou as reclamantes pelo fato de terem ingressado com ação trabalhista contra a cooperativa que intermediava os seus serviços para o Banco do Brasil. Pois bem, como alegado anteriormente, é vedado pelo nosso ordenamento jurídico a discriminação contra candidatos a emprego por terem exercido o direito de ação, que é assegurado constitucionalmente, conforme preceituado no art. $5^{\circ}$, inciso XXXV. Neste diapasão, o conjunto probatório, produzido nestes autos, deixa clara a existência dos elementos caracterizadores da responsabilidade civil da reclamada, passível de correção por meio de indenização por danos morais ${ }^{673}$.
\end{abstract}

No campo penal, há certos tipos relacionados a dados. O Código Penal tipifica a conduta geral de "[d]ivulgar alguém, sem justa causa, conteúdo de documento particular ou de correspondência confidencial, de que é destinatário ou detentor, e cuja divulgação possa produzir dano a outrem" ${ }^{974}$, sendo que a Lei 9.983, de 14 de julho de 2000, inseriu tipos específicos relacionados à informática cometidos quase que exclusivamente contra a Administração Pública, como o de “inserção de dados falsos em sistema de informações" "675, de "modificação ou alteração não autorizada de sistema de informações"676, de "[d]ivulgar, sem justa causa, informações sigilosas ou reservadas, assim definidas em lei, contidas ou não nos sistemas de informações ou banco de dados da Administração Pública"677, de permitir ou facilitar, "mediante atribuição, fornecimento e empréstimo de senha ou qualquer outra forma, o acesso de pessoas não autorizadas a

\footnotetext{
${ }^{673}$ Recurso Ordinário 00157-2006-092-15-00-5 RO, Relator Juiz Flávio Nunes Campos, decisão publicada no DJ de 13 de julho de 2007.

${ }^{674}$ Artigo 153.

${ }^{675}$ Artigo 313-A: "[i]nserir ou facilitar, o funcionário autorizado, a inserção de dados falsos, alterar ou excluir indevidamente dados corretos nos sistemas informatizados ou bancos de dados da Administração Pública com o fim de obter vantagem indevida para si ou para outrem ou para causar dano".

${ }^{676}$ Artigo 313-B: "“[m]odificar ou alterar, o funcionário, sistema de informações ou programa de informática sem autorização ou solicitação de autoridade competente".

${ }^{677}$ Artigo 153, parágrafo $1^{\circ}$-A.
} 
sistemas de informações ou banco de dados da Administração Pública",678 e de se utilizar, “indevidamente, do acesso restrito" ${ }^{679}$. Essa Lei ainda mudou o parágrafo $1^{\circ}$ do artigo 327 para equiparar a funcionário público, além daquele que exerce cargo, emprego ou função em entidade paraestatal, aquele que trabalha para empresa prestadora de serviço contratada ou conveniada para a execução de atividade típica da Administração Pública.

Não se abarcam todas as possíveis ilegalidades cometidas com dados, pois não há tipo que trate da utilização de dados obtidos ilicitamente, sem conhecimento do indivíduo a que se referem, pois ainda que se considere que o crime do artigo 313-B abrange a sua transferência, nenhum deles criminaliza o uso. Como o Direito Penal não comporta interpretação extensiva ou analógica em prejuízo do reú, estar-se-ia punindo, na melhor das hipóteses, aquele que passa as informações, mas não aquele que as recebe e delas se vale para quaisquer fins.

Por outro lado, o tipo do artigo 313-B representa pequeno "avanço" em relação ao do "caput" do artigo 153, que só incide se da divulgação puder resultar dano à vítima, o mesmo ocorrendo com o artigo $154^{680}$.

Ademais, há outras normas que acabam interferindo na questão dos dados, embora indiretamente, como a proteção contra invasão de domicílio, o segredo de justiça, as diversas modalidades de sigilo profissional, principalmente o do psicólogo, do médico e do advogado $^{681}$, além dos crimes que podem ser praticados por meios eletrônicos, como o estelionato $^{682}$.

\footnotetext{
${ }^{678}$ Artigo 325, parágrafo $1^{\circ}$, inciso I.

${ }^{679}$ Artigo 325, parágrafo $1^{\circ}$, inciso II.

${ }^{680}$ Se a intenção dos artigos 153 e 154 do Código Penal é proteger a vida privada, criticável é sua redação, pois se se pode imaginar que, muitas vezes, o indivíduo não queira ver segredos divulgados por poderem causar-lhe danos patrimoniais ou morais, haverá situações em que o seu desejo de não os ver expostos advenha, simplesmente, de sua vontade de não ter aspectos de sua vida divulgados, mesmo que o fato ou ato não lhe seja desabonador. No extremo, pode-se citar o caso de um indivíduo contribuir financeiramente com certa instituição beneficente, sob a condição de anonimato: sua conduta não é social ou moralmente reprovável, tampouco ilícita, mas a sua exposição ao público, contra sua vontade, viola a sua privacidade.

${ }^{681}$ O Código Penal apena a conduta de "violação do segredo profissional" no artigo 154: "Revelar alguém, sem justa causa, segredo, de que tem ciência em razão de função, ministério, ofício ou profissão, e cuja revelação possa produzir dano a outrem". A Lei 8.906, de 4 de julho de 1994, que dispõe sobre o Estatuto da Advocacia e a Ordem dos Advogados do Brasil, por exemplo, arrola dentre os direitos dos advogados (artigo $7^{\circ}$, incisos II e XIX, respectivamente): “a inviolabilidade de seu escritório ou local de trabalho, bem como de seus instrumentos de trabalho, de sua correspondência escrita, eletrônica, telefônica e telemática, desde que relativas ao exercício da advocacia" e "recusar-se a depor como testemunha em processo no qual funcionou ou deva funcionar, ou sobre fato relacionado com pessoa de quem seja ou foi advogado, mesmo quando autorizado ou solicitado pelo constituinte, bem como sobre fato que constitua sigilo profissional", tipificando como infração disciplinar "violar, sem justa causa, sigilo profissional" (artigo 34, inciso VII, destaque nosso).

${ }^{682} \mathrm{O}$ estelionato, nessa área, pode ter lugar, por exemplo, através de uma página da Internet criada para parecer uma página verdadeira de instituição financeira, por meio da qual o agente induz fraudulentamente a vítima a digitar dados sigilosos, como número de agência, conta e senha de acesso, utilizados mais tarde para
} 
Além dessas normas de caráter eminentemente material, existe, no campo processual, uma vedação geral à admissibilidade das provas obtidas por meios ilícitos ${ }^{683}$. Porém, como a própria Constituição só oferece proteção direta, e indiscutível, ao sigilo das comunicações telefônicas, cujo levantamento, se for o caso, deve ser ordenada por autoridade judicial, há bastante discricionariedade ao legislador e aos juízes ${ }^{684}$.

O Código de Processo Penal, com as alterações da Lei 11.690/2008, relativamente às provas, estabelece as restrições quanto ao estado da pessoa previstas na legislação civil $^{685}$ e repudia as provas ilícitas, “assim entendidas as obtidas em violação a normas constitucionais ou legais" ${ }^{" 686}$, determinando o seu desentranhamento, bem como as provas delas derivadas, "salvo quando não evidenciado o nexo de causalidade entre umas e outras, ou quando as derivadas puderem ser obtidas por uma fonte independente ${ }^{687}$ das primeiras" $" 688$.

O Código de Processo Civil traz extensa regulação acerca da prova, dispondo como regra que "[t]odos os meios legais, bem como os moralmente legítimos, ainda que não especificados neste Código, são hábeis para provar a verdade dos fatos, em que se funda a ação ou a defesa" ${ }^{689}$. Entretanto, traz algumas restrições em relação à sua produção, como a não obrigatoriedade da parte de depor sobre fatos criminosos ou torpes que lhe forem imputados ou a cujo respeito, por estado ou profissão, deva guardar sigilo ${ }^{690}$. Outra se refere à dispensa de a parte e o terceiro exibirem em juízo o documento ou a coisa concernente a negócios da própria vida da família; cuja apresentação puder violar dever de honra; se a publicidade do documento redundar em desonra à parte ou ao terceiro, bem como a seus parentes consangüíneos ou afins até o terceiro grau, ou lhes representar perigo de ação penal; se a exibição acarretar a divulgação de fatos, a cujo respeito, por estado ou

\footnotetext{
operações bancárias não autorizadas, como saques em caixas eletrônicos ou transferências para outras contas. ${ }^{683}$ Artigo $5^{\circ}$, inciso LVI, da Constituição Federal.

${ }^{684}$ Fisher e Adler (2007), por exemplo, discorrem sobre a erosão da "exclusionary rule" nos Estados Unidos da América em virtude de várias exceções construídas pela Suprema Corte, como, por exemplo, a da "boa fé", através da qual uma prova obtida por uma autoridade agindo em boa-fé, a despeito de violar a Quarta e Décima Quarta Emendas, era admissível em juízo, ou a de que evidências obtidas ilegalmente podiam ser usadas para contestar a credibilidade uma testemunha (p. 746-747). Também citando casos a partir dos quais a Corte permitiu o uso de evidências obtidas em violação à Constituição, Doernberg (2005-2006, p. 261262).

${ }^{685}$ Artigo 155, parágrafo único.

686 Artigo 157, "caput".

687 “Considera-se fonte independente aquela que por si só, seguindo os trâmites típicos e de praxe, próprios da investigação ou instrução criminal, seria capaz de conduzir ao fato objeto da prova" (artigo 157, parágrafo $\left.2^{\circ}\right)$.

${ }^{688}$ Artigo 157, parágrafo $1^{\circ}$.

${ }^{689}$ Artigo 332.

${ }^{690}$ Artigo 347, incisos I e II. Não se aplica "às ações de filiação, de desquite e de anulação de casamento", segundo o parágrafo único desse mesmo artigo.
} 
profissão, devam guardar segredo; e se subsistirem outros motivos graves que, segundo o prudente arbítrio do juiz, justifiquem a recusa da exibição ${ }^{691}$.

Note-se que como quase toda a regulação encontra-se na legislação ordinária, o nível e o tipo de proteção à vida privada variará de acordo com o tratamento conferido pela lei: quanto mais ela for permissiva, mais restritas serão as hipóteses de ilicitude e, por conseguinte, de inadmissibilidade da prova.

\subsubsection{O habeas data e outras leis referentes ao acesso a bancos de dados ou arquivos.}

Atualmente, o "habeas data" é um remédio constitucional que assegura ao impetrante o direito de ter o conhecimento sobre dados seus presentes em registros ou bancos de dados governamentais ou de caráter público e de retificá-los, de explicá-los ou então de contestá-los, neste último caso, quando, embora verdadeiros, estejam sob pendência judicial ou amigável ${ }^{692}$.

A negativa ou ausência de resposta no âmbito administrativo é considerada indispensável para configuração do interesse de agir na sua impetração ${ }^{693}$. Restou estabelecido também que o direito assegurado pelo "habeas data" não se confunde com o direito de obter certidões do Poder Público ${ }^{694}$.

Uma primeira limitação ao "habeas data" surge da sua própria construção no dispositivo constitucional, que o restringe a bancos de dados governamentais ou de caráter público. A Lei 9.507/1997 parece alargar o entendimento de registro ou banco de dados de caráter público, ao defini-lo como "todo registro ou banco de dados contendo informações que sejam ou que possam ser transmitidas a terceiros ou que não sejam de uso privativo do órgão ou entidade produtora ou depositária das informações" ${ }^{\text {695 }}$, pois abrangeria informações que pudessem ser transmitidas, e não apenas aquelas coletadas com o fim expresso de compartilhamento ou repasse. Contudo, a parte final desse mesmo dispositivo ressalva aquelas informações que sejam de "uso privativo" do órgão ou entidade produtora

\footnotetext{
${ }^{691}$ Artigo 363, incisos I a V.

${ }^{692}$ Artigo 50, inciso LXXII, alíneas "a" e "b", da Constituição Federal, e artigo $7^{\circ}$, incisos I a III, da Lei $9.507 / 1997$.

${ }^{693}$ Artigo $8^{\circ}$, parágrafo único e incisos, da Lei 9.507/1997, Súmula 2 do STJ, e Recurso em Habeas Data 24/DF, Relator Ministro Maurício Corrêa, no Apêndice A, número 14, e Recurso em Habeas Data 22/DF, Relator Ministro Marco Aurélio, também no Apêndice A, número 14, ambos do STF.

${ }^{694}$ Habeas Data 107/DF, Relator Ministro José Delgado, e Embargos de Declaração no Habeas Data 67/DF, Relatora Ministra Denise Arruda, ambos do STJ, no Apêndice B, número 22.

${ }^{695}$ Artigo $1^{\circ}$, parágrafo único
} 
ou depositária das informações.

Essa redação traz certa complicação porque pode haver situações em que os dados, embora recolhidos com finalidade legítima e, a princípio, de uso privativo do gerador ou detentor do banco de dados, como, por exemplo, os dados dos empregados recolhidos pelo empregador para controle que sejam oferecidos ou transferidos para outros. É o caso das famosas "listas negras" de trabalhadores: dados gerados para uso interno passam a ser compartilhados para barrar do mercado de trabalho certos empregados "indesejados". Nessa hipótese, então, estaria o banco de dados do empregador alcançado pelo "habeas data"? Poder-se-ia interpretar a primeira parte do parágrafo único desse artigo $1^{\text {o }}$, "que possam ser transmitidas a terceiros", como abrangendo esses dados.

Contudo, o STF, em ação na qual a autora pleiteava ao Banco do Brasil as informações constantes de sua ficha funcional, entendeu que o coator era empresa sujeita a regime de direito privado, apesar de integrar a Administração Indireta na qualidade de sociedade de economia mista, não sendo ente governamental para fins desse remédio, e que o uso da ficha de pessoal é restrito a seu possuidor, o banco empregador, e não disponível a terceiros ${ }^{696}$. O Ministro Sepúlveda Pertence, acompanhando o voto condutor, arrematou: “[...] Eventualmente, havendo abuso de informações, falsas ou injuriosas, o caso se resolverá no campo penal ou no campo da responsabilidade civil”.

Nesse precedente, o entendimento implicitamente firmado foi no sentido de se verificar a finalidade original do banco de dados. O Ministro Relator expressamente afirma que a hipótese clássica de banco de caráter público é a dos serviços de proteção ao crédito $^{697}$.

Por sua vez, o STJ chegou a entender que a Caixa Econômica Federal detinha legitimidade passiva para figurar no pólo passivo de "habeas data" impetrado com o objetivo de se obter dados sobre descontos efetuados em conta corrente, por ser empresa pública e, portanto, integrar a Administração Indireta ${ }^{698}$. Esse Tribunal também entendeu cabível "habeas data" para impetrante que objetivava acesso a seus dados funcionais junto à Aeronáutica ${ }^{699}$, e a militar que visava à obtenção de cópia de parecer que embasou sua exoneração ${ }^{700}$.

\footnotetext{
${ }^{696}$ Recurso Extraordinário 165304/MG, Relator Ministro Octavio Gallotti, no Apêndice A, número 14.

${ }^{697}$ Aliás, o próprio Código de Proteção e Defesa do Consumidor estabelece que "[o]s bancos de dados e cadastros relativos a consumidores, os serviços de proteção ao crédito e congêneres são considerados entidades de caráter público" (artigo 43, parágrafo $4^{\circ}$ ).

${ }^{698}$ Recurso Especial 929381/AL, Relator Ministro Francisco Falcão, Apêndice B, número 22.

${ }^{699}$ Habeas Data 91/DF, Relator Ministro Arnaldo Esteves Lima, no Apêndice B, número 22.

${ }^{700}$ Habeas Data 84/DF, Relatora Ministra Maria Thereza de Assis Moura, no Apêndice B, número 22. Mas
} 
Outras leis tratam de outros aspectos concernentes a bancos de dados ou arquivos, como a Lei 8.159 , de 8 de janeiro de 1991, que define arquivos privados e públicos, mas só especifica critérios e formas para se obter informações destes, inclusive com a expressa permissão que, via Poder Judiciário, seja determinada "a exibição reservada de qualquer documento sigiloso, sempre que indispensável à defesa de direito próprio ou esclarecimento de situação pessoal da parte" ${ }^{\text {701 }}$. Também é permitido o acesso ao cidadão naquilo que diga respeito à sua pessoa, ao seu interesse particular ou do interesse coletivo ou geral, mediante requerimento ao órgão ou entidade competente ${ }^{702}$. Só são relevantes para essa Lei os arquivos privados identificados como de interesse público e social ${ }^{703}$.

A Lei 11.111, de 5 de maio de 2005, que "[r]egulamenta a parte final do disposto no inciso XXXIII do art. $5^{\circ}$ da Constituição Federal e dá outras providências", determina que as informações constantes de documentos públicos relacionadas à intimidade, vida privada, honra e imagem de pessoas somente poderão ser franqueadas ao interessado, ou, se morto ou ausente, ao cônjuge, aos ascendentes ou aos descendentes ${ }^{704}$.

Mas nenhuma dessas leis dispõe sobre a utilização do "habeas data" como instrumento de acesso a e controle de dados pessoais, não podendo ser usado quanto a dados presentes em qualquer base, arquivos privados ou de uso originariamente privado.

\subsubsection{Regulação da Internet no Brasil, com enfoque na segurança nas comunicações eletrônicas.}

No aspecto legal, a regulação da Internet no Brasil resume-se a um sistema hierarquizado com atribuição de registrar os nomes de domínio no país (endereço com terminação “.br”), além de funções de assessoria política e técnica ao governo e aos agentes que operam nesse mercado, incluindo os usuários.

\footnotetext{
não seria abrangido pelos "habeas data" (julgados do STJ no Apêndice B, número 23): (i) cópia de processo administrativo do interesse em que o impetrante é parte (Recurso Especial 904447/RJ, Relator Ministro Teori Albino Zavascki); (ii) emissão de certidão para obtenção do benefício de adicional do tempo de serviço (Recurso Especial 781969/RJ, Relator Ministro Luiz Fux, em que se entendeu, também, que o direito à informação previsto no artigo $5^{\circ}$, inciso XXXIII, da Constituição Federal, não é protegido pelo "habeas data"); (iii) acesso a informações sobre os critérios utilizados em prova de concurso público (Agravo Regimental no Habeas Data 127/DF, Relator Ministro João Otávio de Noronha); (iv) obtenção de informação quanto a andamento de procedimento administrativo (Habeas Data 123/DF, Relator Ministro Castro Meira); (v) obtenção de informações de inquérito policial sigiloso (Agravo Regimental nos Embargos de Declaração no Habeas Data 98/DF, Relator Ministro Teori Albino Zavascki).

701 Artigo 24, "caput".

${ }^{702}$ Artigo 37, inciso II, do Decreto 4.553, de 27 de dezembro de 2002.

${ }^{703}$ Ver artigos 11 a 16.

${ }^{704}$ Artigo $7^{\circ}$, parágrafo único.
} 
No topo está o Comitê Gestor da Internet no Brasil ("CGI.br") 705 , cujo "braço executivo", isto é, o ente responsável pela implementação de suas políticas e projetos, é, desde dezembro de 2005, o Núcleo de Informação e Coordenação do Ponto br ("NIC.br") 706 , uma associação civil sem fins lucrativos, pessoa jurídica de direito privado, que tem por objetivos ${ }^{707}$ o registro de nomes de domínio sob o Domínio de Primeiro Nível ("DPN”) “.br" e a distribuição, promoção e manutenção dos endereços "IPs" ("Internet Protocol"), além da operação de computadores, servidores, rede e toda a infraestrutura necessária, de modo a garantir a boa funcionalidade da operação de registro e manutenção dos domínios sob o “.br”.

Um dos serviços mantidos pelo "NIC.br" é o Centro de Estudos, Resposta e Tratamento de Incidentes de Segurança no Brasil (“CERT.br”), um grupo que tem por missão: (i) ser um ponto único para notificações de incidentes de segurança, de modo a prover a coordenação e o apoio necessário no processo de resposta a incidentes, colocando as partes envolvidas em contato quando necessário; (ii) estabelecer um trabalho colaborativo com outras entidades, como as polícias, provedores de acesso e serviços de Internet e "backbones"; (iii) dar suporte ao processo de recuperação e análise de sistemas comprometidos; e (iv) oferecer treinamento na área de resposta a incidentes de segurança, especialmente para membros de "CSIRTs", próprio grupo (CERT.br, 2008b; HOEPERS, 2007, p. 4).

Conforme o "site" do CERT.br", "incidente de segurança" pode ser definido como qualquer evento adverso, confirmado ou sob suspeita, relacionado à segurança de sistemas de computação ou de redes de computadores, como: (i) tentativas de ganhar acesso não autorizado a sistemas ou dados; (ii) ataques de negação de serviço; (iii) uso ou acesso não autorizado a um sistema; (iv) modificações em um sistema, sem o conhecimento, instruções ou consentimento prévio do dono do sistema; e (v) o desrespeito à política de segurança ou à política de uso aceitável de uma empresa ou provedor de acesso (CERT.br, 2008a).

Notificado, o "CERT.br" articula-se com os mantenedores dos "sites" que estejam hospedando páginas contendo, por exemplo, código de programação malicioso, como cavalos de tróia, para que as removam, e com os fabricantes de programas antivírus

\footnotetext{
${ }^{705}$ Criado pela Portaria Interministerial do Ministro de Estado das Comunicações e do Ministro de Estado da Ciência e Tecnologia 147, de 31 de maio de 1995, alterada pelo Decreto 4.829, de 3 de setembro de 2003.

${ }^{706}$ Conforme Comunicado ao Público do CGI.br de 14 de fevereiro de 2006.

${ }^{707}$ Artigo $4^{\circ}$ do seu Estatuto Social.

708 Sigla utilizada para Grupos de Segurança e Resposta a Incidentes, tanto no Brasil quanto internacionalmente.
} 
(CERT.br, 2008a).

Assim, esse grupo atua como um ponto de referência no combate ao mau uso ou abuso da parte da Internet que se situa no Brasil, fazendo contato e participando de fóruns internacionais, além de auxiliar os agentes encarregados da aplicação da lei, embora não seja um órgão "policial", ou dotado de poder de polícia. Enfim, exerce uma espécie de atividade de auto-regulação de segurança, junto com os outros agentes e usuários da rede.

O serviço de Registro de Domínios para a Internet no Brasil ("Registro.br”) registra, mediante pagamento, "nomes de domínio" “.br”, por periodicidade de doze meses $^{709}$, aos quais se atribui um endereço ou bloco de endereço IP. Os que desejam um nome de domínio têm de se cadastrar no "site" do Registro.br fornecendo inúmeros dados, como nome, CPF ou CNPJ ou e informações de contato ${ }^{710}$.

Os números de IP (uma faixa de números) são atribuídos, assim, a uma pessoa física ou jurídica, ligados a um "nome de domínio", cadastrado, no Brasil, no Registro.br, com dados que devem ser verdadeiros, sob pena de cancelamento se, dentre outros, o solicitante não corrigir a razão social ou nome e o CNPJ ou CPF, e de ver prejudicados posteriores pedidos de registro ${ }^{711}$.

Vê-se que é possível identificar o titular do domínio no qual ocorra eventual abuso ou mau uso da Internet no Brasil, sendo que esse titular, por sua vez, tem condições técnicas de identificar exatamente o nome do usuário seu que acessou a Internet em dado instante, ou então, no mínimo, o IP de quem tenha acessado seu domínio. É possível, inclusive, o rastreamento de conexões, em articulação com o CERT.br e outros CSIRTs nacionais e internacionais, bem como através da colaboração entre autoridades.

A lei, entretanto, não exige o cadastro dos usuários dos endereços IP. Uma eventual alteração do Decreto 4.829/2003 poderia fazê-lo, indiretamente, ao exigir como um dos compromissos do requerente a domínio ".br" a constituição e manutenção de tal cadastro de usuários, mas não poderia obrigá-lo ao repasse desses dados por se referirem a terceiros e por não ser o CGI.br provido de poder de polícia.

Ademais, o simples repasse da base de dados de usuários não permite necessariamente ligar um número de IP a uma pessoa, pois a maioria dos provedores, por economia, atribui a cada conexão um número aleatório disponível no momento ("IP dinâmico"), e não um fixo ("IP fixo"). Não há, também, uma obrigação legal de

\footnotetext{
${ }^{709}$ Artigo $8^{\circ}$, parágrafo $1^{\circ}$, da Resolução 002/2005 do CGI.br.

${ }^{710}$ Ver artigo $5^{\circ}$ da Resolução 002/2005 do CGI.br.

${ }^{711}$ Ver artigo $9^{\circ}$, parágrafo $1^{\circ}$, incisos III e V, e artigo 10, inciso III, alínea “c”, da Resolução 002/2005 do CGI.br.
} 
armazenamento dos registros de conexão ("logs"), cabendo a cada provedor decidir se e por quanto tempo mantém tais informações.

Desse modo, não existindo um órgão regulador com poder de polícia relativo à Internet, isto é, uma autoridade pública, e nem outras obrigações decorrentes de qualquer lei que estabeleça aos provedores de acesso deveres específicos para facilitar a investigação de fatos, essa matéria fica relegada a eventuais normas esparsas e à vontade dos agentes do mercado (fornecedores dos serviços e usuários).

À ANATEL, conforme a Lei 9.472/1997, cabe apenas regular as condições de acesso, pelos interessados, ao uso das redes de telecomunicações para a prestação de "serviços de valor adicionado", como o de acesso à Internet ${ }^{712}$, já que esse tipo de serviço não é considerado "serviço de telecomunicação"713. Ou seja, o serviço de acesso à Internet não é regulado pela Lei 9.472/1997 nem, portanto, pela ANATEL, mas os meios de acesso (via cabo ou rádio), sim, devendo a empresa que deseje provê-los obter autorização para explorar serviço de telecomunicação que dê suporte a essa atividade (ANATEL, 2008) ${ }^{714}$.

Não lhe compete, também, escapando ao âmbito da Lei 9.472/1997 e da Lei 8.977/1995, "Lei do Serviço de TV a Cabo", a regulação de redes fechadas de transmissão de dados, as denominadas "intranets".

No tocante ao VoIP, a ANATEL afirma não lhe competir a regulação da tecnologia em si, mas só do serviço, desde que haja qualquer atribuição conferida por lei (ANATEL, 2005). Aliás, esse é praticamente o teor do artigo 22, "caput", do Regulamento dos Serviços de Telecomunicações, aprovado pela Resolução 73, de 25 de novembro de 1998, da ANATEL.

O Regulamento do Serviço de Comunicação Multimídia, aprovado no Anexo à Resolução 272/2001, da ANATEL, dispõe sobre a autorização para a oferta de capacidade de transmissão, emissão e recepção de informações multimídia, utilizando quaisquer meios, a assinantes dentro de uma área de prestação de serviço ${ }^{715}$. Essa autorização é a comumente utilizada para aqueles que desejam explorar os meios de acesso à Internet ${ }^{716}$.

\footnotetext{
${ }^{712}$ Artigo 61, parágrafo $2^{\circ}$.

${ }^{713}$ Artigo 61, parágrafo $1^{\circ}$.

${ }^{714}$ Por exemplo, o artigo $7^{\circ}$ do Anexo à Resolução 272, de 9 de agosto de 2001, da ANATEL, que aprovou o Regulamento do Serviço de Comunicação Multimídia ("SCM"), garante aos interessados o uso das redes de suporte do "SCM" para provimentos de "serviços de valor adicionado", de forma não discriminatória e a preços e condições justos e razoáveis.

715 Artigo $3^{\circ}$, "caput", artigo 4", inciso VI, e artigo 10 do Regulamento. "Informações multimídia" são "sinais de áudio, vídeo, dados, voz e outros sons, imagens, textos e outras informações de qualquer natureza", de acordo com o artigo $4^{\circ}$, inciso I, desse Regulamento.

${ }^{716}$ Mas esse Serviço de Comunicação Multimídia é diferenciado, pelo Regulamento, do Serviço Telefônico Fixo Comutado destinado ao uso do público em geral (STFC) e dos serviços de comunicação eletrônica de
} 
Esse Regulamento dispõe:

Art. 57. A prestadora observará o dever de zelar estritamente pelo sigilo inerente aos serviços de telecomunicações e pela confidencialidade quanto aos dados e informações do assinante, empregando todos os meios e tecnologia necessárias [sic: necessários] para assegurar este direito dos usuários.

Parágrafo único. A prestadora tornará disponíveis os dados referentes à suspensão de sigilo de telecomunicações para a autoridade judiciária ou legalmente investida desses poderes que determinar a suspensão de sigilo.

Arrola, dentre os direitos do assinante, a inviolabilidade e o segredo de sua comunicação, respeitadas as hipóteses e condições constitucionais e legais de quebra de sigilo de telecomunicações ${ }^{717}$.

O Regulamento do Serviço Telefônico Fixo Comutado Destinado ao Uso do Público em Geral - STFC, aprovado pela Resolução 426, de 9 de dezembro de 2005, da ANATEL, dispõe que "independentemente da tecnologia aplicada na construção de redes de suporte ao STFC, devem ser cumpridos integralmente os requisitos técnicos e estruturais de continuidade, acesso, disponibilidade e confidencialidade, estabelecidos na regulamentação" ${ }^{, 18}$. Além disso, enumera como direitos dos usuários ${ }^{719}$ : (i) a inviolabilidade e o segredo de sua comunicação, respeitadas as hipóteses e condições constitucionais e legais de quebra de sigilo de telecomunicações e as atividades de intermediação da comunicação dos portadores de deficiência, nos termos da regulamentação; (ii) a privacidade nos documentos de cobrança e na utilização, pela prestadora, de seus dados pessoais não constantes da Lista Telefônica Obrigatória e Gratuita ("LTOG”), os quais não podem ser compartilhados com terceiros, ainda que coligados, sem prévia e expressa autorização do usuário, ressalvados os dados necessários para fins exclusivos de faturamento; (iii) obtenção gratuita, mediante solicitação encaminhada ao serviço de atendimento de usuários mantido pela prestadora, da não divulgação do seu código de acesso em relação de assinantes e no serviço de informação

massa, tais como o Serviço de Radiodifusão, o Serviço de TV a Cabo, o Serviço de Distribuição de Sinais Multiponto Multicanal (MMDS) e o Serviço de Distribuição de Sinais de Televisão e de Áudio por Assinatura via Satélite (DTH) (artigo $3^{\circ}$, parágrafo único, do Regulamento), e não se permite a oferta de serviço com as características do STFC, em especial o encaminhamento de tráfego telefônico por meio da rede de SCM simultaneamente originado e terminado nas redes do STFC (artigo 66). A ANATEL ressalta que "[...] contratos de prestação de SCM não podem impor restrições à transmissão de nenhum tipo de sinal (áudio, vídeo, dados, voz e outros sons, imagens, textos e outras informações), por ser um serviço abrangente que, por definição, possibilita a oferta de capacidade de transmissão, emissão e recepção de informações multimídia definidas como sinais de áudio, vídeo, dados, voz e outros sons, imagens, textos e outras informações" (ANATEL, 2005, destaque dela).

${ }^{717}$ Artigo 59, inciso V.

${ }^{718}$ Artigo 10, inciso VI.

${ }^{719}$ Artigo 11, incisos VI, XI, XV e XXIV, respectivamente. 
de código de acesso de assinante do STFC; e (iv) comunicação prévia da inclusão do nome do assinante em cadastros, bancos de dados, fichas ou registros de inadimplentes, condicionado à manutenção de seu cadastro atualizado junto à prestadora.

$\mathrm{O}$ artigo 23 desse Regulamento atribui à prestadora a responsabilidade pela manutenção do sigilo das comunicações em toda a rede, exceto nas dependências do imóvel indicado pelo assinante, bem como pela "confidencialidade" dos "dados e informações", através dos meios e tecnologias que assegurem o correspondente direito do usuário, enquanto o artigo 24 determina que, em caráter oneroso ${ }^{720}$,

[a] prestadora deve tornar disponíveis os recursos tecnológicos e facilidades necessários à suspensão de sigilo de telecomunicações, determinada por autoridade judiciária ou legalmente investida desses poderes, e manter controle permanente de todos os casos, acompanhando a efetivação dessas determinações, e zelando para que elas sejam cumpridas, dentro dos estritos limites autorizados.

O artigo 25 dispõe não constituir quebra de sigilo a identificação, pelo assinante chamado, do assinante que origina a chamada, quando este não põe restrição à sua identificação, devendo a prestadora oferecer as facilidades de bloqueio de identificação do usuário que origina a chamada, bem como a de bloqueio de chamada a ele dirigida.

A Lei 8.977/1995, por sua vez, não estabelece, diretamente, qualquer direito ou dever atinente ao sigilo das comunicações, remetendo, genericamente, à aplicabilidade dos preceitos da legislação de telecomunicações em vigor e de outros regulamentos baixados pelo Poder Executivo ${ }^{721}$, o que é praticamente repetido pelo Regulamento aprovado pelo Decreto 2.206, de 14 de abril de 1997. Fica a critério do intérprete, portanto, encontrar as normas específicas que se aplicam ao setor, lembrando que também pelo serviço de televisão a cabo podem trafegar dados, seja através do acesso à Internet, considerado serviço de valor adicionado, seja através de voz, pelo VoIP, por exemplo, com as limitações legais inerentes a cada tipo de "licença", quando aplicável"

Enfim, a legislação de telecomunicações artificialmente cria diversos tipos de prestação de serviços submetidos a variados tipos de "licença" (concessão, permissão ou autorização), tendo importância a tecnologia da rede a ser usada na exploração do que ela define como "serviço de telecomunicação" (por exemplo, se cabo ou rádio), mas não a empregada no tráfego das informações (se digital ou analógica, se é utilizado o protocolo

\footnotetext{
${ }^{720}$ Artigo 24, parágrafo $1^{\circ}$.

${ }^{721}$ Artigo $1^{\circ}$.

${ }^{722} \mathrm{O}$ que tem ocorrido, comumente, é a celebração de contratos entre empresas detentoras de concessão para serviço de televisão a cabo e de "licença" para prestação de STFC, a fim de se permitir o livre trânsito de comunicações de voz de uma rede para outra.
} 
VoIP ou outro qualquer).

Desse modo, um titular de uma autorização para prestar SCM não pode, a princípio, prestar STFC, mesmo que por tecnologia VoIP, se não obtiver a "licença" adequada, direta ou indiretamente.

Especificamente no tocante ao sigilo das comunicações, a legislação trata da sua proteção sem atentar com maior rigor para as peculiaridades de cada tecnologia, permitindo, de qualquer forma, sem detalhar, o seu levantamento por decisão de autoridade judicial ou legalmente competente para tanto.

A interceptação "tradicional", que se dá entre dois ou mais aparelhos telefônicos que se conectam por um meio que não permite armazenamento das informações que por ele trafegam, só capta o objeto de comunicações que se dão, legalmente, a partir do momento da decisão competente, quando começa o procedimento de escuta. Nesse caso, poucas dúvidas restam quanto às obrigações do prestador de serviço, que tem de disponibilizar os meios necessários a atender tal requisição.

Contudo, o que ocorre no caso das comunicações que trafegam por meios eletrônicos, por exemplo, que podem ser sempre armazenadas e, portanto, capturadas, por sua própria natureza? Devem os prestadores de SCM ou STFC guardar todo o tráfego que por eles passa, a fim de fornecer provas para uma eventual investigação autorizada ou iniciada por autoridade competente? Se sim, por quanto tempo?

Pela legislação em vigor, a postura da ANATEL é correta, no sentido de que não pode extrapolar sua competência para estabelecer normas relacionadas às tecnologias empregadas no acesso à Internet ou a outras redes públicas que não se enquadrem no conceito de "serviço de telecomunicação" ou no de garantia de acesso isonômico às redes de telecomunicações aos prestadores de "serviços de valor adicionado", como os de acesso à Internet.

Porém, isso não significa que a regulação não deve adaptar-se às especificidades das tecnologias, principalmente quando a legislação é dúbia. Explica-se: se as normas do setor devem focar no serviço prestado e nos meios de acesso, e se nada impede que um STFC ocorra por VoIP, que tecnicamente configura "transmissão de dados", embora regulatoriamente encaixe-se na categoria de comunicação por voz (telefonia), qual regra sobre sigilo aplicar-se-ia, a mais restritiva, das comunicações telefônicas, que só podem ser interceptadas para apuração de crimes na forma da Lei 9.296/1996, ou, em tese, a mais 
branda, de dados $?^{723}$

Não fica claro, também, se a interceptação poderia incidir sobre quaisquer das informações trafegadas, como, por exemplo, textos de cunho íntimo, vídeos e fotos, enfim, informações não disponíveis nas comunicações telefônicas "comuns", que permitem um nível mais detalhado de conhecimento acerca do indivíduo.

Por último, a legislação é obscura quanto a eventual competência da ANATEL para regular e fiscalizar o sigilo de certos tipos de comunicação eletrônica que trafegam pela Internet, como os "e-mails", por exemplo, que não contenham a voz.

\subsection{Perspectivas concretas de regulação da matéria.}

Vários projetos relacionados ao tema da privacidade nas comunicações eletrônicas foram apresentados ao longo das duas últimas décadas na Câmara dos Deputados e no Senado Federal. Neste Capítulo, destacamos alguns deles atualmente ativos (em tramitação).

Assim, passamos diretamente aos Projetos de Lei, procurando analisá-los no seu estágio mais recente no processo legislativo, com o objetivo de evitar duplicidade de enumeração, quando possível, e de discorrer sobre um texto, não raro, abandonado ou largamente modificado ${ }^{724}$.

\subsubsection{Projetos de Lei em trâmite no Senado Federal.}

O Projeto de Lei do Senado ("PLS") 135/2003725, que "[d]ispõe sobre os crimes contra a intimidade e a vida privada das pessoas [...] em conformidade com o inciso $\mathrm{X}$ do artigo $5^{\circ}$ da Constituição Federal", objetiva acrescentar o artigo 139-A ao Código Penal, nesses termos:

Art. 139-A Tornar público fato da intimidade e da vida privada das pessoas, sem a autorização devida:

Pena - detenção de 1 (um) a 6 (seis) meses e multa.

\footnotetext{
${ }^{723}$ Se se entender que os dados "estáticos", armazenados, mesmo que incidentalmente, não constituem fluxo de dados e seriam, por exemplo, meros arquivos.

${ }^{724}$ Observamos que não obtivemos registro, nas páginas da Internet das duas instituições, de Propostas de Emenda à Constituição tratando das comunicações, da informática ou da privacidade.

${ }^{725}$ Publicado no Diário do Senado Federal de 16 de abril de 2003, p. 07801. Esse Projeto é praticamente uma "repetição" do PLS 283/2001, arquivado em 26 de março de 2003.
} 
A sua justificativa observa:

[o]s crimes contra a honra já encontram-se devidamente regulamentados. De forma semelhante, podemos observar a existência de diversas ações de reparação por uso indevido da imagem das pessoas, mas nada existe no sentido de garantir a intimidade e a vida privada das pessoas, um dos direitos fundamentais garantido no art. $5^{\circ}$ da Constituição Federal.

O PLS 95/2003 “dispõe sobre a privacidade na Internet”, estabelecendo a obrigação de sigilo a provedores de acesso, órgãos públicos, comerciantes, prestadores de serviços, e a outros que, em virtude de suas atividades, venham a receber informações de terceiros, a título oneroso ou não. Estabelece também o direito de acesso a qualquer pessoa sobre informações suas detidas por quaisquer pessoas físicas ou jurídicas, bem como a possibilidade de levantamento do sigilo pelo Ministério Público quando necessário para suas investigações. Define ainda "informação pessoal" como "aquela, de qualquer natureza, pertinente à pessoa, tais como seus hábitos, seus interesses, sua identificação, seus endereços físicos e virtuais e seus meios financeiros", e cria alguns tipos penais.

O PLS 87/2004 727 , a seu turno, trata da privacidade dos usuários de programas de computador ("softwares"), acrescentando os artigos $8^{\circ}$-A a $8^{\circ}$-C à Lei 9.609, de 19 de fevereiro de 1998, que regula a propriedade intelectual de tais programas, e tem por objetivo principal acabar com o que denomina "espionagem eletrônica", isto é, a instalação, na máquina do usuário, de rotinas de programação, sem seu conhecimento, total ou parcial, que têm por fim coletar informações sub-repticiamente e enviar ao computador do "espião".

Se nesses Projetos mencionados parece haver uma ênfase na proteção do indivíduo, outros existem em que o enfoque é o combate ao abuso ou mau uso de um direito e à criminalidade, ou a atos anti-sociais, praticados através da tecnologia da eletrônica (“informática”). Dentre esses, podem-se citar: (i) o PLS 279/2003 ${ }^{728}$, que pretende obrigar os prestadores de serviço de correio eletrônico via Internet a cadastrar seus usuários, devendo velar pela veracidade das informações prestadas, inclusive mediante compartilhamento de informações com outras instituições, e determina o armazenamento de um "extrato" das comunicações por dez anos, atribuindo à ANATEL a competência

\footnotetext{
${ }^{726}$ Publicado no Diário do Senado Federal de 2 de abril de 2003, p. 05646. Encontra-se desde 24 de janeiro de 2007 na Comissão de Constituição, Justiça e Cidadania ("CCJ").

${ }^{727}$ Publicado no Diário do Senado Federal de 16 de abril de 2004, p. 10323. Encontra-se desde 6 de fevereiro de 2007 na CCJ.

${ }_{728}$ Publicado no Diário do Senado Federal de 16 de julho de 2003, p. 18087-8. Desde 24 de janeiro de 2007 na CCJ.
} 
para fazer valer essa lei, assegurado o sigilo; (ii) o PLS 463/2003 ${ }^{729}$, que obriga os provedores de hospedagem de páginas na Internet a fornecer, sob pena de multa, trimestralmente, ao Departamento de Classificação Indicativa do Ministério da Justiça, relação completa das páginas que hospedam, bem como dos responsáveis por sua elaboração, com o objetivo de coibir e punir a prática da pedofilia; (iii) os PLS 367/2003, $36 / 2004$ e $21 / 2004^{730}$, que tramitam em conjunto, que almejam coibir as mensagens eletrônicas não solicitadas ("spam”), comerciais ou publicitárias, estabelecendo obrigações para identificação do responsável pelo seu envio e do responsável pela base de dados ou cadastro de endereços utilizado, a proibição de os provedores de acesso à Internet fornecerem a terceiros os endereços eletrônicos de seus clientes, sem autorização expressa, inclusive com a criação de um cadastro nacional em que se publicaria lista com opção de rejeição total ou parcial de usuários para o recebimento de tal tipo de mensagem, gerenciado, curiosamente, pela entidade governamental responsável pelo Cadastro Nacional de Registro de Identificação Civil, criado pela Lei 9.454/1997, não regulamentada até hoje; e (iv) o PLS 151/2000, enviado à Câmara dos Deputados, que prevê, em síntese, que os provedores de acesso à Internet devem manter, obrigatoriamente, cadastro dos seus clientes e registro das conexões realizadas através deles pelo período de um ano, de modo a permitir identificá-los, restringindo o fornecimento dessas informações às autoridades somente por determinação judicial ${ }^{731}$.

Procurando atualizar a presente legislação sobre interceptações telefônicas, citamos o PLS 230/2006 ${ }^{732}$ e o PLS 321/2007 $7^{733}$.

O primeiro basicamente aumenta o escopo da Lei 9.296/1996, estendendo a proteção a "comunicações de qualquer natureza", inclui o crime de interceptação de comunicações sem autorização judicial ou com objetivos não autorizados em lei dentre as hipóteses de não concessão de fiança, no artigo 323 do Código de Processo Penal, e explicita que a prova obtida em desacordo com essa Lei será nula de pleno direito, não

\footnotetext{
${ }^{729}$ Publicado no Diário do Senado Federal de 14 de novembro de 2003, p. 36938. Encaminhado ao Plenário, em 26 de setembro de 2007, para votação do Requerimento 711/2007 para que seja remetido à Comissão de Ciência, Tecnologia, Inovação, Comunicação e Informática (“CCT”).

${ }^{730}$ Publicado no Diário do Senado Federal de 3 de março de 2004, p. 05503-4. Esses três Projetos foram avaliados pela CCJ, com parecer pela rejeição dos PLS 367/2003 e 36/2004 e aprovação, na forma do substitutivo, do PLS 21/2004, e encontram-se, atualmente, aguardando apreciação do plenário de requerimento para que sejam enviados à apreciação da CCT.

${ }^{731}$ Publicado no Diário do Senado Federal de 6 de setembro de 2001, p. 20926, conforme Substitutivo aprovado pela Comissão de Educação do Senado (“CE”).

${ }_{732}$ Publicado no Diário do Senado Federal de 26 de julho de 2006, p. 25020-1.

${ }^{733}$ Publicado no Diário do Senado Federal de 13 de junho de 2007, p. 19380-1, reapresentando o mesmo conteúdo do PLS 44/2005, arquivado.
} 
produzindo efeito "jurídico-processual", além de restringir a possibilidade de o juiz autorizar de ofício a interceptação somente em caso de "clamor público".

O segundo, sem relação com o PLS 230/2006, modifica a Lei 9.296/1996 para acabar com o prazo das interceptações, em caso de "indispensabilidade" da prova, e cria para as empresas telefônicas a obrigação de conservação, pelo prazo mínimo de três anos, da data, horário da ligação, terminal de origem e destino, números dos telefones conectados e proprietários das linhas, independentemente da origem ou destino das chamadas.

O Projeto de Lei 525/2007 $7^{734}$, remetido à Câmara dos Deputados, onde se tornou o PL 4.047/2008 e foi apensado ao PL 1.258/1995, que propõe nova regulamentação às interceptações, proíbe

[...] a comercialização de equipamentos destinados especificamente à interceptação, escuta, gravação e decodificação das comunicações telefônicas, incluindo programas de informática e aparelhos de varredura, salvo nas hipóteses e condições fixadas no regulamento desta Lei, sendo obrigatório o registro no órgão competente ${ }^{735}$.

O PLS 741/2007, aprovado em decisão terminativa pela CCJ, sem recurso, em 24 de novembro de 2008, e enviado à Câmara dos Deputados, obriga os fabricantes e os comerciantes de equipamentos de escuta e monitoramento telefônico a comunicarem ao Departamento de Polícia Federal os dados cadastrais de quem os adquira, mesmo que o equipamento tenha sido cedido a título provisório ou precário ${ }^{736}$.

Destaque-se ainda o PLS 321/2004, que "[d]ispõe sobre a proteção, o tratamento e o uso de dados pessoais e dá outras providências", que abrange tanto pessoas físicas e jurídicas, independentemente do mecanismo utilizado no tratamento, quando sua coleta, armazenamento ou utilização ocorrer em território nacional ou em local onde seja aplicável a lei brasileira ${ }^{737}$.

Esse Projeto traz várias definições, dentre as quais destacamos: (i) "dado pessoal": toda informação, de qualquer natureza e independentemente do respectivo suporte, passível de ser armazenada, processada ou transmitida, relativa a pessoas identificadas ou identificáveis; (ii) "tratamento de dados pessoais": qualquer operação ou conjunto de operações, em um ou mais bancos de dados, independentemente do mecanismo utilizado; (iii) "tratamento": a pesquisa, o recolhimento, o registro, a organização, a classificação, a

\footnotetext{
${ }^{734}$ Texto disponível no "site" da Câmara dos Deputados: <http://www.camara.gov.br>.

${ }^{735}$ Artigo 26.

${ }^{736}$ Texto disponível no "site" do Senado Federal: $<$ http://www.senado.gov.br>.

${ }^{737}$ Artigo $1^{\circ}$, "caput" e parágrafo único.
} 
comparação, a valoração, a conservação, a modificação, a adaptação, a alteração, a recuperação, a consulta, a utilização, a transferência, a transmissão, por difusão ou por qualquer outra forma de comunicação, a interconexão, o bloqueio, o descarte e a destruição da informação; (iv) "dados sensíveis": informações pessoais que revelem a origem racial ou étnica, as opiniões políticas, as convicções religiosas, ideológicas ou filosóficas, a filiação e atuação sindical, o estado de saúde ou a orientação sexual da pessoa natural titular dos dados, bem como as informações genéticas; e (v) "interconexão de dados": forma de tratamento de informações pessoais que consiste na transferência de dados de um banco a outro, mantido ou não pelo mesmo proprietário, com finalidade semelhante ou distinta.

Ele procura restringir o tratamento dos dados às finalidades para os quais é coletado, e determina, no mínimo, a ciência do titular dos dados, quando não for exigida expressa, específica e inequívoca autorização, como para os "dados sensíveis" e a interconexão internacional de dados.

São previstos uma série de direitos do titular dos dados, que concernem, essencialmente, à informação e controle sobre eles, com os correlativos deveres dos proprietários e gestores dos bancos de dados.

Refere-se expressamente à proteção da vida privada e da intimidade e ao dever de sigilo e sua abrangência, necessário à proteção dos dados, traz nova definição de banco de dados público ${ }^{738}$ e define banco de dados privado, estabelecendo responsabilidade civil objetiva, com direito à reparação expressa por danos materiais e morais decorrentes do tratamento irregular ou ilícito dos dados, dos proprietários e gestores dos bancos de dados, além de sanções administrativas aplicáveis pelas autoridades a que forem atribuídas, em cada nível federativo, tal competência, como multa, suspensão temporária de atividade, intervenção administrativa e interdição, total ou parcial, da atividade exercida pelo proprietário ou gestor de banco de dados, mantendo a Lei 8.159/1991, que dispõe sobre a política nacional de arquivos públicos e privados.

\subsubsection{Projetos de Lei em trâmite na Câmara dos Deputados.}

Existem na Câmara dos Deputados vários Projetos de Lei ("PL") cuidando de diferentes aspectos ou pontos da privacidade, como: (i) a proteção contra a violação do

${ }^{738}$ Mais abrangente do que o conceito da Lei 9.507/1997. 
direito por meio das ligações telefônicas indesejadas de "telemarketing": PL 866/2007 739 , apensado ao PL 2387/2003 ${ }^{740}$; (ii) a regulação de bancos de dados de proteção ao crédito e de relações comerciais: PL 5.961/2005 $5^{741}$, apensado ao PL 836/2003 ${ }^{742}$, sendo que ambos tramitam conjuntamente com uma série de Projetos que tratam do mesmo assunto; e (iii) a regulação e tarifação dos danos morais relativos à honra, nome, imagem e intimidade: PL $7.124 / 2002^{743}$, ao qual outros foram apensados.

O PL 3.016/2000 ${ }^{744}$, ao qual foram apensados outros Projetos, como o 5.403/2001, sendo criada Comissão Especial para deliberar sobre todos, trata do registro de todas as “transações" efetuadas e de cadastro de usuários por provedores de acesso a redes de computadores destinadas a uso público, inclusive a Internet, com prazo mínimo para o armazenamento dessas informações e penalidades pelo descumprimento dessa obrigação.

O PL 29/2007 745 , com o qual tramitam outros Projetos, “dispõe sobre a organização e exploração das atividades de comunicação social eletrônica", mas nada traz a respeito da privacidade e proteção de dados pessoais.

O PL 1.704/2007 746 , na forma do Substitutivo aprovado na CCJ, por sua vez, tipifica o crime de violação de correspondência e comunicações eletrônicas, ao alterar a redação do artigo 151 do Código Penal:

Art. 151. Devassar indevidamente o conteúdo de correspondência real ou eletrônica fechada, dirigida a outrem:

$\S 10$

II - quem indevidamente divulga, transmite a outrem ou utiliza abusivamente comunicação telegráfica, radioelétrica ou eletrônica dirigida a terceiro, ou conversação telefônica entre outras pessoas;

$\S 3^{\circ}$ - Se o agente comete o crime, com abuso de função em serviço postal, telegráfico, radioelétrico, eletrônico ou telefônico:

O PL 2.186/2003 ${ }^{747}$, em trâmite com outros, pretende coibir o "spam” através de

\footnotetext{
${ }^{739}$ Publicado no Diário da Câmara dos Deputados de 9 de maio de 2007, p. 21711-21712.

${ }^{740}$ Publicado no Diário da Câmara dos Deputados de 12 de novembro de 2003, p. 60655-60656.

${ }^{741}$ Publicado no Diário da Câmara dos Deputados de 12 de outubro de 2005, p. 49629-49633.

742 Publicado no Diário da Câmara dos Deputados de 20 de maio de 2003, p. 21439-21440.

${ }^{743}$ Publicado no Diário da Câmara dos Deputados de 29 de agosto de 2002, p. 41170.

${ }^{744}$ Publicado no Diário da Câmara dos Deputados de 25 de maio de 2000, 27200-27201.

745 Publicado no Diário da Câmara dos Deputados de 28 de fevereiro de 2007, p. 06828-06831, encontra-se em fase de audiência pública na Comissão de Defesa do Consumidor (“CDC”), segundo informação disponível no "site" da Câmara dos Deputados: <http://www.camara.gov.br>.

746 Publicado no Diário da Câmara dos Deputados de 24 de agosto de 2007, p. 42176, parecer da "CCJ" publicado no Diário da Câmara dos Deputados de 23 de abril de 2008, p. 16901, Col. 01, Letra A.

${ }^{747}$ Publicado no Diário da Câmara dos Deputados de 22 de outubro de 2003, p. 55973-55974, redação do
} 
um sistema de "opt-in", isto é, as mensagens comerciais só poderiam ser enviadas quando os destinatários tiverem aceitado recebê-las, ou quando já houvesse relação comercial préexistente entre remetente e destinatário, criando para os provedores a obrigação de manter registro das transações de envio de grandes volumes de mensagens eletrônicas, manter e divulgar relação de usuários que optem pelo recebimento de mensagens comerciais e colocar à disposição dos usuários, gratuitamente, programas para eliminação das mensagens indesejadas.

Alguns Projetos para combater as "organizações criminosas", como o PL $7.622 / 2006^{748}$, apensado ao PL $2.751 / 2000^{749}$, prevêem a possibilidade de as autoridades, mediante simples "requerimento" ou "ofício", terem imediato acesso a todos os dados cadastrais bancários, informações eleitorais, comerciais, de provedores de Internet e dados telefônicos de interesse da investigação.

O PL 4.361/2004 $4^{750}$ prevê a obrigação de as "lan houses" e congêneres criar e manter cadastro atualizado de seus clientes e determina o armazenamento dessas informações por sessenta meses, condicionado o seu fornecimento a ordem ou autorização judicial.

Existem, ainda, os Projetos que tratam dos crimes informáticos ou praticados com uso da informática, como o PL 84/1999 ${ }^{751}$, que, dentre outros, tipifica: (i) a obtenção, transferência ou fornecimento não autorizado de dado ou informação em rede de computadores, dispositivo de comunicação ou sistema informatizado; (ii) a divulgação, utilização, disponibilização ou comercialização de dados e informações pessoais contidas em sistema informatizado com finalidade distinta da que motivou seu registro; e (iii) a interrupção ou perturbação de serviço telegráfico, telefônico, informático, telemático,

Substitutivo aprovado nos termos do parecer do Relator da Comissão de Ciência e Tecnologia, Comunicação e Informática da Câmara dos Deputados, segundo informação disponível no "site" da Câmara dos Deputados: <http://www.camara.gov.br>.

${ }^{748}$ Publicado no Diário da Câmara dos Deputados de 21 de dezembro de 2006, p. 56449-56450.

${ }^{749}$ Publicado no Diário da Câmara dos Deputados de 18 de abril de 2000, p. 16171-16172.

750 Publicado no Diário da Câmara dos Deputados de 18 de novembro de 2004, p. 49405, redação do Substitutivo na forma do parecer do Relator da Comissão de Seguridade Social e Família de 11 de setembro de 2007, segundo informação disponível no "site" da Câmara dos Deputados: <http://www.camara.gov.br>. No Estado de São Paulo, há a Lei Estadual 12.228, de 11 de janeiro de 2006, que obriga os estabelecimentos comerciais que ofertam a locação de computadores e máquinas para acesso à Internet, utilização de programas e de jogos eletrônicos a criar e manter cadastro atualizado dos seus usuários, contendo nome completo, data de nascimento, endereço, telefone e número do documento de identidade (artigo $2^{\circ}$, incisos I a $\mathrm{V})$, bem como do registro da hora inicial e final de acesso, com a identificação do usuário e da máquina por ele utilizada, pelo prazo mínimo de sessenta meses (artigo $2^{\circ}$, parágrafos $2^{\circ}$ e $4^{\circ}$ ). Além disso, proíbe o fornecimento desses dados a terceiros, salvo por autorização expressa do usuário, ou ordem ou autorização judicial.

${ }^{751}$ Publicado no Diário da Câmara dos Deputados de 11 de maio de 1999, p. 19975-19976, texto aprovado pelo Senado Federal publicado no Diário da Câmara dos Deputados de 9 de agosto de 2008, p. 36340-36346. 
dispositivo de comunicação, rede de computadores ou sistema informatizado.

Traz algumas definições, dentre as quais destacamos: (i) "dados informáticos": qualquer representação de fatos, de informações ou de conceitos sob forma suscetível de processamento numa rede de computadores ou dispositivo de comunicação ou sistema informatizado; e (ii) "dados de tráfego": todos os dados informáticos relacionados com sua comunicação efetuada por meio de uma rede de computadores, sistema informatizado ou dispositivo de comunicação, gerados por eles como elemento de uma cadeia de comunicação, indicando origem da comunicação, o destino, o trajeto, a hora, a data, o tamanho, a duração ou o tipo do serviço subjacente.

Por último, estabelece a obrigação ao responsável pelo provimento de acesso à rede de computadores mundial, comercial ou do setor público de manter em ambiente controlado e de segurança, pelo prazo de três anos, com o objetivo de provimento de investigação pública formalizada, os dados de endereçamento eletrônico da origem, hora, data e a referência "GMT" da conexão efetuada por meio de rede de computadores e fornecê-los exclusivamente à autoridade investigatória mediante prévia requisição judicial, além da de colaborar com as autoridades, resguardado o sigilo, inclusive informando-as sobre denúncias que tenham recebido e que contenham indícios da prática de crime sujeito a acionamento penal público incondicionado, cuja perpetração haja ocorrido no âmbito da rede de computadores sob sua responsabilidade.

O PL 1.713/1996 ${ }^{752}$, além de trazer novos tipos penais, objetiva regular as redes integradas de computadores e alguns de seus aspectos, dentre os quais o uso das informações constantes em bancos de dados, definindo informações pessoais (aquelas que permitam a identificação direta ou indireta de alguém) e proibindo a disseminação das informações sensíveis (origens raciais, opiniões políticas, filosóficas, religiosas ou sexuais e a filiação a qualquer entidade), salvo autorização expressa de seu titular. Proíbe também que qualquer decisão administrativa ou judicial baseie-se, exclusivamente, para a definição do perfil do acusado ou da parte, em dados obtidos mediante o cruzamento de informações automatizadas, condicionando esse cruzamento para obtenção de dados sigilosos a ordem judicial.

${ }^{752}$ Publicado no Diário da Câmara dos Deputados de 18 de abril de 1996, p. 10032-10035. 
O PL 1.443/2007 $7^{753}$ propunha a alteração ampla da Lei 9.296/1996. Dentre as principais mudanças, encontrava-se a inclusão em seu âmbito da captação de imagem e som ambiental, e o estabelecimento de um rol exaustivo de crimes que autorizavam a interceptação: (i) terrorismo; (ii) tráfico de substância entorpecente e drogas afins; (iii) tráfico de pessoas e subtração de incapazes; (iv) quadrilha ou bando; (v) contra a administração pública; (vi) contra a ordem econômica e financeira; (vii) falsificação de moeda; (viii) extorsão simples e extorsão mediante seqüestro; (ix) contrabando; (x) homicídio qualificado e roubo seguido de morte; (xi) estupro e atentado violento ao pudor; (xii) ameaça ou injúria quando cometidas por telefone; e (xiii) outros decorrentes de organização criminosa.

Proibia a interceptação e gravação de comunicação mantida entre o suspeito ou acusado e seu defensor, relativamente aos fatos objeto de apuração em inquérito policial ou processo penal, vedando o uso de prova obtida desse modo.

Informações de outros crimes detectados de maneira fortuita, praticados por pessoas que não eram alvo de investigação, não seriam aceitas como prova, salvo se o indiciado estivesse na iminência de cometimento de um delito.

As autoridades policiais deveriam instruir os pedidos de interceptação ou captação com cópia da portaria do inquérito policial instaurado a respeito, sendo-lhes assegurado o direito de acesso ao cadastro de assinantes das concessionárias do serviço público de telefonia, mediante senha pessoal e intransferível.

Estabelecia o prazo máximo de trinta dias para a medida, renovável uma única vez, se comprovada a indispensabilidade da prova, salvo nos casos de terrorismo e de extorsão mediante seqüestro, em que não haveria prazo, e previa a criação de bancos de dados nos Tribunais referentes aos pedidos de interceptação e captação, "com a finalidade de fiscalizar e evitar a concessão simultânea dessa medida".

Também permitia ao juiz que deferiu a medida que autorizasse a divulgação do conteúdo da interceptação ou captação, desde que não houvesse a possibilidade de comprometer a produção de prova no inquérito policial ou no processo penal e de causar prejuízo material ou moral ao investigado ou acusado, assegurado o acesso a todos os órgãos de imprensa, sem distinção e em audiência pública.

Por fim, trazia alguns tipos penais, aumentando a abrangência do previsto no artigo 10 da Lei 9.296 e criando outros com o objetivo de coibir a divulgação não autorizada de

\footnotetext{
${ }^{753}$ Publicado no Diário da Câmara dos Deputados de 12 de julho de 2007, p. 35689.
} 
conteúdo das comunicações, inclusive por autoridades, e de evitar obstáculos na execução das medidas de interceptação ou captação, bem como previa o direito de resposta daquele atingido pela quebra indevida do sigilo, em espaço proporcional ao da notícia.

Esse Projeto acabou sendo apensado, como outros, ao PL 1.258/1995 ${ }^{754}$, o qual, na forma do parecer da Comissão de Segurança Pública e Combate ao Crime Organizado ${ }^{755}$, adota propostas semelhantes às do PL 1.443/2007.

De diferente, considera lícita a prova vinda de captação de imagem e som ambiental, independentemente de autorização judicial, que constitua registro de flagrante de infração penal; remove o rol de crimes, exigindo apenas a existência de indício de prática de qualquer um; e retira o prazo de interceptação e captação também nos casos de tráfico de entorpecentes, tráfico de armas e improbidade administrativa.

O PL 3.893/2008 ${ }^{756}$ altera a Lei 6.538/1978, sob a justificativa de "explicitar" a ausência do sigilo do correio eletrônico corporativo, renumerando o parágrafo único para $1^{\circ}$, para acrescer o seguinte parágrafo $2^{\circ}$ ao seu artigo $5^{\circ}$, que se refere à inviolabilidade do sigilo da correspondência:

Excluem-se das disposições previstas no caput e no $\S 1^{\circ}$ deste artigo as correspondências eletrônicas encaminhadas ou recebidas por sistemas de correio eletrônico corporativo mantidos por organizações privadas e fornecidos para seus empregados, funcionários, terceirizados, estagiários, bolsistas e assemelhados para o uso exclusivamente no interesse do serviço.

Finalmente, há o PL 3.272/2008 ${ }^{757}$, ao qual foi apensado o PL 4.036/2008 ${ }^{758}$, ambos de iniciativa do Poder Executivo, abordados a seguir. Seus textos encontram-se nos Anexos B e C.

\subsubsection{O Anteprojeto da Comissão de Juristas do Ministério da Justiça de 2003 e os Projetos de Lei 3.272/2008 e 4.036/2008.}

Buscando melhorar a sistematização e tratamento do levantamento do sigilo das comunicações, o Ministério da Justiça instituiu, através da Portaria/MJ no 116, de 13 de

\footnotetext{
${ }^{754}$ Publicado no Diário da Câmara dos Deputados de 12 de janeiro de 1996, p. 00524.

755 Publicado no Diário da Câmara dos Deputados de 8 de fevereiro de 2008, página 0568.

${ }^{756}$ Publicado no Diário da Câmara dos Deputados de 15 de setembro de 2008, encontra-se desde essa data na Comissão de Trabalho, de Administração e Serviço Público, segundo informação disponível no "site" da Câmara dos Deputados: 〈http://www.camara.gov.br>.

${ }_{757}^{75}$ Publicado no Diário da Câmara dos Deputados de 26 de abril de 2008, p. 17698-17703.

758 Publicado no Diário da Câmara dos Deputados de 26 de setembro de 2008, segundo informação disponível no "site" da Câmara dos Deputados: <http://www.camara.gov.br>.
} 
fevereiro de 2003, uma Comissão de Juristas, composta por Ada Pellegrini Grinover, Antônio Carlos de Almeida Castro, Antônio Magalhães Gomes Filho, Antônio Scarance Fernandes e Luiz Guilherme Vieira, de que resultou a apresentação, no mesmo ano, de um Anteprojeto ao Ministro ${ }^{759}$.

$\mathrm{O}$ artigo $1^{\circ}$ trazia uma lista exaustiva de crimes que autorizavam a "interceptação, o impedimento, a interrupção, a escuta e a gravação das comunicações telefônicas”, nos seus incisos I a XIV: (i) tráfico de substâncias entorpecentes e drogas afins; (ii) tráfico de seres humanos e subtração de incapazes; (iii) tráfico de armas, munições e explosivos; (iv) tráfico de espécimes da fauna silvestre; (v) lavagem de dinheiro; (vi) contra o sistema financeiro nacional; (vii) contra a ordem econômica e tributária; (viii) contra a administração pública, desde que punidos com pena de reclusão; (ix) falsificação de moeda ou a ela assimilados; (x) roubo, extorsão simples, extorsão mediante seqüestro, seqüestro e cárcere privado; (xi) homicídio doloso; (xii) ameaça quando cometida por telefone; (xiii) decorrente de ações praticadas por organização criminosa; e (xiv) decorrente de ações de terrorismo.

Equiparava às "comunicações telefônicas" todas as formas de telecomunicação, em referência expressa à definição do artigo 60, parágrafo $1^{\circ}$, da Lei 9.472/1997 ${ }^{760}$, e determinava sua aplicação a conversas entre presentes:

\footnotetext{
[a]s gravações clandestinas de conversas entre presentes, bem como a captação e a interceptação ambiental de sinais eletromagnéticos, óticos ou acústicos, e o seu registro, análise e utilização, sujeitam-se às mesmas regras previstas nesta lei, no que forem cabíveis ${ }^{761}$.
}

Por outro lado, apesar de eximir da regulação da Lei "a gravação de conversa própria, sem conhecimento do interlocutor, por telefone ou por outros meios", restringia sua divulgação ao exercício regular de um direito ${ }^{762}$.

O Anteprojeto atribuía legitimidade para pleitear ao juiz o deferimento de qualquer das medidas ${ }^{763}$ : (i) à autoridade policial, ouvido o Ministério Público; (ii) ao próprio Ministério Público; (iii) ao ofendido ou seu representante legal, na hipótese de ameaça cometida por telefone; e (iv) ao suspeito ou acusado.

Os requisitos para concessão do pedido eram detalhados e rígidos, exigindo-se a demonstração da estrita necessidade da operação técnica e da impossibilidade de a prova

\footnotetext{
${ }^{759}$ Ver Anexo A desta dissertação.

${ }^{760}$ Artigo $1^{\circ}$, parágrafo único.

${ }^{761}$ Artigo $2^{\circ}$.

${ }^{762}$ Artigo $4^{\circ}$.

${ }^{763}$ Artigo $5^{\circ}$, "caput" e parágrafo $2^{\circ}$.
} 
ser obtida por outros meios ${ }^{764}$, podendo a autoridade policial e o Ministério Público requisitarem das prestadoras de serviço de telefonia, exclusivamente para instruir o pleito, o cadastro relativo ao nome, número de telefone e endereço do titular da linha ou do local onde o aparelho estivesse instalado ${ }^{765}$.

O sujeito passivo era o "investigado"766, sendo que da decisão judicial autorizadora da medida deveria constar obrigatoriamente a "indicação de indícios suficientes de autoria ou participação do investigado em qualquer dos crimes referidos no artigo $1^{\circ}$, salvo impossibilidade manifesta devidamente justificada" ${ }^{267}$. Vedava, ainda, quaisquer das operações do artigo $1^{\circ}$, "caput", e artigo $2^{\circ}$ relativamente às comunicações que se dessem entre o suspeito ou acusado e seu defensor ${ }^{768}$.

Esse procedimento deveria ser distribuído e autuado apartadamente, sob segredo de justiça $^{769}$, cabendo recurso em sentido estrito, sem efeito suspensivo, "devendo o tribunal, se for o caso, determinar a inutilização da prova eventualmente obtida, bem como a sua forma, de modo a preservar a intimidade dos envolvidos" ${ }^{\text {770 }}$. Esse recurso deveria ser processado sem a oitiva do acusado ou suspeito, em caso de indeferimento ${ }^{771}$.

Um dos pontos principais do Anteprojeto estava no seu artigo $9^{\circ}$, que estipulava o prazo máximo de quinze dias para as operações, renovável por igual período, sempre por ordem judicial motivada, desde que permanecessem os requisitos autorizadores da medida, até o total de sessenta dias. Exceção a esse prazo máximo dava-se em relação aos crimes permanentes, enquanto não cessasse a permanência. Além disso, a partir do segundo pedido de renovação, exigia-se a apresentação ao juiz de relatório circunstanciado das operações realizadas até o momento para se verificar a "excepcionalidade" no caso concreto.

Outra parte de destaque era a tratada no Capítulo V, que, cuidando "[d]a utilização da prova resultante das operações", procedendo a uma espécie de regulação específica, no âmbito dessa Lei, do inciso LVI do artigo $5^{\circ}$ da Constituição Federal ${ }^{772}$, proibia peremptoriamente o uso de quaisquer resultados de interceptação, impedimento, interrupção, escuta e gravação, realizados fora dos casos, modalidades e formas

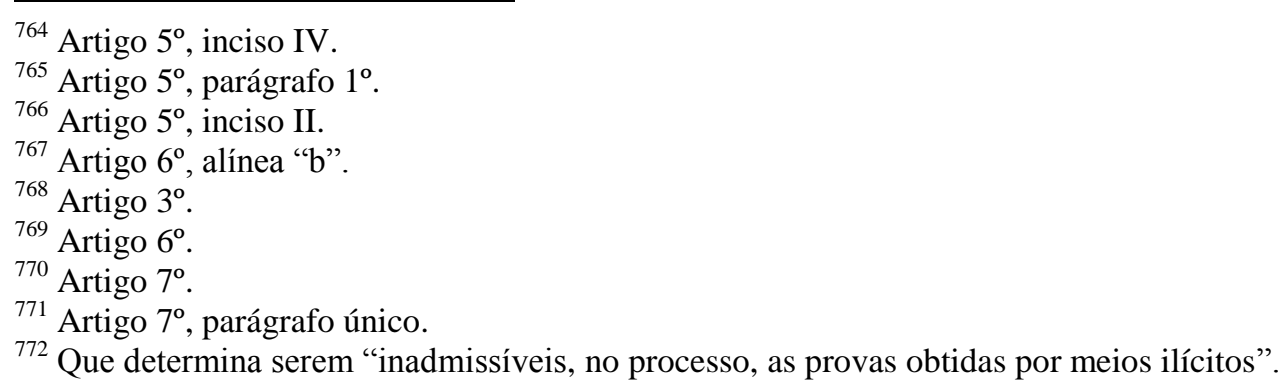


estabelecidos na lei, como prova "em qualquer investigação, processo ou procedimento, seja qual for sua natureza",773, ou para instrução de processos ou investigações relativos a crimes diversos daqueles para que foi concedida a autorização, salvo quando se tratasse de crime conexo ou então algum daqueles arrolados no artigo $1^{\circ}$, outra hipótese de deflagração do denominado "incidente probatório" dos artigos 16 e $17^{774}$.

$\mathrm{O}$ “incidente probatório" era um mecanismo que dava acesso às partes ao material colhido, a fim de concretizar a ampla defesa. Exaurida a diligência, o juiz daria ciência ao Ministério Público, ao suspeito ou acusado e a seu defensor ${ }^{775}$, que teriam um prazo mínimo de dez dias para examinar os autos circunstanciados, escutar as gravações e indicar os trechos que desejassem transcritos ${ }^{776}$. Ao juiz competiria, então, determinar a transcrição dos trechos pedidos, bem como daqueles que entendesse "pertinentes e relevantes" $" 777$. As dúvidas a respeito da gravação ou da voz seriam dirimidas pelo magistrado, com aplicação, no que coubesse, dos artigos 145 a 148 do Código de Processo Penal, que tratam do "incidente de falsidade" "778, sendo que das decisões judiciais dessa fase caberia o recurso em sentido estrito, com efeito suspensivo restrito ao incidente probatório $^{779}$.

Uma das cópias das gravações ou registros análogos ficaria nos autos, outra ficaria arquivada para consulta pelas partes, em juízo, durante todo o trâmite do processo, até o trânsito em julgado, quando deveriam ser destruídas na forma indicada pelo magistrado ${ }^{780}$. Essas cópias deveriam vir acompanhandas de autos circunstanciados com o resumo das operações.

Os inquéritos ou processos que contivessem elementos informativos obtidos na forma do Anteprojeto correriam em segredo de justiça, ressalvadas as prerrogativas das partes e do defensor ${ }^{781}$.

O objetivo expresso do segredo de justiça e da destruição posterior dos registros das comunicações era o de velar pela "intimidade dos envolvidos",782 e "pela preservação da inviolabilidade e privacidade da prova",783.

\footnotetext{
773 Artigo 18.

774 Artigo 19.

${ }_{775}$ Artigo 16, "caput”.

${ }^{776}$ Artigo 16, parágrafo $1^{\circ}$

${ }^{777}$ Artigo 16, parágrafo $2^{\circ}$

${ }^{778}$ Artigo 16, parágrafo $3^{\circ}$

${ }^{779}$ Artigo 16, parágrafo $4^{\circ}$.

${ }^{780}$ Ver artigos 12, parágrafo único, e 17, “caput” e parágrafo único.

${ }^{781}$ Artigo 28.

${ }^{782}$ Artigo 17, "caput", parte final.

${ }^{783}$ Artigo 17, parágrafo único, parte final.
} 
Por sua vez, os dados relativos a origem, destino e duração das chamadas telefônicas deveriam ser mantidos pelas operadoras pelo prazo de cinco anos ${ }^{784}$.

Outros dispositivos regulavam aspectos burocráticos e técnicos, com a finalidade de centralizar o controle e realização das operações permitidas na proposta de lei, através da criação de um órgão próprio e exclusivo, sob responsabilidade direta da Chefia de Polícia e sujeito à fiscalização do Ministério Público, atribuindo competências regulamentares ao Ministério da Justiça e à ANATEL ${ }^{785}$, além de prever ressarcimento às prestadores de serviços de telecomunicações pela operações realizadas na forma do Anteprojeto ${ }^{786}$.

Por fim, criava vários tipos penais ${ }^{787}$, que englobavam a conduta de realizar as operações descritas no "caput" do artigo $1^{\circ}$ fora dos casos previstos no Anteprojeto, bem como a de divulgar as comunicações gravadas, inclusive conversa própria, sem o conhecimento do interlocutor, salvo para o exercício regular de um direito ${ }^{788}$.

O Ministério da Justiça acolheu partes desse Anteprojeto, além de sugestões de vários órgãos públicos, entidades públicas e privadas e profissionais do setor ${ }^{789}$, e, em 16 de abril de 2008, o Poder Executivo federal encaminhou à Câmara dos Deputados a Mensagem 190/2008, que se tornou o Projeto de Lei 3.272/2008, cujo objeto é a regulamentação da parte final do inciso XII do artigo $5^{\circ}$ da Constituição Federal, com a revogação expressa da Lei 9.296/1996 $6^{790}$, trazendo algumas mudanças.

Continua a se aplicar aos sistemas de "tecnologia da informação e telemática",791, mas também dispõe que se considera "quebra do sigilo das comunicações telefônicas de qualquer natureza todo ato que intervém no curso dessas comunicações com a finalidade de conhecer as informações que estão sendo transmitidas, incluindo a interceptação, escuta e gravação" ${ }^{\text {792 }}$, sujeitando o registro, a análise e a utilização dessas informações ao quanto aplicável dessa lei ${ }^{793}$. Mas questão como a da inviolabilidade das mensagens eletrônicas, mormente quando ainda armazenadas no servidor do computador do provedor do serviço,

\footnotetext{
${ }^{784}$ Artigo 29, parágrafo único.

${ }^{785}$ Ver, por exemplo, artigos 12 a 14.

${ }^{786}$ Artigo 15.

${ }^{787}$ Artigos 20 a 27.

788 Artigo 23.

${ }^{789}$ Ver Exposição de Motivos no 37, EMI no 0037 MJ/MC, no Anexo B desta dissertação.

${ }^{790}$ Artigo 26.

${ }^{791}$ Artigo $1^{\circ}$, parágrafo $3^{\circ}$. Segundo a sua Exposição de Motivos, "[o Projeto de Lei,] no § $3^{\circ}$, estende ao fluxo de comunicações em sistemas de tecnologia da informação e telemática a possibilidade de quebra do sigilo, entendendo, como o fazem juristas do porte de Tércio Sampaio Ferraz, entre outros, que a Constituição ao dizer comunicação telefônica refere-se a todo e qualquer meio de comunicação instantânea sendo, portanto, possível a quebra deste sigilo embasada por ordem judicial" (destaque do original).

${ }^{792}$ Artigo $1^{\circ}$, parágrafo $1^{\circ}$.

${ }^{793}$ Artigo $1^{\circ}$, parágrafo $3^{\circ}$.
} 
continua não resolvida.

Além disso, não prevê certas regulações específicas necessárias a seu melhor cumprimento, como, por exemplo, uma eventual obrigação de armazenar os dados externos das comunicações, especialmente das eletrônicas, por certo prazo, pelas prestadoras de serviços de telecomunicações.

Por sua vez, a gravação de conversa própria é afastada do âmbito de aplicação do Projeto de $\mathrm{Lei}^{794}$, mas inclui “[a]s gravações ambientais de qualquer natureza, quando realizadas pela autoridade policial" ${ }^{\text {795 }}$.

A interceptação continua a ser permitida para todos os crimes apenados com reclusão, mas estende-se a autorização para aqueles apenados somente com detenção, nos casos em que a conduta delituosa tiver sido realizada por meio dessas modalidades de comunicação ${ }^{796}$. Desse modo, o critério principal continuar sendo a pena em abstrato de reclusão, o que já abarca um vasto número de crimes, e inclui uma permissão bastante aberta, relacionada ao meio por que se realiza a conduta, qualquer que seja ${ }^{797}$.

O pedido de interceptação pode ser feito somente pela autoridade policial, ouvido o Ministério Público, ou por este, excluída a possibilidade de o ofendido e do acusado ou investigado o fazer ${ }^{798}$

O Projeto de Lei dispõe sobre os requisitos que o pedido e a decisão autorizadora da medida devem apresentar, mas não permite que se requeira diretamente à prestadora de serviço de telecomunicações dados cadastrais do indivíduo sujeito à interceptação.

$\mathrm{O}$ procedimento concernente à medida de levantamento do sigilo deve ser distribuído e autuado em apartado, correndo em segredo de justiça ${ }^{799}$, que abrange também os inquéritos e processos que contiverem elementos informativos ou provas obtidos na

\footnotetext{
${ }^{794}$ Artigo $3^{\circ}$.

795 Artigo 20.

${ }^{796}$ Artigo $2^{\circ}$.

797 A Exposição de Motivos desse Projeto de Lei afirma: “[a]ponta-se na doutrina especializada como grande defeito da atual Lei de Interceptação (Lei no 9.296, de 24 de julho de 1996), a inobservância do princípio da proporcionalidade, pois ao mesmo tempo em que permite a quebra do sigilo das comunicações telefônicas de qualquer natureza relativamente a todos os crimes punidos com reclusão, independentemente da conduta criminosa, deixa à margem os crimes punidos com detenção para os quais a quebra do sigilo se apresentaria como meio mais adequado de investigação como, por exemplo, no crime de ameaça feita pelo telefone. Este defeito é corrigido no art. $2^{\circ}$ do texto pretendido que, mantendo a previsão de quebra do sigilo de comunicações telefônicas de qualquer natureza para as hipóteses relacionadas a crimes apenados com reclusão, estende esse mecanismo de investigação/prova aos delitos apenados com detenção quando a conduta delituosa tiver sido cometida através de meios de comunicação instantânea. Assim, crimes como ameaça e estelionato, quando praticados pelo telefone, não ficarão fora da possível quebra do sigilo de comunicações telefônicas, o que facilitará de forma significativa a apuração e elucidação do caso, em respeito ao princípio da proporcionalidade".

798 Artigo $4^{\circ}$.

799 Artigo 50, "caput".
} 
forma do Projeto de $\mathrm{Lei}^{800}$.

Da decisão que indeferir o pedido, cabe recurso em sentido estrito do Ministério Público, que tramitará também em segredo de justiça, sem oitiva do investigado ou acusado, podendo o relator deferir liminarmente a "quebra"

O prazo para interceptação não pode exceder períodos de sessenta dias, renováveis por iguais e sucessivos períodos, desde que permaneçam os pressupostos autorizadores da medida, até o máximo de trezentos e sessenta dias, salvo em caso de crime permanente, enquanto durar a permanência ${ }^{802}$. Cada renovação depende de ordem judicial ${ }^{803}$, mas não se exige mais qualquer requisito de demonstração de excepcional necessidade da renovação da interceptação no pedido e na decisão judicial. Se o investigado ou acusado passar a usar outro número, código ou identificação, a autoridade policial deve fazer novo pedido ao juiz ${ }^{804}$.

A interceptação deve ser implementada pela prestadora de serviços de comunicação, sob supervisão da autoridade policial e fiscalização do Ministério Público ${ }^{805}$. Terminadas as diligências, o juiz deve intimar o acusado ou investigado para que se manifeste sobre a interceptação, “fornecendo-lhe cópia identificável de todo o material produzido" ${ }^{\text {806 }}$.

Os registros das comunicações devem ser mantidos em cartório enquanto a decisão judicial não transitar em julgado, e pelo menos enquanto for possível a revisão criminal ${ }^{807}$.

Proíbe-se a utilização da prova obtida por meio da quebra de sigilo das comunicações telefônicas de qualquer natureza realizada sem a observância dessa Lei "em qualquer investigação, processo ou procedimento, seja qual for sua natureza" ${ }^{\text {" }}$, mas se surgirem indícios de crime diverso daquele para o qual a autorização foi dada e que não lhe seja conexo, "a autoridade deverá remeter ao Ministério Público os documentos necessários para as providências cabíveis" ${ }^{\circ 09}$.

Nas "Disposições Finais", autoriza o Poder Executivo a instituir, para fins

\footnotetext{
${ }^{800}$ Artigo 18.

${ }^{801}$ Artigo 6 ${ }^{\circ}$, “caput” e parágrafo único.

${ }^{802}$ Artigo $5^{\circ}$, parágrafo $1^{\circ}$.

${ }^{803}$ Artigo $5^{\circ}$, parágrafo $3^{\circ}$.

${ }^{804}$ Artigo $5^{\circ}$, parágrafo $4^{\circ}$.

${ }^{805}$ Artigos $8^{\circ}$ e $9^{\circ}$.

${ }^{806}$ Artigo 13. De acordo com a Exposição de Motivos do Projeto de Lei: “[a]ssim substitui-se a obrigação de transcrição das cópias destinadas às partes, muitas vezes infactível dependendo da quantidade de horas gravadas, pela entrega de cópias identificáveis com o mesmo teor da versão original”.

${ }^{807}$ Artigo 15, "caput" e parágrafo único.

808 Artigo 17.

${ }^{809}$ Artigo 16.
} 
exclusivamente estatísticos e de planejamento de ações policiais, sistema centralizado de informações sobre quebra de sigilo de comunicações telefônicas de qualquer natureza, na forma do regulamento, que "não conterá o conteúdo das comunicações realizadas nem os códigos de identificação ou outros elementos e meios capazes de identificar os envolvidos, inclusive investigados e acusados" ${ }^{\prime 10}$, além de estabelecer a gratuidade da implementação das interceptações por parte das prestadoras de serviço ${ }^{811}$.

Por fim, insere o artigo 151-A no Código Penal, que tipifica a violação de sigilo de comunicação telefônica de qualquer natureza, sem autorização judicial ou com objetivos não autorizados em lei ${ }^{812}$, e determina a aplicação subsidiária das disposições do Código de Processo Penal e do Código de Processo Penal Militar ${ }^{813}$.

"Complementando" esse Projeto de Lei, ao qual foi apensado, sobrepondo-se-lhe em alguns pontos, o Poder Executivo encaminhou à Câmara dos Deputados o PL 4.036/2008, que traz as seguintes modificações: (i) revoga o artigo 10 da Lei 9.296/1996 e o inciso II do parágrafo $1^{\circ}$ do artigo 151 do Código Penal; (ii) altera a redação do inciso III desse mesmo parágrafo $1^{\circ}$; (iii) insere os artigos 151-A e 151-B ao Código Penal, que tratam, respectivamente: (a) das condutas de "[r]ealizar, diretamente ou por meio de terceiros, ou permitir que se realize, interceptação de comunicação de qualquer natureza, sem autorização judicial ou com objetivos não autorizados em lei" ${ }^{814}$, "violar o sigilo ou o segredo de justiça das informações obtidas por meio de interceptação de comunicação de qualquer natureza; ou" \$15 “utilizar o resultado de interceptação de comunicação telefônica ou telemática para fins diversos dos previstos em lei" importar, comercializar, oferecer, emprestar, adquirir, possuir, manter sob sua guarda ou ter em depósito, sem autorização ou em desacordo com determinação legal ou regulamentar, equipamentos destinados especificamente à interceptação, escuta, gravação e

\footnotetext{
${ }^{810}$ Artigo 21, "caput” e parágrafo único. "O referido sistema será utilizado, assim como outros países já o fazem, como elemento de controle da sociedade sobre esse meio de invasão de privacidade que é a quebra do sigilo das comunicações telefônicas de qualquer natureza. Objetivará informar a quantidade de quebras de sigilo autorizadas e em curso em cada unidade da Federação, as espécies de crimes, o tempo médio de sua duração, entre outras informações de cunho exclusivamente estatístico a serem disciplinadas em regulamento", conforme a Exposição de Motivos do Projeto de Lei.

${ }^{811}$ Artigo 22.

${ }^{812}$ Artigo 23. De acordo com a Exposição de Motivos, “[...] o art. 23 traz para o âmbito do Código Penal a conduta delituosa prevista na atual Lei de escuta, por ser de melhor técnica jurídica. Com efeito, corrige-se a forma pela qual o tipo penal hoje é previsto, sem, contudo, modificar o núcleo do tipo. Destarte, não se trata de criminalizar nova conduta, nem de 'abolitio criminis', visto tratar-se de mera adequação redacional, em consonância com a construção dos tipos penais pátrios”.

${ }^{813}$ Artigo 25.

${ }^{814}$ Redação proposta para o artigo 151-A, "caput”.

${ }^{815}$ Redação proposta para o artigo $151-\mathrm{A}$, parágrafo $1^{\circ}$, inciso I.

${ }^{816}$ Redação proposta para o artigo $151-A$, parágrafo $1^{\circ}$, inciso II.
} 
decodificação das comunicações telefônicas, incluindo programas de informática e aparelhos de varredura" ${ }^{\wedge 17}$; e a (iv) previsão da pena de demissão aos funcionários da União que realizarem, direta ou indiretamente, sem autorização judicial ou com objetivos não autorizados em lei, bem como que violarem o sigilo ou segredo de justiça das informações obtidas por meio de interceptação ${ }^{818}$.

\subsection{Análise crítica das perspectivas de regulação, levando-se em consideração o sistema vigente no país, nos Estados Unidos da América e no âmbito supranacional europeu.}

Como apontado na Exposição de Motivos do Anteprojeto e na Mensagem que acompanha o Projeto de Lei 3.272/2008 aludido, e como deflui da Convenção sobre o Cibercrime e de seu Relatório Explicativo, bem como da jurisprudência da Corte Européia de Direitos Humanos e de vários julgados do STF e do STJ, deve haver uma adequação entre o direito à privacidade e interesses públicos específicos e de terceiros.

As restrições ao poder das autoridades em geral existem para permitir que o indivíduo possa desenvolver plenamente sua personalidade sem receio de censura prévia ou posterior, e sem que sofra repressões ou represálias de toda ordem. Por isso se instituiu, dentre outros, o voto secreto, a proteção da casa e a inviolabilidade das comunicações.

Argumenta-se que os direitos fundamentais, como a privacidade, não podem ser usados para acobertar ilícitos. Mas a legislação, amparada no texto constitucional, prevê formas e condições para que se os investiguem. Não existem direitos absolutos, mas devese ter em mente que a interferência do Estado na vida do indivíduo, especialmente no que tange à sua liberdade, também não pode ser absoluta. Ou seja, a pergunta que deve ser feita é: quando pode o Estado pôr um indivíduo sob vigilância e como isso deve ocorrer? ? $^{819}$

103. [...], os critérios do artigo 30 [da Convenção Americana de Direitos Humanos $]^{820}$ aplicam-se de fato a todos os casos em que a expressão lei ou locuções equivalentes são empregadas pela Convenção a propósito das restrições

\footnotetext{
${ }^{817}$ Redação proposta para o artigo 151-B, “caput”.

${ }^{818}$ Ver artigos $1^{\circ}$ e $2^{\circ}$.

${ }^{819}$ Sykes (2000, p. 19, tradução nossa) argumenta: “A questão não é necessariamente se você tem algo a esconder; é se você deve ter algum controle sobre quem sabe - ou quem tem acesso - aos detalhes da sua vida. [...]". No original: "The question is not necessarily whether you have anything to hide; it is whether you should have some control over who knows - or who has access to - the details of your life. [...]".

${ }^{820}$ Dispõe esse artigo 30: "As restrições permitidas, de acordo com esta Convenção, ao gozo e exercício dos direitos e liberdades nela reconhecidos, não podem ser aplicadas senão de acordo com leis que forem promulgadas por motivo de interesse geral e com o propósito para o qual houverem sido estabelecidas" (Anexo ao Decreto 678/1992).
} 
que ela mesma autoriza a respeito de cada um dos direitos protegidos. $\mathrm{O}$ artigo 30 não pode ser interpretado como uma espécie de autorização geral para estabelecer novas restrições aos direitos protegidos pela Convenção, que se agregaria às limitações permitidas na regulamentação particular de cada um deles. Pelo contrário, o que o artigo pretende é impor uma condição adicional para que as restrições, singularmente autorizadas, sejam legítimas.

104. A redação do artigo 30 [...] autoriza a possibilidade de limitar ou restringir certas liberdades e direitos convencionalmente garantidos, observando-se para isso o cumprimento de determinadas e taxativas condições, entre as quais que a medida não seja ilegítima, que obedeça a motivos de interesse geral e que não se distancie do propósito desta última natureza, para o qual foi implementada.

105. Por esse motivo, a proteção dos direitos humanos requer que os atos estatais que os afetem de maneira fundamental não fiquem ao arbítrio do poder público, mas que sejam cercados de um conjunto de garantias destinadas a assegurar que não sejam infringidos os atributos invioláveis da pessoa, dentre as quais talvez a mais relevante deva ser que as limitações sejam determinadas por uma lei aprovada pelo Poder Legislativo, de acordo com o disposto na Constituição. (OEA, 2007, p. 18, destaque nosso) ${ }^{821}$.

Esquecer ou desconsiderar a proteção do indivíduo contra o poder estatal a fim de perseguir a qualquer custo a ordem e a segurança públicas é dar margem à instituição de um Estado Policial, em que todos devem sujeitar-se ao escrutínio diuturno das autoridades com o objetivo de assegurar a estrita obediência às leis, com prejuízo da individualidade ${ }^{822}$. O Estado, cujas competências e limites são estabelecidos pela Constituição Federal, existe como um garantidor de uma convivência social pacífica, como um instrumento

\footnotetext{
${ }^{821}$ Nesse sentido, CIDH (1986).

${ }^{822}$ Nesse sentido, Doneda (2006, p. 142). Comentando o artigo 32, número 8, da Constituição de Portugal, anotam Miranda e Medeiros (2005, p. 362): “[a] realização da justiça do caso é um valor constitucional, mas não é um valor absoluto, que possa ser perseguido por qualquer forma. Quando os meios utilizados para a obtenção das provas forem proibidos ou condicionados pela Constituição para a salvaguarda de outros valores, os elementos probatórios por essa forma obtidos não podem ser utilizados em circunstância alguma; ficam radicalmente inquinados do vício de inconstitucionalidade e o sistema não pode tolerar que a Justiça seja prosseguida por meios inconstitucionais". No âmbito processual, especialmente penal, tem-se uma limitação à persecução da verdade: “[...] a verdade material (ou real) é uma verdade histórica e, portanto, não significa que tudo está permitido. Só pode ser alcançada de acordo com os ditâmes [sic] do Estado de Direito, respeitando-se seus limites. Nem tudo é lícito no âmbito probatório. Urge compatibilizar a produção da prova com direitos fundamentais do suspeito ou acusado, tais como dignidade, intimidade etc. A intromissão na vida privada e sigilosa de uma pessoa só pode dar-se conforme o estritamente previsto em lei. É imprescindível a legitimidade da atuação estatal na origem de qualquer prova, mas principalmente na que envolve a privacidade. [...]" (L. GOMES, 1997). Para Grinover, Fernandes e Gomes Filho (2001, p. 132), a "verdade material" deve ser uma "verdade judicial, prática e, sobretudo, não uma verdade obtida a todo preço: uma verdade processualmente válida". Nesse sentido também, Avolio (2003). Na Ação Penal 479/RJ (ver Apêndice B, número 5), em trâmite no STJ, o Relator Ministro Felix Fischer afirmou: "A 'Lex Fundamentalis', expressamente, no art. $5^{\circ}$, inciso LVI, determina que 'são inadmissíveis, no processo, as provas obtidas por meios ilícitos', tendo, portanto, optado o legislador constituinte pelo [sic] prevalência da garantia do 'substantive due process of law' em detrimento da busca desmedida pela chamada verdade real. Tal postulado - o do 'due process of law' - conforme entendimento jurisprudencial consagrado pelo Pretório Excelso [no Habeas Corpus 69.912/RS] [...] Aliás, em verdade, a limitação probatória se revela no repúdio à instauração de ação penal calcada em prova obtida, quer seja por violação à normas de direito material (provas ilícitas), quer seja por violação à normas de direito processual (provas ilegítimas). Na realidade, no entanto, é de se gizar, a concepção havida, inclusive, por muitos, como ultrapassada, daquilo que vem a ser verdade real, não é aceita pela dogmática moderna. [...]" (destaques dele).
} 
atuando a favor da manutenção da coesão. É um meio, e não um fim em si mesmo ${ }^{823}$.

A segurança pública, nesse contexto, tem como objetivo coibir os comportamentos anti-sociais preventiva e repressivamente, mas enquanto e na medida do necessário para a coexistência dos indivíduos ${ }^{824}$. O Direito Penal deve ser verdadeiramente o último recurso do legislador, para proteger os bens jurídicos de maior relevância ${ }^{825}$, sob pena de se criar cidadãos autômatos com medo do governo.

Não se defende o abuso ou mau uso dos direitos fundamentais, mas tampouco se aprova a criação do indivíduo "transparente", nu aos olhos das autoridades públicas, com todas as informações disponíveis o tempo todo ${ }^{826}$.

A necessidade de se combater a criminalidade não pode transformar-se na procura indiscriminada pelo ilícito. A presunção de não culpabilidade serve de garantia contra essa conduta $^{827}$.

Algumas mudanças trazidas ao Código de Processo Penal indicam uma postura de ponderação entre a busca da verdade real e a proteção do indivíduo. O novo artigo 156,

${ }^{823}$ Aliás, a Constituição Federal, ao estabelecer como um dos fundamentos da República Federativa do Brasil a "dignidade da pessoa humana", no artigo $3^{\circ}$, inciso III, reconhece que o indivíduo não deve ser tratado como meio, mas como fim, o que, reflexamente, importa na concepção do Estado brasileiro justamente como uma entidade constituída em prol das pessoas. Tanto isso é verdade que o artigo $4^{\circ}$, no que concerne a esse ponto, põe como objetos da República, no artigo $4^{\circ}$, incisos I e IV, respectivamente, "construir uma sociedade livre, justa e solidária" e "promover o bem de todos, sem preconceitos de origem, raça, sexo, cor, idade e quaisquer outras formas de discriminação". Especificamente no tocante à prova, incluindo, portanto, as relativas às interceptações, valemo-nos de Grinover, Fernandes e Gomes Filho (2001, p. 129-130): “O direito à prova, conquanto constitucionalmente assegurado, por estar inserido nas garantias da ação e da defesa e do contraditório [...], não é absoluto, encontrando limites. [...] É que os direitos do homem, segundo a moderna doutrina constitucional, não podem ser entendidos em sentido absoluto, em face da natural restrição resultante do princípio da convivência das liberdades, pelo que não se permite que qualquer delas seja exercida de modo danoso à ordem pública e às liberdades alheias. As grandes linhas evolutivas dos direitos fundamentais, após o liberalismo, acentuaram a transformação dos direitos individuais em direitos do homem inserido na sociedade. [...] E é exatamente no processo penal, onde avulta a liberdade do indivíduo, que se torna mais nítida a necessidade de se colocarem limites à atividade instrutória. A dicotomia defesa social/direitos de liberdade assume freqüentemente conotações dramáticas no juízo penal; e a obrigação de o Estado sacrificar na medida menor possível os direitos de personalidade do acusado transforma-se na pedra de toque de um sistema de liberdades públicas”. Também nesse sentido, ver Avolio (2003).

${ }^{824}$ Ver L. Gomes (1997) e Pitombo (1999).

${ }^{825}$ Ver Jesus (1998) e Mirabete (1997).

${ }^{826}$ Segundo o Grupo de Trabalho do Artigo 29 (2007b, p. 2, tradução nossa), “o direito fundamental à privacidade e, em particular, o à autodeterminação informacional mantêm o sangue de nossas sociedades informacionais modernas mesmo em tempos em que a luta contra o terrorismo e o crime organizado torna mais difícil acertar o equilíbrio correto entre exigências de segurança e a proteção de direitos individuais. Um cidadão transparente nunca será compatível com a dignidade humana". No original: "The fundamental right to privacy and in particular the right to informational self determination remain the lifeblood of our modern information societies even in times where the fight against terrorism and organised crime makes it harder to strike the right balance between security demands and the protection of individual rights. A transparent citizen will never be compatible with human dignity" (tradução nossa). Ver também a respeito Streck (1997). ${ }^{827}$ Artigo $5^{\circ}$, inciso LVII, da Constituição Federal. Discute-se se há diferença entre "presunção de não culpabilidade" e "presunção de inocência". Entendemos, de qualquer modo, que esse dispositivo impôe o ônus da prova a quem acusa. Nesse sentido, e mais a respeito em, L. Gomes (1997), que entende ainda que esse dispositivo impõe uma regra de tratamento. 
inciso I, por exemplo, com a redação dada pela Lei 11.690/2008, estabelece que o juiz pode, de ofício, “ordenar, mesmo antes de iniciada a ação penal, a produção antecipada de provas consideradas urgentes e relevantes, observando a necessidade, adequação $e$ proporcionalidade da medida" (destaque nosso).

Essa Lei também dispõe sobre a inadmissibilidade das provas ilícitas no processo penal, que devem ser desentranhadas ${ }^{828}$, e positiva a teoria da ilicitude por derivação, ao

${ }^{828}$ Streck entende que não cabe a aplicação do princípio da proporcionalidade quanto à admissibilidade das provas obtidas com violação da Lei 9.296/1996 (1997). Há quem faça distinção entre provas ilícitas e provas ilegítimas: as primeiras constituem violação de direito material legal ou constitucional, enquanto as últimas violam normas de direito processual. As provas ilícitas seriam absolutamente vedadas, enquanto as ilegítimas teriam solução dentro do processo, com a cominação de sanções, como a nulidade. Ver a respeito, dentre outros, L. Gomes (1997), para quem a regra da inadmissibilidade da prova ilícita encontra única exceção no âmbito do processo penal, qual seja, se em favor do acusado, "porque agora interessa mais a proclamação da inocência que a preservação da intimidade ou privacidade", mas somente em seu benefício (p. 147). Nery Junior (2002, p. 159), defendendo a aplicação do princípio da proporcionalidade, entende que "[a] ilicitude do meio de obtenção de prova seria afastada quando, por exemplo, houver justificativa para a ofensa a outro direito por aquele que colhe a prova ilícita. É o caso do acusado que, para provar sua inocência, grava clandestinamente conversa telefônica entre outras duas pessoas. Age em legítima defesa, que é causa da exclusão da anti-juridicidade, de modo que essa prova antes de ser ilícita é, ao contrário, lícita, ainda que fira o direito constitucional de inviolabilidade da intimidade, previsto no art. $5^{\circ}, \mathrm{X}, \mathrm{CF}$, que, como já se disse, não é absoluto". Grinover, Fernandes e Gomes Filho (2001) também defendem a prova ilícita "pro reo", e, no que se refere à teoria das provas ilícitas por derivação, remetem às exceções da "fonte independente" ("independent source") e da descoberta inevitável ("inevitable discovery"), pela qual a prova seria descoberta por outro modo. Avolio (2003, p. 72-73), a seu turno, disserta: "[n]ão resta dúvida, como afirmou Ada Grinover, que a Constituição deixou em aberto a questão da admissibilidade das provas ilícitas por derivação. Mas se nos afigura primordial, como pareceu a Trocker, perquerir a 'ratio' das normas violadas pelo comportamento contrário à Constituição. Desta forma, efetuando o mesmo raciocínio utilizado pelo autor peninsular, se a prova ilícita tomada por referência comprometer a proteção de valores fundamentais, como a vida, a integridade física, a privacidade ou a liberdade, essa ilicitude há de contaminar a prova dela referida, tornando-a ilícita por derivação e, portanto, igualmente inadmissível no processo. [...] A questão de fundo não difere em se tratando de provas obtidas ilicitamente ou de provas ilícitas por derivação. Haverá, sempre, uma referência constitucional, cujo enfoque deverá ser o das liberdades públicas [...]", não importando, para ele, o momento processual em que surgiu a ilicitude (p. 89). A nova redação do artigo 157, "caput", do Código de Processo Penal considera ilícitas as provas obtidas "em violação a normas constitucionais ou legais", sem distinção entre materiais e processuais, e, portanto, como entendemos, tratando-as indistintamente quanto à sua inadmissibilidade no processo. A Constituição da República Portuguesa estabelece que "[s]ão nulas todas as provas obtidas mediante tortura, coaç̧ão, ofensa da integridade física ou moral da pessoa, abusiva intromissão na vida privada, no domicílio, na correspondência ou nas telecomunicações" (artigo 32, número 8). Esse artigo 32 trata das "garantias de processo criminal", e essa nulidade seria absoluta (MIRANDA; MEDEIROS, 2005, p. 362). O Código de Processo Penal de Portugal, por sua vez, estabelece a observância dos requisitos e condições dos seus artigos 187 a 189 sob pena de nulidade (artigo 190), além de dispor que "[s]ó podem valer como prova as conversações ou comunicações que: (a) O Ministério Público mandar transcrever ao órgão de polícia criminal que tiver efectuado a interceptação e a gravação e indicar como meio de prova na acusação; (b) $\mathrm{O}$ arguido transcrever a partir das cópias previstas no número anterior [que permite a ele e ao assistente examinar os suportes técnicos das conversações ou comunicações e obter cópias das partes que pretende juntar ao processo, bem como dos relatórios relativos à medida] e juntar ao requerimento de abertura da instrução ou à contestação; ou (c) $\mathrm{O}$ assistente transcrever a partir das cópias previstas no número anterior [o mesmo que se refere a alínea "b"] e juntar ao processo no prazo previsto para requerer a abertura da instrução, ainda que não a requeira ou não tenha legitimidade para o efeito" (artigo 188, número 9, alíneas "a" a "c"). O seu artigo 125, número 3, arremata, no ponto: "[r]essalvados os casos previstos na lei, são igualmente nulas, não podendo ser utilizadas, as provas obtidas mediante intromissão na vida privada, no domicílio, na correspondência ou nas telecomunicações sem o consentimento do respectivo titular". O Código de Processo Penal da Itália possui disposições similares: veda o uso do resultado das interceptações para outros procedimentos, salvo se 
determinar que são inadmissíveis as provas derivadas das ilícitas, "salvo quando não evidenciado o nexo de causalidade entre umas e outras, ou quando as derivadas puderem ser obtidas por uma fonte independente das primeiras" ${ }^{\text {}}, 29$.

A privacidade vem protegida no inciso $X$ do artigo $5^{\circ}$ da Constituição Federal, enquanto o sigilo das comunicações telefônicas vem resguardado no inciso XII, restringindo o levantamento para fins de investigação criminal e instrução processual penal $^{830}$, nas hipóteses e na forma da lei.

A extensão da regulação da interceptação das comunicações telefônicas aos sistemas de informática e telemática ${ }^{831}$ parece afrontar esse artigo $5^{\circ}$, inciso XII, pois estende a exceção a outros meios de comunicação, em oposição ao conhecido parâmetro interpretativo de que as restrições a direitos fundamentais devem ser interpretadas restritivamente, conforme lição de Maximiliano $(1981, \text { p. } 313)^{832}$.

Contudo, esse mesmo exaustivamente citado autor, na mesma obra, a partir do parágrafo seguinte ao da famosa citação, disserta:

\begin{abstract}
Entretanto em Direito Público esse preceito não pode ser aplicado à risca: o fim para que foi inserto o artigo na lei, [sic] sobreleva a tudo. Não se admite a interpretação que entrave a realização plena do escopo visado pelo texto. Dentro da letra rigorosa dele procure-se o objetivo da norma suprema; seja este atingido, e será perfeita a exegese.

$[\ldots]$

Quando as palavras forem suscetíveis de duas [ou mais] interpretações, uma estrita, outra ampla, adotar-se-á aquela que for mais consentânea com o fim
\end{abstract}

indispensável para a verificação de delitos para os quais seja obrigatória a prisão em flagrante (artigo 270, número 1) e proíbe o uso do resultado obtido fora dos casos da lei ou sem a observância das disposições dos artigos 267 e 268, números 1 e 3 , que tratam das formas e pressupostos da medida e de alguns pontos relativos à sua execução (artigo 271). Proíbe também o uso das conversas ou comunicações que tenham por objeto fatos conhecidos em razão de ministério, ofício ou profissão travadas por pessoas arroladas no artigo 200, número 1, como os ministros de confissão religiosa, os advogados e os médicos (artigo 271, número 2). Note-se que esse Código ainda prevê um procedimento relativo a documentos anônimos e atos relativos a interceptações ilegais (artigo 240), além de possuir uma disposição geral que veda a utilização de provas obtidas com violação das proibições estabelecidas pela lei, sendo que pode ser determinada sua inutilização até de ofício e em qualquer estado ou grau de jurisdição (artigo 191, números 1 e 2). Ver, a respeito, Tramontano (2008, p. 450-452). O ECPA, dos Estados Unidos da América, determina a "exclusionary rule", como visto, para alguns casos, existindo também ponderações na jurisprudência.

${ }^{829}$ Artigo 157, parágrafo $1^{\circ}$. Mais a respeito da "fonte independente de prova" em L. Gomes (1997).

${ }^{830} \mathrm{Em}$ outros países, há quem sustente a inviabilidade jurídica da determinação ou continuidade de interceptação em relação a alguém formalmente acusado e enfrentando processo penal, em virtude, por exemplo, do direito ao silêncio e da não obrigatoriedade de depor ou de dizer a verdade dos familiares próximos. Ver a respeito, dentre outros, Mata-Mouros (2003). No Brasil, a autorização para que o levantamento do sigilo ocorra no processo vem da redação conferida ao inciso XII do artigo $5^{\circ}$ da Constituição Federal pelo poder constituinte originário, inexistindo uma hierarquia interna de normas nesse sentido. Por outro lado, parece-nos que nada impede, a princípio, o legislador ordinário, o intérprete e o aplicador da lei de estabelecerem certas restrições quanto à utilização das comunicações interceptadas, principalmente em virtude do parágrafo $2^{\circ}$ desse mesmo artigo $5^{\circ}$ do texto constitucional e da concorrência de outros direitos fundamentais em jogo, como o próprio direito ao silêncio.

${ }^{831}$ Artigo $1^{\circ}$, parágrafo único da Lei 9.296/1996.

${ }^{832}$ Já mencionado em nota de rodapé do Capítulo 5.2 desta dissertação. 
transparente da norma positiva. (MAXIMILIANO, 1981, p. 313-314, destaque do autor).

Além disso, deve-se lembrar que o parágrafo $2^{\circ}$ do artigo $5^{\circ}$ da Constituição Federal dispõe que "[o]s direitos e garantias expressos nesta Constituição não excluem outros decorrentes do regime e dos princípios por ela adotados, ou dos tratados internacionais em que a República Federativa do Brasil seja parte”. Essa cláusula traz pelo menos duas implicações básicas, a nosso ver: estabelece que os incisos do artigo $5^{\circ}$ não são exaustivos, e que as garantias e direitos ali estabelecidos devem ser interpretados de forma a conferir melhor eficácia à proteção dos fins a que se destinam.

Isso significa, então, que o inciso XII deve ser aplicado de acordo com sua razão de ser, isto é, a de proteger as comunicações reservadas ${ }^{833}$ da interferência e conhecimento indiscriminado de terceiros, inclusive das autoridades públicas.

[...] O brocardo - "inclusio unius alterius est exclusio" [-], como todo argumento "a contrario", exige, talvez, ainda maior e mais discreta reserva da parte de quem o empregue no Direito Constitucional, do que se reclama em se tratando de Direito Privado. Nem sempre o fato de se mencionar um caso determinado obrigará a excluir todos os outros; nem tampouco a negativa a respeito de uma hipótese particular implicará a afirmativa tocante às demais. (MAXIMILIANO, 1981, p. 314).

Assim, a exclusão interpretativa dos "dados" da exceção constitucional tende a esvaziar o dispositivo, ou tornar sua aplicação esdrúxula, principalmente na medida em que a digitalização torne-se o padrão. Isso porque se a interceptação for possível somente quanto às comunicações telefônicas, vedada às de dados, ter-se-ia que só seria legalmente apreensível o conteúdo de comunicações telefônicas não eletrônicas, ou seja, uma ligação telefônica realizada por meio eletrônico estaria acobertada por um sigilo, a princípio, absoluto, sem nenhum motivo aparente.

Poder-se-ia contra-argumentar que seriam invioláveis todas as comunicações de dados, exceto se constituíssem comunicações telefônicas, isto é, de voz ${ }^{834}$. Contudo, o mesmo parâmetro de interpretação restritiva extremada que leva à inviolabilidade da comunicação de dados levaria ao seu sigilo qualquer que fosse seu conteúdo, inclusive a voz. Indo além, tal parâmetro levaria o aplicador da norma a entender, em última análise, que o sigilo recai sobre os "dados" em si, pois inexiste referência expressa à "comunicação" ou "transmissão" de dados, ao contrário da referência às comunicações

833 O caráter de reserva da comunicação é essencial para situá-lo nesse regime de interceptação, diferenciando-o da comunicação social. Ver, nesse sentido, Marinelli (2007, pp. 24-25).

${ }^{834}$ A própria redação do "caput" do artigo $1^{\circ}$ da Lei 9.296/1996 refere-se a comunicações telefônicas "de qualquer natureza”. 
telegráficas e telefônicas. Ou seja, os dados, em trânsito ou estáticos, seriam absolutamente resguardados.

Dificuldade parecida abater-se-ia sobre o conceito de "comunicações telefônicas". "Telefônicas" pode referir-se tanto ao conteúdo das comunicações quanto ao modo por que se dão. Num sentido estrito, "telefônicas" seriam, no primeiro caso, aquelas comunicações que contivessem a voz humana; no segundo, as que ocorressem por meio do sistema telefônico de comunicação. Qual interpretação seria mais restritiva e, portanto, mais protetora dos direitos fundamentais: a de que a interceptação poderia dar-se em relação a qualquer comunicação que tivesse a voz humana ou sobre aquelas que se dessem pelo sistema telefônico?

Em relação ao conteúdo, se o sistema for analógico, não há problema, mas se for digital, tem-se "dados" e cai-se na questão de "interpretação restritiva” já mencionada acima. Em relação ao meio, deixam-se descobertas as comunicações consideradas telefônicas que, no entanto, não necessariamente fluem pelo sistema telefônico, como pode ocorrer numa conversa por voz ocorrida pela Internet através de cabos de empresas de televisão por assinatura ${ }^{835}$.

Aliás, se um deficiente auditivo mudo, por exemplo, utilizasse um meio eletrônico de comunicação escrita instantânea que trafegasse pelos cabos de empresa de televisão por assinatura para conversar com outro, e, mais, se o "software" emulasse uma voz humana para o seu interlocutor, estaria essa conversa coberta por um sigilo absoluto, pois nem o meio nem o conteúdo seriam telefônicos, pois uma "voz" gerada por computador é apenas uma simulação, em flagrante desequilíbrio jurídico em relação àqueles que conversassem por meios não eletrônicos telefônicos, por voz.

Ademais, o argumento de que as comunicações telefônicas não deixam rastros, o que justificaria a possibilidade de interceptação apenas quanto a elas, utilizado, como visto, dentre outros, por Ferraz Junior $(1992,2001)$ e pelo STF, é convincente e, num primeiro momento, tem sentido, especialmente se se focar apenas nas comunicações telefônicas tradicionais, analógicas. Porém, não se deve esquecer que as cartas tradicionais e os telegramas somem das mãos do remetente e podem ser destruídos pelo destinatário, pois afinal, nada os obriga a mantê-los, e embora as comunicações eletrônicas deixem, naturalmente, um rastro, que pode ser tecnicamente resgatado ${ }^{836}$, é também fato que, no

\footnotetext{
${ }^{835}$ Embora seja necessária uma autorização específica da ANATEL para esse tipo de transmissão de dados, como visto no Capítulo 5.2.3 desta dissertação.

${ }^{836}$ A vulnerabilidade é inerente aos sistemas eletrônicos, porque a própria tecnologia usada na prestação dos
} 
estado atual, podem ser apagadas ou simplesmente tornarem-se parcial ou totalmente irrecuperáveis pelas sucessivas desgravações e regravações de dados realizadas pelos agentes que atuem, incidental ou diretamente, na transmissão das mensagens, e pelos interlocutores, inclusive por motivos de restrição de espaço de armazenamento.

$\mathrm{O}$ argumento da restrição da interceptação às comunicações telefônicas, então, cai por terra, principalmente em face da digitalização das redes telefônicas. Nesse cenário, a ressalva da parte final do inciso XII do artigo $5^{\circ}$ da Constituição Federal tornar-se-ia vazia e as comunicações telefônicas, uma das espécies de comunicações eletrônicas, absolutamente invioláveis.

Uma alternativa seria estabelecer a obrigatoriedade para os intermediários de armazenar, sob sigilo, o conteúdo das conversas, mas isso seria economicamente inviável e de constitucionalidade igualmente duvidosa, pois seria equivalente a obrigar as prestadoras de serviço de telefonia a gravar permanentemente as conversas realizadas por seus usuários, a fim de deixá-las a disposição de eventual requisição da justiça, importando numa ampla e indiscriminada invasão na esfera privada dos indivíduos, sem autorização judicial e sem a existência de uma investigação criminal ou de um processo penal em curso.

De qualquer modo, mesmo que se entendesse que "comunicações telefônicas" abarcaria, excepcionalmente, aquelas feitas por qualquer meio técnico, inclusive eletrônico, enfocando o meio em vez da natureza do conteúdo (a voz), chegar-se-iam a outros impasses, como, por exemplo, o de qual regime é aplicável a uma videoconferência $^{837}$ : se feita por meios eletrônicos, o da interceptação telefônica ou o do sigilo teoricamente absoluto dos dados, ou então se aplicaria o da interceptação em relação ao som, com a vedação de aquisição das imagens? Afinal, já que o vídeo não é indicado expressamente no inciso XII do artigo $5^{\circ}$, teria ele proteção, especialmente se em formato não digital, levando-se em consideração o fato de que "dados" denota tecnologia eletrônica ou informática? ${ }^{838}$

serviços enseja a produção de rastros (um "espelho") de todas as comunicações que passam por eles, não só dos denominados "dados de tráfego", mas do conteúdo, enquanto nas comunicações telefônicas tradicionais este só pode ser captado por intervenção externa (dispositivos de interceptação de toda sorte). Ver mais a respeito em B. Rodrigues (2008, tomo I, p.52). Esse fato não diminui a expectativa de reserva que se tem sobre as comunicações eletrônicas, existindo métodos para se alcançar a inviolabilidade e integridade, o mais comum a criptografia, muito utilizada em transações bancárias e comerciais efetuadas pela Internet. Sobre a criptografia, ver Barrera e Okai (1999), Colliard e Letteron (2005), Edgett (2002-2003) e Strossen (2000).

${ }^{837}$ Comunicação por imagens em movimento geralmente com som.

${ }^{838}$ É possível que toda essa confusão interpretativa tenha tido início com a extrapolação da competência da Comissão de Redação da Assembléia Constituinte que deu origem à Constituição Federal de 1988, como sustentara anteriormente Grinover (1997). Desde sua concepção, no Anteprojeto Afonso Arinos, elaborado 
pela Comissão Provisória de Estudos Constitucionais, instituída pelo Decreto 91.450, de 18 de julho de 1985, o objeto do dispositivo era a regulação do sigilo das comunicações em geral, com o estabelecimento expresso da hipótese de levantamento. Era o texto do seu artigo 38: "É inviolável o sigilo da correspondência e das comunicações em geral, salvo autorização da justiça, nos casos previstos em lei, por necessidade de investigação criminal" (Diário Oficial da República Federativa do Brasil, Seção I, Suplemento Especial ao $n^{\circ}$ 185, de 26 de setembro de 1986, p. 7). Na Comissão de Sistematização, o $1^{\circ}$ Substitutivo, proposto em 26 de janeiro de 1987, dispunha, no seu artigo 6º , parágrafo 39: "É inviolável o sigilo da correspondência e das comunicações telegráficas ou telefônicas, salvo por ordem judicial, nos casos e na forma que a lei estabelecer, para fins de instrução processual". O $2^{\circ}$ Substitutivo, que foi aprovado nessa data, propunha a seguinte redação (artigo $5^{\circ}$, parágrafo 12): "É inviolável o sigilo da correspondência e das comunicações telegráficas, telefônicas e de dados, salvo por ordem judicial, nos casos e na forma que a lei estabelecer, para fins de instrução processual". Posteriormente, votou-se favoravelmente ao destaque 6199/87, Emenda n ES 21152-8, quando se acrescentou "investigação criminal" ao lado de "instrução processual" (Diário da Assembléia Nacional Constituinte, Suplemento "C", de 21 de janeiro de 1988, p. 1000-1001). O 2 Substitutivo com essa Emenda foi o texto que chegou ao Plenário, "Projeto A", onde se lia no artigo $6^{\circ}$, parágrafo 12: "É inviolável o sigilo da correspondência e das comunicações telegráficas, telefônicas e de dados, salvo por ordem judicial, nos casos e na forma que a lei estabelecer, para fins de investigação criminal e instrução processual". Contudo, aprovou-se emenda, cujo texto não consta do Diário da Constituinte, com a finalidade de limitar a exceção do sigilo apenas às comunicações telefônicas, pelo que consta de passagem de fala transcrita de Ulysses Guimarães: “[...] A emenda resultou de um acordo no sentido de fazer com que o sigilo não prevaleça somente no caso do telefone, mas por determinação judicial e nas investigações criminais ou de instrução processual. Era muito lato o texto anterior, admitindo a vulneração do sigilo também para os demais casos correspondentes etc. Circunscrevem-se exclusivamente à censura e à escuta telefônica [...]" (Diário da Assembléia Nacional Constituinte de 4 de fevereiro de 1988, p. 6914). Na votação de emendas e destaques no segundo turno ao texto do Projeto de Constituição, aparece referência à seguinte redação (artigo $5^{\circ}$, inciso XIII): "é inviolável o sigilo da correspondência e das comunicações telegráficas [,] de dados e telefônicas, salvo, no último caso, por ordem judicial, nas hipóteses e na forma que a lei estabelecer para fins de investigação criminal e instrução processual" (Diário da Assembléia Nacional Constituinte, 4 de agosto de 1988, nº 286, p. 84). Porém, o texto que teria chegado à Comissão de Redação dispunha: "É inviolável o sigilo da correspondência e das comunicações telegráficas, de dados e telefônicas, salvo, em último caso, por ordem judicial nas hipóteses e na forma que a lei estabelecer para fins de investigação criminal e instrução processual" (Ata Circunstanciada da $4^{\mathrm{a}}$ Reunião Ordinária de 14 de setembro de 1988, Diário da Assembléia Nacional Constituinte, Suplemento B, p. 120). Lembre-se que a Comissão de Redação deveria apenas "polir" a linguagem e a redação do texto sem lhe alterar o sentido: "Do ponto de vista do Relator [da Comissão, Bernardo Cabral], o trabalho que foi feito buscou basicamente isto: eliminar erros e contradições, fundir, quando possível, textos que estivessem em demasia e, além de tudo, fazer com que tudo aquilo que fosse polêmico ou objeto de uma discussão talvez mais política ou que pudesse suscitar, pelo menos, alguma discussão política ficasse, então, como objeto de recomendação. [...] Não há inovação de texto, não há introdução de palavras que possam alterar o conteúdo básico e a intenção da norma. O que há é apenas a supressão de contradições, de palavras em demasia, de excessos, enfim, à procura de corrigir erros de concordância e, acima de tudo, propiciando o enxugamento, na busca da simplicidade do texto" (Relator Adjunto José Fogaça, Ata da $1^{\text {a }}$ Reunião Ordinária de 13 de setembro de 1988, Diário da Assembléia Nacional Constituinte, Suplemento B, p. 5). O então Constituinte Nelson Jobim, secundado por Luiz Viana, Ibsen Pinheiro e outros, chamara a atenção para esse fato: “[...] Vão surgir questões em que haverá dúvida de interpretação sobre o que foi aprovado. Se houver dúvida de interpretação nós não somos o foro competente para isso, para tentar escolher uma das interpretações possíveis e criar uma redação para substituir a decisão do Plenário que tenha escolhido entre duas interpretações" (Ata Circunstanciada da $1^{\mathrm{a}}$ Reunião Ordinária de 13 de setembro de 1988, Diário da Assembléia Nacional Constituinte, Suplemento B, p. 13). Contudo, em diversos momentos a Comissão criou, alterou ou suprimiu o sentido de normas aprovadas pelo Plenário (ver, dentre outros, p. 31 - 32 e 37 do Diário da Assembléia Nacional Constituinte, Suplemento B). Foi o que aconteceu com o inciso XII do artigo $5^{\circ}$, cuja alteração redacional atingiu o mérito. Primeiro, na $4^{\mathrm{a}}$ Reunião Ordinária, de 14 de setembro de 1988, (Ata Circunstanciada da $4^{a}$ Reunião Ordinária de 14 de setembro de 1988, Diário da Assembléia Nacional Constituinte, Suplemento B, p. 120), quando, considerado expressamente o texto aprovado pelo Plenário, acrescentou-se o adjetivo "penal" a "instrução processual", a fim de restringir a medida a este âmbito; segundo, na $8^{\text {a }}$ Reunião Ordinária, foi acrescentado "comunicações" antes de "telefônicas", com o objetivo de ampliar a proteção aos dados em si (Ata Circunstanciada da $8^{\text {a }}$ Reunião Ordinária de 14 de setembro de 1988, Diário da Assembléia Nacional Constituinte, Suplemento B p. 210), o que foi aprovado (aqui passou a ser artigo $4^{\circ}$, inciso XII). Ademais, em algum momento, após a chegada do texto no Plenário ou na Comissão 
Entendemos, portanto, que esse dispositivo constitucional objetiva assegurar, como regra, a inviolabilidade das comunicações reservadas em geral, sendo legítimo o entendimento de que protege outras formas não previstas expressamente pelo poder originário, através da aplicação do parágrafo $2^{\circ}$ do artigo $5^{\circ}$ da Constituição Federal, que autoriza uma aplicação adaptativa do texto constitucional no âmbito dos direitos fundamentais em face da realidade histórica, permitindo o levantamento do sigilo tanto das comunicações telefônicas não digitais como das de dados, isto é, das comunicações eletrônicas $^{839}$.

Só não é possível, no Brasil, pela Constituição Federal de 1988, em virtude de opção explícita feita pelo poder constituinte originário, estender a regulação da interceptação ao conteúdo das correspondências tradicionais (cartas) propriamente ditas e das comunicações telegráficas (em trânsito) ${ }^{840}$.

Isto posto, a tendência de aumentar a abrangência da regulação é observável tanto na Lei 9.296/1996 ${ }^{841}$, quanto no Anteprojeto da Comissão de Juristas do Ministério da Justiça $^{842}$ e no Projeto de Lei 3.272/2008 ${ }^{843}$, bem como nos Estados Unidos da América ${ }^{844}$, na União Européia ${ }^{845}$ e no Conselho da Europa ${ }^{846} 847$.

de Redação e a $8^{\text {a }}$ Reunião Ordinária desta, houve uma alteração no texto, na passagem "em último caso" para a redação "no último caso" (Ata Circunstanciada da $8^{a}$ Reunião Ordinária de 14 de setembro de 1988, Diário da Assembléia Nacional Constituinte, Suplemento B p. 210). Pode ter sido um lapso na leitura feita pelo Constituinte Plínio Arruda Sampaio na $4^{\mathrm{a}}$ Reunião, ou um erro na transcrição da $4^{\mathrm{a}}$ ou da $8^{\mathrm{a}}$ Reunião da Comissão de Redação, pode ser que tenha sido a emenda aprovada no Plenário, mas não encontramos nos documentos compulsados a justificativa para essa mudança nem qualquer votação a ela relativa, nem razões objetivas para essas discrepâncias.

${ }^{839}$ Para L. Gomes (1997, p. 100), “[a] locução 'comunicação telefônica', em conseqüência, está enriquecida. Não é simplesmente a conversação dos provectos anos sessenta, senão a transmissão, emissão ou recepção de símbolos, caracteres, sinais, escritos, imagens, sons ou informações de qualquer natureza, por meio da telefonia, estática ou móvel (celular)". Para esse autor, não importa o meio técnico (1997, p. 112), e, embora a Lei 9.296/1996 regule a interceptação aparentemente além do texto constitucional, também protege essas diferentes modalidades no seu artigo 10 (1997, p. 168-169).

${ }^{840}$ Outras legislações permitem a interceptação de quaisquer comunicações em dadas circunstâncias, inclusive das correspondências, como ocorre na Espanha, Portugal e Itália.

${ }^{841}$ Artigo $1^{\circ}$, "caput" e parágrafo único.

${ }^{842}$ No artigo $1^{\circ}$, parágrafo único, e artigo $2^{\circ}$, embora essa Comissão tenha expressado o entendimento de que um dos defeitos da Lei 9.296/1996 é o transbordamento da autorização constitucional para prever interceptações de comunicações em sistemas de informática, segundo Exposição de Motivos do Anteprojeto da Comissão, que pode ser consultado no Anexo A desta dissertação.

${ }^{843}$ Artigo $1^{\circ}$, parágrafo $3^{\circ}$.

${ }^{844}$ Ver ECPA.

${ }^{845}$ Artigo $2^{\circ}$, alíneas "d" e "h", e artigo $5^{\circ}$, número 1, da Diretiva 2002/58/CE, e artigo $2^{\circ}$, alínea "a", da Diretiva 2002/21/CE. Pode-se mencionar ainda a Carta de Direitos Fundamentais, que em seu artigo $7^{\circ}$ refere-se a "comunicações", termo mais amplo que correspondência, empregado no artigo $8^{\circ}$ da Convenção Européia de Direitos Humanos. Ver, nesse sentido, Eriksson (2006, p. 78 e 85).

${ }^{846}$ Artigos $2^{\circ}, 20$ e 21 da Convenção sobre o Cibercrime. Aliás, é o texto do item 206 do "Relatório Explicativo sobre a Convenção sobre o Cibercrime": "[a] interceptação de telecomunicações refere-se, normalmente, às redes de telecomunicações tradicionais. Estas redes podem incluir infra-estruturas por cabo, 
Lembre-se que o Brasil é signatário do Pacto de São José da Costa Rica, que determina que a lei deve proteger o indivíduo contra ingerências arbitrárias ou abusivas na sua vida privada e em sua correspondência ${ }^{848}$, cujos princípios devem ser observados ${ }^{849}$.

Estabelecida a abrangência do vocábulo "comunicações" 850 ("eletrônicas") nesse contexto, é necessária uma adequação do que se entende por "interceptação".

A aplicação do sentido estrito de "interceptar" (captação contemporânea à conversa por terceiro) é insuficiente para abranger todas as possibilidades de conhecimento do conteúdo das comunicações eletrônicas. Por exemplo, se os provedores de acesso à Internet

quer de cabo metálico quer de fibras ópticas, bem como interligações com redes sem fio, incluindo sistemas telefónicos móveis e sistemas de transmissão por microondas. Nos dias de hoje, também as comunicações móveis se encontram facilitadas por um sistema de redes de satélite especiais. As redes informáticas consistem igualmente numa infra-estrutura por cabos fixa e independente, mas são mais frequentemente operadas como uma rede virtual através de ligações efectuadas por meio de infra-estruturas de telecomunicação, permitindo assim a criação de redes informáticas ou a ligação de redes de dimensão global. Em resultado da convergência das tecnologias da informação e das telecomunicações, torna-se pouco nítida a distinção existente entre as telecomunicações e as comunicações informáticas, bem como a especificidade das suas infra-estruturas. Assim, a definição de "sistema informático" constante do Artigo $1^{\circ}$ não limita a forma segundo a qual os dispositivos ou o grupo de dispositivos devem estar interligados. Os artigos $20^{\circ} \mathrm{e}$ $21^{\circ}$ aplicam-se, portanto, a comunicações específicas transmitidas por meio de um sistema informático, nelas se incluindo a transmissão de uma comunicação através de redes de telecomunicação antes de ser recebida por um outro sistema informático". Nesse sentido, o artigo 189 do Código de Processo Penal lusitano. Ver, ainda, B. Rodrigues (tomo I, 2008, p. 38-39, 48-50) e Albuquerque (2008, p. 526-529).

${ }^{847}$ Algumas Constituições européias reconhecem o direito à vida privada e ao segredo das comunicações. Por exemplo, a Constituição Espanhola de 1978: "[s]e garantiza el secreto de comunicaciones y, en especial, de las postales, telegráficas y telefónicas, salvo resolución judicial [tradução nossa: é garantido o segredo das comunicações e, em especial, das postais, telegráficas e telefônicas, salvo decisão judicial]" (artigo 18.3); a da República Portuguesa: "[o] domicílio e o sigilo da correspondência e dos outros meios de comunicação privada são invioláveis", "[é] proibida toda a ingerência das autoridades públicas na correspondência, nas telecomunicações e nos demais meios de comunicação, salvos os casos previstos na lei em matéria de processo criminal", "[a] informática não pode ser utilizada para tratamento de dados referentes a convicções filosóficas ou políticas, filiação partidária ou sindical, fé religiosa, vida privada e origem étnica, salvo mediante consentimento expresso do titular, autorização prevista por lei com garantias de não discriminação ou para processamento de dados estatísticos não individualmente identificáveis" (artigo 34, números 1 e 4, e 35, número 3, respectivamente); e a da República Italiana: “[1]a libertà e la segretezza della corrispondenza e di ogni altra forma di comunicazione sono inviolabili. La loro limitazione può avvenire soltanto per atto motivato dell'autorità giudiziaria con le garanzie stabilite dalla legge [tradução nossa: [a] liberdade e o segredo de correspondência e de qualquer outra forma de comunicação são invioláveis. Só podem ser limitadas por ato motivado da autoridade judiciária com as garantias estabelececidas pela lei]" (artigo 15). Segundo, por exemplo, Crisafulli e Paladin (1990, p. 92), "[o] âmbito da garantia é absoluta e transcende mesmo as formas de expressão atuais (correspondência epistolar, comunicações telegráficas e telefônicas, transmissões por cabo e assim por diante) para compreender qualquer outra forma de comunicação que se configure no crescente desenvolvimento técnico dos meios de comunicação" (tradução nossa). No original: "[1]a portata della garanzia è assoluta e trascende le stesse forme espressive attuali (corrispondenza epistolare, comunicazioni telegrafiche e telefoniche, transmissioni via cavo e così via) per ricomprendere qualunque altra forma di comunicazione si configuri nel crescente sviluppo tecnico dei mezzi di comunicazione". Em Portugal, houve alargamento do tratamento através da IV Revisão Constitucional, que incluiu a referência a "demais meios de comunicação" no número 4 do artigo 34 da Constituição (MIRANDA; MEDEIROS, 2005, p. 373), e de mudanças no Código de Processo Penal e leis especiais (ALBUQUERQUE, 2008, p. 524).

${ }^{848}$ Artigo 11, números 2 e 3.

${ }^{849}$ Artigo $5^{\circ}$, parágrafo $2^{\circ}$, da Constituição Federal.

${ }^{850}$ Que incluem, portanto, "e-mails" e outras comunicações pela Internet, por exemplo (CANOTILHO; MOREIRA, 2007; MIRANDA; MEDEIROS, 2005). 
tivessem a liberdade, ou o costume, de registrar o conteúdo de todas as comunicações que por eles trafegam, poderiam vender, ceder ou dar conhecimento a qualquer um, sem incorrer em qualquer ilegalidade, no tocante à "interceptação" ilegal, posto que os dados armazenados são gravados e transferíveis por cópia digital "a posteriori”, quando encerrada a transmissão, inexistindo a contemporaneidade. Isto é, se se entendesse “interceptação" só como o conhecimento simultâneo do conteúdo das comunicações eletrônicas, bastaria aguardar algum tempo para possibilitar um uso legítimo dos dados armazenados, escapando à incidência do comando constitucional e da Lei 9.296/1996. Aplicar-se-ia sempre, possivelmente, por interpretação extensiva, o regime de "busca e apreensão" do artigo 240, parágrafo $1^{\circ}$, alíena “f”, do Código de Processo Penal, que cuida da apreensão de "cartas, abertas ou não, destinadas ao acusado ou em seu poder, quando haja suspeita de que o conhecimento do seu conteúdo possa ser útil à elucidação do fato".

Mas a salvaguarda contra a captação por terceiros estabelecida pelo artigo $5^{\circ}$, inciso XII, visa à inviolabilidade do conteúdo das comunicações reservadas em trânsito. Isso pode ser verificado ao se analisar o caso das "correspondências", definidas como "toda comunicação de pessoa a pessoa, por meio de carta, através da via postal, ou por telegrama", sendo que "carta" é "objeto de correspondência, com ou sem envoltório, sob a forma de comunicação escrita, de natureza administrativa, social, comercial, ou qualquer outra, que contenha informação de interesse específico do destinatário" ${ }^{\text {851. }}$.

Logo, exclui aquilo que não é comunicação propriamente, como as encomendas, definidas pelo artigo 47 da Lei 6.538/1978 como objetos com ou sem valor mercantil, para encaminhamento por via postal, e é por esse motivo que não constitui "violação de sigilo de correspondência postal" a abertura de "carta" 852 que apresente indícios de conter objeto sujeito a pagamento de tributos, ou de conter valor não declarado, objeto ou substância de expedição, uso ou entrega proibidos ${ }^{853}$.

\footnotetext{
${ }^{851}$ Artigo 47 da Lei 6.538/1978.

${ }_{853}^{852}$ Parece que a norma quis referir-se à invólucro, pacote.

${ }^{853}$ Artigo 10, incisos II e III.Veja-se o Recurso Ordinário em Habeas Corpus 10537/RJ, Relator Ministro Edson Vidigal, julgado pelo STJ (Apêndice B, número 17): "PENAL. PROCESSUAL. TIGRE DE PELÚCIA CONTENDO COCAÍNA. APREENSÃO DE ENCOMENDA NA AGÊNCIA DOS CORREIOS ANTES DE SER ENTREGUE AO DESTINATÁRIO. AÇÃO PENAL. PROVA ILÍCITA. QUEBRA DE SIGILO DE CORRESPONDÊNCIA. 1. Correspondência, para os fins tutelados pela Constituição da República (art. $5^{\circ}$, VII) é toda comunicação de pessoa a pessoa, por meio de carta, através da via postal ou telegráfica. (Lei no 6.538/78). 2. A apreensão pelo Juiz competente, na agência dos Correios, de encomenda, na verdade tigre de pelúcia com cocaína, não atenta contra a Constituição da República, art. 5º, VII. Para os fins dos valores tutelados, encomenda não é correspondência. 3. Recurso Ordinário conhecido mas não provido". No Recurso Ordinário em Habeas Corpus 6719/SP, Relator Ministro Fernando Gonçalves (Apêndice B, número 17), o STJ entendeu que minuta de carta já enviada não constitui carta para efeitos da proteção constitucional à correspondência: "RHC. PROVA. SIGILO DE CORRESPONDÊNCIA.
} 
Conciliam-se escolhas político-sociais: a inviolabilidade das comunicações, em respeito à privacidade, de um lado, com a necessidade de fiscalização tributária e de repressão a condutas criminosas, interesses públicos relevantes específicos ${ }^{854}$.

O conceito amplo de "interceptar" abrange, então, no âmbito das comunicações eletrônicas, a obtenção do seu conteúdo por qualquer modo por terceiro ${ }^{855}$.

O Anteprojeto da Comissão de Juristas valia-se de cinco condutas para abordá-lo, cujos conceitos extraem-se da Exposição de Motivos: (i) interceptação propriamente dita:

VIOLAÇÃO. 1. Violação de correspondência, com maltrato à liberdade de pensamento resguardada pela Constituição Federal, somente se concretiza quando se tratar de 'correspondência fechada'. De outro lado, a apreensão de documento, representado por minuta de carta já remetida, mediante autorização judicial, não representa afronta ao direito assegurado pelo art. $5^{\circ}, \mathrm{X}, \mathrm{da} \mathrm{CF}$ (intimidade, vida privada etc), porque idêntica proteção é reservada à honra das pessoas, não podendo aquela (intimidade) servir de salvaguarda para maltrato a esta (honra). 2. RHC improvido". Ver, nesse sentido, B. Rodrigues (tomo I, 2008, p. 111-112). Em outro caso, o STJ entendeu que o homem preso não tem o mesmo nível de direitos que o livre, num caso em que houve escuta telefônica, com autorização judicial, mas antes do advento da Lei 9.296/1996 (Habeas Corpus 3982/RJ, Relator Ministro Adhemar Maciel, no Apêndice B, número 5). A Corte adotou aí o princípio da proporcionalidade ou razoabilidade para manter a validade das provas assim obtidas, em virtude do interesse público. Por sua vez, no Habeas Corpus 70814/SP, Relator Ministro Celso de Mello (Apêndice A, número 13), o STF entendeu: "[a] administração penitenciária, com fundamento em razões de segurança pública, de disciplina prisional ou de preservação da ordem jurídica, pode, sempre excepcionalmente, e desde que respeitada a norma inscrita no art. 41, parágrafo único, da Lei n. 7.210/84, proceder à interceptação da correspondência remetida pelos sentenciados, eis que a cláusula tutelar da inviolabilidade do sigilo epistolar não pode constituir instrumento de salvaguarda de práticas ilícitas". Silva Júnior (2004) discorre a respeito da relatividade do sigilo da correspondência, embora não expresso no inciso XII do artigo $5^{\circ}$ da Constituição Federal, como quando, por exemplo, há troca de mensagens entre presos planejando uma fuga, ou cartabomba. Ver ainda B. Rodrigues (2008, tomo I, p. 136-137; 456-475), Colliard e Letteron (2005, p. 373) e Oberdorff (2008). A Corte Européia de Direitos Humanos entende que é possível o controle sobre a correspondência dos presidiários dentro de certos limites, como se vê em Boyle and Rice v. the United Kingdom (Application ns. 9659/82; 9658/82), julgado pelo Plenário em 27 de abril de 1988, e Silver and Others v. the United Kingdom (Application 5947/72; 6205/73; 7052/75; 7061/75; 7107/75; 7113/75; 7136/75), julgado pela Câmara em 25 de março de 1983. Em comentário a artigo análogo da Constituição de Portugal, Miranda e Medeiros (2005, p. 373) entendem, em sentido diverso, que "[o] conteúdo do direito ao sigilo da correspondência e dos outros meios de comunicação privada que o $\mathrm{n}^{\circ} 1$ [do artigo 34] estabelece abrange todas as espécies de comunicação de pessoa a pessoa, escrita ou oral, incluindo objectos (encomendas) que não contenham qualquer comunicação escrita ou oral". Assim entendem também Canotilho e Moreira (2007). Cervini (1997) entende que a proteção das comunicações do inciso XII do artigo $5^{\circ}$ da Constituição Federal tem feição garantista, de caráter formal, não devendo confundir-se com o direito à intimidade, de caráter substancial, pois protege-as independentemente de seu conteúdo (p. 31-34).

${ }^{854}$ Mesmo as cartas não podem ser devassadas a contento: o Código de Processo Penal estabelece a necessidade de suspeita de que o conhecimento do seu conteúdo possa ser útil à elucidação do fato criminoso na busca e apreensão (artigo 240, parágrafo $1^{\circ}$, alínea “f”), não admitindo em juízo as cartas particulares interceptadas ou obtidas por meios criminosos (artigo 233). Anotamos que o sigilo da correspondência realmente não pode ser tido como absoluto, como um fim em si mesmo, mas que, por outro lado, só pode ser afastado, em decorrência da redação do texto constitucional, em caráter excepcional, notadamente quando houver grande ou iminente risco a outros direitos de igual estatura, como o direito à vida, própria ou de outros. Ilustrativamente, lembrem-se as excludentes de ilicitude do artigo 23 do Código Penal.

${ }^{855}$ Miranda e Medeiros entendem que o sigilo protege, também, informações relativas ao próprio tráfego das comunicações (espécie, hora, duração) (2005, p. 373). Nesse sentido, Canotilho e Moreira (2007, p. 544). No Brasil, J. Silva entende que o inciso XII do artigo $5^{\circ}$ da Constituição Federal protege tanto as comunicações telefônica quanto os dados que elas deixam registrados (2007, p. 105). Nesse sentido, Greco Filho (2005, p. 10-11). Em sentido contrário, L. Gomes (1997, p. 103-104), segundo o qual a Lei 9.296/1996 não regula os dados telefônicos, mas seu sigilo pode ser quebrado com autorização de outra lei, como, por exemplo, o artigo 198 do Código Tributário Nacional, artigo 399 do Código de Processo Civil, artigo 54 da Lei Complementar 85/1993, dentre outras. 
captação por um terceiro da conversa entre dois interlocutores; (ii) impedimento: intervenção para que a comunicação não chegue a seu destino; (iii) interrupção: obstrução da comunicação, em determinado momento; (iv) escuta: interceptação feita com o conhecimento de um dos interlocutores; e (v) gravação das conversas captadas: qualquer registro $^{856}$.

O Projeto de Lei 3.272/2008 prefere a expressão "quebra do sigilo" a “interceptação" e usa um conceito aberto, com uma pequena lista não taxativa:

[...] considera-se quebra do sigilo das comunicações telefônicas de qualquer natureza todo ato que intervém no curso dessas comunicações com a finalidade de conhecer as informações que estão sendo transmitidas, incluindo a interceptação, escuta e gravação ${ }^{857}$.

Em dispositivo separado, determina que "[o] registro, a análise e a utilização da informação contida nas comunicações, objeto de quebra de sigilo por ordem judicial, sujeitam-se, no que couber, ao disposto nesta Lei" ${ }^{\prime 858}$.

A Diretiva 2002/58/CE da União Européia determina que os países devem proibir nomeadamente a escuta, a instalação de dispositivos de escuta, o armazenamento ou outras formas de interceptação ou vigilância de comunicações e dos respectivos dados de tráfego

${ }^{856}$ Essas distinções têm origem doutrinária, como se vê, por exemplo, em Avolio (2003), Greco Filho (2005). Grinover (1997), Grinover, Fernandes e Gomes Filho (2001), Jesus (1997), L. Gomes (1997) e Mendes (1999). Greco Filho (2005, p. 5, 7-9) ainda denomina a gravação feita por um dos interlocutores de "gravação unilateral clandestina" e a difere da "escuta telefônica", que seria interceptação realizada por terceiro, mas com o consentimento de um dos interlocutores, sendo que, no seu entender, ambas as situações são irregulamentáveis, escapando ao âmbito do inciso XII do artigo $5^{\circ}$ da Constituição Federal, porque dependem do confronto do direito à intimidade com a justa causa para a gravação ou interceptação, como o estado de necessidade e a defesa de direito. Streck (1997, p. 38), por sua vez, entende que o artigo $1^{\circ}$, "caput", da Lei 9.296/1996 abrange quaisquer interceptações feitas por terceiro, com ou sem consentimento de um dos interlocutores, excluindo a gravação feita por um interlocutor sem o consentimento do outro, que pode ser permitida como prova quando houver justa causa, como sucede nas gravações em caso de seqüestro de conversas entre sequiestradores e familiares da vítima. L. Gomes (1997, p. 96) entende que esse dispositivo refere-se tanto à interceptação em sentido estrito quanto à escuta telefônica (interceptação de conversa alheia com conhecimento de um dos interlocutores), não abrangendo, porém, a gravação de conversa telefônica própria (captação feita por um dos interlocutores). O Tribunal Constitucional espanhol já considerou que há vulneração do direito à inviolabilidade das comunicações pela apreensão física da mensagem, do conhecimento de seu conteúdo de modo ilícito ou se se impede a própria comunicação na sentença 114/1984, FJ no 7 (Rodríguez, 2004, p. 108). O Código de Processo Penal português refere-se a interceptar e gravar (artigo 187). Ver B. Rodrigues (2008, tomo I, p. 80-96). Na Itália, ver, dentre outros, Marinelli (2007), segundo o qual o atual Código de Processo Penal, ao contrário do anterior, não leva em consideração a interrupção e o impedimento das comunicações. Lembre-se que a Convenção Européia de Direitos Humanos utiliza, em seu artigo $8^{\circ}$, o vocábulo "ingerência", também presente na Constituição de Portugal, e que, segundo Canotilho e Moreira (2007, p. 545): “[...] é mais vasto [do que o sigilo de correspondência e outros meios de comunicação privados], envolvendo nomeadamente a liberdade de envio e de recepção de correspondência, a proibição de retenção ou de apreensão, bem como de interferência (telefónica etc.), etc. O preceito em análise [no caso, artigo 34 da Constituição portuguesa] refere-se apenas às 'autoridades públicas', mas a proibição de ingerência vale, por maioria de razão, para as entidades privadas [...]".

${ }^{857}$ Artigo $1^{\circ}$, parágrafo $1^{\circ}$. Abarca também as gravações ambientais realizadas por autoridade policial, de acordo com o artigo 20.

${ }^{858}$ Artigo $1^{\circ}$, parágrafo $2^{\circ}$. 
por pessoas que não os "utilizadores", enquanto o ECPA define "interceptação" como aquisição auditiva (“aural”) ou por qualquer outro meio do conteúdo das comunicações.

A preocupação é a de estabelecer um equilíbrio entre a proteção da inviolabilidade das comunicações e a necessidade de certa flexibilidade quanto à obtenção e utilização de seu conteúdo.

O Projeto de Lei 3.272/2008, ao separar em dois parágrafos diferentes a comunicação e o seu uso posterior, insinua, mas não desenvolve, um tratamento diferente entre a "comunicação" 859 e o seu uso posterior ${ }^{860}$.

Mais simples, a nosso ver, é adotar o conceito mais amplo, isto é, de "interceptação" como qualquer forma de conhecimento do conteúdo da comunicação por terceiro, incluindo sua (eventual) divulgação, como propunha o Anteprojeto, e como o faz, em grau aparentemente um pouco menor, o Projeto de Lei 3.272/2008 ${ }^{861}$.

No campo das comunicações eletrônicas, isso implica um tratamento diverso conforme o ponto em que se encontre a mensagem eletrônica: elas se submetem ao regime da interceptação enquanto estiverem em trânsito, abrangendo o envio, a transmissão, o armazenamento incidental e o recebimento. Antes do envio pelo remetente e após o recebimento (ou acesso) pelo destinatário, submeter-se-iam a um regime de busca e apreensão digital, que, contudo, não encontra regulação específica no nosso ordenamento positivo. É um documento em formato eletrônico ${ }^{862}$.

\footnotetext{
${ }^{859}$ Ver sua Exposição de Motivos.

${ }^{860}$ Esse "uso posterior" pode não ter um fim ilegítimo, mas importar em violação da lei de interceptação. Um bom exemplo é a captação ou difusão sem autorização do conteúdo de conversa mantida por autoridades públicas sobre uma questão de interesse público, como uma licitação. Que norma regula essa conduta? O artigo $1^{\circ}$, parágrafo $2^{\circ}$, do Projeto de Lei 3.272/2008 evita uma posição peremptória sobre o assunto. Ver o caso RADIO TWIST, A.S. v SLOVAKIA, da Corte Européia de Direitos Humanos, e a Petição 2702/RJ, julgada pelo Supremo Tribunal Federal (no Apêndice A, número 11, desta dissertação).

${ }^{861}$ Não importa se o terceiro conta com o consentimento de um dos interlocutores. Caso contrário, como notado em VAN VONDEL v. THE NETHERLANDS pela Corte Européia de Direitos Humanos, bastaria às autoridades públicas valerem-se de agentes privados para escapar ao âmbito do regime mais rígido da interceptação. Como o sigilo recai sobre a comunicação, que é relacional, a renúncia específica por parte de um dos interlocutores não diminui e muito menos elimina o direito em relação ao outro.

${ }^{862}$ Ver, nesse sentido, Crisafulli e Paladin (1990). O direito norte-americano, na origem do ECPA, procurou estabelecer um tratamento diferenciado a comunicações em trânsito e a comunicações armazenadas, levando em consideração, ainda, se se tratavam de informações relativas ao seu conteúdo ou não, embora, em virtude da redação da lei, já houvesse ambigüidades quanto ao regime aplicável (o de "interceptação", mais rígido e controlado, ou o de "acesso", com menos requisitos e menor rigor) a comunicações eletrônicas como o "email”. Martin (2006-2007) defende, no contexto do ECPA, que às mensagens eletrônicas armazenadas temporariamente ("transient electronic storage"), isto é, em trânsito, incidentalmente à transmissão, deve ser aplicado o regime das interceptações, mais rígido, do Wiretap Act, o que nos parece adequado em relação ao que propomos no Brasil. Veja-se, também, Avolio (2003). O ideal seria o legislador atuar para estabelecer dispositivos próprios, como o fez o italiano, para determinar a busca e apreensão de documentos digitais, com medidas que permitam a cópia eletrônica idêntica e íntegra, para fins de prova, pois embora uma mensagem eletrônica encontre-se em um suporte físico, com este não se confunde, ao passo que uma cópia em papel é uma mera reprodução desses dados armazenados abertos e interpretados por um programa de
} 
A caracterização do trânsito da mensagem eletrônica depende da observância desses requisitos. É por isso que entendemos, por exemplo, que o "e-mail" enviado, mas ainda não recebido ou acessado pelo destinatário, encontra-se em trânsito, a ele aplicandose o regime da interceptação ${ }^{863}$.

Interpretamos a redação do artigo $1^{\circ}$, parágrafo único, da Lei 9.296/1996, e do artigo $1^{\circ}$, parágrafo $3^{\circ}$, do Projeto de Lei $3.272 / 2008$ nesse sentido ${ }^{864}$ : qualquer modalidade de comunicação eletrônica reservada ${ }^{865}$, qualquer que seja a sua manifestação (som, vídeo e texto $)^{866}$, deve ter seu conteúdo em trânsito protegido, sendo-lhe aplicável o regime

computador, não sendo os dados propriamente ditos. No atual estado legislativo, teria de ser aplicado o regime de busca e apreensão de cartas, com essas cautelas adicionais, inclusive garantindo-se abertamente às partes a possibilidade de se contestar ou atestar a veracidade e integridade dos dados por mecanismos tecnologicamente idôneos.

${ }^{863}$ Nesse sentido, Rodríguez (2004, p. 159). Ver também B. Rodrigues (2008, tomo I, p. 183-184). O Código de Processo Penal português estabelece a aplicação do regime das escutas telefônicas "às conversações ou comunicações transmitidas por qualquer meio técnico diferente do telefone, designadamente correio eletrónico ou outras formas de transmissão de dados por via telemática, mesmo que se encontrem guardadas em suporte digital, e à interceptação das comunicações entre presentes" (artigo 189, número 1). Veja-se a respeito, ainda, o item 190 do Relatório Explicativo da Convenção sobre o Cibercrime: “[o] Artigo 19 é consagrado aos dados informatizados armazenados. A este respeito, é colocada a questão que incide sobre o facto de se uma mensagem de correio eletrónico não aberta, em espera na caixa de correio de um fornecedor de serviços de Internet, até que o respectivo destinatário efectue o descarregamento para o seu sistema informático, deverá ser considerada como constituindo dados armazenados ou dados em curso de transferência. Ao abrigo da legislação adoptada por algumas Partes, a referida mensagem de correio eletrônico faz parte integrante de uma comunicação, pelo que o seu conteúdo apenas poderá ser conhecido mediante a aplicação do poder de interceptação, enquanto que, segundo outros sistemas jurídicos, a dita mensagem se considera pertencer ao domínio dos dados armazenados aos quais se refere o Artigo 190 [...]”". B. Rodrigues descreve alguns entendimentos doutrinários a respeito da situação do correio eletrônico, e defende que o "e-mail" armazenado e lido constitui documento que contém dados de caráter pessoal, sujeito, portanto, às normas correlatas da Constituição e da União Européia (2008, tomo I, p. 444-450). Na França, há precedente da Câmara Social da Corte de Cassação, de 2 de outubro de 2001, que considera o correio eletrônico uma forma de correspondência (COLLIARD; LETTERON, 2005, p. 378-379). Para uma discussão a respeito dos aspectos temporal e "contextual" das mensagens eletrônicas, Marinelli (2007, especialmente p.16-17). Sobre a proteção penal na Itália, levando-se em consideração essas circunstâncias, embora valendose dos termos "dinâmico" e "estático" para referir-se, respectivamente, às mensagens (eletrônicas) em trânsito e às já exauridas (consideradas como dados armazenados e como tal protegidas), Pecorella (2006).

${ }^{864}$ A Comissão de Juristas do Anteprojeto considerava essa "extensão" inconstitucional, como mencionado, mas ao mesmo tempo determinava a aplicação da regulação das interceptações telefônicas a qualquer forma de telecomunicação (artigo $1^{\circ}$, parágrafo único).

865 "Esta exigência de canal fechado [do artigo 18.3 da Constituição da Espanha] aplicada às formas de comunicação [...] que se produzam na Internet faz com que o direito ao sigilo das comunicações, como já se disse, aplique-se ao correio eletrônico, às comunicações telefônicas que tenham lugar na rede, às videoconferências, ao envio de mensagens SMS através da Internet e ao uso do 'chat' quando se emprega a opção que limita a comunicação a dois interlocutores” (Rodríguez, 2004, p. 99, tradução nossa). No original: "Esta exigencia de canal cerrado aplicada a las formas de comunicación [...] que se producían en Internet da lugar a que el derecho al secreto de las comunicaciones, como ya se dijo, se aplique al correo electrónico, a las comunicaciones telefónicas que tienen lugar em la Red, a las videoconferencias, al envío de mensajes SMS a través de Internet y al uso del chat cuando se emplea la opción que limita la comunicación a dos interlocutores". No mesmo sentido, em Portugal, B. Rodrigues (2008).

${ }^{866}$ L. Gomes (1997, p. 112-115) entende que a Lei 9.296/1996 aplica-se a toda espécie de conteúdo das comunicações: dados, sons, imagens, escritos, sinais etc, o que interfere diretamente na abrangência do tipo consubstanciado no seu artigo 10. A única referência a captação ou interceptação de "sinais eletromagnéticos, óticos ou acústicos", o que inclui, portanto, a videovigilância, encontra-se no inciso IV da Lei 9.034/1995 inserido pela Lei 10.217/2001. 
jurídico da interceptação.

Estabelecida a amplitude da norma do artigo $5^{\circ}$, inciso XII, da Constituição Federal, verificam-se os requisitos que estabelece: (i) a necessidade de ordem judicial; (ii) a relação necessária (finalidade) a uma investigação criminal ou instrução processual penal; e (iii) hipóteses e formas estabelecidas em lei ${ }^{867}$.

"Hipóteses" denota excepcionalidade: embora haja certa margem de apreciação ao legislador ordinário, não pode arrolar ou construir os casos de tal modo que transforme a interceptação em regra, sob risco de anular a proteção ao sigilo das comunicações.

Assim, a lei não pode simplesmente repetir o comando constitucional, mas razoavelmente estipular em quais circunstâncias e por que modos dar-se-á a autorização judicial. Antes da edição da Lei 9.296/1996, era pacífico o entendimento no STF de que esse inciso XII do artigo $5^{\circ}$ da Constituição Federal não era auto-aplicável e que o artigo 57, inciso II, alínea “e”868, do então vigente Código Brasileiro de Telecomunicações ${ }^{869}$ não fora recepcionado ${ }^{870}$.

A Lei 9.296/1996 adotou três critérios concomitantes para autorizar a medida ${ }^{871}$, que são, em síntese, a existência de indícios razoáveis de autoria ou participação em infração penal ${ }^{872}$ punível com reclusão e a impossibilidade de a prova ser produzida por outros meios ${ }^{873}$, sendo que deve haver um fato investigado ("situação objeto da investigação", fato prévio) descrito com clareza ${ }^{874}$.

O Projeto de Lei 3.272/2008 segue no mesmo sentido e acrescenta os crimes

\footnotetext{
${ }^{867}$ De acordo com Albuquerque (2008, p. 138, destaque do autor), “[q]uando o meio de obtenção de prova implicar um elevado grau de instrusão na privacidade do suspeito (ou um 'potencial aditivo de perigo inerente ao ataque aos direitos fundamentais' [...]), ele deve ser previsto por uma lei expressa ( $\operatorname{artigo} 26^{\circ}, \mathrm{n}^{\circ} 1$ e 2 da CRP [Constituição da República Portuguesa], e, semelhantemente, o dito acórdão do Bunsdesverfassungsgericht de 12.4.2005, e o acórdão do TEDH [Tribunal Europeu de Direitos do Homem] Vetter v. França, de 31.5.2005)".

${ }^{868}$ Era a redação desse dispositivo: “Art 57. Não constitui violação de telecomunicação: [...] II - O conhecimento dado: [...] e) ao juiz competente, mediante requisição ou intimação dêste”.

${ }^{869}$ Lei 4.117/1962.

${ }^{870}$ HC 69912/RS, HC 69912/RS-segundo e outros, conforme Apêndice A, número 2, desta dissertação.

${ }^{871}$ Artigo $2^{\circ}$, incisos I a III.

${ }^{872}$ Conforme Albuquerque (2008, p. 509, destaque do autor), em Portugal, o "juiz tem de verificar, aquando da autorização da escuta, se existem 'indícios fundados' da prática destes crimes [do rol], já que o alvo da escuta tem, pelo menos, de ser suspeito da prática dos factos criminosos ou de ser intermediário de mensagens destinadas ou provenientes do suspeito [...]".

873 Alguns autores entendem que os incisos I e II do artigo $2^{\circ}$ da Lei 9.296/1996 traduzem-se, respectivamente, em "fumus boni iuris" e "periculum in mora". Ver Avolio (2003), Grinover, Fernandes e Gomes Filho (2001) e Jesus (1997). Para L. Gomes (1997), o primeiro engloba a existência de dados concretos que demonstrem a probabilidade da responsabilidade criminal e a de existência concreta do fato criminoso, não sendo o bastante "fatos duvidosos", "meras possibilidades" ou "conjecturas" (p. 179-180), enquanto o "periculum in mora" traduz-se num juízo de necessidade, que integra o princípio da proporcionalidade (p. 181-184). Mais em relação ao "fumus boni iuris" em Nery Junior (2002).

${ }^{874}$ Artigos $2^{\circ}$, inciso III e parágrafo único, e $4^{\circ}$.
} 
apenados com detenção, "quando a conduta delituosa tiver sido realizada por meio dessas modalidades de comunicação" ${ }^{\text {,75. }}$.

O Anteprojeto da Comissão de Juristas exigia a clara descrição da situação objeto da investigação, a qualificação do investigado ou esclarecimentos pelos quais seja possível identificá-lo, salvo impossibilidade manifesta justificada, e a indicação de indícios suficientes da prática de qualquer dos crimes de uma lista que adotava, bem como a demonstração de que essa "operação técnica" era estritamente necessária e da impossibilidade de a prova ser obtida por outros meios ${ }^{876}$.

A Constituição não indica qual forma a lei deve adotar nesse ponto. Contudo, sendo uma exceção, deve ser autorizada subsidiariamente, em último caso, se a produção de prova por outros meios for impossível ou de desproporcional dificuldade, em situações mais graves ${ }^{877}$, nas quais existam indícios de materialidade de uma conduta criminosa,

${ }^{875}$ Artigo 20, "caput".

${ }^{876}$ Artigo 5 , incisos I a IV. Em Portugal, a interceptação e a gravação só podem ser autorizadas "se houver razões para crer que a diligência é indispensável para a descoberta da verdade ou que a prova seria, de outra forma, impossível ou muito difícil de obter, por despacho fundamentado do juiz da instrução e mediante requerimento do Ministério Público" (artigo 187, número 1) quanto a uma lista de crimes (alíneas "a" a "g" desse mesmo artigo). Ver a respeito Canotilho e Moreira (2007, p. 543), segundo quem a lei “[...] não poderá legitimar escutas telefónicas (interceptação, gravação de conversação ou comunicações telefónicas) para a investigação de quaisquer crimes, devendo limitar-se a crimes particularmente graves (cfr. Cód. Proc. Penal, art. $187^{\circ}$ ); nem estender ilimitadamente o universo das pessoas suspeitas à escuta (alargamento das escutas a terceiros que não têm relação com os factos sujeitos à investigação) [...]” (destaque deles). Na Itália, o Código de Processo Penal ("Codice di Procedura Penale") permite a interceptação, mediante requerimento do Ministério Público, por decisão motivada do juiz quando estiverem presentes graves indícios de crime e a medida for "absolutamente indispensável" aos fins da continuidade das investigações, conforme artigo 267, número 1, relativamente à lista de crimes do artigo 266, número 1, alíneas "a" a "f-bis". Por outro lado, o Código de Processo Penal ("Ley de Enjuiciamiento Criminal") da Espanha praticamente resume-se a autorizar a intervenção nas comunicações telefônicas do investigado ou processado, por decisão motivada de um juiz, se houver indícios de se obter por esse meio a descoberta ou a comprovação de algum fato ou circunstância "importante" à causa (artigo 579, número 2). As lacunas foram e continuam a ser preenchidas pela jurisprudência e doutrina. Lá é também autorizada a interceptação no processo penal militar, com requisitos similares, nos pedidos efetuados pelo Centro Nacional de Inteligência, cuja lei é um pouco mais detalhada, e também no juízo concursal (concurso de credores). Ver a esse respeito, dentre outros, Rodríguez (2004, pp. 116-119), e o caso VALENZUELA CONTRERAS v. SPAIN, julgado pela Corte Européia de Direitos Humanos em 1998, especialmente parágrafo 34. Já o Código de Processo Penal francês ("Code de procédure pénale") prevê a possibilidade de interceptação, registro e transcrição de "correspondências" transmitidas por meio das telecomunicações em matéria criminal e correcional, se a pena cominada for igual ou superior a dois anos de prisão, por ordem do juiz de instrução, "quando as necessidades de informação o exigir", sob sua autoridade e seu controle (artigo 100).

877 "A excepcionalidade dos meios de obtenção de prova reserva-se aos que ofendem mais gravemente os direitos fundamentais do cidadão. A realização da justiça e a descoberta da verdade material encontra-se limitada por dois vértices: por um lado, prefere-se não obtê-la a ofender 'brutalmente' quaisquer direitos pessoais e princípios fundamentais (tais como a vida, a integridade física e psíquica, a dignidade da pessoa humana), sob pena de a justiça ser amoral e enferma; por outro, está sujeita ao recurso ao meio menos oneroso para aqueles direitos e princípios, i. é, se a realização do exame e da revista ao(s) suspeito(s) preenche o quadro probatório - real e pessoal - do processo, não deve ser efectuada a busca ou a apreensão ou a escuta telefónica ou não deve recorrer-se ao agente infiltrado. Como meio de obtenção de prova, a escuta telefônica deve, também, cingir-se ao estritamente necessário ou exigível probatório e não a uma desmesurada fruição. Pressuposto extraído do enquadramento sistemático das escutas telefónicas. O legislador consagrou as escutas telefónicas em último lugar dos meios de obtenção de prova [numa referência 
sendo que, em qualquer caso, os sujeitos investigados devem ser determinados ou determináveis $^{878}$.

Entendemos que se aplica no Brasil o que Albuquerque (2008, p. 507) escreve sobre os critérios de "indispensabilidade" ou de produção de prova "impossível ou muito difícil" estabelecidos no artigo 187, número, do Código de Processo Penal português:

\begin{abstract}
[o]s referidos critérios são apurados em face do conjunto de elementos de prova que existem no momento da prolação da decisão sobre o requerimento do MP [Ministério Público] e não em função do que a final se revele ter sido o conteúdo das escutas telefónicas e a sua importância probatória (acórdão do TRC, de 6.12.2006, in CJ, XXXI, V, 54), nem em função de pré-juízos sobre a eventual inutilidade da diligência (acórdão do TRC, de 19.12.2006, in CJ, XXXI, 5, 59, e jurisprudência nele citada) ${ }^{879}$. [...] Em regra, a escuta telefónica não deve ser determinada como primeiro meio de obtenção de prova logo na abertura do inquérito, nem com base em mera denúncia anónima, mesmo que desta se possam retirar 'indícios da prática do crime ${ }^{880}$. No início do inquérito, a natureza precoce do processo deve aconselhar a máxima prudência na utilização de meios de obtenção de prova com grande impacto intrusivo. Igual prudência se impõe diante da denúncia anónima, atento o carácter intrinsecamente insuficiente e lacunoso desta denúncia. A determinação da escuta telefónica, num caso como no outro, só não constitui uma interferência desproporcional e desnecessária em casos excepcionais, isto é, nos casos em que ela constitua o único meio de obtenção da prova de um crime que já se incidia nos autos. (destaques do autor) ${ }^{881}$.
\end{abstract}

Ou, nas palavras de Streck (1997, p. 67), em vista da Lei 9.296/1996:

à disposição desses meios de obtenção de prova no texto do Código de Processo Penal português] colocando em primeiro lugar os exames, depois as revistas e as buscas, seguidamente as apreensões e, por último, as escutas telefónicas. Deste, mais grave só o agente infiltrado, cujo regime o legislador consagrou em diploma autónomo" (VALENTI, 2004, p. 18).

${ }^{878}$ Nesse sentido, Marinelli (2007). L. Gomes (1997, p. 189) arremata: “[...] Se porventura o Juiz não conta com condições de indicar o sujeito passivo, isso significa que o primeiro pressuposto da interceptação não está preenchido. Logo, não é o caso de determiná-la. [...]”.

879 "Por exemplo, justifica-se a escuta telefónica para obtenção de elementos de prova dos crimes de ofensas corporais e homicídio tentado, em face do segredo e conivência de todos os que se envolveram no crime e dos que poderiam prestar informações úteis (acórdão do TRL, de 22.11.2005, in CJ, XXX, 5, 137), como se justifica a escuta telefónica para obtenção de elementos de identificação dos autores e cúmplices de vários crimes de furto qualificado em residências, de valor superior a 15.000.000\$00, investigados em vários processos separados, mas com um 'modus operandi' semelhante, mas não para recuperar os bens furtados (com esta restrição, acórdão do TRP, de 8.3.2000, in CJ, XXV, 2, 230)” (ALBUQUERQUE, 2008, p. 507).

${ }^{880}$ No Habeas Corpus 64096/PR, Relator Ministro Arnaldo Esteves Lima (Apêndice B, número 5, desta dissertação), o STJ entendeu que a denúncia anônima não é apta, isoladamente, para fundamentar e autorizar a interceptação telefônica, inclusive porque a falta de identificação inviabiliza a responsabilização pela prática de denunciação caluniosa.

${ }^{881}$ Note-se que a inexistência de outros meios disponíveis significa outros meios processuais em relação ao fato investigado e, também, aos meios materiais, e não, isoladamente, quanto a estes últimos. Ou seja, a interceptação das comunicações não pode ser desde logo adotada porque é o meio de mais fácil acesso e manipulação, embora, na realidade, observe-se que a existência, ou não, de dadas tecnologias terá grande influência para as autoridades encarregadas da investigação e do juiz criminal. Ver quanto ao requisito da inexistência de outros meios disponíveis, considerando que devem ser levados em conta os meios legaisprocessuais, e não, por exemplo, a falta de peritos, dentre outros, Streck (1997) e Jesus (1997). Para Corvini (1997, p. 62), a simples possibilidade de se testar uma via probatória do tipo ordinário deveria inibir toda a possibilidade de se recorrer aos procedimentos reputados de "extraordinários", como a interceptação. 
[...] o Juiz deverá fazer uma avaliação da necessidade da escuta telefônica, sendo que, para tanto, deverá ter em mente que a interceptação - portanto a quebra da privacidade - é a única forma possível e razoável para proteger outros valores fundamentais da coletividade e da defesa da ordem jurídica. [...] Deverá responder a pergunta: Há (outros) meios menos incisivos na esfera protegida da intimidade do que a realização da escuta ${ }^{882}$ (destaques do autor).

Claro que haverá discordância sobre o que é "grave" o suficiente para autorizar a interceptação. Observa-se que a lista de crimes do ECPA vem aumentando constantemente, enquanto o Anteprojeto da Comissão de Juristas trazia uma lista de crimes relativamente reduzida.

Por sua vez, o Projeto de Lei 3.272/2008 estende a permissão a crimes apenados com detenção, quando praticados por meio de comunicação, além de abrir margem a que outras condutas que constituam fatos típicos sejam investigadas pelo Ministério Público, a seu critério, sem restrição expressa alguma quanto à possibilidade de utilização do resultado da interceptação como prova em outros procedimentos ou processos. ${ }^{883}$.

Já a Convenção sobre o Cibercrime determina apenas que a interceptação de dados relativos ao conteúdo deve ser permitida no tocante a um "leque de infrações graves, a definir em direito interno" ${ }^{884}$. O seu Relatório Explicativo considera que as infrações previstas na Convenção devem autorizar, a princípio, tal medida, mas que compete aos Estados determinar como isso se dará ${ }^{885}$.

${ }^{882} \mathrm{O}$ autor ainda prossegue: “[...] À evidência, se o Juiz autorizar a escuta telefônica sem levar em consideração essa proporcionalidade, as provas colhidas estarão absolutamente "envenenadas"” (p. 70-71).

${ }^{883}$ Conforme a sua Exposição de Motivos, "[...] em obediência ao princípio da proporcionalidade [...]. O rol é bastante amplo, de modo a compreender novas modalidades criminosas (como o chamado seqüestro relâmpago, os crimes contra a ordem tributária, o tráfico de espécimes da fauna silvestre, o tráfico de armas, munições e explosivos). Trata-se de crimes de natureza grave, mas também particularmente adequados a serem investigados na forma prevista na lei, ou então de crimes tipicamente cometidos por telefone, como o de ameaça. [...] O defeito maior da vigente lei 9.296, de 24 de julho de 1996, que dispõe sobre interceptações telefônicas e de fluxo de comunicações em sistemas de informática e telemática, talvez consista exatamente na inobservância do princípio da proporcionalidade, quando, por exemplo, permite a interceptação relativamente a todos os crimes punidos com pena de reclusão - no que não observa o princípio da adequação e da não excessividade, estendendo a operação técnica indicada para qualquer tipo de crime, desde que punido com reclusão, e deixando de fora crimes punidos com detenção, mas para os quais a interceptação se apresenta como o meio mais adequado de investigação, como na ameaça cometida por telefone; quando permite o pedido formulado verbalmente, o que evidentemente corrói a verificação da necessidade e da adequação" (grifos dos autores). Lembre-se, também, que a Lei Complementar 105/2001, que cuida do sigilo das operações financeiras, lista, embora exemplificativamente, alguns crimes (artigo $1^{\circ}$, parágrafo $4^{\circ}$, incisos I a IX): (i) de terrorismo; (ii) de tráfico ilícito de substâncias entorpecentes ou drogas afins; (iii) de contrabando ou tráfico de armas, munições ou material destinado a sua produção; (iv) de extorsão mediante seqüestro; (v) contra o sistema financeiro nacional; (vi) contra a Administração Pública; (vii) contra a ordem tributária e a previdência social; (viii) lavagem de dinheiro ou ocultação de bens, direitos e valores; e (ix) praticado por organização criminosa.

${ }^{884}$ Artigo 21, "caput".

${ }^{885}$ Item 214. O item 228 do Relatório Explicativo dessa Convenção menciona atividades em relação às quais a interceptação é útil, quando a comunicação constitui uma ameaça de crime ou assédio, uma "conspiração" de índole criminosa ou declarações falsas, além de proporcionar a reunião de provas sobre infrações passadas e futuras, como tráfico de estupefacientes, homicídio e infrações de cunho econômico. Ver também o item 
O texto constitucional oferece pistas do que pode ser considerado grave: terrorismo e racismo ${ }^{886}$; tortura ou tratamento desumano ou degradante ${ }^{887}$; tráfico ilícito de entorpecentes e drogas afins ${ }^{888}$; a ação de grupos armados, civis ou militares, contra a ordem constitucional e o Estado Democrático ${ }^{889}$; os crimes hediondos ${ }^{890}$; e o abuso, a violência e a exploração sexual da criança e do adolescente ${ }^{891}$.

Os crimes hediondos, tentados ou consumados, são arrolados pela Lei 8.072, de 25 de julho de 1990: (i) homicídio ${ }^{892}$, quando praticado em atividade típica de grupo de extermínio, ainda que cometido por um só agente, e homicídio qualificado ${ }^{893}$; (ii) latrocínio $^{894}$; (iii) extorsão qualificada pela morte ${ }^{895}$; (iv) extorsão mediante seqüestro e na forma qualificada ${ }^{896}$; (v) estupro ${ }^{897}$; (vi) atentado violento ao pudor $^{898}$; (vii) epidemia com resultado morte ${ }^{899}$; (viii) falsificação, corrupção, adulteração ou alteração de produto destinado a fins terapêuticos ou medicinais ${ }^{900}$; e (ix) genocídio ${ }^{901}$.

212 do Relatório Explicativo dessa Convenção. O Código de Processo Penal português traz a seguinte lista de crimes (artigo 187, número 1, alíneas "a" a "g"): (i) aqueles puníveis com pena de prisão superior, no seu máximo, a três anos; (ii) relativos ao tráfico de estupefacientes; (iii) de detenção de arma proibida e de tráfico de armas; (iii) de contrabando; (iv) de injúria, de ameaça, de coação, de devassa da vida privada e perturbação da paz e do sossego, quando cometidos através do telefone; (v) de ameaça com prática de crime ou de abuso e simulação de sinais de perigo; e (vi) de evasão, quando o "arguido" haja sido condenado por algum desses crimes. Observa-se, na prática, que o primeiro é um critério geral subsidiário ligado à pena. Anote-se que "arguido", segundo o Código de Processo Penal, é "todo aquele contra quem for deduzida acusação ou requerida instrução num processo penal" (artigo 57, número 1). O Código de Processo Penal italiano ("Codice di Procedura Penale") apresenta, por sua vez, a seguinte lista de crimes (artigo 266, número 1, alíneas "a" a "f-bis"): (i) não culposos para os quais esteja prevista a pena de prisão perpétua ou de reclusão superior, no máximo, a cinco anos; (ii) contra a administração pública para os quais está prevista a pena de reclusão não inferior, no máximo, a cinco anos; (iii) relativos a substâncias estupefacientes ou psicotrópicas; (iv) relativos a armas e a substâncias explosivas; (v) de contrabando; (vi) de injúria, ameaça, usura, atividade financeira abusiva, abuso de informações privilegiadas, manipulação do mercado, incômodo ou perturbação às pessoas por meio do telefone; e (vii) de distribuição, divulgação, difusão ou publicação, com qualquer meio, por via telemática, de material pornográfico envolvendo menor de dezoito anos, ou de divulgação de notícia ou informação para o aliciamento ou a exploração sexual de menores de dezoito anos. Já a Espanha e a França não trazem qualquer lista, como visto.

${ }_{887}^{886}$ Artigo $4^{\circ}$, inciso VIII, e artigo $5^{\circ}$, incisos XLII e XLIII.

${ }^{887}$ Artigo $5^{\circ}$, incisos III e XLIII.

${ }_{888}^{888}$ Artigo $5^{\circ}$, inciso XLIII, e artigo 243, "caput" e parágrafo único.

${ }^{889}$ Artigo $5^{\circ}$, inciso XLIV.

${ }^{890}$ Artigo $5^{\circ}$, inciso XLIII.

${ }^{891}$ Artigo 227, parágrafo $4^{\circ}$. O Ministro Paulo Brossard, no julgamento do Habeas Corpus 69912/RS pelo STF (ver Apêndice A, número 2, dissertação), teceu várias considerações nesse sentido em seu voto sobre a lei que regulamentaria o inciso XII do artigo $5^{\circ}$ da Constituição Federal (na época do julgamento, ainda não existia a Lei 9.296/1996).

${ }^{892}$ Artigo 121 do Código Penal.

${ }^{893}$ Artigo 121, parágrafo $2^{\circ}$, incisos I, II, III, IV e V, do Código Penal.

${ }_{894}^{894}$ Artigo 157, parágrafo $3^{\circ}$, "in fine", do Código Penal.

${ }^{895}$ Artigo 158, parágrafo $2^{\circ}$, do Código Penal.

${ }^{896}$ Artigo 159, "caput", e parágrafos $1^{\circ}, 2^{\circ}$ e $3^{\circ}$, do Código Penal.

${ }_{897}^{897}$ Artigo 213 e sua combinação com o artigo 223, "caput" e parágrafo único, do Código Penal.

${ }^{898}$ Artigo 214 e sua combinação com o artigo 223, "caput” e parágrafo único, do Código Penal.

${ }^{899}$ Artigo 267, parágrafo $1^{\circ}$, do Código Penal.

900 Artigo 273, "caput" e parágrafos $1^{\circ}, 1^{\circ}$-A e $1^{\circ}$-B, do Código Penal, com a redação dada pela Lei no ${ }^{9} .677$, de 2 de julho de 1998. 
Assim, se é impossível trazer uma lista unânime, algumas condutas são consideradas graves já pela própria Constituição Federal, complementada pelo legislador ordinário. Parece-nos que o critério exclusivo da pena de reclusão é demasiado amplo, ferindo a excepcionalidade determinada pelo artigo $5^{\circ}$, inciso XII, do texto constitucional, abarcando um universo grande de condutas e, por conseguinte, permitindo a multiplicação de interceptações lastreadas nessa permissão para investigar esse número exorbitante de condutas $^{902}$.

Deve existir uma ponderação sobre a necessidade e a extensão da invasão da privacidade do indivíduo para se combater um mal de maior gravidade para a sociedade, além de condutas que costumam utilizar os meios de comunicação, como a extorsão mediante seqüestro. Exemplificativamente, deveriam estar incluídos crimes contra a saúde pública e a Administração Pública, posto que afetam diretamente um grande número de pessoas indistintamente, e os crimes praticados por quadrilhas ou bandos, e outros, como a pedofilia, principalmente quando cometida através da Internet ${ }^{903}$.

O ordenamento prevê, e deve fazê-lo, as medidas apropriadas de investigação, processo e punição criminal, mas esse aparato deve funcionar com base em decisões realmente motivadas ${ }^{904}$ e com finalidades especificadas, cabendo ao juiz e ao Ministério Público controlar e coibir abusos e desvios.

Veja-se a situação no âmbito da Convenção sobre o Cibercrime:

${ }^{901}$ Previsto nos artigos $1^{\mathrm{o}}, 2^{\mathrm{o}}$ e $3^{\mathrm{o}}$ da Lei 2.889 , de $1^{\mathrm{o}}$ de outubro de 1956.

902 Quanto à necessidade de se averiguar a gravidade do crime, buscando-a no ordenamento brasileiro, como a Lei de Crimes Hediondos, ou em comparação com o estrangeiro, Greco Filho (2005), Grinover (1997) e Streck (1997). Streck ainda afirma que "[...] a discussão acerca da proporcionalidade torna-se recorrente. Fica claro que somente se justifica a invasão da esfera dos direitos fundamentais do indivíduo para o combate dos crimes que representem ameaça aos valores constitucionais, erigidos como metas pelo Estado Democrático de Direito" (1997, p. 57, destaque do autor), e que o objetivo da Lei 9.296/1996 é combater a criminalidade sofisticada, a macrocriminalidade, como os crimes de "colarinho branco", sonegação de impostos e corrupção, razão pela qual deveria incidir, também, sobre os crimes de responsabilidade (p. 57-58). Corvini (1997) critica o critério da Lei 9.296/1996 da pena em abstrato, pois abarca uma enorme quantidade de crimes, sendo "permissiva" (p. 61). Nery Junior (2002, p. 169) entende que o legislador foi além ao eleger os crimes apenados com reclusão como autorizadores da escuta telefônica por ordem judicial, mas aquém "quando deixou de contemplar os crimes de ameaça e contra a honra, quando cometidos por meio telefônico, ou as contravenções penais mais fortemente recriminadas pela sociedade, como é o caso do jogo de bicho", defendendo a aplicação do princípio da proporcionalidade para que se possam utilizar da interceptação nesses casos.

${ }^{903}$ Ver, no mesmo sentido, a Convenção sobre o Cibercrime e seu Relatório Explicativo. A Lei 8.069, de 13 de julho de 1990, por exemplo, crimininaliza a conduta de "[o]ferecer, trocar, disponibilizar, transmitir, distribuir, publicar ou divulgar por qualquer meio, inclusive por meio de sistema de informática ou telemático, fotografia, vídeo ou outro registro que contenha cena de sexo explícito ou pornográfica envolvendo criança ou adolescente", incorrendo na mesma pena de reclusão, de três a seis anos, e multa, quem "assegura, por qualquer meio, o acesso por rede de computadores às fotografias, cenas ou imagens de que trata o "caput' deste artigo" (artigo 241-A, "caput" e parágrafo $1^{\circ}$, inciso II, com a redação dada pela Lei 11.829 , de 25 de novembro de 2008).

904 A fundamentação do juiz deve ser real, e não mera repetição das alegações da autoridade policial ou do Ministério Público ou dos termos da lei. Ver Jesus (1997) e L. Gomes (1997). 
[...] a Convenção não exige nem autoriza a vigilância ou a recolha, geral ou indiscriminada, de grandes quantidades de dados de tráfego. Do mesmo modo, a Convenção não permite a realização de "missões de exploração" através das quais se espera descobrir actividades de índole criminosa, sendo estas situações muito diferentes das investigações levadas a cabo relativamente a casos específicos de criminalidade. Por este motivo, a ordem judicial ou outra que autorize a recolha deverá indicar expressamente quais as comunicações cujos dados de tráfego deverão ser recolhidos ${ }^{905}$.

Logo, a interceptação das comunicações deve estar sujeita a condições e garantias:

[...] No domínio da interceptação, a presente Convenção [sobre o Cibercrime] não prevê salvaguardas específicas, para além de limitar a autorização de interceptação de dados de conteúdo às investigações relativas a infracções penais graves, de acordo com as disposições da legislação nacional. Todavia, as condições e salvaguardas importantes neste domínio, e aplicáveis em conformidade com a legislação nacional, são as seguintes: supervisão por parte de um órgão judiciário ou outro independente; especificidade das comunicações ou das pessoas alvo de interceptação; necessidade, subsidiariedade e proporcionalidade (por exemplo, condições jurídicas justificativas da aplicação da medida; ineficácia de outras medidas com menor grau de intrusão); limitação do período de duração da interceptação; direito de recurso. Muitas destas salvaguardas reflectem o espírito da Convenção Européia dos Direitos do Homem e a sua subsequente jurisprudência $[\ldots]^{906}$.

Uma das condições e garantias aplicáveis são, portanto, os limites de tempo para a interceptação, que devem levar em consideração a necessidade da medida para a investigação em questão e a possibilidade maior ou menor de sua extensão a outras condutas criminosas: quanto mais condutas autorizarem a medida, maiores devem ser os limites de tempo. Isso porque o principal objetivo dos limites de tempo é evitar abusos por parte das autoridades e restringir a ingerência na vida privada ${ }^{907}$.

Atuam nesse sentido, também, as restrições à possibilidade de extensão das interceptações e à lista dos fatos criminosos que autorizam a medida, pois quanto mais fatos puderem ser investigados e mais comunicações interceptadas, independentemente daqueles que deram início à medida, maiores as oportunidades de abuso desse instrumento de coleta de prova e mais profunda a constrição da privacidade dos indivíduos.

Entretanto, o entendimento majoritário do STJ e do STF é de que a Lei 9.296/1996 permite indefinidas prorrogações de prazo, por períodos de até quinze dias cada, e de que crimes conexos descobertos durante a medida podem ser investigados.

\footnotetext{
905 Item 219 do Relatório Explicativo da Convenção. No mesmo sentido, ver B. Rodrigues (2008, tomo I, p. 253-255).

906 Item 215 do Relatório Explicativo da Convenção sobre o Cibercrime.

907 Cervini (1997, p. 56) assinala que o estabelecimento de um prazo para a prática das interceptações permite, ao menos em teoria, a avaliação e reconsideração periódica da necessidade da medida por parte do juiz, que poderá proceder, se for o caso, a sua suspensão ou prorrogação.
} 
O Anteprojeto propunha o prazo de até quinze dias, renovável por igual período, com a possibilidade, em virtude da "excepcionalidade do caso concreto", de novas renovações por igual período, até o limite máximo de sessenta dias, e a ausência desse teto em relação a crime permanente, enquanto não cessasse a permanência ${ }^{908}$. Além disso, proibia que os resultados das operações técnicas realizadas fossem utilizados para a instrução de processos ou investigações relativos a crimes diversos daqueles para os quais a autorização fosse dada, salvo quando se tratasse de crime conexo ou de outro crime constante do rol do artigo $1^{\text {0909. }}$.

O Projeto de Lei 3.272/2008, por sua vez, estabelece a possibilidade de interceptações por períodos de até sessenta dias, permitida sua prorrogação por iguais e sucessivos períodos, até o máximo de trezentos e sessenta dias ininterruptos, salvo se se tratar de crime permanente, enquanto não cessar a permanência ${ }^{910}$.

De outro lado, proíbe o uso da prova obtida por meios não previstos no Projeto para qualquer investigação, processo ou procedimento, seja qual for a sua natureza ${ }^{911}$, e dispõe:

Na hipótese de a quebra do sigilo das comunicações telefônicas de qualquer natureza revelar indícios de crime diverso daquele para o qual a autorização foi dada e que não lhe seja conexo, a autoridade deverá remeter ao Ministério Público os documentos necessários para as providências cabíveis ${ }^{912}$.

Enfim, o Projeto de Lei explicita a possibilidade de estender a interceptação a crimes conexos e a de várias prorrogações da interceptação, estipula um prazo máximo total, a que os crimes permanentes não se sujeitam, e possibilita o uso de indícios de crimes

\footnotetext{
${ }^{908}$ Artigo $9^{\circ}$, "caput" e parágrafos $1^{\circ}$ e $2^{\circ}$. , medida que pode ser determinada por prazo de até três meses, Na Espanha, como visto, o prazo é de até três meses, renovável por iguais períodos (artigo 579, número 3, do Código de Processo Penal), o mesmo ocorrendo em Portugal (artigo 187, número 6, do Código de Processo Penal), onde o órgão de polícia criminal deve efetuar a interceptação e gravação e levar ao Ministério Público, de quinze em quinze dias, os correspondentes suportes técnicos, bem como os respectivos autos e relatórios referentes à medida e o conteúdo descoberto. O Ministério Público, por sua vez, leva ao conhecimento do juiz esses elementos no prazo de quarenta e oito horas (ver artigo 188, números 1 , 3 e 4 do Código de Processo Penal). O Código de Processo Penal italiano estabelece o prazo máximo de quinze dias, prorrogáveis por períodos sucessivos de quinze dias, por decisão motivada do juiz, desde que permaneçam os pressupostos autorizadores da medida (indícios graves de crime e indispensabilidade da interceptação para fins de prosseguimento das investigações) (artigo 267, números 1 e 3). No caso de delitos relacionados à criminalidade organizada, lei específica ameniza esses requisitos, podendo ser determinada a interceptação quando "necessária" ao desenvolvimento das investigações e a existência de "suficientes" indícios de crime, e não "graves". Ver Canzio e Carano (2006, p. 68). Na França, o Código de Processo Penal dispõe que a medida pode ser determinada por um período de até quatro meses, passível de prorrogação nas mesmas condições e forma (artigo 100-2), sendo que a ordem deve conter todos os elementos de identificação da ligação a ser interceptada, a infração que a motiva e a sua duração (artigo 100-1). Ver Guinchard e Buisson (2008) e Pradel (2006).

909 Artigo 19.

${ }^{910}$ Artigo $5^{\circ}$, parágrafo $1^{\circ}$.

911 Artigo 17.

912 Artigo 16.
} 
não relacionados ao objeto da investigação descobertos no curso da medida para instauração de investigação ${ }^{913}$.

Entendemos ser desnecessário o estabelecimento de um prazo máximo total para a medida, pois pode se mostrar, no caso concreto, insuficiente ou demasiado ${ }^{914}$. O melhor é estabelecer prazos periódicos pequenos, a fim de permitir o controle de perto pelo juiz ${ }^{915}$, com a necessária verificação da existência ou subsistência dos requisitos autorizadores da interceptação no final de cada lapso de tempo.

O controle pelo juiz é indispensável ${ }^{916}$, enquanto a vigilância do Ministério Público encontra guarida nos artigos 127, “caput”, e 129, incisos II e VII, da Constituição

${ }^{913}$ Rodríguez entende que, na Espanha, onde a lei é silente a esse respeito, a descoberta de fatos não ligados com aqueles para os quais se autorizou a intervenção não pode, aí, ser usado como prova, mas pode servir para abrir nova investigação como "notitia criminis" (2004, p. 134). Em Portugal, Albuquerque entende que só podem ser aproveitados em outro processo, instaurado ou a instaurar, os "conhecimentos fortuitos" obtidos através de uma escuta telefônica que se destine a fazer prova de um crime do catálogo legal em relação a pessoa do catálogo legal de alvos (2008, p. 511). M. Gonçalves entende que o número 7 do artigo 187 do Código de Processo Penal português, inserido pela Lei 48/2007, estabeleceu justamente essa regra (2007, p. 425-427). Ele cita ainda acórdão do STJ lusitano nesse sentido (p. 429/430). Por essa restrição, também Mata-Mouros (2003, p. 91-92). Ver mais a respeito dos "conhecimentos fortuitos" em Aguilar (2004), que faz distinção entre estes e os "conhecimentos da investigação" (p. 17-18): "[t]emos, então, que os conhecimentos da investigação serão os factos, obtidos através de uma escuta telefónica legalmente efectuada, que se reportam ou ao crime cuja investigação legitimou a realização daquela ou a um outro delito (pertencente ou não ao catálogo legal) que esteja baseado na mesma situação histórica de vida ('historischen Lebenssachverhalt') daquele. Note-se que o que o critério aferidor do segundo segmento da definição por nos [sic] proposta, não se confundindo com o problema do objecto do processo, não deixa, não obstante, de ter uma natureza eminentemente processual. Isto é, entre a acção do catálogo ('Katalogtat') cuja investigação determinou a realização da escuta telefónica e a acção (pertencente ou não ao catálogo) desta forma descoberta terá de haver uma identidade de investigação no sentido processual. [...] Pelo que, em contrapartida, conhecimentos fortuitos serão aqueles factos (ou conhecimentos) obtidos através de uma escuta telefónica legalmente efectuada e que não se reportem, nem ao crime cuja investigação determinou a realização daquela, nem a qualquer outro delito (pertencente ou não ao catálogo legal) que esteja baseado na mesma situação histórica de vida daquele. Ou seja, os conhecimentos fortuitos definem-se negativamente face aos conhecimentos de investigação. Daí o seu carácter residual”.

${ }^{914}$ No recente Habeas Corpus 76686/PR, Relator Ministro Nilson Naves, julgado pela Sexta Turma do STJ, entendeu-se que o prazo pode ir além dos trinta dias (quinze mais quinze) estipulados pelo artigo $5^{\circ}$ da Lei 9.296/1996, desde que "haja decisão exaustivamente fundamentada", sob pena de "evidente violação do princípio da razoabilidade". Ver Apêndice B, número 5, desta dissertação. Entendemos que a Lei 9.296/1996, apesar das mais variadas defesas em torno da interpretação diversa, inclusive por parte dos Tribunais superiores, limitou, para o bem ou para o mal, o prazo máximo, em tese, para trinta dias, se o primeiro prazo foi do teto de quinze dias. Ou seja, entendemos que a lei diz o que nela está escrito: só pode haver uma prorrogação, por período de tempo igual ao do prazo inicial da medida autorizado pelo juiz. O que disso desbordar será nulo relativamente à produção de prova, sob pena de se desconsiderar o que dispõe o inciso XII do artigo $5^{\circ}$ da Constituição Federal. A questão da gravidade ou complexidade da infração investigada em dado caso concreto certamente é relevante, mas não justifica o afastamento do que determina a legislação. Lembre-se que argumentação semelhante já havia antes da regulamentação do dispositivo constitucional pela Lei 9.296/1996, e, então, o próprio STF entendeu, a despeito de outras considerações, que a limitação exigia a atuação do legislador ordinário. Apesar de a Lei 9.296/1996 deixar certas questões em aberto, nesse ponto é clara, apesar de, concordamos, insatisfatória. Se a opção tivesse sido por prorrogações indefinidas, teria sido usada outra redação, a exemplo de leis estrangeiras (Portugal, Espanha), como a construção "[...] quinze dias, prorrogável por iguais períodos", no plural.

${ }_{915}$ Nesse sentido, Albuquerque (2008, p. 514-515).

${ }^{916}$ Interpretação do artigo $5^{\circ}$, inciso XII, da Constituição Federal. 
Federal $^{917}$, ao passo que a execução das operações, propiciada pela prestadora de serviço pertinente, deve ser feita pela autoridade policial $^{918}$.

No mais, tanto o Anteprojeto da Comissão de Juristas quanto o Projeto de Lei 3.272/2008 procuram estabelecer claramente o dever de as autoridades policiais remeterem todo o material para o juiz competente ${ }^{919}$, bem como o direito de acesso integral ao resultado das interceptações ${ }^{920}$, além dos meios para assegurar sua inviolabilidade ${ }^{921}$, e a possibilidade expressa de se impugnar o seu conteúdo através do incidente de falsidade do Código de Processo Penal ${ }^{922}$. O controle sobre a legitimidade da prova, isto é, do meio pelo

917 Ver artigo 12 do Anteprojeto da Comissão de Juristas, artigo 10 do Projeto de Lei 3.272/2008 e artigo $9^{\circ}$, inciso III, da Lei Complementar 75/1993. A supervisão do Ministério Público deve ser obrigatória. Nesse sentido, Corvini (1997).

${ }^{918}$ Streck (1997) defende que deveria ser estendida ao Ministério Público a possibilidade de realizar as interceptações, já que pode investigar. Corvini (1997) entende que a execução pelas autoridades policiais deve ser restritivamente interpretada como execução meramente material, devendo o controle operativo ser efetuado pelo Ministério Público ou, num cenário ideal, pelo juiz.

${ }^{919} \mathrm{O}$ artigo 14 da Resolução 59, de 9 de setembro de 2008, do Conselho Nacional de Justiça explicita que as autoridades competentes, quando pedirem prorrogação de prazo, devem apresentar os áudios com o inteiro teor das comunicações interceptadas. Esse artigo refere-se "a áudios (CD/DVD) com inteiro teor das comunicações captadas".

${ }^{920} \mathrm{O}$ artigo $9^{\circ}$, parágrafo único, da Lei 9.296/1996 dispõe que é facultada a presença do acusado ou de seu representante legal no incidente de inutilização de gravação, que pode ocorrer na fase do inquérito, instrução processual ou após esta ("caput" desse artigo). Resta uma lacuna, porém, quando a lei restringe-se ao "acusado" e, ao mesmo tempo, permite a ocorrência do incidente de inutilização mesmo na fase de investigação. Isso porque pode ocorrer de, no curso das investigações, descobrirem-se partícipes ou cúmplices, os quais, dependendo do momento em que ocorrer a destruição das "gravações", poderão ser prejudicados em seu direito de defesa, pois não terão tido oportunidade de acessá-las e se pronunciarem a respeito. Inclusive poderão ter sido destruídas gravações que lhe seriam favoráveis. Além disso, apesar de se inferir desse mesmo dispositivo da lei que, por lógica, o acusado deve ter acesso às gravações propriamente ditas, há julgados que entendem que basta o acesso às transcrições das conversas telefônicas, como, por exemplo, o Habeas Corpus 91518/MG, Relator Ministro Napoleão Nunes Maia Filho (ver Apêndice B, número 5, desta dissertação). L. Gomes (1997) entende que o terceiro também pode requerer a inutilização e presenciar a sua efetivação, mas que, de todo modo, uma vez provocado, cabe ao juiz fazer a seleção do que interessa ou não ao processo. Essa posição é compartilhada por Grinover, Fernandes e Gomes Filho (2001). O Código de Processo Penal italiano assegura aos defensores das partes, ao Ministério Público e ao juiz acesso ao resultado integral das interceptações, que, depois, são selecionadas (artigo 268, números 4, 6 e 7). É assegurado também aos defensores o direito de extrair cópia das transcrições e do conteúdo das interceptações em suporte idôneo (artigo 268, número 8). Já o artigo 188, número 6 e respectivas alíneas, do Código de Processo Penal de Portugal parece não assegurar esse direito expressamente ao estabelecer várias hipóteses em que o juiz deve determinar a "destruição imediata dos suportes técnicos e relatórios manifestamente estranhos ao processo". Ver a respeito, dentre outros, Albuquerque (2008, p. 516-522) e M. Gonçalves (2007, p. 432/436). Algo parecido ocorre na França, onde o Código de Processo Penal só estabelece ao juiz da instrução ou do oficial da polícia judiciária a ele subordinado competência para a transcrição da "correspondência" (comunicação) "útil à manifestação da verdade", da qual é lavrada uma ata (artigo 100-5), sem a previsão da participação do acusado ou processado. O Código de Processo Penal da Espanha é silente a respeito, dispondo somente sobre a abertura de correspondência postal, que é feita pelo juiz e para a qual é citado o interessado, para presenciar, por si mesmo ou por representante por ele designado, a operação (artigos 584 e 585).

${ }^{921}$ A Resolução 59/2008 do Conselho Nacional de Justiça procurar estabelecer meios de assegurar a inviolabilidade, inclusive pela encriptação dos áudios, das transcrições das conversas relevantes e dos relatórios apresentados ao juiz com "chaves" por ele definidas enquanto condutor do processo criminal (artigo 14, parágrafo $2^{\circ}$ ).

${ }_{922}$ Nem sempre os nossos Tribunais asseguram esse direito, como se vê, por exemplo, no Habeas Corpus 30545/PR, em que o STJ negou a possibilidade de realização de perícia para verificar se houve tratamento 
qual foi obtida e da sua integridade, bem como da sua admissibilidade no processo, é outro modo de combate a condutas ilícitas ${ }^{923}$.

Dever-se-iam especificar os limites subjetivos da medida, ou seja, quem pode determiná-la, requerê-la e contra quem pode ser determinada, desde logo e no curso das investigações, e em que circunstâncias.

Quem pode determinar a interceptação parece ser simples: a autoridade judicial ${ }^{924}$. Contudo, o artigo 58, parágrafo $3^{\circ}$, da Constituição Federal atribui às Comissões Parlamentares de Inquérito criadas conjunta ou isoladamente pela Câmara dos Deputados e pelo Senado Federal "poderes de investigação próprios das autoridades judiciais” (grifo nosso) "para a apuração de fato determinado e por prazo certo, sendo suas conclusões, se for o caso, encaminhadas ao Ministério Público, para que promova a responsabilidade civil ou criminal dos infratores".

O STF já teve diversas oportunidades de se manifestar sobre os limites dos poderes investigatórios das Comissões ${ }^{925}$, sendo que, no tocante às interceptações telefônicas, o entendimento é de que não têm competência para determinar, por ato próprio, levantamento do sigilo das comunicações, tampouco o de quebrar segredo de justiça a elas relativo, pois não têm poder instrutório ou investigatório para fins penais ${ }^{926}$.

Quem pode requerer: a autoridade policial, só no curso das investigações, e o Ministério Público, também no processo. Quem deveria poder fazê-lo: o ofendido, ao menos em alguns crimes ${ }^{927}$.

Ademais, deveria haver um detalhamento da responsabilidade de cada um no pedido e na execução da medida, com a determinação de que haja autorização de superior hierárquico, no caso da polícia, com identificação nominal e número funcional de cada um, e a necessária limitação interna de acesso às informações concernentes à interceptação, a

digital das conversas para atribuir a autoria de conversas a outros (Relator Ministro Felix Fischer, no Apêndice B, número 5). O Anteprojeto de Lei da Comissão de Juristas, como visto, trazia dispositivos específicos (artigo 16, parágrafos $3^{\circ}$ e $4^{\circ}$ ), assim como o faz o Projeto de Lei 3.272/2008 (artigo 14). O Código de Processo Penal italiano prevê expressamente a possibilidade de perícia das gravações (artigos 268, número 7, e 220 e seguintes).

923 Afirmam Grinover, Fernandes e Gomes Filho (2001, p. 25): “[...] as garantias constitucionais-processuais, mesmo quando postas aparentemente em benefício da parte, visam em primeiro lugar ao interesse público na condução do processo segundo as regras do devido processo legal. Resulta daí que o ato processual, praticado em infringência à norma ou ao princípio constitucional de garantia, poderá ser juridicamente inexistente ou absolutamente nulo; não há espaço, nesse campo, para atos irregulares sem sanção, nem para nulidades relativas".

${ }_{924}$ Artigo $5^{\circ}$, inciso XII, da Constituição Federal.

925 Ver Apêndice A, números 3 e 12, desta dissertação.

926 Medida Liminar referendada pelo Pleno no Mandado de Segurança 27483/DF, Relator Ministro Cezar Peluso, no Apêndice A, número 12.

${ }^{927}$ Ver L. Gomes (1997). O Anteprojeto ainda previa a possibilidade de o suspeito ou acusado requerer. 
fim de se proteger o sigilo das comunicações.

Quanto à parte subjetiva passiva, a Lei 9.296/1996 apenas refere-se a “investigados", no parágrafo único do artigo $2^{\circ}$, levando a um entendimento de que qualquer um, desde que não se encaixe em pelo menos um dos critérios de exclusão dos incisos I a III, pode ter suas comunicações interceptadas a qualquer momento.

Certamente que uma interpretação estrita dos incisos I e III do artigo $2^{\circ}$ pode levar à limitação da extensão subjetiva da interceptação aos autores ou partícipes do fato investigado específico, embora nem sempre bem delimitado ${ }^{928}$. Mas, na inexistência de disposições expressas na Lei nesse sentido, subsiste uma situação de instabilidade quanto ao poder estatal nessa área e uma conseqüente tensão com os direitos fundamentais dos indivíduos.

Assim, devem ser definidos os sujeitos passivos, os alvos da medida. Consideramos lapidar, nesse ponto, a delimitação efetivada pelo Código de Processo Penal de Portugal, que dispõe no seu artigo 187, número 4:

A interceptação e a gravação previstas nos números anteriores [hipóteses objetivas, isto é, o catálogo de crimes] só podem ser autorizadas, independentemente da titularidade do meio de comunicação utilizado, contra:

a) Suspeito ou arguido;

b) Pessoa que sirva de intermediário, relativamente à qual haja fundadas razões para crer que recebe ou transmite mensagens destinadas ou provenientes de suspeito ou arguido; ou

c) Vítima de crime, mediante o respectivo consentimento, efectivo ou presumido.

Logo, pensamos ser prudente estabelecer explicitamente que a medida só pode ser autorizada em relação ao fato investigado e àqueles envolvidos nele ${ }^{929}$, com a desconsideração jurídica da eventual captação de conversas de terceiros que tenham se

\footnotetext{
${ }^{928} \mathrm{O}$ fato tem de ser passado, isto é, tem de haver fortes evidência da materialidade do crime, e não meras suspeitas ou conjecturas. Ver Cervini (1997, p. 62-65), para quem a adoção da medida de interceptação numa situação de total indefinição ou em relação a quem sequer ostenta a condição de acusado será ausente de fundamento legitimador. "Não existe interceptação telefônica pré-delitual, fundada em mera conjectura ou periculosidade (de uma situação ou de uma pessoa). Não é possível interceptação telefônica para verificar se uma determinada pessoa, contra a qual inexiste qualquer indício, está ou não cometendo algum crime. É absolutamente defesa a chamada 'interceptação de prospeç̧ão', desconectada da realização de um fato delituoso, sobre o qual ainda não se conta com indícios suficientes. No nosso 'ius positum', em suma, só se admite interceptação pós-delitual. E a finalidade última dessa medida cautelar tem que ser uma investigação criminal (ou instrução penal). Não é possível, conseqüentemente, interceptação para fins civis, comerciais, industriais, administrativos, políticos etc. Nem sequer para investigação que envolva direitos difusos (coletivos). Não cabe interceptação em ação civil pública, ação de enriquecimento ilícito etc" (L. GOMES, 1997, p. 117-118). Grinover, Fernandes e Gomes Filho (2001) entendem que pode ser aproveitada prova em relação à pessoa não mencionada na autorização judicial da medida desde que os elementos colhidos estejam ligados ao fato que está sendo investigado.

${ }_{929}$ Ver a respeito Greco Filho (2005, p. 27-29).
} 
utilizado dos meios de comunicações através dos quais os investigados ligados ao fato comunicam-se $\mathrm{e}^{930}$, e a obrigação de imediata comunicação ao juiz.

Deve-se regular, ainda, a interceptação de conversas abrangidas pelo segredo, como é o caso do médico e o do advogado ${ }^{931}$.

A Lei 8.906/1994 traz como direito dos advogados a inviolabilidade das suas comunicações, desde que relativas ao exercício da advocacia, permitindo a busca e apreensão de sua "correspondência escrita, eletrônica, telefônica e telemática" através de mandado judicial a ser cumprido na presença de representante da Ordem dos Advogados do Brasil, ressalva que não se aplica aos clientes que estejam sendo investigados como partícipes ou co-autores no mesmo fato que deu ensejo à expedição do mandado, como decorre da redação do seu artigo $7^{\circ}$, inciso II e parágrafos $6^{\circ}$ e $7^{0932}$.

O Projeto de Lei 3.272/2008, por sua vez, traz disposição semelhante no seu artigo

${ }^{930}$ Em outras palavras, como a interceptação é dirigida a comunicações de dadas pessoas, através da aplicação de meios técnicos, e não em relação, por exemplo, a um número de telefone isoladamente considerado, não podem ser captadas ou licitamente utilizadas conversas travadas por outros que não tenham conexão com o fato e não estejam indicados no pedido de interceptação, como membros de uma mesma família que partilhem o telefone utilizando-o para os mais diversos fins. Ver a respeito Albuquerque (2008, p. 509), que, comentando o artigo $187^{\circ}$ do Código de Processo Penal lusitano, afirma: "[...] a existência do catálogo de alvos obsta à determinação de escutas telefónicas em processo contra incertos. O legislador pretendeu que a autorização judicial tivesse por referência as conversações mantidas por pessoas concretas, ainda que não seja conhecida a sua identidade civil. São, portanto, inadmissíveis as escutas determinadas a grupos de pessoas cujo único traço comum é o de ocuparem habitualmente ou esporadicamente um determinado espaço físico" (destaque do autor). Em recente julgado do STJ, o Ministro Nilson Naves, em voto-vista, entendeu que provas resultantes de interceptação telefônica são ilícitas se não constam no requerimento da autoridade policial e nem na decisão do juízo de autorização do monitoramento a qualificação e, tampouco, a identificação do investigado (ver Habeas Corpus 89023/MS, Relatora Desembargadora Jane Silva, no Apêndice B, número 5).

${ }^{931}$ Ver Streck (1997, p. 38-39) e Greco Filho (2005, p. 32). Em Portugal, a redação atual do Código de Processo Penal proíbe "a interceptação e a gravação de conversações ou comunicações entre o arguido e seu defensor, salvo se o juiz tiver fundadas razões para crer que elas constituem objecto ou elemento de crime" (artigo $187^{\circ}$, número 5), proteção estendida àquelas pessoas legitimadas pela lei a recusar depoimento em nome do segredo profissional (artigo 188 , número 6, alínea "b"). Ver Albuquerque (2008). Na França, o Código de Processo Penal proíbe, sob pena de nulidade, a transcrição das "correspondências" (comunicações) com um advogado "relevante ao exercício dos direitos da defesa" (artigo 100-5).

932 A Lei 8.906/1994 já trazia como direito dos advogados, na redação original do inciso II do artigo $7^{\circ}$, "ter respeitada, em nome da liberdade de defesa e do sigilo profissional, a inviolabilidade de seu escritório ou local de trabalho, de seus arquivos e dados, de sua correspondência e de suas comunicações, inclusive telefônicas ou afins, salvo caso de busca ou apreensão determinada por magistrado e acompanhada de representante da OAB [Ordem dos Advogados do Brasil]". A Lei 11.767, de 7 de agosto de 2008, alterou esse inciso, que passou a dispor: "a inviolabilidade de seu escritório ou local de trabalho, bem como de seus instrumentos de trabalho, de sua correspondência escrita, eletrônica, telefônica e telemática, desde que relativas ao exercício da advocacia". Também foram acrescidos os parágrafos $6^{\circ}$ e $7^{\circ}$ a esse artigo $7^{\circ}$ : "§ $6^{\circ}$ Presentes indícios de autoria e materialidade da prática de crime por parte de advogado, a autoridade judiciária competente poderá decretar a quebra da inviolabilidade de que trata o inciso II do 'caput' deste artigo, em decisão motivada, expedindo mandado de busca e apreensão, específico e pormenorizado, a ser cumprido na presença de representante da $\mathrm{OAB}$, sendo, em qualquer hipótese, vedada a utilização dos documentos, das mídias e dos objetos pertencentes a clientes do advogado averiguado, bem como dos demais instrumentos de trabalho que contenham informações sobre clientes. $\S 7^{\circ}$ A ressalva constante do $\S 6^{\circ}$ deste artigo não se estende a clientes do advogado averiguado que estejam sendo formalmente investigados como seus partícipes ou co-autores pela prática do mesmo crime que deu causa à quebra da inviolabilidade". 
$2^{\circ}$, parágrafo único: “[e]m nenhuma hipótese poderão ser utilizadas as informações resultantes da quebra de sigilo das comunicações entre o investigado ou acusado e seu defensor, quando este estiver atuando na função". Assim já o fazia o Anteprojeto da Comissão de Juristas no seu artigo $3^{\circ}$.

No entanto, não há previsão expressa, atual ou nos Projetos de Lei consultados, a respeito de conversas de outras pessoas que têm proteção especial, o que entendemos ser indispensável, inclusive para que não haja diferença entre situações que merecem tratamento semelhante ${ }^{933}$.

Objetivamente, devem ser definidos quais fatos descobertos no curso das investigações autorizam a extensão da interceptação (sempre por ordem do juiz), o que se encontra umbilicalmente ligado à questão dos sujeitos que podem ser alvo da medida.

A Lei 9.296/1996 não dispõe a respeito, e seria de se supor, como já visto, que os fatos teriam, pelo menos, de caracterizar um crime permitido pelo artigo $2^{\circ}$, o que, no tocante ao requisito da pena máxima, vem sendo desconsiderado pela jurisprudência.

Entendemos que os fatos descobertos devem ter conexão com o original, bem como ser relativos aos seus sujeitos passivos, sendo que a interceptação só pode ser autorizada se presentes os demais requisitos estabelecidos pela lei ${ }^{934}$.

Os fatos conexos não precisam ter a mesma tipificação do principal, considerandose que, não raro, a interceptação visa à investigação de quadrilha ou bando que pode exercer várias atividades criminosas.

Pode acontecer que, no curso da investigação criminal, se descubra o
envolvimento de outras pessoas que não as inicialmente "referenciadas" ou o
uso, pelo suspeito, de outros números de telefone que os inicialmente
identificados. Trata-se do problema da ampliação objectiva (alargamento do
número de telefones a intervir) e subjectiva (ampliação do número de pessoas a
intervir). Importa equacionar o tema da ampliação objectiva e subjectiva à luz do
princípio da proporcionalidade. Como já o referimos, os parâmetros definidores
da proporcionalidade da medida da intervenção nas comunicações telefónicas

${ }^{933}$ Pode-se estabelecer um paralelo com o artigo 207 do Código de Processo Penal, segundo o qual "[s]ão proibidas de depor as pessoas que, em razão de função, ministério, ofício ou profissão, devam guardar segredo, salvo se, desobrigadas pela parte interessada, quiserem dar o seu testemunho". Há precedente do STJ que leva esse fato em consideração, apesar de se tratar de relação entre advogado e cliente: "[c]onversa pessoal e reservada entre advogado e cliente tem toda a proteção da lei, porquanto, entre outras reconhecidas garantias do advogado, está a inviolabilidade de suas comunicações. [...] Como estão proibidas de depor as pessoas que, em razão de profissão, devem guardar segredo, é inviolável a comunicação entre advogado e cliente. [...] Na hipótese, conquanto tenha a paciente concordado em conceder a entrevista ao programa de televisão, a conversa que haveria de ser reservada entre ela e um de seus advogados foi captada clandestinamente. Por revelar manifesta infração ética o ato de gravação - em razão de ser a comunicação entre a pessoa e seu defensor resguardada pelo sigilo funcional -, não poderia a fita ser juntada aos autos da ação penal. [...]" (Trecho da ementa do Habeas Corpus 59967/SP, Relator Ministro Nilson Naves, no Apêndice $B$, número 5, destaque nosso).

${ }_{934}$ Atualmente, os do artigo $2^{\circ}$ da Lei 9.296/1996. 
passam pelo respeito dos imperativos constitucionais em matéria de restrição de direitos fundamentais. [...] iniciada uma investigação relativamente a certa pessoa ou número de telefone, com base em indícios determinados, o alargamento da medida a outras pessoas ou telefones apenas estará legitimado quando se mantenha a ligação inicial de suspeita relativamente ao sujeito passivo inicial ou quando, no decurso da medida, se descobrirem indícios ou factos determinados cuja existência legitimaria, por si só, uma autónoma decisão judicial de intervenção. A ampliação, seja objectiva ou subjectiva, implica um juízo fundamentado do juiz e a revisão dos critérios que legitimam a autorização da medida de levantamento do segredo nas comunicações, nomeadamente analisando-se se se mantêm os pressupostos da intervenção inicial. (B. RODRIGUES, 2008, tomo I, p. 297-298, destaques do autor).

Ficam excluídos, então, aqueles fatos totalmente dissociados, aqueles que não digam respeito ao ou não tenham relação com o sujeito passivo e aqueles que não passam pelo filtro de admissibilidade de autorização da medida ${ }^{935}$.

Resta a questão dos conhecimentos fortuitos, isto é, aqueles atinentes a possíveis condutas criminosas não relacionadas ao objeto ou sujeito da medida de interceptação original. Entendemos que a possibilidade de uso das informações nesse caso depende do regime adotado.

Se mantido o sistema atual, em que não há um catálogo de crimes e nem de sujeitos passivos, mas um critério baseado na pena de reclusão em abstrato aplicável, a princípio, a qualquer investigado, entendemos que conhecimentos fortuitos sobre outros crimes não podem ser utilizados de qualquer maneira, pois abrir-se-ia a possibilidade de extensão indefinida de investigações de quaisquer condutas, inclusive daquelas que sequer teriam a possibilidade de autorizar a interceptação, ocasionando uma violação à excepcionalidade positivada pela parte final do inciso XII do artigo $5^{\circ}$ da Constituição Federal.

Entretanto, se adotado o sistema de um catálogo de crimes graves, como sugerimos, com a definição clara dos sujeitos passivos, entendemos que tal descoberta pode ser utilizada como prova em outro processo criminal se se encaixar nos requisitos de indispensabilidade do meio de produção de prova e de enquadramento do sujeito passivo e da conduta criminosa no rol da lei de interceptação, sendo que o juiz do processo "principal", aquele em que surgiu o conhecimento fortuito, deve remeter todo o material

935 Esse é o entendimento também de Greco Filho (2005), que defende a necessidade de existência de concurso de crimes, continência ou conexão. Streck entende que, se o crime descoberto estiver dentro da cadeia de fatos atribuídos aos autores (sujeitos investigados), não há problema em se utilizar da prova assim obtida. Caso não façam parte dessa cadeia de fatos, entende que essa prova não pode ser utilizada para instaurar processo contra o sujeito, mas constituirá indício apto para, por exemplo, fundamentar um novo pedido de interceptação quanto a essa descoberta, mas nunca como prova bastante para instauração da ação penal (1997, p. 93-99). Jesus (1997) entende que, se durante a realização da diligência surjam elementos de um outro delito distinto do objeto original da medida, a prova assim obtida não pode ser utilizada para essa investigação, sendo nula de pleno direito: “[...] Nesse caso, a autoridade policial ou o MP [Ministério Público] deve solicitar nova diligência visando à investigação do outro delito" (p. 467). Veja-se, ainda, Corvini (1997, p. 65-66). 
concernente ao crime para o juiz competente, que terá de assegurar o contraditório e a ampla defesa ao investigado ou acusado ${ }^{936}$.

Se o fato não se encaixar nos requisitos autorizadores da medida, entendemos que a informação pode ser usada como "notitia criminis", apta a autorizar a abertura de nova investigação, desde que se trate de uma infração constante desse catálogo ${ }^{937}$. Isso por uma questão de razoabilidade, ou seja, de sopesamento entre valores em jogo: como já limitada a medida intrusiva a um número restrito de situações graves previamente delimitadas pelo legislador, a investigação de fatos igualmente graves não ofende o ordenamento e mantém um equilíbrio entre a proteção dos direitos do indivíduo e os da sociedade.

Discussões surgem em situações extremas, ou casos-limite, sendo exemplos comuns o da descoberta de ilícito grave ou de situação de iminente risco à segurança ou à saúde da coletividade através de uma interceptação ilegal: ficariam as autoridades de mãos atadas, impossibilitadas de agir em virtude da ilicitude do meio de descoberta? Ou se apreendida grande quantidade de narcóticos com um indivíduo, deveria a droga ser liberada?

O artigo 10 da Lei 9.296/1996, embora conste de diploma autônomo, submete-se às regras gerais do Código Penal, que prevê excludentes de ilicitude, como a legítima defesa e o estado de necessidade. Por essa razão, as autoridades poderiam e deveriam (dever do ofício) agir para evitar o atentado em nosso caso hipotético, mas, processualmente, as evidências descobertas por esse modo ilícito não poderiam embasar um processo criminal contra os suspeitos ou acusados. Serviriam, no máximo, como "notitia criminis" apta a iniciar uma investigação.

O mesmo se diga a respeito da apreensão da droga, considerada, por si mesma, ilícita pela legislação brasileira, que deve ser mantida sob custódia do Estado, podendo-se até prender o seu possuidor em flagrante. Mas, mesmo aí, não poderá ser usado como prova o resultado da interceptação ilegal ${ }^{938}$.

\footnotetext{
936 Assim é hoje em Portugal, como consta do artigo $187^{\circ}$, número 7, do Código de Processo Penal. Ver, por exemplo, Albuquerque (2008).

${ }^{937}$ Ver a respeito do tema L. Gomes (1997).

${ }^{938}$ Ver, nesse sentido, Jesus (1997). Em outras palavras, entendemos que a exclusão processual das provas derivadas diretamente da interceptação ilegal não importa na sua "devolução" àquele de quem foi retirada, pois a interpretação combinada do incisos XII e LVI do artigo $5^{\circ}$ da Constituição Federal atinge o processo, não necessariamente os efeitos externos, embora possa produzi-los. Por exemplo, uma pena de prisão cominada somente com base numa prova ilegal: a sua exclusão do processo penal acarreta a nulidade da pena, e, por conseguinte, a liberdade do indivíduo, por, no mínimo, ausência de provas. Lembre-se, ademais, que o tráfico de entorpecentes é um dos poucos crimes pelo qual a própria Constituição Federal demonstra particular repúdio, como se vê nos artigos $5^{\circ}$, incisos XLIII e LI, e 243, "caput" e parágrafo único. Contudo, o STF, no Habeas Corpus 76203/SP, Relator Ministro Marco Aurélio, Relator para o Acórdão Ministro
} 
Por sua vez, a exclusão de ilicitude penal da conduta do agente nesses casos não importará numa exclusão de ilicitude, ou, quiçá, “ilegitimidade” processual da evidência obtida sem as prescrições da Lei.

Porém, fora dessas situações de exclusão de ilicitude, em que há um risco iminente a outro bem jurídico de superior importância, o eventualmente descoberto deve ser desconsiderado, com a anulação da decisão judicial que tenha se baseado na prova ilícita, ou do processo inteiro, sob pena de tornar letra morta a ordem constitucional e legal ${ }^{939}$.

Enfim, pensamos que melhor seria adotar uma lista exaustiva de crimes, incluindo também circunstâncias pelos quais crimes são praticados, isto é, por intermédio das comunicações, com a possibilidade restrita de se utilizar provas relativas a crimes conexos ou ligados ao objeto da interceptação original, sempre com autorização judicial e com atendimento dos requisitos legais.

Anotamos que deve ser observada, qualquer que seja a lei regulamentadora, a limitação constitucional à finalidade da prova colhida: investigação criminal e instrução processual penal $^{940}$.

Nelson Jobim (ver Apêndice A, número 2, desta dissertação), entendeu que a apreensão de dez quilos de cocaína constituía prova autônoma, apesar de se ter chegado a ela somente através de interceptação telefônica efetuada antes da edição da Lei 9.296/1996, sendo que todas as provas vieram dos resultados dessa medida, as quais seriam, a rigor, ilegais, inclusive conforme entendimento firmado pelo próprio Tribunal. O Ministro Nelson Jobim chegou a afirmar em seu sucinto voto que "[s]e chegássemos a aplicar o princípio da contaminação absoluta, teríamos que devolvê-la [a droga], uma vez que ela teria sido apreendida ilicitamente", conclusão que refutamos: embora a apreensão fosse, a rigor, ilícita, a própria detenção da droga também era ilícita. A nulidade do processo poderia resultar, aí, na liberdade do réu, por falta de provas no processo penal, mas a droga permaneceria apreendida, inclusive por disposição do artigo 40 da então vigente Lei 6.368, de 21 de outubro de 1976.

${ }_{939}$ Isso porque, pela nossa visão, a adoção dessa modalidade de exclusão de ilicitude de obtenção de provas causa mais danos à sociedade do que benefícios, pois: (i) "flexibiliza" de tal modo a garantia do artigo $5^{\circ}$, incisos XII e LVI, da Constituição Federal que, na prática, anula esses dispostivos; (ii) gera insegurança entre as pessoas, pois qualquer coisa que digam ou façam pode vir a ser usada contra elas por uma noção de estado de necessidade, legítima defesa, inexigibilidade de conduta diversa, proporcionalidade, dentre outros; (iii) favorece o estabelecimento de um Estado e uma sociedade de vigilância, pois, afinal, é possível que, a qualquer momento, descubram-se ilícitos (penais e outros) que possam justificar o uso de uma prova obtida por interceptação igualmente ilícita, ou outros meios. Se se puder gravar conversas alheias (fora do regime da lei), o que impede a invasão não autorizada de casas para se buscar indícios, e utilizá-los num processo, de crimes relacionados à pedofilia, por exemplo? De acordo com L. Gomes (1997, p. 119-120), "[n]esses casoslimite, o máximo que se poderia permitir seria a interceptação telefônica apenas para evitar a calamidade, nunca como prova judicialmente válida para incriminar qualquer pessoa".

${ }_{940}$ Artigo $5^{\circ}$, inciso XII, parte final. Comungam desse entendimento Greco Filho (2005), L. Gomes (1997) e Streck (1997). L. Gomes argumenta (1997, p. 119): “[...] Urge o respeito à vontade do constituinte ('fins criminais'). Ao permitir a interceptação, como quebra que é do sigilo das comunicações, somente para 'fins criminais', já fazia uso da ponderação e da proporcionalidade, que agora não pode ser ampliada na prática. Impõe-se, por último, acrescentar: essa prova criminal deve permanecer em 'segredo de justiça'. É inconciliável o empréstimo de prova com o segredo de justiça assegurado no art. 1 [da Lei 9.296/1996]". Esse critério, estabelecido pelo constituinte originário, não vem sendo observado, ressalte-se, pois várias decisões têm autorizado o uso do resultado da interceptação como prova emprestada até mesmo em processos administrativos. Com relação à prova emprestada, além de precedentes do STF já mencionados, há autores que lhe são favoráveis. Nesse sentido, afirma Nery Junior (2002, p. 167): “[s]endo norma de exceção, o 
Seria importante também instituir e regulamentar uma notificação dos sujeitos alvo de interceptações, ou seja, do direito de o indivíduo ser notificado posteriormente a respeito da existência de interceptação autorizada e realizada contra si, mormente quando dela não tenha aparecido qualquer indício de prática criminosa. Anota Streck (1997, p. 85), comentando o artigo $9^{\circ}$ da Lei 9.296/1996:

\begin{abstract}
Parece ser de bom alvitre que as pessoas citadas nas interceptações, e que não tenham qualquer relação com o fato investigado, sejam informadas a respeito do conteúdo da gravação. Tal providência se justifica na medida em que, após a conclusão da instrução, as provas somente podem ser inutilizadas mediante requerimento do Ministério Público ou da parte interessada. Parte interessada deve ser lido, aqui, "lato sensu", compreendendo-se qualquer pessoa cujos dados tenham sido recolhidos e que não tenham relação com o fato em discussão no processo ou na investigação.
\end{abstract}

A Corte Européia de Direitos Humanos, em KLASS AND OTHERS v. GERMANY, entendeu que a possibilidade de notificação subseqüente de interceptação realizada e encerrada deve levar em consideração que a atividade ou o perigo a respeito dos quais foram adotadas medidas de vigilância podem perdurar por anos ou décadas após

disposto no inciso XII do art. $5^{\circ}$ da CF deve ser interpretado restritivamente. Quer isto dizer que somente o juiz criminal pode autorizar a interceptação telefônica, quando ocorrerem as hipóteses previstas na Constituição Federal. O juiz do cível não pode determinar escuta telefônica para formar prova direta no processo civil. Entretanto, entendemos ser admissível a produção da prova obtida licitamente (porque autorizada pela $\mathrm{CF}$ ) para investigação criminal ou instrução processual penal, como prova emprestada, no processo civil. Para que seja admissível a prova emprestada no processo civil a doutrina exige que a parte contra quem vai ser produzida tenha efetivamente participado do processo penal de onde proveio a prova a ser emprestada. Caso contrário, em atenção ao princípio do contraditório, a parte terá de ratificar a prova no juízo cível. Mas, de qualquer sorte, admite-se a prova emprestada, como regra, do processo penal para o processo civil, dadas a unidade da jurisdição e teoria geral da prova". Mendes afirma que "[a] doutrina exige [...] para a admissibilidade dessa prova emprestada no processo civil, que a parte contra quem ela vai ser produzida tenha participado no processo penal de que promana a dita prova. Caso contrário, para não ferir o princípio do contraditório, a 'parte' terá de ratificar essa prova no juízo cível” (1999, p. 153). Ver, pela admissibilidade da prova emprestada, tomadas certas cautelas, Albuquerque (2008), Burnier Júnior (1999), Grinover (1997) e Mendes (1999). Observe-se a argumentação de Grinover, Fernandes e Gomes Filho (2001, p. 196-197) pela admissibilidade do resultado das interceptações como prova emprestada para processos entre as mesmas partes: “[a]s opiniões dividem-se, mas, de nossa parte, pensamos ser possível o transporte da prova. O valor constitucionalmente protegido pela vedação das interceptações telefônicas é a intimidade. Rompida esta, licitamente, em face do permissivo constitucional, nada mais resta a preservar. Seria uma demasia negar-se a recepção da prova assim obtida, sob a alegação de que estaria obliquamente vulnerado o comando constitucional. Ainda aqui, mais uma vez, deve prevalecer a lógica do razoável. [...] Nessa linha de interpretação, cuidados especiais devem ser tomados para evitar que o processo penal sirva exclusivamente como meio oblíquo para legitimar a prova no processo civil. Se o juiz perceber que esse foi o único objetivo da ação penal, não deverá admitir a prova na causa cível”. Pela inadmissibilidade da prova para fins extrapenais, "como inquérito civil ou administrativo e ação civil pública", Jesus (1997, p. 462). No tocante especificamente ao processo administrativo, nos casos em que o mesmo fato caracteriza, por exemplo, uma infração funcional, grave ou não, entendemos ser tal fato irrelevante, pois a questão não se resolve pela independência das esferas (penal e administrativa), mas, sim, por uma vedação de proibição de prova, a de utilização do resultado de interceptações de comunicações em processos não penais. Dessa maneira, pode o mesmo fato ser objeto de investigação e punição em várias esferas, mas, à exceção da penal, não poderá ser utilizada a prova decorrente da interceptação. Ver discussão a respeito na Questão de Ordem no Inquérito 2424/RJ, Relator Ministro Cezar Peluso, julgado pelo STF (Apêndice A, número 3, desta dissertação). 
a suspensão dessas medidas, além de haver o risco de se expor os métodos de operação dos serviços de inteligência ${ }^{941}$. No caso específico, entendeu que a legislação alemã instituía um sistema de controle de abusos suficiente, além de haver o dever de notificação do sujeito após um lapso de tempo razoável, de modo a não prejudicar o propósito da interceptação $^{942}$, mas enfatizou que embora as etapas de autorização e realização da interceptação sejam necessariamente secretas, por essa mesma razão,

[...] é essencial que os próprios procedimentos estabelecidos [na lei] devam providenciar adequadas e equivalentes garantias salvaguardando os direitos individuais. Adicionalmente, os valores de uma sociedade democrática devem ser seguidos o mais fielmente possível nos procedimentos de supervisão para que os limites da necessidade, dentro do significado do artigo $8^{\circ}$, parágrafo $2^{\circ}$ (art. 8 2), não sejam excedidos. [...] O Estado de Direito ["rule of law"] implica, entre outros, que uma interferência pelas autoridades executivas nos direitos de um indivíduo deve sujeitar-se a um efetivo controle normalmente assegurado pelo judiciário, ao menos como último recurso, controle judicial oferecendo as melhores garantias de independência, imparcialidade e de procedimento adequado $^{943}$.

Em outras palavras, como a vigilância é secreta, se não houver notificação posterior do indivíduo, a lei deve ser precisa, clara e estabelecer métodos eficientes de controle interno, bem delimitados, de preferência por autoridades dotadas do máximo de independência e parcialidade possível, e, pelo que pensamos, por pelo menos uma que não seja a que peça ou realize a interceptação, como já ocorre no Brasil, através do Judiciário.

No tocante à execução propriamente da interceptação e aos seus custos, o Projeto de Lei 3.272/2008, ao contrário do Anteprojeto e da Lei 9.296/1996, transfere-os à "prestadora responsável pela comunicação" "944. Isso contribui para dois efeitos danosos: o potencial crescimento do número de interceptações ${ }^{945}$ e o repasse dos custos aos usuários.

\footnotetext{
${ }^{941}$ Parágrafo 58 do acórdão.

${ }_{942}^{9}$ Parágrafo 59 do acórdão.

${ }^{943}$ Parágrafo 55 do acórdão. No original: “[...] it is essential that the procedures established should themselves provide adequate and equivalent guarantees safeguarding the individual's rights. In addition, the values of a democratic society must be followed as faithfully as possible in the supervisory procedures if the bounds of necessity, within the meaning of Article 8 para. 2 (art. 8-2), are not to be exceeded. [...]The rule of law implies, inter alia, that an interference by the executive authorities with an individual's rights should be subject to an effective control which should normally be assured by the judiciary, at least in the last resort, judicial control offering the best guarantees of independence, impartiality and a proper procedure".

944 Ver Anexo B desta dissertação.

${ }^{945}$ Mais detalhes têm aparecido na "CPI das Escutas Telefônicas Clandestinas", instalada em 19 de dezembro de 2007 na Câmara dos Deputados, "com a finalidade de investigar escutas telefônicas clandestinas/ilegais, conforme denúncia publicada na revista Veja, edição 2.022, n. 33, de 22 de agosto de 2007”. Informações prestadas à Comissão pelas empresas de telefonia apontavam cerca de trezentas e setenta e cinco mil interceptações autorizadas no ano de 2007, embora não tenham sido divulgados os critérios de contabilização (CPI, 2008), enquanto o CNJ estimava em cerca de doze mil o número de telefones sendo interceptados até outubro de 2008, sem contabilizar os Estados de São Paulo, Alagoas, Mato Grosso, Paraíba e Tocantins (CNJ, 2008). O grande número de interceptações não é um fenômeno exclusivo do Brasil, sendo observado também, por exemplo, em Portugal (MATA-MOUROS, 2003; VALENTI, 2004) e na Itália (PAOLINI;
} 
A nosso ver, um dos fatores limitadores dos abusos do Estado é o custo: a possibilidade de atos de intervenção "gratuitos" desestimula a racionalização de sua prática ${ }^{946}$. Desse modo, entendemos que o Estado custear os gastos, sem “isenções".

Por outro lado, o Projeto de Lei 3.272/2008 prevê um controle centralizado do número de interceptações autorizadas, para fins estatísticos, o que acabou sendo criado pelo Conselho Nacional de Justiça por meio da Resolução 59/2008, que tem por fim “aperfeiçoar e uniformizar o sistema de medidas cautelares referentes às interceptações telefônicas, de informática e telemática" ${ }^{947}$, ou seja, padronizar os procedimentos relativos a essa medida, ao determinar a obrigatoriedade de os juízos investidos de competência criminal informarem, mensalmente, às Corregedorias dos respectivos tribunais, em caráter sigiloso, a quantidade de interceptações em andamento e a quantidade de ofícios expedidos às operadoras de telefonia ${ }^{948}$. Essas Corregedorias, por sua vez, devem enviar para a Corregedoria Nacional de Justiça esses dados até o dia dez do mês seguinte ao de referência ${ }^{949}$.

Tal base de dados ${ }^{950}$ pode servir como desestímulo a abusos e, ao mesmo tempo, fonte para aprimoramentos. O ideal seria a criação, por lei, da obrigação dos executores materiais das medidas de enviar dados sobre o número de interceptações realizadas, para comparação com as informações enviadas pelas autoridades judiciais, a fim de se verificar descompassos, e, desse modo, ilegalidades. Obviamente que o método de contagem das interceptações teria de ser unificado para evitar discrepâncias formais.

De qualquer modo, todas as etapas, desde o pedido de autorização de interceptação até o fim das operações, com o uso e entrega dos resultados, além do acesso e extração de cópias, devem ser auditáveis, isto é, passíveis de registro, sem burla, com a finalidade de se aferir e apurar a responsabilidade de cada um durante o processo.

A prestação de contas através da "auditoria", no quanto possível, automática (registros eletrônicos via "software" ou "hardware"), ajuda a evitar autorizações e

\footnotetext{
ZAVATTARO, 2007).

${ }^{946} \mathrm{Na}$ Itália, a execução das operações deve ser feita, como regra, somente por equipamentos instalados na procuradoria da República, podendo, excepcionalmente, serem utilizados equipamentos de serviço público ou da polícia judiciária (artigo 268, número 4, do Código de Processo Penal). Na França, o Código de Processo Penal conferem ao juiz da instrução ou oficial da polícia judiciária a ele subordinado competência para requerer os serviços de qualquer agente encarregado da prestação de serviços de telecomunicação para procecer à instalação de um dispositivo de interceptação (artigo 100-3).

${ }_{947}$ Primeiro "[c]onsiderando" e artigo $1^{\circ}$.

${ }_{948}$ Artigo 18, "caput" e incisos I e II.

949 Essa Resolução ainda prevê que o Conselho Nacional de Justiça avaliará, em cento e oitenta dias, a eficácia das medidas por ela implantadas, adotando, se for o caso, outras providências para seu aperfeiçoamento (artigo 21).

${ }^{950}$ Esse tipo de base de dados existe nos Estados Unidos da América, nos moldes do ECPA.
} 
interceptações "oficiosas", bem como a disseminação ilícita de informações, inclusive à imprensa. A identificação única e inevitável de cada cópia gerada pelo sistema de interceptação permite rastrear a sua origem e destino ${ }^{951}$. Adicionalmente, a lei poderia prever a responsabilização pela posse e uso de cópias não autorizadas ou para fins não permitidos $^{952}$.

A procedimentalização detalhada ${ }^{953}$, a "auditoria" (registro) e a notificação são importantes para ajudar a aferir e controlar a legalidade das interceptações, medidas intrinsecamente sub-reptícias de intervenção na vida do indivíduo, isto é, meio secreto de vigilância $^{954}$.

Adicionalmente, é importante o controle legal sobre os equipamentos e "softwares" utilizados nas interceptações. Atualmente, fica a critério de cada autoridade escolhê-los, instalá-los e utilizá-los. Dever-se-ia, portanto, regular a fabricação, aquisição, venda, empréstimo e uso, através de algum órgão estatal, talvez do Ministério da Justiça, ou então da ANATEL, de modo que se permita, principalmente, seu rastreamento e obediência às normas legais. Lembre-se que o ECPA traz disposições nesse sentido ${ }^{955}$, assim como o

951 O artigo 13 do Projeto de Lei 3.272/2008 determina que a cópia extraída seja identificável.

952 O Projeto de Lei 3.272/2008 só veda o uso de provas obtidas em desacordo com a lei em processos, o Anteprojeto também somente estabelecia restrições nesse sentido, ao passo que a vigente Lei 9.296/1996 é silente. Criminalmente, todos penalizam a violação a violação do segredo de justiça (artigo 10 da Lei 9.296/1996, artigo 23 do Projeto de Lei 3.272/2008 e artigo $3^{\circ}$ do Projeto de Lei 4.036/2008), sendo que os Projetos de Lei 3.272/2008 e 4.036/2008 tipificam também a violação do sigilo das comunicações (artigos 23 e $3^{\circ}$, respectivamente). A violação do sigilo das comunicações ou mesmo do segredo de justiça pode ser interpretada como abrangendo a mera posse de cópia não identificada, já que os textos propostos não exigem resultado para um dos crimes, mas, pelo contrário, separa, a exemplo do que se dá hoje no artigo 10 da Lei 9.296/1996, daquele que exige fins ou objetivos não autorizados em lei (artigo 23 do Projeto de Lei 3.272/2008 e artigo $3^{\circ}$ do Projeto de Lei 4.036/2008). Contudo, exceto no caso do Projeto de Lei 3.272/2008, a simples posse de cópia não identificável hoje não tem, a princípio, repercussão jurídica, pois a sua existência não é exigida pela lei nem para aqueles que lhe tem acesso legitimamente garantido, como o acusado.

953 Para Cervini (1997), o detalhamento do regramento é uma conseqüência ineludível da excepcionalidade da interceptação das comunicações. Parte desse detalhamento deu-se com já citada Resolução 59/2008 do Conselho Nacional de Justiça, que ainda determina que o "Conselho Nacional de Justiça desenvolverá, conjuntamente com a Agência Nacional de Telecomunicações - ANATEL, estudos para implementar rotinas e procedimentos inteiramente informatizados, assegurando o sigilo e segurança dos sistemas no âmbito do Judiciário e das operadoras" (artigo 20). Contudo, entendemos que o Conselho Nacional de Justiça tem competência limitada para estabelecer e supervisionar uma aplicação de um procedimento de interceptação na cadeia inteira da medida, pois existem agentes que não integram o Poder Judiciário e, dessa forma, escapam, segundo nosso entendimento, da obrigatoriedade de observância de suas normas, como, no caso, as operadoras de telefonia, as autoridades policiais e o Ministério Público (embora, por exemplo, o artigo 14 dessa Resolução 59/2008 estabeleça obrigações para as operadoras de telefonia).

954 Vejam-se, além do já citado KLASS AND OTHERS v. GERMANY, os casos MALONE v. UNITED KINGDOM, de 1984, KRUSLIN v. FRANCE, de 1990, e KHAN v. UNITED KINGDOM, de 2000, todos da Corte Européia de Direitos Humanos.

955 Parágrafos 2512 e 2513 do Tìtulo 18 do U.S. Code. O Código Penal francês estabelece ser crime a fabricação, importação, detenção, exposição, oferta, locação ou venda, na ausência de autorização ministerial, dentro das condições de autorização fixadas por decreto do Conselho de Estado, de aparelhos concebidos para interceptar, apropriar, utilizar ou divulgar correspondências enviadas, transmitidas ou 
Projeto de Lei 4.036/2008 ${ }^{956}$.

Além dos dados de conteúdo (as conversas propriamente ditas), existem os dados externos das comunicações eletrônicas, como origem, destino, duração e localização, que constituem dados pessoais, já que relativos a um indivíduo identificado ou identificável. Como tais, são abrangidos pelo direito à privacidade, que confere ao indivíduo a faculdade de controle e proteção das informações atinentes a ele.

Alguns desses dados são recolhidos pelas prestadoras de serviço, como as de telefonia, para cobrança. Outros, dependendo da empresa ou do tipo do serviço, não. Assim, para possibilitar as investigações, deve ser estabelecida uma obrigação às prestadoras de serviço de comunicação de armazenamento dos dados externos das comunicações por certo tempo, resguardados por sigilo.

O Anteprojeto da Comissão de juristas previa a obrigação das prestadoras de serviço de telefonia conservarem, por cinco anos, as informações relativas à origem, destino e duração de todas as conversas telefônicas ${ }^{957}$, enquanto o Projeto de Lei da Câmara 84/1999 prevê, no seu último Substitutivo, o prazo de três anos ${ }^{958}$. A Diretiva 2006/24/CE da União Européia determina o de seis meses a dois anos, proibindo expressamente o armazenamento do conteúdo das comunicações ${ }^{959}$. A Lei 9.296/1996 e o Projeto de Lei 3.272/2008 são omissos.

A Lei 6.538/1978 remete ao sigilo da correspondência e dispõe o que não constitui sua violação, mas não chega a mencionar expressamente, por exemplo, o sigilo quanto aos dados do destinatário e do remetente, embora disponha sobre a existência de sigilo profissional sobre a existência de correspondência de que as pessoas encarregadas do serviço postal tenham conhecimento em razão de suas funções ${ }^{960}$. A Lei 9.472/1997 confere ao usuário o direito de não ter divulgado, caso não o requeira, o seu código de acesso $^{961}$, bem como ao respeito de sua privacidade na utilização de seus dados pessoais

recebidas por meio das telecomunicações, ou para captar, registrar e transmitir as palavras pronunciadas a título privado ou confidencial, ou a imagem de uma pessoa que se encontra em um lugar privado, sem seu consentimento (ver artigo 226-3 combinado com os artigos 226-1 e 226-15). De acordo com o regulamento desse artigo, a autorização é dada pelo Primeiro Ministro, após parecer de uma Comissão Consultiva composta por vários ministros e autoridades, além de duas pessoas de reconhecida competência.

${ }^{956}$ No artigo 151-B a ser introduzido no Código Penal pelo artigo $3^{\circ}$ do Projeto de Lei. Ver Anexo C desta dissertação. Ver também os Projetos de Lei do Senado 741/2007 e 525/2007.

957 Artigo 29, parágrafo único.

${ }^{958}$ Ver Capítulo 5.3.2.

${ }_{959}$ Artigos $6^{\circ}$ e $5^{\circ}$, número 2.

${ }^{960}$ Artigo $6^{\circ}$.

${ }^{961}$ Artigo $3^{\circ}$, inciso VI. 
pela prestadora de serviço ${ }^{962}$. Ela também proíbe as operadoras de divulgar as informações individuais do usuário sem a sua anuência expressa e específica ${ }^{963}$.

A Convenção contra o Cibercrime deixa a critério de cada país estabelecer proteção idêntica ou não ao do conteúdo das comunicações ${ }^{964}$, enquanto o ECPA, nos Estados Unidos da América, cuida, em capítulo à parte, desses dados externos, mas estabelece requisitos menos rigorosos para sua aquisição por parte das autoridades do que aqueles colocados para aquisição do conteúdo das comunicações.

Entendemos que tais dados só podem ser obtidos por autorização de lei, resguardada a privacidade do indivíduo garantida pela Constituição Federal e o equilíbrio da proteção diante de outros interesses relevantes concorrentes, mas não abrangidos pela Lei 9.296/1996.

Nesse âmbito, deveria também ser previsto o direito de o indivíduo ter acesso, em conjunto ou alternativamente ao direito de ter ciência do conteúdo de comunicações suas interceptadas, após razoável janela de tempo, de acordo com as circunstâncias, aos dados externos seus captados por terceiros.

A faculdade de conhecer, recolher e apagar os dados pessoais é essencial, pois nem sempre a condenação civil, ou, quiçá, penal, é suficiente para resguardar a vida privada do indivíduo. O novo Código Civil condiciona o controle sobre a divulgação de escritos, a transmissão da palavra, ou a publicação, a exposição ou a utilização da imagem de uma pessoa ao ferimento da honra, da boa fama ou da respeitabilidade do indivíduo, ou à destinação a fins comerciais ${ }^{965}$, e dispõe que o juiz, a requerimento do interessado, pode adotar as providências necessárias para impedir ou fazer cessar ato que viole a vida privada do indivíduo ${ }^{966}$.

A partir desse artigo 21 seria possível construir um direito sobre os dados pessoais, mas, sem maior densidade normativa, ficaria ele ao sabor do entendimento de cada juiz e, de qualquer maneira, de contornos nebulosos, pois, além de sucinto, surge claro desse dispositivo apenas um direito de defesa, de impedir ou fazer cessar, e não positivo. O que

\footnotetext{
${ }^{962}$ Artigo $3^{\circ}$, inciso IX.

963 Artigo 72, parágrafo $1^{\circ}$.

${ }^{964}$ Foi o que fez Portugal em seu Código de Processo Penal, na redação atual.

965 Artigo 20.

966 Artigo 21. Ver críticas sobre a redação desses artigos 20 e 21, quando ainda tramitava o Projeto de Lei de Código Civil, em Jabur (2000). Na França, o Código Penal (“Code Pénal”), dentro do Capítulo dos "atentados à personalidade", seção referente aos "atentados à vida privada" (Seção I do Capítulo VI), estabelece a punição não só do uso da informação relativa a uma pessoa, mas também da simples apropriação por terceiro não autorizado, englobando a palavra escrita e falada e a imagem (artigos 226-1 e 226-2). Ver Colliard e Letteron (2005), que afirmam, ainda, que os juízes da área cível tendem a seguir as orientações dos dispositivos penais, com temperamentos, embora não raro subjetivos (p. 372).
} 
estabelece expressamente é um direito a medidas judiciais de proteção, e não um direito geral à proteção de dados pessoais. Não há, por exemplo, reconhecimento de um direito de obter no campo extrajudicial a cessação da violação.

Quer-se dizer que embora o juiz possa adotar medidas "positivas", como a busca e apreensão de materiais lesivos à vida privada de uma pessoa, esse agir não decorre, atualmente, de um direito ou complexo de direitos ou faculdades relativos aos dados pessoais, mas, sim, de uma tutela inibitória prevista no Código Civil $^{967}$ e do poder de cautela conferido pelo Código de Processo Civil ${ }^{968}$ ao Judiciário para preservar outros direitos reconhecidos pelo ordenamento, sendo este uma proteção da prestação jurisdicional, mais do que dos jurisdicionados ${ }^{969}$.

$\mathrm{O}$ artigo 21 do Código Civil confere um instrumento de proteção ao direito à privacidade ("vida privada"), mas não se encontra em nenhuma outra parte do ordenamento jurídico brasileiro, à parte da Convenção aprovada pelo Decreto Legislativo 186/2008, do Congresso Nacional, menção aos “dados pessoais" enquanto categoria, espécie ou subespécie de direito.

E ainda que, apesar disso tudo, se entendesse que a proteção da categoria dos dados pessoais encontra-se nesse artigo 21, poderá ela ser insuficiente. Por exemplo, valendo-nos do caso das "listas negras" de trabalhadores, o direito conferido ao empregado pelo Código Civil pode se exaurir no momento em que se impeça ou se retire de circulação o seu histórico, com o eventual recebimento de compensação por danos, sem que surja para o empregador e mesmo àqueles que tiverem contato com essas informações a obrigação necessária de, por exemplo, apagá-los ou editá-los. Ou seja, a medida judicial protetiva da

\footnotetext{
${ }^{967}$ Artigo 21. Para Cachapuz (2006, p. 206), “[...] se antes da Lei 10.406, de 10 de janeiro de 2002, era necessário recorrer à cláusula geral do art. 159 do Código Civil para resguardar a efetiva tutela de exclusividade a uma esfera de privacidade, a fundamentação racional para a tutela dos direitos à intimidade $\mathrm{e}$ à vida privada restou suficientemente facilitada pela redação conferida pelo art. 21 do novo Código Civil. Primeiro, porque o artigo foi inserido num capítulo inédito à codificação civil, tornando possível a concretização legislativa de um direito geral de personalidade voltado à regulação específica das relações jurídico-privadas. Segundo, porque o art. 21 tratou não apenas de disciplinar sobre a tutela da personalidade sob uma ótica indenizatória, mas também de conferir à intimidade e à vida privada - esta mencionada de forma expressa, abrangendo a esfera mais restrita da intimidade - a nota da exclusividade peculiar à esfera da privacidade". A autora propõe uma interpretação integrada com o artigo 187 do Código Civil e conclui que este "[...] oferece à tutela da intimidade e da vida privada no âmbito das relações entre privados uma orientação em relação ao horizonte de sentido que se pretende reconhecer e alcançar ao íntimo e ao privado. É pelo art. 187 que se podem corrigir rumos em relação às soluções alcançadas, tendo em vista o direito subjetivo de personalidade reconhecido no art. 21 do Código Civil. Mais ainda, o art. 187 permite o ingresso, pelo discurso, do que se faz relevante proteger em relação à esfera da privacidade, oferecendo a razão prática ao que é objeto de ponderação pela via argumentativa" (p. 210). Sobre a tutela inibitória na proteção da privacidade, ver Podestá (2001).

${ }_{968}$ Por exemplo, artigo 798.

${ }^{969}$ Ver a respeito, dentre outros, Machado (2008).
} 
vida privada poderá ter resultados equivalentes aos que resultariam de um direito específico relativo aos dados pessoais, mas serão, nos termos da legislação vigente, incidentais.

Uma alteração legislativa do "habeas data" poderia torná-lo um instrumento amplo de resguardo dessa categoria de dados. Poder-se-ia atribuir ao indivíduo o direito material de amplo controle de suas informações, abrangendo terceiros, com o objetivo de lhe proporcionar instrumentos para coibir ou minimizar abusos e maus usos, o que se aplicaria, sem dúvida, aos dados externos gerados por suas comunicações ${ }^{970}$.

Anotamos, ainda, que o acesso estatal a informações e conversas reservadas, por meios lícitos, não as transforma em dados de domínio público, inclusive dos meios de comunicação social, como bem nos mostra a legislação concernente aos dados fiscais, bancários e telefônicos e mesmo das interceptações telefônicas, que determina que a medida seja processada em autos apartados, apensados ao principal, sob sigilo ${ }^{971}$.

$\mathrm{O}$ artigo $5^{\circ}$, inciso LX, da Constituição Federal dispõe que "a lei só poderá restringir a publicidade dos atos processuais quando a defesa da intimidade ou o interesse social o exigirem", ao passo que a Emenda Constitucional 45, de 30 de dezembro de 2004, ao alterar a redação do inciso IX do artigo 93, explicitando a regra de publicidade de todos os julgamentos dos órgãos do Poder Judiciário, ressalvou a possibilidade de a lei "limitar a presença, em determinados atos, às próprias partes e a seus advogados, ou somente a estes, em casos nos quais a preservação do direito à intimidade do interessado no sigilo não prejudique o interesse público à informação". Isso decorre da necessidade de acomodação entre aspectos da vida privada do indivíduo e o direito à informação social ${ }^{972}$.

No artigo 220, parágrafo $1^{\circ}$, a Constituição Federal estabelece:

[n]enhuma lei conterá dispositivo que possa constituir embaraço à plena liberdade de informação jornalística em qualquer veículo de comunicação social, observado o disposto no art. $5^{\circ}$, IV, V, X, XIII e XIV.

$\mathrm{O}$ inciso $\mathrm{X}$ do artigo $5^{\circ}$ é justamente o que trata da inviolabilidade da intimidade,

\footnotetext{
${ }^{970} \mathrm{O}$ artigo 5 "caput” e parágrafo único, da Lei 9.507/1997, que foi vetado, dispunha: “[a]rt. 5º O órgão ou entidade depositária do registro ou do banco de dados comunicará à pessoa interessada o fornecimento de informações a seu respeito, solicitadas por seus usuários ou por terceiros, fornecendo a identificação do solicitante e o teor das informações. Parágrafo único. Da informação prestada ao usuário ou a terceiro, o depositário fará constar, se houver, a explicação ou contestação a que se refere o $\S 2^{\circ}$ do art. $4^{\circ}$ ”.

${ }_{971}$ Artigo 80 "caput", da Lei 9.296/1996.

972 Sobre essa acomodação, ver Gregório e Paiva (2005). Os tribunais também devem ter cuidado ao divulgar nas suas páginas na Internet informações sobre processos judiciais indiscriminadamente, principalmente reclamações trabalhistas, pois podem ser usados como "bases de dados" contra aqueles que buscam um emprego. Ver Paiva e Cuervo (2002a).
} 
vida privada, honra e imagem das pessoas, com a garantia de indenização pelo dano moral ou material decorrente de sua violação, e, embora não haja referência ao inciso XII do artigo $5^{\circ}$, deve-se lembrar que este restringe o levantamento do sigilo à investigação criminal e instrução processual penal. Além disso, a não referência aos outros incisos do artigo $5^{\circ}$ não afastam a sua aplicabilidade, pois os direitos fundamentais atuam sobre todo o complexo normativo, inclusive outras normas originárias da Constituição ${ }^{973}$.

Por sua vez, a Lei 5.250, de 9 de fevereiro de 1967 ("Lei de Imprensa"), dispõe, no âmbito da responsabilidade civil:

\begin{abstract}
Nos casos de calúnia e difamação, a prova da verdade, desde que admissível na forma dos arts. $20^{974}$ e $21^{975}$, excepcionada no prazo da contestação, excluirá a responsabilidade civil, salvo se o fato imputado, embora verdadeiro, diz respeito à vida privada do ofendido e a divulgação não foi motivada em razão de interesse público ${ }^{976}$.
\end{abstract}

Essa Lei é mais flexível em relação à reserva das autoridades e servidores públicos, em harmonia com a Constituição Federal vigente, que estabelece que a Administração deve pautar-se, dentre outros, pela legalidade, moralidade e publicidade. Contudo, não

\footnotetext{
${ }^{973}$ Senão se poderia chegar a conclusões absurdas, como, por exemplo, a de que o jornalista poderia torturar a sua fonte para obter as informações que deseja porque o inciso III do artigo $5^{\circ}$ da Constituição Federal não é expressamente mencionado nesse parágrafo $1^{\circ}$ do artigo 220. Quanto à interpretação das normas constitucionais, remetemos, novamente, à Maximiliano (1981).

974 “Art . 20. Caluniar alguém, imputando-lhe falsamente fato definido como crime: Pena: Detenção, de 6 (seis) meses a 3 (três) anos, e multa de 1 (um) a 20 (vinte) salários-mínimos da região. § $1^{\circ} \mathrm{Na}$ mesma pena incorre quem, sabendo falsa a imputação, reproduz a publicação ou transmissão caluniosa. § $2^{\circ}$ Admite-se a prova da verdade, salvo se do crime imputado, embora de ação pública, o ofendido foi absolvido por sentença irrecorrível. § $3^{\circ}$ Não se admite a prova da verdade contra o Presidente da República, o Presidente do Senado Federal, o Presidente da Câmara dos Deputados, os Ministros do Supremo Tribunal Federal, Chefes de Estado ou de Govêrno estrangeiro, ou seus representantes diplomáticos".

975 "Art . 21. Difamar alguém, imputando-lhe fato ofensivo à sua reputação: Pena: Detenção, de 3 (três) a 18 (dezoito) meses, e multa de 2 (dois) a 10 (dez) salários-mínimos da região. $\S 1^{\circ}$ A exceção da verdade somente se admite: a) se o crime é cometido contra funcionário público, em razão das funções, ou contra órgão ou entidade que exerça funções de autoridade pública; b) se o ofendido permite a prova. $\S 2^{\circ}$ Constitui crime de difamação a publicação ou transmissão, salvo se motivada por interêsse público, de fato delituoso, se o ofendido já tiver cumprido pena a que tenha sido condenado em virtude dele".

${ }^{976}$ Artigo 49, parágrafo $1^{\circ}$, destaque nosso. O Supremo Tribunal Federal suspendeu a vigência de vários dispositivos dessa Lei, inclusive dos artigos 20 e 21, em Medida Cautelar na Argüição de Descumprimento de Preceito Fundamental 130/DF, decisão tomada pelo Plenário em 27 de fevereiro de 2008, divulgada no Diário de Justiça eletrônico 211, de 6 de novembro de 2008, prorrogada em Questão de Ordem em julgamento de 4 de setembro de 2008, divulgada em no mesmo Diário de Justiça: "[...] Verificação, desde logo, de descompasso entre a Carta de 1988 e os seguintes dispositivos da Lei de Imprensa, a evidenciar a necessidade de concessão da cautelar requerida: a) a parte inicial do $\S 2^{\circ}$ do art. $1^{\circ}$ (a expressão 'a espetáculos e diversões públicas, que ficarão sujeitos à censura, na forma da lei, nem'); b) íntegra do $\S 2^{\circ}$ do art. $2^{\circ}$ e dos arts. $3^{\circ}, 4^{\circ}, 5^{\circ}, 6^{\circ}$ e 65 ; c) parte final do art. 56 (o fraseado 'e sob pena de decadência deverá ser proposta dentro de 3 meses da data da publicação ou transmissão que lhe der causa'); d) $\S \S 3^{\circ}$ e $6^{\circ}$ do art. 57 ; e) $\S \S 1^{\circ}$ e $2^{\circ}$ do art. 60 e a íntegra dos arts. 61, 62, 63 e 64; f) arts. 20, 21, 22 e 23; g) arts. 51 e 52. 5. A suspensão da eficácia dos referidos dispositivos, por 180 dias (parágrafo único do art. 21 da Lei no 9.868/99, por analogia), não impede o curso regular dos processos neles fundamentados, aplicando-se-lhes, contudo, as normas da legislação comum, notadamente, o Código Civil, o Código Penal, o Código de Processo Civil e o Código de Processo Penal". Sobre a tensão entre informação e privacidade, ver Barbosa (1995), Ceneviva (2005) e M. Ferreira (2001).
} 
institui uma isenção geral em relação a quaisquer aspectos, ressaltando a necessidade de correlação às funções das autoridades e servidores, ou de interesse público, que, conforme jurisprudência da Corte Européia de Direitos Humanos, não se confunde com o interesse mórbido pelos aspectos privados que não concernem a vida pública do indivíduo ${ }^{977}$. No que interessa ao tema, em nenhum momento permite a captura ou, notoriamente, a divulgação pela imprensa do resultado da interceptação de comunicações ${ }^{978}$.

A Lei 9.296/1996 também não prevê a possibilidade de a imprensa fazer uso, de qualquer modo, do conteúdo das comunicações interceptadas. Pelo contrário, estabelece medidas que visam a resguardar a privacidade do indivíduo e ainda criminaliza a interceptação das comunicações e a quebra do segredo de justiça sem autorização judicial ou com objetivos não autorizados em lei ${ }^{979}$.

De qualquer maneira, entendemos que a Lei 9.296/1996 deve ser, no mínimo,

977 Ver a Resolução 428/1970 da Assembléia Parlamentar do Conselho da Europa, cabeçalho “C”, item 1, o artigo $9^{\circ}$ da Diretiva 95/46/CE, e os casos VON HANNOVER v. GERMANY e RADIO TWIST, A.S. v. SLOVAKIA julgados pela Corte Européia de Direitos Humanos.

978 Entretanto, há, por exemplo, o Projeto de Lei da Câmara 1.258/1995, que permite ao juiz autorizar a divulgação do conteúdo da interceptação ou captação, desde que não haja a possibilidade de comprometimento da produção de prova no inquérito policial ou no processo penal e de causar prejuízo material ou moral ao investigado ou acusado.

979 Artigo 10. O Ministro Sepúlveda Pertence, Relator da Petição 2702/RJ, do STF (ver Apêndice A, número 11, desta dissertação), afirmou peremptoriamente, em seu voto, que "no âmbito da proteção ao sigilo das comunicações, não há como emprestar peso relevante, na ponderação entre os direitos fundamentais colidentes, ao interesse público no conteúdo das mensagens veiculadas, nem à notoriedade ou ao protagonismo político ou social dos interlocutores". De fato, a redação do inciso XII do artigo $5^{\circ}$ da Constituição Federal parece não abrir margem a que isso se dê, pois a interceptação é excepcionalmente autorizada para fins de investigação criminal e instrução processual penal. Afirma Siqueira Filho (1997, p. 479): “[c]om certeza, será razoável admitir como ilícita (e mais, criminosa) a postura assumida por determinados jornalistas, em divulgar trechos de conversações ou fluxo de comunicações, sem permissão dos interessados. A lei é bastante clara ao restringir o uso da quebra do sigilo das comunicações para fins de investigação criminal ou para instrução processual penal. A utilização com outro objetivos, muitas vezes inconfessáveis, deve dar ensejo à imposição da sanção criminal cominada à espécie. Reporta-se, ainda, o dispositivo [artigo 10 da Lei 9.296/1996] à quebra do segredo de justiça. No caso, será sujeito ativo do delito em análise todo aquele que tiver acesso às informações e emprestar-lhe a publicidade indevida, comunicando o seu conteúdo a outrem ou à coletividade. Então, pode figurar como autor do crime em tela, em tese, a autoridade policial, o seu subordinado, o representante do Ministério Público, o advogado, o serventuário da Justiça, o magistrado ou o técnico de concessionária do serviço público, que, no exercício de suas atribuições, teve, legitimamente, a oportunidade de ter o referido acesso. Também pode figurar como sujeito ativo, até mesmo, o próprio acusado da prática do crime sob investigação, considerando que pode, com seu comportamento, prejudicar a apuração dos fatos e, ainda, violar a intimidade do outro interlocutor. Com muito mais razão, cometerá o delito quem, indevidamente obtendo as informações em tela, repassá-las a quem quer que seja”. L. Gomes (1997) ressalta que no tocante a esse meio probatório não vigora a "publicidade externa", ou seja, o povo e a imprensa não podem dele tomar conhecimento, tanto em respeito ao interesse público, quanto para a proteção da intimidade do investigado. Por outro lado, Grinover, Fernandes e Gomes Filho (2001) entendem que, após a degravação e retirada da transcrição dos trechos que não dizem respeito aos fatos a serem provados, não há nenhum sentido na manutenção do sigilo. No âmbito do Conselho da Europa, a Corte Européia de Direitos Humanos, ao menos no caso RADIO TWIST, A.S. v SLOVAKIA, de 2006, entendeu que o fato de a interceptação da conversa entre duas autoridades públicas ter ocorrido ilicitamente não impedia a emissora de rádio de transmitir o seu conteúdo. Mais a respeito da tensão entre liberdade de imprensa e vida privada em Rocha (2001) e Taylor (2005-2006). 
respeitada, em conformidade com o inciso XII do artigo $5^{\circ}$ da Constituição Federal e com as observações que fizemos ${ }^{980}$.

Lembramos que as comunicações eletrônicas devem ter um tratamento distinto no âmbito penal e no não penal. No primeiro, a permissividade das interceptações vem da própria Constituição Federal e é regulada pela lei de interceptações e pela legislação processual penal. Nas outras áreas, a regra é a da impossibilidade de interceptação do conteúdo das comunicações, mesmo com ordem judicial ${ }^{981}$.

Claro que nos referimos a "interceptação" como captação do conteúdo por terceiro. Assim, fora desse caso, é possível a gravação ou registro do conteúdo das comunicações de acordo com a situação.

É inconteste, por exemplo, encontrando previsão em outras legislações ${ }^{982}$, a legalidade da gravação de conversa eletrônica (telefone, "e-mail”) entre a vendedora de um bem ou serviço e o consumidor, inclusive para provar a realização do negócio ou do atendimento.

$\mathrm{Na}$ área trabalhista, questão de grande destaque é a concernente aos "e-mails" “corporativos", isto é, os que o empregador fornece a seus empregados para o desempenho de suas funções nessa qualidade. Eles são, a princípio, restritos às atividades do negócio, e, assim como cartas comerciais tradicionais, sujeitos à leitura por outros empregados ou chefes da companhia, de acordo com a divisão interna de atribuições, já que, nesses termos, não se verifica juridicamente uma interceptação, pois a empresa é a remetente ou destinatária da comunicação.

Entendemos, porém, que o conteúdo das comunicações pessoais, se realizadas através de conta eletrônica pessoal, ou de conta de correio fornecida pelo empregador sem

\footnotetext{
${ }^{980}$ O Brasil está para ser julgado pelo Corte Interamericana de Direitos Humanos por violação, dentre outros, ao artigo 11 do Pacto de São José da Costa Rica, que protege a vida privada e a correspondência do indivíduo contra ingerências arbitrárias ou abusicas. É o Caso Arley José Escher e outros ("interceptação de linhas de organizações sociais"), n. 12.353, apresentado pela Comissão Interamericana de Direitos Humanos. O relatório da Comissão (OEA, 2007) aponta as seguintes irregularidades, no caso concreto, relativamente à interceptação: (i) ausência de competência do major da polícia militar para requerer interceptação telefônica em investigação criminal comum; (ii) a ausência de decisão fundamentada do juízo que a autorizou, já que não indicou a forma em que se devia ter dado a diligência, nem o prazo, limitando-se a despachar: "[r]. e A. Defiro. Oficie-se"; (iii) a prorrogação das escutas e gravações além do prazo do artigo $5^{\circ}$ da Lei 9.296/1996, pois duraram quarenta e nove dias; (iv) a extensão da interceptação a outra linha telefônica, sem autorização judicial, em violação ao artigo 10 da Lei 9.296/1996; (v) a ausência de notificação do Ministério Público sobre a medida; e (vi) a divulgação, na televisão e na imprensa escrita, de trechos das gravações obtidas, em violação ao artigo $1^{\circ}$ da Lei. Por fim, a Comissão solicita à Corte que ordene ao Estado brasileiro, dentre outros, "que aprove e implemente ações imediatas para assegurar o cumprimento dos direitos dispostos nos artigos 8.1,11,16 e 25 da Convenção Americana, de maneira que se tornem efetivos os direitos à proteção especial da privacidade e à liberdade de associação das pessoas físicas no Brasil” (OEA, 2007, p.34).

${ }^{981}$ Ver, por exemplo, L. Gomes (1997).

982 Ver artigo $5^{\circ}$, número 2, da Diretiva 2002/58/CE.
} 
o mais amplo aviso interno (aos empregados) e externo (aos demais) não pode ser devassado ${ }^{983} 984$. Porém, ainda que atendidos esses critérios mínimos, a vigilância não pode

${ }^{983}$ Um endereço de correio eletrônico no formato "cargo@empresa.com.br" é, segundo nosso entendimento, essencial para indicar a impossibilidade de o empregado valer-se dele para enviar e receber mensagens de cunho pessoal. Já, no nosso entender, uma conta no formato "nome_do_empregado@empresa.com.br" merece o mesmo tratamento de uma conta pessoal, independente do contrato de trabalho ou de aviso do empregador para o empregado, principalmente em relação aos terceiros, destinatários ou remetentes das mensagens, pois não têm como saber se o seu interlocutor está usando "e-mail" pessoal ou corporativo, especialmente aqueles que enviam a mensagem para o trabalhador. Contudo, veja-se o raciocínio de Araujo: "[o] ambiente de trabalho deve ser cercado de sobriedade e profissionalismo. Isso não significa que o empregado não possa ter o seu próprio 'e-mail' e se corresponder pessoalmente. Essa condição não se confunde com o 'e-mail' utilizado pela empresa para suas atividades, o que fará com que ela esteja envolvida em todas as manifestações produzidas pelo empregado. O 'e-mail', com o nome do domínio da empresa, estabelece limite claro do ambiente de trabalho. Há sinal claro de que se está diante de um instrumento de trabalho. Há de se entender a situação. Não estamos discutindo o 'e-mail' do empregado, que serve para suas comunicações diárias com seus familiares, amigos e relações amorosas. Estamos cuidando de um 'e-mail' que leva o nome da empresa em seu domínio e, portanto, passível de responsabilização nos termos da jurisprudência já sumulada. Entendemos, desta forma, que o 'e-mail' com o domínio da empresa escapa da proteção constitucional do direito à intimidade e à privacidade, constituindo instrumento de trabalho e, portanto, passível de controle pela empresa. [...] [Mas] entendemos essencial que o empregado seja avisado de forma clara e inequívoca sobre o poder de fiscalização da empresa de seu correio eletrônico, assim como deve ficar inequivocamente demonstrado que o 'e-mail' da empresa deve ser utilizado apenas para questões profissionais, sendo vedado qualquer tipo de veiculação estranha aos fins da empresa e dos objetivos da empregadora" (2002, p. 117 e 119). Belmonte também distingue a conta de "e-mail" pessoal da corporativa, para defender que, quanto a esta, não há direito ao sigilo, mesmo que o endereço eletrônico institucional seja nominal (pessoal) e protegido com senha, entendendo, de qualquer modo, que sempre é possível ao empregador fazer controle geral formal (dados externos, não do conteúdo das mensagens), como número de mensagens enviadas e recebidas, horários, destinatários, dentre outros (2004).

${ }^{984}$ Entendemos ser irrelevante o fato isolado de o computador e a conta de correio eletrônico serem fornecidos pelo ou de propriedade do empregador, como já escrevêramos anteriormente (MESQUITA, 2007, p. 252): "Perigoso atribuir amplo acesso ao empresário tão-somente por ser sua a propriedade dos bens [e meios] necessários ao acesso à Internet e recepção de 'e-mails'; seria o mesmo que lhe permitir devassar a correspondência tradicional dos empregados caso as cartas fossem escritas com papel e caneta por ele fornecidos". Rodríguez nota que, independente da titularidade dos instrumentos de trabalho, tal intervenção afeta também o direito dos destinatários ao segredo das comunicações (2004, p. 162). Em sentido contrário, Figueirôa Júnior (2005). O Tribunal Superior do Trabalho tem alguns precedentes no sentido que o "e-mail" fornecido pelo empregador para fins estritamente de trabalho e de sua "propriedade" podem ser monitorados, tanto o conteúdo quanto os aspectos internos, porque não existe quanto a ele "razoável expectativa de privacidade". Ver, dentre outros, o Recurso de Revista 613/2000-013-10-00.7, Relator Ministro João Oreste Dalazen, julgado pela Primeira Turma em 18 de maio de 2005, decisão publicada no Diário da Justiça de 10 de junho de 2005, e o Agravo de Instrumento em Recurso de Revista 1649/2001-001-03-00.7, Relator Ministro Pedro Paulo Manus, julgado pela Sétima Turma em 26 de novembro de 2008, decisão publicada no Diário da Justiça de 5 de dezembro de 2008. Entendemos também que só o aviso do empregador ao empregado da possibilidade de devassa do conteúdo de "e-mails" particulares também não permite o levantamento do sigilo, pois é notório que o empregado não tem poder de barganha em relação ao contratante, e, principalmente, por se tratar de um direito fundamental assegurado pela Constituição Federal que não permite tal renúncia irrestrita. No sentido de impossibilidade de interceptação da correspondência, Barros (2001) e Mistrongue e Kersten (2004). Em sentido contrário, L. Silva (2006) e Novo (2005). Ver ainda discussão em Paiva (2002b) e Paesani e Baptista (2006), e em Silveira Neto e Paiva (2004), em que cada um defende uma posição. Moutouh e Jean (2003b, pp. 95-96), após considerarem o "e-mail" um novo tipo de correspondência escrita, citam uma decisão paradigmática da Corte de Cassação francesa: "Desde a decisão 'Nikon' (Cass. Soc., 2 outubro 2001, DS, 2001, p.915; GP, 17-18 abril 2002, nota Bridenne), sabe-se doravante que 'mesmo no tempo e no lugar de trabalho, o empregado tem o direito ao respeito da intimidade de sua vida privada, que inclui particularmente o segredo das correspondências. $\mathrm{O}$ empregador não pode, portanto, ignorar certas liberdades fundamentais e tomar conhecimento de mensagens pessoais emitidas ou recebidas pelo empregado graças a um instrumento de informática posto à sua disposição para seu trabalho, e isso mesmo no caso do empregador ter proibido uma utilização não profissional do computador" (tradução nossa). Lippmann (1998) entende que, em casos excepcionais, podem as comunicações ser monitoradas, em 
se dar pela simples vontade do empregador, mas deve ser motivada por graves razões ou em virtude da natureza especial do trabalho desenvolvido. O mesmo se dá em relação aos elementos externos das comunicações ${ }^{985}$. O trabalhador não perde seus direitos fundamentais enquanto se encontra à disposição do empregador, dentro ou fora do local de trabalho $^{986}$, e isso inclui as suas comunicações.

Nesse campo, aliás, o Código de Prática sobre a Proteção dos Dados Pessoais dos Trabalhadores da Organização Internacional do Trabalho (ILO, 1997) adota, dentre outros, os seguintes princípios: (i) os dados pessoais dos trabalhadores coletados em razão de medidas técnicas ou organizacionais para assegurar a segurança e o funcionamento adequado de sistemas de informação não devem ser usados para controlar o seu comportamento; (ii) os dados coletados por monitoramento eletrônico não devem ser os únicos fatores para avaliar o desempenho dos trabalhadores; (iii) os trabalhadores e seus representantes devem ser informados de qualquer processo de coleta e suas regras, bem como de seus direitos; e (iv) os trabalhadores não podem abrir mão de seus direitos de privacidade $^{987}$.

virtude da natureza do cargo, como no "telemarketing" e na mesa de operação de bolsa de valores, por exemplo, ou da gravidade da conduta (suspeita) do empregado, como por suspeita de fraude, mas, neste último caso, somente com autorização judicial. L. Gomes, embora dissertando a respeito das comunicações telefônicas, afirma (1997, p. 150): “[...] A usual prática de algumas empresas de 'grampear' seus telefones para controlar as comunicações dos seus empregados é crime (art. 10 [da Lei 9.296/1996]. Os titulares do sigilo são os comunicadores, não o dono da linha ou o empregador. E se a empresa anuncia publicamente o 'grampeamento'? Mesmo assim, se realizar a interceptação, é crime. Razões particulares da empresa não podem estar acima das razões constitucionais da preservação do sigilo. [...] O dono da linha telefônica e a empresa podem proibir o uso, por terceiros, de suas linhas. Mas não podem 'grampeá-las"'. Ver mais a respeito do tema em Aranda (2001-2002), Fazekas (2004), Hubbartt (1998) e Vallebona (2001).

985 No sentido de possibilidade de controle moderado do uso do "e-mail" sem violação dos direitos fundamentais do empregado, ver, dentre outros, embora nem sempre concordando quanto à extensão e aos meios, D. Gomes (2005), Mesquita (2007), Niger (2006), Paiva (2002b) e Zainaghi (2005).

${ }^{986}$ Sobre a situação em Portugal: "[a] relação laboral pode também levantar questões relativas à intimidade da vida privada. O Tribunal Constitucional considerou que não era inconstitucional a previsão legal de exames médicos destinados à verificação da aptidão física e psíquica do trabalhador para o exercício de sua profissão, bem como a elaboração e registo informático de fichas clínicas e de aptidão (Acórdão nº 368/02). Mas já seria inconstitucional o pedido de informações, por parte do próprio empregador, relativas à saúde ou estado de gravidez, ainda que 'particulares exigências inerentes à natureza da actividade profissional o justifiquem'. O tribunal considerou que, por essa via, se autorizava uma excessiva intromissão na esfera privada do trabalhador ou do candidato ao emprego, dado não ser esse o meio menos introsivo [sic] para saber se o trabalhador está ou não apto para o trabalho (Acórdão no 306/03)" (Miranda e Medeiros, 2005 , p. 291, destaque dos autores). “[...] A protecção dos direitos de personalidade dos trabalhadores (cfr. Cód. Trab., arts. $17^{\circ}$ e ss.) impõe que o eventual acesso das entidades patronais a informações relativas à vida privada do trabalhador (saúde, estado de gravidez) deve obedecer a um procedimento justo de recolha dessas informações (ex.: através de um médico sujeito ao dever de sigilo) e à observância estrita do princípio da proibição do excesso (as informações necessárias, adequadas e proporcionais) para o exercício de determinadas actividades (cfr. AcTC no 306/03)" (CANOTILHO; MOREIRA, 2007, p. 468). Ver também Abreu e Zimmermann (2005), Barros (2001), Nascimento (2003), P. Oliveira (2005), Silveira Neto e Paiva (2004) e Simón (2003).

${ }^{987}$ Por outro lado, o Código especifica que o monitoramento secreto só pode ser permitido se estiver em conformidade com a legislação nacional (deve haver previsão específica a respeito em lei) ou se houver 
Por último, entendemos que o registro de conversa própria no geral que se dê por meio de comunicação eletrônica, com ou sem ciência do interlocutor, desde que não seja usado pelas autoridades para burlar o regime das interceptações, deveria ser permitido, especialmente em juízo ${ }^{988}$, preferencialmente através de lei, ao menos em algumas circunstâncias $^{989}$.

suspeita (forte), com bases razoáveis, de atividades criminosas ou outras condutas ilícitas, enquanto o monitoramento contínuo só deve ser permitido se necessário para saúde e segurança ou para a proteção de propriedade (ILO, 1997, p. 4, 18-19).

988 A Lei 9.610, de 19 de fevereiro de 1998 ("Lei de Direitos Autorais"), dispõe que "[a]s cartas missivas, cuja publicação está condicionada à permissão do autor, poderão ser juntadas como documento de prova em processos administrativos e judiciais" (artigo 34). A jurisprudência do STF e do STJ tem permitido o registro de conversa própria sem o conhecimento do interlocutor em algumas circunstâncias, como já mencionado (ver Apêndices A, número 2, e B, número 5).

989 Wambier (1990) entende que a gravação feita por uma das partes numa conversa telefônica sem o conhecimento da outra viola o direito à intimidade previsto no artigo $5^{\circ}$, inciso X, da Constituição Federal. L. Gomes (1997) entende que a Lei 9.296/1996 não regula as gravações clandestinas, tanto telefônicas quanto ambientais, nem as interceptações ambientais, sendo necessária a existência de lei para que sejam válidas como prova, exceto se for para benefício do réu, em virtude do princípio da proporcionalidade (p. 105-112). Grinover, Fernandes e Gomes Filho (2001, p. 197-198) entendem que a interceptação de conversa entre presentes (interceptações ambientais) viola o inciso $\mathrm{X}$ do artigo $5^{\circ}$ da Constituição Federal, dependendo a sua admissibilidade da existência de lei, que o autoriza apenas no caso de ilícitos decorrentes de ações praticadas por quadrilha ou bando ou organizações ou associações criminosas de qualquer tipo (Lei 10.217/2001, que alterou a Lei 9.034/1995). As gravações clandestinas também podem violar esse dispositvo, se foram divulgadas sem justa causa (GRINOVER; FERNANDES; GOMES FILHO, 2001, p. 198-200). Na Itália, citando julgados, Gaito e Bargi (2007) entendem que não constitui interceptação e não estão sujeitos aos ditames da lei processual penal, neste ponto, a gravação de conversa por um dos interlocutores, haja vista que ele pode, salvo circunstâncias especiais (segredo de ofício ou de Estado, por exemplo), testemunhar em juízo sobre a conversa que travou. 


\section{CONCLUSÃO.}

A Constituição Federal de 1988 protege o direito à privacidade e à inviolabilidade do sigilo das comunicações.

A privacidade é o direito de ampla autodeterminação do indivíduo, com os poderes derivados de agir, não agir ou resistir. É uma liberdade de ser, estar, ir e vir “como quiser", que pode ser limitada por outros interesses ou direitos relevantes, dependendo do caso concreto. Ela acompanha o indivíduo, abrangendo relações suas com o Estado e com outras pessoas. Esse entendimento encontra abrigo na jurisprudência da Corte Européia de Direitos Humanos, responsável pela interpretação e aplicação da Convenção Européia de Direitos Humanos, e, em certa medida, na da Suprema Corte dos Estados Unidos da América, além de se insinuar em alguns julgados do STJ e do STF.

O sigilo das comunicações é uma forma de garantia da privacidade, embora o texto constitucional não distinga a proteção em termos de conteúdo. O inciso XII do artigo $5^{\circ}$ nomeia somente quatro modalidades de comunicação e prevê o levantamento do sigilo inequivocamente só quanto às telefônicas. Contudo, a nosso ver, esse dispositivo, combinado com o parágrafo $2^{\circ}$ do artigo $5^{\circ}$ da Constituição Federal, permite a interpretação teleológica de que é possível o levantamento do sigilo das comunicações de dados e das telefônicas, além de outras formas de comunicação que se encaixem no conceito de comunicação reservada, durante o trânsito, por quaisquer meios que se dêem, nas hipóteses e formas da lei, para a finalidade de investigação criminal e instrução processual penal. Ficam excluídas apenas a correspondência e as comunicações telegráficas, por escolha do constituinte originário.

Considerando a evolução das telecomunicações, que converge para uma ampla digitalização, adotamos a nomenclatura "comunicações eletrônicas”, de modo similar a que o fazem os Estados Unidos da América, no ECPA, e a União Européia, nas Diretivas 2002/58/CE e 2006/24/CE, não para excluir, mas para marcar uma atualização da regulação do sigilo das comunicações em virtude do advento de novas tecnologias, atuais e futuras, que proporcionem uma vasta captação e tratamento de dados a baixo custo, inclusive para evitar a evasão do regime de proteção constitucional-legal através de meios ou técnicas não expressamente referidos no ordenamento jurídico positivo.

$\mathrm{O}$ inciso XII do artigo $5^{\circ}$ da Constituição Federal protege as comunicações reservadas em trânsito: "reservadas" porque destinadas a um número finito de 
interlocutores, e não a um universo indistinto de pessoas, o que exclui as comunicações sociais, tratadas especificamente inclusive em outra parte da Constituição Federal; e "em trânsito" porque as mensagens eletrônicas, antes de iniciadas e depois de acessadas, constituem "documentos" ou "dados".

As comunicações eletrônicas passam basicamente por três estágios: envio, transmissão (que engloba o armazenamento incidental) e recepção (acesso). Quando a mensagem eletrônica encontra-se "em trânsito", ou seja, a partir do envio até o acesso, aplica-se o inciso XII do artigo $5^{\circ}$ da Constituição Federal completado pela lei ordinária. Antes do envio e após o acesso, submete-se a um regime de busca e apreensão digital, não explicitamente regulado pelo ordenamento jurídico positivo.

Como a interpretação das normas não pode levar a desvirtuamentos de sua finalidade, entendemos que "interceptação", nesse contexto, deve ser entendida como a obtenção e a eventual divulgação por terceiro do conteúdo da comunicação eletrônica em trânsito, e não somente como o conhecimento das mensagens contemporaneamente ao seu envio. Senão bastaria aos provedores de acesso à Internet, por exemplo, manter uma cópia das mensagens que por eles trafegam, inclusive as de voz, para que as autoridades escapassem ao regime mais rígido da interceptação.

Continua sujeita ao regime da interceptação a comunicação em que apenas um ou alguns dos interlocutores renunciam ao seu sigilo sem o conhecimento dos demais, pois sendo proteção de uma relação entre indivíduos, somente a concordância de todos os participantes, a princípio, pode tornar a divulgação do conteúdo lícita.

As comunicações eletrônicas geram dois tipos de dados: (i) os externos, relativos ao "continente", tais como elementos identificadores do remetente e do destinatário, horário, duração e posicionamento geográfico; e (ii) os internos, relativos ao conteúdo das comunicações. Ambos são protegidos pelo direito à privacidade, mas entendemos que só os últimos encontram proteção direta no sigilo constitucional das comunicações.

Desse modo, o regime jurídico aplicável aos dados externos pode ser o mesmo do do conteúdo ou outro, mas entendemos que a restrição deve ocorrer para um fim legítimo por um modo de obtenção previsto em lei que assegure um equilíbrio entre os direitos e os interesses públicos em jogo. Anotamos que os dados externos, por se referirem a um indivíduo identificado ou identificável, enquadram-se, ainda, na categoria jurídica dos “dados pessoais", que o Conselho da Europa e a União Européia, por exemplo, reconhece como digna de proteção especial, e que encontra menção na "Convenção sobre os Direitos das Pessoas com Deficiência e de seu Protocolo Facultativo, assinados em Nova Iorque, 
em 30 de março de 2007" aprovada, no Brasil, pelo Decreto Legislativo 186/2008, do Congresso Nacional, com força de Emenda Constitucional.

Por sua vez, o regime de obtenção do conteúdo deve observar os requisitos estampados na norma constitucional, regulamentado pela legislação inferior. Atualmente, é a Lei 9.296/1996 que permite a interceptação das comunicações telefônicas, de qualquer natureza, e do fluxo de comunicações em sistemas de informática e telemática, desde que atendidos três critérios concomitantes: (i) a existência de indícios razoáveis da autoria ou participação em infração penal; (ii) a impossibilidade de a prova ser feita por outros meios disponíveis; e (iii) o fato investigado constituir infração penal punível com pena de reclusão.

Entendemos que principalmente a adoção do critério objetivo da pena de reclusão é demasiado amplo e limitado, pois abarca uma grande quantidade de crimes e, ao mesmo tempo, deixa de lado outros que só podem ser investigados através dessa medida, mas são apenados, por exemplo, com detenção, como o crime de ameaça, previsto no artigo 147 do Código Penal, quando praticado por meio eletrônico.

Além disso, a lei não determina com clareza quem pode determiná-la (questão das Comissões Parlamentares de Inquérito), requerê-la (caso dos ofendidos) e, especialmente, quem pode ser alvo da medida, incluindo a questão das atividades albergadas por sigilo, o que repercute diretamente na possibilidade da extensão da interceptação e do uso do seu resultado como prova. É criticável, ainda, a redação da lei na parte em que estabelece o prazo de duração da medida, pois tem levado à discussão sobre a possibilidade ou não de indefinidas prorrogações.

A atuação da jurisprudência do STF e do STJ, por sua vez, tem enfraquecido o sistema de regulação da interceptação, pois vem entendendo que: (i) pode-se utilizar o resultado da interceptação como prova emprestada até mesmo em processo administrativo, inclusive contra terceiros, em violação à restrição de finalidade da medida a investigação criminal e instrução processual penal; (ii) pode ser estendida a medida para investigar fatos conexos ao principal apenados com detenção, em violação ao artigo $2^{\circ}$, inciso III, da Lei 9.296/1996; (iii) os prazos podem ser sucessiva e indefinidamente prorrogados, desde que se considere a prorrogação importante para a investigação ou instrução, em violação direta ao $\operatorname{artigo} 5^{\circ}$ da Lei 9.296/1996.

A lei regulamentadora do dispositivo constitucional não pode ser tomada como uma mera formalidade, a partir da qual se tornam cabíveis as mais variadas interpretações para amenizar ou desconsiderar os limites por ela estabelecidos nos casos concretos. Em que 
pese, muitas vezes, a existência de outros interesses relevantes conflitantes, como a segurança pública, desconsiderar os limites bem ou mal estipulados pela Lei 9.296/1996 é, em última análise, violar diretamente a excepcionalidade consagrada no preceito constitucional. Antes do surgimento dessa lei, relembre-se, a jurisprudência dominante do STF era no sentido da ilegalidade e conseqüente nulidade de todas as provas oriundas de interceptações autorizadas por juízes, por mais grave que fosse o fato investigado.

Logo, sob a vigência da atual redação da Lei 9.296/1996, entendemos, principalmente, que: (i) pode haver extensão subjetiva da medida, desde que presentes todos os requisitos do artigo $2^{\circ}$ em relação ao sujeito alvo e ao fato investigado, e haja conexão subjetiva e objetiva com o fato principal; (ii) deve ser proibida a prova emprestada a qualquer outro processo, criminal ou não, haja vista que as hipóteses de cabimento da medida ora positivadas são tão amplas que permitiria, na prática, a extensão da interceptação a um universo grande de comunicações, levando a uma significativa redução ou ao aniquilamento da sua natureza excepcional; e (iii) a medida só pode ser prorrogada por uma vez, por duração idêntica à da autorizada inicialmente, sendo que o prazo de uma e outra não pode superar quinze dias, sendo, portanto, nulas as provas obtidas além desse tempo.

Desse modo, após análise e consideração da jurisprudência do STF e do STJ, do Anteprojeto de Lei da Comissão de Juristas do Ministério da Justiça de 2003, dos Projetos de Lei em trâmite no Congresso Nacional, destacadamente os Projetos de Lei 3.272/2008 e 4.036/2008, na Câmara dos Deputados, do direito comparado dos Estados Unidos da América e da União Européia (e alguns de seus países), bem como da doutrina nacional e estrangeira, pugnamos por uma revisão da Lei 9.296/1996 para que, concomitantemente: (i) seja alterado o critério do inciso III do seu artigo $2^{\circ}$, substituindo-o por um catálogo de crimes graves, além daqueles que só possam ser investigados ou provados através da interceptação, como, por exemplo, a ameaça por mensagem eletrônica; (ii) sejam estabelecidos nomeadamente os sujeitos que podem determinar, requerer e ser alvos da medida; (iii) sejam estabelecidas expressamente as hipóteses que possibilitam a autorização de extensão subjetiva da medida; (iv) se permita a extensão subjetiva da medida se os fatos descobertos no seu curso tiverem conexão com o fato original e sejam atendidos os demais critérios autorizadores, principalmente o catálogo de crimes e o de sujeitos passivos; (v) se autorize a utilização do resultado da interceptação e documentação a ela relativa como prova emprestada em outros processos penais, desde que o fato investigado faça parte do catálogo de crimes e o sujeito integre o rol de pessoas sujeitas à 
medida, e vede-se expressamente, por conseguinte, fora desses casos, a utilização em outros processos, notadamente não penais; (vi) se remova o limite máximo total de prazo, mas mantenham-se prazos curtos periódicos, exigindo-se sempre nova autorização judicial, com supervisão do Ministério Público e fundamentação circunstanciada que demonstre a continuidade dos pressupostos que permitem a medida e a necessidade de sua renovação; (vii) se estabeleça que a execução das operações seja efetivada diretamente pela polícia e, ou, pelo Ministério Público, cabendo aos particulares apenas o dever de colaboração; (viii) sejam os agentes que intermedeiem as comunicações, na qualidade de prestadores de serviço, proibidos de armazenar o conteúdo das comunicações eletrônicas incidentalmente armazenadas, sem autorização dos usuários, bem como sejam obrigados a apagá-las quando requisitados; (ix) os agentes que intermedeiam as comunicações, na qualidade de prestadores de serviço, sejam obrigados a armazenar por certo tempo os dados externos referentes a essas comunicações; $(x)$ se estabeleça claramente o direito à ampla defesa e ao contraditório através da possibilidade de acesso integral dos investigados ou acusados relativamente às comunicações suas que tiverem sido interceptadas, inclusive com indicação à possibilidade processual de se impugnar e averiguar a autenticidade e a fidelidade do conteúdo das interceptações; (xi) se estabeleçam medidas para assegurar a auditoria automática e necessária de toda a operação, inclusive das cópias do resultado das interceptações e dos documentos pertinentes, que devem ser identificados e, dessa forma, atrelados àqueles que as requisitam, a fim de se controlar a circulação dessas informações sigilosas e apurar as responsabilidades por eventual uso indevido; (xii) se crie um banco de dados central, ao qual devem ser remetidos dados sobre a quantidade de interceptações autorizadas pelos juízes, com a indicação dos órgãos que emitiram as ordens, bem como das ordens executadas pelas autoridades e pelos prestadores de serviço de comunicação eletrônica, para fins estatísticos e de controle, à semelhança do que estabeleceu a Resolução 59/2008 do CNJ; (xiii) se instituam meios para que o indivíduo possa saber, pelo menos após uma janela mínima de segurança, salvo situações excepcionais, que devem ser definidas na lei, se teve comunicações suas interceptadas, como mais uma forma de controle social; (xiv) seja regulado pelo Estado, em síntese, o comércio e a utilização de máquinas e "softwares" destinados à interceptação, com a sua identificação; e (xv) se crie a responsabilidade, inclusive penal, se pertinente, pela aquisição, utilização e divulgação não autorizadas do conteúdo das comunicações eletrônicas, por qualquer um, além da posse e uso de cópia não autorizada ou não identificada desse conteúdo.

Consideramos de especial importância as mudanças propostas nos itens "i" a "vi", 
"x" e "xii", a fim de permitir um equilíbrio razoável entre o direito à privacidade e ao sigilo das comunicações reservadas, de um lado, e outros direitos ou interesses concorrentes, de outro, como a segurança pública.

No âmbito não penal, entendemos que a regra continua sendo a da inviolabilidade do conteúdo das comunicações eletrônicas por terceiros. Deve-se permitir a gravação das conversas em certas situações, mas não interceptação, como a que se dá entre a vendedora de um bem ou serviço e o consumidor, inclusive para provar a realização do negócio ou do atendimento.

Na área trabalhista, a proteção aplicável em face do empregado ou funcionário e de seus interlocutores dependerá da análise da situação concreta, especialmente se o meio de comunicação eletrônica é conferido pelo empregador para o fim único, exclusivo e inequívoco, com notificação do empregado e com uma marca ou aviso público, como endereço de e-mail no formato “cargo@empresa.com.br”, que denote que a pessoa age e responde em nome da empresa ou órgão, como se fosse a própria instituição. A ausência de todas essas características combinadas não permite que o empregador ou superior hierárquico tenha acesso às comunicações travadas por seus subordinados, sendo irrelevante o fato isolado de os meios físicos e lógicos serem fornecidos pelo empregador.

Quanto a outras situações, como a produção de prova em processo civil ou administrativo, por exemplo, através da interceptação das comunicações eletrônicas, anotamos que não existe previsão constitucional para tanto, sendo que mesmo a jurisprudência do STF e do STJ entende possível o seu uso em outros processos apenas por meio do método da "prova emprestada", que criticamos.

Entendemos que os dados externos, por sua vez, podem ser obtidos, desde que haja previsão legal, ou em circunstâncias especiais, com razoabilidade, quando, por exemplo, houver justificativa excepcional, em virtude da natureza do serviço ou da função ou de fundadas razões de que esteja havendo desvios de conduta.

Por último, admite-se, como exceção geral, em todos os casos, a utilização de informações obtidas indevidamente por meio de interceptação para evitar grave e iminente ou atual perigo, como o risco à vida de terceiros, circunstância que pode excluir até mesmo a ilicitude da conduta, mas nunca para ensejar a produção de prova válida num processo.

O Projeto de Lei 3.272/2008 aborda vários dos aspectos que levantamos, ao adotar um conceito de "quebra de sigilo das comunicações telefônicas de qualquer natureza" que abarca "todo ato que intervém no curso dessas comunicações com a finalidade de conhecer as informações que estão sendo transmitidas, incluindo a interceptação, escuta e gravação", 
bem como o registro, a análise e a utilização dessa informação; a proibição de utilização das comunicações travadas entre o investigado ou acusado e seu defensor, quando este estiver atuando na função, sendo silente, porém, em relação a outras espécies de sigilo profissional; ao estabelecer expressamente a possibilidade de inúmeras prorrogações, embora determine um teto máximo como regra; ao explicitar que a autoridade policial deve remeter ao juiz todo o material produzido; ao facultar ao investigado ou acusado a obtenção de cópia identificável de todo o material produzido; ao estabelecer a possibilidade de impugnação de autenticidade do material; ao estabelecer uma "exclusionary rule" específica para as provas obtidas mediante "quebra de sigilo" ilícita; e ao autorizar o Poder Executivo a constituir um banco de dados com fins estatísticos.

O Projeto de Lei 4.036/2008, também de iniciativa do Poder Executivo, completa, de certa forma, a proposta de alteração da lei em vigor, ao estabelecer, até certo ponto de maneira sobreposta ao Projeto de Lei 3.272/2008, novos crimes, inclusive um relativo à produção, fabricação, importação, comercialização, oferta, empréstimo, aquisição, posse, guarda ou depósito, sem autorização ou em desacordo com determinação legal ou regulamentar, de "equipamentos destinados especificamente à interceptação, escuta, gravação e decodificação das comunicações telefônicas, incluindo programas de informática e aparelhos de varredura".

Porém, o Projeto de Lei 3.272/2008 continua propondo a adoção de um critério baseado na pena de reclusão, e inclui os apenados com detenção quando a conduta delituosa tiver sido realizada por meio dessas modalidades de comunicação (reservada). Também não veda ou restringe a utilização do resultado das interceptações em relação a outros crimes não relacionados ao objeto da investigação autorizadora da medida. Pelo contrário, permite a interpretação de que quaisquer delitos mencionados ou encontrados podem ser investigados, ao apenas determinar a remessa dos documentos ao Ministério Público para que sejam tomadas as "providências necessárias".

Também não se vislumbra uma delimitação clara dos sujeitos que podem requerer, autorizar e ser alvo da medida, e não há previsão do dever de não gravar ou apagar o conteúdo das comunicações eletrônicas pelos prestadores de serviços, tampouco o de armazenar por certo prazo seus dados externos.

Além disso, o Projeto de Lei 3.272/2008 continua lacônico no tocante às comunicações eletrônicas, dispondo tão-somente que a lei aplica-se ao "fluxo de comunicações em sistemas de tecnologia de informática e telemática", o que, apesar do amplo conceito de "quebra de sigilo" que adota, não resolve dúvidas quanto ao regime 
aplicável ao conteúdo das transmissões incidentalmente armazenado, como, por exemplo, em relação aos "e-mails".

Portanto, a nosso ver, não tem havido grande preocupação com o caráter de excepcionalidade da obtenção do conteúdo das comunicações por terceiros e, por conseguinte, com um equilíbrio entre o direito à privacidade e ao sigilo das comunicações e outros direitos e interesses concorrentes relevantes específicos, como a segurança pública, em conformidade com o disposto nos incisos XII e X do artigo $5^{\circ}$ da Constituição Federal, pendendo a balança, por enquanto, para o lado da invasão da vida privada, sendo necessária uma revisão da questão pelos intérpretes e aplicadores da lei e através de alterações legislativas. 


\section{BIBLIOGRAFIA}

ABREU, Lília Leonor; ZIMMERMANN, Deyse Jacqueline. Direito à intimidade X revista pessoal do empregado. LTr Suplemento Trabalhista, ano 41, n. 154/05, p. 695-698, 2005.

ADIERS, Leandro Bittencourt. Sigilo bancário, monitoramento e reserva de privacidade. Revista da Associação dos Juízes do Rio Grande do Sul - AJURIS, ano XXXI, n. 93, p. 137-153, mar. 2004.

AGUILAR, Francisco. Dos conhecimentos fortuitos obtidos através de escutas telefónicas: contributo para o seu estudo nos ordenamentos jurídicos alemão e português. Coimbra: Almedina, 2004.

AlbuQuerque, Paulo Pinto de. Comentário do Código de Processo Penal à luz da Constituição da República e da Convenção Europeia dos Direitos do Homem. $2^{\mathrm{a}}$ ed. Lisboa: Universidade Católica, 2008.

ALDERMAN, Ellen; KENNEDY, Caroline. The right to privacy. New York: Vintage Books, 1997.

ALMEIDA, Teodoro Bastos. O direito à privacidade e a protecção de dados genéticos: uma perspectiva de direito comparado. Boletim da Faculdade de Direito da Universidade de Coimbra, vol. LXXIX, p. 355-436, 2003.

ANATEL. ANATEL esclarece uso do VoIP para oferta de serviço de voz. Brasília, 9 nov. 2005.2 Disponível em: <http://www.anatel.gov.br/Portal/verificaDocumentos/documento.asp?numeroPublicacao= $114665 \&$ assuntoPublicacao $=$ Anatel $\% 20$ esclarece $\% 20$ uso $\% 20 \% 20 \mathrm{de} \% 20$ VoIP $\% 20$ para $\% 2$ 0oferta $\% 20 \% 20 \mathrm{de} \% 20$ servios $\% 20 \mathrm{de} \% 20 \mathrm{voz} \% 20 \&$ caminhoRel=null\&filtro=1\&document oPath=biblioteca/releases/2005/release_09_11_2005ad(1).pdf>. Acesso em: 9 jan. 2009.

Internet: dúvidas freqüentes. Brasília, [2008]. Disponível em: <http://www.anatel.gov.br/Portal/exibirPortalPaginaEspecial.do?acao=\&codItemCanal=12 $66 \&$ codigoVisao $=4 \&$ nomeVisao $=$ Cidad $\%$ E3o\&nomeCanal $=$ Internet\&nomeItemCanal $=D$ \%FAvidas\%20freq\%FCentes>. Acesso em: 8 jan. 2009.

ARANDA, Javier Thibault. Information technology and worker's privacy: the Spanish law. Comparative Labor Law \& Policy Journal, vol. 23, n. 4, p. 431-470, 2001-2002.

ARAUJO, Luiz Alberto David. A correspondência eletrônica do empregado (“e-mail”) e o poder diretivo do empregador. Revista de Direito Constitucional e Internacional, ano 10, n. 40, p. 96-121, jul./set. 2002. 
AVOLIO, Luiz Francisco Torquato. Provas ilícitas: interceptações telefônicas, ambientais e gravações clandestinas. $3^{\mathrm{a}}$ ed. São Paulo: Revista dos Tribunais, 2003.

BALTAZAR JUNIOR, José Paulo. Considerações sobre o sigilo bancário. Revista Brasileira de Ciências Criminais, ano 9, n. 36, p. 102-131, out/dez 2001.

BARBOSA, Sílvio Henrique Vieira. "Informação X privacidade: o dano moral resultante do abuso da liberdade de imprensa". Revista de Direito Civil, Imobiliário, Agrário e Empresarial, ano 19, n. 73, p. 70-78, jul./set. 1995.

BARRERA, Maria Helena; OKAI, Jason Montague. Digital correspondence: recreating privacy paradigms. International Journal of Communications Law and Policy, n. 3, p. 1-14, summer 1999.

BARRETT, Catherine M. FBI Internet Surveillance: the need for a natural rights application of the Fourth Amendment to insure Internet privacy. The Richmond Journal of Law and Technology, vol. 8, n. 3, spring 2002. Disponível em: <http://law.richmond.edu/jolt/v8i3/article16.html>. Acesso em: 9 jan. 2009.

BARROS, Alice Monteiro. Regulamentação das relações de trabalho e a privacidade do trabalhador. Revista do Tribunal Regional do Trabalho da $1^{\text {a }}$ Região, n. 17, p. 238260, dez. 2001.

BARROS NETO, João Pinheiro de. Administração Pública no Brasil: uma breve história dos correios. São Paulo: Annablume, 2004.

BASTOS, Celso Ribeiro. Comentários à Constituição do Brasil (promulgada em 5 de outubro de 1988). São Paulo: Saraiva, 1989. v. 2.

BEARD, Alice Marie. The right to privacy vs. the First Amendment: is a private person protected against the publicizing of his private facts? [S.1.:s.n]: 1978. Disponível em: <http://members.aol.com/alicebeard/law/samples/privacy.htm>. Acesso em: 13 fev. 2007.

BELLAVISTA, Alessandro. I poteri dell'imprenditore e la "privacy" del lavoratore. II Diritto del Lavoro, anno LXXVI, n. 3, p. 149-183, magg./giugno 2002.

BELMONTE, Alexandre Agra. O controle da correspondência eletrônica nas relações de trabalho. Revista LTr, ano 68, n. 9, p. 1031-1042, set. 2004.

BONADUCE, Leonilda. La tutela della "privacy" nel rapporto di lavoro dipendente: gli obblighi del titolare e i diritti del lavoratore. Lavoro e previdenza oggi, anno XXVIII, $\mathrm{n}$. 3-4, p. 225-240, mar./apr. 2001.

BROWN, Duncan H.; BLEVINS, Jeffrey Layne. The Safe-Harbor Agreement between the United States and Europe: a missed opportunity to balance the interests of e-commerce and 
privacy online? Journal of Broadcasting \& Electronic Media, vol. 46, p. 565-585, dec. 2002.

BURNIER JÚNIOR, João Penido. Das provas obtidas ilicitamente e das provas contrárias à moral. Direito-USF, v. 16, n. 2, p. 71-80, 1999.

CACHAPUZ, Maria Cláudia. Intimidade e vida privada no novo Código Civil brasileiro: uma leitura orientada no discurso jurídico. Porto Alegre: Sergio Antonio Fabris, 2006.

CALDIROLA, Debora. Il diritto alla riservatezza. Padova: CEDAM, 2006.

CANOTILHO, J. J. Gomes; MOREIRA, Vital. Constituição da República Portuguesa anotada. $4^{a}$ ed. (Coimbra), $1^{a}$ ed. (Revista dos Tribunais). São Paulo: Revista dos Tribunais; Coimbra: Coimbra, 2007. v. I.

CANZIO, Giovanni; CARANO, Domenica Carano (coord.). Rassegna della Giurisprudenza di legittimità: la Giurisprudenza delle Sezioni Unite Penali della Corte di Cassazione - Anno 2005. Roma: Corte Suprema di Cassazione, Genn. 2006. Disponível em: $<$ http://www.cortedicassazione.it/Notizie/GiurisprudenzaPenale/RelazioniPen/Relazion iPen.asp?ID=6>. Acesso em: 9 jan. 2009.

CARVALHO, Luis Gustavo Grandinetti Castanho de. Direito à privacidade. Revista da Escola da Magistratura do Estado do Rio de Janeiro - EMERJ, vol. 1, n. 2, p. 51-76, 1998.

CASTRO, Catarina Sarmento e. Direito da Informática, privacidade e dados pessoais. Coimbra: Almedina, 2005.

CASTRO, Luiz Fernando Martins. Proteção de dados pessoais. Revista CEJ, n. 19, p. 4045, dez. 2002.

CATE, Fred H. Principles of Internet privacy. Connecticut Law Review, vol. 32, p. 877896, 1999-2000.

CENEVIVA, Walter. Direito à privacidade nos sistemas de informação. Revista de Direito Imobiliário, ano 28, n. 59, p. 292-307, jul./dez. 2005.

CERT.br. FAQ: perguntas freqüentes ao CERT.br. [S.1.:s.n.], 2008a. Disponível em: <http://www.cert.br/docs/certbr-faq.html>. Acesso em: 8 jan. 2009.

Missão. [S.1.:s.n.], 2008b. Disponível em: <http://www.cert.br/missao.html>. Acesso em: 8 jan. 2009. 
CERVINI, Raúl. Comentarios preliminares y aproximacion critica a la Ley 9.296 del 24 de julio de 1996. In: GOMES, Luiz Flávio; CERVINI, Raúl. Interceptação telefônica: Lei 9.296, de 24.07.96. São Paulo: Revista dos Tribunais, 1997. p. 21-72.

CHOUKR, Fauzi Hassan. Comentários sobre o Anteprojeto de Investigação Criminal. Revista dos Tribunais, ano 90, vol. 789, p. 457-481, jul. 2001.

CIDH - Corte Interamericana de Derechos Humanos. Opinión Consultiva OC-6/86 del 9 de mayo de 1986: la expresión "leyes" en el artículo 30 de la Convención Americana sobre Derechos Humanos. San José, 9 mayo 1986. Disponível em: <http://www.corteidh.or.cr/docs/opiniones/seriea_06_esp.pdf>. Acesso em: 19 jan. 2009.

CIFUENTES, Santos. La responsabilidad frente al derecho personalísimo de los datos personales. Lecciones y ensayos: Facultad de Derecho y Ciencias Sociales Universidad de Buenos Aires, Buenos Aires, n. 72/73/74, p. 111-118, 1998-1999.

CNJ - CONSELHO NACIONAL DE JUSTIÇA. Cerca de 12 mil telefones são monitorados com autorização judicial. Agência CNJ de Notícias, Brasília, 18 nov. 2008. Disponível em: $<$ http://www.cnj.jus.br/index.php?option=com_content\&view=article\&id=5484: cerca-de12-mil-telefones-sao-monitorados-com-autorizacao-judicial$\&$ catid=1:notas $\&$ Itemid=675> . Acesso em: 13 jan. 2009 .

COLB, Sherry F. A world without privacy: why property does not define the limits of the right against unreasonable searches and seizures. Michigan Law Review, vol. 102, p. 889903, 2003-2004.

COLLIARD, Claude-Albert; LETTERON, Roseline. Libertés publiques. $8^{\mathrm{e}}$ éd. Paris: Dalloz, 2005.

COMISSÃO EUROPÉIA. A network of independent experts to assess the safeguarding of fundamental rights by the European Union Member States. [S.1.], [2007].

Disponível em: <http://ec.europa.eu/justice_home/cfr_cdf/index_en.htm>. Acesso em: 9 dez. 2007.

COSSU, Cipriano. Dal caso Soraya alla nuova legge sulla tutela della riservatezza. Contratto e impresa, Padova, quattordicesimo anno, n. 1, p. 49-72, 1998.

COSTA, José de Faria; MONIZ, Helena. Algumas reflexões sobre a criminalidade informática em Portugal. Boletim da Faculdade de Direito da Universidade de Coimbra, vol. LXXIII, n. 73, p. 297-345, 1997.

COSTA JÚNIOR, Paulo José. O direito de estar só: a tutela penal do direito à intimidade. $3^{\mathrm{a}}$ ed. São Paulo: Siciliano Jurídico, 2004. 
CPI - Escutas Telefônicas Clandestinas. Transcrição da 81 ${ }^{\text {a }}$ Reunião Extraordinária, de 18 de dezembro de 2008. Brasília, 18 dez. 2008. Disponível em: <http://apache.camara.gov.br/portal/arquivos/Camara/internet/comissoes/temporarias53/cp i/cpiescut/notas/NT181208.pdf >. Acesso em: 13 jan. 2009.

CRETELla JÚNIOR, José. Comentários à Constituição brasileira de 1988. $2^{\mathrm{a}}$ ed. Rio de Janeiro: Forense Universitária, 1990. v. 1.

CRISAFULLI, Vezio; PALADIN, Livio (coord.). Commentario breve alla Costituzione. Padova: CEDAM, 1990.

DElmanto, Celso et al. Código Penal Comentado. $5^{\text {a }}$ ed. Rio de Janeiro: Renovar, 2000.

DHONT, Jan et al. Safe Harbor Decision implementation study at the request of the European Comission, Internal Market DG. Namur: Centre de Recherche Informatique et Droit - CRID. 19 apr. 2004.

DILASCIO, Tracey. How safe is the Safe Harbor? U.S. and E.U. data privacy law and the enforcement of the FTC's Safe Harbor Program. Boston University International Law Journal, vol 22, p. 399-424, 2004.

DINIZ, Maria Helena. Dicionário jurídico. São Paulo: Saraiva, 1998a. v. 2.

Dicionário jurídico. São Paulo: Saraiva, 1998b. v. 3.

Dicionário jurídico. São Paulo: Saraiva, 1998c. v. 4.

DOERNBERG, Donald L. "Can you hear me now?": expectations of privacy, false friends, and the perils of speaking under the Supreme Court's Fourth Amendment jurisprudence. Indiana Law Review, vol. 39, p. 253-308, 2005-2006.

DOMÍNGUEZ, Ana Garriga. La nueva Ley Orgánica 15/1999, de 13 de diciembre, de protección de datos personales, i un cambio de filosofía?. Anales de la Cátedra Francisco Suarez, n. 34, p. 299-321, 2000.

DONEDA, Danilo. Da privacidade à proteção de dados pessoais. Rio de Janeiro: Renovar, 2006.

DOUSE, Steven C. The concept of privacy and the Fourth Amendment. University of Michigan Journal of Law Reform, vol. 6, p. 154-189, 1972-1973.

EDGETT, Sean J. Double-clicking on Fourth Amendment protection: encryption creates a reasonable expectation of privacy. Pepperdine Law Review, vol. 30, p. 339-366, 2002- 
2003.

EDPS - European Data Protection Supervisor. Annual Report 2004. Brussels, 18 mar. 2005. Disponível em: <http://www.edps.europa.eu>. Acesso em: 9 jan. 2008.

ERIKSSON, Maja. Article 7 - Respect for private and family life. In: EU Network of Independent Experts on Fundamental Rights. Commentary of the Charter of Fundamental Rights of the European Union. [S.1.], June 2006. Disponível em: $<$ http://ec.europa.eu/justice_home/doc_centre/rights/charter/docs/network_commentary_fi nal\%20_180706.pdf >. Acesso em: 9 jan. 2009.

ETZIONI, Amitai. The limits of privacy. New York: Basic Books, 1999.

FAMIGLIETTI, Gianluca. Il diritto alla riservatezza o la riservatezza come diritto. Appunti in tema di riservatezza ed "intimidad" sulla scorta della giurisprudenza della Corte costituzionale e del "Tribunal Constitucional". Intervento al Seminario "Bio-tecnologie e valore costituzionali: il contributo della giustizia costituzionale". Forum di quaderni constituzionali, 2004. Disponível em: <http://www.forumcostituzionale.it>. Acesso em: 15 ago. 2007.

FAZEKAS, Christopher Pearson. "1984" is still a fiction: electronic monitoring in the workplace and U.S. privacy law. Duke Law \& Technology Review, n. 15, 2004. Disponível em: <http://www.law.duke.edu/journals/dltr/articles/2004dltr0015.html>. Acesso em: 9 jan. 2009.

FEDERAL TRADE COMMISSION. Privacy online: fair information practices in the electronic marketplace - A report to Congress. [S.1.:s.n], May 2000. Disponível em: <http://www.ftc.gov>. Acesso em: 9 jan. 2009.

FERRAZ JUNIOR, Tercio Sampaio. Privacidade e publicidade no limiar do século XXI. Revista da Academia Brasileira de Direito Constitucional, vol. 5, p. 491-501, 2004.

" "Sigilo bancário". Revista de Direito Bancário, do Mercado de Capitais e da Arbitragem, ano 4, n. 14, p. 13-27, out./dez. 2001.

Sigilo de dados: o direito à privacidade e os limites à função fiscalizadora do Estado. Cadernos de Direito Constitucional e Ciência Política, São Paulo, v. 1, n. 1, p. 77-90. 1992.

FERREIRA, Ivette Senise. A intimidade e o Direito Penal. Revista Brasileira de Ciências Criminais, ano 2, n. 5, p. 96-106, jan./mar. 1994.

FERREIRA, Manuel Alceu Affonso. Informação e intimidade: essas velhas inimigas. Revista de julgados do Tribunal de Alçada Criminal do Estado de São Paulo, v. 51, p. 13-20, maio/jun. 2001. 
FERREIRA, Pinto. Comentários à Constituição brasileira. São Paulo: Saraiva. 1989. v. 1.

FERREIRA FILHO, Manoel Gonçalves. Comentários à Constituição brasileira de 1988. São Paulo: Saraiva, 1990. v. 1.

FIGUEIRÔA JÚNIOR, Narciso. O uso de "e-mail" no ambiente de trabalho. LTr Suplemento Trabalhista, ano 41, n. 106/05, p. 481-483, 2005.

FIORIGLIO, Gianluigi. Temi di informatica giuridica. Roma: [s.n.], 2004. Disponível em <http://www.dirittodellinformatica.it/eBooks/TemiIG.pdf>. Acesso em: 3 maio 2007.

FISHER, Louis; ADLER, David Gray. American Constitutional Law. Constitutional rights: civil rights and civil liberties. $7^{\text {th }}$ ed. Durham: Carolina Academic, 2007. v. 2.

FRA - European Union Agency for Fundamental Rights. FRA - European Union Agency for Fundamental Rights (FRA) frequently asked questions. [S.1.], 12 jul. 2007. Disponível em: <http://fra.europa.eu/fra/material/pub/FRA/faq_en.pdf>. Acesso em: 9 dez. 2007.

FREITAS, Paulo Henrique de Souza; TRECENTI, Fernanda Eloísa. O sigilo bancário e o direito à privacidade: constitucionalidade da Lei Complementar $\mathrm{n}^{\circ} 105$. Revista do Instituto de Pesquisas e Estudos do Centro de Pós-Graduação da ITE, Bauru, n. 44, p. 209-239, set./dez. 2005.

FUNARO, Vânia M. B. de Oliveira (coord.). Diretrizes para a apresentação de dissertações e teses da USP: documento eletrônico e impresso. São Paulo: SIBi-USP, 2004.

GAITO, Alfredo; BARGI, Alfredo (org.). Codice di Procedura Penale annotato com la giurisprudenza. Torino: UTET Giuridica, 2007.

GARNER, Bryan A (ed.). Black's Law dictionary. $8^{\text {th }}$ ed. St. Paul: Thomson-West, 2007.

GERSTEIN, Robert S. Privacy and self-incrimination. Ethics, vol. 80, n. 2, p. 87-101, jan. 1970.

GOMES, Daniela Alves. Direito a intimidade do empregado. LTr Suplemento Trabalhista, ano 41, n. 148/05, p. 663/666, 2005.

GOMES, Luiz Flávio. Comentários à Lei 9.296, de 24.07.96. In: GOMES, Luiz Flávio; CERVINI, Raúl. Interceptação telefônica: Lei 9.296, de 24.07.96. São Paulo: Revista dos Tribunais, 1997. 
GONÇALVES, José Renato. Regime dos "dados pessoais" informatizados (algumas notas sobre a articulação entre as Leis $n^{\circ}$ 65/93 e $n^{\circ}$ 67/98). Scientia Iuridica: Revista de Direito Comparado português e brasileiro, tomo LI, n. 292, p. 63-80, jan./abr. 2002.

GONÇAlVES, Manuel Lopes Maia. Código de Processo Penal: anotado. 16 ${ }^{\mathrm{a}}$ ed. Coimbra: Almedina, 2007.

GORMLEY, Ken. One hundred years of privacy. Wisconsin Law Review, p. 1335-1442, 1992.

GOUVEIA, Jorge Bacelar. A protecção de dados informatizados e o fenómeno religioso em Portugal. Revista da Faculdade de Direito da Universidade de Lisboa, vol. XXXIV, p. 181-238, 1993.

GOUVEIA, Jorge Bacelar. Os direitos fundamentais à protecção dos dados pessoais informatizados. Revista da Faculdade de Direito Milton Campos, vol. 1, n. 2, p. 169194, 1995.

GRECO FILHO, Vicente. Interceptação telefônica: considerações sobre a Lei n. 9.296, de 24 de julho de 1996. $2^{\text {a }}$ ed. São Paulo: Saraiva, 2005.

GREGÓRIO, Carlos; PAIVA, Mário. Proteção de dados pessoais no âmbito judicial. Lex Jurisprudência do Supremo Tribunal Federal, ano 27, n. 313, p. 5-27, jan. 2005.

GRINOVER, Ada Pellegrini. O regime brasileiro das interceptações telefônicas. Revista CEJ, vol. 1, n. 3, set./dez. 1997. Disponível em: <http://www2.cjf.jus.br/ojs2/index.php/cej/article/view/108/151>. Acesso em: 2 dez. 2008.

GRINOVER, Ada Pellegrini; FERNANDES, Antonio Scarance; GOMES FILHO, Antonio Magalhães. As nulidades no processo penal. $7^{\text {a }}$ ed. São Paulo: Revista dos Tribunais, 2001.

GROSS, Hyman. The concept of privacy. New York University Law Review, vol. 42, p. 34-54. 1967.

GRUPO DE TRABALHO DO ARTIGO 29 - GRUPO DE PROTECÇÃO DAS PESSOAS NO QUE DIZ RESPEITO AO TRATAMENTO DE DADOS PESSOAIS. WP 4 Primeiras orientações sobre as transferências de dados para países terceiros: eventual metodologia a adoptar para avaliar a adequação do grau de protecção. Documento de trabalho adotado em 26 de junho de 1997. Bruxelles: Comissão Européia. 1997. Disponível em: <http://www.europa.eu.int/comm/privacy>. Acesso em: 9 jan. 2009.

WP 9 - Observações preliminares relativas ao uso de cláusulas contratuais no contexto da transferência de dados pesssoais para países terceiros. Documento de trabalho adotado em 22 de abril de 1998. Bruxelles: Comissão Européia, 1998a. 
Disponível em: <http://www.europa.eu.int/comm/privacy>. Acesso em: 9 jan. 2009.

WP 12 - Transferência de dados pessoais para países terceiros: aplicação dos artigos $25^{\circ}$ e $26^{\circ}$ da Directiva comunitária relativa à protecção dos dados. Documento de trabalho adotado em 24 de julho de 1998. Bruxelles: Comissão Européia, 1998b. Disponível em: <http://www.europa.eu.int/comm/privacy>. Acesso em: 9 jan. 2009.

WP 27 - Parecer 7/99 sobre o nível de protecção de dados fornecido pelos princípios de "porto seguro", publicados em conjunto com as questões mais frequentes (FAQ) e outros documentos conexos, em 15 e 16 de Novembro de 1999, pelo "Department of Commerce" dos EUA. Documento de trabalho adotado em 3 de dezembro de 1999. Bruxelles: Comissão Européia, 1999. Disponível em: <http://www.europa.eu.int/comm/privacy>. Acesso em: 9 jan. 2009.

WP 32 - Parecer 4/2000 sobre o nível de protecção assegurado pelo conjunto de princípios de "Porto Seguro". Documento de trabalho adotado em 16 de maio de 2000. Bruxelles: Comissão Européia, 2000. Disponível em: <http://www.europa.eu.int/comm/privacy>. Acesso em: 9 jan. 2009.

WP 38 - Parecer 1/2001 sobre o projecto de decisão da Comissão relativa às cláusulas contratuais-tipo aplicáveis à transferência de dados pessoais para países terceiros em conformidade com o $n^{\circ} 4$ do artigo $26^{\circ}$ da Directiva 95/46/CE (projecto distribuído ao grupo de trabalho em 17 de janeiro de 2001). Documento de trabalho adotado em 26 de janeiro de 2001. Bruxelles: Comissão Européia, 2001a. Disponível em: <http://www.europa.eu.int/comm/privacy>. Acesso em: 9 jan. 2009.

WP 47 - Parecer 7/2001 sobre o projecto de decisão da Comissão (versão de 31 de agosto de 2001) relativa às cláusulas contratuais-tipo aplicáveis à transferência de dados pessoais para subcontrantes estabelecidos em países terceiros, em conformidade com o $n^{\circ} 4$ do artigo $2^{\circ}$ da Directiva 95/46/CE. Documento de trabalho adotado em 13 de setembro de 2001. Bruxelles: Comissão Européia, 2001b. Disponível em: <http://www.europa.eu.int/comm/privacy>. Acesso em: 9 jan. 2009.

. WP 74 - Transfers of personal data to third countries: Applying Article 26 (2) of the EU Data Protection Directive to Binding Corporate Rules for International Data Transfers. Documento de trabalho adotado em 3 de junho de 2003. Bruxelles: Comissão Européia, 2003a. Disponível em: <http://www.europa.eu.int/comm/privacy>. Acesso em: 9 jan. 2009.

WP 84 - Parecer 8/2003 sobre o projecto de cláusulas contratuais-tipo apresentado por um grupo de organizações empresariais ("modelo de contrato alternativo"). Documento de trabalho adotado em 17 de dezembro de 2003. Bruxelles: Comissão Européia, 2003b. Disponível em: <http://www.europa.eu.int/comm/privacy>. Acesso em: 9 jan. 2009. 
Issuing Common Options on Adequate Safeguards Resulting from "Binding Corporate Rules". Documento de trabalho adotado em 14 de abril de 2005. Bruxelles: Comissão Européia, 2005a. Disponível em: 〈http://www.europa.eu.int/comm/privacy>. Acesso em: 9 jan. 2009.

WP 108 - Working Document Establishinga Model Checklist Application for Approval of Binding Corporate Rules. Documento de trabalho adotado em 14 de abril de 2005. Bruxelles: Comissão Européia, 2005b. Disponível em: <http://www.europa.eu.int/comm/privacy>. Acesso em: 9 jan. 2009.

WP 114 - Documento de trabalho sobre uma interpretação comum do $\mathrm{n}^{0} 1$ do artigo $26^{\circ}$ da Directiva 95/46/CE de 24 de Outubro de 1995. Documento de trabalho adotado em 25 de novembro de 2005. Bruxelles: Comissão Européia, 2005c. Disponível em: <http://www.europa.eu.int/comm/privacy>. Acesso em: 9 jan. 2009.

WP 136 - Parecer 4/2007 sobre o conceito de dados pessoais. Documento adotado em 20 de junho de 2007. Bruxelles: Comissão Européia, 2007a. Disponível em: <http://www.europa.eu.int/comm/privacy>. Acesso em: 9 jan. 2009.

WP 144 - Resolution by the Article 29 Working Party on the 2nd European Data Protection Day. Documento adotado em 5 de dezembro de 2007. Bruxelles: Comissão Européia, 2007b. Disponível em: 〈http://www.europa.eu.int/comm/privacy>. Acesso em: 9 jan. 2009.

GUINCHARD, Serge; BUISSON, Jacques. Manuel: Procédure Pénale. $4^{\mathrm{e}}$ éd. Paris: Lexis Nexis, 2008.

HEIMES, Rita. Internet privacy law, policy, and practice: state, federal, and international perspectives. Maine Law Review, v. 54, p. 95-114, 2002.

HENDRICKS, Evan; HAYDEN, Trudy; NOVIK, Jack D. Your right to privacy. $2^{\text {nd }}$ ed. Carbondale: Southern Illinois University, 1990.

HEYDE, Wolfgang. Article 1 - Human Dignity. In: EU Network of Independent Experts on Fundamental Rights. Commentary of the Charter of Fundamental Rights of the European Union. [S.1.], June 2006. Disponível em: <http://ec.europa.eu/justice_home/doc_centre/rights/charter/docs/network_commentary_fi nal\%20_180706.pdf $>$. Acesso em: 9 jan. 2009.

HOEPERS, Cristine. Atuação do CERT.br. [S.l.:s.n.], 2007. Disponível em: <http://www.cert.br>. Acesso em: 9 jan. 2008.

HUBBARTT, William S. The new battle over workplace privacy. New York: AMACOM, 1998. 
ILO - International Labour Organization. Protection of workers' personal data: an ILO code of practice. Geneva: International Labour Organization, 1997.

INSTITUTO ANTÔNIO HOUAISS. Dicionário Houaiss da língua portuguesa. Rio de Janeiro: Objetiva, 2004. Disponível em: 〈http://houaiss.uol.com.br>. Acesso em: 16 fev. 2007.

JABUR, Gilberto Haddad. Liberdade de pensamento e direito à vida privada: conflitos entre direitos da personalidade. São Paulo: Revista dos Tribunais, 2000.

JESUS, Damário E. de. Direito Penal. 21ª ed. São Paulo: Saraiva, 1998. v. 1.

Interceptação de comunicações telefônicas - Notas à Lei 9.296, de 24.07.1996.

Revista dos Tribunais, ano 86, v. 735, p. 458-473, 1997.

JONES, Stephen P. Reasonable expectations of privacy: searches, seizures, and the concept of Fourth Amendment standing. University of Memphis Law Review, v. 27, p. 907-986, 1996-1997.

KAMBAS, William J. A safety net in the e-marketplace: the Safe Harbor principles offer comprehensive privacy protection without stopping data flow. ILSA Journal of International \& Comparative Law, v. 9, p. 149-184, 2002-2003.

KERR, Orin. Technology, privacy, and the courts: a reply to Colb and Swire. Michigan Law Review, v. 102, p. 933-943, 2003-2004a.

The Fourth Amendment and new technologies: constitutional myths and the case for caution. Michigan Law Review, v. 102, p. 801-888, 2003-2004b.

LEE, Laurie Thomas. The USA Patriot Act and telecommunications: privacy under attack. Rutgers Computer \& Technology Law Journal, v. 29, p. 371-403, 2003.

LEPAGE, Joëlle; WATY, Emilie. Écoutes téléphoniques et protection européenne des droits de l'homme: le système Echelon. Revue de la Faculté de droit de l'Université de Liège, quarante-neuvième année, n. 2004/2, p. 280-285, 2004.

LIMBERGER, Têmis. O direito à intimidade do cliente bancário: uma proposta de interpretação conjugando a sistemática constitucional, consumeirista e civilista. Direito \& Justiça: Revista da Faculdade de Direito da PUCRS, ano XXIV, v. 26, n. 2, p. 169/192, 2002.

LIPPMANN, Ernesto. Do direito à privacidade do empregado, nos tempos da Internet. Revista LTr, ano 62, n. 4, p. 483-486, abr. 1998. 
LUSKY, Louis. Invasion of privacy: a clarification of concepts. Political Science Quarterly, v. 87, n. 2, p. 192-209, 1972.

MACEDO JÚNIOR, Ronaldo Porto. Privacidade, mercado e informação. Justitia, ano 61, vs. 185/188, p. 245-259, jan./dez. 1999.

MACHADO, Antônio Cláudio da Costa. Código de Processo Civil interpretado: artigo por artigo, parágrafo por parágrafo. $7^{\mathrm{a}}$ ed. Barueri: Manole, 2008.

MARINELLI, Claudio. Intercettazioni processuali e nuovi mezzi di ricerca della prova. Torino: G. Giappichelli, 2007.

MARKESINIS, Basil; ALPA, Guido. Il diritto alla "privacy" nell'esperienza de "common law" e nell'esperienza italiana. Rivista trimestrale di diritto e procedura civile, Milano, anno LI, n. 2, p. 417-454, giugno 1997.

MARQUES, José Augusto Garcia. A Lei n 10/91, de 29 de abril: Lei de Protecção de dados pessoais face à informática. Documentação e Direito Comparado da Procuradoria-Geral da República, Lisboa, n. 47/48, p. 379-423, 1991.

MARTIN, Samantha L. Interpreting the Wiretap Act: applying ordinary rules of "transit" to the Internet context. Cardozo Law Review, v. 28, p. 441-477, 2006-2007.

MARTINS, Alberto. Protecção de dados pessoais informatizados na Constituição da República Portuguesa. Documentação e Direito Comparado da Procuradoria-Geral da República, Lisboa, n. 47/48, p. 425-436, 1991.

MATA-MOUROS, Maria de Fátima. Sob escuta. São João do Estoril: Principia, 2003.

MAURO, Raffaella Di. Tutela della privacy: diritti dell'interessato al trattamento dei dati personali, tutela giurisdizionale e amministrativa, responsabilità civile del datore di lavoro. Lavoro e previdenza oggi, anno XXVII, n. 12, p. 2178-2191, dic. 2000.

MAXIMILIANO, Carlos. Hermenêutica e aplicação do direito. $9^{\text {a }}$ ed. Rio de Janeiro: Forense, 1981.

MENDES, Maria Gilmaíse de Oliveira. Direito à intimidade e interceptações telefônicas. Belo Horizonte: Mandamentos, 1999.

MESQUITA, Rodrigo Octávio de Godoy Bueno Caldas. Da inviolabilidade do sigilo de correspondência eletrônica ou "e-mail" no ordenamento jurídico brasileiro e alguns reflexos nas relações trabalhistas e no Direito Penal. In: Associação Brasileira de Direito de Informática e Telecomunicações (org.). Concurso nacional de monografias da ABDI sobre Direito de Informática e Telecomunicações - 2002 a 2004. São Paulo: Associação 
Brasileira de Direito de Informática e Telecomunicações - ABDI, 2007. p. 233-259.

MINISTÉRIO DAS COMUNICAÇÕES. Documento de Encaminhamento da Lei Geral das Telecomunicações, comentando-a: E.M. no 231/MC. Brasília: [s.n.], 10 dez. 1996.

MIRABETE, Julio Fabbrini. Código Penal Interpretado. $2^{a}$ ed. São Paulo: Atlas, 2001.

. Manual de Direito Penal. 12ª ed. São Paulo: Atlas, 1997. v. 1.

MIRANDA, Jorge; MEDEIROS, Rui. Constituição portuguesa anotada. Coimbra: Coimbra, 2005. t. I.

MISTRONGUE, Alessandra Loyola; KERSTEN, Felipe de Oliveira. Invasão de privacidade: a violação de "e-mails" nas relações de trabalho à luz da ordem jurídicoconstitucional brasileira. Revista LTr, ano 68, n. 3, p. 310-322, mar. 2004..

MONTEIRO, Washington de Barros. Curso de Direito Civil. 13 a ed. São Paulo: Saraiva, 1974. v. 3.

MOUTOUH, Hugues; RIVERO, Jean. Libertés publiques. Tome I. $9^{\mathrm{e}}$ éd. Paris: Universitaires de France, 2003a.

Libertés publiques. Tome II. $7^{\mathrm{e}}$ éd. Paris: Universitaires de France, $2003 \mathrm{~b}$.

NARA - National Archives and Records Administration. A more perfect Union: the creation of the U.S. Constitution. [S.l.s.n.], [2007a]. Disponível em: $<$ http://www.archives.gov/exhibits/charters/constitution_history.html >. Acesso em: 12 jan. 2009.

Disponível

Bill of Rights - The Virginia Declaration of Rights. [S.1.:s.n.], [2007b]. $<$ http://www archives gov/exhibits/charters/virginia_declaration_of rights.html> Acesso em: 12 jan. 2009.

NASCIMENTO, Amauri Mascaro. Princípios do direito do trabalho e direitos fundamentais do trabalhador. Revista LTr, ano 67, n. 8, p. 903-916, ago. 2003.

NERY JUNIOR, Nelson. Princípios do processo civil na Constituição Federal. $7^{\mathrm{a}}$ ed. São Paulo: Revista dos Tribunais, 2002.

NIGER, Sergio. Le nuove dimensioni della privacy: dal diritto alla riservatezza alla protezione dei dati personali. Padova: CEDAM, 2006.

NIGRI, Deborah Fisch. Computadores: ameaça ou benefício para a desburocratização - 
direitos do cidadão. Doutrina Adcoas, ano I, n. 3, p. 67-72, mar. 1998.

NOVO, Catia Guimarães Raposo. A utilização de meios eletrônicos corporativos à luz do princípio da proporcionalidade. LTr Suplemento Trabalhista, ano 41, n. 099/05, p.447450, 2005.

OBERDORFF, Henri. Droits de l'homme et libertés fondamentales. Paris: L.G.D.J, 2008.

OEA - ORGANIZAÇÃO DOS ESTADOS AMERICANOS. Comissão Interamericana de Direitos Humanos. Demanda perante a Corte Interamericana de Direitos Humanos no caso Arley José Escher e outros (interceptação de linhas telefônicas de organizações sociais) (Caso 12.353) contra a República Federativa do Brasil. Washington, 20 dez. $2007 . \quad$ Disponível em: <http://www.iachr.org/demandas/12.353\%20Arley\%20Escher\%20y\%20otros\%2020\%20di ciembre\%202007\%20PORT.pdf>. Acesso em: 19 jan. 2009.

OECD. OECD Guidelines on the Protection of Privacy and Transborder Flows of Personal Data. $\quad$ [S.1.], $1980 . \quad$ Disponível em: <http://www.oecd.org/document/18/0,3343,en_2649_34255_1815186_1_1_1_1,00.html>. Acesso em: 14 out. 2008.

Protection of privacy and personal data. [S.1.], [2008]. Disponível em: <http://www.oecd.org/document/26/0,3343,en_2649_34255_1814170_1_1_1_1,00.html>. Acesso em: 14 out. 2008.

OLIVEIRA, Paulo Eduardo Vieira de. A privacidade da pessoa humana no ambiente de trabalho. Revista da Faculdade de Direito da Universidade de São Paulo, v. 100, p. 147-167, 2005.

OLIVEIRA, Régis de. Aspectos constitucionais do sigilo bancário. Revista de Direito Mercantil, Industrial, Econômico e Financeiro, v. 34, n. 39, p. 98-104, jul./set. 1995.

PAESANI, Liliana Minardi; BAPTISTA, Ezio Carlos S. A privacidade na sociedade da informação: breves reflexões. Revista do Curso de Direito do Centro Universitário das Faculdades Metropolitanas Unidas - UniFMU, ano 20, n. 28, p. 13-24, 2006.

PAIVA, Mário Antônio Lobato de. A intimidação informática do trabalhador. Revista do Tribunal Regional do Trabalho da 15 $^{\mathbf{a}}$ Região, Campinas, n. 18, p. 220-238, 2002a..

O monitoramento do correio eletrônico no ambiente de trabalho. Revista CEJ, Brasília, v. 6, n. 19, p. 24-39, dez. 2002b.

PAOLINI, A.; Zavattaro, D. Intercettazioni telefoniche e ambientali: metodi, limiti e sviluppi nella trascrizione e verbalizzazione. Torino: Centro Scientifico, 2007. 
PARENT, W. A. Privacy, morality, and the Law. Philosophy and Public Affairs, v. 12, n. 4, p. 269-288, autumn 1983.

PECORELLA, Claudia. Diritto Penale dell'Informatica. Padova: CEDAM, 2006.

PIERANGELI, José Henrique. Códigos Penais do Brasil: evolução histórica. $2^{a}$ ed. São Paulo: Revista dos Tribunais, 2004.

PINTO, Paulo Cardoso Correia da Mota. A protecção da vida privada e a Constituição. Boletim da Faculdade de Direito da Universidade de Coimbra, Coimbra, v. LXXVI, p. 153-204, 2000.

PITOMBO, Cleunice A. Valentim Bastos. Considerações sobre a tutela da intimidade e vida privada no processo penal. Revista Brasileira de Ciências Criminais, São Paulo, v. 7, n. 26, p. 59-79, abr./jun. 1999.

PODESTÁ, Fábio Henrique. Direito à intimidade em ambiente da Internet. In: DE LUCCA, Newton; SIMÃO FILHO, Adalberto (coord.). Direito \& Internet: aspectos jurídicos relevantes. Bauru: Edipro, 2001. p. 155-176.

POSNER, Richard A. The economics of privacy. The American Economic Review, v. 71, n. 2, p. 405-409, May 1981.

PRADEL, Jean. Procédure Penale. 13 éd. Paris: Éditions Cujas, 2006.

PRIVACILLA.ORG. Privacy and government: the HEW Report. [S.1.:s.n.], 2001. Disponível em: <http://www.privacilla.org/government/hewreport.html>. Acesso em: 4 jan. 2009.

PROSSER, William. Privacy. California Law Review, v. 48, n. 3, p. 383-423, Aug. 1960.

REIDENBERG, Joel R. E-commerce and trans-atlantic privacy. Houston Law Review, v. 38, p. 717-749, 2001-2002.

REGAN, Priscilla M. Safe harbors or free frontiers? Privacy and transborder data flows. Journal of Social Issues, v. 59, n. 2, p. 263-282, 2003.

RIBEIRO, Luciana Antonini. A privacidade e os arquivos de consumo na Internet: uma primeira reflexão. Revista de Direito do Consumidor, ano 11, n. 41, p. 151-165, jan./mar. 2002.

RIGAUX, François. La liberté de la vie privée. Revue internationale de droit comparé, quarante-troisième année, n. 3, p. 539-563, juil./sept. 1991. 
La protection de la vie privée et des autres biens de la personnalité. Bruxelles: Émile Bruylant, 1990.

ROCHA, Eládio Torret. Ética, liberdade de informação, direito à privacidade e reparação civil pelos ilícitos de imprensa. Revista dos Tribunais, São Paulo, ano 90, v. 793, p. 77 88, nov. 2001.

RODRIGUES, Benjamim Silva. Das escutas telefónicas. Coimbra: Coimbra, 2008. t. I.

RODRIGUES, Silvio. Direito Civil: parte geral. 29ª ed. São Paulo: Saraiva, 1999. v. 1.

RODRÍGUEZ, José Julio Fernández. Secreto e intervención de las comunicaciones en internet. Madrid: Thomson-Civitas, 2004.

ROSSATO, Andrea. Diritto alla riservatezza. Rivista di Diritto Civile, Padova, anno XLV, n. 2, p. 287-312, mar./apr. 1999.

SAMPAIO, José Adércio Leite. Direito à intimidade e à vida privada: uma visão jurídica da sexualidade, da família, da comunicação e informações pessoais, da vida e da morte. Belo Horizonte: Del Rey, 1998.

SÁNCHEZ, Miguel Revenga. Servicios de inteligencia y derecho a la intimidad. Revista Española de Derecho Constitucional, Madrid, año 21, n. 61, p. 59-80, enero/abr. 2001.

SCHRIVER, Robert R. You cheated, you lied: the Safe Harbor Agreement and its enforcement by the Federal Trade Commission. Fordham Law Review, v. 70, p. 27772818, 2001-2002.

SECRETARY OF HEALTH, EDUCATION AND WELFARE. Records, computers and the rights of citizens: report of the Secretary's Advisory Committee on Automated Personal Data Systems. [S.1.], July 1973. Disponível em: <http://aspe.hhs.gov/datacncl/1973privacy/tocprefacemembers.htm>. Acesso em: 9 jan. 2009 ,

SHAPIRO, Eric. All is not fair in the privacy trade: the Safe Harbor Agreement and the World Trade Organization. Fordham Law Review, v. 71, p. 2781-2822, 2002-2003.

SHIMANEK, Anna E. Do you want milk with those cookies?: complying with the Safe Harbor privacy principles. The Journal of Corporation Law, v. 26, p. 455-477, 20002001.

SILVA, De Plácido e. Vocabulário jurídico. $2^{\mathrm{a}}$ ed. São Paulo, Rio de Janeiro: Forense, 1967. v. 2. 
SILVA, Leda Maria Messias da. Monitoramento de "e-mails" e "sites", a intimidade do empregado e o poder de controle do empregador: abrangência e limitações. Revista LTr, São Paulo, v. 70, n. 1, p. 65-71, jan. 2006.

SILVA, José Afonso da. Comentário contextual à Constituição. $3^{\text {a }}$ ed. São Paulo: Malheiros, 2007.

Curso de Direito Constitucional Positivo. 24a ed. São Paulo: Malheiros, 2005.

SILVA JÚNIOR, Walter Nunes da. O tratamento constitucional do sigilo da correspondência. Revista de Informação Legislativa, Brasília, ano 41, n. 163, p. 193-214, jul./set. 2004.

SILVEIRA, Paulo A. Caliendo Velloso da. Proteção de dados no direito comparado. Estudos jurídicos, São Leopoldo, V. 30, n. 80, p. 87-104, set./dez. 1997.

SILVEIRA NETO, Antônio; PAIVA, Mário Antônio Lobato de. A privacidade do trabalhador no meio informático. Revista do Instituto de Pesquisas e Estudos - Divisão Jurídica do Centro de Pós-Graduação da ITE - Bauru, Bauru, n. 39, p. 343-358, jan./abr. 2004.

SIMÓN, Sandra Lia. Revistas pessoais: direito do empregador ou desrespeito aos direitos humanos fundamentais do empregado? Revista do Tribunal Superior do Trabalho, Brasília, ano 69, n. 2, p. 55-71, jul./dez. 2003.

SIQUEIRA FILHO, Élio Wanderley de. A escuta telefônica: comentários à Lei 9.296/96. Revista dos Tribunais, São Paulo, ano 86, v. 737, p. 471-480, março 1997.

SOLOVE, Daniel J. A taxonomy of privacy. University of Pennsylvania Law Review, v. 154, n. 3, p. 477-564, jan. 2006.

Conceptualizing privacy. California Law Review, v. 90, p. 1087-1155, 2002.

SOLOVE, Daniel J.; ROTENBERG, Marc; SCHWARTZ, Paul M. Information privacy law. $2^{\text {nd }}$ ed. New York: Aspen, 2006.

SOMA, John T.; RYNERSON, Stephen D.; BEALL-EDER, Britney D. An analysis of the use of bilateral agreements between transnational trading groups: the U.S./EU e-commerce privacy safe harbor. Texas International Law Journal, v. 39, p. 171-214, 2003-2004.

SOUZA, Carlos Affonso Pereira de. Contornos atuais do direito à imagem. Revista Forense, Rio de Janeiro, v. 99, n. 367, p. 45-68, maio/jun. 2003.

STEPHENS JR, Otis H.; SCHEB II, John M. American Constitutional Law: civil rights 
and liberties. $4^{\text {th }}$ ed. Belmont: Thomson-Wadsworth, 2008. v. II.

STRECK, Lenio Luiz. As interceptações telefônicas e os direitos fundamentais: a Lei 9.296/96 e seus reflexos penais e processuais. Porto Alegre: Livraria do Advogado, 1997.

STROSSEN, Nadine. Cybercrimes v. cyberliberties. International Review of Law, Computers \& Technology, v. 14, n. 1, p. 11-24, 2000.

SUNOSKY, James T. Privacy online: a primer on the European Union's Directive and United States' Safe Harbor privacy principles. Currents: International Trade Law Journal, v. 9, p. 80-90, 2000.

SWIRE, Peter P. Katz is dead. Long live Katz. Michigan Law Review, v. 102, p. 904-932, 2003-2004.

SYKES, Charles. J. The end of privacy: the attack in personal rights - at home, at work, on-line, and in court. New York. St. Martin, 2000.

SZANIAWSKI, Elimar. Considerações sobre o direito à intimidade das pessoas jurídicas. Revista dos Tribunais, São Paulo, ano 79, v. 657, p. 25-31, jul. 1990.

TALlMAN, David A. Financial institutions and the Safe Harbor Agreement: securing cross-border financial data flows. Law \& Policy in International Business, v. 34, p. 747 782, 2002-2003.

TAYLOR, Stephanie D. Small hope floats?: how the lower courts have sunk the right of privacy. West Virginia Law Review, v. 108, p. 459-500, 2005-2006.

TRAMONTANO, Luigi. Codice de Procedure Penale spiegato con esempi pratici, dottrina, giurisprudenza, schemi, tabelle e appendice normativa. $6^{\text {a }}$ ed. Piacenza: Casa Editrice La Tribuna, 2008.

UNIÃO EUROPÉIA. Carta dos direitos fundamentais. [S.1.], 20 jan. 2008. Disponível em: <http://www.europa.eu/scadplus/leg/pt/lvb/133501.htm>. Acesso em: 5 jan. 2008.

\begin{tabular}{lcccc} 
Glossary. & [S.1.], & [2007]. & Disponível & em: \\
\hline$<$ http://europa.eu/scadplus/leg/en/lvb/133021.htm>. Acesso em: 9 de dez. 2007. &
\end{tabular}

U.S.-EU "Safe Harbor" Data Privacy Arrangement. The American Journal of International Law, v. 95, n. 1, p. 156-59, Jan. 2001.

VALENTI, Manuel Monteiro Guedes. Escutas telefónicas: da excepcionalidade à vulgaridade. Coimbra: Almedina, 2004.

VALLEBONA, Antonio. Il controllo delle comunicazioni telefoniche del lavoratore. Il 
Diritto del Lavoro, anno LXXV, n. 4, p. 357-362, luglio/ag. 2001.

VASCONCELOS, Pedro Pais de. Direito de personalidade. Coimbra: Almedina, 2006.

VIEIRA, Sônia Aguiar do Amaral. Inviolabilidade da vida privada e da intimidade pelos meios eletrônicos. São Paulo: Juarez de Oliveira, 2002.

WAMBIER, Luiz Rodrigues. "Prova - gravação magnética - conduta imoral e ilegal". Revista de Processo, São Paulo, ano 15, n. 59, p. 273-276, jul./set. 1990.

WARREN, Samuel D.; BRANDEIS, Louis D. The right to privacy. Harvard Law Review, vol. IV, n. 5, p. 193-220, Dec. 1890.

ZAINAGHI, Domingos Sávio. O uso do "e-mail" pelos empregados e o direito à privacidade. LTr Suplemento Trabalhista, ano 41, n. 153/05, p. 691-693, 2005. 


\section{APÊNDICE A - JULGADOS DO SUPREMO TRIBUNAL FEDERAL}

\section{Algumas indicações da privacidade.}

No Recurso Extraordinário 84937/BA, julgado pela Primeira Turma em 5 de novembro de $1976^{990}$, Relator Ministro Rodrigues Alckmin, entendeu-se que a circunstância agravante da pena prevista na então parte final da alínea "g" do inciso II do artigo 44 do Código Penal, que encontra correspondência na alínea "g" do inciso II do atual 61, qual seja, a de o agente cometer o crime prevalecendo-se de relação de hospitalidade, prescinde da "noção de intimidade" e de permanência no local, bastando que a presença do infrator tenha se consolidado por razões de cortesia social. Não se discutiu, contudo, a "noção de intimidade".

No Habeas Corpus 58883/RJ, de relatoria do Ministro Soares Muñoz, julgado em 26 de maio de $1981^{991}$, impetrado a favor de um militar que havia cometido uxoricídio dentro de residência que pertencia à administração militar e havia sido julgado e condenado pela justiça comum, a Primeira Turma entendeu que a competência fora corretamente estabelecida, porque a titularidade do bem imóvel, da casa, não implica interferência da União na privacidade do casal, e nem, por conseguinte, a competência da justiça militar para julgar o crime.

Em outra ocasião, o STF entendeu que o artigo 573 do antigo Código Civil, Lei 3.071, de $1^{\circ}$ de janeiro de 1916 , que dispunha que "[o] proprietário pode embargar a construção do prédio que invada a área do seu, ou sobre este deite goteiras, bem como a daquele, em que, a menos de metro e meio do seu, se abra janela, ou se faça eirado, terraço, ou varanda", aplicava-se independentemente de proporcionar visão direta ou oblíqua do prédio vizinho, conforme a sua Súmula 414. Foi no Recurso Extraordinário 100037/RS, Relator Ministro Francisco Rezek, julgado em 18 de outubro de 1983 pela Segunda Turma ${ }^{992}$.

Segundo o voto do Ministro Relator, “[...] [a] presunção que a lei consagra é a de que a construção de janelas ou varandas a certa distância do prédio vizinho importa prejuízo à sua privacidade". Contudo, citando doutrina de Carvalho Santos, após afirmar que o artigo 573 era exemplificativo e que abarcava todas as edificações similares a

\footnotetext{
${ }^{990}$ Decisão publicada na RTJ vol. 00081-02, p. 00602. Todos os julgados constantes deste Apêndice foram retirados do "site" do STF: <http://www.stf.jus.br>.

${ }_{991}$ Decisão publicada no Diário da Justiça de 9 de outubro de 1981, p. 10055.

992 Decisão publicada no Diário da Justiça de 18 de novembro de 1983, p. 17961.
} 
varandas, como mirantes, por exemplo, entendeu que as portas construídas a menos de um metro e meio do muro divisório estavam excluídas da incidência desse dispositivo ${ }^{993}$.

\section{Conversa telefônica e ambiental.}

O Recurso Extraordinário 100094/PR, julgado pela Primeira Turma em 28 de junho de $1984^{994}$, Relator Ministro Rafael Mayer, tratava de um caso em que um indivíduo impetrara mandado de segurança contra o despacho de um juiz, em incidente de falsidade de documento em embargos de terceiros, que determinara audiência pública para abertura do lacre e degravação de fita magnética que continha conversa telefônica gravada entre o autor, que não era parte na ação, e a advogada dos embargados. Essa gravação tinha por escopo fazer prova contra declaração escrita firmada pelo impetrante de que residia no imóvel em disputa na qualidade de locatário dos embargantes "possuidores".

O Relator, cujo voto foi acompanhado unanimemente pela Turma, entendeu que a captação de conversa telefônica feita sem o conhecimento do outro,

para servir $[\ldots .$.$] como dado a comprometer a sua integridade pessoal, incorre na$
infringência dos mais elementares princípios da ética e do mínimo de lealdade
que deve presidir as relaçôes humanas. É uma prova desvestida, portanto, de
legitimidade moral reclamada pelo art. 332 do CPC.

Entendeu, ainda, que possibilitar a um dos interlocutores fazer uso da comunicação telefônica gravada, por ser de sua propriedade, implicaria "mutilar a garantia do sigilo das comunicações telefônicas", pois violaria seu direito de escolher o destinatário de sua comunicação e, citando Orlando Gomes, violaria o seu direito ao recato, "pelo qual se protege o indivíduo contra intrusões de outro na esfera personalíssima que lhe é reservada".

No Recurso em Habeas Corpus 63834/SP, Relator Ministro Aldir Passarinho, julgado pela Segunda Turma em 18 de dezembro de $1986^{995}$, entendeu-se que gravações clandestinas constituem provas ilícitas e, portanto, imprestáveis.

No Recurso em Habeas Corpus 67058/RS, Relator Ministro Francisco Rezek,

\footnotetext{
993 O artigo 1.301 do atual Código Civil praticamente repete a segunda parte desse antigo art. 573: "[é] defeso abrir janelas, ou fazer eirado, terraço ou varanda, a menos de metro e meio do terreno vizinho". Dentre outros, Monteiro (1974, p. 156) afirma, comentando o dispositivo do Código Civil anterior, que "[c]om essa proibição visa o legislador a salvaguardar a vida íntima das famílias, resguardando-as, dentro de suas casas, do indiscreto devassamento dos vizinhos". E continua: “[s]e não existe, porém, possibilidade de tal vexame, prevalece a liberdade de construção" (1974, p. 156).

${ }_{994}$ Decisão publicada no Diário da Justiça de 24 de agosto de 1984, p. 13482.

995 Decisão publicada no Diário da Justiça de 5 de junho de 1987, p. 11112.
} 
julgado em 3 de março de $1989^{996}$, decidiu-se que gravação de conversa sem caráter reservado, no caso, reunião entre autoridade pública federal e usuários do serviço sob sua supervisão, para cuidar de assuntos atinentes a seu ofício, não constituía prova ilícita.

No Habeas Corpus 69818/SP, Relator Ministro Sepúlveda Pertence, julgado pela Primeira Turma em 3 de novembro de $1992^{997}$, entendeu-se que a gravação de conversa entre presos em flagrante e autoridades policiais não se enquadrava na hipótese do sigilo das comunicações telefônicas, mas, em tese, na do direito ao silêncio. Contudo, este direito não aproveitaria a terceiros, objeto da delação dos presos, e que, ainda, no caso específico, os co-réus tinham ciência da gravação.

No Habeas Corpus 69912/RS, Relator Ministro Sepúlveda Pertence, Relator para o acórdão Ministro Carlos Velloso, julgado pelo Tribunal Pleno em 30 de junho de $1993^{998}$, entendera-se que a sentença impugnada proferida no processo penal em questão não se baseara apenas na degravação de conversa telefônica oriunda de interceptação ordenada por juiz, não invalidando as outras provas. Contudo, anulado o acórdão, por impedimento do Ministro Néri da Silveira, proferiu-se nova decisão ${ }^{999}$, em que prevaleceram cinco dos votos anteriormente proferidos, entendendo-se que a citada prova contaminou as demais, aplicando-se a teoria da ilicitude por derivação.

Esse acórdão marcou o entendimento do STF de que a Constituição Federal de 1988 não recepcionou o artigo 57, inciso II, alínea “e”, da Lei 4.117/1962, que dispunha não constituir violação de telecomunicação o conhecimento dado ao juiz competente, mediante requisição ou intimação deste. É a ementa:

CONSTITUCIONAL. PENAL. PROVA ILICITA: "DEGRAVAÇÃO” DE ESCUTAS TELEFONICAS. C.F., ART. 5., XII. LEI N. 4.117, DE 1962, ART. 57, II, "E", "HABEAS CORPUS": EXAME DA PROVA. I. - O SIGILO DAS COMUNICAÇÕES TELEFONICAS PODERA SER QUEBRADO, POR ORDEM JUDICIAL, NAS HIPÓTESES E NA FORMA QUE A LEI ESTABELECER PARA FINS DE INVESTIGAÇÃO CRIMINAL OU INSTRUÇÃO PROCESSUAL PENAL (C.F., ART. 5., XII). INEXISTÊNCIA DA LEI QUE TORNARA VIAVEL A QUEBRA DO SIGILO, DADO QUE O INCISO XII DO ART. 5. NÃO RECEPCIONOU O ART. 57, II, "E", DA LEI 4.117, DE 1962, A DIZER QUE NÃO CONSTITUI VIOLAÇÃO DE TELECOMUNICAÇÃO O CONHECIMENTO DADO AO JUIZ COMPETENTE, MEDIANTE REQUISIÇÃO OU INTIMAÇÃO DESTE. E QUE A CONSTITUIÇÃO, NO INCISO XII DO ART. 5., SUBORDINA A RESSALVA A UMA ORDEM JUDICIAL, NAS HIPÓTESES E NA FORMA ESTABELECIDA EM LEI. II. - NO CASO, A SENTENÇA OU O ACÓRDÃO

\footnotetext{
${ }^{996}$ Decisão publicada no Diário da Justiça de 31 de março de 1989, p. 04330.

${ }^{997}$ Decisão publicada no Diário da Justiça de 27 de novembro de 1992, p. 22302.

${ }^{998}$ Decisão publicada no Diário da Justiça de 26 de novembro de 1993, p.25532.

${ }^{999}$ Habeas Corpus segundo, 69912/RS, Relator Ministro Sepúlveda Pertence, julgado pelo Tribunal Pleno em 16 de dezembro de 1993, decisão publicada no Diário da Justiça de 25 de março de 1994, p. 06012.
} 
IMPUGNADO NÃO SE BASEIA APENAS NA "DEGRAVAÇÃO" DAS ESCUTAS TELEFONICAS, NÃO SENDO POSSIVEL, EM SEDE DE "HABEAS CORPUS", DESCER AO EXAME DA PROVA. III. - H.C. INDEFERIDO.

No Inquérito 657/DF, julgado pelo Tribunal Pleno em 30 de setembro de $1993^{1000}$, o Relator Ministro Carlos Velloso afirmou que “[n]ão há, ao que penso, ilicitude em alguém gravar uma conversa que mantém com outrem, com a finalidade de documentá-la, em caso de negativa”.

O Ministro Francisco Rezek, concordando com o Relator, discorreu:

[...] dificilmente se encontraria na ordem jurídica reinante algo que nos autorizasse a ver como ilícita essa gravação de uma conversa a dois, por um dos interlocutores. É a ação do terceiro, é a interferência do terceiro - no grampeamento telefônico, na violação de correspondência alheia - que fere determinadas normas expressas na própria Carta da República. Quando, entretanto, um dos participantes da comunicação oral ou escrita entende de documentá-la de algum modo, ainda que na inconsciência da outra parte, isso não configura, em princípio, afronta à regra protetiva do sigilo. $\mathrm{O}$ resultado pode variar entre a indiscrição inofensiva e a mais reprovável vilania; mas não há, aí, um ato ilícito. Admitiria que normas protetivas da privacidade, de estatura também constitucional, poderiam ser invocadas em repressão ao uso que um dos interlocutores queira fazer da carta ou da gravação do entendimento a dois, quando visa, por exemplo, a auferir lucro à custa da notoriedade da imagem alheia; um propósito bem diverso, daquele de desencadear a ação da Justiça Pública.

O Ministro Celso de Mello, entretanto, teve entendimento diverso:

Tenho para mim que a gravação de conversação com terceiros, feita através de fita magnética, sem o conhecimento de um dos sujeitos da relação dialógica, não pode ser contra este utilizada em juízo, uma vez que esse procedimento precisamente por realizar-se de modo sub-reptício - envolve quebra de privacidade, sendo, em conseqüência, nula a eficácia jurídica da prova coligida por esse meio.

O fato de um dos interlocutores desconhecer a circunstância de que a conversação que mantém com outrem está sendo objeto de gravação atua, a meu juízo, como causa obstativa desse meio de prova.

$\mathrm{O}$ reconhecimento constitucional do direito à privacidade $\left(\mathrm{CF}\right.$, art. $\left.5^{\circ}, \mathrm{X}\right)$ desautoriza o valor probante do conteúdo de fita magnética que registra, de forma clandestina, o diálogo mantido com alguém que venha a sofrer a persecução penal do Estado.

A gravação de diálogos privados, quando executada com total desconhecimento de um dos seus partícipes, apresenta-se eivada de absoluta desvalia, especialmente quando o órgão da acusação penal postula, com base exclusivamente nela, a prolação de um decreto condenatório.

$[\ldots]$

A busca da verdade real constitui o objetivo último perseguido pelo processo penal condenatório. Essa pesquisa da realidade, no entanto, sofre decisivas limitações impostas pelas exigências ético-jurídicas que informam o nosso ordenamento positivo.

O desenvolvimento dos recursos tecnológicos e a necessidade de preservar a esfera de privacidade do indivíduo reclamam - para que se conciliem, em nome

${ }^{1000}$ Decisão publicada no Diário da Justiça de 19 de novembro de 1993, p. 24659. 
do interesse público, as relações que antagonizam, no âmbito do processo penal, a acusação e a defesa - que a prova penal consistente na reprodução magnética de conversações mantidas pelo acusado com terceiros decorra de procedimento lícito.

O Tribunal acabou, por fim, recebendo a denúncia, a fim de instaurar a ação penal.

Na Ação Penal 307-3/DF, julgada pelo Tribunal Pleno em 13 de dezembro de $1994^{1001}$, Relator Ministro Ilmar Galvão, discutiu-se a validade de prova consistente em gravação de conversa telefônica por um dos interlocutores, sem o conhecimento dos demais, e, também, de dados inseridos na memória de computador.

O Relator, após expor a diferença doutrinária entre prova ilícita, a obtida com violação de normas de direito material (como intimidade, vida privada, integridade, dentre outras), e prova ilegítima, a obtida com violação de normas processuais, entendeu que conversa telefônica gravada, mesmo que por um dos interlocutores, sem conhecimento e consentimento dos demais, era "írrita", e, portanto, nula, incidindo o inciso LVI do artigo $5^{\circ}$ da Constituição Federal:

[n]o caso, a imprestabilidade do texto da conversa telefônica resultaria de a gravação haver sido feita sem o conhecimento de uma das partes. A garantia violada com tal gravação seria justamente a da intimidade, em que envolta a comunicação telefônica, cujo sigilo é estabelecido pelo art. $5^{\circ}$, inc. XII, da Carta Federal.

Os dados inseridos na memória de computador foram descartados por terem sido obtidos a partir de apreensão das máquinas pela Receita Federal sem autorização judicial e sem consentimento dos "moradores", ou equivalentes, do domicílio, afrontando a garantia da inviolabilidade do domicílio inscrita no inciso XI do artigo $5^{\circ}$ da Constituição Federal,

[m]as, mesmo que a apreensão material do micro-computador, no recinto da empresa, se houvesse dado em uma das situações fáticas previstas no inc. XI, do art. $5^{\circ}$, da Carta Federal, ou houvesse sido feita em cumprimento a determinação judicial, ainda assim, não estaria nela compreendido o conteúdo ideológico de sua memória, razão pela qual a Polícia Federal não poderia ter-se apropriado dos dados contidos naquele micro-computador, para mandar decodificá-los ao seu alvedrio, como fez, acobertados que se achavam pelo sigilo, o qual, conquanto se possa ter por corolário da inviolabilidade do próprio recinto dos escritórios da empresa, acha-se especificamente contemplado no inc. XII, do mesmo artigo, ao lado da correspondência e das comunicações telegráficas e telefônicas. Aliás, nos tempos modernos, em que todos os trabalhos datilográficos das empresas é realizado por meio de digitação, a invasão da memória dos computadores implica fatalmente a quebra do sigilo não apenas de dados em geral, desde os relativos a simples agenda até os relacionados a fórmulas e cálculos, mas também de toda correspondência, epistolar e telegráfica, em relação aos quais o manto constitucional é de natureza absoluta, já que não deixou espaço reservado ao trabalho normativo do legislador ordinário, como se fez com as comunicações

${ }^{1001}$ Decisão publicada no Diário da Justiça de 13 de outubro 1995, p. 34247. 
telefônicas.

Outro argumento levantado aí foi o de não existir, então, a lei regulamentadora do inciso XII do art. $5^{\circ}$ da Constituição Federal, como ressaltou, explicitamente, o Revisor Ministro Moreira Alves:

Pelos termos em que está redigido esse dispositivo [inciso XII do artigo $5^{\circ}$ da Constituição Federal], que só abre exceção para as comunicações telefônicas, é possível sustentar-se que as demais inviolabilidades só admitem sejam afastadas por texto constitucional expresso. Mas, ainda quando se admita que possam ser postas de lado [as outras inviolabilidades que não a de comunicação telefônica] nas hipóteses e na forma prevista na lei, o que é certo é que não há lei que disponha a respeito no concernente - que é o que importa no momento - à inviolabilidade dos dados aludidos no citado texto constitucional [inciso XII do artigo $5^{\circ}$ ].

O Ministro Moreira Alves entendeu, ainda, que o artigo 233 do Código de Processo Penal aplica-se, por identidade de razão, às gravações "sub-reptícias" de conversas telefônicas por um de seus interlocutores, cuja redação é a seguinte:

Art. 233. As cartas particulares, interceptadas ou obtidas por meios criminosos, não serão admitidas em juízo.

Parágrafo único. As cartas poderão ser exibidas em juízo pelo respectivo destinatário, para a defesa de seu direito, ainda que não haja consentimento do signatário.

O Ministro Carlos Velloso, contudo, traçou uma distinção entre uma gravação efetuada por um terceiro entre duas outras pessoas, que seria ilícita, e uma feita por um dos interlocutores, lícita. Segundo ele, se houvesse infração, estaria no plano meramente ético, não existindo lei proibindo essa conduta no ordenamento jurídico brasileiro, entendendo que o artigo 233 do Código de Processo Penal referir-se-ia exatamente a terceiro, já que o destinatário não intercepta carta que lhe é enviada. Quanto aos dados, acompanhou os votos do Relator e do Revisor.

No seu voto, o Ministro Celso de Mello entendeu, por sua vez, que a gravação clandestina, mesmo feita por um dos interlocutores, é ilícita e imprestável como prova, porque fere o direito à privacidade resguardado no inciso $\mathrm{X}$ do artigo $5^{\circ}$ da Constituição Federal. No atinente aos dados, entendeu que as provas obtidas com base neles eram ilícitas por violação do domicílio ${ }^{1002}$.

O Ministro Sepúlveda Pertence eliminou a degravação da memória dos computadores pela invasão ilícita de domicílio, e, quanto às gravações das conversas

${ }^{1002}$ Ver o Habeas Corpus 80949 a respeito da ilicitude por derivação (ou "fruit of the poisonous tree") neste Apêndice A, número. 
telefônicas, admitindo, em certas situações, a serem analisadas caso a caso, as feitas por um dos interlocutores sem a ciência dos outros, afirmou:

Não é o simples fato de a conversa se passar entre duas pessoas que dá, ao diálogo, a nota de intimidade, a confiabilidade na discrição do interlocutor, a favor da qual, aí sim, caberia invocar o princípio constitucional da inviolabilidade do círculo de intimidade, assim como da vida privada.

O Ministro Sydney Sanches apenas excluiu a tese da ilicitude das provas por derivação, ao passo que o Ministro Néri da Silveira concordou com os votos do Relator e do Revisor quanto aos dados, mas fez uma ressalva quanto às conversas telefônicas: referência a elas feita em depoimentos não estariam contaminadas e nem deveriam ser excluídas dos autos da ação penal, mas somente a degravação dessas conversas, feita ilicitamente.

O extrato de ata, de 9 de dezembro de 1994, assim consignou:

Decisão: o Tribunal acolheu a preliminar da defesa, para declarar inadmissível a prova consistente no laudo de degravação de conversa telefônica e no laudo de degravação de registro de memória de computador, vencidos os Ministros Carlos Velloso, Sepúlveda Pertence e Néri da Silveira, que só julgavam inadmissível a prova referente ao computador. Em relação à segunda preliminar, relativamente à repercussão da prova inadmissível sobre as demais, o Tribunal rejeitou essa preliminar, vencidos o Ministro Celso de Mello e, em menor extensão, os Ministros Carlos Velloso, Sepúlveda Pertence e Néri da Silveira, nos termos dos votos que proferiram. [...].

A ementa foi a seguinte, no trecho pertinente:

[...] 1.1. Inadmissibilidade, como prova, de laudos de degravação de conversa telefônica e de registros contidos na memória de micro computador, obtidos por meios ilícitos (art. 5., LVI, da Constituição Federal); no primeiro caso, por se tratar de gravação realizada por um dos interlocutores, sem conhecimento do outro, havendo a degravação sido feita com inobservância do princípio do contraditório, e utilizada com violação a privacidade alheia (art. 5., X, da CF); e, no segundo caso, por estar-se diante de micro computador que, além de ter sido apreendido com violação de domicilio, teve a memória nele contida sido degravada ao arrepio da garantia da inviolabilidade da intimidade das pessoas (art. 5., X e XI, da CF). 1.2. Improcedência da acusação. Relativamente ao primeiro episódio, em virtude não apenas da inexistência de prova de que a alegada ajuda eleitoral decorreu de solicitação que tenha sido feita direta ou indiretamente, pelo primeiro acusado, mas também por não haver sido apontado ato de oficio configurador de transação ou comércio com o cargo então por ele exercido. No que concerne ao segundo, pelo duplo motivo de não haver qualquer referência, na degravação sido feita com inobservância do princípio do contraditório, e utilizada com violação à privacidade alheia (art. 5., X, da CF); e, no segundo caso, por estar-se diante de micro computador que, além de ter sido apreendido com violação de domicílio, teve a memória nele contida sido degravada ao arrepio da garantia da inviolabilidade da intimidade das pessoas (art. 5., X e XI, da CF). [...].

No Habeas Corpus 74678/SP, Relator Ministro Moreira Alves, julgado pela 
Primeira Turma em 10 de junho de $1997^{1003}$, entendeu-se que

[a]fastada a ilicitude de tal conduta - a de, por legítima defesa, fazer gravar e divulgar conversa telefônica ainda que não haja o conhecimento do terceiro que está praticando crime -, é ela, por via de consequiência, lícita e, também conseqüentemente, essa gravação não pode ser tida como prova ilícita, para invocar-se o artigo $5^{\circ}$, LVI, da Constituição com fundamento em que houve violação da intimidade (art. $5^{\circ}, \mathrm{X}$, da Carta Magna). [...].

No Habeas Corpus 80948/ES, julgado pela Segunda Turma em 7 de agosto de $2001^{1004}$, o Relator Ministro Néri da Silveira entendeu em passagem do seu voto:

[...] O Ministério Público bem se legitima a investigar, ou a fazê-lo a polícia, a partir de informações em que se preserve o sigilo da fonte, se ela assim o desejar, mas jamais quando a fonte, de que promana trabalho investigatório, constitui-se, solitariamente, em clandestina interceptação de conversa telefônica, ou ambiental, sempre que tal suceda em espaço privado. (destaques dele).

Como o único elemento de prova era a gravação clandestina, deferiu-se o Habeas Corpus para determinar o trancamento da investigação penal contra o paciente.

No Habeas Corpus 80949-9/RJ, Relator Ministro Sepúlveda Pertence, julgado pela Primeira Turma em 30 de outubro de $2001^{1005}$, entendeu-se que gravação de conversa telefônica alheia por terceiro, mas com ciência de um dos interlocutores, insere-se dentro da proteção ao sigilo das comunicações telefônicas, só passível de violação mediante prévia e regular autorização judicial. Quanto a esse ponto, é a ementa:

6. A prova obtida mediante a escuta gravada por terceiro de conversa telefônica alheia é patentemente ilícita em relação ao interlocutor insciente da intromissão indevida, não importando o conteúdo do diálogo assim captado. 7. A ilicitude da escuta e gravação não autorizadas de conversa alheia não aproveita, em princípio, ao interlocutor que, ciente, haja aquiescido na operação; aproveita-lhe, no entanto, se, ilegalmente preso na ocasião, o seu aparente assentimento na empreitada policial, ainda que existente, não seria válido. 8. A extensão ao interlocutor ciente da exclusão processual do registro da escuta telefônica clandestina - ainda quando livre o seu assentimento nela - em princípio, parece inevitável, se a participação de ambos os interlocutores no fato probando for incindível ou mesmo necessária à composição do tipo criminal cogitado, qual, na espécie, o de quadrilha. [...].

Nesse mesmo caso, entendeu-se que o uso de gravação de "conversa informal" entre policiais e investigados constitui, na realidade, interrogatório sub-reptício, violando o direito ao silêncio dos acusados, decorrente do direito a não se auto-incriminar, invalidando prova assim obtida, principalmente se não houver aviso quanto a esse direito e

\footnotetext{
${ }^{1003}$ Decisão publicada no Diário da Justiça de 15 de agosto de 1997, p. 37036.

${ }^{1004}$ Decisão publicada no Diário da Justiça de 19 de dezembro de 2001, p. 00004.

${ }^{1005}$ Decisão publicada no Diário da Justiça de 14 de dezembro de 2001, p. 00026.
} 
documentação formal.

Quanto à validade das provas ilícitas no processo, produziu-se a seguinte decisão, expressa na ementa:

\begin{abstract}
Da explícita proscrição da prova ilícita, sem distinções quanto ao crime objeto do processo $\left(\mathrm{CF}\right.$, art. $\left.5^{\circ}, \mathrm{LVI}\right)$, resulta a prevalência da garantia nela estabelecida sobre o interesse na busca, a qualquer custo, da verdade real no processo: conseqüente impertinência de apelar-se ao princípio da proporcionalidade - à luz de teorias estrangeiras inadequadas à ordem constitucional brasileira - para sobrepor, à vedação constitucional da admissão da prova ilícita, considerações sobre a gravidade da infração penal objeto da investigação ou da imputação.
\end{abstract}

Já no Habeas Corpus 76203/SP, Relator Ministro Marco Aurélio, Relator para o acórdão Ministro Nelson Jobim, julgado, pela Segunda Turma, em 16 de junho de $1998^{1006}$, o entendimento foi distinto.

Tratava-se de uma operação policial, fundada em interceptações telefônicas autorizadas pelo Poder Judiciário, mas antes da edição da Lei 9.296/96, a partir das quais foi possível a apreensão de cerca dez quilos de cocaína, a prisão em flagrante dos traficantes e a promoção da ação penal, ao fim da qual foram condenados. Todas as provas resultaram dessas escutas.

Seguindo a linha adotada pelo próprio Supremo anteriormente, o Ministro Marco Aurélio entendeu serem ilícitas todas as provas obtidas a partir das escutas, "fulminando", assim, o processo penal que resultou na condenação dos traficantes, no que foi acompanhado pelo Ministro Maurício Corrêa.

Contudo, o Ministro Nelson Jobim, em voto sucinto, abriu divergência vencedora, invocando uma interpretação restritiva da teoria da contaminação da prova, dizendo que a prova, no caso, era a apreensão da droga. O Ministro Carlos Velloso, em voto igualmente curto, afirmou que ignorar a apreensão de tamanha quantidade de entorpecente violaria o devido processo legal substantivo.

O Ministro Néri da Silveira afirmou que as outras provas eram autônomas, sustentavam-se por si mesmas, não derivando exclusivamente das interceptações telefônicas.

A ementa ficou como segue:

HABEAS CORPUS. PROCESSO PENAL. ESCUTA TELEFÔNICA. OUTROS MEIOS DE PROVA. LICITUDE. Escuta telefônica que não deflagra ação penal, não é causa de contaminação do processo. Não há violação ao direito à privacidade quando ocorre apreensão de droga e prisão em flagrante de

${ }^{1006}$ Decisão publicada no Diário da Justiça de 17 de novembro de 2000, p. 00010. 
traficante. Interpretação restritiva do princípio da árvore dos frutos proibidos. Habeas corpus indeferido.

De todo modo, o STF consolidara, até a edição da Lei 9.296/96, que regulamentou o inciso XII do artigo $5^{\circ}$ da Constituição Federal, o entendimento de que qualquer espécie de interceptação telefônica era ilícita, salvo se para legítima defesa. Vejam-se, por exemplo, além dos casos já citados, o Habeas Corpus 72588/PR, julgado pelo Tribunal Pleno, sob relatoria do Ministro Maurício Corrêa, em 12 de junho de $1996^{1007}$; o Habeas Corpus 73351/SP, Relator Ministro Ilmar Galvão, julgado pela Primeira Turma em 9 de maio de $1996^{1008}$; e o Habeas Corpus 73722/RJ, Relator Ministro Octavio Gallotti, julgado pela Primeira Turma em 28 de junho de $1996^{1009}$, em que se determinou o desentranhamento dos autos do processo penal das transcrições decorrentes de degravação de interceptações telefônicas autorizadas por juiz.

No Habeas Corpus 75338/RJ, cujo julgamento, afetado ao Plenário pela Segunda Turma, deu-se em 11 de março de $1998^{1010}$, sob relatoria do Ministro Nelson Jobim, o Tribunal entendeu, conforme ementa, que

[...] [é] lícita a gravação de conversa telefônica feita por um dos interlocutores, ou com sua autorização, sem ciência do outro, quando há investida criminosa deste último. É inconsistente e fere o senso comum falar-se em violação do direito à privacidade quando interlocutor grava diálogo com seqüestradores, estelionatários ou qualquer tipo de chantagista. [...].

O Ministro Sepúlveda Pertence ressaltou o seu pensamento de que

[o] art. 5', XII [...], protege os interlocutores da ciência, por terceiro, à "sorrelfa", mediante a chamada interceptação telefônica, do que entre os dois se conversou. Nada mais do que isso. Ali não se contém proibição alguma de que um dos interlocutores faça a prova da conversa de que participou: então o que pode incidir é outro tipo de proibição [...][,] não apenas de ordem moral, mas [...] de ordem jurídica, como as decorrentes dos deveres explícitos de sigilo que atingir a gravação, não por ter sido gravada, e sim por ter sido revelada a outrem: é o caso do advogado, do médico, do confessor. E até em outras relações não explicitamente protegidas com a obrigação legal do sigilo, quando se possa invocar, na revelação da conversa e, "a fortiori", na sua gravação, traição a deveres nascidos da esfera da intimidade em que se tenha passado: aí vem à tona outra garantia individual; [sic] a que protege a intimidade e impõe reserva a todos que dela participem.

No Habeas Corpus 83515/RS, Relator Ministro Nelson Jobim, julgado em 16 de

\footnotetext{
${ }^{1007}$ Decisão publicada no Diário da Justiça de 4 de agosto de 2000, p. 00003.

${ }^{1008}$ Decisão publicada no Diário da Justiça de 19 de março de 1999, p. 00009.

${ }^{1009}$ Decisão publicada no Diário de Justiça de 14 de março de 2003, p. 00039.

${ }^{1010}$ Decisão publicada no Diário da Justiça de 25 de setembro de 1998.
} 
setembro de $2004^{1011}$, o Tribunal Pleno, por maioria, vencido o Ministro Marco Aurélio, confirmou vários dos entendimentos adotados pela Quinta Turma do STJ no HC 13274/RS: (i) o artigo $5^{\circ}$ da Lei 9.296/96 não limita o número de vezes que pode ser renovada a interceptação telefônica; (ii) a interceptação telefônica pode ser usada quando indispensável para o aprofundamento e confirmação dos indícios de prova até então coletados, além de essencial para levantar dados e informações que não poderiam ser obtidos de outro modo; (iii) a Lei 9.296/96 não exige a transcrição das conversas gravadas para os pedidos de renovação da interceptação, o que poderia até inviabilizar a operação. $\mathrm{O}$ que se exige é uma explicação resumida das conversas até então gravadas e da necessidade de continuidade da interceptação; (iv) a ciência dos procedimentos de interceptação deve ser dada ao Ministério Público, prioritariamente, pela polícia, e a sua falta é superada pela participação próxima de membro da instituição nas diligências; e (v) o inciso III do artigo $2^{\circ}$ da Lei 9.296/96 restringe o método a crime apenável, pelo menos, com reclusão, pois sendo

[...] intervenção drástica na privacidade do cidadão, a interceptação somente pode ser motivada com base em crime grave, no Brasil, punível, pelo menos, com pena de reclusão. Tenta-se evitar, assim, a banalização do procedimento de interceptação telefônica com o início da diligência pautado na apuração de crime com menor gravidade. (excerto do voto do Ministro Relator).

Contudo, se da interceptação telefônica surgirem indícios de crimes conexos, ainda que apenados com detenção, nada impede que sejam utilizados na persecução penal legitimamente, já que, “[d]e outra forma, nunca seria possível a interceptação telefônica para a investigação de crimes apenados com reclusão quando forem estes conexos com crimes punidos com detenção", de acordo ainda com o Ministro Relator.

O Ministro Marco Aurélio, porém, dissentiu em dois pontos. Primeiramente, quanto ao artigo $5^{\circ}$ da Lei 9.296/96, que, no seu entendimento, permite a interceptação telefônica por apenas 15 dias, prorrogável, excepcionalmente, uma vez, por igual período. Em suas palavras:

[...] Deve-se conferir algum significado, sob o ângulo vernacular, à expressão "por igual tempo", que não quer dizer "por igual tempo e sucessivamente", de forma indeterminada, considerados idênticos períodos. Creio que a interpretação histórica, com o surgimento da Lei 9.296, de 24 de julho de 1996, precisa ser levada em conta, sob pena de se banalizar a interceptação telefônica, sob pena de se olvidar que a regra, repito, é a privacidade como direito constitucional do cidadão.

${ }^{1011}$ Decisão publicada no Diário da Justiça de 4 de março de 2005, p. 00011. 
Segundo, entendeu que o artigo $6^{\circ}$, e seus parágrafos $1^{\circ}$ e $2^{\circ}$, da Lei exige transcrição completa das gravações resultantes da interceptação, mesmo para o pedido de renovação da interceptação.

É a ementa:

HABEAS CORPUS. INTERCEPTAÇÃO TELEFÔNICA. PRAZO DE VALIDADE. ALEGAÇÃO DE EXISTÊNCIA DE OUTRO MEIO DE INVESTIGAÇÃO. FALTA DE TRANSCRIÇÃO DE CONVERSAS INTERCEPTADAS NOS RELATÓRIOS APRESENTADOS AO JUIZ. AUSÊNCIA DE CIÊNCIA DO MINISTÉRIO PÚBLICO ACERCA DOS PEDIDOS DE PRORROGAÇÃO. APURAÇÃO DE CRIME PUNIDO COM PENA DE DETENÇÃO. 1. É possível a prorrogação do prazo de autorização para a interceptação telefônica, mesmo que sucessivas, especialmente quando o fato é complexo a exigir investigação diferenciada e contínua. Não configuração de desrespeito ao art. $5^{\circ}$, caput, da L. 9.296/96. 2. A interceptação telefônica foi decretada após longa e minuciosa apuração dos fatos por CPI estadual, na qual houve coleta de documentos, oitiva de testemunhas e audiências, além do procedimento investigatório normal da polícia. Ademais, a interceptação telefônica é perfeitamente viável sempre que somente por meio dela se puder investigar determinados fatos ou circunstâncias que envolverem os denunciados. 3. Para fundamentar o pedido de interceptação, a lei apenas exige relatório circunstanciado da polícia com a explicação das conversas e da necessidade da continuação das investigações. Não é exigida a transcrição total dessas conversas o que, em alguns casos, poderia prejudicar a celeridade da investigação e a obtenção das provas necessárias (art. $6^{\circ}$, $\S 2^{\circ}$, da L. 9.296/96). 4. Na linha do art. $6^{\circ}$, caput, da L. 9.296/96, a obrigação de cientificar o Ministério Público das diligências efetuadas é prioritariamente da polícia. O argumento da falta de ciência do MP é superado pelo fato de que a denúncia não sugere surpresa, novidade ou desconhecimento do procurador, mas sim envolvimento próximo com as investigações e conhecimento pleno das providências tomadas. 5. Uma vez realizada a interceptação telefônica de forma fundamentada, legal e legítima, as informações e provas coletas dessa diligência podem subsidiar denúncia com base em crimes puníveis com pena de detenção, desde que conexos aos primeiros tipos penais que justificaram a interceptação. Do contrário, a interpretação do art. $2^{\circ}$, III, da L. 9.296/96 levaria ao absurdo de concluir pela impossibilidade de interceptação para investigar crimes apenados com reclusão quando forem estes conexos com crimes punidos com detenção. "Habeas corpus" indeferido.

No Habeas Corpus 87341/PR, Relator Ministro Eros Grau, julgado em 7 de fevereiro de $2006^{1012}$, o STF entendeu que a gravação da prática de crime de falsidade ideológica, consistente na exigência de dinheiro para inserir falsa informação de excesso de contingente em certificado de dispensa de incorporação, realizada pelo alistando a pedido de rede de televisão, consistia em "notitia criminis", compelindo as autoridades ao poder-dever de investigar. O Ministro Sepúlveda Pertence expressamente consignou seu entendimento de que não é ilícita documentação cinematográfica da prática de um crime, salvo se o agente encontra-se numa situação de intimidade, que não era o caso, o de corrupção passiva praticada numa repartição pública.

${ }^{1012}$ Decisão publicada no Diário da Justiça de 3 de março de 2006, p. 00030. 


\section{Interceptação telefônica, escuta ambiental e prova emprestada.}

Na Segunda Questão de Ordem no Inquérito 2424/RJ, Relator Ministro Cezar Peluso, julgada pelo Tribunal Pleno em 20 de junho de $2007^{1013}$, o STF entendeu, por maioria, que

[d]ados obtidos em interceptação de comunicações telefônicas e em escutas ambientais, judicialmente autorizadas para produção de prova em investigação criminal ou em instrução processual penal, podem ser usados em procedimento administrativo disciplinar, contra a mesma ou as mesmas pessoas em relação às quais foram colhidos, ou contra outros servidores cujos supostos ilícitos teriam despontado à colheita dessa prova. (excerto da ementa).

O Tribunal autorizou a utilização de dados assim obtidos pelo STJ para instaurar processo administrativo contra terceiro não investigado inicialmente.

O voto condutor do Relator, após apontar as duas visões básicas acerca da possibilidade de uso da prova emprestada nesse campo, pró e contra, e após ponderar acerca da diferença entre a produção da prova delineada no inciso XII do artigo $5^{\circ}$ da Constituição Federal e o uso lícito da prova obtido com a "violação da intimidade", nos termos legais, prossegue:

[...] o que de todo me não parece ajustar-se às normas discerníveis nos textos constitucional e legal, enquanto ingredientes do sistema, é que os resultados prático-retóricos da interceptação autorizada não possam produzir efeitos ou ser objeto de consideração nos processos e procedimentos não penais, perante o órgão ou órgãos competentes, contra a mesma pessoa que se atribua, agora do ponto de vista de outra qualificação jurídica de ilicitude em dano do Estado, a prática ou autoria do mesmo ato que, para ser apurado na sua dimensão jurídicocriminal, foi alvo de interceptação lícita, como exigência do superior interesse do mesmíssimo Estado, ou, ainda, contra pessoa que, posto não sendo suspeita nem investigada originária, apareceu, no curso da colheita da prova contra outrem, como tal.

Dito de maneira mais direta, não posso conceber como insultuoso à Constituição nem à lei o entendimento de que a prova oriunda de interceptação lícita, autorizada e realizada em procedimento criminal, trate-se de inquérito ou processo-crime, contra certa pessoa, na condição de suspeito, indiciado ou réu, pode ser-lhe oposta, na esfera competente, pelo mesmo Estado, encarnado por órgão administrativo ou judiciário a que esteja o agente submisso, como prova do mesmíssimo ato, visto agora sob a qualificação jurídica de ilícito administrativo ou disciplinar. O raciocínio vale, "mutatis mutandis", em relação a quem, como servidor do mesmo Estado, despontou como possível autor de crime ou de infração administrativa.

Neste quadro, tenho que se desvanecem as objeções.

Está nele, por pressuposto, excluída toda idéia de "fraus legis" ou de "fraus constitutionis", que o juízo da prova poderia, em caso contrário, abortar. O de que se cuida é só da hipótese de recurso ético à fonte de prova legítima do mesmo ato histórico, suscetível de mais de uma qualificação jurídico-normativa de ilicitude, como acontece com fatos a um só tempo configuradores de ilícito

${ }^{1013}$ Decisão publicada no Diário da Justiça de 24 de agosto de 2007, p. 00055. 
penal e administrativo (fatos elementares de várias "fattispecie" normativas), e imputável à mesma pessoa ou agente, em dano de interesse público e confronto com órgão estatal diverso do Ministério Público. É o que se passa, e não só por exemplo, com o caso de crime ou crimes graves que, imputáveis a autoridade ou agente público, constituam também ilícitos disciplinares a que se cominem, por força de análoga gravidade - que não é de muito menor grau em relação à importância dos bens sociais ofendidos -, sanções administrativas extremas.

Não há excogitar aí, nem de longe, outra ou nova ruptura da inviolabilidade pessoal das comunicações telefônicas, senão apenas o reconhecimento de igual valia ou repercussão jurídico-probatória da mesma interceptação autorizada por conta da aparência do caráter também criminoso do mesmo ato ou fato histórico. Tal é a razão óbvia por que não teria propósito nem sentido argüir, aqui, vício de inobservância ou alargamento daquela específica limitação constitucional da garantia, pois se trata apenas de tirar da mesma fonte de prova, sem outra ofensa qualquer à intimidade já devassada do agente, a capacidade, que lhe é ínsita, de servir de meio de convencimento da existência do mesmo fato, ou, em palavras mais técnicas, a idoneidade de se prestar, noutro processo ou procedimento, à reconstituição historiográfica do ato já apurado na esfera criminal. Nisso, não se aprofunda, alarga nem agrava a quebra lícita da intimidade que já se operou, mas tão-só se reconhece a necessidade de, com apoio na eficácia da prova resultante, assegurar, em tutela de interesse público de não menor relevo, a aplicação de outras conseqüências jurídicas ao mesmo ato ilícito, considerado noutro plano normativo.

[...]

Isso tudo significa apenas afirmar que, no âmbito normativo do uso processual dos resultados documentais da interceptação, o mesmo interesse público na repressão de ato criminoso grave que, por sua magnitude, prevalece sobre a garantia da inviolabilidade pessoal, justificando a quebra que a limita, reaparece, com gravidade só reduzida pela natureza não criminal do ilícito administrativo e respectivas sanções, segundo avaliação e percepção de sua evidente supremacia no confronto com o direito individual à intimidade.

Outra interpretação do art. $5^{\circ}$, inc. XII, da Constituição da República, e do art. $1^{\circ}$ da Lei 9.296/96, equivaleria a impedir ao mesmo Estado, que já conhece o fato na sua expressão ou recorte histórico correspondente a figura criminosa e, como tal, já licitamente apurado na órbita penal, ou que o conheceu no procedimento investigatório, invocar-lhe a prova oriunda da interceptação para, sob as garantias do justo processo da lei (“due process of law”), no procedimento próprio, aplicar ao agente a sanção que quadre à gravidade do eventual ilícito administrativo, em tutela de relevante interesse público e restauração da integridade do ordenamento jurídico.

E, neste caso, significaria impedir que os órgãos estatais competentes se valham dessa prova, que lhes é também imprescindível ao desempenho dos misteres correicionais, tanto quanto o é na esfera penal, para apuração de eventuais ilícitos disciplinares de autoridades ou agentes investidos nas mais conspícuas funções do Estado Democrático de direito e que podem, em tese, dada a relativa autonomia conceitual dos ilícitos teóricos e não menos relativa independência das respectivas jurisdições, ser absolvidos aqui e punidos ali. Não posso compreender - para usar eloqüente expressão de FRANCO CORDERO ("Procedura Penale", Milano, Giuffrè, $7^{\text {a }}$ ed., 2003, p. 659, no 64.31) - essa como "fobia della prova", que levaria à ficção de se reputarem os fatos, cuja existência é já conhecida do mesmo Estado, "tanquam non essent". Não é lícito fingir que o Estado ignore a prática de ilícitos administrativos, cujos indícios lhe foram revelados na produção legítima da prova, ainda quando orientada a investigar comportamento de outras pessoas. (grifos dele).

O Ministro Marco Aurélio, em voto vencido, declarou seu entendimento de que a limitação ao sigilo das comunicações telefônicas é exceção, permitida apenas para investigação criminal e persecução penal. 
Esse acórdão, na verdade, apenas reiterou e estendeu a possibilidade do uso da prova emprestada contra terceiros, pois contra os mesmos investigados já havia sido deferida autorização, nesse sentido, para uso pelo STJ e pelo CNJ, na Questão de Ordem no Inquérito 2424/RJ, Relator Ministro Cezar Peluso, julgada pelo Pleno em 25 de abril de $2007^{1014}$. O Relator lá ressalvara, porém, que não sustentava "tese de caráter absoluto que serviria para qualquer processo de caráter não penal”, vencido também o Ministro Marco Aurélio.

Na Questão de Ordem no Inquérito 2725/SP, Relator Ministro Carlos Britto, julgada pelo Tribunal Pleno em 25 de junho de $2008^{1015}$, o STF autorizou o compartilhamento de informações obtidas a partir de interceptação telefônica com o Conselho de Ética e Decoro Parlamentar da Câmara dos Deputados:

EMENTA: QUESTÃO DE ORDEM. INQUÉRITO POLICIAL. SUPERVISÃO
DO SUPREMO TRIBUNAL FEDERAL. PEDIDO VEICULADO PELO
CONSELHO DE ÉTICA E DECORO PARLAMENTAR DA CÂMARA DOS
DEPUTADOS: COMPARTILHAMENTO DAS INFORMAÇÕES.
FINALIDADE: APURAÇÕES DE CUNHO DISCIPLINAR. PRESENÇA DE
DADOS OBTIDOS MEDIANTE INTERCEPTAÇÃO TELEFÔNICA,
JUDICIALMENTE AUTORIZADA. PROVA EMPRESTADA.
ADMISSIBILIDADE. JUÍZO DE PROPORCIONALIDADE (INCISO XII DO
ART. $5^{\circ}$ E $\S 2^{\circ}$ DO ART. 55 DA CF/88). PRECEDENTES. 1. A medida
pleiteada pelo Conselho de Ética e Decoro Parlamentar da Câmara dos
Deputados se mostra adequada, necessária e proporcional ao cumprimento dos
objetivos do parágrafo $2^{\circ}$ do artigo 55 da Constituição Federal de 1988. 2 .
Possibilidade de compartilhamento dos dados obtidos mediante interceptação
telefônica, judicialmente autorizada, para o fim de subsidiar apuraçôes de cunho
disciplinar. Precedente específico: Segunda Questão de Ordem no Inquérito
2.424 (Ministro Cezar Peluso). 3. Questão de Ordem que se resolve no sentido
do deferimento da remessa de cópia integral dos autos ao Sr. Presidente do
Conselho de Ética e Decoro Parlamentar da Câmara dos Deputados, a quem
incumbirá a responsabilidade pela manutenção da cláusula do sigilo de que se
revestem as informações fornecidas.

\section{Fiscalização de tributo.}

Na Medida Cautelar na Ação Direta de Inconstitucionalidade 736/DF, julgada pelo Tribunal Pleno em 4 de junho de $1992^{1016}$, o Relator Ministro Carlos Velloso entendeu que “[...] o fato de a lei exigir que o contribuinte, no interesse da fiscalização do tributo, declare o valor de mercado de seus bens, não me parece atentatório ao direito à intimidade ou à privacidade [...]", argumentação seguida pela maioria.

\footnotetext{
${ }^{1014}$ Decisão publicada no Diário da Justiça de 24 de agosto de 2007, p. 00055.

1015 Decisão disponibilizada no Diário da Justiça eletrônico 182, de 25 de setembro de 2008.

${ }^{1016}$ Decisão publicada no Diário da Justiça de 14 de junho de 2002, p. 00126.
} 


\title{
5. Exame de DNA.
}

No Habeas Corpus 71373/RS, julgado pelo Tribunal Pleno em 10 de novembro de $1994^{1017}$, o STF debateu-se sobre a possibilidade de um indivíduo que se recuse a extrair sangue e fazer o exame de DNA, em ação de investigação de paternidade, ser compelido, pelo juízo, inclusive sob vara, a fazê-lo.

O Relator Ministro Francisco Rezek, em seu voto, resumiu a questão ao seguinte ponto: qual direito deve preponderar, o da criança à sua real, e não apenas presumida, identidade, ou o do possível pai à sua intangibilidade física?

Após ressaltar o grau de certeza quase absoluta que tal exame proporciona, rebateu a alegação do impetrante de que não havia lei que o obrigasse a fazer o exame, argumentando que

\begin{abstract}
[...] tem o magistrado a faculdade de determinar as provas que julgar necessárias à perfeita instrução do processo, podendo a parte, por igual, propor a realização de todas aquelas em direito permitidas, tal como fez o paciente em sua contestação [...]. É o que diz o art. 130 do CPC, complementado pelo art. 332, que inclui "todos os meios moralmente legítimos, ainda que não especificados neste código". [...] Lembra o impetrante que não existe lei que o obrigue a realizar o exame. Haveria, assim, afronta ao art. $5^{\circ}$-II da CF. Chega a afirmar que sua recusa pode ser interpretada, conforme dispõe o artigo $343-\S 2^{\circ}$ do CPC, como uma confissão (art. $6^{\circ}$ ). Mas não me parece, ante a ordem jurídica da república neste final de século, que isso frustre a legítima vontade do juízo de apurar a vontade real. [...] O sacrifício imposto à integridade física do paciente é risível quando confrontado com o interesse do investigante, bem assim com a certeza que a prova pericial pode proporcionar à decisão do magistrado.
\end{abstract}

No que tange a alegação de afronta à tutela da intimidade, entendeu que a intimidade de um não pode escusá-lo de satisfazer a pretensão do outro de o ver reconhecido como pai.

O Ministro Ilmar Galvão, entendendo que a ação de investigação visa, sobretudo, a um objetivo de cunho moral, acompanhou o voto do Relator, bem como os Ministros Carlos Velloso e Sepúlveda Pertence.

Contudo, o entendimento vencedor foi o do Relator para o acórdão, Ministro Marco Aurélio, cujos excertos principais do voto transcrevem-se:

Na espécie, tem-se que, em determinado processo civil - ação de investigação de paternidade - requereu-se (as Autoras [supostas filhas] devem tê-lo feito com o objetivo de comprovar fato constitutivo do direito) o exame denominado DNA, em relação ao qual não coloco dúvidas quanto à valia, à segurança do resultado. Aquele que deveria fornecer, do próprio corpo, a substância indispensável para que fosse realizado recusou-se a tanto. E o que fez o Colegiado [o Tribunal de

${ }^{1017}$ Decisão publicada no Diário da Justiça de 22 de novembro de 1996, p. 45686. 
Justiça estadual] no exercício do crivo revisional? Tal como o Juízo, determinou a submissão do Paciente ao exame, contra a respectiva vontade. E mais: a condução "debaixo de vara", como se fosse possível colocar o Paciente em uma camisa de força e aí levá-lo ao laboratório para, imobilizado, ver recolhido, do próprio corpo - repito - o material necessário. [...] para mim a violência é ímpar e discrepa, sobremaneira, não só da ordem constitucional em vigor, como também das normas instrumentais comuns aplicáveis à espécie. É certo que inexiste, no Código de Processo Civil, dispositivo que discipline, de forma expressa, o tema. Todavia, há outros dos quais, uma vez interpretados, emanam luz suficiente à definição das consequiências da recusa. Refiro-me ao teor do $\S 2^{\circ}$ do artigo 343 do Código de Processo Civil, quanto ao depoimento pessoal, à intimação para prestá-lo, mostrando-se o destinatário silente e deixando de comparecer em Juízo. Qual é a conseqüência prevista, expressamente, no Código de Processo Civil? A execução específica da ordem judicial? Não. O legislador encontrou outra solução: a admissibilidade - ficta, é certo - dos fatos. Distingam-se as posições - de réu e de testemunha. Dou mais um exemplo: o do artigo 359, que cuida da exibição de documento, quando a parte é intimada para tanto, mas não o faz. A repercussão jurídica não é, em si, a prisão ou a ameaça à mesma, para que apresente o documento. [...] Ninguém está compelido, pela ordem jurídica, a adentrar a Justiça para questionar a respectiva paternidade, da mesma forma que há conseqüências para o fato de vir aquele que é apontado como pai a recusar-se ao exame que objetive o esclarecimento da situação. É certo que compete aos cidadãos em geral colaborar com o Judiciário, ao menos na busca da prevalência dos respectivos interesses e que o sacrifício - na espécie, uma simples espetadela - não é tão grande assim. Todavia, princípios constitucionais obstaculizam a solução dada à recusa. Refiro-me, em primeiro lugar, ao da legalidade, no que ninguém é obrigado a fazer ou deixar de fazer alguma coisa senão em virtude de lei. [...] Ainda que houvesse [lei], estaria maculada, considerados os interesses em questão - eminentemente pessoais e a inegável carga patrimonial - pela inconstitucionalidade. Digo isto porquanto a Carta da República [...] consigna que são invioláveis a intimidade, a vida privada, a honra e a imagem das pessoas - inciso $\mathrm{X}$ do rol das garantias constitucionais (artigo $5^{\circ}$ ). Onde ficam a intangibilidade do corpo humano, a dignidade da pessoa, uma vez agasalhada a esdrúxula forma de proporcionar a uma das partes, em demanda civil, a feitura de uma certa prova? [...] É irrecusável o direito do Paciente de não permitir que se lhe retire, das próprias veias, porção de sangue, por menor que seja, para a realização do exame. A recusa do Paciente há de ser resolvida não no campo da violência física, da ofensa à dignidade humana, mas no plano instrumental, reservado ao Juízo competente - ou seja, o da investigação de paternidade - a análise cabível e a definição, sopesadas a prova coligida e a recusa do réu. Assim o é porque a hipótese não é daquelas em que o interesse público sobrepõe-se ao individual, como a das vacinações obrigatórias em época de epidemias, ou mesmo o da busca da preservação da vida humana, naqueles conhecidos casos em que convicções religiosas arraigadas acabam por conduzir à perda da racionalidade.

Os Ministros Sydney Sanches, Néri da Silveira, Moreira Alves e Octavio Gallotti seguiram seu voto, e a ementa foi a seguinte:

INVESTIGAÇÃO DE PATERNIDADE - EXAME DNA - CONDUÇÃO DO RÉU "DEBAIXO DE VARA". Discrepa, a mais não poder, de garantias constitucionais implícitas e explícitas - preservação da dignidade humana, da intimidade, da intangibilidade do corpo humano, do império da lei e da inexecução específica e direta de obrigação de fazer - provimento judicial que, em ação civil de investigação de paternidade, implique determinação no sentido de o réu ser conduzido ao laboratório, "debaixo de vara", para coleta do material indispensável à feitura do exame DNA. A recusa resolve-se no plano jurídicoinstrumental, consideradas a dogmática, a doutrina e a jurisprudência, no que 
voltadas ao deslinde das questões ligadas à prova dos fatos.

A Questão de Ordem na Reclamação 2040/DF, Relator Ministro Néri da Silveira, julgada pelo Tribunal Pleno em 21 de fevereiro de $2002^{1018}$, tratava do caso de uma extraditanda que engravidou, enquanto presa nas dependências da Polícia Federal, em Brasília, aguardando o fim do processo de extradição, e acusou policiais de a terem estuprado, de modo que, portanto, um deles seria o pai. Contudo, não prestou queixa e recusou-se a realizar exame de DNA.

Aberto procedimento administrativo pela Polícia Federal para apurar o fato, um juiz federal autorizou a coleta da placenta, durante o parto, para realização do exame de DNA em comparação com material colhido, voluntariamente, de vários policiais federais e alguns presos, com a finalidade de se determinar a paternidade e proceder-se à devida responsabilização.

Após discutir se a competência era mesmo do STF para apreciar o caso, o Tribunal entendeu que, no confronto entre o direito à intimidade da mãe e o direito à honra e à imagem dos integrantes da Polícia Federal acusados e à imagem da própria instituição, prevaleciam estas, conforme a ementa:

Reclamação. Reclamante submetida ao processo de Extradição n. ${ }^{\circ}$ 783, à disposição do STF. 2. Coleta de material biológico da placenta, com propósito de se fazer exame de DNA, para averiguação de paternidade do nascituro, embora a oposição da extraditanda. 3. Invocação dos incisos X e XLIX do art. $5^{\circ}$, da $\mathrm{CF} / 88$. 4. Ofício do Secretário de Saúde do DF sobre comunicação do Juiz Federal da $10^{\mathrm{a}}$ Vara da Seção Judiciária do DF ao Diretor do Hospital Regional da Asa Norte - HRAN, autorizando a coleta e entrega de placenta para fins de exame de DNA e fornecimento de cópia do prontuário médico da parturiente. 5 . Extraditanda à disposição desta Corte, nos termos da Lei n. ${ }^{\circ}$ 6.815/80. Competência do STF, para processar e julgar eventual pedido de autorização de coleta e exame de material genético, para os fins pretendidos pela Polícia Federal. 6. Decisão do Juiz Federal da $10^{\mathrm{a}}$ Vara do Distrito Federal, no ponto em que autoriza a entrega da placenta, para fins de realização de exame de DNA, suspensa, em parte, na liminar concedida na Reclamação. Mantida a determinação ao Diretor do Hospital Regional da Asa Norte, quanto à realização da coleta da placenta do filho da extraditanda. Suspenso também o despacho do Juiz Federal da $10^{\text {a }}$ Vara, na parte relativa ao fornecimento de cópia integral do prontuário médico da parturiente. 7. Bens jurídicos constitucionais como "moralidade administrativa", "persecução penal pública" e "segurança pública" que se acrescem, - como bens da comunidade, na expressão de Canotilho, - ao direito fundamental à honra $\left(\mathrm{CF}\right.$, art. $\left.5^{\circ}, \mathrm{X}\right)$, bem assim direito à honra e à imagem de policiais federais acusados de estupro da extraditanda, nas dependências da Polícia Federal, e direito à imagem da própria instituição, em confronto com o alegado direito da reclamante à intimidade e a preservar a identidade do pai de seu filho. 8. Pedido conhecido como reclamação e julgado procedente para avocar o julgamento do pleito do Ministério Público Federal, feito perante o Juízo Federal da $10^{\mathrm{a}}$ Vara do Distrito Federal. 9. Mérito do pedido do Ministério Público Federal julgado, desde logo, e deferido, em parte, para

${ }^{1018}$ Decisão publicada no Diário da Justiça de 27 de junho de 2003, p. 00031. 
autorizar a realização do exame de DNA do filho da reclamante, com a utilização da placenta recolhida, sendo, entretanto, indeferida a súplica de entrega à Polícia Federal do "prontuário médico" da reclamante.

No Recurso Extraordinário 248869/SP, Relator Ministro Maurício Corrêa, julgado em 7 de agosto de $2003^{1019}$, em que se discutiu a legitimidade do Ministério Público para ajuizar ação de investigação de paternidade a pedido da mãe da criança, a Segunda Turma remeteu os autos para o Pleno, que entendeu:

$[\ldots]$

4. A Lei 8560/92 expressamente assegurou ao Parquet, desde que provocado pelo interessado e diante de evidências positivas, a possibilidade de intentar a ação de investigação de paternidade, legitimação essa decorrente da proteção constitucional conferida à família e à criança, bem como da indisponibilidade legalmente atribuída ao reconhecimento do estado de filiação. Dele decorrem direitos da personalidade e de caráter patrimonial que determinam e justificam a necessária atuação do Ministério Público para assegurar a sua efetividade, sempre em defesa da criança, na hipótese de não reconhecimento voluntário da paternidade ou recusa do suposto pai.

5. O direito à intimidade não pode consagrar a irresponsabilidade paterna, de forma a inviabilizar a imposição ao pai biológico dos deveres resultantes de uma conduta volitiva e passível de gerar vínculos familiares. Essa garantia encontra limite no direito da criança e do Estado em ver reconhecida, se for o caso, a paternidade.

$[\ldots]$.

O Ministro Nelson Jobim chegou a argüir, ressalvando, porém, que não era a situação em tela, porque havia solicitação da genitora, que

[...] [e]ssa legitimação extraordinária, absoluta do Ministério Público [prevista na Lei 8.560, de 29 de dezembro de 1992, de ajuizar ação de investigação de paternidade], independente de manifestação da mãe, representa, a meu juízo, uma enorme intervenção em algo que seria do Estado na intimidade das pessoas $[\ldots]$.

O Ministro Cezar Peluso, contrapondo-se a ele, afirmou:

[p]arece-me não estar aqui propriamente em jogo a questão do direito à intimidade. É que tal direito pressupõe sujeito capaz de avaliar o seu próprio mundo interior. O caso de que estamos tratando é de menor que, não sendo capaz de exercer por si esse poder, necessita de alguém para fazê-lo em seu nome. Aqui está o cerne do problema. Creio que o menor tem direito subjetivo, que é o direito fundamental versado na causa, personalíssimo e de caráter indisponível, à sua identidade histórica. [...].

${ }^{1019}$ Decisão publicada no Diário da Justiça de 12 de março de 2004, p. 00038. 


\section{Privacidade na Lei $9.034 / 1995$.}

Na Medida Cautelar da Ação Direta de Inconstitucionalidade 1517/UF ${ }^{1020}$, ajuizada pela ADEPOL contra o artigo $3^{\circ}$ e parágrafos da Lei 9.034, de 3 de maio de 1995, que permitia a realização de diligência pessoal pelo juiz quando houvesse possibilidade de violação de sigilo garantido pela Constituição ou por lei, adotado o mais rigoroso segredo de justiça, a autora alegou, dentre outros, violação ao princípio da publicidade das decisões judiciais, protegido no inciso LX do artigo $5^{\circ}$, da imparcialidade do juiz, albergado nos incisos LIV e LVI desse mesmo artigo, bem como da "exclusividade" da polícia judiciária na condução do procedimento investigatório especial garantida no artigo 144, parágrafo primeiro, inciso IV, e parágrafo $4^{\circ}$, da Constituição Federal.

Contudo, o Tribunal Pleno, por maioria, seguindo o voto do Relator Ministro Maurício Corrêa, entendeu, no que nos interessa, conforme trecho da ementa, que:

[...] e) as normas contidas no art. $144, \S 1^{\circ}$, inciso IV, e $\S 4^{\circ}$ não devem ser interpretadas como limitativas do dever da prestação jurisdicional, cuja extensão vai desde a apuração dos fatos até a decisão judicial, elastério esse compreendido no conceito de exercício da magistratura; f) competindo ao Judiciário a tutela dos direitos e garantias individuais previstos na Constituição, não há como imaginarse ser-lhe vedado agir, direta ou indiretamente, em busca da verdade material mediante o desempenho das tarefas de investigação criminal, até porque estas não constituem monopólio do exercício das atividades de polícia judiciária; g) a participação do juiz na fase pré-processual da persecução penal é a garantia do respeito aos direitos e garantias fundamentais, sobretudo os voltados para a intimidade, a vida privada, a honra e a imagem da pessoa acerca de quem recaem as diligências, e para a inviolabilidade do sigilo protegido pelo primado constitucional; h) não há cogitar-se de violação das garantias constitucionais do devido processo legal e da ampla defesa, pois os $\S \S 3^{\circ}$ e $5^{\circ}$ do art. $3^{\circ}$ da Lei $n^{\circ}$ 9.034/95 até asseguram o acesso das partes às provas objeto da diligência; i) a coleta de provas não implica valorá-las e não antecipa a formação de juízo condenatório; j) a diligência realizada pelo juiz, sob segredo de justiça, não viola o princípio constitucional da publicidade previsto no inciso LX do art. $5^{\circ}$, que admite restringi-lo. [...].

Saiu vencido o Ministro Sepúlveda Pertence, que entendeu que se estava restabelecendo o "juízo inquisitorial”. A Ação, no fim, foi julgada extinta sem julgamento de mérito por falta de legitimidade ativa da requerente em 22 de outubro de 2002.

$\mathrm{O}$ artigo $3^{\circ}$, contudo, foi esvaziado pelo STF no julgamento da Ação Direta de Inconstitucionalidade 1570/DF, em 12 de fevereiro de $2004^{1021}$, em que a maioria dos Ministros entendeu que: (i) no concernente aos dados, informações e documentos

${ }^{1020}$ Ação julgada em 30 de abril de 1997, decisão publicada no Diário da Justiça de 22 de novembro de 2002, p. 00055.

${ }_{1021}$ Decisão publicada no Diário da Justiça de 22 de outubro de 2004, p. 0004. 
bancários e financeiros, teria havido revogação pela Lei Complementar 105, de 10 de janeiro de $2001^{1022}$; (ii) no mérito, a realização de diligência pessoal pelo juiz da causa viola o princípio da imparcialidade do juiz e, por conseguinte, do devido processo legal, declarando a inconstitucionalidade desse artigo $3^{\circ}$ no tocante ao trato dos dados fiscais e eleitorais. Em outras palavras, acabou-se com o procedimento previsto nesse artigo.

\section{Privacidade e o Código Penal Militar.}

No Habeas Corpus 79285/RJ, julgado pela Primeira Turma em 31 de agosto de $1999^{1023}$, o Relator Ministro Moreira Alves, entendeu, em seu voto, acompanhado por unanimidade, que

[...] [i]nexiste a pretendida inconstitucionalidade do art. 235 do CPM [Código Penal Militar] por ofensa ao artigo $5^{\circ}, X$, da Constituição Federal [...]. Com efeito, a inviolabilidade da intimidade não é direito absoluto a ser utilizado como garantia à permissão da prática de crimes sexuais, principalmente em face de outros princípios constantes da Carta Magna. Assim, a própria Constituição, em seu artigo $227, \S 4^{\circ}$, é enfática ao determinar que "a lei punirá severamente o abuso, a violência e a exploração sexual da criança e do adolescente", atos que se fazem as mais das vezes na intimidade. E esse dispositivo do CPM prevê como delito "o praticar, ou permitir o militar que com ele se pratique ato libidinoso, homossexual ou não, em lugar sujeito a administração militar", visando, portanto, a resguardar a disciplina, que, consoante o artigo 142 da Carta Magna, é uma das bases sobre as quais se organizam as Forças Armadas. Note-se que, no caso, o ato libidinoso foi praticado com menor de dezoito anos, o que, se não fosse crime militar, seria enquadrado no delito de corrupção de menores (artigo 218 do Código Penal), com pena mais grave.

\section{Publicidade dos atos processuais, Comissão Parlamentar de Inquérito e privacidade.}

Na Medida Cautelar no Mandado de Segurança 24832/DF, Tribunal Pleno, Relator Ministro Cezar Peluso, julgado em 18 de março de $2004^{1024}$, o entendimento da maioria foi de que não se pode restringir a gravação e transmissão de sessão pública de Comissão Parlamentar de Inquérito, em observância ao princípio da publicidade, salvo, se for o caso, em hipóteses como a do inciso IX do artigo 93 da Constituição Federal. É a ementa:

COMISSÃO PARLAMENTAR DE INQUÉRITO. Depoimento. Indiciado. Sessão pública. Transmissão e gravação. Admissibilidade. Inexistência aparente de dano à honra e à imagem. Liminar concedida. Referendo negado. Votos

\footnotetext{
${ }^{1022}$ Artigo $1^{\circ}$, parágrafo $4^{\circ}$, inciso IX.

${ }^{1023}$ Decisão publicada no Diário da Justiça de 12 de novembro de 1999, p. 00091.

${ }^{1024}$ Decisão publicada no Diáro da Justiça de 18 de agosto de 2006, p. 00019.
} 
vencidos. Não aparentam caracterizar abuso de exposição da imagem pessoal na mídia, a transmissão e a gravação de sessão em que se toma depoimento de indiciado, em Comissão Parlamentar de Inquérito.

\section{Privacidade e ação penal privada concorrente.}

No Recurso Ordinário em Habeas Corpus 82549-4/PA, Relator Ministro Eros Grau, julgado em 24 de agosto de $2004^{1025}$, a Primeira Turma reafirmou o entendimento de que

[a] legitimidade para a propositura da ação penal privada nos crimes contra a honra é, via de regra, do ofendido. Essa regra sofre exceção quando o crime é praticado contra servidor público, em razão do exercício do cargo, dada a necessidade de tutelar outro bem jurídico, que é o prestígio da Administração Pública. Nessa circunstância a ação penal passa a ser pública condicionada à representação. Contudo, para dar efetividade ao preceito constitucional que tutela a intimidade, a vida privada, a honra e a imagem das pessoas, a legitimidade deve ser concorrente, cabendo tanto a ação penal privada, quanto a ação penal pública condicionada à representação do funcionário. [...].

\section{Publicidade de documentos.}

Segundo o Recurso em Mandado de Segurança 23036/RJ, Relator Ministro Maurício Corrêa, Relator para o acórdão Ministro Nelson Jobim, julgado pela Segunda Turma em 28 de março de $2006^{1026}$, os Poderes não podem limitar a publicidade de documentos por atos discricionários, somente em casos excepcionais:

\footnotetext{
RECURSO EM MANDADO DE SEGURANÇA. SUPERIOR TRIBUNAL MILITAR. CÓPIA DE PROCESSOS E DOS ÁUDIOS DE SESSÕES. FONTE HISTÓRICA PARA OBRA LITERÁRIA. ÂMBITO DE PROTEÇÃO DO DIREITO À INFORMAÇÃO (ART. 5', XIV DA CONSTITUIÇÃO FEDERAL). 1. Não se cogita da violação de direitos previstos no Estatuto da Ordem dos Advogados do Brasil (art. $7^{\circ}$, XIII, XIV e XV da L. 8.906/96), uma vez que os impetrantes não requisitaram acesso às fontes documentais e fonográficas no exercício da função advocatícia, mas como pesquisadores. 2. A publicidade e o direito à informação não podem ser restringidos com base em atos de natureza discricionária, salvo quando justificados, em casos excepcionais, para a defesa da honra, da imagem e da intimidade de terceiros ou quando a medida for essencial para a proteção do interesse público. 3. A coleta de dados históricos a partir de documentos públicos e registros fonográficos, mesmo que para fins particulares, constitui-se em motivação legítima a garantir o acesso a tais informações. 4. No caso, tratava-se da busca por fontes a subsidiar elaboração de livro (em homenagem a advogados defensores de acusados de crimes políticos durante determinada época) a partir dos registros documentais e fonográficos de sessões de julgamento público. 5. Não configuração de situação excepcional a limitar a incidência da publicidade dos documentos públicos (arts. 23 e 24 da L. 8.159/91) e do direito à informação. Recurso ordinário provido.
}

1025 Decisão publicada no Diário da Justiça de 19 de novembro de 2004, p. 00030.

${ }^{1026}$ Decisão publicada no Diário da Justiça de 25 de agosto de 2006, p. 00067. 


\section{Informação jornalística, gravação clandestina e privacidade.}

Na Petição 2702/RJ, julgada pelo Tribunal Pleno, em 18 de setembro de $2002^{1027}$, o Relator Ministro Sepúlveda Pertence, lecionou, citando doutrina:

[...] a garantia do sigilo das diversas modalidades técnicas de comunicação pessoal - objeto do art. $5^{\circ}$, XII - independe do conteúdo da mensagem transmitida e, por isso - diversamente do que têm afirmado autores de tomo -, não tem o seu alcance limitado ao resguardo das esferas da intimidade ou da privacidade dos interlocutores.

Tratava-se de um caso em que um candidato à Presidência da República, de um lado, e uma organização jornalística, de outro, discutiam sobre a possibilidade de divulgação, por esta, em meios escritos e falados, de conversas telefônicas mantidas por aquele com terceiros, envolvendo suposto suborno de um auditor fiscal da Receita Federal.

O Relator houve por bem mandar desentranhar as gravações e sua análise pericial dos autos, sob o argumento de que

[...] diversamente do que sucede nas hipóteses normais de conflito entre a liberdade de informação e os direitos da personalidade - no âmbito da proteção ao sigilo das comunicações, não há como emprestar peso relevante, na ponderação entre os direitos fundamentais colidentes, ao interesse público no conteúdo das mensagens veiculadas, nem à notoriedade ou ao protagonismo político ou social dos interlocutores.

O Ministro Marco Aurélio, divergindo, defendeu a supremacia do interesse coletivo de ser informado sobre o individual, entendendo que proibir os meios de comunicação de informar à população acerca do conteúdo das gravações consistia em censura prévia judicial, mas o Tribunal acabou seguindo o voto do Relator, por maioria.

\section{Sigilo de dados bancários, fiscais, telefônicos e outros.}

No Recurso em Mandado de Segurança 9057, Relator Ministro Gonçalves de Oliveira, julgado pelo Tribunal Pleno em 13 de setembro de $1961^{1028}$, ficou decidido que “[...] [o] cadastro do banco é excluído do exame dos peritos, que devem se limitar aos negócios das partes em litígio, não tendo o poder de examinar, na perícia, quaisquer outros dados ou lançamentos estranhos ao objeto do litígio".

O Relator destacou em seu voto:

${ }^{1027}$ Decisão publicada no Diário da Justiça de 19 de setembro de 2003, p. 00016.

${ }^{1028}$ Decisão publicada no Diário da Justiça de 26 de outubro de 1961, p. 02386. 
[é] certo que o sigilo bancário não é absoluto e ele cede, muitas vezes, a valores dignos de consideração, como se dá para perfeita instrução de processos criminais, como decidira esta Suprema Corte, no recurso de mandado de segurança $\mathrm{n}^{\mathrm{o}} 1.047$, de que foi relator nosso eminente colega exmo. Sr. Ministro Ribeiro da Costa (sessão de 6-9-1949). Mas, nas questões de ordem patrimonial, os exames hão de se fazer com cautela. Nem [a]os peritos se poderá dar o privilégio, apenas porque são peritos, de se inteirarem dos negócios do Banco. $[\ldots]$.

No Habeas Corpus 39308, Relator Ministro Pedro Chaves, julgado em 19 de setembro de 1962 pelo Tribunal Pleno ${ }^{1029}$, o STF concedeu ordem para evitar constrangimento e eventual prisão de superintendente de hospital público que se recusava a fornecer à polícia e ao juízo criminal ficha de paciente que teria praticado aborto consentido, a fim de se confirmar a existência do crime. Por maioria, o Pleno entendeu que os fichários de hospitais, ainda que públicos, são cobertos pelo sigilo, que só pode ceder, em condições excepcionalíssimas, em caso de "justa causa", como notificação compulsória em hipótese de moléstia contagiosa. "Justa causa", porém, não é a mera suspeita de ocorrência de crime ${ }^{1030}$.

Em vários casos, foi reafirmado que não existe sigilo absoluto, como no que tange a livros comerciais, por exemplo, no Recurso Extraordinário 52480, Relator Ministro Evandro Lins, julgado pela Primeira Turma em 24 de outubro de $1963^{1031}$, e no Recurso Extraordinário 52817, Relator Ministro Evandro Lins, julgado pela Primeira Turma em 23 de setembro de $1963^{1032}$.

A Questão de Ordem na Petição 577, julgada pelo Tribunal Pleno em 25 de março de $1992^{1033}$, Relator Ministro Carlos Velloso, tratava de um caso em que um delegado de polícia federal, em virtude de cintas de dinheiro, utilizadas por duas agências bancárias, encontradas em latas de lixo de um ex-Ministro, para instruir inquérito policial sob sua presidência, requisitara autorização judicial para que os respectivos gerentes informassem se existiam contas correntes em nome do investigado e de sua esposa, bem como, em caso positivo, fornecessem os extratos bancários de ambos referentes a certo período.

O Relator afirmou que o sigilo bancário é espécie de direito à privacidade, inerente à personalidade das pessoas e consagrado pela Constituição Federal, no artigo $5^{\circ}$, inciso X,

\footnotetext{
${ }^{1029}$ Decisão publicada no Diário da Justiça de 6 de dezembro de 1962, p. 03729.

${ }^{1030}$ Ver ainda Recurso Extraordinário 60176/GB, Relator Ministro Luis Gallotti, julgado em 17 de junho de 1966 pela Terceira Turma, decisão publicada no Diário da Justiça de 9 de novembro de 1966, p. 03882.

${ }^{1031}$ Decisão publicada no Diário da Justiça de 17 de dezembro de 1963, p. 04446.

1032 Decisão publicada no Diário da Justiça de 17 de outubro de 1963, p. 03535.

${ }^{1033}$ Decisão publicada no Diário da Justiça de 23 de abril de 1993, p. 06918.
} 
e que a faculdade conferida ao Judiciário ${ }^{1034}$ de requisitar informações relativas a pessoas que implicam quebra de sigilo pressupõe que a autoridade judiciária proceda "com a cautela, prudência e moderação, virtudes inerentes à magistratura, ou que os magistrados devem possuir". Seu voto foi pelo indeferimento do pedido por não se encontrar instruído com prova de que o ex-Ministro estava sendo indiciado e, tampouco, existir elementos mínimos de autoria do delito aptos a justificar a medida.

O Ministro Marco Aurélio entendeu que o artigo $5^{\circ}$, inciso XII, da Constituição Federal autorizava a quebra dos dados, e de modo mais amplo do que o entendido pelo Relator:

[...] leio, para minha reflexão, o que poderia ser o preceito do inciso XII do artigo $5^{\circ}$ da Constituição Federal. Repito: leio o que poderia ser e o faço, portanto, com adaptação - esse preceito:

"é inviolável o sigilo da correspondência, das comunicações telegráficas" - e aqui já operei uma adaptação, suprimindo o conectivo "e" - "de dados e das comunicações telefônicas, salvo, no último caso, por ordem judicial, nas hipóteses e na forma que a lei estabelecer para fins de investigação criminal ou instrução processual penal".

Senhor Presidente, fosse este o teor do inciso XII do artigo $5^{\circ}$, não teria a menor dúvida em reconhecer a existência de quatro casos contemplados na norma. $\mathrm{O}$ primeiro, alusivo à "correspondência"; o segundo, referente às "comunicações telegráficas"; o terceiro, aos "dados" e o quarto às "comunicações telefônicas". A ressalva à preservação do sigilo estaria, sob essa óptica, ligada apenas ao último caso, ao atinente às comunicações telefônicas.

No texto, vejo o emprego de dois conectivos "e" a revelar que temos, na verdade, não quatro casos, mas apenas dois: o primeiro, abrangendo a "correspondência" e as "comunicações telegráficas": "é inviolável o sigilo da correspondência e das comunicações telegráficas"; o segundo, a envolver "dados" e "comunicações telefônicas". Se estou certo neste enfoque, rechaço a possibilidade de se ter o sigilo relativo a "dados" como inafastável. O sigilo, a meu ver, pode ser afastado mediante aplicação do que se contém na parte final do preceito: "salvo, no último caso, por ordem judicial, nas hipóteses e na forma que a lei estabelecer para fins de investigação criminal ou instrução processual penal".

Na hipótese dos autos, procura-se elucidar a ocorrência, ou não, de crime contra a Administração Pública. O aparelho policial, e, agora, o Judiciário foram acionados para definir se o referido crime restou configurado. Posso e devo ter presente o anseio da própria sociedade em ver esclarecidos os fatos que reiteradamente vêm sendo noticiados. O que se requer, nesta "Petição", é que o Judiciário autorize, e pode fazê-lo - pelo menos estou convencido disto - a obtenção de "dados" conducentes à melhor elucidação da hipótese. "Dados" que, certamente, o próprio envolvido tem interesse em que sejam revelados, porque milita a favor dele a presunção de inocência, até prova em contrário.

Ora, se no próprio dispositivo constitucional alude-se à simples investigação criminal, não posso me valer do fato de o suspeito ainda não ter sido indiciado, para, a mercê dele, simplesmente indeferir o que a autoridade policial entende indispensável à elucidação visada.

O Ministro Sepúlveda Pertence, acompanhando o Relator no indeferimento, argumentou:

${ }^{1034}$ Com base no vigente artigo 38 da Lei 4.595/1964, que se considerou recepcionado pela nova ordem constitucional. 
[...] o mínimo a exigir [para que se pudesse autorizar o acesso a dados sigilosos] será que a autoridade policial, sob sua responsabilidade, informe o Tribunal, ao menos sobre a relação de pertinência entre a prova pretendida, com as informações bancárias, e o objeto das investigações em curso. [...] não posso conceder a violação do direito ao sigilo bancário, por mais relativo que ele seja, com base apenas no noticiário da imprensa [acompanhava a petição uma cópia de notícia de jornal a respeito das cintas de dinheiro encontradas].

O Ministro Paulo Brossard também indeferiu o pedido, ressalvando, contudo, que “[...] mais do que as leis, a Constituição assegura o direito à privacidade. Esse direito, porém, não é absoluto, admite temperamentos. O sigilo bancário é um aspecto do direito à privacidade, não é, porém, absoluto". O Ministro Marco Aurélio acabou sendo o voto vencido.

No Agravo Regimental em Inquérito 897-5/DF, julgado pelo Tribunal Pleno em 23 de novembro de $1994^{1035}$, Relator Ministro Francisco Rezek, entendeu-se que, em inquérito policial, mesmo a determinação de "quebra" do sigilo bancário não se submete ao princípio do contraditório.

No Mandado de Segurança 21729/DF, julgado pelo Tribunal Pleno em 5 de outubro de $1995^{1036}$, o Ministro Maurício Corrêa entendeu que no direito à privacidade estão contidos desdobramentos, como, no caso, o direito ao sigilo bancário e ao fiscal, em interpretação combinada com o artigo 145 , parágrafo $1^{\circ}$, da Constituição Federal, na parte em que menciona o respeito aos direitos individuais, que só pode ser excepcionado por decisão judicial ou de Comissão Parlamentar de Inquérito, não podendo o Ministério Público requerer informações cobertas por sigilo sem intermédio do Judiciário. Segundo ele,

[u]ma das conseqüências do entendimento de que o direito ao sigilo bancário pertence à categoria maior do direito à privacidade é que, destinado a proteger o indivíduo, não protege operações bancárias praticadas em contas fictícias - que não têm privacidade a ser juridicamente protegida - nem pode ser invocado para acobertar crimes ou outros ilícitos, sejam administrativos ou civis. Em suma, este direito tutela, apenas, as operações lícitas. Além disso, deve ser considerado que o direito à privacidade é um direito individual que pode ser oposto "erga omnes" e com mais ênfase ao Estado, mas ele, por outro lado, tem por limite interesses maiores - de natureza política - que dizem respeito ao interesse público. Quando dois direitos ungidos em leis da mesma hierarquia entram em conflito, a prevalência de um sobre o outro é decidida segundo uma escala axiológica; mas este padrão de valores não é fornecido pela Constituição, cabendo ao intérprete da lei, orientado pelas regras de hermenêutica e de exegese e levando em conta o estágio sócio-cultural contemporâneo aos fatos, dizer sobre esta prevalência. Hoje, é aceito pela quase unanimidade que o interesse público prevalece sobre o particular. Esta Corte, em inúmeros julgados, vem dizendo reiteradamente que o

${ }^{1035}$ Decisão publicada no Diário da Justiça de 24 de março de 1995, p. 06806.

${ }^{1036}$ Decisão publicada no Diário da Justiça de 19 de outubro de 2001, p. 00033. 
direito ao sigilo bancário é um direito limitado, não absoluto, e que pode ceder a interesses públicos em determinadas e restritas situações, sempre orientadas para a busca da verdade no interesse da justiça, seja em causas de natureza penal, administrativa ou civil.

O Ministro Celso de Mello lecionou que a intimidade é

[...] valor constitucionalmente assegurado [...], cuja proteção normativa busca erigir e reservar, "sempre em favor do indivíduo" - e contra a ação expansiva do arbítrio do Poder Público - uma esfera de autonomia intangível e indevassável pela atividade desenvolvida pelo aparelho do Estado. [...] $\mathrm{O}$ direito à inviolabilidade dessa franquia individual [...] ostenta, no entanto, caráter meramente relativo. Não assume e nem se reveste de natureza absoluta. Cede, por isso mesmo, "e sempre em caráter excepcional", às exigências impostas pela "preponderância" axiológica e jurídico-social do interesse público.

Ressalvou, ainda, que o levantamento do sigilo não pode ser feito para apurar ilícitos indeterminados, não podendo transformar-se em "instrumento de indiscriminada devassa da vida privada dos cidadãos".

Em outro ponto do seu voto, afirmou que "[a] inviolabilidade do sigilo de dados, tal como proclamada pela Carta Política em seu art. $5^{\circ}$, XII, 'torna essencial' que as exceções derrogatórias à prevalência desse postulado só possam emanar de órgãos estatais - 'os órgãos do Poder Judiciário' - aos quais a própria Constituição Federal outorgou essa especial prerrogativa de ordem jurídica”.

Já o Ministro Francisco Rezek entendeu que o sigilo bancário é de índole infraconstitucional e que, ademais, o inciso XII do artigo $5^{\circ}$ protege a comunicação de dados, e não os dados propriamente.

O Ministro Carlos Velloso, como outros Ministros, reafirmou seu entendimento de que o sigilo bancário é espécie do direito à privacidade.

Por maioria de votos, o Tribunal acabou decidindo que não existe sigilo bancário oponível ao Ministério Público, para instruir procedimento administrativo em defesa do patrimônio público, quando o banco age na qualidade de executor de política governamental. A ementa é a seguinte:

Mandado de Segurança. Sigilo bancário. Instituição financeira executora de política creditícia e financeira do Governo Federal. Legitimidade do Ministério Público para requisitar informações e documentos destinados a instruir procedimentos administrativos de sua competência. 2. Solicitação de informações, pelo Ministério Público Federal ao Banco do Brasil S/A, sobre concessão de empréstimos, subsidiados pelo Tesouro Nacional, com base em plano de governo, a empresas do setor sucroalcooleiro. 3. Alegação do Banco impetrante de não poder informar os beneficiários dos aludidos empréstimos, por estarem protegidos pelo sigilo bancário, previsto no art. 38 da Lei no 4.595/1964, e, ainda, ao entendimento de que dirigente do Banco do Brasil S/A não é

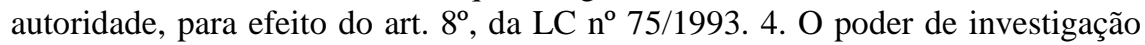


do Estado é dirigido a coibir atividades afrontosas à ordem jurídica e a garantia do sigilo bancário não se estende às atividades ilícitas. A ordem jurídica confere explicitamente poderes amplos de investigação ao Ministério Público - art. 129, incisos VI, VIII, da Constituição Federal, e art. $8^{\circ}$, incisos II e IV, e $\S 2^{\circ}$, da Lei Complementar $n^{\circ} 75 / 1993$. 5. Não cabe ao Banco do Brasil negar, ao Ministério Público, informações sobre nomes de beneficiários de empréstimos concedidos pela instituição, com recursos subsidiados pelo erário federal, sob invocação do sigilo bancário, em se tratando de requisição de informações e documentos para instruir procedimento administrativo instaurado em defesa do patrimônio público. Princípio da publicidade, "ut" art. 37 da Constituição. 6. No caso concreto, os empréstimos concedidos eram verdadeiros financiamentos públicos, porquanto o Banco do Brasil os realizou na condição de executor da política creditícia e financeira do Governo Federal, que deliberou sobre sua concessão e ainda se comprometeu a proceder à equalização da taxa de juros, sob a forma de subvenção econômica ao setor produtivo, de acordo com a Lei nº 8.427/1992. 7 . Mandado de segurança indeferido.

Confirmando que o Ministério Público não pode "quebrar", por si próprio, sem "interferência" de autoridade judiciária, o sigilo bancário de alguém, ver, ainda, Recurso Extraordinário 215301/CE, julgado pela Segunda Turma, sob relatoria do Ministro Carlos Velloso, em 13 de abril de $1999^{1037}$.

A Medida Cautelar na Ação Direta de Inconstitucionalidade 1790/DF, Relator Ministro Sepúlveda Pertence, julgada pelo Tribunal Pleno em 23 de abril de $1998^{1038}$, atacava a Medida Provisória 1.638-1, reedição de 13 de fevereiro de 1998, que alterou dispositivos da Lei 9.492, de 10 de setembro de 1997, que regulamenta os serviços concernentes ao protesto de títulos, permitindo, em síntese, no que importa, o fornecimento de listas plurinominais pelos cartórios às entidades representativas da indústria e do comércio, ou àquelas vinculadas à proteção do crédito, dos protestos tirados e dos cancelamentos efetuados, com a nota de se tratar de informação reservada, e, também, o fornecimento de certidões de protestos não cancelados "a quaisquer interessados, desde que por escrito" 1039 . A autora da ação, a Associação dos Notários e Registradores do Brasil (“ANOREG"), alegou que esses dispositivos violavam, dentre outros, o direito à privacidade.

O Relator não entendeu assim, afirmando que essa lei deve se coadunar com o tratamento que o Código de Defesa do Consumidor confere aos bancos de dados, não existindo, portanto, violação do direito à privacidade. Conforme a ementa:

[...] A convivência entre a proteção da privacidade e os chamados arquivos de consumo, mantidos pelo próprio fornecedor de crédito ou integrados em bancos de dados, tornou-se um imperativo da economia da sociedade de massas: de viabilizá-la cuidou o CDC [Código de Defesa do Consumidor], segundo o molde

${ }^{1037}$ Decisão publicada no Diário da Justiça de 28 de maio de 1999, p. 00024.

${ }^{1038}$ Decisão publicada no Diário da Justiça de 8 de setembro de 2000, p. 00004.

${ }^{1039}$ Nova redação conferida ao artigo 31 dessa lei pela aludida medidas provisória. 
das legislações mais avançadas: ao sistema instituído pelo Código de Defesa do Consumidor para prevenir ou reprimir abusos dos arquivos de consumo, hão de submeter-se as informações sobre os protestos lavrados, uma vez obtidas na forma prevista no edito impugnado e integradas aos bancos de dados das entidades credenciadas à certidão diária de que se cuida: é o bastante a tornar duvidosa a densidade jurídica do apelo da argüição à garantia da privacidade, que há de harmonizar-se à existência de bancos de dados pessoais, cuja realidade a própria Constituição reconhece (art. $5^{\circ}$, LXXII, "in fine") e entre os quais os arquivos de consumo são um dado inextirpável da economia fundada nas relações massificadas de crédito.

O Mandado de Segurança 23452/RJ, Relator Ministro Celso de Mello, julgado pelo Tribunal Pleno em 16 de setembro de $1999^{1040}$, confirmou os poderes das Comissões Parlamentares de Inquérito de decretar, por autoridade própria, a quebra dos sigilos bancário, fiscal e telefônico ${ }^{1041}$, atribuídos pelo artigo 58 , parágrafo $3^{\circ}$, da Constituição

Federal, delineando-os, conforme os seguintes trechos pertinentes da ementa:

[...] LIMITAÇÕES AOS PODERES INVESTIGATÓRIOS DA COMISSÃO PARLAMENTAR DE INQUÉRITO. - A Constituição da República, ao outorgar às Comissões Parlamentares de Inquérito "poderes de investigação próprios das autoridades judiciais" (art. 58, $\S 3^{\circ}$ ), claramente delimitou a natureza de suas atribuições institucionais, restringindo-as, unicamente, ao campo da indagação probatória, com absoluta exclusão de quaisquer outras prerrogativas que se incluem, ordinariamente, na esfera de competência dos magistrados e Tribunais, inclusive aquelas que decorrem do poder geral de cautela conferido aos juízes, como o poder de decretar a indisponibilidade dos bens pertencentes a pessoas sujeitas à investigação parlamentar. A circunstância de os poderes investigatórios de uma CPI serem essencialmente limitados levou a jurisprudência constitucional do Supremo Tribunal Federal a advertir que as Comissões Parlamentares de Inquérito não podem formular acusações e nem punir delitos (RDA 199/205, Rel. Min. PAULO BROSSARD), nem desrespeitar o privilégio contra a auto-incriminação que assiste a qualquer indiciado ou testemunha (RDA 196/197, Rel. Min. CELSO DE MELLO - HC 79.244-DF, Rel. Min. SEPÚLVEDA PERTENCE), nem decretar a prisão de qualquer pessoa, exceto nas hipóteses de flagrância (RDA 196/195, Rel. Min. CELSO DE MELLO -RDA 199/205, Rel. Min. PAULO BROSSARD). [...] A QUEBRA DO SIGILO CONSTITUI PODER INERENTE À COMPETÊNCIA INVESTIGATÓRIA DAS COMISSÕES PARLAMENTARES DE INQUÉRITO. - O sigilo bancário, o sigilo fiscal e o sigilo telefônico (sigilo este que incide sobre os dados/registros telefônicos e que não se identifica com a inviolabilidade das comunicações telefônicas) - ainda que representem projeções específicas do direito à intimidade, fundado no art. $5^{\circ}, \mathrm{X}$, da Carta Política - não se revelam oponíveis, em nosso sistema jurídico, às Comissões Parlamentares de Inquérito, eis que o ato que lhes decreta a quebra traduz natural derivação dos poderes de investigação que foram conferidos, pela própria Constituição da República, aos órgãos de investigação parlamentar. As Comissões Parlamentares de Inquérito, no entanto, para decretarem, legitimamente, por autoridade própria, a quebra do sigilo bancário, do sigilo fiscal e/ou do sigilo telefônico, relativamente a pessoas por elas investigadas, devem demonstrar, a partir de meros indícios, a existência concreta de causa provável que legitime a medida excepcional (ruptura da esfera de intimidade de quem se acha sob investigação), justificando a necessidade de sua efetivação no procedimento de ampla investigação dos fatos determinados que deram causa à instauração do inquérito

${ }^{1040}$ Decisão publicada no Diário da Justiça de 12 de maio de 2000, p. 00020.

${ }^{1041}$ De dados telefônicos, e não a interceptação do conteúdo das comunicações. 
parlamentar, sem prejuízo de ulterior controle jurisdicional dos atos em referência $\left(\mathrm{CF}\right.$, art. $5^{\circ}, \mathrm{XXXV)}$. - As deliberações de qualquer Comissão Parlamentar de Inquérito, à semelhança do que também ocorre com as decisões judiciais (RTJ 140/514), quando destituídas de motivação, mostram-se írritas e despojadas de eficácia jurídica, pois nenhuma medida restritiva de direitos pode ser adotada pelo Poder Público, sem que o ato que a decreta seja adequadamente fundamentado pela autoridade estatal. - O caráter privilegiado das relações Advogado-cliente: a questão do sigilo profissional do Advogado, enquanto depositário de informações confidenciais resultantes de suas relações com o cliente. MOTIVAÇÃO PER RELATIONEM CONSTANTE DA DELIBERAÇÃO EMANADA DA COMISSÃO PARLAMENTAR DE INQUÉRITO. Tratando-se de motivação per relationem, impõe-se à Comissão Parlamentar de Inquérito - quando esta faz remissão a elementos de fundamentação existentes aliunde ou constantes de outra peça - demonstrar a efetiva existência do documento consubstanciador da exposição das razões de fato e de direito que justificariam o ato decisório praticado, em ordem a propiciar, não apenas o conhecimento do que se contém no relato expositivo, mas, sobretudo, para viabilizar o controle jurisdicional da decisão adotada pela CPI. É que tais fundamentos - considerada a remissão a eles feita - passam a incorporar-se ao próprio ato decisório ou deliberativo que a eles se reportou. Não se revela viável indicar, a posteriori, já no âmbito do processo de mandado de segurança, as razões que deveriam ter sido expostas por ocasião da deliberação tomada pela Comissão Parlamentar de Inquérito, pois a existência contemporânea da motivação - e não a sua justificação tardia - constitui pressuposto de legitimação da própria resolução adotada pelo órgão de investigação legislativa, especialmente quando esse ato deliberativo implicar ruptura da cláusula de reserva pertinente a dados sigilosos. A QUESTÃO DA DIVULGAÇÃO DOS DADOS RESERVADOS E O DEVER DE PRESERVAÇÃO DOS REGISTROS SIGILOSOS. - A Comissão Parlamentar de Inquérito, embora disponha, ex propria auctoritate, de competência para ter acesso a dados reservados, não pode, agindo arbitrariamente, conferir indevida publicidade a registros sobre os quais incide a cláusula de reserva derivada do sigilo bancário, do sigilo fiscal e do sigilo telefônico. Com a transmissão das informações pertinentes aos dados reservados, transmite-se à Comissão Parlamentar de Inquérito - enquanto depositária desses elementos informativos -, a nota de confidencialidade relativa aos registros sigilosos. Constitui conduta altamente censurável - com todas as conseqüências jurídicas (inclusive aquelas de ordem penal) que dela possam resultar - a transgressão, por qualquer membro de uma Comissão Parlamentar de Inquérito, do dever jurídico de respeitar e de preservar o sigilo concernente aos dados a ela transmitidos. Havendo justa causa - e achando-se configurada a necessidade de revelar os dados sigilosos, seja no relatório final dos trabalhos da Comissão Parlamentar de Inquérito (como razão justificadora da adoção de medidas a serem implementadas pelo Poder Público), seja para efeito das comunicações destinadas ao Ministério Público ou a outros órgãos do Poder Público, para os fins a que se refere o art. 58, $\S 3^{\circ}$, da Constituição, seja, ainda, por razões imperiosas ditadas pelo interesse social - a divulgação do segredo, precisamente porque legitimada pelos fins que a motivaram, não configurará situação de ilicitude, muito embora traduza providência revestida de absoluto grau de excepcionalidade. POSTULADO CONSTITUCIONAL DA RESERVA DE JURISDIÇÃO: UM TEMA AINDA PENDENTE DE DEFINIÇÃO PELO SUPREMO TRIBUNAL FEDERAL. O postulado da reserva constitucional de jurisdição importa em submeter, à esfera única de decisão dos magistrados, a prática de determinados atos cuja realização, por efeito de explícita determinação constante do próprio texto da Carta Política, somente pode emanar do juiz, e não de terceiros, inclusive daqueles a quem se haja eventualmente atribuído o exercício de "poderes de investigação próprios das autoridades judiciais". A cláusula constitucional da reserva de jurisdição que incide sobre determinadas matérias, como a busca domiciliar $\left(\mathrm{CF}\right.$, art. $5^{\circ}$, $\mathrm{XI})$, a interceptação telefônica $\left(\mathrm{CF}\right.$, art. $\left.5^{\circ}, \mathrm{XII}\right)$ e a decretação da prisão de qualquer pessoa, ressalvada a hipótese de flagrância $\left(\mathrm{CF}\right.$, art. $\left.5^{\circ}, \mathrm{LXI}\right)$ - traduz a 
noção de que, nesses temas específicos, assiste ao Poder Judiciário, não apenas o direito de proferir a última palavra, mas, sobretudo, a prerrogativa de dizer, desde logo, a primeira palavra, excluindo-se, desse modo, por força e autoridade do que dispõe a própria Constituição, a possibilidade do exercício de iguais atribuições, por parte de quaisquer outros órgãos ou autoridades do Estado. Doutrina. - O princípio constitucional da reserva de jurisdição, embora reconhecido por cinco (5) Juízes do Supremo Tribunal Federal - Min. CELSO DE MELLO (Relator), Min. MARCO AURÉLIO, Min. SEPÚlVEDA PERTENCE, Min. NÉRI DA SILVEIRA e Min. CARLOS VELLOSO (Presidente) - não foi objeto de consideração por parte dos demais eminentes Ministros do Supremo Tribunal Federal, que entenderam suficiente, para efeito de concessão do writ mandamental, a falta de motivação do ato impugnado.

Confirmando essa competência das Comissões Parlamentares de Inquérito para decretar, em ato motivado e com objeto bem delimitado ("fato certo e concreto"), a “quebra" dos sigilos fiscal, bancário e telefônico: (i) Mandado de Segurança 23639/DF, Relator Ministro Celso de Mello, julgado pelo Tribunal Pleno em 16 de novembro de $2000^{1042}$; (ii) Mandado de Segurança 23652/DF, Relator Ministro Celso de Mello, julgado em 22 de novembro de 2000 ${ }^{1043}$; (iii) Mandado de Segurança 23964/DF, Relator Ministro Celso de Mello, julgado pelo Tribunal Pleno em 30 de agosto de $2001^{1044}$; (iv) Mandado de Segurança 23851/DF, Relator Ministro Celso de Mello, julgado pelo Tribunal Pleno em 26 de setembro de 2001 ${ }^{1045}$; (v) Habeas Corpus 84758/GO, Relator Ministro Celso de Mello, julgado pelo Tribunal Pleno em 25 de maio de 2006 ${ }^{1046}$; e (vi) Agravo Regimental no Inquérito 2206/DF, Relator Ministro Marco Aurélio, julgado pelo Tribunal Pleno em 10 de novembro de $2006^{1047}$. Vários dos acórdãos ressaltam, explicitamente, que a "quebra" de sigilo não pode ser usada como instrumento de devassa indiscriminada. Assim, não pode haver levantamendo geral do segredo para buscar irregularidades ou crimes que justifiquem essa "quebra", trilhando, portanto, um caminho "inverso" ao permitido pela legislação.

No Habeas Corpus 75232/RJ, Relator Ministro Carlos Velloso, Relator para o acórdão Ministro Maurício Corrêa, julgado pelo Tribunal Pleno em 7 de maio de $1997^{1048}$, o primeiro entendeu que os dados referentes a ligações telefônicas, guardados pelas operadoras de sistemas de telefonia, ou seja, os extratos referentes aos números chamados, inserem-se na proteção das "comunicações telefônicas" do inciso XII do artigo $5^{\circ}$ da Constituição Federal: “[...] comunicações telefônicas não significam, apenas, as conversas

\footnotetext{
1042 Decisão publicada no Diário da Justiça de 16 de fevereiro de 2001, p. 00091.

${ }^{1043}$ Decisão publicada no Diário da Justiça de 16 de fevereiro de 2001, p. 00092.

${ }^{1044}$ Decisão publicada no Diário da Justiça de 21 de junho de 2002, p. 00098.

1045 Decisão publicada no Diário da Justiça de 21 de junho de 2002, p. 00098.

${ }^{1046}$ Decisão publicada no Diário da Justiça de 16 de junho de 2006, p. 00005.

${ }^{1047}$ Decisão publicada no Diário da Justiça de 2 de fevereiro de 2007, p. 00073.

1048 Decisão publicada no Diário da Justiça de 24 de agosto de 2001, p. 00043.
} 
havidas por telefone, mas tudo o que com elas - comunicações telefônicas - se relaciona. [...]". Logo, a disciplina de "quebra" desses dados teria de ser a da Lei 9.296/1996. Reconheceu que uma CPI tem poderes para ordenar, por si, a "quebra" do sigilo de dados ou registros telefônicos, mas tem de seguir os parâmetros e especificações compatíveis dessa lei.

O Ministro Sepúlveda Pertence, por sua vez, entendeu que os registros telefônicos não encontram proteção nesse dispositivo constitucional, que protege só a "comunicação de dados", e não os dados em si. Chegou, porém, a propor a conversão do "habeas corpus" em mandado de segurança, mas a maioria não acompanhou a proposta e acabou não o conhecendo, por entender que não havia risco à liberdade de locomoção. É a ementa:

HABEAS-CORPUS. FINALIDADE: PROTEÇÃO AO DIREITO DE
LOCOMOÇÃO. CPI DOS TÍTULOS PÚBLICOS. QUEBRA DE SIGILO
TELEFÔNICO: SALVAGUARDA DO DIREITO À INTIMIDADE.
AUSÊNCIA DE AMEAÇA À LIBERDADE DE IR E VIR. VIA IMPRÓPRIA
DO WRIT. Objetivando as razões da impetração salvaguardar o direito à
intimidade, sem demonstração de que a quebra do sigilo telefônico determinada
por ato da CPI instituída para apurar irregularidades na emissão de títulos
públicos constitua efetiva ameaça à liberdade de ir e vir do paciente, não é o
habeas-corpus a via adequada à cessação do imputado ato ilegal. Habeas corpus
não conhecido.

A Segunda Turma não conheceu do Recurso Extraordinário 219780/PE, Relator Ministro Carlos Velloso, julgado em 13 de abril de 1999, mas entendeu que o sigilo bancário, espécie de direito à privacidade, só pode ser quebrado com observância das disposições que o regem ${ }^{1049}$ :

CONSTITUCIONAL. SIGILO BANCÁRIO: QUEBRA. ADMINISTRADORA
DE CARTÕES DE CRÉDITO. CF, art. $5^{\circ}$, X. I. - Se é certo que o sigilo
bancário, que é espécie de direito à privacidade, que a Constituição protege art.
$5^{\circ}$, X não é um direito absoluto, que deve ceder diante do interesse público, do
interesse social e do interesse da Justiça, certo é, também, que ele há de ceder na
forma e com observância de procedimento estabelecido em lei e com respeito ao
princípio da razoabilidade. No caso, a questão foi posta, pela recorrente, sob o
ponto de vista puramente constitucional, certo, entretanto, que a disposição
constitucional é garantidora do direito, estando as exceções na norma
infraconstitucional. II. - R.E. não conhecido.

O Supremo firmou o entendimento de que cabe "habeas corpus" para impugnar autorização judicial para fazer prova em procedimento penal e, também, quando em jogo eventual constrangimento à liberdade física, contra decisão denegatória de mandado de segurança, conforme Habeas Corpus 84869, Relator Ministro Sepúlveda Pertence, julgado

${ }^{1049}$ Decisão publicada no Diário da Justiça de 10 de setembro de 1999, p. 00023. 
pela Primeira Turma em 21 de junho de $2005^{1050}$, em que se destacou que "não cabe invocar proteção constitucional da privacidade em relação a registros públicos”, como Cartórios de Registro de Imóveis e Juntas Comerciais.

No Recurso Extraordinário 418416/SC, Relator Ministro Sepúlveda Pertence, julgado pelo Tribunal Pleno em 10 de maio de $2006^{1051}$, o STF resolveu estabelecer a exata extensão do inciso XII do artigo $5^{\circ}$ da Constituição Federal no que se refere à inviolabilidade dos dados: o sigilo recai sobre a comunicação de dados, e não sobre os dados em si. Veja-se o item IV da ementa:

[...] IV - Proteção constitucional ao sigilo das comunicações de dados - art. $5^{\circ}$, XVII, da CF: ausência de violação, no caso. 1. Impertinência à hipótese da invocação da AP 307 (Pleno, 13.12.94, Galvão, DJU 13.10.95), em que a tese da inviolabilidade absoluta de dados de computador não pode ser tomada como consagrada pelo Colegiado, dada a interferência, naquele caso, de outra razão suficiente para a exclusão da prova questionada - o ter sido o microcomputador apreendido sem ordem judicial e a conseqüente ofensa da garantia da inviolabilidade do domicílio da empresa - este segundo fundamento bastante, sim, aceito por votação unânime, à luz do art. $5^{\circ}$, XI, da Lei Fundamental. 2. Na espécie, ao contrário, não se questiona que a apreensão dos computadores da empresa do recorrente se fez regularmente, na conformidade e em cumprimento de mandado judicial. 3. Não há violação do art. $5^{\circ}$. XII, da Constituição que, conforme se acentuou na sentença, não se aplica ao caso, pois não houve "quebra de sigilo das comunicações de dados (interceptação das comunicações), mas sim apreensão de base física na qual se encontravam os dados, mediante prévia e fundamentada decisão judicial". 4. A proteção a que se refere o art.5 $5^{\circ}$, XII, da Constituição, é da comunicação "de dados" e não dos "dados em si mesmos", ainda quando armazenados em computador. (cf. voto no MS 21.729, Pleno, 5.10.95, red. Néri da Silveira - RTJ 179/225, 270) [...].

Anote-se, ainda nesse caso, passagem do voto do Ministro Carlos Ayres Britto:

[...] a Constituição não confunde privacidade ["rectius": vida privada] com intimidade. Tanto que usa de duas palavras diferentes, ligando uma à outra pela conjunção aditiva "e". Privacidade, para mim, é uma comunicação reservada entre pessoas, digamos, em "en petit comité". É a pessoa se relacionando com os seus amigos, com seus parentes. Ao passo que intimidade é a pessoa consigo mesma, sozinha. Exemplo: alguém escrevendo um diário - está no uso de sua intimidade. [...] Ao passo que uma comunicação por "e-mail” já é privacidade; uma carta já é privacidade. Porém, um diário, não; é absolutamente intimidade. Quando a pessoa está consigo mesma, é intimidade; quando está com os seus amigos, parentes -, aí se dá a privacidade. Agora, tanto a intimidade como a privacidade têm o seu "locus", o seu "habitat" na casa em que se mora ou em que se trabalha. Vejam como os três incisos se entrelaçam [os incisos X, XI e XII, do art. $5^{\circ}$ da Constituição Federal] [...].

No Recurso Extraordinário 461366/DF, Relator Ministro Marco Aurélio, julgado em 3 de agosto de $2007^{1052}$, a Primeira Turma entendeu que "[a] atuação fiscalizadora do

${ }^{1050}$ Decisão publicada no Diário da Justiça de 19 de agosto de 2005, p. 00046.

${ }^{1051}$ Decisão publicada no Diário da Justiça de 19 de dezembro de 2006, p. 00037.

1052 Decisão divulgada no Diário da Justiça Eletrônico 117, de 4 de outubro de 2007. 
Banco Central do Brasil não encerra a possibilidade de, no campo administrativo, alcançar dados bancários de correntistas, afastando o sigilo previsto no inciso XII do artigo $5^{\circ}$ da Constituição Federal".

No Referendo em Medida Cautelar no Mandado de Segurança 27483/DF, Relator Ministro Cezar Peluso, julgado pelo Pleno em 14 de agosto de $2008^{1053}$, o STF entendeu que, como não têm mais poder que os juízes, uma Comissão Parlamentar de Inquérito não tem competência para

[...] revogar, cassar, compartilhar, ou de qualquer outro modo quebrar sigilo legal e constitucionalmente imposto a processo judiciário. Trata-se de competência privativa do Poder Judiciário, ou seja, matéria da chamada reserva jurisdicional, onde o Judiciário tem, não apenas a primeira, mas também a última palavra. [...] [porque inclusive] nem outros órgãos jurisdicionais [que não os competentes para a causa respectiva] podem quebrar esse sigilo, não o podendo, a fortiori, as CPIs. [...]. (excerto do voto do Relator, destaques dele).

No caso, o Presidente da CPI das Escutas Telefônicas Clandestinas havia requisitado às operadoras de telefonia que remetessem cópias de todos os ofícios ordenando interceptações telefônicas no ano de 2007. Várias operadoras de telefonia fixa e imóvel então impetraram mandado de segurança contra esse ato, a fim de resguardar a intimidade das pessoas, entendimento acolhido pelo STF.

O Ministro Relator sugeriu que, se a Comissão tivesse interesse, poderia requisitar as seguintes informações: (i) relação dos juízos que expediram os mandados, bem como a quantidade destes e dos terminais objeto das ordens (quantos mandados e quantos terminais); (ii) relação dos órgãos policiais específicos destinatários das ordens judiciais; (iii) relação dos órgãos que requereram as interceptações; (iv) relação das cidades em que se situam os terminais objeto das ordens de interceptações; e (v) duração total de cada interceptação. Por outro lado, ficaria vedada a remessa dos seguintes dados: (i) número de cada processo; (ii) nome de qualquer das partes ou dos titulares dos terminais interceptados; (iii) os números dos terminais; e (iv) cópias dos mandados e das decisões que os acompanharam ou que os determinaram.

É a ementa:

EMENTAS: 1. COMISSÃO PARLAMENTAR DE INQUÉRITO. Interceptação telefônica. Sigilo judicial. Segredo de justiça. Quebra. Impossibilidade jurídica. Requisição de cópias das ordens judiciais e dos mandados. Liminar concedida. Admissibilidade de submissão da liminar ao Plenário, pelo Relator, para referendo. Precedentes (MS no 24.832-MC, MS no 26.307-MS e MS no 26.900MC). Voto vencido. Pode o Relator de mandado de segurança submeter ao

${ }^{1053}$ Decisão divulgada no Diário da Justiça Eletrônico 192, de 9 de outubro de 2008. 
Plenário, para efeito de referendo, a liminar que haja deferido. 2. COMISSÃO PARLAMENTAR DE INQUÉRITO - CPI. Prova. Interceptação telefônica. Decisão judicial. Sigilo judicial. Segredo de justiça. Quebra. Requisição, às operadoras, de cópias das ordens judiciais e dos mandados de interceptação. Inadmissibilidade. Poder que não tem caráter instrutório ou de investigação. Competência exclusiva do juízo que ordenou o sigilo. Aparência de ofensa a direito líquido e certo. Liminar concedida e referendada. Voto vencido. Inteligência dos arts. $5^{\circ}, \mathrm{X}$ e LX, e 58, $\S 3^{\circ}$, da CF, art. 325 do CP, e art. 10, cc. art. $1^{\circ}$ da Lei federal $n^{\circ}$ 9.296/96. Comissão Parlamentar de Inquérito não tem poder jurídico de, mediante requisição, a operadoras de telefonia, de cópias de decisão nem de mandado judicial de interceptação telefônica, quebrar sigilo imposto a processo sujeito a segredo de justiça. Este é oponível a Comissão Parlamentar de Inquérito, representando expressiva limitação aos seus poderes constitucionais.

No Agravo Regimental no Inquérito 2206/DF, já mencionado, entendeu-se, conforme ementa:

[...] [o] deferimento de diligência requerida pelo Ministério Público há de fazerse em sintonia com as balizas subjetivas e objetivas da investigação em curso, descabendo providências que extravasam o campo da razoabilidade, como, por exemplo, a quebra de sigilo bancário generalizada.

Destacamos, ainda, trecho do voto da Ministra Cármen Lúcia: “[...] [o]s segredos do ser são absolutos - aquilo que digo em um confessionário, o que digo ao médico -; os segredos do ter não o são [...]".

O STF chegou a entender também que a Administração não pode proceder à apreensão de livros contábeis e documentos fiscais em escritório, nos ambientes fechados ao público, sem autorização judicial, sendo eventuais provas assim obtidas ilícitas, como, por exemplo, no Habeas Corpus 82788/RJ, Relator Ministro Celso de Mello, julgado pela Segunda Turma em 12 de abril de $2005^{1054}$.

\section{Sigilo de correspondência.}

No Recurso em Mandado de Segurança 11274, Relator Ministro Evandro Lins, julgado pelo Tribunal Pleno em 27 de novembro de $1963^{1055}$, o Supremo entendeu, nas palavras do Relator:

[a] inviolabilidade da correspondência assegurada na Constituição não envolve, evidentemente, a correspondência comercial, para efeitos de fiscalização, quando a carta já chegou ao destinatário. O interesse público sobrepõe-se, no caso, ao interesse privado. [...].

\footnotetext{
${ }^{1054}$ Decisão publicada no Diário da Justiça de 2 de junho de 2006, p. 00043.
}

${ }^{1055}$ Decisão publicada no Diário da Justiça de 16 de abril de 1964. 
No Habeas Corpus 70814/SP, Relator Ministro Celso de Mello, julgado em $1^{\circ}$ de março de $1994^{1056}$, a Primeira Turma entendeu, conforme ementa, que

[a] A administração penitenciária, com fundamento em razões de segurança pública, de disciplina prisional ou de preservação da ordem jurídica, pode, sempre excepcionalmente, e desde que respeitada a norma inscrita no art. 41, parágrafo único, da Lei n. 7.210/84, proceder a interceptação da correspondência remetida pelos sentenciados, eis que a cláusula tutelar da inviolabilidade do sigilo epistolar não pode constituir instrumento de salvaguarda de praticas ilícitas. [...].

\title{
14. Habeas data.
}

No Recurso Ordinário em Habeas Data 22/DF, Relator Ministro Marco Aurélio, Relator para o Acórdão Ministro Celso de Mello, julgado pelo Pleno do Supremo em 19 de setembro de $1991^{1057}$, estabeleceu-se o entendimento acerca do interesse de agir quanto ao habeas data:

\begin{abstract}
E M E N T A: HABEAS DATA - NATUREZA JURÍDICA - REGIME DO PODER VISÍVEL COMO PRESSUPOSTO DA ORDEM DEMOCRÁTICA - A JURISDIÇÃO CONSTITUCIONAL DAS LIBERDADES - SERVIÇO NACIONAL DE INFORMAÇÕES (SNI) - ACESSO NÃO RECUSADO AOS REGISTROS ESTATAIS - AUSÊNCIA DO INTERESSE DE AGIR RECURSO IMPROVIDO. - A Carta Federal, ao proclamar os direitos e deveres individuais e coletivos, enunciou preceitos básicos, cuja compreensão é essencial a caracterização da ordem democrática como um regime do poder visível. - O modelo político-jurídico, plasmado na nova ordem constitucional, rejeita o poder que oculta e o poder que se oculta. Com essa vedação, pretendeu o constituinte tornar efetivamente legítima, em face dos destinatários do poder, a prática das instituições do Estado. - O habeas data configura remédio jurídico-processual, de natureza constitucional, que se destina a garantir, em favor da pessoa interessada, o exercício de pretensão jurídica discernível em seu tríplice aspecto: (a) direito de acesso aos registros; (b) direito de retificação dos registros e (c) direito de complementação dos registros. - Trata-se de relevante instrumento de ativação da jurisdição constitucional das liberdades, a qual representa, no plano institucional, a mais expressiva reação jurídica do Estado às situações que lesem, efetiva ou potencialmente, os direitos fundamentais da pessoa, quaisquer que sejam as dimensões em que estes se projetem. - $\mathrm{O}$ acesso ao habeas data pressupõe, dentre outras condições de admissibilidade, a existência do interesse de agir. Ausente o interesse legitimador da ação, torna-se inviável o exercício desse remédio constitucional. - A prova do anterior indeferimento do pedido de informação de dados pessoais, ou da omissão em atendê-lo, constitui requisito indispensável para que se concretize o interesse de agir no habeas data. Sem que se configure situação prévia de pretensão resistida, há carência da ação constitucional do habeas data. (destaque nosso).
\end{abstract}

Esse posicionamento foi confirmado no Recurso em Habeas Data 24/DF, Relator Ministro Maurício Corrêa, julgado pela Segunda Turma do Supremo Tribunal Federal em

\footnotetext{
${ }^{1056}$ Decisão publicada no Diário da Justiça de 24 de junho de 1994, p. 16649.
}

${ }^{1057}$ Decisão publicada no Diário da Justiça de $1^{\circ}$ de setembro de 1995, p. 27378. 
28 de novembro de $1996^{1058}$, já sob a égide da Lei 9.507/1997.

O Tribunal, em ação no qual a autora pleiteava ao Banco do Brasil as informações constantes de sua ficha funcional, entendeu que o coator era empresa sujeita a regime de direito privado, apesar de integrar a Administração Indireta na qualidade de sociedade de economia mista, não sendo ente governamental para fins desse remédio, e que o uso da ficha de pessoal é restrito a seu possuidor, o banco empregador, e não disponível a terceiros. A decisão foi prolatada no Recurso Extraordinário 165304/MG, Relator Ministro Octavio Gallotti, julgado pelo Tribunal Pleno em 19 de outubro de $2000^{1059}$. 


\title{
APÊNDICE B - JULGADOS DO SUPERIOR TRIBUNAL DE JUSTIÇA.
}

\section{Intimidade e citação em processo penal.}

No Recurso Especial 93254/RS, Relator Ministro Luiz Vicente Cernicchiaro, julgado em 8 de outubro de $1996^{1060}$, a Sexta Turma assim entendeu quanto à citação por edital em processo penal:

RESP - PROCESSUAL PENAL - CITAÇÃO - EDITAL - INTIMIDADE - A citação leva ao conhecimento do réu a existência de processo. Cumpre especificar a imputação. Em se tratando de citação - edital, basta a menção ao artigo de lei correspondente, a fim de ser preservada a intimidade.

Segundo o Relator,

\begin{abstract}
[q]uando esse ato [a citação] é efetivado por edital, dada a publicidade que possa decorrer, em homenagem à intimidade, recomenda-se discrição, sendo bastante a indicação do artigo da lei que capitula a infração penal. Caso contrário, o resguardo do réu e da vítima ficará afetado. Daí a parcimônia da informação, sem quebrar o chamamento pela imprensa. Atinge-se a finalidade, respeitando-se a reserva da vida privada tanto do réu, quanto da vítima.
\end{abstract}

\section{Direito de imagem.}

O Recurso Especial 58101/SP, Relator Ministro Cesar Asfor Rocha, julgado pela Quarta Turma em 16 de setembro de $1997^{1061}$, tratava de uma ação que uma atriz e modelo ajuizara contra uma empresa que publicara uma foto sua, em 1991, retirada de um vídeo publicitário que fizera para uma outra empresa, em 1985, em que aparecia com os seios desnudos. O seu contrato autorizara o uso da sua imagem por tempo determinado apenas para aquele fim. A ação objetivava indenização por uso indevido da imagem da autora. A ré alegou que a imagem fora usada para ilustrar matéria de cunho eminentemente jornalístico, tese sufragada pelo Tribunal "a quo".

Segundo o Relator, o deslinde da controvérsia reclamava

[...] a conciliação de dois valores sagrados das sociedades culturalmente avançadas, quais sejam o da liberdade da informação (no seu sentido mais genérico, aí incluindo-se a divulgação da imagem) e o da proteção à intimidade, em que o resguardo da própria imagem está subsumido. (grifo nosso).

\footnotetext{
${ }^{1060}$ Decisão publicada no Diário da Justiça de 5 de maio de 1997, p. 17139.
}

${ }^{1061}$ Decisão publicada no Diário da Justiça de 9 de março de 1998, p. 114. 
O caso dos autos, conforme prossegue o Relator em seu voto, não se tratava de fotografia tirada espontaneamente e nem em acontecimento público:

[o]ra, a lesão ao direito à imagem independe dos fins a que se serviu a cogitada fotografia. Pouco importa ter ou não sido utilizada comercialmente, bem como que tenha ou não, dessa divulgação, decorrido lucro ou aumento de circulação da revista, pois esses são elementos absolutamente dispensáveis para o aferimento do ato ilícito praticado pela recorrida, que acontece com a simples divulgação da imagem, nas circunstâncias apontadas, já que a ofensa é "in re ipsa”, embora não se possa olvidar que essa espécie de fotografia quase sempre permite o aumento das vendas das revistas. [...] Por outro lado, o só fato de a recorrente já ter posado outras vezes nua não importa no perdimento do direito à sua imagem, nem pode levar a que se tenha por reduzida a garantia de sua privacidade. De igual sorte, a só circunstância de que a recorrente possa ser pessoa célebre e conhecida, não induz a que se conclua que essa prerrogativa de que se cogita possa ser limitada. [...] De outra banda, mesmo que se pudesse considerar como jornalística a matéria cogitada, não se poderia admitir a publicação de imagem íntima, em cena de nudez, que só foi licenciada, como sempre afirmado, para específicos fins.

A Turma seguiu por unanimidade o voto do Relator, resultando na seguinte ementa:

CIVIL. DIREITO DE IMAGEM. REPRODUÇÃO INDEVIDA. LEI N. 5.988/73 (ART. 49, I, "F"). DEVER DE INDENIZAR. CÓDIGO CIVIL (ART. 159). A imagem é a projeção dos elementos visíveis que integram a personalidade humana, é a emanação da própria pessoa, é o eflúvio dos caracteres físicos que a individualizam. A sua reprodução, conseqüentemente, somente pode ser autorizada pela pessoa a que pertence, por se tratar de direito personalíssimo, sob pena de acarretar o dever de indenizar que, no caso, surge com a sua própria utilização indevida. É certo que não se pode cometer o delírio de, em nome do direito de privacidade, estabelecer-se uma redoma protetora em torno de uma pessoa para torná-la imune de qualquer veiculação atinente à sua imagem; todavia, não se deve exaltar a liberdade de informação a ponto de se consentir que o direito à própria imagem seja postergado, pois a sua exposição deve condicionar-se à existência de evidente interesse jornalístico que, por sua vez, tem como referencial o interesse público, a ser satisfeito, de receber informações, isso quando a imagem divulgada não tiver sido captada em cenário público ou espontaneamente. Recurso conhecido e provido.

O Recurso Especial 85905/RJ, Relator Ministro Ari Pargendler, julgado pela Terceira Turma em 19 de novembro de $1999^{1062}$, embora refira-se, na ementa, ao direito de imagem, não foi conhecido por não ter havido dano moral e também por questões processuais:

CIVIL. USO INDEVIDO DA IMAGEM. INDENIZAÇÃO DE DANOS MORAIS. O uso não autorizado de uma foto que atinge a própria pessoa, quanto ao decoro, honra, privacidade, etc., e, dependendo das circunstâncias, mesmo sem esses efeitos negativos, pode caracterizar o direito à indenização pelo dano moral, independentemente da prova de prejuízo. Hipótese, todavia, em que o autor da ação foi retratado de forma acidental, num contexto em que o objetivo

${ }^{1062}$ Decisão publicada no Diário da Justiça de 13 de dezembro de 1999, p. 140. 
não foi a exploração de sua imagem. Recurso especial não conhecido.

O Recurso Especial 595600/SC, Relator Ministro Cesar Asfor Rocha, julgado pela Quarta Turma em 18 de março de $2004^{1063}$, tratava de uma ação ajuizada por uma mulher, que não era atriz, modelo e nem pessoa que auferia lucros profissionalmente com sua imagem, flagrada com os seios desnudos numa praia, que teve fotografia sua publicada num jornal do Estado de Santa Catarina. O pedido era de indenização por danos morais. $\mathrm{O}$ Relator destacou que,

[n]a espécie, a recorrida [o jornal] divulgou fotografia, sem chamada sensacionalista, de imagem da recorrente praticando "topless" "numa praia lotada em pleno feriado" [...]. Isto é, a própria recorrente optou por revelar sua intimidade, ao expor o peito desnudo em local público de grande movimento, inexistindo qualquer conteúdo pernicioso na veiculação, que se limitou a registrar sobriamente o evento sem sequer citar o nome da autora. Assim, se a demandante expõe sua imagem em cenário público, não é ilícita ou indevida sua reprodução sem conteúdo sensacionalista pela imprensa, uma vez que a proteção à privacidade encontra limite na própria exposição realizada.

Seu voto foi seguido por unanimidade:

DIREITO CIVIL. DIREITO DE IMAGEM. TOPLESS PRATICADO EM CENÁRIO PÚBLICO. Não se pode cometer o delírio de, em nome do direito de privacidade, estabelecer-se uma redoma protetora em torno de uma pessoa para torná-la imune de qualquer veiculação atinente a sua imagem. Se a demandante expõe sua imagem em cenário público, não é ilícita ou indevida sua reprodução pela imprensa, uma vez que a proteção à privacidade encontra limite na própria exposição realizada. Recurso especial não conhecido.

O Recurso Especial 440150/RJ, Relator Ministro Francisco Peçanha Martins, julgado pela Segunda Turma em 19 de abril de $2005^{1064}$, cuidava de uma ação proposta por um menor, representado por sua mãe, pleiteando danos morais contra o Município do Rio de Janeiro, que publicara a foto do menino, sem autorização, em periódico de cunho didático e científico de circulação restrita destinado aos professores da rede pública de ensino. O voto do Relator consignou:

[o] conceito de intimidade refere-se aos fatos e manifestações verificados na esfera mais restrita dos relacionamentos estabelecidos pela pessoa. São as relações firmadas com a família e com amigos mais íntimos. Outrossim, em se tratando do conceito de vida privada, tem-se o alargamento dessas vinculações. Ela diz respeito aos relacionamentos no âmbito profissional, do ensino regular, acadêmico, comercial, religioso, dentre outros, porém limitados pela proximidade e confiança. [...] Imiscuir-se nessas relações, sem a devida autorização, consiste em violar direito de privacidade, garantia fundamental, inclusive. Ao utilizar a imagem do estudante para ilustrar o periódico, sem a competente anuência dos seus pais, o ente federativo violou o direito da pessoa

${ }^{1063}$ Decisão publicada no Diário da Justiça de 13 de setembro de 2004, p. 259.

${ }^{1064}$ Decisão publicada no Diário da Justiça de 6 de junho de 2005, p. 250. 
de se manter distante da publicidade indesejada e de resguardar a sua privacidade.

A decisão foi unânime:

PROCESSUAL CIVIL. ADMINISTRATIVO. RESPONSABILIDADE CIVIL DO ESTADO. IMAGEM. USO INDEVIDO. DANO MORAL. INDENIZAÇÃO. CABIMENTO. 1. Ingerência na vida privada, sem a devida autorização da pessoa, consiste em violar direito de privacidade. 2. Cabe indenização por dano moral pelo uso indevido da imagem que, por se tratar de direito personalíssimo que garante ao indivíduo a prerrogativa de objetar sua exposição, no que se refere à sua privacidade. 3. Recurso especial do Ministério Público do Estado do Rio de Janeiro provido e recurso especial de Daniel Faria Loureiro parcialmente provido.

\section{Sigilo bancário.}

Do Agravo Regimental no Inquérito 187/DF, Relator Ministro Salvio de Figueiredo Teixeira, julgado pela Corte Especial em 21 de agosto de $1996^{1065}$, produziu-se a seguinte ementa a respeito do sigilo bancário:

DIREITO CONSTITUCIONAL E PROCESSUAL PENAL. PEDIDO DE
QUEBRA DE SIGILO BANCÁRIO. DIREITO NÃO-ABSOLUTO À
INTIMIDADE. INDÍCIOS DE AUTORIA. VERDADE REAL.
DEFERIMENTO. JUÍZO DE VALOR SOBRE A PROVA PRETENDIDA.
RECURSO DESPROVIDO. I - É certo que a proteção ao sigilo bancário
constitui espécie do direito à intimidade consagrado no art. $5^{\circ}$, X, da
Constituição, direito esse que revela uma das garantias do indivíduo contra o
arbítrio do Estado. Todavia, não consubstancia ele direito absoluto, cedendo
passo quando presentes circunstâncias que denotem a existência de um interesse
público superior. Sua relatividade, no entanto, deve guardar contornos na própria
lei, sob pena de se abrir caminho para o descumprimento da garantia à
intimidade constitucionalmente assegurada. II - Tendo o inquérito policial por
escopo apurar a existência do fato delituoso, completa deve ser a investigação
criminal, em prestígio ao princípio da verdade real ínsito ao direito processual
penal. III - É impossível exercitar, "ab initio", um juízo de valor a respeito da
utilidade do meio de prova pretendido, tendo em vista que ele pode ser válido ou
não diante do contexto de todas as provas que efetivamente vierem a ser
colhidas.

No mesmo sentido, ver o Recurso Ordinário em Mandado de Segurança 9887/PR, Relatora Ministra Eliana Calmon, julgado pela Segunda Turma em 14 de agosto de $2001^{1066}$.

No Recurso Ordinário em Mandado de Segurança 8716/GO, Relator Ministro

\footnotetext{
1065 Decisão publicada no Diário da Justiça de 16 de setembro de 1996, p. 33651.

1066 Decisão publicada no Diário da Justiça de $1^{\circ}$ de outubro de 2001, p. 180, cuja ementa é: “ADMINISTRATIVO - SIGILO BANCÁRIO - SUSPEITA DE CRIME FINANCEIRO. 1. Doutrina e jurisprudência estão acordes quanto à inexistência de direito absoluto à privacidade, porque pode ser afastada a proteção deste direito quando razões plausíveis superem o direito individual. 2. Avaliação das razões que levam à quebra do princípio com o aval do Judiciário. 3. Recurso improvido".
} 
Milton Luiz Pereira, julgado pela Primeira Turma em 31 de março de $1998^{1067}$, ressaltou-se o entendimento de que o sigilo bancário, embora decorrente do direito à intimidade do inciso $\mathrm{X}$ do $\operatorname{artigo} 5^{\circ}$ da Constituição Federal, não é absoluto, cedendo diante do interesse público, por autorização judicial, mediante fundadas razões, como, no caso, inquérito civil preparatório de futura ação civil pública cuidando de malversação de dinheiro público por parte de prefeito e familiares:

AÇÃO CAUTELAR (EXIBIÇÃO DE DOCUMENTOS BANCÁRIOS).
LEGITIMIDADE DO MINISTÉRIO PÚBLICO ESTADUAL.
PROVIDÊNCIAS INVESTIGATÓRIAS URGENTES E PREPARATÓRIAS
PARA O INQUÉRITO CIVIL E AÇÃO CIVIL PÚBLICA. CONSTITUIÇÃO
FEDERAL, ARTS. 5., X E XII, 37, 127 E 129. LEI 4.595/64 (ART. 38). LEI
7.347/85. LEI 4.728/65 (ART. 4., PAR. 2.) E LEI 8.625/93 (ARTS. 25 E 26). 1.
A parla de relevante interesse público e social, ampliou-se ao âmbito de
atividades do Ministério Público para realizar atividades investigatórias,
alicerçando informações para promover o inquérito e ação civil pública (C.F.,
arts. 127 e 129, III, - Lei 7.347/85, arts. $1^{\circ}$ e $5^{\circ}$ ). 2. O sigilo bancário não é um
direito absoluto, quando demonstradas fundadas razões, podendo ser desvendado
por requisição do Ministério Público em medidas e procedimentos
administrativos, inquéritos e ações, mediante requisição submetida ao Poder
Judiciário. 3. A "quebra de sigilo" compatibiliza-se com a norma inscrita no art.
$5^{\circ}$, X e XII, C.F., consono jurisprudência do STF. 4. O princípio do contraditório
não prevalece no curso das investigações preparatórias incetadas [sic] pelo
Ministério Público (RE 136.239 - AG. REG. EM INQUÉRITO 897 - DJU de
24.03.95). 5. Não constitui ilegalidade ou abuso de poder, provimento judicial
aparelhando o MP na coleta de urgentes informações para apuração de ilícitos
civis e penais. 6. Recurso improvido.

O Habeas Corpus 8317/PA, Relator Ministro Fernando Gonçalves, julgado pela Sexta Turma em 28 de março de $2000^{1068}$, foi impetrado contra acórdão da Terceira Turma do Tribunal Regional Federal da $3^{\text {a }}$ Região, que determinara a quebra de sigilo bancário, entre outros, do paciente em dada ação penal. A Turma, seguindo orientação do STF, entendeu ser cabível "habeas corpus" toda vez que de um processo penal ou inquérito puder surgir, ainda que indiretamente, restrição à liberdade de locomoção:

HABEAS CORPUS. QUEBRA DE SIGILO BANCÁRIO.
ADMISSIBILIDADE. 1 - A idoneidade do "habeas corpus" como meio de
afastar constrangimento decorrente da violação do sigilo bancário,
desdobramento do direito à intimidade e à privacidade, que, por sua vez
compreende-se no campo mais amplo do direito à liberdade, consoante
autorizada doutrina, vem sendo admitida pela jurisprudência quando se tratar de
processo penal ou inquérito policial. 2 - Ordem concedida dada a carência de
fundamentação do despacho impositivo da violação do sigilo bancário sem
indicar elementos mínimos de prova quanto à autoria do delito.

O Recurso Ordinário em Mandado de Segurança 9880/PR, Relator Ministro

${ }^{1067}$ Decisão publicada no Diário da Justiça de 25 de maio de 1998, p. 11.

${ }^{1068}$ Decisão publicada no Diário da Justiça de 15 de maio de 2000, p. 201. 
Vicente Leal, julgado pela Sexta Turma em 25 de abril de $2000^{1069}$, também menciona a necessidade de prévia autorização judicial para a quebra do sigilo bancário:

\begin{abstract}
Mandado de segurança. Quebra de sigilo bancário. Autorização judicial. Crime contra o sistema financeiro nacional. Legalidade. - $\mathrm{O}$ ordenamento jurídico constitucional, a despeito de elevar à dignidade de garantia fundamental o direito à inviolabilidade da intimidade e da vida privada, autoriza a quebra de sigilo mediante prévia autorização judicial, na qual se justifique a necessidade da medida para fins de investigação criminal ou instrução processual criminal. Não se encontra eivada de ilegalidade a quebra de sigilo bancário determinada pela autoridade judiciária competente, fundada na necessidade de se apurar o crime de evasão de divisas e operação de câmbio não autorizada. - Recurso ordinário desprovido.
\end{abstract}

O Habeas Corpus 25560/PB, Relator Ministro Gilson Dipp, julgado pela Quinta Turma em 18 de novembro de $2003^{1070}$, deixa claro que o sigilo bancário, embora não absoluto, não pode ser arbitrariamente "quebrado":

CRIMINAL. HC. PATROCÍNIO INFIEL. APROPRIAÇÃO INDÉBITA. QUEBRA DE SIGILO BANCÁRIO. FUNDAMENTAÇÃOO SUFICIENTE. AUSÊNCIA DE PROTEÇÃO ABSOLUTA AO SIGILO. RESPALDO LEGAL. SUFICIENTE DELIMITAÇÃO TEMPORAL E DE FATOS. RELATIVIDADE DO DIREITO À PRIVACIDADE. LEGALIDADE DA MEDIDA. TRANCAMENTO DE INQUÉRITO POLICIAL. AUSÊNCIA DE JUSTA CAUSA NÃO-EVIDENCIADA. IMPROPRIEDADE DO WRIT. PRECEDENTES. ORDEM DENEGADA. Não há ilegalidade na decisão que decreta a quebra do sigilo bancário do paciente, se a mesma encontra-se devidamente fundamentada, demonstrando a presença de indícios suficientes de participação em crime. $\mathrm{O}$ sigilo bancário não possui proteção absoluta, dando lugar à exceção de "quebra" do mesmo, quando se verificar a presença de circunstâncias que evidenciem o interesse público a ser preservado. Hipótese em que a quebra de sigilo encontra respaldo legal, com pedido subsumido ao conteúdo normativo regulador da espécie. Não há irregularidade na decretação, se sobressai suficiente delimitação, temporal e de fatos, justificando a relatividade do direito à privacidade, frente a interesses de ordem pública, social e da própria justiça. Não se reconhece a falta de justa causa para o inquérito, quando o procedimento é baseado em elementos informativos que demonstram a prática, em tese, de crime e indicam a autoria. $\mathrm{O}$ mero indiciamento em inquérito não caracteriza constrangimento ilegal reparável via "habeas corpus". Precedentes. Ordem denegada.

No Habeas Corpus 21608/PR, Relator Ministro Jorge Scartezzini, julgado pela Quinta Turma em 24 de junho de $2003^{1071}$, firmou-se o entendimento de que a ilicitude de quebra de sigilo bancário, fiscal e telefônico não permite o trancamento de ação penal, desde que haja outras provas idôneas, por si, a embasar a persecução criminal:

PROCESSUAL PENAL - CRIME CONTRA O SISTEMA FINANCEIRO LAVAGEM DE DINHEIRO - QUEBRA DE SIGILO BANCÁRIO, FISCAL E

${ }^{1069}$ Decisão publicada no Diário da Justiça de 15 de maio de 2000, p. 202.
${ }^{1070}$ Decisão publicada no Diário da Justiça de 19 de dezembro de 2003 , p. 517.
${ }^{1071}$ Decisão publicada no Diário da Justiça de 15 de dezembro de 2003 , p. 330. 
DE CORRESPONDÊNCIA SEM AUTORIZAÇÃO JUDICIAL TRANCAMENTO DA AÇÃO PENAL - INVIABILIDADE - DENÚNCIA LASTREADA EM OUTRAS PROVAS. - É inviável o trancamento da ação penal quando a denúncia lastreia-se em outras provas que não aquelas apontadas como ilícitas. Assim, ainda que haja o reconhecimento da ilicitude da quebra de sigilo - bancário, fiscal e de correspondência - sem autorização judicial, o fato é que a peça inaugural encontra-se apta a dar prosseguimento à ação penal. Ordem denegada.

\section{O Recurso Especial 506232/PR, Relator Ministro Luis Fux, julgado pela Primeira} Turma em 2 de dezembro de $2003^{1072}$, firmou precedente a respeito da aplicabilidade, a fatos pretéritos, de normas tributárias destinadas a obter informações dos contribuintes:

TRIBUTÁRIO. NORMAS DE CARÁTER PROCEDIMENTAL. APLICAÇÃO INTERTEMPORAL. UTILIZAÇÃO DE INFORMAÇÕES OBTIDAS A PARTIR DA ARRECADAÇÃO DA CPMF PARA A CONSTITUIÇÃO DE CRÉDITO REFERENTE A OUTROS TRIBUTOS. RETROATIVIDADE PERMITIDA PELO ART. $144, \S 1^{\circ}$ DO CTN.

1. O resguardo de informações bancárias era regido, ao tempo dos fatos que permeiam a presente demanda (ano de 1998), pela Lei 4.595/64, reguladora do Sistema Financeiro Nacional, e que foi recepcionada pelo art. 192 da Constituição Federal com força de lei complementar, ante a ausência de norma regulamentadora desse dispositivo, até o advento da Lei Complementar $105 / 2001$.

2. O art. 38 da Lei 4.595/64, revogado pela Lei Complementar 105/2001, previa a possibilidade de quebra do sigilo bancário apenas por decisão judicial.

3. Com o advento da Lei 9.311/96, que instituiu a CPMF, as instituições financeiras responsáveis pela retenção da referida contribuição, ficaram obrigadas a prestar à Secretaria da Receita Federal informações a respeito da identificação dos contribuintes e os valores globais das respectivas operações bancárias, sendo vedado, a teor do que preceituava o $\S 3^{\circ}$ da art. 11 da mencionada lei, a utilização dessas informações para a constituição de crédito referente a outros tributos.

4. A possibilidade de quebra do sigilo bancário também foi objeto de alteração legislativa, levada a efeito pela Lei Complementar 105/2001, cujo art, $6^{\circ}$ dispõe: "Art. $6^{\circ}$ As autoridades e os agentes fiscais tributários da União, dos Estados, do Distrito Federal e dos Municípios somente poderão examinar documentos, livros e registros de instituições financeiras, inclusive os referentes a contas de depósitos e aplicações financeiras, quando houver processo administrativo instaurado ou procedimento fiscal em curso e tais exames sejam considerados indispensáveis pela autoridade administrativa competente."

5. A teor do que dispõe o art. 144, $\S 1^{\circ}$ do Código Tributário Nacional, as leis tributárias procedimentais ou formais têm aplicação imediata, ao passo que as leis de natureza material só alcançam fatos geradores ocorridos durante a sua vigência.

6. Norma que permite a utilização de informações bancárias para fins de apuração e constituição de crédito tributário, por envergar natureza procedimental, tem aplicação imediata, alcançando mesmo fatos pretéritos.

7. A exegese do art. $144, \S 1^{\circ}$ do Código Tributário Nacional, considerada a natureza formal da norma que permite o cruzamento de dados referentes à arrecadação da CPMF para fins de constituição de crédito relativo a outros tributos, conduz à conclusão da possibilidade da aplicação dos artigos $6^{\circ}$ da Lei Complementar 105/2001 e $1^{\circ}$ da Lei $10.174 / 2001$ ao ato de lançamento de tributos cujo fato gerador se verificou em exercício anterior à vigência dos citados diplomas legais, desde que a constituição do crédito em si não esteja

${ }^{1072}$ Decisão publicada no Diário da Justiça de 16 de fevereiro de 2004, p. 211. 
alcançada pela decadência.

8. Inexiste direito adquirido de obstar a fiscalização de negócios tributários, máxime porque, enquanto não extinto o crédito tributário a Autoridade Fiscal tem o dever vinculativo do lançamento em correspondência ao direito de tributar da entidade estatal.

9. Recurso Especial provido.

O Relator, inicialmente, traçou um breve histórico da evolução legislativa no Brasil em relação ao sigilo bancário: até 2001, a matéria era regulada pelo artigo 38 da Lei 4.595/1965, que regula o Sistema Financeiro Nacional, recepcionada pelo artigo 192 da Constituição Federal de 1988 com força de lei complementar. Esse dispositivo só previa a "quebra" do sigilo mediante decisão judicial. Segundo o Ministro, mesmo sob esse artigo, o STJ assentara o entendimento de que a "quebra" de sigilo bancário do contribuinte prescindia de autorização judicial.

A partir da Lei 9.311/1996, que instituiu a CPMF, as instituições financeiras passaram a ser obrigadas a fornecer à Secretaria da Receita Federal informações a respeito da identificação dos contribuintes e os valores globais de suas operações bancárias, embora, inicialmente, não fosse permitido que tais informações fossem usadas para a constituição de crédito tributário referente a outras contribuições e impostos, de acordo com o seu artigo 11 , parágrafo $3^{\circ}$.

Com o advento da Lei Complementar 105/2001, artigos $5^{\circ}$ e $6^{\circ}$, possibilitou-se o acesso a dados bancários sigilosos a qualquer agente físcal, sem necessidade de autorização judicial, prosseguiu o Relator, tanto mais após a Lei 10.174/2001, que, alterando a redação do parágrafo $3^{\circ}$ do artigo 11 da Lei 9.311/1996, passou a facultar à Secretaria da Receita Federal o uso das informações obtidas com a CPMF para a instauração de "[...] procedimento administrativo tendente a verificar a existência de crédito tributário relativo a impostos e Contribuições e para lançamento, no âmbito do procedimento fiscal, do crédito tributário porventura existente [...]”".

A partir disso tudo, baseando-se em interpretação do artigo 144 , parágrafo $1^{\circ}$, do Código Tributário Nacional, diferenciando norma material, que deve ser a da época do fato, da norma formal, de aplicabilidade imediata, o Relator entendeu que "[...] a norma que permite a utilização de informações bancárias para fins de apuração e constituição de crédito tributário, por envergar natureza procedimental, tem aplicação imediata, atingindo fatos pretéritos. [...]".

O Ministro José Delgado, acompanhando o voto do Relator, asseverou que o sigilo bancário 
[...] cede todas as vezes que as transações bancárias são denotadoras de ilicitude. O princípio da moralidade pública e privada é que tem força de natureza absoluta. Nenhum cidadão pode, sob o alegado manto ou garantias fundamentais, cometer ilícitos. O sigilo bancário é garantido pela Constituição Federal como direito fundamental para guardar a intimidade das pessoas desde que não sirva para encobrir ilícitos.

No Recurso Especial 532004/SC, que trata do mesmo tema, julgado pela Segunda Turma em 6 de setembro de $2005^{1073}$, confirmaram-se esse e outros precedentes da Primeira e Segunda Turmas.

A Relatora Ministra Eliana Calmon afirmou, aí, que, "[à] luz dos novos diplomas, reposicionou-se a jurisprudência a partir da suspensão pelo STF dos efeitos de uma decisão dada em favor do sigilo, pelas instâncias ordinárias (Ação Cautelar 33/PR)”. Nesse ponto, parece ter-se enganado a Ministra, já que nessa Ação, ainda em trâmite no STF, o Relator Ministro Marco Aurélio deferiu a liminar pleiteado nos seguintes termos ${ }^{1074}$ :

Defiro a liminar pleiteada, obstaculizando, até a decisão final do Extraordinário, o fornecimento de informações bancárias da requerente à Receita. Dê-se ciência desta decisão à União, citando-a para o conhecimento da ação proposta. Caso já tenha havido o fornecimento das informações bancárias, observe-se o sigilo, congelando-se a obtenção dos dados, que não poderão ser acionados para os efeitos pretendidos. Encaminhe-se, por fac-símile, o inteiro teor desta decisão à União e à Receita Federal, sem prejuízo da pessoalidade imposta por lei. Imprima-se urgência na degravação e revisão desta decisão. Junte-se cópia desta ato ao processo em que interposto o Recurso Extraordinário $n^{\circ}$ 389.808/PR. Publique-se.

Até o momento, há duas decisões a favor da liminar, e duas contra, à concessão de efeito suspensivo a esse Recurso Extraordinário 389808/PR, que também está pendente de julgamento.

A Ministra ainda entendeu que a Lei Complementar 105/2001 e a Lei 10.174/2001 aplicam-se a fatos geradores anteriores à entrada de sua vigência, posto que não haveria direito adquirido dos contribuintes a ver seu sigilo "quebrado" apenas por autorização judicial, por não se tratar de direito subjetivo incorporado ao patrimônio da pessoa, mas somente "garantia" afastável a qualquer tempo.

A ementa, afinal, é:

TRIBUTÁRIO - SIGILO BANCÁRIO - INSTAURAÇÃO DE PROCESSO ADMINISTRATIVO COM BASE EM REGISTROS DA CPMF LEGISLAÇÃO POSTERIOR APLICADA A FATOS PRETÉRITOS. 1. Doutrina e jurisprudência, sob a égide da CF 88, proclamavam ser o sigilo bancário corolário do princípio constitucional da privacidade (inciso XXXVI do art. $5^{\circ}$ ), com a possibilidade de quebra por autorização judicial, como previsto

${ }^{1073}$ Decisão publicada no Diário da Justiça de 3 de outubro de 2005, p. 171.

${ }^{1074}$ Decisão de 10 de julho de 2003, conforme "site" do STF: <http://www.stf.jus.br>. 
em lei (art. 38 da Lei 4.595/96). 2. Mudança de orientação, com o advento da LC $105 / 2001$, que determinou a possibilidade de quebra do sigilo pela autoridade fiscal, independentemente de autorização do juiz, coadjuvada pela Lei 9.311/96, que instituiu a CPMF, alterada pela Lei 10.174/2001, para possibilitar aplicação retroativa. 3. Afasta-se a tese do direito adquirido para, encarando a vedação antecedente como mera garantia e não princípio, aplicar-se a regra do art. 144, § $1^{\circ}$, do CTN que pugna pela retroatividade da norma procedimental. 4. Recurso especial provido.

A respeito, mencionem-se, ainda: (i) Recurso Especial 505493/PR, Relator Ministro Franciulli Netto, julgado pela Segunda Turma em 17 de junho de $2004^{1075}$; (ii) Medida Cautelar 7512/SP, Relator Ministro Luiz Fux, julgado pela Primeira Turma em 5 de agosto de $2004^{1076}$; (iii) Recurso Especial 691601/SC, Relatora Ministra Eliana Calmon, julgado pela Segunda Turma em 8 de novembro de 2005 ${ }^{1077}$; e (iv) Recurso Especial 668012/PR, Relator Ministro Castro Meira, julgado pela Segunda Turma em 20 de junho de $2006^{1078}$.

No Recurso Ordinário em Mandado de Segurança 15062/MG, Relator Ministro Paulo Medina, julgado pela Sexta Turma em 20 de setembro de $2005^{1079}$, decidiu-se:

PENAL E PROCESSUAL PENAL. RECURSO ORDINÁRIO EM MANDADO DE SEGURANÇA. QUEBRA DO SIGILO BANCÁRIO. IMPUGNAÇÃO POR MANDADO DE SEGURANÇA. VIA ADEQUADA. "HABEAS CORPUS". INADMISSIBILIDADE. RECURSO A QUE SE DÁ PROVIMENTO. É cabível mandado de segurança para a proteção de direito líquido e certo ameaçado ou violado por ato de autoridade pública ou agente de pessoa jurídica no exercício de atribuições do poder público. Em casos de quebra de sigilo bancário, quando se coloca em questionamento o direito à intimidade do acusado, mostra-se cabível a impetração de mandado de segurança, tendo em vista que no processo penal não há recurso adequado. Recurso a que se dá provimento.

\section{Sigilo de dados telefônicos.}

Citam-se o Recurso Ordinário em Mandado de Segurança 17346/PR, Relator Ministro Arnaldo Esteves Lima, julgado pela Quinta Turma em 8 de março de $2005^{1080}$, e o Recurso Especial 605687/AM, Relatora Ministra Nancy Andrighi, julgado pela Terceira Turma em 2 de junho de $2005^{1081}$, que cuidam do sigilo dos dados telefônicas, isto é, de informações a respeito dos números discados e duração das chamadas, cujas ementas são, respectivamente:

\footnotetext{
1075 Decisão publicada no Diário da Justiça de 8 de novembro de 2004, p. 201.

${ }^{1076}$ Decisão publicada no Diário da Justiça de 30 de agosto de 2004, p. 199.

${ }^{1077}$ Decisão publicada no Diário da Justiça de 21 de novembro de 2005, p. 190.

${ }^{1078}$ Decisão publicada no Diário da Justiça de 28 de agosto de 2006, p. 272.

${ }^{1079}$ Decisão publicada no Diário da Justiça de 7 de novembro de 2005, p. 383.

${ }^{1080}$ Decisão publicada no Diário da Justiça de 18 de abril de 2005, p. 354.

${ }^{1081}$ Decisão publicada no Diário da Justiça de 20 de junho de 2005, p. 273.
} 
PENAL E PROCESSUAL PENAL. RECURSO EM MANDADO DE SEGURANÇA. QUEBRA DE SIGILO TELEFÔNICO. IMPUGNAÇÃO POR MEIO DE MANDADO DE SEGURANÇA. VIA ADEQUADA. HABEAS CORPUS. IMPOSSIBILIDADE. RECURSO A QUE SE DÁ PARCIAL PROVIMENTO. 1. A decretação da quebra de sigilo telefônico do recorrente não atinge, ainda que de maneira reflexa, a sua liberdade de locomoção, de modo que o remédio constitucional do "habeas corpus" revela-se medida inidônea para impugná-la. 2. Tratando-se de proteção ao direito à intimidade, mostra-se cabível a impetração de mandado de segurança. 3. Recurso a que se dá parcial provimento.

PROCESSUAL CIVIL. DOCUMENTO. JUNTADA. LEI GERAL DAS TELECOMUNICAÇÕES. SIGILO TELEFÔNICO. REGISTRO DE LIGAÇÕES TELEFÔNICAS. USO AUTORIZADO COMO PROVA. POSSIBILIDADE. AUTORIZAÇÃO PARA JUNTADA DE DOCUMENTO PESSOAL. ATOS POSTERIORES. "VENIRE CONTRA FACTUM PROPRIUM". SEGREDO DE JUSTIÇA. ART. 155 DO CÓDIGO DE PROCESSO CIVIL. HIPÓTESES. ROL EXEMPLIFICATIVO. DEFESA DA INTIMIDADE. POSSIBILIDADE. - A juntada de documento contendo o registro de ligações telefônicas de uma das partes, autorizada por essa e com a finalidade de fazer prova de fato contrário alegado por essa, não enseja quebra de sigilo telefônico nem violação do direito à privacidade, sendo ato lícito nos termos do art. $72, \S 1 .^{\circ}$, da Lei n. ${ }^{\circ}$ 9.472/97 (Lei Geral das Telecomunicações). Parte que autoriza a juntada, pela parte contrária, de documento contendo informações pessoais suas, não pode depois ingressar com ação pedindo indenização, alegando violação do direito à privacidade pelo fato da juntada do documento. Doutrina dos atos próprios. - O rol das hipóteses de segredo de justiça não é taxativo, sendo autorizado o segredo quando houver a necessidade de defesa da intimidade. Recurso especial conhecido e provido.

\title{
5. Gravação de conversa e interceptação.
}

No Recurso Especial 2194/RJ, Relator Ministro Bueno de Souza, Relator para o acórdão Ministro Fontes de Alencar, julgado pela Quarta Turma em $1^{\circ}$ de dezembro de $1994^{1082}$, o Tribunal rechaçou prova consistente em gravação clandestina de conversa telefônica:

\begin{abstract}
PROCESSO CIVIL. PROVA. A GRAVAÇÃO CLANDESTINA, EM FITA MAGNÉTICA, DE CONVERSA TELEFÔNICA NÃO É MEIO DE PROVA LEGAL E MORALMENTE LEGÍTIMO. RECURSO ESPECIAL ATENDIDO. MAIORIA.
\end{abstract}

Habeas Corpus 3982/RJ, Relator Ministro Adhemar Maciel, julgado pela Sexta Turma em 5 de dezembro de $1995^{1083}$ :

CONSTITUCIONAL E PROCESSUAL PENAL. "HABEAS CORPUS". ESCUTA TELEFÔNICA COM ORDEM JUDICIAL. RÉU CONDENADO POR FORMAÇÃO DE QUADRILHA ARMADA, QUE SE ACHA CUMPRINDO PENA EM PENITENCIÁRIA, NÃO TEM COMO INVOCAR

1082 Decisão publicada no Diário da Justiça de $1^{\circ}$ de julho de 1996, p. 24054.

${ }^{1083}$ Decisão publicada no Diário da Justiça de 26 de fevereiro de 1996, p. 4084. 
DIREITOS FUNDAMENTAIS PRÓPRIOS DO HOMEM LIVRE PARA TRANCAR AÇÃO PENAL (CORRUPÇÃO ATIVA) OU DESTRUIR GRAVAÇÃO FEITA PELA POLÍCIA. O INCISO LVI DO ART. 5. DA CONSTITUIÇÃO, QUE FALA QUE "SÃO INADMISSÍVEIS AS PROVAS OBTIDAS POR MEIO ILÍCITO”, NÃO TEM CONOTAÇÃO ABSOLUTA. HÁ SEMPRE UM SUBSTRATO ÉTICO A ORIENTAR O EXEGETA NA BUSCA DE VALORES MAIORES NA CONSTRUÇÃO DA SOCIEDADE. A PRÓPRIA CONSTITUIÇÃO FEDERAL BRASILEIRA, QUE É DIRIGENTE E PROGRAMÁTICA, OFERECE AO JUIZ, ATRAVÉS DA “ATUALIZAÇÃO CONSTITUCIONAL" (VERFASSUNGSAKTUALISIERUNG), BASE PARA O ENTENDIMENTO DE QUE A CLÁUSULA CONSTITUCIONAL INVOCADA É RELATIVA. A JURISPRUDÊNCIA NORTE-AMERICANA, MENCIONADA EM PRECEDENTE DO SUPREMO TRIBUNAL FEDERAL, NÃO É TRANQÜILA. SEMPRE É INVOCÁVEL O PRINCÍPIO DA "RAZOABILIDADE" (REASONABLENESS). O "PRINCIPIO DA EXCLUSÃO DAS PROVAS ILICITAMENTE OBTIDAS" (EXCLUSIONARY RULE) TAMBEM LÁ PEDE TEMPERAMENTOS. ORDEM DENEGADA.

O Recurso Ordinário em Mandado de Segurança 5352/GO, Relator Ministro Luiz Vicente Cernicchiaro, Relator para o acórdão Ministro Adhemar Maciel, julgado pela Sexta Turma em 27 de maio de $1996^{1084}$, tratava de um caso em que o marido, suspeitando da conduta de sua esposa, gravara conversa telefônica mantida entre ela e o amante, situação agravada pelo fato de a esposa, para facilitar seus encontros, ministrar calmante às duas filhas menores.

A mulher foi denunciada por crime tipificado na Lei de Tóxicos, e a fita havia sido juntada como prova. A ré, então, impetrou mandado de segurança pedindo o desentranhamento da prova por ser ilícita. Perdendo nas instâncias inferiores, ajuizou esse Recurso Ordinário.

O Ministro Luiz Vicente Cernicchiaro, negando provimento ao recurso, acompanhado pelo Ministro Anselmo Santiago, opôs-se expressamente à tese corrente na época acerca da ilegalidade de qualquer espécie de interceptação telefônica por ausência de lei regulamentadora. Entendeu que, em alguns casos, a lei não era imprescindível:

[...] Assim, se alguém estiver cometendo crime ou na iminência de cometê-lo. Se o domicílio, nesse ponto, com [sic: como] expressão da intimidade, não tem a garantia da reserva, é evidente, também não se deve tratar no tocante a ligações telefônicas. Além do mais, a intimidade, juridicamente, é o direito que alguém tem de não ser perturbado pela sociedade. É o direito da pessoa ausentar-se do ciclo social, de viver como indivíduo e não como "socius". E a intimidade diz respeito a uma pessoa ou, eventualmente, a pluralidade de agentes. Acredito, no tocante à fidelidade conjugal, o comportamento de um dos cônjuges é de interesse do outro cônjuge. No caso concreto, a conduta da esposa não poderia ser interceptada por estranho, salvo do marido que tem interesse também no seu comportamento. No caso, não é estranho. [...] Em face destas considerações, levando em conta que a gravação foi feita pelo marido e por isso não feriu o direito à intimidade. A mulher tem obrigação do dever de fidelidade conjugal. $\mathrm{O}$

${ }^{1084}$ Decisão publicada no Diário da Justiça de 25 de novembro de 1996, p. 46227. 
fato interessava também a ele. Tanto assim, com base nesse acontecimento, poderá solicitar a desconstituição do vínculo matrimonial.

Contudo, o Ministro Adhemar Maciel abriu divergência e foi seguido pelos demais.

Segundo ele, o

[...] fato de haver sido a gravação feita pelo marido em nada altera sua ilegalidade. Eu só admitiria a legalidade se o marido tivesse participado da conversa. Mas não participou. Logo, é um "extraneus". Ademais, o inciso XII do art. $5^{\circ}$ da Constituição só admite gravação, valendo como prova judicial, quando houver permissão prévia do juiz natural, e nos termos da lei. A lei, como se sabe, ainda não existe. [...].

É, enfim, ementa:

CONSTITUCIONAL E PROCESSUAL CIVIL. MANDADO DE SEGURANÇA. ESCUTA TELEFÔNICA. GRAVAÇÃO FEITA POR MARIDO TRAÍDO. DESENTRANHAMENTO DA PROVA REQUERIDO PELA ESPOSA: VIABILIDADE, UMA VEZ QUE SE TRATA DE PROVA ILEGALMENTE OBTIDA, COM VIOLAÇÃO DA INTIMIDADE INDIVIDUAL. RECURSO ORDINÁRIO PROVIDO. I - A impetrante/recorrente tinha marido, duas filhas menores e um amante médico. Quando o esposo viajava, para facilitar seu relacionamento espúrio, ela ministrava "Lexotan" às meninas. O marido, já suspeitoso, gravou a conversa telefônica entre sua mulher e o amante. A esposa foi penalmente denunciada (tóxico). Ajuizou, então, ação de mandado de segurança, instando no desentranhamento da decodificação da fita magnética. II - Embora esta Turma já se tenha manifestado pela relatividade do inciso XII (última parte) do art. $5^{\circ}$ da CF/1988 (HC3.982/RJ, Rel. Min. Adhemar Maciel, DJU DE 26/02/1996), no caso concreto o marido não poderia ter gravado a conversa ao arrepio de seu cônjuge. Ainda que impulsionado por motivo relevante, acabou por violar a intimidade individual de sua esposa, direito garantido constitucionalmente (art. $\left.5^{\circ}, \mathrm{X}\right)$. Ademais, o STF tem considerado ilegal a gravação telefônica, mesmo com autorização judicial (o que não foi o caso), por falta de lei ordinária regulamentadora (RE 85.439/RJ, Min. Xavier de Albuquerque e HC 69.912/RS, Min. Pertence). III - RECURSO ORDINÁRIO PROVIDO.

No Recurso Especial 9012/RJ, Relator Ministro Cláudio Santos, Relator para o acórdão Ministro Nilson Naves, julgado pela Terceira Turma em 24 de fevereiro de $1997^{1085}$, o voto vencedor considerou ilegítima a prova consistente na gravação de conversa telefônica de terceiro, testemunha na ação de reconhecimento de paternidade em questão, com o demandado, apresentada pela autora. Decidiu-se que era ilegal, nos termos do artigo 332 do Código de Processo Civil, e inadmissível no processo por força do disposto no artigo $5^{\circ}$, inciso LVI, da Constituição Federal ${ }^{1086}$.

O Ministro Nilson Naves, por sua vez, entendeu não haver ilícito na hipótese, pois,

${ }^{1085}$ Decisão publicada no Diário da Justiça de 14 de abril de 1997, p. 12735.

${ }^{1086}$ Não fica claro nos autos, na verdade, se a conversa gravada deu-se entre a testemunha e a parte adversa, como aparece no relatório do Ministro Cláudio Santos, ou entre a primeira e a autora da ação de paternidade, como aparece no voto do Ministro Nilson Naves. O único ponto certo é o fato de a gravação ter sido realizada pela própria testemunha, interlocutora, sem conhecimento da outra parte. 
em suas palavras,

[e]ntre os valores da intimidade das pessoas e de busca da verdade nos processos, qual o valor mais nobre? A meu ver, diz respeito à verdade. [...] Chega-se à verdade através da prova, cujo ônus incumbe ao autor, quanto ao fato constitutivo do seu direito. Mas existe fato de difícil prova! A saber, da produção da prova. Impedir que alguém a produza, digamos, por meio de gravação de conversas telefônicas, seria, meu sentir, o mal maior. Isto não quer dizer que o fim justifique os meios. No entanto, há caso em que se não se admitir tal prova, inútil seria o processo. [...] Sou favorável à maior liberdade, tocante à realização da prova. O processo não é um instrumento que o Estado põe à disposição dos litigantes? Não façam justiça pelas próprias mãos! Recorram ao Estado-juiz. Então, não se justifica cercear a liberdade dos contendores, relativamente à prova. Em si, a gravação telefônica não é ato ilícito. Não deixa de haver conversação entre a pessoa que esteja ligando e a secretária eletrônica, nem por isso tornou-se proibido o uso da tal secretária. Não tem a testemunha o dever de depor? Sim, é sua obrigação. Todos temos o dever de dar testemunho dos fatos, uma vez convocados pela autoridade judiciária. [...] por que não se admitir seja uma fita degravada, se a conversa gravada possa não corresponder ao conteúdo do depoimento? Acho que se tem de admitir, em nome de valor mais nobre, o da apuração da verdade material.

O Ministro Eduardo Ribeiro, por sua vez, afirmou não se tratar de interceptação telefônica, posto que a conversa foi gravada por interlocutora, e acrescentou:

Dir-se-á que, de um modo ou outro, se estará violando o sigilo garantido às comunicações telefônicas. O argumento, que já vi lançado, prova, entretanto, demais. A acolhê-lo, seria mister reconhecer que vedado aos próprios interlocutores revelar o conteúdo da conversa, o que parece absurdo. Entretanto, se se admite possa um deles transmiti-lo a terceiro, não se vislumbra porque não lhe seja dado demonstrar, mediante o registro feito, que está a dizer a verdade.

Não vejo a diferença que possa haver, quanto à legitimidade do meio, entre a divulgação de conversa mantida por telefone e a que se faz pessoalmente. Ora, não será possível a alguém comprovar o respectivo conteúdo, por meio do testemunho de um terceiro que estivesse presente? Por que, então, ter como ilegítimo valha-se de um meio mais seguro que é a gravação?

Considero que, em regra, quando alguém mantém determinada conversação, seja pessoalmente, seja com o uso de meios eletrônicos, arrisca-se a ver a mesma divulgada, o que configurará, quando muito, uma inconfidência, cujo grau de censurabilidade não chega a tornar ilícita a prova.

Note-se que o sigilo da correspondência é igualmente resguardado. Entretanto, seu uso como prova, ainda sem permissão do autor, é expressamete autorizado por lei (Lei 5.988/73 [a então vigente Lei de Direitos Autorais], artigo 33 e Código de Processo Penal art. 233 parágrafo único. Abstenho-me de mencionar o Código de Processo Civil, art. 376, por não estar explícito que independa de consentimento.

Existem, é certo, exceções, algumas delas constituindo mesmo crime (Código Penal, artigos 153 e 154). Não se admitirá a divulgação, sem justa causa, de fatos que digam com a privacidade das pessoas. Caberá ao juiz avaliar. Generalizar a proibição é que não me parece adequado.

Em suma, o que não se tolera é a indevida escuta de conversa telefônica alheia, como não se admite a violação de correspondência. Não a divulgação por quem participou de uma, ou foi destinatário da outra. [...].

Por outro lado, o Ministro Waldemar Zveiter, acompanhando o Ministro Cláudio Santos, defendeu o entendimento de que "[...] ao admitir-se a escuta de gravação telefônica 
inconsentida como meio legítimo de prova estar-se-á desvelando, também, conversa de terceiro estranho a lide com a quebra do sigilo que lhe é constitucionalmente garantido".

O Ministro Costa Leite desempatou a votação seguindo o Ministro Nilson Naves.

O Recurso Ordinário em Habeas Corpus 7216/SP, Relator Ministro Edson Vidigal, julgado pela Quinta Turma em 28 de abril de $1998^{1087}$, cuidava de um caso de gravação de conversa telefônica por um dos interlocutores:

PENAL. PROCESSUAL. GRAVAÇÃO DE CONVERSA TELEFÔNICA POR UM DOS INTERLOCUTORES. PROVA LÍCITA. PRINCÍPIO DA PROPORCIONALIDADE. "HABEAS CORPUS". RECURSO. 1. A gravação de conversa por um dos interlocutores não é interceptação telefônica, sendo lícita como prova no processo penal. 2. Pelo Princípio da Proporcionalidade, as normas constitucionais se articulam num sistema, cujo [sic] harmonia impõe que, em certa medida, tolere-se o detrimento a alguns direitos por ela conferidos, no caso, o direito à intimidade. 3. Precedentes do STF. 4. Recurso conhecido mas não provido.

O Recurso Ordinário em Habeas Corpus 7321/PR, Relator Ministro Felix Fischer, julgado pela Quinta Turma em 9 de junho de $1998^{1088}$, referia-se à utilização, em processo penal, de gravação do depoimento de testemunhas:

PROCESSUAL PENAL. RECURSO ORDINÁRIO DE "HABEAS CORPUS". FASE DO ART. 499 DO CPP. TESTEMUNHAS REFERIDAS. DEGRAVAÇÃO DE FITA. AMPLA DEFESA. I - Sendo provável a utilidade das declarações de testemunhas referidas no decorrer da instrução, o indeferimento do requerimento da defesa, por ocasião do art. 499 do CPP, indica hipótese de cerceamento. II - Não restando esclarecida a suposta ilicitude da gravação, a sua degravação - cujo valor deverá ser apreciado posteriormente deve ser deferida. Recurso conhecido e parcialmente provido.

No Recurso Ordinário em Habeas Corpus 10534/RJ, Relator Ministro Edson Vidigal, julgado em 13 de novembro de $2000^{1089}$, a Quinta Turma entendeu que não violava a intimidade ou privacidade gravação de conversa por um dos interlocutores, ainda que sem a ciência dos demais, principalmente quando servisse para assegurar a fidelidade do que afirmado:

PROCESSUAL. RECURSO EM HABEAS CORPUS. GRAVAÇÃO DE CONVERSA REALIZADA POR UM DOS INTERLOCUTORES. PROVA LEGÍTIMA. 1. A jurisprudência desta Corte tem firmado o entendimento de que a gravação de conversa por um dos interlocutores não configura interceptação telefônica, sendo lícita como prova no processo penal. 2. Recurso Ordinário a que se nega provimento.

No Recurso Ordinário em Habeas Corpus 10429/MG, Relator Ministro Jorge

${ }^{1087}$ Decisão publicada no Diário da Justiça de 25 de maio de 1998, p. 125.

1088 Decisão publicada no Diário da Justiça de 10 de agosto de 1998, p. 76.

${ }^{1089}$ Decisão publicada no Diário da Justiça de 11 de dezembro de 2000, p. 218. 
Scartezzini, julgado pela Quinta Turma em 13 de março de $2001^{1090}$, a paciente, advogada, pretendia o trancamento de ação penal baseada numa conversa telefônica travada entre ela e um de seus clientes, gravada por ele, em que aquela acusava juízes e promotores da comarca em que atuava de corrupção passiva, sob o argumento de que tal prova era ilícita, por ter sido feita sem o seu consentimento. A Turma reafirmou o entendimento de que não é ilícita prova consistente em conversa telefônica gravada por um dos interlocutores:

PROCESSO PENAL - TRANCAMENTO DA AÇÃO PENAL - JUSTA
CAUSA - PROVA LÍCITA - OFENSA CONTRA A HONRA DE JUÍZES E
PROMOTORES - GRAVAÇÃO FEITA POR UM DOS INTERLOCUTORES.
- A gravação feita por um dos seus interlocutores, exclui a ilicitude do meio de
obtenção da prova. O Supremo Tribunal Federal, nesta esteira, tem entendido
que não há qualquer violação constitucional ao direito de privacidade quando a
vítima grava diálogo com qualquer tipo de criminoso (HC 75.338/RJ, Rel.
Ministro NELSON JOBIM, DJU 25.09.1998). Este, também é o entendimento
jurisprudencial adotado por esta Egrégia Corte ( RHC 7216/SP, Rel. Ministro
EDSON VIDIGAL, DJU 28.04.1998) - Ademais, convém ressaltar que o
trancamento da ação penal, por falta de justa causa, somente deve ocorrer em
situações excepcionais, ou seja, quando os fatos forem desenganadamente
atípicos ou não houver qualquer evidência de envolvimento do acusado em fato
passível de enquadramento na lei penal. - Nenhuma das duas hipóteses se aplica,
porém, ao caso vertente. - Recurso desprovido.

No Habeas Corpus 23891/PA, Relator Ministro Felix Fischer, julgado pela Quinta Turma em 23 de setembro de $2003^{1091}$, o Tribunal entendeu, conforme trecho da ementa, que: “[...] III - A gravação de conversações através do telefone da vítima, com o seu conhecimento, nas quais restam evidentes extorsões cometidas pelos réus, exclui suposta ilicitude dessa prova (precedentes do Excelso Pretório). [...]”.

O Recurso Ordinário em Habeas Corpus 13274/RS, Relator Ministro Gilson Dipp, julgado pela Quinta Turma em 19 de agosto de $2003^{1092}$, firma posição acerca de vários pontos controversos da Lei 9.296/1996, conforme ementa:

CRIMINAL. RHC. CRIMES CONTRA A ORDEM TRIBUTÁRIA, A SAÚDE PÚBLICA, O SISTEMA FINANCEIRO NACIONAL, AGIOTAGEM, LAVAGEM DE DINHEIRO E FORMAÇÃO DE QUADRILHA. INTERCEPTAÇÃO TELEFÔNICA. NULIDADES. PRAZO DE DURAÇÃO. NÃO COMPROVAÇÃO DA INDISPENSABILIDADE DA INTERCEPTAÇÃO, QUANDO DA AUTORIZAÇÃO DAS RENOVAÇÕES. AUTORIZAÇÃ̃O DA INTERCEPTAÇÃO ANTES DA EFETIVAÇÃO DE QUALQUER OUTRO MEIO DE PROVA. CONFIABILIDADE QUESTIONÁVEL DAS DEGRAVAÇÕES. IMPROPRIEDADE DO HABEAS CORPUS. AUSÊNCIA DE TRANSCRIÇÕES DAS CONVERSAS INTERCEPTADAS NOS RELATÓRIOS DA POLÍCIA AO JUÍZO. CIENTIFICAÇÃO DO MINISTÉRIO PÚBLICO SOBRE AS MEDIDAS

\footnotetext{
${ }^{1090}$ Decisão publicada no Diário da Justiça de 20 de agosto de 2001, p. 489.

${ }^{1091}$ Decisão publicada no Diário da Justiça de 28 de outubro de 2003, p. 308.

1092 Decisão publicada no Diário da Justiça de 29 de setembro de 2003, p. 276.
} 
INVESTIGATÓRIAS. GRAVAÇÕES ENTRE INVESTIGADO E ADVOGADO. DELITOS APENADOS COM DETENÇÃO. LICITUDE DAS INTERCEPTAÇÕES TELEFÔNICAS. RECURSO DESPROVIDO. I. A interceptação telefônica deve perdurar pelo tempo necessário à completa investigação dos fatos delituosos. II. O prazo de duração da interceptação deve ser avaliado pelo Juiz da causa, considerando os relatórios apresentados pela Polícia. III. O habeas corpus é meio impróprio para a análise das alegações que não encontram pronto respaldo nos documentos carreados ao feito, quais sejam, de que as interceptações teriam sido deferidas sem que a polícia procedesse anteriormente a qualquer ato investigatório dos delitos, de que a prova dos crimes de que foram acusados os pacientes poderia ter sido obtida por outros meios, e da confiabilidade questionável das degravações juntadas aos autos. IV. Não se pode exigir que o deferimento das prorrogações (ou renovações) seja sempre precedido da completa transcrição das conversas, sob pena de frustrar-se a rapidez na obtenção da prova. V. Não se faz necessária a transcrição das conversas a cada pedido de renovação da escuta telefônica, pois o que importa, para a renovação, é que o Juiz tenha conhecimento do que está sendo investigado, justificando a continuidade das interceptações, mediante a demonstração de sua necessidade. VI. A lei exige que seja feita a transcrição das gravações ao final da escuta, a fim de que o conteúdo das conversas seja juntado ao processo criminal. VII. Não procede a alegação de nulidade nas interceptações pelo fato de o Ministério Público não ter sido cientificado do deferimento das medidas investigatórias, se sobressai que o Parquet acompanhou toda a investigação dos fatos, inclusive a interceptação das comunicações telefônicas dos pacientes, não sendo necessário que fosse formalmente intimado de cada prorrogação das escutas. VIII. O Juiz, ao determinar a escuta telefônica, o faz com relação às pessoas envolvidas, referindo os números de telefones, não cabendo à autoridade policial fazer qualquer tipo de "filtragem". IX. A avaliação dos diálogos que serão usados como prova cabe ao Julgador, quando da sentença. X. Hipótese em que não foi determinada a quebra do sigilo do advogado em nenhum momento, ocorrendo apenas gravações e transcrições automáticas de algumas ligações recebidas do advogado pelos investigados. XII. Se, no curso da escuta telefônica - deferida para a apuração de delitos punidos exclusivamente com reclusão - são descobertos outros crimes conexos com aqueles, punidos com detenção, não há porque excluí-los da denúncia, diante da possibilidade de existirem outras provas hábeis a embasar eventual condenação. XIII. Não se pode aceitar a precipitada exclusão desses crimes, pois cabe ao Juiz da causa, ao prolatar a sentença, avaliar a existência dessas provas e decidir sobre condenação, se for o caso, sob pena de configurar-se uma absolvição sumária do acusado, sem motivação para tanto. XIV. É lícita a interceptação telefônica deferida por Autoridade Judicial, atendendo representação feita pela Polícia, de maneira fundamentada e em observância às exigências legais. XV. Recurso desprovido.

No Recurso Ordinário em Habeas Corpus 14041/PA, Ministro José Arnaldo da Fonseca, julgado pela Quinta Turma em 20 de novembro de $2003^{1093}$, entendeu-se que:

[...] De acordo com a jurisprudência dominante, a gravação realizada por um dos envolvidos nos fatos supostamente criminosos é considerada como prova lícita, ainda mais porque serve de amparo da notícia sobre o crime de quem a promoveu. Inocorre o dito flagrante preparado quando o próprio acusado é quem conduz o ato delituoso, não sendo, portanto, induzido por qualquer ação da vítima. [...]. (trecho da ementa).

Veja-se ainda o Habeas Corpus 33110/SP, Relator Ministro José Arnaldo da

${ }^{1093}$ Decisão publicada no Diário da Justiça de 9 de dezembro de 2003, p. 236. 
Fonseca, julgado pela Quinta Turma em 27 de abril de $2004^{1094}$ :

HABEAS CORPUS. DENÚNCIA. RECEBIMENTO. Gravações de conversas por um dos interlocutores não é interceptação telefônica, sendo lícita como prova no processo penal, máxime se a ela se agregam outros elementos de prova. "Pelo Princípio da Proporcionalidade, as normas constitucionais se articulam num sistema, cuja harmonia impõe que, em certa medida, tolere-se o detrimento a alguns direitos por ela conferidos, no caso, o direito à intimidade." Precedentes do STF e do STJ. Ordem denegada.

No Habeas Corpus 30545/PR, Relator Ministro Felix Fischer, julgado pela Quinta Turma em 20 de novembro de $2003^{1095}$, o STJ negou a possibilidade de realização de perícia para verificar se houve tratamento digital das conversas para atribuir a autoria de conversas a outros:

PROCESSUAL PENAL. HABEAS CORPUS. ESCUTA TELEFÔNICA.
DEGRAVAÇÃO DAS CONVERSAS. PEDIDO INDEFERIDO. ACESSO AO
CONTEÚDO DISPONIBILIZADO. DEFESA POSSIBILITADA. PERÍCIA.
AUTENTICIDADE DOS DIÁLOGOS. DESNECESSIDADE. CONVERSAS
IMPUGNADAS DESCONSIDERADAS PELA SENTENÇA.
INVESTIGAÇÃO POLICIAL. ATOS. FÉ PÚBLICA. SIMPLES ALEGAÇO
DE IMPARCIALIDADE. FALTA DE PROVAS. DESCABIMENTO.
I - A afirmação de que parte das gravações telefônicas efetuadas dizem respeito a
períodos não abrangidos pela autorização judicial não foi abordada na
impetração originária. Impossibilidade de apreciação, sob risco de ocorrer
supressão de instância.
II - Não obstante, in casu, tenha sido indeferido o pleito de degravação das
conversas telefônicas, é de se observar que, por outro lado, possibilitou-se o
acesso da defesa ao seu conteúdo durante a instrução processual, podendo o
acusado, como de fato o fez, defender-se da prova que contra si fora produzida.
III - Violação aos princípios da ampla defesa e do contraditório não
caracterizada.
IV - Descabido o argumento da necessidade de realização de perícia para
verificação da autoria dos diálogos se, em um total de 6.000 (seis mil), foram
impugnados apenas 3 (três) que, inclusive, foram expungidos pela sentença
condenatória sem que se adentrasse ao mérito da sua autenticidade, porquanto o
juiz sentenciante os considerou desinfluentes para a solução do caso.
V - A simples alegação, sem provas, de que as investigações policiais estariam
eivadas de parcialidade, não tem o condão de desconstituir a presunção de
veracidade de que são revestidos os atos praticados por agentes dotados de fé
pública. Não é motivo, também, para a realização de perícia em todo o material
produzido pela autoridade policial, a fim de apurar eventual "tratamento digital"
das gravações, supostamente realizado no intuito de atribuir a autoria de
conversas a outros que não seus reais emissores.
VI- Ausente o prejuízo para a defesa, não há porquê [sic] decretar a nulidade do
processo criminal. Precedentes. Ordem denegada.

No Habeas Corpus 29174/RJ, Relator Ministro Jorge Scartezzini, julgado pela Quinta Turma em $1^{\text {o }}$ de junho de $2004^{1096}$, tecem-se algumas considerações acerca da teoria da ilicitude por derivação:

${ }^{1094}$ Decisão publicada no Diário da Justiça de 24 de maio de 2004, p. 318.

${ }^{1095}$ Decisão publicada no Diário da Justiça de 15 de dezembro de 2003, p. 340.

1096 Decisão publicada no Diário da Justiça de 2 de agosto de 2004, p. 440. 
PROCESSO PENAL - TRANCAMENTO DA AÇÃO PENAL - CONCUSSÃO PRATICADO EM CONTINUIDADE DELITIVA - VEREADORA - FORO PRIVILEGIADO - AFRONTA À CONSTITUIÇÃO FEDERAL - CESSAÇÃO DO MANDATO - ART. 84 DO CPP - INAPLICABILIDADE INEXISTÊNCIA DE ATO ADMINISTRATIVO DO AGENTE NOTIFICAÇÃO PARA A DEFESA PRELIMINAR - DESNECESSIDADE CRIME INAFIANÇÁVEL - GRAVAÇÕES TELEFÔNICAS - PROVA ILÍCITA - IMPROCEDÊNCIA - NÃO INCIDÊNCIA DA "TEORIA DOS FRUTOS DA ÁRVORE ENVENENADA" - PRESENÇA DE JUSTA CAUSA - ORDEM DENEGADA. - O art. 161, IV, "d”, 3, da Constituição do Estado do Rio de Janeiro mostra-se atentatório à Carta da República, posto que compete exclusivamente à União legislar sobre matéria processual penal e penal (art. 22, I, da Carta Política Federal), como é o caso dos autos: estipulação de foro privilegiado para vereadores. Precedentes. - Ademais, mesmo que se considerasse válida a regra inserta na Constituição Estadual, a paciente teve seu mandato cassado antes do recebimento da denúncia. Como o Supremo Tribunal Federal cancelou a Súmula 394, em 25.08.99 (Inq 687 QO/SP, Rel. Ministro SYDNEY SANCHES, DJU de 09.11.2001), passou a predominar o entendimento de que cessado o exercício funcional, encerrava-se a competência especial por prerrogativa de função, sendo que o feito deveria baixar à instância singular. - Inaplicabilidade do art. 84 do Código de Processo Penal, modificado pela Lei 10.628/02, visto que passou a prescrever, quando cessada a função pública, a continuidade de foro especial tão somente para os processos criminais que envolvam "atos administrativos do agente". - Não se reputa ilegal a falta de notificação prévia para o oferecimento de defesa preliminar, se a soma das penas mínimas perfaz um "quantum" superior a 02 anos de reclusão, mostrando-se inafiançável o delito. Inteligência dos arts. 323, I, e 514, ambos do CPP. - A gravação feita por um dos seus interlocutores exclui a ilicitude do meio de obtenção da prova, não havendo que se falar em violação constitucional ao direito de privacidade quando a vítima grava diálogo com qualquer tipo de criminoso. Precedentes do STF e do STJ. - A teoria "dos frutos da árvore envenenada" não é incindível [sic] "in casu", posto que as gravações telefônicas não foram obtidas ilicitamente. Mesmo assim, tais elementos probatórios não constituem o único material probante que embasa a exordial acusatória. Ademais, as provas testemunhais não foram obtidas por derivação da conversa telefônica, não havendo que se falar em "contaminação pelo veneno". - O trancamento da ação penal por falta de justa causa somente deve ocorrer em situações excepcionais, ou seja, apenas quando se constata, "prima facie", a atipicidade da conduta, a incidência de causa de extinção da punibilidade, a ausência de indícios de autoria ou de prova da materialidade do delito, ou, ainda, a indiscutível deficiência da peça vestibular. Hipóteses inocorrentes no caso sub examen. - Ordem denegada.

Habeas Corpus 37590/SP, Relator Ministro José Arnaldo da Fonseca, julgado pela Quinta Turma em 19 de outubro de $2004^{1097}$ :

\begin{abstract}
HABEAS CORPUS. DENÚNCIA E PRISÃO CAUTELAR FUNDADAS EM INTERCEPTAÇÕES E GRAVAÇÕES DE COMUNICAÇÕES E EM OUTROS INDÍCIOS DE PROVA. Alegação de sua ilicitude e invalidade, nos termos dos incisos III, art. $1^{\circ}, \mathrm{X}, \mathrm{XI}$ e XII, LV e LVI, art. $5^{\circ}$, da Constituição Federal e do art. $5^{\circ}$, da Lei 9296/96. Inocorrência das irrogações. As interceptações e gravações telefônicas ocorreram por determinação judicial e perduraram pelo tempo necessário à elucidação dos fatos delituosos, revestidos de complexidade e envolvendo organização criminosa, com o que não se violou a Lei 9296/96. Ordem denegada.
\end{abstract}

${ }^{1097}$ Decisão publicada no Diário da Justiça de 22 de novembro de 2004, p. 370. 
O Habeas Corpus 33553/CE, Relatora Ministra Laurita Vaz, julgado pela Quinta Turma em 17 de março de $2005^{1098}$, discorre sobre a hipótese de descoberta de prova de outro crime através de interceptação telefônica cuja autorização não menciona o nome do terceiro envolvido:

\begin{abstract}
HABEAS CORPUS. PROCESSUAL PENAL. PRISÃO PREVENTIVA. AUSÊNCIA DOS REQUISITOS AUTORIZADORES. REVOGAÇÃO DA PRISÃO CAUTELAR. PERDA DO OBJETO. PROVA. ESCUTA TELEFÔNICA. ILICITUDE. INEXISTÊNCIA. MINISTÉRIO PÚBLICO. LEGITIMIDADE. 1. Constatada a revogação da prisão preventiva do ora Paciente, resta esvaído parte do objeto do presente writ, que visava ao reconhecimento de constrangimento ilegal pela manutenção da prisão cautelar. 2 . É lícita a prova de crime diverso, obtida por meio de interceptação de ligações telefônicas de terceiro não mencionado na autorização judicial de escuta, desde que relacionada com o fato criminoso objeto da investigação. 3. A legitimidade do Ministério Público para conduzir diligências investigatórias decorre de expressa previsão constitucional, oportunamente regulamentada pela Lei Complementar n. ${ }^{\circ}$ 75/93. É consectário lógico da própria função do órgão ministerial - titular exclusivo da ação penal pública -, proceder a coleta de elementos de convicção, a fim de elucidar a materialidade do crime e os indícios de autoria. 4. Writ prejudicado em parte e, na parte conhecida, denegado.
\end{abstract}

No Recurso Ordinário em Habeas Corpus 14672/RJ, Relatora Ministra Laurita Vaz, julgado pela Quinta Turma em 28 de junho de $2005^{1099}$, deu-se importância, além do fato de a gravação ter sido realizada pela vítima, à circunstância de se tratar, de acordo com trecho da ementa, “[...] de gravação de funcionários públicos no exercício de sua função pública, e não de conversa particular ou sigilosa, o que afasta a incidência do art. $5^{\circ}$, inciso $\mathrm{X}$, da Constituição Federal, que garante a intimidade da vida privada. [...]". Considerou, portanto, a prova lícita.

No Habeas Corpus 57961/SP, Relator Ministro Felix Fischer, julgado pela Quinta Turma em 21 de junho de $2007^{1100}$, entendeu-se que não é possível estabelecer uma regra geral abstrata relativa à possibilidade ou não de gravação de conversa própria:

PROCESSUAL PENAL. HABEAS CORPUS SUBSTITUTIVO DE RECURSO ORDINÁRIO. ART. 121, DO CÓDIGO PENAL. GRAVAÇÃO DE CONVERSA TELEFÔNICA POR UM DOS INTERLOCUTORES. AUTOR DA GRAVAÇÃO QUE NÃO A REALIZOU PARA A PRÓPRIA DEFESA E, TAMPOUCO, EM RAZÃO DE INVESTIDA CRIMINOSA. INDEVIDA VIOLAÇÃO DA PRIVACIDADE. ILICITUDE DA PROVA.

I - No "Supremo Tribunal, não tem voga a afirmação apodítica dessa licitude (licitude da gravação de conversa realizada por um dos interlocutores), (...): a hipótese de gravação de comunicação telefônica própria, sem ciência do interlocutor, tem sido aqui examinada caso a caso, e ora reputada prova ilícita,

\footnotetext{
${ }^{1098}$ Decisão publicada no Diário da Justiça de 11 de abril de 2005, p. 338.

${ }^{1099}$ Decisão publicada no Diário da Justiça de 29 de agosto de 2005, p. 367.

${ }^{1100}$ Decisão publicada no Diário da Justiça de 12 de novembro de 2007, p. 242.
} 
por violação da privacidade (...), ora considerada lícita, se utilizada na defesa de direito do autor ou partícipe da gravação, em especial, se vítima ou destinatária de proposta criminosa de outro (...)." (cf, HC 80949-9/RJ, 1ª Turma, Rel. Ministro Sepúlveda Pertence, DJ de 14/12/2001).

II - Portanto, a análise da licitude ou não da gravação de conversa por um dos interlocutores sem a ciência do outro deve ser casuística, i.e., deve ser caso a caso.

III - No caso em tela, a gravação da conversa telefônica foi realizada pela amásia do réu, tão-somente com o intuito de responsabilizá-lo pelo crime, uma vez que a vítima do homicídio era pessoa com quem ela mantinha relação amorosa. Dessa forma, como se percebe, tal prova (gravação telefônica) foi colhida com indevida violação de privacidade (art. $5^{\circ}, \mathrm{X}$, da $\mathrm{CF}$ ) e não como meio de defesa ou em razão de investida criminosa, razão pela qual deve ser reputada ilícita. Writ concedido a fim de que a prova obtida em virtude da gravação telefônica seja excluída dos autos.

Na Ação Penal Originária 479/RJ, Relator Ministro Felix Fischer, julgada pela Corte Especial em 29 de junho de $2007^{1101}$, a Corte entendeu que a análise do conteúdo de gravação oculta de conversa realizada por um dos interlocutores, cujo conteúdo não era integralmente inteligível, embora houvesse, em tese, investida criminosa do outro, violava a intimidade deste, protegida pelo artigo $5^{\circ}$, inciso X, da Constituição Federal, tornando a prova imprestável. É a ementa:

AÇÃO PENAL ORIGINÁRIA. RECEBIMENTO DA DENÚNCIA.
GRAVAÇÃO AMBIENTAL REALIZADA POR UM DOS
INTERLOCUTORES SEM O CONHECIMENTO DO OUTRO. INVESTIDA
CRIMINOSA NÃO CONFIGURADA. ILICITUDE DA PROVA. AFRONTA À
PRIVACIDADE (ART. 5 $5^{\circ}$, X, DA CF). INVESTIGAÇÃO. MINISTÉRIO
PÚBLICO. INQUERITO CIVIL E CRIMINAL. ART. 33, PARÁGRAFO
ÚNICO, DA LOMAN. CONJUNTO PROBATÓRIO INSUFICIENTE PARA
SUSTENTAR O RECEBIMENTO DA EXORDIAL ACUSATÓRIA. ART. $6^{\circ}$
DA LEI 8.038/90. I - A análise da licitude ou não da gravação de conversa por um dos interlocutores sem a ciência do outro deve ser verificada de caso a caso.

II - Quando a gravação se refere a fato pretérito, consumado e sem exaurimento ou desdobramento, danoso e futuro ou concomitante, tem-se, normalmente e em princípio, a hipótese de violação à privacidade. Todavia, demonstrada a investida criminosa contra o autor da gravação, a atuação deste - em razão, inclusive, do teor daquilo que foi gravado - pode, às vezes, indicar a ocorrência de excludente de ilicitude (a par da quaestio do princípio da proporcionalidade). A investida, uma vez caracterizada, tornaria, daí, lícita a gravação (precedente do Pretório Excelso, inclusive, do c. Plenário). Por outro lado, realizada a gravação às escondidas, na residência do acusado, e sendo inviável a verificação suficiente do conteúdo das degravações efetuadas, dada a imprestabilidade do material, sem o exato delineamento da hipotética investida, tal prova não pode ser admitida, porquanto violadora da privacidade de participante do diálogo (art. $5^{\circ}$, inciso X, da CF).

III - A atuação do Ministério Público no inquérito civil tem previsão legal (art. $8^{\circ}$, $\S 1^{\circ}$ da Lei $\left.n^{\circ} 7.347 / 85\right)$. Tal não se confunde com a situação do inquérito criminal envolvendo magistrado de segundo grau (art. 33, parágrafo único, da LOMAN).

IV - No processo penal, a exordial acusatória deve vir acompanhada de um fundamento probatório mínimo apto a demonstrar, ainda que de modo indiciário,

${ }^{1101}$ Decisão publicada no Diário de Justiça de $1^{\text {o }}$ de outubro de 2007, p. 198. 
a efetiva realização do ilícito penal por parte do denunciado. Se não houver uma base empírica mínima a respaldar a peça vestibular, de modo a torná-la plausível, inexistirá justa causa a autorizar a persecutio criminis in iudicio. Tal acontece, como in casu, quando a situação fática não está suficientemente reconstituída.

V - Acolhida a primeira preliminar relativa à ilicitude da prova obtida mediante gravação clandestina. Rejeitada a segunda preliminar referente à alegada usurpação da função da polícia judiciária pelo Ministério Público. Denúncia rejeitada por falta de justa causa.

No Habeas Corpus 59967/SP, Relator Ministro Nilson Naves, julgado em 29 de junho de $2006^{1102}$, a Sexta Turma, por maioria, entendeu que uma fita que continha, numa parte, entrevista concedida voluntariamente pela ré, e, noutra, conversa captada clandestinamente entre ela e seu advogado, tendo sido ambas exibidas em programa de televisão de alcance nacional, tinha de ser excluída dos autos do processo penal movido contra ela e mais dois pelo crime de homicídio. Isso porque, segundo o voto do Relator, a parte ilícita "per se" (captação clandestina da conversa com o advogado) "contaminava" a parte que seria lícita, a entrevista voluntária, pois a fita formaria um todo "artístico" ou jornalístico indissociável, em que uma parte trazia implicações para a outra.

O Ministro Paulo Medina, por sua vez, voto vencido, entendeu que a exclusão da parte ilícita bastava para sanar a irregularidade.

É a ementa:

Advogado. Sigilo profissional/segredo (violação). Conversa privada entre advogado e cliente (gravação/impossibilidade). Prova (ilicitude/contaminação do todo). Exclusão dos autos (caso). Expressões injuriosas (emprego). Risca (determinação). 1. São invioláveis a intimidade, a vida privada e o sigilo das comunicações. Há normas constitucionais e normas infraconstitucionais que regem esses direitos. 2. Conversa pessoal e reservada entre advogado e cliente tem toda a proteção da lei, porquanto, entre outras reconhecidas garantias do advogado, está a inviolabilidade de suas comunicações. 3. Como estão proibidas de depor as pessoas que, em razão de profissão, devem guardar segredo, é inviolável a comunicação entre advogado e cliente. 4. Se há antinomia entre valor da liberdade e valor da segurança, a antinomia é solucionada a favor da liberdade. 5. É, portanto, ilícita a prova oriunda de conversa entre o advogado e o seu cliente. $\mathrm{O}$ processo não admite as provas obtidas por meios ilícitos. 6. Na hipótese, conquanto tenha a paciente concordado em conceder a entrevista ao programa de televisão, a conversa que haveria de ser reservada entre ela e um de seus advogados foi captada clandestinamente. Por revelar manifesta infração ética o ato de gravação - em razão de ser a comunicação entre a pessoa e seu defensor resguardada pelo sigilo funcional -, não poderia a fita ser juntada aos autos da ação penal. Afinal, a ilicitude presente em parte daquele registro alcança todo o conteúdo da fita, ainda que se admita tratar-se de entrevista voluntariamente gravada - a fruta ruim arruína o cesto. 7. A todos é assegurado, independentemente da natureza do crime, processo legítimo e legal, enfim, processo justo. 8. É defeso às partes e aos seus advogados empregar expressões injuriosas e, de igual forma, ao representante do Ministério Público. 9. Havendo o emprego de expressões injuriosas, cabe à autoridade judiciária mandar riscálas. 10. Habeas corpus deferido para que seja desentranhada dos autos a prova

${ }^{1102}$ Decisão publicada no Diário da Justiça de 25 de setembro de 2006, p. 316. 
ilícita. 11. Mandado expedido no sentido de que sejam riscadas as expressões injuriosas.

No Habeas Corpus 64096/PR, Relator Ministro Arnaldo Esteves, julgado pela Quinta Turma em 27 de maio de $2008^{1103}$, o STJ entendeu que a denúncia anônima, por si só, não é apta a autorizar a medida de interceptação telefônica:

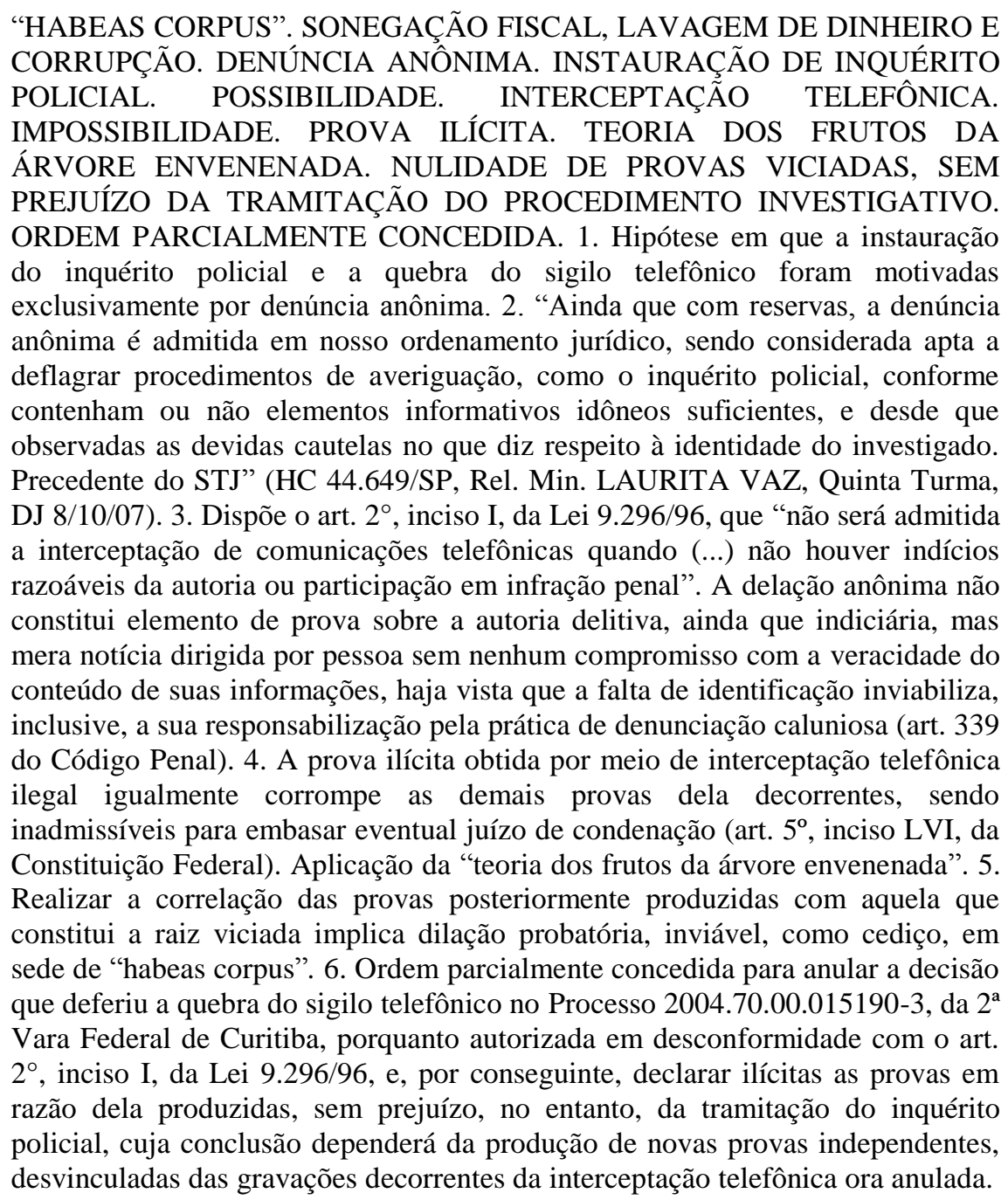

Mas, no Habeas Corpus 85968/SP, Relator Ministro Napoleão Nunes Maia Filho, julgado pela Quinta Turma em 19 de junho de $2008^{1104}$, o STJ entendeu que a interceptação não exige a prévia instauração de inquérito policial ou ação penal:

\begin{tabular}{|c|c|c|}
\hline "HAF & ANACONDA. & PACIENTE \\
\hline CONDENADO & FALSIDADE IDEOLÓGICA, & ULATO \\
\hline PREVARICAÇ & INEXISTÊNCIA & LIDADE \\
\hline CED & TELEFÔ & QUEBRA \\
\hline GILIO & DEVIDAMENTE & AUTORIZAD \\
\hline & $\pi \tilde{\Omega}$ & \\
\hline
\end{tabular}

${ }^{1103}$ Decisão disponibilizada no Diário da Justiça Eletrônico de 4 de agosto de 2008.

${ }^{1104}$ Decisão publicada no Diário da Justiça Eletrônico de 18 de agosto de 2008. 


\section{AÇÃO PENAL. PRECEDENTES DO STJ. ORDEM DENEGADA.}

1. A alegação é de constrangimento ilegal por força de interceptações telefônicas realizadas no âmbito da investigação da Polícia Federal denominada Operação Anaconda, que originou a Ação Penal 129/SP (Reg. 2003.03.00.065345-6) e culminou com a condenação do paciente pela prática dos crimes de falsidade ideológica, peculato e prevaricação (arts. 299, 312 e 319 do CPB) à pena total de 6 anos e 6 meses de reclusão e 1 ano de detenção, mais 138 dias-multa, com a conseqüente perda do cargo de Agente da Polícia Federal, nos termos do art. 92, I, a do CPB.

2. Esta Corte já decidiu ser prescindível a prévia instauração de inquérito ou ação penal para a decretação de quebra de sigilo telefônico; isso porque, a interceptação telefônica, disciplinada na Lei 9.296/96, tem natureza de medida cautelar preparatória, exigindo-se apenas a demonstração da existência de indícios razoáveis da autoria ou participação em infração penal punida com reclusão (REsp. 827.940/SP, Rel. Min. LAURITA VAZ, DJU 03.03.08 e HC 20.087/SP, Rel. Min. GILSON DIPP, DJU 20.09.03).

3. A assertiva de que teria havido monitoramento indevido (sem autorização judicial) do terminal telefônico 9687-0186 no período de 22.11.02 a 18.12 .02 e de 02.01.03 a 13.03.03, não está comprovada pela documentação acostada aos autos. O que ocorreu foi a transferência, efetuada pela própria operadora de Telefonia Celular, das chamadas efetuadas do terminal telefônico 9985-6898, cuja interceptação havia sido previamente autorizada, durante um certo período de tempo, para o terminal 9687-0186, por suspeita de clonagem do aparelho primitivo. As chamadas recebidas continuavam a ser captadas pelo número anterior. O áudio do terminal 9687-0186 não foi fornecido pela Companhia Telefônica enquanto não providenciada a respectiva autorização judicial, o que somente ocorreu em 18.12.02.

4. Ordem denegada, em consonância com o parecer ministerial.

No Habeas Corpus 91518/MG, Relator Ministro Napoleão Nunes Maia Filho, julgado pela Quinta Turma em 5 de junho de $2008^{1105}$, o Tribunal negou acesso às gravações das conversas interceptadas ao paciente:

"HABEAS CORPUS". TRÁFICO DE DROGAS. LEI 6.368/76. INOBSERVÂNCIA DO ART. 38 DA LEI 10.409/2002. INTERROGATÓRIO MARCADO ANTES DO ESGOTAMENTO DO PRAZO PARA A APRESENTAÇÃO DA DEFESA PRELIMINAR. INTIMAÇÃO DO ADVOGADO CONSTITUÍDO PARA O OFERECIMENTO DA REFERIDA PEÇA, SEM SUCESSO. NOMEAÇÃO DE DEFENSOR DATIVO ESPECIALMENTE PARA A APRESENTAÇÃO DA DEFESA PRÉVIA, QUE, AO FINAL, FOI OFERTADA. NULIDADE DEPENDENTE DA DEMONSTRAÇÃO OBJETIVA DO PREJUÍZO. PROCESSO QUE OBEDECEU RIGOROSAMENTE OS PRINCÍPIOS DO CONTRADITÓRIO E DA AMPLA DEFESA. PREJUÍZO NÃO DEMONSTRADO. INTELIGÊNCIA DOS ARTS. 563 E 565 DO CPP E DA SÚMULA 563/STF. REQUERIMENTO DE ENTREGA DOS CD'S E FITAS COM AS CONVERSAS TELEFÔNICAS GRAVADAS COM AUTORIZAÇÃO JUDICIAL. TRANSCRIÇÕES CONSTANTES DOS AUTOS. ORDEM DENEGADA.

1. No âmbito do Processo Penal, não se deve declarar nulidade quando não resultar prejuízo comprovado para a parte que a alega (arts. 563 e 565 do CPP e Súmula 563/STF). Dessa forma, a inobservância do art. 38 da Lei 10.409/2002, à luz de uma interpretação sistemática do capítulo das nulidades do CPP, não traduz nulidade absoluta.

2. O Supremo Tribunal Federal acolhe o entendimento de que o princípio geral norteador das nulidades em Processo Penal - pas de nullité sans grief - é

${ }^{1105}$ Decisão publicada no Diário da Justiça Eletrônico de 18 de agosto de 2008. 
igualmente aplicável em casos de nulidade absoluta (HC 85.155/SP, Rel. Min. ELLEN GRACIE, DJU 15.04.05 e AI-AgR. 559.632/MG, Rel. Min. SEPÚLVEDA PERTENCE, DJU 03.02.06).

3. Registre-se que, no caso concreto, foram respeitados os princípios constitucionais da ampla defesa e do contraditório, com citação regular, interrogatório na presença do Advogado, intimação do Causídico constituído para apresentar a defesa preliminar e, ante a inércia, nomeação de Defensor Dativo especialmente para o oferecimento da referida peça processual e alegações finais regularmente oferecidas, além de inexistir sequer insinuação sobre qual seria o prejuízo sofrido, razão pela qual é vazia a alegação de nulidade.

4. Ofende a lógica do razoável, em prejuízo da efetiva atuação jurisdicional, a pretendida declaração de nulidade, em todos os casos, com a repetição dos atos processuais, sem um mínimo de alegação ou demonstração objetiva de prejuízo.

5. Não há necessidade de exibir às partes as fitas ou cd's das gravações das escutas telefônicas, quando todas as conversas foram transcritas e se encontram nos autos com amplo acesso à defesa do paciente.

6. Writ denegado, em que pese o parecer ministerial pela concessão parcial da ordem.

O Habeas Corpus 76686/PR, Relator Ministro Nilson Naves, julgado pela Sexta Turma em 9 de setembro de $2008^{1106}$, só confirmou a tese da possibilidade de várias prorrogações da interceptação:

Comunicações telefônicas. Sigilo. Relatividade. Inspirações ideológicas. Conflito. Lei ordinária. Interpretações. Razoabilidade.

1. É inviolável o sigilo das comunicações telefônicas; admite-se, porém, a interceptação "nas hipóteses e na forma que a lei estabelecer".

2. Foi por meio da Lei $\mathrm{n}^{\circ} 9.296$, de 1996 , que o legislador regulamentou o texto constitucional; é explícito o texto infraconstitucional - e bem explícito - em dois pontos: primeiro, quanto ao prazo de quinze dias; segundo, quanto à renovação "renovável por igual tempo uma vez comprovada a indispensabilidade do meio de prova".

3. Inexistindo, na Lei $n^{\circ}$ 9.296/96, previsão de renovações sucessivas, não há como admiti-las.

4. Já que não absoluto o sigilo, a relatividade implica o conflito entre normas de diversas inspirações ideológicas; em caso que tal, o conflito (aparente) resolvese, semelhantemente a outros, a favor da liberdade, da intimidade, da vida privada, etc. É que estritamente se interpretam as disposições que restringem a liberdade humana (Maximiliano).

5. Se não de trinta dias, embora seja exatamente esse, com efeito, o prazo de lei (Lei $n^{\circ}$ 9.296/96, art. $5^{\circ}$ ), que sejam, então, os sessenta dias do estado de defesa (Constituição, art. 136, $\S 2^{\circ}$ ), ou razoável prazo, desde que, é claro, na última hipótese, haja decisão exaustivamente fundamentada. Há, neste caso, se não explícita ou implícita violação do art. $5^{\circ}$ da Lei no 9.296/96, evidente violação do princípio da razoabilidade.

6. Ordem concedida a fim de se reputar ilícita a prova resultante de tantos e tantos e tantos dias de interceptação das comunicações telefônicas, devendo os autos retornar às mãos do Juiz originário para determinações de direito.

O Habeas Corpus 89023/MS, Relatora Desembargadora Jane Silva, julgado pela Sexta Turma em 7 de outubro de $2008^{1107}$, almejava o trancamento de ação penal relativa a

${ }^{1106}$ Decisão publicada no Diário da Justiça Eletrônico de 10 de novembro de 2008.

${ }^{1107}$ Decisão publicada no Diário da Justiça Eletrônica de 17 de novembro de 2008. 
crime contra a ordem tributária, inclusive a nulidade das interceptações telefônicas efetuadas, por não ter ocorrido o lançamento:

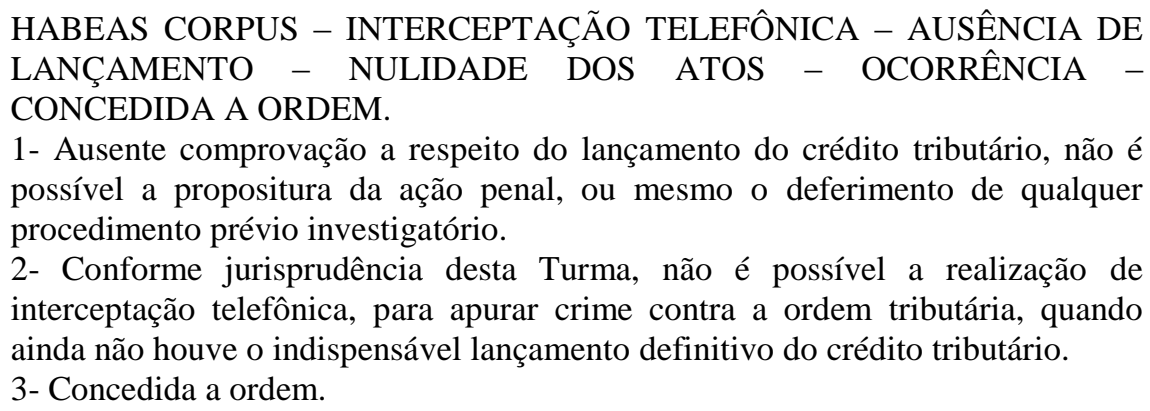

No voto-vista, o Ministro Nilson Naves entendeu que, no caso, a ordem devia ser concedida por não atendimento do disposto no parágrafo único do artigo $2^{\circ}$ da Lei 9.296/1996, isto é, por não ter sido identificado o investigado e nem justificada a ausência de identificação.

\title{
6. Privacidade dos dados pessoais.
}

O Recurso Ordinário em Habeas Corpus 8493/SP, Relator Ministro Luiz Vicente Cernicchiaro, julgado pela Sexta Turma em 20 de maio de $1999^{1108}$, trata do sigilo de informações cadastrais:

\begin{abstract}
RHC - CONSTITUCIONAL - PROCESSUAL PENAL - INFORMAÇÕES CADASTRAIS - SIGILO - Quando uma pessoa celebra contrato especificamente com uma empresa e fornece dados cadastrais, a idade, o salário, endereço. É evidente que o faz a fim de atender às exigências do contratante. Contrata-se voluntariamente. Ninguém é compelido, é obrigado a ter aparelho telefônico tradicional ou celular. Entretanto, aquelas informações são reservadas, e aquilo que parece ou aparentemente é algo meramente formal pode ter conseqüências seríssimas; digamos, uma pessoa, um homem, resolva presentear uma moça com linha telefônica que esteja no seu nome. Não deseja, principalmente se for casado, que isto venha a público. Daí, é o próprio sistema da telefonia tradicional, quando a pessoa celebra contrato, estabelece, como regra, que o seu nome, seu endereço e o número constarão no catálogo; entretanto, se disser que não o deseja, a companhia não pode, de modo algum, fornecer tais dados. Da mesma maneira, temos cadastro nos bancos, entretanto, de uso confidencial para aquela instituição, e não para ser levado a conhecimento de terceiros.
\end{abstract}

Veja-se também o Recurso Especial 306570/SP, Relatora Ministra Eliana Calmon, julgado pela Segunda Turma em 18 de outubro de $2001^{1109}$ :

\footnotetext{
${ }^{1108}$ Decisão publicada no Diário da Justiça de 2 de agosto de 1999, p. 224.

${ }^{1109}$ Decisão publicada no Diário da Justiça de 18 de fevereiro de 2002, p. 340.
} 
EXECUÇÃO - REQUISIÇÃO DE INFORMAÇÃO DE ENDEREÇO DO RÉU AO BANCO CENTRAL - IMPOSSIBILIDADE. 1. Embora na hipótese dos autos não se pretenda, através de requisição ao Banco Central, obter informações acerca de bens do devedor passíveis de execução, mas tão-somente o endereço, o raciocínio jurídico a ser adotado é o mesmo. 2. O contribuinte ou o titular de conta bancária tem direito à privacidade em relação aos seus dados pessoais, além do que não cabe ao Judiciário substituir a parte autora nas diligências que lhe são cabíveis para demandar em juízo. 3. Recurso especial não conhecido.

O STJ, em vários casos, deixou assentado o entendimento de que o Judiciário não pode substituir-se à parte credora na persecução e realização de providências para localizar bens do devedor para a satisfação de seu crédito, exceto, em situações excepcionais, quando demonstrados o esgotamento de todas as medidas extrajudiciais de localização desses bens e os devidos esforços envidados para tanto, em respeito à privacidade.

Atingidos tais requisitos pelo credor, contudo, o STJ entende possível a requisição de expedição de ofícios, pelo juízo competente, a instituições financeiras, ao Banco Central, à Secretaria da Receita Federal, dentre outros, inclusive usando o convênio BACEN-JUD celebrado entre o Conselho da Justiça Federal e o Banco Central do Brasil.

A ementa do Agravo Regimental no Recurso Especial 627669/RS, Relator Ministro José Delgado, julgado pela Primeira Turma no dia 19 de agosto de $2004^{1110}$, bem sumaria a posição do Tribunal, trazendo, inclusive, vários precedentes:

PROCESSUAL CIVIL, TRIBUTÁRIO E ADMINISTRATIVO. AGRAVO REGIMENTAL. EXECUÇÃO FISCAL. QUEBRA DE SIGILO BANCÁRIO. INVASÃO DE PRIVACIDADE. EXPEDIÇÃO DE OFÍCIO A INSTITUIÇÕES BANCÁRIAS. SOLICITAÇÃO DE INFORMAÇÕES SOBRE APLICAÇÕES FINANCEIRAS DO EXECUTADO. EXCEPCIONALIDADE DA MEDIDA. NÃO-ESGOTAMENTO DE TODOS OS MEIOS PARA LOCALIZAR BENS PASSÍVEIS DE PENHORA. PRECEDENTES. 1. Agravo regimental contra decisão que proveu o Especial do[a] agravada. 2. O acórdão "a quo" deferiu pedido de expedição a instituições bancárias para informações sobre a existência de aplicações financeiras em nome da recorrente. 3. A jurisprudência do Superior Tribunal de Justiça é pacífica e remansosa no sentido de que: - "O contribuinte ou o titular de conta bancária tem direito à privacidade em relação aos seus dados pessoais, além do que não cabe ao Judiciário substituir a parte autora nas diligências que lhe são cabíveis para demandar em juízo." (REsp no 306570/SP, $2^{\mathrm{a}}$ Turma, Rel ${ }^{\mathrm{a}} \mathrm{Min}^{\mathrm{a}}$ ELIANA CALMON, DJ de 18/02/2002) - "A requisição judicial, em matéria deste jaez, apenas se justifica desde que haja intransponível barreira para a obtenção dos dados solicitados por meio da via extrajudicial e, bem assim, a demonstração inequívoca de que a exeqüente envidou esforços para tanto, o que se não deu na espécie, ou, pelo menos, não foi demonstrado. Falecendo demonstração cabal de que foram exauridas, sem êxito, as vias administrativas para obtenção de informações referentes aos bens dos sócios, não há demonstração de vulneração aos arts. 399 do CPC e 198 CTN, que conferem ao magistrado a possibilidade de requisitá-las." (REsp n ${ }^{\circ}$ 204329/MG, $2^{\mathrm{a}}$ Turma, Rel. Min. FRANCIULLI NETTO, DJ de 19/06/2000) - "As informações sobre a movimentação bancária do executado só devem ser expostas em casos de grande relevância para a prestação jurisdicional. 'In casu', a varredura das contas em

${ }^{1110}$ Decisão publicada no Diário da Justiça de 27 de setembro de 2004, p. 264. 
nome do executado, visando posterior penhora, não justifica a quebra do sigilo bancário." (AgReg no AG $\mathrm{n}^{\mathrm{o}}$ 225634/SP, 2 ${ }^{\mathrm{a}}$ Turma, Rel ${ }^{\mathrm{a}}$ Min $^{\mathrm{a}}$ NANCY ANDRIGHI, DJ de 20/03/2000) - "O interesse patrimonial do credor não autoriza, em princípio, a atuação judicial, ordenando a quebra do sigilo bancário, na busca de bens do executado para satisfação da dívida." (REsp n ${ }^{\circ} 144062 / \mathrm{SP}$, $2^{a}$ Turma, Rel. Min. FRANCISCO PEÇANHA MARTINS, DJ de 13/03/2000) "Não merece trânsito recurso especial que discute questão já superada no âmbito do Superior Tribunal de Justiça, qual seja, a impossibilidade de quebra de sigilo bancário como forma de possibilitar, no interesse exclusivo da instituição credora e não da Justiça, a expedição de ofício ao Banco Central para obtenção de dados acerca de depósitos em nome do devedor passíveis de penhora pela exeqüente." (REsp no 181567/SP, 4a Turma, Rel. Min. ALDIR PASSARINHO JÚNIOR, DJ de 21/02/2000) 4. Inexistência de comprovação de esgotamento de todos os meios para localizar bens em nome do executado. 5. Agravo regimental não provido.

Nesse sentido, ver, ainda: (i) Agravo Regimental no Recurso Especial 644456/SC, Relator Ministro José Delgado, Relator para o acórdão Ministro Teori Albino Zavascki, julgado pela Primeira Turma em 15 de fevereiro de $2005^{1111}$, que permitiu o uso do convênio BACEN-JUD para localizar bens do devedor; e (ii) Agravo Regimental no Agravo de Instrumento 689472/SC, Relator Ministro José Delgado, julgado em 15 de dezembro de $2005^{1112}$, em que se entendeu não ter havido esgotamento dos meios extrajudiciais pelo INSS para encontrar, no caso, bens do devedor.

Veja-se, também, o Habeas Corpus 15026/SC, Ministro Vicente Leal, julgado pela Sexta Turma em 24 de setembro de $2002^{1113}$ :

CONSTITUCIONAL. PROCESSUAL PENAL. HABEAS-CORPUS. SIGILO DE DADOS. QUEBRA. BUSCA E APREENSÃO. INDÍCIOS DE CRIME. INVESTIGAÇÃO CRIMINAL. LEGALIDADE. CF, ART. 5º XII. LEIS 9.034/95 E 9.296/96. - Embora a Carta Magna, no capítulo das franquias democráticas ponha em destaque o direito à privacidade, contém expressa ressalva para admitir a quebra do sigilo para fins de investigação criminal ou instrução processual penal (art. $\left.5^{\circ}, \mathrm{XII}\right)$, por ordem judicial. - A jurisprudência pretoriana é unissonante na afirmação de que o direito ao sigilo bancário, bem como ao sigilo de dados, a despeito de sua magnitude constitucional, não é um direito absoluto, cedendo espaço quando presente em maior dimensão o interesse público. - A legislação integrativa do canon constitucional autoriza, em sede de persecução criminal, mediante autorização judicial, "o acesso a dados, documentos e informações fiscais, bancários, financeiras e eleitorais" (Lei $\mathrm{n}^{\circ}$ 9.034/95, art. 2 $2^{\circ}$, III), bem como "a interceptação do fluxo de comunicações em sistema de informática e telemática" (Lei no 9.296/96, art. 1º, parágrafo único). - Habeas-corpus denegado.

O Recurso Especial 489378/SP, Relator Ministro Fernando Gonçalves, julgado pela Quarta Turma em 12 de agosto de $2003^{1114}$, delimita a extensão do "levantamento" do

\footnotetext{
${ }^{1111}$ Decisão publicada no Diário da Justiça de 4 de abril de 2005, p. 201.

${ }^{1112}$ Decisão publicada no Diário da Justiça de 6 de março de 2006, p. 189.

${ }^{1113}$ Decisão publicada no Diário da Justiça de 4 de novembro de 2002, p. 266, que ressalta a relatividade do sigilo de dados.

${ }^{114}$ Decisão publicada no Diário da Justiça de 25 de agosto de 2003, p. 320.
} 
sigilo dos dados:

RECURSO ESPECIAL. PEDIDO DE INFORMAÇÕES A ÓRGÃOS PÚBLICOS. POSSIBILIDADE. 1. O pedido de informações a órgãos públicos (Receita Federal, Banco Central, etc) visando localizar bens susceptíveis de penhora, em processo de execução, é feito, segundo entendimento pretoriano, no "interesse da justiça como instrumento necessário para o Estado cumprir o seu dever de prestar jurisdição.” 2. As informações, no entanto, guardam caráter sigiloso e serão de uso restrito, com resguardo da privacidade do devedor. 3 . Recurso especial não conhecido.

\title{
7. Intimidade e Administração Pública.
}

Recurso Ordinário em Mandado de Segurança 14163/MS, Relatora Ministra Eliana Calmon, julgado pela Segunda Turma em 27 de agosto de $2002^{1115}$ :

ADMINISTRATIVO E PROCESSO CIVIL - CERTIDÃO. 1. A remuneração dos servidores públicos está prevista em lei, com publicidade ampla para conhecimento dos interessados. 2. Diferentemente, não pode o cidadão ter acesso à intimidade de cada servidor. 3. Impossibilidade de conceder a Administração certidão nominal dos ganhos de cada servidor. 4. Recurso ordinário improvido.

Veja-se também o Recurso Ordinário em Mandado de Segurança 21021/RJ, Relator Ministro Francisco Falcão, julgado pela Primeira Turma em 16 de maio de $2006^{1116}$ :

\begin{abstract}
ADMINISTRATIVO E CONSTITUCIONAL. ACESSO À LISTA DE SERVIDORES CONTRATADOS PARA TRABALHAR EM HOSPITAL ESTADUAL. DIREITO DE INFORMAÇÃO. PRINCÍPIO DA PUBLICIDADE. INEXISTÊNCIA DE VIOLAÇÃO DO DIREITO À INTIMIDADE E À VIDA PRIVADA. I - O servidor público, na administração direta, como é o caso, quando de sua nomeação tem seu nome divulgado publicamente, justamente para atender ao princípio da publicidade. Ora, quando do ingresso do servidor não se perquire sobre a existência de violação à intimidade ou vida privada daquela pessoa, uma vez que, "in casu", não existe mesmo tal desrespeito, mas sim uma necessária observação aos preceitos legais de acessibilidade aos cargos públicos. II - Não é diferente quando se pretende, amparado no direito à informação e ao princípio da publicidade administrativa, a lista dos nomes daqueles servidores, que outrora já constaram em relação pública com acesso para todos os interessados, inexistindo qualquer ataque a intimidade dos mesmos, porquanto não se está cogitando de intromissão ao universo particular de cada servidor, nem qualquer ingerência no âmbito das relações subjetivas de cada um deles. III - Recurso provido.
\end{abstract}

\section{Sigilo da análise da conduta pessoal e social do concursando.}

Recurso Ordinário em Mandado de Segurança 13381/MG, Relator Ministro

${ }^{1115}$ Decisão publicada no Diário da Justiça de 16 de setembro de 2002, p. 161.

${ }^{1116}$ Decisão publicada no Diário da Justiça de $1^{\circ}$ de junho de 2006, p. 146. 
Hamilton Carvalhido, julgado pela Sexta Turma em 10 de setembro de $2002^{1117}$ :

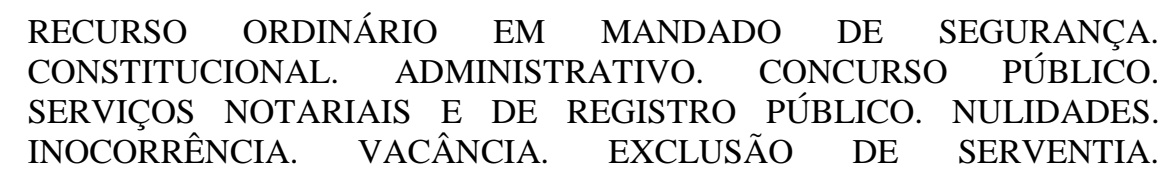
INEXISTÊNCIA DE DIREITO. 1. Dispensável a citação de concursandos como litisconsortes necessários, eis que os candidatos, mesmo aprovados, não titularizam direito líquido e certo à nomeação. 2. A participação da Ordem dos Advogados do Brasil, do Ministério Público, de notário e registrador indicado pela ANOREG não inclui a fase de elaboração do edital do concurso para ingresso na atividade notarial e de registro, porque constitui ato preparatório. (artigo 15 da Lei 8.935/94). 3. A exigência editalícia de que os candidatos sejam bacharéis em Direito ou possuam dez anos de exercício em serviço notarial ou de registro não fere o princípio da isonomia porque, além de necessária para o exercício das funções que demandam conhecimento jurídico teórico e prático, possui respaldo legal. 4. A análise da conduta pessoal e social do concursando está prevista no artigo 14 da Lei $n^{\circ} 8.935 / 94$. O caráter sigiloso da investigação visa proteger a privacidade do próprio candidato, que possui o direito de acesso às informações e de recorrer ao Conselho da Magistratura. 5. Não viola a proibição de delegação para elaboração e correção de provas do concurso (artigo $2^{\circ}$ da Lei Estadual $n^{\circ} 13.167 / 99$ ) a contratação da FUMARC para a organização do concurso e a aplicação das provas. 6 . Os critérios de desempate adotados pelo edital do concurso em questão são legais porque acordes com a Resolução n ${ }^{\circ}$ 350/99 do Tribunal de Justiça de Minas Gerais, e com a legislação estadual aplicável. 7. A desídia do Poder Público em realizar concurso no prazo determinado pelo artigo 236, parágrafo $3^{\circ}$, da Constituição da República, não tem o condão de consolidar situação jurídica constituída de forma precária, sem a observância dos requisitos próprios. 8. Não possui direito a excluir do Concurso Público de Provimento de vagas nos Serviços Notariais e de Registros Públicos, Tabelião para cuja serventia do foro extra-judicial fora designado em caráter precário, porque não aprovado em concurso público, nem preenche os requisitos do artigo 208 da Constituição da República de 1967, com a redação dada pela Emenda Constitucional $\mathrm{n}^{\mathbf{0}} 22$, de 29 de junho de 1982, para se ver extraordinariamente efetivado na função. 9. Precedentes. 10. Recurso improvido.

\section{Imprensa e intimidade.}

O Recurso Especial 221757/SP, Relator Ministro Ruy Rosado de Aguiar, julgado pela Quarta Turma em 16 de setembro de $1999^{1118}$, tratou da questão do uso de fotografias para fins diversos daqueles para os quais foram tiradas inicialmente:

RESPONSABILIDADE CIVIL. Dano moral. Fotografias. Revista. A cessão de fotografias feitas para um determinado fim, mostrando cenas da intimidade da entrevistada, é fato ilícito que enseja indenização se, da publicação desse material, surgir constrangimento à pessoa, não tendo esta concedido entrevista ao veículo que o divulgou. Recurso conhecido e provido.

O Recurso Especial 192786/RS, Relator Ministro Nilson Naves, julgado pela

${ }^{1117}$ Decisão publicada no Diário da Justiça de 4 de agosto de 2003, p. 426.

${ }^{1118}$ Decisão publicada no Diário da Justiça de 27 de março de 2000, p. 112. 
Terceira Turma em 23 de novembro de $1999^{1119}$, trata da valoração do dano moral:

Responsabilidade civil. Imprensa (publicação de notícia ofensiva). Ofensa à honra. Dano moral. Valor da indenização. 1. Consoante a decisão recorrida, "Valor indenizatório a ser estabelecido de acordo com o critério do prudente arbítrio judicial de modo a compor o dano moral de modo razoável e que não se ponha irrisório para a empresa jornalística, pondo-se como forma de efetiva proteção na preservação dos direitos constitucionais à intimidade e do nome das pessoas. Inaplicabilidade do tarifamento previsto na Lei de Imprensa, diante do fato de a reportagem beirar o dolo eventual, hipótese a afastar sua incidência, além de se mostrarem irrisórios os valores naquela estabelecidos, também não preencherem os requisitos da reparação e, principalmente, da sua atuação como freio às violações dos direitos da personalidade". Em tal sentido, na jurisprudência do STJ, REsp's 52.842 e 53.321, DJ's de 27.10.97 e 24.11.97. 2. Súmulas $283 / \mathrm{STF}$ e $7 / \mathrm{STJ}$, quanto a cláusula "diante do fato de a reportagem beirar o dolo eventual". 3. Inexistência de dissídio jurisprudencial. 4. Recurso especial não conhecido.

Recurso Especial 613374/MG, Relatora Ministra Nancy Andrighi, julgado pela Terceira Turma em 17 de maio de $2005^{1120}$ :

Direito civil. Indenização por danos morais. Publicação em jornal. Reprodução de cognome relatado em boletim de ocorrências. Liberdade de imprensa. Violação do direito ao segredo da vida privada. Abuso de direito. - A simples reprodução, por empresa jornalística, de informações constantes na denúncia feita pelo Ministério Público ou no boletim policial de ocorrência consiste em exercício do direito de informar. - Na espécie, contudo, a empresa jornalística, ao reproduzir na manchete do jornal o cognome - "apelido" - do autor, com manifesto proveito econômico, feriu o direito dele ao segredo da vida privada, e atuou com abuso de direito, motivo pelo qual deve reparar os consequientes danos morais. Recurso especial provido.

Restou vencido o Ministro Carlos Alberto Menezes Direito, posto que a notícia de jornal reproduzia fato descrito em boletim de ocorrência, entre outros, inclusive o “apelido" que motivou a ação de indenização por danos morais.

Recurso Especial 818764/ES, Relator Ministro Jorge Scartezzini, julgado pela Quarta Turma em 15 de fevereiro de $2007^{1121}$ :

RECURSO ESPECIAL - RESPONSABILIDADE CIVIL - DANO MORAL DIREITO DE INFORMAÇÃO - ANIMUS NARRANDI - DIREITO À HONRA - DISCUSSÃO VEDADA NESTA SEARA - REEXAME DE PROVA INADMISSIBILIDADE - SÚMULA 07/STJ - DISSÍDIO JURISPRUDENCIAL - QUANTUM INDENIZATÓRIO - POSSIBILIDADE DE REVISÃO PELO STJ - VALOR QUE EXTRAPOLA OS LIMITES DO RAZOÁVEL INEXISTÊNCIA - MANUTENÇÃO DO MONTANTE FIXADO PELAS INSTÂNCIAS ORDINÁRIAS - RECURSO NÃO CONHECIDO.

1. A responsabilidade civil decorrente de abusos perpetrados por meio da imprensa abrange a colisão de dois direitos fundamentais: a liberdade de informação e a tutela dos direitos da personalidade (honra, imagem e vida

${ }^{1119}$ Decisão publicada no Diário da Justiça de 27 de março de 2000, p. 95.

${ }^{1120}$ Decisão publicada no Diário da Justiça de 12 de setembro de 2005, p. 321.

${ }^{1121}$ Decisão publicada no Diário da Justiça de 12 de março de 2007, p. 250. 
privada). A atividade jornalística deve ser livre para informar a sociedade acerca de fatos cotidianos de interesse público, em observância ao princípio constitucional do Estado Democrático de Direito; contudo, o direito de informação não é absoluto, vedando-se a divulgação de notícias falaciosas, que exponham indevidamente a intimidade ou acarretem danos à honra e à imagem dos indivíduos, em ofensa ao fundamento constitucional da dignidade da pessoa humana.

2. No que pertine à responsabilidade pelo dano cometido através da imprensa, o Tribunal a quo, ao apreciar as circunstâncias fático-probatórias, entendeu pela caracterização do dano moral, assentando que o recorrente abusou do direito de transmitir informações através da imprensa. Maiores digressões sobre o tema implicariam o reexame da matéria probatória, medida absolutamente vedada na via estreita do recurso especial, a teor da Súmula 07 desta Corte. Precedentes.

3. No que se refere à reparação por danos morais, tem-se que o valor arbitrado judicialmente não escapa ao controle do STJ, conforme remansosa jurisprudência desta Corte. Precedentes.

4. A lesão a direitos de natureza moral merece ser rechaçada mediante a fixação de indenização que repare efetivamente o dano sofrido, notadamente quando se trate de autoridade pública ocupante de cargo relevante na estrutura do Poder Judiciário Estadual, de modo que o patamar mantido pelo Tribunal a quo merece ser prestigiado. Precedentes.

5. Recurso especial não conhecido.

\section{Internet e privacidade.}

No Recurso Ordinário em Habeas Corpus 18116/SP, Relator Ministro Hélio Quaglia Barbosa, julgado pela Sexta Turma em 16 de fevereiro de $2006^{1122}$, o STJ entendeu que conversa realizada em "sala de bate papo" da internet, ao menos em ambiente virtual irrestrito, não é amparado pelo sigilo das comunicações:

RECURSO EM HABEAS CORPUS. PENAL. ART. 241. INTERNET. SALA DE BATE PAPO. SIGILO DAS COMUNICAÇÕES. INVIABILIDADE. TRANCAMENTO DO INQUÉRITO POLICIAL. NECESSIDADE DE EXAME APROFUNDADO DO CONJUNTO PROBATÓRIO. INADEQUAÇÃO DA VIA ELEITA.

1. A conversa realizada em "sala de bate papo" da internet, não está amparada pelo sigilo das comunicações, pois o ambiente virtual é de acesso irrestrito e destinado a conversas informais.

2. O trancamento do inquérito policial em sede de recurso em habeas corpus é medida excepcional, somente admitida quando constatada, prima facie, a atipicidade da conduta ou a negativa de autoria.

3. Recurso que se nega provimento, com a recomendação de que o juízo monocrático determine a realização imediata da perícia requerida pelo parquet nos autos, sob pena de trancamento da ação penal.

\section{Comunicação da prisão.}

Recurso Ordinário em Habeas Corpus 1526/RJ, Relator Ministro Luiz Vicente

${ }^{1122}$ Decisão publicada no Diário da Justiça de 6 de março de 2006, p. 443. 
Cernicchiaro, julgado pela Sexta Turma em 29 de outubro de $1991^{1123}$ :

\begin{abstract}
RHC - INQUÉRITO POLICIAL - PRISÃO - COMUNICAÇÃO AO JUIZ COMPETENTE E À FAMILIA DO PRESO OU À PESSOA POR ELE INDICADA (CONST., ART. 5, LXII) - A Constituição da República visa a resguardas o "status libertatis", ensejando a pessoas de confiança do preso o conhecimento do fato, a fim de, diante de qualquer ilegalidade, ser afrontado o vício jurídico. A participação imediata do juiz competente é impostergável. A comunicação à família ou a pessoa pelo preso indicada configura direito público, subjetivo. A interpretação, porém, deve ser finalística. Pode ocorrer que o preso não tenha interesse, ou mesmo não deseje que tal aconteça. Urge respeito à sua intimidade. Se terceira pessoa, ainda que estranha à família ou pelo preso indicada, intervier, e de modo eficaz compensar a ausência de alguém do rol constitucional, suprida estará a situação jurídica. Exemplificativamente, a presença de defensor.
\end{abstract}

\title{
12. Lei de Imprensa.
}

Recurso Ordinário em Habeas Corpus 3296/SC, Relator Ministro Jesus Costa Lima, julgado pela Quinta Turma em 15 de dezembro de $1993^{1124}$ :

CONSTITUCIONAL E PROCESSUAL PENAL. LEI DE IMPRENSA. AÇÃO PENAL. TRANCAMENTO. 1. A Constituição considera livre a manifestação do pensamento, proíbe o anonimato, e assegura o direito de resposta, a inviolabilidade da intimidade, a vida privada, a honra e a imagem das pessoas, o que derroga a chamada Lei de Imprensa, a qual continua em vigor naquilo em que não contraria a Carta Magna. 2. Ordem indeferida de trancamento de diversas ações penais, que se mantêm.

Recurso Especial 439584/SP, Relator Ministro Carlos Alberto Menezes Direito, julgado pela Terceira Turma em 15 de outubro de $2002^{1125}$ :

Liberdade de informação e direito à honra, à dignidade, à intimidade, à vida privada: artigos $5^{\circ}, \mathrm{X}$, e 220 da Constituição Federal. Plano constitucional. Art. $1^{\circ}$ da Lei $n^{\circ} 5.250 / 67$. Valor do dano moral. 1. Está no plano constitucional decidir sobre o balanceamento entre o direito à honra, à dignidade, à intimidade, à vida privada, e à liberdade de informação, com a interpretação dos artigos $5^{\circ}$, X, e 220 da Constituição Federal. Tal questão, sem dúvida, é relevante neste trânsito da vida republicana e compete ao Supremo Tribunal Federal decidi-la. 2. Não se revê nesta Corte o valor do dano moral quando a fixação não configura exorbitância, exagero, despropósito, falta de razoabilidade ou insignificância, o que não existe no presente feito. 3. Para os efeitos do art. $1^{\circ}$ da Lei de Imprensa, o abuso, no plano infraconstitucional, está na falta de veracidade das afirmações veiculadas, capazes de gerar indignação, manchando a honra do ofendido. Neste feito, o Acórdão recorrido afastou as acusações formuladas do contexto do tema tratado nos artigos escritos pelo réu e identificou a ausência de veracidade das afirmações. $\mathrm{O}$ interesse público, em nenhum momento, nos casos como o dos autos, pode autorizar a ofensa ao direito à honra, à dignidade, à vida privada, à intimidade da pessoa humana. 4. Recursos especiais não conhecidos.

${ }^{1123}$ Decisão publicada no Diário da Justiça de 25 de novembro de 1991, p. 17084.

${ }^{1124}$ Decisão publicada no Diário da Justiça de 21 de fevereiro de 1994, p. 2180.

1125 Decisão publicada no Diário da Justiça de 9 de dezembro de 2002, p. 341. 


\section{Segredo de justiça.}

Recurso Ordinário em Mandado de Segurança 4848/DF, Relator Ministro Demócrito Reinaldo, julgado pela Primeira Turma em 5 de abril de $1995^{1126}$ :

PROCESSUAL CIVIL. MANDADO DE SEGURANÇA. ATO JUDICIAL. NEGATIVA DE CONSULTA DE AUTOS. AÇÃO DE INVESTIGAÇÃO DE PATERNIDADE QUE CORRE EM SEGREDO DE JUSTIÇA (ARTIGOS 40 E 155 DO CPC E ARTIGO 89, INCISO XIV, DO ENTÃO VIGENTE ESTATUTO DA ORDEM DOS ADVOGADOS DO BRASIL). PEDIDO CONFUSO E DEFECTIVO. I - Em ação de investigação de paternidade, com a instrução concluída, e que corre em segredo de justiça, por força de dispositivos de ordem pública, que visam ao resguardo da intimidade das partes, não tendo o advogado, impetrante de mandado de segurança, procuração nos autos, nenhum direito lhe confere a legislação de examinar o processo. II - Consoante o disposto nos artigos 40 e 155 do CPC, o exame dos processos que correm em segredo de justiça, ainda que em cartório, fica restrito aos advogados das partes. "In casu", como o impetrante não juntou procuração aos autos, nem requereu essa providência, falece-lhe direito líquido e certo, para justificar tal pretensão. Demais disso, como é cediço, no mandado de segurança, o pedido deve ser certo e determinado, o que não se verifica na espécie, entremostrando-se o pleito confuso e defectivo. III - Recurso a que se nega provimento, sem discrepância.

Recurso Ordinário em Mandado de Segurança 3738/CE, Relator Ministro Edson Vidigal, julgado pela Quinta Turma em 24 de março de $1997^{1127}$ :

PROCESSUAL CIVIL. ADVOGADO. DIREITO DE RETIRAR AUTOS. TRAMITAÇÃO EM SEGREDO DE JUSTIÇA. LEI 4.215/1963, ART. 89, XVII. CPC, ART. 40, 155. 1. O instituto de segredo de justiça visa proteger a intimidade das partes envolvidas no processo. Todavia, não há se falar em sua aplicação para proteger a parte de seu próprio defensor legal. 2. O direito de vista dos autos fora do cartório pelo advogado devidamente constituído, no caso em tela, encontra-se devidamente fundamentado na Lei 4.215/1963, art. XVII; bem como no CPC, arts. 40 e 155. 3. Recurso provido.

\section{Sanção administrativa do ECA: direito de imagem da criança e do adolescente.}

Recurso Especial 55168/RJ, Relator Ministro Luiz Vicente Cernicchiaro, julgado pela Sexta Turma em 28 de agosto de $1995^{1128}$ :

RESP - CRIANÇA E ADOLESCENTE - ECA - SANÇÃO
ADMINISTRATIVA - ADOLESCENTE - FALECIMENTO - A CRIANÇA E
O ADOLESCENTE TÊM DIREITO AO RESGUARDO DA IMAGEM E
INTIMIDADE. VEDADO, POR ISSO, OS ÓRGÃOS DE COMUNICAÇÃO
SOCIAL NARRAR FATOS, DENOMINADOS INFRACIONAIS, DE MODO
A IDENTIFICÁ-LOS. O FENÔMENO GANHA GRANDEZA SINGULAR

${ }^{1126}$ Decisão publicada no Diário da Justiça de 8 de maio de 1995, p. 12302.

${ }^{1127}$ Decisão publicada no Diário da Justiça de 5 de maio de 1997, p. 17062.

${ }^{1128}$ Decisão publicada no Diário da Justiça de 9 de outubro de 1995, p. 33620. 
QUANDO A CRIANÇA E O ADOLESCENTE INTEGRAM CLASSE SOCIAL MENOS FAVORECIDA. ADJETIVOS DESAIROSOS, ENTÃO, PASSAM A ESTIGMATIZAR A PESSOA. AINDA QUE AGENTES DE CONDUTA ILÍCITA, NÃO PODEM SER VILIPENDIADOS, EXPOSTOS À EXECRAÇÃO PÚBLICA. O FALECIMENTO NÃO MODIFICA O RACIOCÍNIO. TAMBÉM QUANDO MORTOS SÃO DIGNOS DE PROTEÇÃO EM HOMENAGEM À HONRA.

Recurso Especial 130731/SP, Relator Ministro Francisco Peçanha Martins, julgado pela Segunda Turma em 15 de abril de $2004^{1129}$ :

\begin{abstract}
ADMINISTRATIVO - ESTATUTO DA CRIANÇA E DO ADOLESCENTE (ECA) - PICHAÇÃO - NOTÍCIA EM JORNAL ENVOLVENDO MENORES COMO AGENTES DE CONDUTAS ILÍCITAS - AUTORIZAÇÃO DO JUIZ DA INFÂNCIA E DA JUVENTUDE - INEXISTÊNCIA - SANÇÃO ADMINISTRATIVA - LEI 8.069/90, ART. 247 - PRECEDENTES STJ. - É vedado aos órgãos de comunicação social a divulgação total, ou parcial, de atos ou fatos denominados infracionais atribuídos a criança ou adolescente, sem a devida autorização do MM. Juiz da Infância e da Juventude. - Sendo de conhecimento da imprensa a existência de representação da Curadora contra os menores, por danos ao patrimônio público, descabe a alegação de inocorrência de ato infracional a justificar a conduta do recorrente. - "A criança e o adolescente têm direito ao resguardo da imagem e intimidade. Vedado, por isso, aos órgãos de comunicação social narrar fatos, denominados infracionais, de modo a identificá-los" (REsp. 55.168/RJ, DJ de 9.10.1995). - Recurso especial não conhecido.
\end{abstract}

\title{
15. Instrumento processual para proteger o direito à intimidade.
}

Habeas Corpus 4536/RJ, Relator Ministro William Patterson, Relator para o acórdão Ministro Luiz Vicente Cernicchiaro, julgado pela Sexta Turma em 27 de maio de $1996^{1130}$ :

\begin{abstract}
HC - CONSTITUCIONAL - HABEAS-CORPUS - MANDADO DE SEGURANÇA - O HABEAS-CORPUS E O MANDADO DE SEGURANÇA SÃO AÇÕES CONSTITUCIONALIZADAS, DEFINIDAS NO ART. 5., LXVIII E LXIX. O PRIMEIRO VISA A PRESERVAR O DIREITO DE LOCOMOÇÃO E O SEGUNDO, DIREITO LÍQUIDO E CERTO, NÃO AMPARADO POR HABEAS-CORPUS. A JURISPRUDÊNCIA TEM SIDO TOLERANTE, EM HOMENAGEM À LIBERDADE, ADMITINDO O HABEAS-CORPUS, MESMO QUANDO, INDIRETAMENTE, O DIREITO DE LOCOMOÇÃO ESTIVER AMEAÇADO. NO CASO DOS AUTOS, EVIDENCIA-SE INADEQUADO PORQUE O PEDIDO BUSCA PRESERVAR O DIREITO A INTIMIDADE.
\end{abstract}

\section{Absolvição e registro criminal (intimidade).}

Recurso Ordinário em Mandado de Segurança 6761/SP, Relator Ministro Luiz

${ }^{1129}$ Decisão publicada no Diário da Justiça de 28 de junho de 2004, p. 215.

${ }^{1130}$ Decisão publicada no Diário da Justiça de 21 de outubro de 1996, p. 40272. 
Vicente Cernicchiaro, julgado pela Sexta Turma em 10 de junho de $1996^{1131}$ :

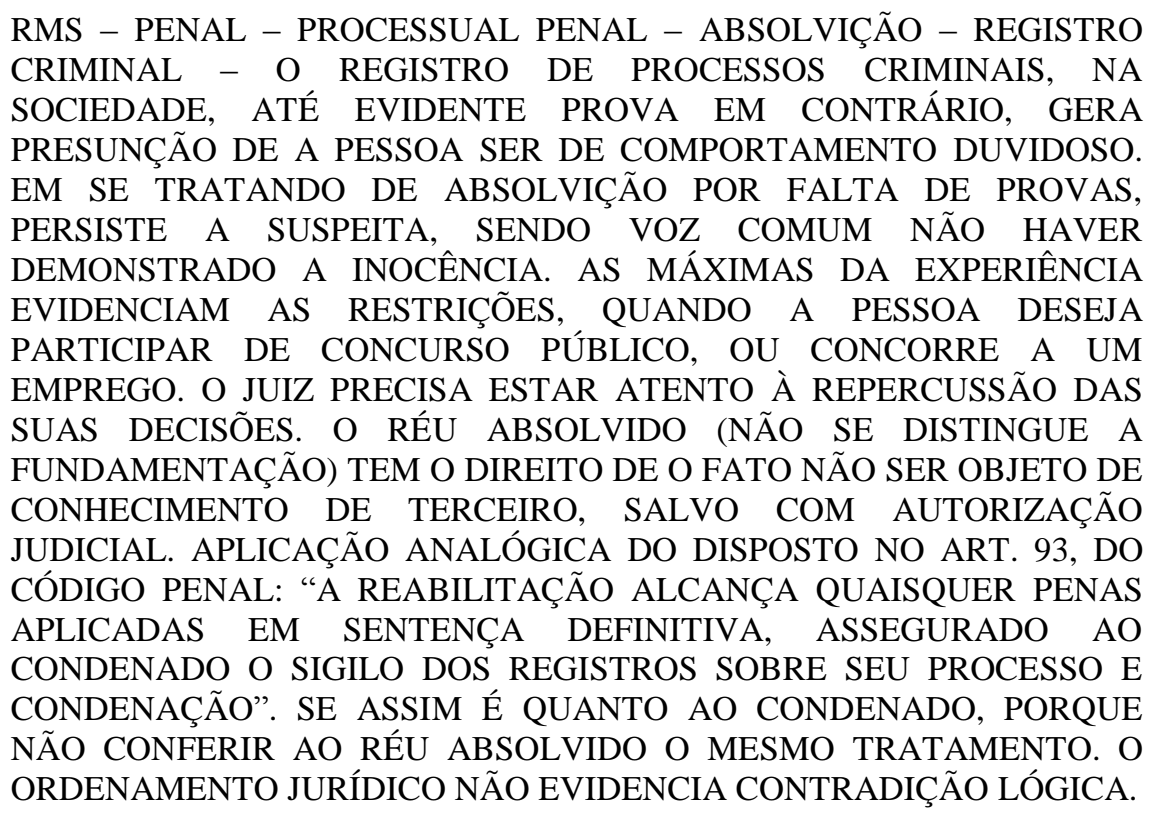

Habeas Corpus 15206/RJ, Relator Ministro Gilson Dipp, julgado pela Quinta Turma em 25 de setembro de $2001^{1132}$ :

\begin{abstract}
HABEAS CORPUS - PROCESSO PENAL - ABSOLVIÇÃO CANCELAMENTO DE REGISTRO NA FOLHA DE ANTECEDENTES ORDEM CONCEDIDA. I - É legítima a pretensão de paciente que, absolvido por não ter concorrido para a infração penal, requer sejam apagadas, de sua folha de antecedentes, quaisquer referências ao processo criminal, visando a evitar prejuízos futuros. Precedente. II- Ordem concedida.
\end{abstract}

Recurso Ordinário em Mandado de Segurança 16202/SP, Relator Ministro Felix Fischer, julgado pela Quinta Turma em 17 de junho de $2003^{1133}$ :

CRIMINAL. RECURSO ORDINÁRIO EM MANDADO DE SEGURANÇA. ANTECEDENTES CRIMINAIS. INQUÉRITOS ARQUIVADOS. REABILITAÇÃO, ABSOLVIÇÃO E RECONHECIMENTO DA PRESCRIÇÃO DA PRETENSÃO PUNITIVA. EXCLUSÃO DE DADOS DO REGISTRO DE IDENTIFICAÇÃO CRIMINAL. DIREITO LÍQUIDO E CERTO. Esta Corte Superior tem entendido que, por analogia ao que dispõe o art. 748 do Código do Processo Penal, que assegura ao reabilitado o sigilo das condenações criminais anteriores na sua folha de antecedentes, devem ser excluídos dos terminais dos Institutos de Identificação Criminal os dados relativos a inquéritos arquivados e a processos em que tenha ocorrido a reabilitação do condenado, a absolvição do acusado por sentença penal transitada em julgado, ou tenha sido reconhecida a extinção da punibilidade do acusado pela prescrição da pretensão punitiva do Estado, de modo a preservar a intimidade do mesmo. Recurso provido.

${ }^{1131}$ Decisão publicada no Diário da Justiça de 11 de novembro de 1996, p. 43777.

${ }^{1132}$ Decisão publicada no Diário da Justiça de 29 de outubro de 2001, p. 224.

${ }^{1133}$ Decisão publicada no Diário da Justiça de 12 de agosto de 2003, p. 246. 
Recurso Ordinário em Habeas Corpus 14376/SP, Relator Ministro José Arnaldo da Fonseca, julgado pela Quinta Turma em 2 de março de $2004^{1134}$ :

RECURSO ORDINÁRIO. PENAL. INQUÉRITO POLICIAL.
ARQUIVAMENTO. EXCLUSÃO DE DADOS DOS TERMINAIS DO
INSTITUTO DE IDENTIFICAÇÃO. SIGILO DAS INFORMAÇÕES. "Por
analogia ao art. 748 do CPP - que assegura ao reabilitado o sigilo das
condenações criminais anteriores na sua folha de antecedentes -, esta Corte
Superior tem entendido que devem ser excluídos dos terminais dos Institutos de
Identificação Criminal os dados relativos a inquéritos arquivados, de modo a
preservar a intimidade do indivíduo. Precedentes." Recurso conhecido e provido.

Recurso Especial 717746/SP, Relator Ministro Gilson Dipp, julgado pela Quinta Turma em 18 de agosto de $2005^{1135}$ :

\begin{abstract}
CRIMINAL. RESP. RECEPTAÇÃO. EXTINÇÃO DA PUNIBILIDADE. PRESCRIÇÃO DA PRETENSÃO PUNITIVA, NA FORMA RETROATIVA. CANCELAMENTO DE REGISTRO NA FOLHA DE ANTECEDENTES. ANALOGIA AO ART. 748 DO CÓDIGO DE PROCESSO PENAL. RECURSO DESPROVIDO. I. Por analogia ao disposto no art. 748 do Código de Processo Penal, também nos casos de inquéritos arquivados, processos em que tenha ocorrido a reabilitação do condenado, ou a absolvição por sentença penal transitada em julgado, ou que tenha sido reconhecida a extinção da punibilidade do acusado pela prescrição da pretensão punitiva do Estado, deve ser preservada a sua intimidade, com a retirada das anotações referentes a tais feitos de sua folha de antecedentes penais - Precedentes. II. Recurso desprovido.
\end{abstract}

\title{
17. Sigilo de correspondência.
}

Recurso Ordinário em Habeas Corpus 6719/SP, Relator Ministro Fernando Gonçalves, julgado pela Sexta Turma em 24 de novembro de $1997^{1136}$ :

\begin{abstract}
RHC. PROVA. SIGILO DE CORRESPONDENCIA. VIOLAÇÃO. 1. A violação de correspondência, com maltrato à liberdade de pensamento resguardada pela Constituição Federal somente se concretiza quando se tratar de "correspondência fechada". De outro lado, a apreensão de documento, representado por minuta de carta já remetida, mediante autorização judicial, não representa afronta ao direito assegurado pelo art. $5^{\circ}, \mathrm{X}$, da $\mathrm{CF}$ (intimidade, vida privada, etc.) porque idêntica proteção é reservada à honra das pessoas, não podendo aquela (intimidade) servir de salvaguarda para maltrato a esta (honra).

2. RHC improvido.
\end{abstract}

Recurso Ordinário em Habeas Corpus 10537/RJ, Relator Ministro Edson Vidigal, julgado pela Quinta Turma em 13 de março de $2001^{1137}$ :

\footnotetext{
${ }^{1134}$ Decisão publicada no Diário da Justiça de 29 de março de 2004, p. 254.

${ }^{1135}$ Decisão publicada no Diário da Justiça de 19 de setembro de 2005, p. 373.

${ }^{1136}$ Decisão publicada no Diário da Justiça de 8 de junho de 1998, p. 178.

${ }^{1137}$ Decisão publicada no Diário da Justiça de 2 de abril de 2001, p. 311.
} 
PENAL. PROCESSUAL. TIGRE DE PELÚCIA CONTENDO COCAÍNA. APREENSÃO DE ENCOMENDA NA AGÊNCIA DOS CORREIOS ANTES DE SER ENTREGUE AO DESTINATÁRIO. AÇÃO PENAL. PROVA ILÍCITA. QUEBRA DE SIGILO DE CORRESPONDÊNCIA. 1. Correspondência, para os fins tutelados pela Constituição da República (art. $5^{\circ}$, VII) é toda comunicação de pessoa a pessoa, por meio de carta, através da via postal ou telegráfica. (Lei $\left.n^{\circ} 6.538 / 78\right)$. 2. A apreensão pelo Juiz competente, na agência dos Correios, de encomenda, na verdade tigre de pelúcia com cocaína, não atenta contra a Constituição da República, art. 5 , VII. Para os fins dos valores tutelados, encomenda não é correspondência. 3. Recurso Ordinário conhecido mas não provido.

\title{
18. Sigilo profissional e intimidade do cliente.
}

Recurso Ordinário em Mandado de Segurança 14134/CE, Relatora Ministra Eliana Calmon, julgado pela Segunda Turma em 25 de junho de $2002^{1138}$ :

\begin{abstract}
ADMINISTRATIVO - SIGILO PROFISSIONAL. 1. É dever do profissional preservar a intimidade do seu cliente, silenciando quanto a informações que lhe chegaram por força da profissão. 2. O sigilo profissional sofre exceções, como as previstas para o profissional médico, no Código de Ética Médica (art. 102). 3. Hipótese dos autos em que o pedido da Justiça não enseja quebra de sigilo profissional, porque pedido o prontuário para saber da internação de um paciente e do período. 4. Recurso ordinário improvido.
\end{abstract}

Embargos de Declaração no Recurso em Mandado de Segurança 14134/CE, Relatora Ministra Eliana Calmon, julgado pela Segunda Turma em 22 de outubro de $2002^{1139}$ :

\begin{abstract}
PROCESSO CIVIL - EMBARGOS DE DECLARAÇÃO - SIGILO PROFISSIONAL - OMISSÕES INEXISTENTES. 1. Explicitado ficou no voto condutor que a entidade hospitalar não está obrigada a enviar à Justiça prontuários médicos. 2. O Tribunal disse, com clareza, que à vista do prontuário, preservados os dados sigilosos quanto à doença e ao tratamento realizado, todos os demais dados relativos à internação não estão ao abrigo do sigilo profissional. 3. Embargos de declaração rejeitados.
\end{abstract}

Recurso Ordinário em Mandado de Segurança 11627/SP, Relator Ministro Garcia Vieira, julgado pela Primeira Turma em 28 de maio de $2002^{1140}$ :

ADMINISTRATIVO E PROCESSUAL CIVIL. MANDADO DE
SEGURANÇA. ATO DE PRESIDENTE DE TRIBUNAL. NOVO SISTEMA
DE LIGAÇOEES TELEFÔNICAS POR INTERMÉDIO DE TELEFONISTAS.
SALA DESTINADA AOS ADVOGADOS. INEXISTENCIA DE DIREITO
LÍQUIDO E CERTO AO EXERCÍCIO DA PROFISSÃO. INDEFERIMENTO
LIMINAR DO MANDAMUS CONFIRMADO EM SEDE DE AGRAVO
REGIMENTAL. RECURSO ORDINÁRIO. IMPROVIMENTO. DECISÃO
MANTIDA PORQUE INCENSURÁVEIS SEUS FUNDAMENTOS. I - A teor

${ }^{1138}$ Decisão publicada no Diário da Justiça de 16 de setembro de 2002, p. 160.

${ }^{1139}$ Decisão publicada no Diário da Justiça de 25 de novembro de 2002, p. 214.

${ }^{1140}$ Decisão publicada no Diário da Justiça de 24 de junho de 2002, p. 184. 
do disposto na Constituição Federal e no Estatuto da Advocacia e da OAB, é assegurado ao advogado, em nome da liberdade e do sigilo profissional, a inviolabilidade de seu escritório ou local de trabalho, de seus arquivos e dados, de sua correspondência e de suas comunicações telefônicas e afins, salvo caso de busca ou apreensão determinada por magistrado e acompanhada de representação da OAB. II - A inviolabilidade do advogado, no exercício de sua profissão, abrange os meios utilizados em sua atuação, nestes incluídos seu escritório e locais de trabalho, correspondência, formas de comunicação, a exemplo da telefônica, todos protegidos pelo sigilo profissional. Nesta última hipótese há de se entender, evidentemente, a inadmissibilidade de interceptação telefônica do local de trabalho do advogado e, por óbvio, da sua própria residência. Inadmissível, contudo, ampliar o verdadeiro sentido de tal prerrogativa, de molde a considerar direito líquido e certo, a ser protegido por mandado de segurança, a utilização de sistema telefônico diferente daquele colocado na sala destinada aos advogados, pelo Tribunal de Alçada Estadual. III - Recurso ordinário improvido.

\section{Sigilo do inquérito policial.}

No Recurso Ordinário em Mandado de Segurança 13496/PR, Relator Ministro José Delgado, julgado em 20 de junho de $2002^{1141}$, a Primeira Turma, por maioria, vencido o Ministro Humberto Gomes de Barros, entendeu que o advogado intimado a depor como testemunha não pode ter acesso a inquérito policial sob sigilo:

RECURSO EM MANDADO DE SEGURANÇA. PROCESSO PENAL. INQUÉRITO POLICIAL. DECRETAÇÃO DE SIGILO. ADVOGADO. VISTAS DOS AUTOS E CÓPIAS DE PEÇAS. VINCULAÇÃO AO EXAME DO CONTEXTO FÁTICO. 1 - Decretado o sigilo do inquérito policial, há que ser mantido se demonstrado que a quebra conduziria à frustração de todo procedimento investigatório. 2 - Não figurando o cliente dos recorrentes como indiciado nos autos de inquérito policial que tramita sob sigilo, a segurança não pode ser concedida, eis que tal medida, poderá conduzir ao fracasso da investigação criminal, bem como violar a intimidade da real indiciada, que teve quebrado o sigilo bancário. 3 - Nenhum direito, por mais importante que seja, pode ser visto como absoluto, ficando sempre condicionado ao exame do contexto fático. 4 - Inexistência de direito líquido e certo a amparar a pretensão dos recorrentes. 5 - Recurso ordinário improvido.

\section{Dano moral decorrente de violação de direitos da personalidade em geral.}

Recurso Especial 506437/SP, Relator Ministro Fernando Gonçalves, julgado pela Quarta Turma em 16 de setembro de $2003^{1142}$ :

RESPONSABILIDADE CIVIL. DANO MORAL. VIOLAÇÃO. DIREITOS DA PERSONALIDADE. INTIMIDADE. VEICULAÇÃO. LISTA TELEFÔNICA. ANÚNCIO COMERCIAL EQUIVOCADO. SERVIÇOS DE MASSAGEM. 1. A conduta da prestadora de serviços telefônicos caracterizada pela veiculação não autorizada e equivocada de anúncio comercial na seção de serviços de

${ }^{1141}$ Decisão publicada no Diário da Justiça de 16 de dezembro de 2002, p. 245.

${ }^{1142}$ Decisão publicada no Diário da Justiça de 6 de outubro de 2003, p. 280. 
massagens, viola a intimidade da pessoa humana ao publicar telefone e endereço residenciais. 2. No sistema jurídico atual, não se cogita da prova acerca da existência de dano decorrente da violação aos direitos da personalidade, dentre eles a intimidade, imagem, honra e reputação, já que, na espécie, o dano é presumido pela simples violação ao bem jurídico tutelado. 3. Recurso especial parcialmente conhecido e provido.

Recurso Especial 521697/RJ, Relator Ministro Cesar Asfor Rocha, julgado pela Quarta Turma em 16 de fevereiro de $2006^{1143}$ :

\begin{abstract}
CIVIL. DANOS MORAIS E MATERIAIS. DIREITO À IMAGEM E À HONRA DE PAI FALECIDO.

Os direitos da personalidade, de que o direito à imagem é um deles, guardam como principal característica a sua intransmissibilidade. Nem por isso, contudo, deixa de merecer proteção a imagem e a honra de quem falece, como se fossem coisas de ninguém, porque elas permanecem perenemente lembradas nas memórias, como bens imortais que se prolongam para muito além da vida, estando até acima desta, como sentenciou Ariosto. Daí porque não se pode subtrair dos filhos o direito de defender a imagem e a honra de seu falecido pai, pois eles, em linha de normalidade, são os que mais se desvanecem com a exaltação feita à sua memória, como são os que mais se abatem e se deprimem por qualquer agressão que lhe possa trazer mácula. Ademais, a imagem de pessoa famosa projeta efeitos econômicos para além de sua morte, pelo que os seus sucessores passam a ter, por direito próprio, legitimidade para postularem indenização em juízo, seja por dano moral, seja por dano material.

Primeiro recurso especial das autoras parcialmente conhecido e, nessa parte, parcialmente provido.

Segundo recurso especial das autoras não conhecido.

Recurso da ré conhecido pelo dissídio, mas improvido.
\end{abstract}

Recurso Especial 890930/RJ, Relatora Ministra Denise Arruda, julgado pela Primeira Turma em 17 de maio de $2007^{1144}$ :

PROCESSUAL CIVIL. ADMINISTRATIVO. RESPONSABILIDADE CIVIL DO ESTADO. ANISTIA (LEI 9.140/95). ALEGADA VIOLAÇÃO DO ART. 535, I E II, DO CPC. NÃO-OCORRÊNCIA. PRESCRIÇÃO. INAPLICABILIDADE DO ART. $1^{\circ}$ DO DECRETO 20.910/32. ACUMULAÇÃO DE REPARAÇÃO ECONÔMICA COM INDENIZAÇÃO POR DANOS MORAIS. POSSIBILIDADE. INTERPRETAÇÃO DO ART. 16 DA LEI 10.559/2002. PRECEDENTES. DESPROVIMENTO.

1. Não viola o art. 535, I e II, do CPC, nem importa negativa de prestação jurisdicional, o acórdão que decide, motivadamente, todas as questões argüidas pela parte, julgando integralmente a lide.

2. A pretensão indenizatória decorrente de violação de direitos humanos fundamentais durante o Regime Militar de exceção é imprescritível. Inaplicabilidade da prescrição qüinqüenal prevista no art. $1^{\circ}$ do Decreto 20.910/32.

3. A Lei 10.559/2002 proíbe a acumulação de: (I) reparação econômica em parcela única com reparação econômica em prestação continuada ( $\operatorname{art.} 3^{\circ}, \S 1^{\circ}$ );

(II) pagamentos, benefícios ou indenizações com o mesmo fundamento, facultando-se ao anistiado político, nesta hipótese, a escolha da opção mais favorável (art. 16).

4. Não há vedação para a acumulação da reparação econômica com indenização

${ }^{1143}$ Decisão publicada no Diário da Justiça de 20 de março de 2006, p. 276.

${ }^{1144}$ Decisão publicada no Diário da Justiça de 14 de junho de 2007, p. 267. 
por danos morais, porquanto se tratam de verbas indenizatórias com fundamentos e finalidades diversas: aquela visa à recomposição patrimonial (danos emergentes e lucros cessantes), ao passo que esta tem por escopo a tutela da integridade moral, expressão dos direitos da personalidade. Aplicação da orientação consolidada na Súmula 37/STJ.

5. Os direitos dos anistiados políticos, expressos na Lei 10.559/2002 (art. $1^{\circ}$, I a V), não excluem outros conferidos por outras normas legais ou constitucionais. Insere-se, aqui, o direito fundamental à reparação por danos morais $(\mathrm{CF} / 88$, art. 5, V e X; CC/1916, art. 159; CC/2002, art. 186), que não pode ser suprimido nem cerceado por ato normativo infraconstitucional, tampouco pela interpretação da regra jurídica, sob pena de inconstitucionalidade.

6. Recurso especial desprovido.

\section{Integridade física.}

Recurso Especial 733990/MG, Relatora Ministra Nancy Andrighi, julgado pela Terceira Turma em 21 de fevereiro de $2006^{1145}$ :

Direito Civil. Acidente do Trabalho. L.E.R. adquirida pela recorrente no desempenho de sua atividade como bancária. Aposentadoria por invalidez. Lesão reversível mediante procedimento cirúrgico. Recusa da recorrente a se submeter a esse procedimento. Legitimidade. Pensão mensal devida pela recorrida, no valor integral da remuneração da recorrente, até o momento da retomada de sua capacidade laborativa.

- O direito à integridade física é fundamental, e procedimentos cirúrgicos não autorizados pelo paciente somente se admitem em casos graves e de extrema urgência.

- Merece reforma o acórdão do Tribunal de origem que negou a reparação dos danos materiais sofridos pela recorrente em função do desenvolvimento de L.E.R., meramente porque a lesão poderia ser revertida por cirurgia que ela recusa a autorizar.

- Estabelecida a incapacidade para o exercício de determinado mister em função de L.E.R., é devida pensão mensal pelo empregador responsável pelas condições de trabalho que favoreceram o desenvolvimento da doença, pensão essa que perdurará até a retomada da capacidade para o trabalho, utilizando-se como parâmetro para essa retomada o controle promovido pelo INSS.

- Deve ser abatida da pensão mensal paga o valor auferido pela recorrente em função de novo trabalho remunerado que ela desenvolva. Tal fato, porém, deve ser comprovado pelo recorrido em ação própria.

- Sendo o acidente do trabalho considerado ato ilícito, incidem juros na forma da Súmula 54/STJ. Determinada, outrossim, a constituição de garantia fidejussória ou fundo de capital (precedentes).

Recurso conhecido e provido.

\section{Habeas data.}

O Recurso Especial 781969/RJ, Relator Ministro Luiz Fux, julgado em 8 de maio de $2007^{1146}$, tratou explicitamente do direito de controle aos dados pessoais no Brasil, discorrendo longamente sobre o "habeas data":

$\begin{array}{llll}\text { RECURSO ESPECIAL. } & \text { ADMINISTRATIVO. HABEAS DATA. } \\ \text { CABIMENTO. OBTENÇÃO } & \text { DE CERTIDÃO JUNTO AO INSTITUTO }\end{array}$

1145 Decisão publicada no Diário da Justiça de 20 de março de 2006, p. 270.

${ }^{1146}$ Decisão publicada no Diário da Justiça de 31 de maio de 2007, p. 348. 
MILITAR DE ENGENHARIA - IME. CONTAGEM PARA O BENEFÍCIO DO ADICIONAL POR TEMPO DE SERVIÇO. DIREITO À INFORMAÇÃO. ART. $5^{\circ}$, XXXIII, DA CARTA MAGNA DE 1.988. IMPROPRIEDADE DA VIA ELEITA. PLEITO QUE DEVE SER DEDUZIDO EM SEDE DE WRIT OF MANDAMUS.

1. A Constituição Federal prevê, em seu art. $5^{\circ}$, LXXII que conceder-se-á habeas data: a) para assegurar o conhecimento de informações relativas à pessoa do impetrante, constantes de registros ou bancos de dados de entidades governamentais ou de caráter público; b) para a retificação de dados, quando não se prefira fazê-lo por processo sigiloso, judicial ou administrativo.

2. A Lei $n^{\circ} 9.507$, de 12 de novembro de 1.997 , por sua vez, ao disciplinar o habeas data, acrescentou mais uma hipótese de cabimento da medida, além daquelas já previstas constitucionalmente, dispondo, em seu art. $7^{\circ}$, III, verbis: para anotação nos assentamentos do interessado, de contestação ou explicação sobre dado verdadeiro mas justificável e que esteja sob pendência judicial ou amigável.

3. Sob esse enfoque, a ratio essendi do habeas data é assegurar, em favor da pessoa interessada, o exercício de pretensão jurídica que se distingue nos seguintes aspectos: a) direito ao acesso de registro; b) direito de retificação de registro e c) direito de complementação de registros. Portanto, o referido instrumento presta-se a impulsionar a jurisdição constitucional das liberdades, representando no plano institucional a mais eloqüente reação jurídica do Estado às situações que lesem, de forma efetiva ou potencial, os direitos fundamentais do cidadão.

4. Embora o art. $5^{\circ}, \mathrm{XXXIII,} \mathrm{da} \mathrm{Carta} \mathrm{Magna} \mathrm{de} 1.988$ tutele o direito à informação, de interesse particular ou coletivo, não se pode afirmar que o habeas data o resguarde. Deveras, o direito à informação abrange os mais variados temas, como, in casu, o direito de petição junto a Administração Pública; enquanto que o habeas data visa assegurar o acesso à informações pertinentes a própria pessoa do impetrante e desconhecidas pelo mesmo. Daí, exsurge a possibilidade de retificação, ou mesmo a exclusão, dos dados, obstando o seu uso indevido. Ademais, o habeas data é servil à garantir o acesso a banco de dados mantidos por entidades governamentais, aí incluídas as concessionárias, permissionários, exercentes de atividades autorizadas, órgãos de restrição ao crédito e até mesmo as empresas de colocação de profissionais no mercado de trabalho, tutelando o que parte da doutrina denomina liberdade informática. Nesse sentido é a doutrina administrativista pátria, que oportunamente se traz á baila: Não se pode dizer que ele constitua garantia do direito à informação previsto no artigo 52, inciso XXXIII, segundo o qual "todos têm direito a receber dos órgãos públicos informações de seu interesse particular; ou de interesse coletivo ou geral, que serão prestadas no prazo da lei, sob pena de responsabilidade, ressalvadas aquelas cujo sigilo seja imprescindível à segurança da sociedade e do Estado". Embora o dispositivo assegure o direito à informação de interesse particular ou de interesse coletivo, ele não se confunde com a informação protegida pelo habeas data, que é sempre relativa à pessoa do impetrante, com a particularidade de constar de banco ou registro de dados. O direito à informação, que se exerce na via administrativa, é mais amplo e pode referir-se a assuntos dos mais variados como o conteúdo de um parecer jurídico, de um laudo técnico, de uma informação constante do processo, de uma prova apresentada em concurso público, do depoimento de uma testemunha etc.; não se refere a dados sobre a própria pessoa do requerente; e pode ter por finalidade a defesa de um interesse particular; como, por exemplo, o exercício do direito de petição perante a própria Administração Pública, ou a defesa de um direito individual perante o Judiciário, ou de um interesse coletivo, como a defesa do patrimônio público. Já o habeas data assegura o conhecimento de informações relativas à própria pessoa do impetrante; e o objetivo é sempre o de conhecer e retificar essas informações, quando errôneas, para evitar o seu uso indevido. Dessa distinção decorrem importantes consequiências: 1. o direito à informação de interesse particular ou coletivo (art. 52, XXXIII), se negado pela Administração, deve ser protegido pela via judicial ordinária ou pelo mandado 
de segurança e não pelo habeas data; 2. o mesmo direito pode ser exercido de forma ampla, com ressalva para as informações "cujo sigilo seja imprescindível à segurança da sociedade e do Estado"; essa restrição não se aplica no caso do habeas data, que protege a própria intimidade da pessoa. Essa conclusão decorre do fato de que o inciso LXXII do artigo 52 não contém a mesma restrição inserida na parte final do inciso XXXIII. Como diz Manoel Gonçalves Ferreira Filho (1989:282), ao comparar este último dispositivo com o referente ao habeas data, "as informações que se podem obter do Poder Público aqui tratadas são de caráter geral, concernentes às atividades múltiplas dos órgãos governamentais e, portanto, justificam a ressalva imposta. Trata-se do direito à informação tãosomente. Aquelas que se pretendem obter mediante impetração de habeas data dizem respeito a dados relativos à pessoa do requerente que, obviamente, não admitem segredo com relação a ele". Esse é também o pensamento de Calmon Passos (1989:139): "no habeas data não se postula a certificação judicial do direito à informação. Esse direito, no tocante à própria pessoa do interessado, foi deferido constitucionalmente sem possibilidade de contestação ou restrição. Nenhuma exceção lhe foi posta, constitucionalmente. A respeito da própria pessoa, o direito à informação é livre de barreiras, inexistindo exceções que o limitem ou excluam" (grifamos) (DI PIETRO, Maria, Direito Administrativo, Ed. Atlas, São Paulo, 2001, 13 ${ }^{\text {a }}$ Edição, p. 615 e 616). O habeas data (art. $5^{\circ}$, LXXII) é um remédio constitucional que tem por objeto proteger a esfera íntima dos indivíduos contra: (a) usos abusivos de registros de dados pessoais coletados por meios fraudulentos, desleais ou ilícitos; (b) introdução nesses registros de dados sensíveis (assim chamados os de origem racial, opinião política, filosófica ou religiosa, filiação partidária e sindical, orientação sexual etc.); (c) conservação de dados falsos ou com fins diversos dos autorizados em lei. Firmín Morales Prats emprega a expressão habeas data ao lado de habeas scriptum e habeas mentem. Este último como expressão jurídica da intimidade. Os dois primeiros, mais ou menos como sinônimos no sentido de direito ao controle da circulação de dados pessoais. As Constituições da Espanha (art. 18) e de Portugal (art. 35) dispõem, respectivamente, sobre o controle do uso da informática e sobre o direito de conhecer o que constar de registros informáticos a seu respeito, mas nenhuma delas e nenhuma outra criou um meio específico de invocar a jurisdição para fazer valer esses direitos reconhecidos. A Constituição de 1988 não traz um dispositivo autônomo que contemple o direito de conhecer e de retificar dados pessoais. Usou o mesmo processo que nas Constituições anteriores se reconhecia à liberdade de locomoção: através da previsão de sua garantia. O direito de conhecimento de dados pessoais e de retificá-Ios é outorgado no mesmo dispositivo que institui o remédio de sua tutela, in verbis: "Art. 5', LXXII - conceder-se-á habeas data: a) para assegurar o conhecimento de informações relativas à pessoa do impetrante, constantes de registros ou bancos de dados de entidades governamentais ou de caráter público; b) para a retificação de dados, quando não se prefira fazê-Io por processo sigiloso, judicial ou administrativo. Vê-se que o direito de conhecer e retificar os dados, assim como o de interpor o habeas data para fazer valer esse direito quando não espontaneamente prestado, é personalíssimo do titular dos dados, do impetrante que, no entanto, pode ser brasileiro ou estrangeiro. Mas uma decisão do ainda Tribunal Federal de Recursos (agora, STJ), em Plenário, admitiu que os herdeiros legítimos do morto ou se cônjuge supérstite poderão impetrar o writ. E uma decisão liberal que supera o entendimento meramente literal do texto, com justiça, pois não seria razoável que se continuasse a fazer uso ilegítimo e indevido dos dados do morto, afrontando sua memória, sem que houvesse meio de corrigenda adequado. $\mathrm{O}$ objeto do habeas data consiste em assegurar: (a) o direito de acesso e conhecimento de informações relativas à pessoa do impetrante/constantes de registros ou bancos de dados de entidades governamentais e de entidades de caráter público; (b) o direito à retificação desses dados, importando isso em atualização, correção e até a supressão, quando incorretos. Em relação ao direito de retificação, o dispositivo constitucional faculta ao impetrante o processo sigiloso, Judicial ou administrativo, dando a entender que, se o processo for sigiloso, não será de habeas data, mas outra ação, 
o que não tem sentido algum. Nem serão necessários dois habeas datas para que uma mesma pessoa tome conhecimento dos dados e proponha sua retificação. Sustentar o contrário é pretender enquadrar instituto novo em velhos esquemas de um procedimentalismo superado. O processo do habeas data pode desenvolver-se em duas fases. Na primeira, o Juiz, de plano, manda notificar o impetrado para apresentar os dados do impetrante, constantes de seu registro, no prazo que estipule; Juntados os dados, o impetrante terá ciência deles, devendo manifestar-se em prazo determinado. Se nada tiver a retificar, di-lo-á e se arquivará o processo. Se tiver retificação a fazer, dirá quais são, fundamentadamente, mediante aditamento à inicial, e então o Juiz determinará a citação do impetrado para a contestação, se quiser, prosseguindo-se nos termos do contraditório. "Entidades governamentais" é uma expressão que abrange órgãos da administração direta ou indireta. Logo, a expressão "entidades de caráter público" não pode referir-se a organismos públicos, mas a instituições, entidades e pessoas jurídicas privadas que prestem serviços para o público ou de interesse público, envolvendo-se aí não só concessionários, permissionários ou exercentes de atividades autorizadas, mas também agentes de controle e proteção de situações sociais ou coletivas, como as instituições de cadastramento de dados pessoais para controle ou proteção do crédito ou divulgadoras profissionais de dados pessoais, como as firmas de assessoria e fornecimento de malas-diretas. Essa doutrina, que já constava das edições anteriores, foi amplamente acolhida pela Lei 9.507, de 12.11.1997, que regulou o direito de acesso a informações e disciplinou o rito processual do habeas data, quando, no parágrafo único do art. $1^{\circ}$, considera de caráter público "todo registro ou banco de dados contendo informações que sejam ou que possam ser transmitidas a terceiros ou que não sejam de uso privativo do órgão ou entidade produtora ou depositária das informações". O habeas data, instituído como remédio constitucional no Brasil, responde, no plano do direito positivo, ao reclamo de Frosini e ao conteúdo básico, pensado por Firmín Morales Prats. Frosini: “A história jurídica da liberdade pessoal no mundo moderno se funda sobre o habeas corpus Act de 1679 [...] oposto à detenção ilegal. Pode-se dizer, com uma paráfrase de caráter metafórico, que na legislação dos Estados modernos se reclame hoje um habeas data, um reconhecimento do direito do cidadão de dispor dos próprios dados pessoais do mesmo modo que tem o direito de dispor livremente do próprio corpo". "O habeas data, ou conjunto de direitos que garante o controle da identidade informática [escreve Firmín Morales], implica o reconhecimento do direito de conhecer, do direito de correção, de subtração ou anulação, e de agregação sobre os dados depositados num fichário eletrônico. Esse elenco de faculdades, que derivam do princípio de acesso aos bancos de dados, constitui a denominada 'liberdade informática' ou direito ao controle dos dados que respeitam ao próprio indivíduo (biológicos, sanitários, acadêmicos, familiares, sexuais, políticos, sindicais...)" (J.A. SILVA, Curso de Direito Constitucional Positivo, Ed. Malheiros, São Paulo, 2004, 23ª Edição, p. 451 e 455).

5. A pretensão do impetrante, de obter certidão para o cômputo do adicional por tempo de serviço, respeita ao direito de informação, cuja previsão encontra-se no art. $5^{\circ}$, XXXIII, da Carta Magna de 1.988, devendo ser pleiteada via mandado de segurança (precedentes: EDcl no HD 67 - DF, Relatora Ministra DENISE ARRUDA, Primeira Seção, DJ de 02 de agosto de 2.004; HD 67 MC - SP, decisão monocrática do Ministro CELSO DE MELLO, DJ de 18 de novembro de 2.004).

6. Recurso especial conhecido e provido, com o fim de declarar a impropriedade da via eleita pelo impetrante.

Restou estabelecido pela jurisprudência que o direito assegurado pelo "habeas data" não se confunde com o direito de obter certidões do Poder Público, como se vê no Habeas 
Tribunal de Justiça em 9 de março de $2005^{1147}$, e nos Embargos de Declaração no Habeas Data 67/DF, Relatora Ministra Denise Arruda, julgados pela Primeira Seção do Superior Tribunal de Justiça de 9 de junho de $2004^{1148}$.

O Tribunal chegou a entender que a Caixa Econômica Federal detinha legitimidade passiva para figurar no pólo passivo de "habeas data" impetrado com o objetivo de se obter dados sobres descontos efetuados em conta corrente, por ser empresa pública e, portanto, integrar a Administração Indireta, no Recurso Especial 929381/AL, Relator Ministro Francisco Falcão, julgado pela Primeira Turma em 4 de outubro de $2007^{1149}$.

Esse Tribunal entendeu cabível "habeas data" para impetrante que objetivava acesso a seus dados funcionais junto à Aeronáutica, no Habeas Data 91/DF, Relator Ministro Arnaldo Esteves Lima, julgado pela Terceira Seção em 14 de março de $2007^{1150}$, e a militar que visava à obtenção de cópia de parecer de que resultara sua exoneração, no Habeas Data 84/DF, Relatora Ministra Maria Thereza de Assis Moura, julgado pela Terceira Seção em 27 de setembro de $2006^{1151}$.

Mas não seria abrangido pelos "habeas data": (i) cópia de processo administrativo do interesse em que o impetrante é parte: Recurso Especial 904447/RJ, Relator Ministro Teori Albino Zavascki, julgado pela Primeira Turma em 8 de maio de $2007^{1152}$; (ii) acesso a informações sobre os critérios utilizados em prova de concurso público: Agravo Regimental no Habeas Data 127/DF, Relator Ministro João Otávio de Noronha, julgado pela Primeira Seção do Superior Tribunal de Justiça em 14 de junho de $2006^{1153}$; (iii) obtenção de informação quanto a andamento de procedimento administrativo: Habeas Data 123/DF, Relator Ministro Castro Meira, julgado pela Primeira Seção do STJ em 22 de março de $2006^{1154}$; (iv) obtenção de informações de inquérito policial sigiloso: Agravo Regimental nos Embargos de Declaração no Habeas Data 98/DF, Relator Ministro Teori Albino Zavascki, julgado pela Primeira Seção em 22 de setembro de $2004^{1155}$.

\footnotetext{
${ }^{1147}$ Decisão publicada no Diário da Justiça de 18 de abril de 2005, p. 202.

${ }^{1148}$ Decisão publicada no Diário da Justiça em 2 de agosto de 2004, p. 273.

${ }^{1149}$ Decisão publicada no Diário da Justiça de 25 de outubro de 2007, p. 137.

${ }^{1150}$ Decisão publicada no Diário da Justiça de 16 de abril de 2007, p. 164.

${ }^{1151}$ Decisão publicada no Diário da Justiça de 30 de outubro de 2006, p. 236.

${ }^{1152}$ Decisão publicada no Diário da Justiça de 24 de maio de 2007, p. 333.

${ }^{1153}$ Decisão publicada no Diário da Justiça de 14 de agosto de 2008, p. 250.

${ }^{1154}$ Decisão publicada no Diário da Justiça de 3 de abril de 2006, p. 197.

${ }^{1155}$ Decisão publicada no Diário da Justiça de 11 de outubro de 2004, p. 211.
} 


\section{ANEXO A - ANTEPROJETO DE LEI DA COMISSÃO MINISTERIAL}

\section{EXPOSIÇÃO DE MOTIVOS}

1 - A quebra do sigilo de comunicações telefônicas, excepcionalmente admitida pela Constituição Federal, na parte final do inciso XII do artigo $5^{\circ}$, exclusivamente para fins de investigação criminal e instrução processual penal, constitui, certamente, poderoso meio posto à disposição do Estado para fins de obtenção da prova, mas também instrumento insidioso de quebra da intimidade, não só do investigado, como também de terceiros.

Por isso, diante do princípio da reserva de lei proporcional, a regulamentação da matéria há de resultar da escrupulosa ponderação dos valores em jogo, observando o princípio da proporcionalidade, entendido como justo equilíbrio entre os meios empregados e os fins a serem alcançados. E a proporcionalidade deve levar em conta os seguintes dados: a - adequação, ou seja a aptidão da medida para atingir os objetivos pretendidos; $\mathrm{b}$ - necessidade, como exigência de limitar um direito para proteger outro, igualmente relevante; c) proporcionalidade estrita, ou seja a ponderação entre a restrição imposta (que não deve aniquilar o direito) e a vantagem alcançada, o que importa na d) não excessividade.

2 - O defeito maior da vigente lei 9.296, de 24 de julho de 1996, que dispõe sobre interceptações telefônicas e de fluxo de comunicações em sistemas de informática e telemática, talvez consista exatamente na inobservância do princípio da proporcionalidade, quando, por exemplo, permite o interceptação relativamente a todos os crimes punidos com pena de reclusão - no que não observa o princípio da adequação e da não excessividade, estendendo a operação técnica indicada para qualquer tipo de crime, desde que punido com reclusão, e deixando de fora crimes punidos com detenção, mas para os quais a interceptação se apresenta como o meio mais adequado de investigação, como na ameaça cometida por telefone; quando permite o pedido formulado verbalmente, o que evidentemente corroi a verificação da necessidade e da adequação.

Mas há outros graves defeitos na lei, como quando transborda da autorização constitucional para prever interceptações de comunicações em sistemas de informática; quando não permite ao acusado o pedido de interceptação; quando não dá vista ao MP do requerimento da diligência pela autoridade policial; quando não dispõe com clareza sobre o 
incidente probatório no qual deve dar-se conhecimento às partes do conteúdo das operações técnicas, em contraditório pleno; quando omite completamente o tratamento das chamadas "interceptações ambientais"; quando considera a interceptação como único meio de intromissão legal numa comunicação telefônica, olvidando o impedimento, a interrupção, a escuta e gravação. E, sobretudo, a lei em vigor não cuida dos controles necessários a evitar os abusos a que frequentemente sua aplicação deu margem: controles sobre a representação e requerimento da polícia e do Ministério Público, controles sobre a autorização judicial e a forma de seu encaminhamento, controles mais rigorosos sobre os prazos e, sobretudo, controles sobre as operações técnicas, hoje deixadas exclusivamente a critério da autoridade policial, sem a fixação de qualquer parâmetro.

3 - O projeto de lei 1258, de 1995, do Senador Pedro Simon, aprovado no Senado no mesmo ano, parou nos meandros da Câmara dos Deputados. Referido Projeto era sensivelmente melhor do que a lei que entrou em vigor, retomando muitas das idéias do Projeto Miro Teixeira (projeto n.3.514/89, aprovado na Câmara dos Deputados). No entanto, decorridos quase dez anos, algumas modificações nas modalidades criminosas justificam a inclusão de novos crimes entre os sujeitos às operações técnicas e, sobretudo, tecnologias mais modernas podem dar o norte para operações técnicas seguras, sob o ponto de vista da inviolabilidade dos elementos probatórios obtidos.

O presente Anteprojeto de Lei, ora apresentado pela Comissão instituída pelo Ministro da Justiça Márcio Thomás Bastos, e constituída por Ada Pellegrini Grinover (coautora do Anteprojeto acolhido pelo Projeto Miro Teixeira), Antônio Carlos de Almeida Castro, Antônio Magalhães Gomes Filho, Antonio Scarance Fernandes e Luiz Guilherme Vieira, quer representar uma melhoria e uma modernização do Projeto do Pedro Simon, que por sua vez se inspirava no Projeto Miro Teixeira, aperfeiçoando-o, sem embargo de novidades ditadas pela experiência dos diversos operadores do direito ouvidos.

Com efeito, além de ouvir em audiência pública as sugestões da Polícia, Federal e Estadual, do Ministério Público e das prestadoras dos serviços de telefonia, além dos técnicos especialistas nos sistemas operacionais, e além de incorporar diversas idéias apresentadas pelo IBCCrim, a Comissão entrou em contato com a Secretaria de Segurança Pública do Distrito Federal e do Rio Grande do Sul, com a Superintendência da Polícia Federal do Distrito Federal, com o Ministério Público de São Paulo e com os juízes do DIPO de São Paulo, ouvindo, ainda, as prestadoras de serviços de telefonia e a ANATEL.

Isso tudo para que, além de avançar nos aspectos jurídicos, o Anteprojeto não 
ficasse distanciado das modernas técnicas de interferência nas comunicações telefônicas, no intuito de garantir a segurança, a inviolabilidade e a preservação do sigilo.

4 - $\quad$ A primeira versão do Anteprojeto, apresentado ao Ministro da Justiça, Dr. Márcio Thomás Bastos, aos 7 de abril de 2003, foi divulgada pela Internet para críticas e sugestões. A convocação foi atendida por várias instituições e diversos operadores do direito, de todas as áreas interessadas.

A Comissão examinou cuidadosamente todas as mensagens recebidas por e-mail, e mais uma, enviada diretamente pela Consultoria Jurídica do Ministério da Justiça. As contribuições foram extremamente valiosas.

O novo Anteprojeto incorporou diversas sugestões do IBCCrim, da AJUFE, dos Juízes Federais do Rio de Janeiro, da ANPR e dos Drs. Edval Novaes, Marcos Josegrei da Silva, Moser Vhoss e Paulo Célio de Souza Leal, entre outras.

Algumas sugestões não puderam ser incorporadas por vulnerarem a Constituição: assim, por exemplo, a extensão da possibilidade de interceptações para a "aplicação da lei penal", a inclusão dos crimes políticos no rol do artigo $1^{\circ}$, a atribuição de poderes processuais a órgão de inteligência policial, que não integra os da persecução penal.

Quando a Comissão percebeu tendências opostas nas sugestões, escolheu o ponto que marcasse uma posição de equilíbrio. E nas questões mais polêmicas entendeu que não devia engessar uma ou outra postura na lei, permitindo à doutrina e sobretudo à jurisprudência construírem sua interpretação: assim ocorreu, por exemplo, com relação à prova emprestada, do processo penal para o administrativo, em que o Anteprojeto agora não toma posição; e com a disposição transitória sobre a aplicabilidade da nova lei aos processos em que a interceptação tiver sido feita com base na Lei n.9.296/96.

Finalmente, não se colheu a sugestão de incluir um glossário na lei, pois a Comissão entendeu difícil e até perigoso emitir conceitos numa matéria ainda em consolidação, em que as definições poderiam limitar as possibilidades de interpretação.

5 - A versão final do Anteprojeto, ora apresentada, aponta, no art. $1^{\mathbf{0}}$, as diversas técnicas de interferência na comunicação telefônica: a interceptação (a captação por um terceiro da conversa entre dois interlocutores), o impedimento (a intervenção para que a comunicação não chegue a seu destino), a interrupção (a obstrução da comunicação, em determinado momento), a escuta (a interceptação feita com o conhecimento de um dos interlocutores) e a gravação das conversas captadas. Às comunicações telefônicas são 
equiparadas todas as formas de telecomunicações, hoje enumeradas na Lei n.9.472/97.

No mesmo artigo, o anteprojeto indica, em obediência ao princípio da proporcionalidade, os crimes relativamente aos quais a interferência é admissível. O rol é bastante amplo, de modo a compreender novas modalidades criminosas (como o chamado seqüestro relâmpago, os crimes contra a ordem tributária, o tráfico de espécimes da fauna silvestre, o tráfico de armas, munições e explosivos). Tata-se de crimes de natureza grave, mas também particularmente adequados a serem investigadados na forma prevista na lei, ou então de crimes tipicamente cometidos por telefone, como o de ameaça.

Logo a seguir, trata das denominadas "interceptações ambientais", tanto de conversas como de sinais eletromagnéticos, óticos ou acústicos, determinando sua sujeição, no que couber, às mesmas regras previstas no Anteprojeto (art.2 ${ }^{\circ}$ ). A este, ao contrário, não fica sujeita a gravação de conversa própria, sem conhecimento do interlocutor, por telefone ou por outros meios, mas sua divulgação só será permitida para o exercício regular de um direito $\left(\operatorname{art} .4^{\mathrm{o}}\right)$.

Desde logo se exclui toda e qualquer intromissão nas comunicações entre o suspeito ou acusado ou seu defensor, de modo mais amplo de quanto o façam a lei em vigor e o projeto Pedro Simon $\left(\operatorname{art} .3^{\circ}\right)$.

$\mathrm{O}$ art. $5^{\circ}$ cuida minuciosamente do pedido, formulado mediante requerimento do MP ou representação da autoridade policial (ciente, neste caso, o MP), que deverá conter todos os elementos, cuidadosamente enumerados, aptos a convencer o juiz da necessidade e da legalidade da operação técnica requerida. Esbatendo uma dúvida prática que tem gerado controvérsia nos tribunais, a lei confere ao MP e à autoridade policial o poder de requisitar das prestadoras dos serviços de telefonia, exclusivamente para os fins de formulação do pedido, o cadastro relativo ao nome, número de telefone e endereço do titular da linha ou do local onde o aparelho estiver instalado. O suspeito ou acusado, assim como ofendido - quando se trate de ameaça cometida por telefone - também poderão formular o pedido.

$\mathrm{O}$ art. $6^{\circ}$ cerca de cuidados a autorização judicial que, precedida de distribuição, e evidentemente fundamentada, deverá referir-se de forma expressa aos pressupostos autorizadores da diligência, taxativamente enumerados. Da decisão que deferir ou indeferir a operação técnica cabe recurso em sentido etrito, sem efeito suspensivo (art. $7^{\circ}$ ); fica claro, no parágrafo único, que o recurso corre em segredo de justiça e, na hipótese de indeferimento do pedido, será processado sem a oitiva do suspeito ou acusado, a fim de resguardar a eficácia da investigação. 
$\mathrm{O}$ art. $8^{\mathrm{o}}$ toma o cuidado de determinar que a ordem judiciária, a ser assinada pelo juiz, contenha o número da linha telefônica (código de acesso) e o código de área, devendo ser entregue, em duas vias, uma para a prestadora do serviço de telefonia e outra à autoridade policial, com ciência ao MP. O parágrafo único do art. 10 fixa prazo às prestadoras de serviços para implementar a realização das operações técnicas. Resolve-se, assim, outra questão prática que gerava dúvidas e escapava de controles.

Especial cuidado tomam os arts. $9^{\circ}$ e 10 com os prazos das operações técnicas, exigindo maior controle do juiz sobre os mesmos.

$\mathrm{O}$ art.11 responde a outra dificuldade prática hoje existente, substituíndo a precatória por qualquer meio rápido de comunicação, a ser confirmado em 48 horas por documento oficial, quando as operações técnicas devam ser realizadas fora da área de competência do juiz. No caso de falta de comunicação oficial, está prevista a imediata suspensão das operações, pelo juiz, e a inutilização da prova porventura colhida.

Especial cuidado mereceram as operações técnicas, durante as quais hoje ocorrem os maiores abusos. Sua execução é atribuída à autoridade policial, sujeita a controle do MP, porquanto o compromisso com o interesse público e com o sigilo, assim como a necessária especialização, desaconselham que a função seja atribuída às operadoras dos serviços de telefonia. Mas o Anteprojeto determina a necessidade de as operações serem efetuadas em órgão próprio, exclusivo e centralizado, sob a responsabilidade direta da Chefia de Polícia. Esses sistemas de gerenciamento centralizado, já existentes em diversos Estados da Federação e no Distrito Federal, asseguram a inviolabilidade da informação obtida, sem engessar as operações. Trata-se de sistema indevassável, cujo padrão deverá ser estabelecido, em 90 dias, pelo Ministério da Justiça, de modo a atender às especificidades das Polícias Federal e Estadual, enquanto caberá à ANATEL, entre outras atribuições, regulamentar o padrão de protocolo a ser utilizado por todas as prestadoras de serviços telecomunicações. Prevê-se a possibilidade de Convênios entre União, Estados e Municípios (arts.12 a 14). Fica claro, no art. 15 e em seu parágrafo único, que o ressarcimento das prestadoras de serviços de telefonia será sempre posterior à sua realização, não podendo se alegar qualquer questão a ele ligada como óbice à implementação das medidas.

Findas as operaçoes técnicas, a autoridade policial encaminhará imediatamente, em duas copias, todo o material obtido ao juiz competente, juntamente com os autos circunstanciados com o resumo das operações realizadas, proibida a permanência de qualquer registro no sistema (art.12, parágrafo único). 
Recebido o material pelo juiz, e não havendo necessidade de diligências complementares previstas na lei, tem início o incidente probatório, em contraditório pleno. As partes escutam em juízo as gravações, indicando os trechos cuja transcrição pretendem, sem prejuízo da atividade supletiva do juiz. Dúvidas sobre a autenticidade da gravação ou da voz serão decididas pelo juiz aplicando-se, no que for cabível, as regras do CPP sobre o incidente de falsidade. Da decisão do juiz sobre as transcrições e as dúvidas de autenticidade cabe recurso em sentido estrito, com efeito suspensivo restrito ao incidente probatório (Art.16).

Segundo o art. 17, a transcrição dos trechos indicados instruirá os autos, conservando-se em cartório, em absoluto segredo de justiça, as fitas magnéticas ou elementos análogos, até o trânsito em julgado da sentença. O parágrafo único do artigo permite que as partes extraiam cópias e escutem as gravações a qualquer tempo. A lei não se preocupa com o incidente de inutilização dos trechos de conversa estranhos à investigação dos crimes, não só porque o produto do Sistema Centralizado é totalmente indevassável, mas sobretudo porque não se pode retirar das partes o direito de voltar a escutar as gravações, que ainda podem ser úteis à defesa e à acusação.

$\mathrm{O}$ art.18 inaugura o Capítulo atinente à utilização da prova resultante de operações, determinando sua imprestabilidade quando feitas fora dos casos, modalidades e formas previstas na lei. E o art. 19, tratando das operações técnicas lícitas, adverte que a prova delas resultante só pode servir em relação aos crimes para os quais houve autorização, com exceção dos crime conexos ou de qualquer dos outros crimes constantes do rol do art. $1^{0}$.

No capítulo VI do Anteprojeto, que cuida das sanções penais, são tipificadas as seguintes condutas: a) proceder às operações de inerceptação, impedimento, interrupção, escuta ou gravação de comunicações telefônicas, e das telecomunicações a elas equiparadas para efeito desta lei, fora dos casos, modalidades e formas estabelecidos nesta lei, com previsão de qualificadora quando o agente for funcionário público; b) gravar clandestinamente a conversa entre presentes, bem como a proceder à captação ou interceptação ambiental de sinais eletromagnéticos, óticos ou acústicos, divulgá-los, decodificá-los, transcrevê-los ou utilizá-los, fora dos casos, modalidades e formas estabelecidos na lei, com previsão de qualificadora quando o agente for funcionário público; c) divulgar ou utilizar o conteúdo das operações ilegais, com previsão de qualificadora quando o agente for funcionário público; d) divulgar ou utilizar, por quaisquer meios, resultado de interceptação, escuta e gravação obtida nos termos da lei, protegida por segredo de justiça; e) divulgar gravação de conversa própria, telefônica ou 
não, executada sem conhecimento do interlocutor, salvo no caso de exercício regular de um direito; f) fazer afirmação falsa ou induzir a erro a autoridade judicial, com o propósito de obter a autorização, com previsão de qualificadora para o funcionário público ; g) autorizar as operações técnicas para finalidades diversas das tratadas na lei; $\mathrm{h}$ ) desobedecer, sem justa causa, à ordem judicial que determina a execução das operações técnicas. Se a divulgação, em qualquer das modalidades tipificadas pela lei, se der por meio de imprensa ou pela internet, prevê-se o aumento de pena de um terço e a apuração da responsabilidade penal segundo os arts. 37 a 39 da Lei n.5.250, de 1967.

Por último, nas disposições finais e transitórias, prevê-se o segredo de justiça para os inquéritos e processos que contenham elementos informativos ou provas obtidos na forma da lei (art.28). O artigo 29, numa disposição transitória, regulamenta a forma de execução das operações técnicas, enquanto o Ministério da Justiça e a ANATEL não definirem e regulamentarem o sistema de gerenciamento, atribuindo ao Chefe de Polícia a responsabilidade de estabelecer a forma de execução, de modo a possibilitar o controle do Ministério Público e a garantir a regularidade, inviolabilidade e privacidade do sistema utilizado; o art. 30 cuida da entrada em vigor da lei, prevendo uma vacatio legis de 60 dias; e, finalmente, o art. 31 revoga expressamente a Lei n. 9.296/96.

6 - Concluindo, a Comissão Especial constituída por Vossa Excelência quer salientar que a filosofia do anteprojeto - enriquecido, em sua versão final, pelas sugestões que incorporou - se funda na ação integrada da Polícia Judiciária e do Ministério Público, bem como na fixação de um sistema unificado de gerenciamento das operações, a ser estabelecido pelo Ministério da Justiça, com a regulamentação das atividades das prestadoras de serviços de telecomunicações, a ser especificada pela ANATEL. Tudo sob o controle do juiz e observados sempre os direitos de defesa, de modo a dotar o Estado de um poderoso meio de investigação, necessário conquanto excepcional, o qual não deve prestar-se a excessos e abusos, mas deve ser perfeitamente adequado aos fins a que se destina.

Brasília, 27 de junho de 2003

Ada Pellegrini Grinover

Antônio Carlos de Almeida Castro 
Antônio Magalhães Gomes Filho

Antônio Scarance Fernandes

Luiz Guilherme Vieira 
ANTEPROJETO DE LEI

Comissão Ministerial

Versão final II

\section{Disciplina o inciso XII, in fine, do artigo $5^{\circ}$ da Constituição Federal e dá outras providências}

O Congresso Nacional decreta:

\section{CAPÍTULO I \\ Da admissibilidade}

Art. $1^{\circ}$. A interceptação, o impedimento, a interrupção, a escuta e a gravação das comunicações telefônicas somente são admissíveis para fins de investigação criminal ou instrução processual penal relativamente aos seguintes crimes:

I - tráfico de substâncias entorpecentes e drogas afins;

II - tráfico de seres humanos e subtração de incapazes;

III - tráfico de armas, munições e explosivos;

IV - tráfico de espécimes da fauna silvestre;

$\mathrm{V}$ - lavagem de dinheiro;

VI - contra o sistema financeiro nacional;

VII- contra a ordem econômica e tributária;

VIII - contra a administração pública, desde que punidos com pena de reclusão;

IX - falsificação de moeda ou a ela assimilados;

$\mathrm{X}$ - roubo, extorsão simples, extorsão mediante seqüestro, seqüestro e cárcere privado;

XI - homicídio doloso;

XII - ameaça quando cometida por telefone;

XIII - decorrente de ações praticadas por organização criminosa;

XIV - decorrente de ações de terrorismo.

Parágrafo único. Equiparam-se às comunicações telefônicas, para efeito desta lei, todas as formas de telecomunicação (artigo 60, par. $1^{\circ}$, da Lei no 9.472/97).

Art. $2^{\circ}$. As gravações clandestinas de conversas entre presentes, bem como a captação e a interceptação ambiental de sinais eletromagnéticos, óticos ou acústicos, e o seu registro, análise e utilização, sujeitam-se às mesmas regras previstas nesta lei, no que forem cabíveis.

Art. $3^{\circ}$. As operações referidas nos artigos anteriores não serão permitidas, em qualquer hipótese, quando se tratar de comunicações entre o suspeito ou acusado e seu defensor.

Art. $4^{\circ}$. Não se sujeita a esta lei a gravação de conversa própria, sem conhecimento do interlocutor, por telefone ou por outros meios, mas sua divulgação só será permitida para o exercício regular de um direito. 
Art. $5^{\circ}$. O pedido será formulado por escrito ao juiz competente, mediante requerimento do Ministério Público ou representação da autoridade policial, ouvido, neste caso, o Ministério Público, e deverá conter:

I. a clara descrição da situação objeto da investigação;

II. a qualificação do investigado ou esclarecimento pelos quais se possa identificá-lo, salvo impossibilidade manifesta devidamente justificada;

III. a indicação da existência de indícios suficientes da prática de qualquer dos crimes previstos no artigo $1^{\mathrm{o}}$;

IV. a demonstração de ser a operação técnica estritamente necessária e da impossibilidade de ser a prova obtida por outros meios.

$\S 1^{\circ}$. O requerimento ou a representação deverá indicar o número da linha telefônica (código de acesso), com seu código de área, podendo o Ministério Público e a autoridade policial requisitar das prestadoras dos serviços de telefonia, exclusivamente para os fins da formulação do pedido, o cadastro relativo ao nome, número de telefone e endereço do titular da linha ou do local onde o aparelho estiver instalado.

$\S 2^{\circ}$. O suspeito ou acusado e, no caso do inciso XII do artigo $1^{\circ}$, o ofendido ou seu representante legal, poderá formular o pedido mediante requerimento dirigido ao juiz competente.

Artigo $6^{\circ}$. O requerimento ou a representação será distribuído e autuado em separado, sob segredo de justiça, devendo o juiz competente, no prazo máximo de 24 horas, proferir decisão fundamentada, que consignará de forma expressa, quando deferida a autorização:

a) a indicação de indícios suficientes da prática de qualquer dos crimes previstos no artigo $1^{\circ}$;

b) a indicação de indícios suficientes de autoria ou participação do investigado em qualquer dos crimes referidos no artigo $1^{\circ}$, salvo impossibilidade manifesta devidamente justificada;

c) a demonstração de ser a providência estritamente necessária, não podendo a prova do crime e de suas circunstâncias ser obtida por outros meios disponíveis;

d) a indicação do número da linha telefônica (código de acesso), incluindo seu código de área, objeto da operação técnica, justificada a sua relação com os fatos investigados.

Art. $7^{\circ}$. Da decisão que deferir ou indeferir o pedido cabe recurso em sentido estrito, sem efeito suspensivo, devendo o tribunal, se for o caso, determinar a inutilização da prova eventualmente obtida, bem como a sua forma, de modo a preservar a intimidade dos envolvidos.

Parágrafo único. O recurso em sentido estrito tramitará em segredo de justiça e, na hipótese de indeferimento do pedido, será processado sem a oitiva do suspeito ou acusado, a fim de resguardar a eficácia da investigação.

Art. $8^{\circ}$. A ordem que determinar a realização da operação técnica, da qual constará por extenso o número da linha telefônica (código de acesso) e o código de área, será assinada pessoalmente pelo juiz e expedida em duas vias, uma para a prestadora de serviços de telefonia e outra para a autoridade policial. 
Art. $9^{\circ}$. O juiz fixará a duração das operações até o prazo de 15 (quinze) dias, renovável por igual período, desde que continuem presentes os pressupostos autorizadores da medida.

$\S 1^{\circ}$. Após a primeira renovação, as demais, por igual período, dependerão da verificação da excepcionalidade do caso concreto, baseada na apresentação ao juiz competente de relatório circunstanciado a respeito do resultado das operações já desenvolvidas, não podendo, contudo, o prazo máximo das operações técnicas exceder a 60 (sessenta) dias, exceto quando se tratar de investigação relativa a crime permanente, enquanto não cessar a permanência.

$\S 2^{\circ}$. Para cada prorrogação, será necessária nova ordem judicial, devidamente motivada, observado o disposto no artigo $6^{\circ}$.

Art. 10. Os prazos previstos no artigo $9^{\circ}$ e seus parágrafos correrão de forma contínua e ininterrupta, a partir da data em que a prestadora do serviço de telefonia proporcionar a realização da operação autorizada, comunicando o fato, por escrito. imediatamente ao juiz.

Parágrafo único. A prestadora do serviço de telefonia deverá implementar a realização da operação autorizada no prazo máximo de 24 (vinte e quatro) horas, contadas a partir da comunicação da decisão judicial.

Art.11. A solicitação de um juiz a outro, para efeito da realização das operações técnicas fora da área de sua competência, será feita por qualquer meio rápido de comunicação, distribuído e autuado sob segredo de justiça, devendo ser confirmada em 48 (quarenta e oito) horas por documento oficial, sem prejuízo do imediato início das operações.

Parágrafo único - Não sendo feita no prazo a comunicação oficial, as operações serão imediatamente suspensas, com inutilizaçao da prova porventura colhida, na forma a ser determinada pelo juiz, de modo a preservar a intimidade dos envolvidos.

\section{CAPÍTU LO III \\ Das operações técnicas}

Art. 12. A execução das operações técnicas de que trata esta lei será efetuada somente pela autoridade policial, em órgão próprio, centralizado e exclusivo, sob a responsabilidade direta da Chefia de Polícia e ficará sujeita à fiscalização do Ministério Público.

Parágrafo único. Findas as operações técnicas, a autoridade policial encaminhará imediatamente, em duas cópias, todo o material obtido ao juiz competente, acompanhado de autos circunstanciados com o resumo das operações realizadas, proibida a permanência de qualquer registro a elas relativo no sistema.

Art. 13. O Ministério da Justiça definirá, no prazo de 90 dias, o padrão de sistema de gerenciamento centralizado, de forma a atender às especificidades das polícias federal e estadual.

$\S 1^{\circ}$ - Definido o sistema descrito neste artigo, a ANATEL regulamentará, no prazo de 90 (noventa) dias, o padrão de protocolo a ser utilizado por todas as prestadoras de serviços de 
telecomunicações.

$\S 2^{\circ}$. Sem prejuízo da aplicabilidade imediata do disposto neste artigo, a União, os Estados e o Distrito Federal poderão celebrar convênios para a disciplina do sistema de gerenciamento centralizado, com vistas a assegurar a máxima eficiência, a preservação do sigilo e a inviolabilidade das informações obtidas.

Art. 14. Caberá à ANATEL, no prazo de 90 (noventa) dias, regulamentar as formas e as condições em que as empresas de telecomunicações prestarão serviços técnicos especializados, quando requisitados pela autoridade policial.

Art. 15. O ressarcimento das empresas pelos serviços prestados e pelo uso da rede de telecomunicações será sempre posterior à realização do serviço e suas formas e condições serão estabelecidas pela ANATEL.

Parágrafo único. A prestadora de serviços de telecomunicações não poderá alegar como óbice à implementação das medidas previstas nesta lei qualquer questão ligada ao ressarcimento pelos serviços.

\section{CAPÍTULO IV \\ Do incidente probatório}

Art.16. Recebido o material obtido nas operações técnicas, e não havendo necessidade de diligências complementares previstas nesta lei, o juiz competente dele dará ciência ao Ministério Público, ao suspeito ou acusado e seu defensor.

$\S 1^{\circ}$. A partir desse momento e em prazo não inferior a $10(\mathrm{dez})$ dias poderão as partes examinar os autos circunstanciados e escutar as gravações, indicando, em 48 (quarenta e oito) horas, os trechos cuja transcrição pretendem.

$\S 2^{\circ}$. O juiz determinará a transcrição dos trechos indicados pelas partes e pela autoridade policial, bem como de outros que entenda pertinentes e relevantes.

$\S 3^{\circ}$. As dúvidas a respeito da autenticidade da gravação ou da voz serão decididas pelo juiz, aplicando-se, no que couber, o disposto nos arts. 145 a 148 do Código de Processo Penal.

$\S 4^{\circ}$. Das decisões previstas nos parágrafos $2^{\circ}$ e $3^{\circ}$ deste artigo cabe recurso em sentido estrito, com efeito suspensivo restrito ao incidente probatório.

Art.17. A transcrição dos trechos indicados instruirá os autos, conservando-se em cartório, em absoluto segredo de justiça, as fitas magnéticas ou elementos análogos, até o trânsito em julgado da sentença, quando serão destruídos na forma a ser indicada pelo juiz, de modo a preservar a intimidade dos envolvidos.

Parágrafo único. É permitido às partes, a qualquer tempo, extraírem cópias das transcrições, através da cópia disponibilizada para esse fim (artigo 12, parágrafo único) e escutarem, em juízo, as gravações, cabendo ao juiz zelar pela preservação da inviolabilidade e privacidade da prova. 


\section{CAPÍTULO V \\ Da utilização da prova resultante das operações}

Art. 18. Os resultados da interceptação, impedimento, interrupção, escuta e gravação, realizados fora dos casos, modalidades e formas estabelecidos nesta lei, não poderão ser utilizados como prova em qualquer investigação, processo ou procedimento, seja qual for sua natureza.

Art. 19. Os resultados das operações ténicas realizadas nos termos desta lei não poderão ser utilizados para a instrução de processos ou investigações relativos a crimes diversos daqueles para os quais a autorização foi dada, salvo quando se tratar de crime conexo ou de outro crime constante do artigo $1^{\circ}$ desta lei, hipótese em que se observará o disposto nos artigos 16 e 17.

\section{CAPÍTULO VI \\ Das sanções penais}

Art. 20 . Interceptar, impedir, interromper, fazer escuta ou gravação de comunicação telefônica e das telecomunicações a ela equiparadas, conforme disposto no artigo $1^{\circ}, \S 1^{\circ}$, fora dos casos, modalidades e formas previstas nesta lei:

Pena - reclusão, de 2 (dois) a 4 (quatro) anos e multa.

$\S 1^{\circ}$. Incorre nas mesmas penas quem divulga ou utiliza o resultado das operações ilegais descritas no caput deste artigo.

$\S 2^{\circ}$. A pena é aumentada de um terço se o agente for funcionário público, prevalecendo-se de seu cargo ou função.

Art. 21. Gravar clandestinamente conversa entre presentes ou fazer a captação ou a interceptação ambiental de sinais eletromagnéticos, óticos ou acústicos, ou o seu registro, análise ou utilização, fora dos casos, modalidades e formas previstas nesta lei:

Pena - reclusão, de 2 (dois) a 4 (quatro) anos e multa.

$\S 1^{\circ}$ - Incorre nas mesmas penas quem divulga, decodifica, transcreve ou utiliza o resultados das operações ilegais descritas no caput deste artigo.

$\S 2^{\circ}$ - A pena é aumentada de um terço se o agente for funcionário público, prevalecendose de seu cargo ou função.

Art. 22. Divulgar ou utilizar, por quaisquer meios, o resultado das operações técnicas, protegidas por segredo de justiça e realizadas nos casos, modalidades e formas previstas nesta lei:

Pena — reclusão, de 1 (hum) a 3 (três) anos e multa. 
Art.23 . Divulgar gravação de conversa própria, por telefone ou por outro meio, gravada sem o conhecimento do interlocutor, salvo para o exercício regular de um direito:

$$
\text { Pena - reclusão, de } 1 \text { (hum) a } 3 \text { (três) anos e multa. }
$$

Art. 24 . No caso dos crimes previstos no parágrafo $1^{\circ}$ do artigo 20 , no parágrafo $1^{\circ}$ do artigo 21 e nos artigos 22 e 23 , a pena é aumentada de um terço se a divulgação se der por meio de jornais e outras publicações periódicas, serviços de radiodifusão e serviços noticiosos, bem como pela internet.

Parágrafo único - A responsabilidade penal, nesses casos, será determinada na forma dos artigos 37 a 39 da Lei n. 5.250, de 9 de fevereiro de 1967.

Art. 25 . Fazer afirmação falsa ou induzir a erro a autoridade judicial, com o propósito de obter autorização para as operações previstas nos artigos $1^{\circ}$ e $2^{\circ}$ desta lei:

Pena - reclusão, de 1 (hum) a 3 (três) anos e multa.

Parágrafo único. A pena é aumentada de metade, se o agente for funcionário público.

Art.26. Autorizar as operações previstas nos artigos $1^{\circ}$ e $2^{\circ}$ para finalidade diversa da que trata esta lei:

$$
\text { Pena - reclusão, de } 1 \text { (hum) a } 3 \text { (três) anos e multa. }
$$

Art.27. Desobedecer, sem justa causa, à ordem judicial que determina a realização das operações técnicas previstas nesta lei:

$$
\text { Pena - detenção, de } 1 \text { (hum) a } 3 \text { (três) anos e multa. }
$$

\section{CAPÍTULO VII \\ Disposições finais e transitórias}

Art. 28. Ressalvadas as prerrogativas das partes e do defensor, correrão em segredo de justiça os inquéritos e processos que contiverem elementos informativos ou provas obtidos na forma desta lei.

Art. 29 - Enquanto o Ministério da Justiça não definir e a ANATEL não regulamentar o sistema de gerenciamento a ser utilizado para os operações técnicas descritas nesta lei, a Chefia de Polícia estabelecerá a forma de sua execução, de modo a possibilitar o controle do Ministério Público e a garantir a regularidade, inviolabilidade e privacidade do sistema utilizado.

Parágrafo único. As prestadoras de serviços de telefonia deverão manter arquivados, pelo prazo de 5 (cinco) anos, as informações relativas à origem, destino e duração de todas as conversas telefônicas.

Art. 30. Esta lei entrará em vigor 60 (sessenta) dias após sua publicação, aplicando-se, no 
que forem compatíveis, as normas do Código de Processo Penal e do Código de Processo Penal Militar.

Art. 31. Ficam revogadas as disposições em contrário e especialmente a Lei $\mathrm{n}^{\circ}$ 9.296, de 24 de julho de 1996. 


\section{ANEXO B - PROJETO DE LEI 3.272/2008}

\section{SUBCHEFIA DE ASSUNTOS PARLAMENTARES}

EMI no 00037 - MJ/MC

Brasília, 26 de fevereiro de 2008.

Excelentíssimo Senhor Presidente da República,

Submetemos à consideração de Vossa Excelência o anexo anteprojeto de lei elaborado a partir das conclusões da Comissão instituída pela Portaria no 116 , de 13 de fevereiro de 2003, do Ministério da Justiça, com o objetivo de regulamentar a última parte do inciso XII do art. 5o da Constituição da República, possibilitando a quebra do sigilo das comunicações telefônicas, exclusivamente para fins de investigação criminal e instrução penal.

2.

A quebra do sigilo de comunicações telefônicas constitui-se em poderoso meio posto à disposição do Estado para fins de obtenção de prova, mas também em instrumento insidioso de quebra da intimidade, não só do investigado como também de terceiros.

3. Diante desse quadro, e em respeito ao princípio da reserva de lei proporcional, a regulamentação da matéria há de resultar da escrupulosa ponderação dos valores em jogo, observado o princípio da proporcionalidade, entendido como justo equilíbrio entre os meios empregados e os fins a serem alcançados, que deve levar em conta os seguintes elementos: a) adequação: a aptidão da medida para atingir os objetivos pretendidos; b) necessidade: como exigência de limitar um direito para proteger outro, igualmente relevante; c) proporcionalidade estrita: a ponderação entre a restrição imposta (que não deve aniquilar o direito); e $d$ ) a vantagem alcançada.

4.

Aponta-se na doutrina especializada como grande defeito da atual Lei de Interceptação (Lei no 9.296, de 24 de julho de 1996), a inobservância do princípio da proporcionalidade, pois ao mesmo tempo em que permite a quebra do sigilo das 
comunicações telefônicas de qualquer natureza relativamente a todos os crimes punidos com reclusão, independentemente da conduta criminosa, deixa à margem os crimes punidos com detenção para os quais a quebra do sigilo se apresentaria como meio mais adequado de investigação como, por exemplo, no crime de ameaça feita pelo telefone. Este defeito é corrigido no art. $2^{o}$ do texto pretendido que, mantendo a previsão de quebra do sigilo de comunicações telefônicas de qualquer natureza para as hipóteses relacionadas a crimes apenados com reclusão, estende esse mecanismo de investigação/prova aos delitos apenados com detenção quando a conduta delituosa tiver sido cometida através de meios de comunicação instantânea. Assim, crimes como ameaça e estelionato, quando praticados pelo telefone, não ficarão fora da possível quebra do sigilo de comunicações telefônicas, o que facilitará de forma significativa a apuração e elucidação do caso, em respeito ao princípio da proporcionalidade.

5 .

Mas há outros graves defeitos na atual Lei, como, por exemplo, quando não dá vista ao membro do Ministério Público do requerimento da diligência requerida pela autoridade policial; quando não dispõe com clareza sobre o incidente probatório no qual se deve dar conhecimento às partes do conteúdo das operações técnicas, em desrespeito à garantia do contraditório, portanto; quando omite completamente o tratamento das chamadas interceptações ambientais; e, sobretudo, a Lei em vigor não trata dos controles necessários para evitar os abusos a que freqüentemente sua aplicação dá margens: controles sobre a autorização judicial e a forma de seu encaminhamento, controles mais rigorosos sobre os prazos e, mais ainda, controles sobre as operações técnicas, hoje deixadas exclusivamente a critério da autoridade policial, sem qualquer parâmetro fixado.

6.

O presente projeto é fruto, além dos trabalhos da Comissão instituída para esse fim, da incorporação de sugestões de vários órgãos públicos, entidades públicas e privadas e profissionais do setor que, além de avançar nos aspectos jurídicos, não se distanciaram das normas técnicas de interferência nas comunicações telefônicas, no intuito de garantir a segurança, a inviolabilidade e a preservação do sigilo.

7. O projeto destaca, no seu art. $1^{\circ} \stackrel{\circ}{-} \S 1^{\circ}$, que se considera quebra do sigilo das comunicações telefônicas de qualquer natureza todo ato que intervenha no curso dessas comunicações com a finalidade de conhecer as informações que estão sendo transmitidas, incluindo a interceptação, a escuta e a gravação. Sendo que, no $\S 3$-, estende ao fluxo de 
comunicações em sistemas de tecnologia da informação e telemática a possibilidade de quebra do sigilo, entendendo, como o fazem juristas do porte de Tércio Sampaio Ferraz, entre outros, que a Constituição ao dizer comunicação telefônica refere-se a todo e qualquer meio de comunicação instantânea sendo, portanto, possível a quebra deste sigilo embasada por ordem judicial.

8.

$\mathrm{O}$ art. 2o-, além de manter a possibilidade de quebra de sigilo para os delitos apenados com reclusão, estendeu essa possibilidade para as hipóteses de crimes punidos com detenção, como já mencionado no item 4 da presente EMI. Entretanto, importante destacar que no parágrafo único do citado artigo proíbe-se a utilização das informações resultantes da quebra de sigilo das comunicações entre o investigado ou acusado e seu defensor, quando este estiver atuando na função, resguardando-se, assim, a constitucional relação advogado/cliente.

9.

A partir do art. 4ㅇ inicia-se o capítulo que cuida do procedimento da quebra de sigilo, sendo mais detalhado e, portanto, inovando significativamente em relação à atual Lei.

10. O próprio art. 4ำ determina que o pedido de quebra de sigilo deverá ser feito por escrito ao juiz, sempre com a participação do membro do Ministério Público, contendo a descrição precisa dos fatos investigados; a indicação da existência de indícios da prática do crime que autoriza a quebra de sigilo; a qualificação do investigado ou acusado; a demonstração de ser a quebra de sigilo imprescindível às investigações; e, quando conhecido, a indicação do código de identificação do sistema de comunicação utilizado.

11. Como se vê, Senhor Presidente, o requerimento de quebra de sigilo das comunicações passa a ser disciplinado de forma mais rigorosa e objetiva, diferente da Lei atual que sequer exige a forma escrita para tal. Este procedimento mais detalhado é fruto do entendimento sobre a quebra do sigilo telefônico, pois se por um lado é importante meio de prova, por outro deve ser disciplinado de forma precisa, considerando que não deixa de ser odioso meio de interferência estatal na vida do particular.

12. Sempre sob segredo de justiça, o incidente processual será autorizado pelo juiz no prazo máximo de vinte e quatro horas, devendo o mandado judicial indicar, na forma dos incisos do art. 5-, os elementos da quebra. Importante avanço, contudo, é a norma do $\S 1$ o ao determinar que o prazo de duração da quebra do sigilo das comunicações não poderá exceder 
a sessenta dias, prorrogável por períodos iguais, até o máximo de trezentos e sessenta dias ininterruptos, salvo quando se tratar de crime permanente.

13. Objetivando maior celeridade da ordem judicial, o $\S 2$ o do art. $7 \stackrel{0}{-}$ autoriza que o mandado judicial seja encaminhado por qualquer meio idôneo, inclusive o eletrônico, desde que comprovada a sua autenticidade.

14. $\mathrm{O}$ art. 8 reza que a prestadora de serviço de comunicação, ao implementar a quebra do sigilo, indicará ao juiz o nome do funcionário responsável, e também que é inadmissível a recusa da prestação do serviço sob justificativa de necessidade de ressarcimento dos custos.

15.

Após a realização das operações técnicas, a autoridade policial encaminhará, no prazo máximo de sessenta dias, ao juiz competente, todo o material produzido, acompanhado de auto circunstanciado que deverá conter o resumo das operações realizadas. Feito o encaminhamento, e não havendo ordem judicial em sentido contrário, a autoridade policial inutilizará por completo todo o material que se mantiver sob sua esfera de responsabilidade. Havendo, entretanto, ordem judicial para que se mantenha o material, este, sob nenhuma hipótese, ficará sob os cuidados da autoridade policial após o trânsito em julgado da sentença absolutória ou expirado o prazo de revisão criminal, quando, então, tanto o material mantido pelo juiz quanto o guardado pela autoridade policial serão destruídos (art $15)$.

16.

Não havendo requerimento de diligências complementares por parte do Ministério Público, o juiz intimará o investigado ou acusado para que se manifeste, em atenção ao princípio do contraditório. Objetivando impedir a quebra do segredo de justiça, todas as cópias disponibilizadas, em mídia eletrônica ou equivalente, serão identificáveis. Assim substitui-se a obrigação de transcrição das cópias destinadas às partes, muitas vezes infactível dependendo da quantidade de horas gravadas, pela entrega de cópias identificáveis com o mesmo teor da versão original.

17. O Capítulo III (arts. 20 a 26) traz as disposições finais, merecendo destaque o art. 21. Nele, fica autorizado o Poder Executivo a instituir sistema centralizado de dados estatísticos sobre quebra do sigilo de comunicações. 
18. O referido sistema será utilizado, assim como outros países já o fazem, como elemento de controle da sociedade sobre esse meio de invasão de privacidade que é a quebra do sigilo das comunicações telefônicas de qualquer natureza. Objetivará informar a quantidade de quebras de sigilo autorizadas e em curso em cada unidade da Federação, as espécies de crimes, o tempo médio de sua duração, entre outras informações de cunho exclusivamente estatístico a serem disciplinadas em regulamento. Em nenhuma hipótese o sistema conterá o conteúdo das comunicações realizadas nem os códigos de identificação ou outros elementos e meios capazes de identificar os envolvidos, inclusive investigados e acusados.

19.

Por fim, o art. 23 traz para o âmbito do Código Penal a conduta delituosa prevista na atual Lei de escuta, por ser de melhor técnica jurídica. Com efeito, corrige-se a forma pela qual o tipo penal hoje é previsto, sem, contudo, modificar o núcleo do tipo. Destarte, não se trata de criminalizar nova conduta, nem de abolitio criminis, visto tratar-se de mera adequação redacional, em consonância com a construção dos tipos penais pátrios.

20. Assim, Senhor Presidente, submetemos ao elevado descortino de Vossa Excelência o anexo anteprojeto de lei, acreditando que, se aceito, estará o Brasil adotando um poderoso meio de investigação adequado aos fins a que se destina, sem, contudo, abalar as garantias constitucionais.

Respeitosamente,

Tarso Fernando Herz Genro Ministro de Estado da Justiça
Hélio Calixto da Costa

Ministro de Estado das Comunicações 


\title{
SUBCHEFIA DE ASSUNTOS PARLAMENTARES
}

\author{
PROJETO DE LEI
}

Regulamenta a parte final do inciso XII do art. $5^{\circ}$ da Constituição e dá outras providências.

O CONGRESSO NACIONAL decreta:

\section{CAPÍTULO I \\ DAS DISPOSIÇÕES GERAIS}

Art. $1^{\circ}$ Esta Lei disciplina a quebra, por ordem judicial, do sigilo das comunicações telefônicas de qualquer natureza, para fins de investigação criminal e instrução processual penal.

$\S 1^{0}$ Para os fins desta Lei, considera-se quebra do sigilo das comunicações telefônicas de qualquer natureza todo ato que intervém no curso dessas comunicações com a finalidade de conhecer as informações que estão sendo transmitidas, incluindo a interceptação, escuta e gravação.

$\S 2^{\underline{o}}$ O registro, a análise e a utilização da informação contida nas comunicações, objeto de quebra de sigilo por ordem judicial, sujeitam-se, no que couber, ao disposto nesta Lei.

$\S 3^{\text {o }}$ O disposto nesta Lei aplica-se ao fluxo de comunicações em sistemas de tecnologia da informação e telemática.

Art. $2^{\underline{0}}$ A quebra do sigilo das comunicações telefônicas de qualquer natureza é admissível para fins de investigação criminal e instrução processual penal relativas aos crimes apenados com reclusão e, na hipótese de crime apenado com detenção, quando a conduta delituosa tiver sido realizada por meio dessas modalidades de comunicação. 
Parágrafo único. Em nenhuma hipótese poderão ser utilizadas as informações resultantes da quebra de sigilo das comunicações entre o investigado ou acusado e seu defensor, quando este estiver atuando na função.

Art. $3^{\underline{0}}$ A gravação de conversa própria, com ou sem conhecimento do interlocutor, não se sujeita às disposições desta Lei.

\section{CAPÍTULO II} DO PROCEDIMENTO

Art. $4^{\underline{0}} \mathrm{O}$ pedido de quebra de sigilo das comunicações telefônicas de qualquer natureza será formulado por escrito ao juiz competente, mediante requerimento do Ministério Público ou representação da autoridade policial, ouvido, neste caso, o Ministério Público, e deverá conter:

I - a descrição precisa dos fatos investigados;

II - a indicação da existência de indícios suficientes da prática do crime objeto da investigação;

III - a qualificação do investigado ou acusado, ou esclarecimentos pelos quais se possa identificá-lo, salvo impossibilidade manifesta devidamente justificada;

IV - a demonstração de ser a quebra de sigilo da comunicação estritamente necessária e da inviabilidade de ser a prova obtida por outros meios; e

V - a indicação do código de identificação do sistema de comunicação, quando conhecido, e sua relação com os fatos investigados.

Art. $5^{\circ} \mathrm{O}$ requerimento ou a representação será distribuído e autuado em separado, sob segredo de justiça, devendo o juiz competente, no prazo máximo de vinte e quatro horas, proferir decisão fundamentada, que consignará de forma expressa, quando deferida a autorização, a indicação:

I - dos indícios suficientes da prática do crime; 
II - dos indícios suficientes de autoria ou participação no crime, salvo impossibilidade manifesta devidamente justificada;

III - do código de identificação do sistema de comunicação, quando conhecido, e sua relação com os fatos investigados; e

IV - do prazo de duração da quebra do sigilo das comunicações.

$\S 1^{0}$ O prazo de duração da quebra do sigilo das comunicações não poderá exceder a sessenta dias, permitida sua prorrogação por iguais e sucessivos períodos, desde que continuem presentes os pressupostos autorizadores da medida, até o máximo de trezentos e sessenta dias ininterruptos, salvo quando se tratar de crime permanente, enquanto não cessar a permanência.

$\S 2^{\underline{0}}$ O prazo correrá de forma contínua e ininterrupta e contar-se-á a partir da data do início da quebra do sigilo das comunicações pela prestadora responsável pela comunicação, que deverá comunicar este fato, imediatamente, por escrito, ao juiz.

$\S 3^{\text {o }}$ Para cada prorrogação será necessária nova decisão judicial fundamentada, observado o disposto no caput.

$\S 4^{\mathrm{o}}$ Durante a execução da medida de quebra de sigilo, caso a autoridade policial identifique que o investigado ou acusado passou a fazer uso de outro número, código ou identificação em suas comunicações, poderá formular, em caráter de urgência, pedido oral, que será reduzido a termo, de nova interceptação ao juiz, cuja decisão deverá ser proferida no prazo máximo de vinte e quatro horas.

$\S 5^{\circ}$ Adotadas as providências de que trata o $\S 4^{\circ}$, os autos seguirão para manifestação do Ministério Público e retornarão à autoridade judiciária que, então, reapreciará o pedido.

Art. $6^{0}$ Contra decisão que indeferir o pedido de quebra de sigilo caberá recurso em sentido estrito do Ministério Público, podendo o relator, em decisão fundamentada, conceder liminarmente o pedido de quebra. 
Parágrafo único. O recurso em sentido estrito tramitará em segredo de justiça e será processado sem a oitiva do investigado ou acusado, a fim de resguardar a eficácia da investigação.

Art. $7^{0}$ Do mandado judicial que determinar a quebra do sigilo das comunicações deverá constar a qualificação do investigado ou acusado, quando identificado, ou o código de identificação do sistema de comunicação, quando conhecido.

$\S 1^{\circ} \mathrm{O}$ mandado judicial será expedido em duas vias, uma para a prestadora responsável pela comunicação e outra para a autoridade que formulou o pedido de quebra do sigilo das comunicações.

$\S 2^{\mathrm{o}} \mathrm{O}$ mandado judicial poderá ser expedido por qualquer meio idôneo, inclusive o eletrônico ou similar, desde que comprovada sua autenticidade.

Art. $8^{\underline{0}}$ A prestadora responsável pela comunicação deverá implementar a quebra do sigilo autorizada, indicando ao juiz o nome do profissional responsável pela operação técnica, no prazo máximo de vinte e quatro horas, contado do recebimento da ordem judicial, sob pena de multa até o efetivo cumprimento da ordem, sem prejuízo das demais sanções cabíveis.

Parágrafo único. A prestadora a que se refere o caput não poderá alegar como óbice para a implementação da quebra do sigilo questão relativa ao ressarcimento dos custos pelos serviços de sua responsabilidade prestados para esse fim, que serão gratuitos.

Art. $9^{0}$ A decretação da quebra de sigilo de comunicação caberá ao juiz competente para o julgamento do crime investigado ou responsável pelo inquérito.

Art. 10. A execução das operações técnicas necessárias à quebra do sigilo das comunicações será efetuada sob a supervisão da autoridade policial e fiscalização do Ministério Público.

Art. 11. Findas as operações técnicas, a autoridade policial encaminhará, no prazo máximo de sessenta dias, ao juiz competente, todo o material produzido, acompanhado de auto circunstanciado, que deverá conter o resumo das operações realizadas. 
Parágrafo único. Decorridos sessenta dias do encaminhamento do auto circunstanciado, a autoridade policial inutilizará qualquer material obtido em virtude da quebra do sigilo das comunicações, salvo determinação judicial em contrário.

Art. 12. Recebido o material produzido, o juiz dará ciência ao Ministério Público para que, se julgar necessário, requeira, no prazo de dez dias, diligências complementares.

Art. 13. Não havendo requerimento de diligências complementares ou após a realização das que tiverem sido requeridas, o juiz intimará o investigado ou acusado para que se manifeste, fornecendo-lhe cópia identificável de todo o material produzido.

Art. 14. As dúvidas a respeito da autenticidade ou integridade do material produzido serão dirimidas pelo juiz, aplicando-se, no que couber, o disposto nos arts. 145 a 148 do Código de Processo Penal.

Art. 15. Conservar-se-á em cartório, sob segredo de justiça, as fitas magnéticas ou quaisquer outras formas de registro das comunicações cujo sigilo fora quebrado até o trânsito em julgado da sentença, quando serão destruídos na forma a ser indicada pelo juiz, de modo a preservar a intimidade dos envolvidos.

Parágrafo único. Não se procederá a referida destruição enquanto for possível a revisão criminal.

Art. 16. Na hipótese de a quebra do sigilo das comunicações telefônicas de qualquer natureza revelar indícios de crime diverso daquele para o qual a autorização foi dada e que não lhe seja conexo, a autoridade deverá remeter ao Ministério Público os documentos necessários para as providências cabíveis.

Art. 17. A prova obtida por meio da quebra de sigilo das comunicações telefônicas de qualquer natureza realizada sem a observância desta Lei não poderá ser utilizada em qualquer investigação, processo ou procedimento, seja qual for sua natureza.

Art. 18. Correrão em segredo de justiça os inquéritos e processos que contiverem 
elementos informativos ou provas obtidos na forma desta Lei.

\section{CAPÍTULO III DAS DISPOSIÇÕES FINAIS}

Art. 20. As gravações ambientais de qualquer natureza, quando realizadas pela autoridade policial, sujeitam-se às disposições desta Lei, no que couber.

Art. 21. Fica o Poder Executivo autorizado a instituir, para fins exclusivamente estatísticos e de planejamento de ações policiais, sistema centralizado de informações sobre quebra de sigilo de comunicações telefônicas de qualquer natureza, na forma do regulamento.

Parágrafo único. O sistema de que trata o caput não conterá o conteúdo das comunicações realizadas nem os códigos de identificação ou outros elementos e meios capazes de identificar os envolvidos, inclusive investigados e acusados.

Art. 22. A Agência Nacional de Telecomunicações - ANATEL regulamentará, no prazo de cento e oitenta dias, o padrão dos recursos tecnológicos e facilidades necessárias ao cumprimento desta Lei, a serem disponibilizados gratuitamente por todas as prestadoras responsáveis pela comunicação.

Art. 23. O Decreto-Lei n⿳ 2.848, de 7 de dezembro de 1940 - Código Penal, passa a vigorar acrescido do seguinte dispositivo:

"Violação do sigilo das comunicações telefônicas

Art. 151-A. Violar sigilo de comunicação telefônica de qualquer natureza, sem autorização judicial ou com objetivos não autorizados em lei:

Pena - reclusão, de dois a quatro anos, e multa.

Parágrafo único. Incorre na mesma pena quem violar segredo de justiça de quebra do sigilo de comunicação telefônica de qualquer natureza." 
$(\mathrm{NR})$

Art. 24. O art. 581 do Decreto-Lei n⿳ำ 3.689, de 3 de outubro de 1941 - Código de Processo Penal, passa a vigorar acrescido do seguinte inciso:

"XXV - que indeferir o pedido de quebra do sigilo das comunicações telefônicas de qualquer natureza." (NR)

Art. 25. Aplicam-se subsidiariamente a esta Lei, no que com ela não colidirem, as disposições do Código de Processo Penal e do Código de Processo Penal Militar.

Art. 26. Revoga-se a Lei n⿳ำ 9.296, de 24 de julho de 1996.

Art. 27. Esta Lei entra em vigor sessenta dias após a data de sua publicação.

Brasília, 


\section{ANEXO C - PROJETO DE LEI 4.036/2008}

\section{PROJETO DE LEI}

Altera as Leis $\mathrm{n}^{\mathrm{os}}$ 4.878, de 3 de dezembro de 1965, 8.112, de 11 de dezembro de 1990, e o Decreto-Lei no 2.848, de 7 de dezembro de 1940 - Código Penal, para dispor sobre sanções administrativas e penais aplicáveis em casos de interceptação de comunicações e de violação de sigilo, e dá outras providências.

\section{O CONGRESSO NACIONAL decreta:}

Art. $1^{\text {o }}$ O caput do art. 48 da Lei $n^{\circ} 4.878$, de 3 de dezembro de 1965 , passa a vigorar com a seguinte redação:

“Art. 48. A pena de demissão, além dos casos previstos na Lei $\mathrm{n}^{\mathrm{o}}$ 8.112, de 11 de dezembro de 1990, será também aplicada quando se caracterizar:” (NR)

Art. $2^{\underline{0}}$ A Lei $\mathrm{n}^{\mathrm{o}}$ 8.112, de 11 de dezembro de 1990, passa a vigorar com as seguintes alterações:

“Art. 117

XX - realizar, diretamente ou por meio de terceiros, ou permitir que se realize, interceptação de comunicação de qualquer natureza, sem autorização judicial ou com objetivos não autorizados em lei; e

XXI - violar o sigilo ou o segredo de justiça das informações obtidas por meio de interceptação de comunicação de qualquer natureza.

"(NR)

"Art. 132.

XIII - transgressão dos incisos IX a XVI, XX e XXI do art. 117.” (NR)

Art. $3^{\text {o }}$ O Decreto-Lei n⿳ำ 2.848, de 7 de dezembro de 1940 - Código Penal, passa a vigorar com as seguintes alterações:

“Art. 151

$\S 1^{\mathrm{o}}$ 
III - quem impede comunicação telegráfica ou radioelétrica dirigida a terceiro, ou conversação telefônica entre outras pessoas;

“Art. 151-A. Realizar, diretamente ou por meio de terceiros, ou permitir que se realize, interceptação de comunicação de qualquer natureza, sem autorização judicial ou com objetivos não autorizados em lei:

Pena - reclusão, de dois a quatro anos, e multa.

$\S 1^{0}$ Incorre na mesma pena quem:

I - violar o sigilo ou o segredo de justiça das informações obtidas por meio de interceptação de comunicação de qualquer natureza; ou

II - utilizar o resultado de interceptação de comunicação telefônica ou telemática para fins diversos dos previstos em lei.

$\S 2^{\underline{o}}$ A pena é aumentada de um terço até metade se o crime previsto no caput ou no $\S 1^{0}$ é praticado por funcionário público no exercício de suas funções." (NR)

"Art. 151-B. Produzir, fabricar, importar, comercializar, oferecer, emprestar, adquirir, possuir, manter sob sua guarda ou ter em depósito, sem autorização ou em desacordo com determinação legal ou regulamentar, equipamentos destinados especificamente à interceptação, escuta, gravação e decodificação das comunicações telefônicas, incluindo programas de informática e aparelhos de varredura:

Pena - reclusão, de dois a quatro anos, e multa." (NR)

Art. $4^{\mathrm{o}}$ Esta Lei entra em vigor na data de sua publicação.

Art. $5^{\underline{0}}$ Ficam revogados o inciso II do $\S 1^{0}$ do art. 151 do Decreto-Lei $\mathrm{n}^{\mathrm{o}} 2.848$, de 7 de dezembro de 1940 - Código Penal, e o art. 10 da Lei nº 9.296, de 24 de julho de 1996.

Brasília, 
$\mathrm{EM} \mathrm{n}^{\circ} 00154-\mathrm{MJ}$

Brasília, 5 de setembro de 2008

Excelentíssimo Senhor Presidente da República,

Tenho a honra de submeter à elevada consideração de Vossa Excelência o anexo Anteprojeto de Lei que altera as Leis 8.112, de 11 de dezembro de 1990, 4.878, de 03 de dezembro de 1964, 8.429, de 02 de junho de 1992, 9.296, de 24 de julho de 1996 e o Decreto-Lei n ${ }^{\circ}$ 2.848, de 7 de dezembro de 1940 - Código Penal, para dispor sobre sanções administrativas, políticas e penais aplicáveis em casos de interceptação de comunicações e de violação de sigilo.

O recente episódio da quebra do sigilo telefônico de autoridades do Legislativo e do Judiciário demonstrou a necessidade de atualização das normas relativas ao tema. $\mathrm{O}$ presente Anteprojeto de Lei tem o escopo de estabelecer sanções a duas condutas, a saber:

(i) realizar interceptação de comunicação sem autorização judicial; e

(ii) violar o sigilo das informações obtidas por meio de interceptação de comunicação.

Tais condutas, portanto, se perpetradas por servidor público civil da União, passam a ser causa de demissão. Além disso, a prática dessas condutas por agentes públicos passa a sofrer os efeitos da Lei de Improbidade Administrativa: a perda da função pública, a suspensão dos direitos políticos de três a cinco anos, o pagamento de multa e a proibição de contratar com o Poder Público.

No caso específico das sanções penais, há uma outra conduta alcançada, qual seja, utilizar o resultado de interceptação de comunicação para obter vantagem indevida ou com o fim de caluniar, difamar, injuriar, constranger ou ameaçar terceiros.

Em decorrência das alterações propostas, amplia-se o alcance dos tipos atualmente previstos no Código Penal e na Lei 9.926, de 24 de julho de 1996, além de restar exacerbada a pena prevista pelo Código Penal para a conduta daquele que utiliza abusivamente de resultado de interceptação ilegal, passando da atual previsão de detenção de um a seis meses ou multa, para reclusão de dois a quatro anos e multa.

São estas, Senhor Presidente, as razões que me levam a submeter o presente texto à apreciação de Vossa Excelência

Respeitosamente, 